
(n)

Q

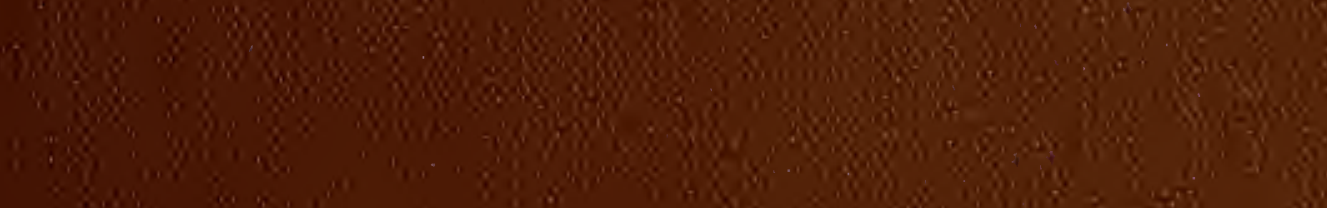




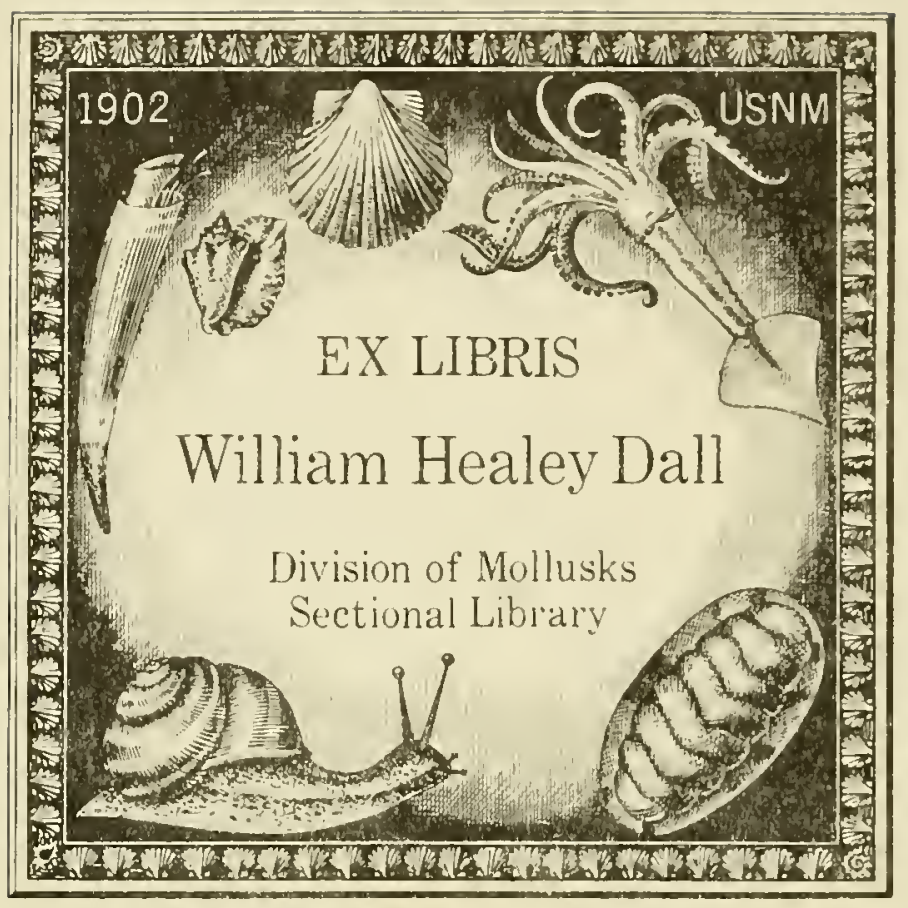








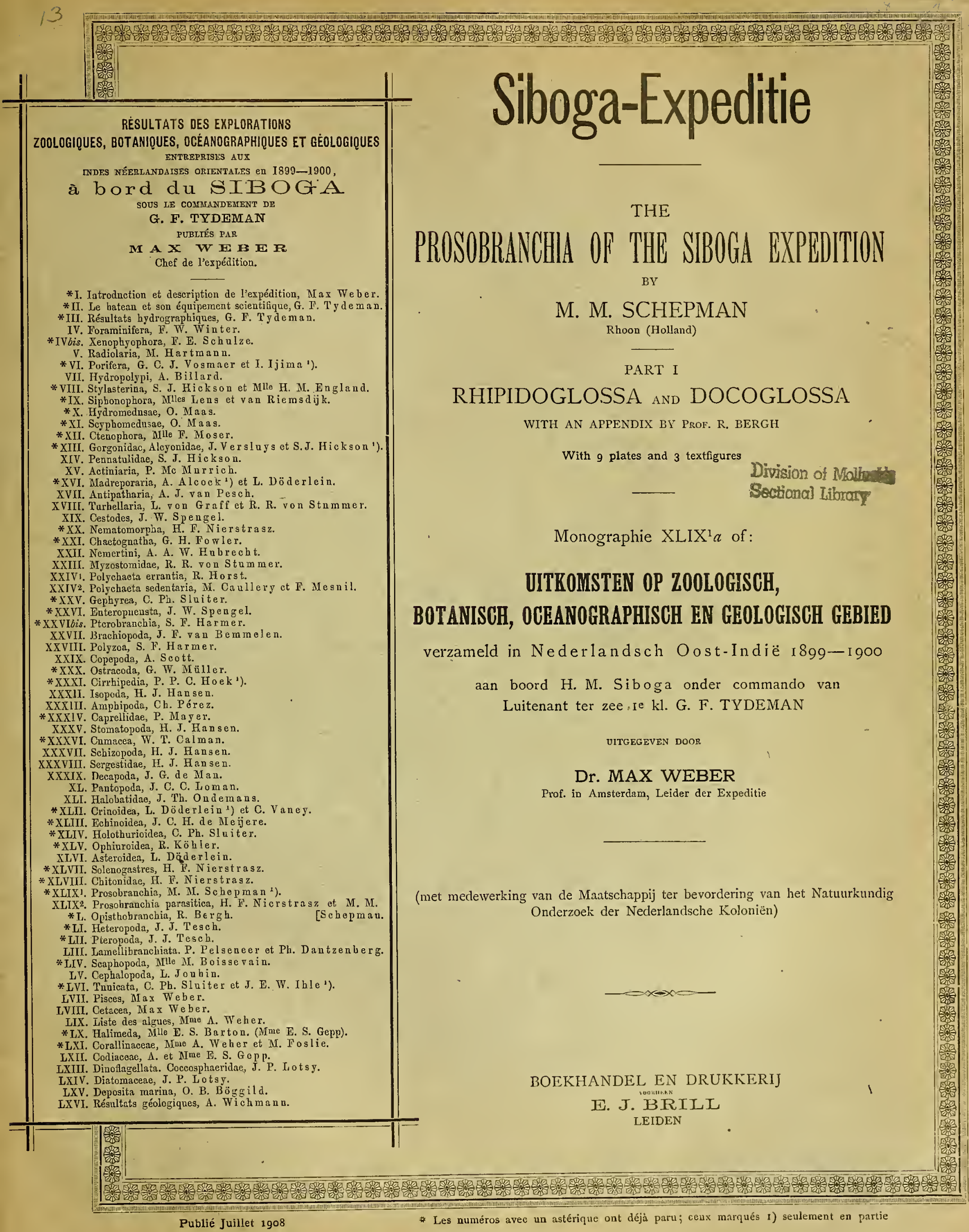


Voor de uitgave van de resultaten der Siboga-Expeditie hebben bijdragen beschikbaar gesteld:

De Maatschappij ter bevordering van het Natuurkundig Onderzoek der Nederlandsche Koloniën.

Het Ministerie van Koloniën.

Het Ministerie van Binnenlandsche Zaken.

Het Koninklijk Zoologisch Genootschap "Natura Artis Magistra" te Amsterdam.

De ,Oostersche Handel en Reederij" te Amsterdam.

De Heer B. H DE WaAl Oud-Consul-Generaal der Nederlanden te Kaapstad.

M. B. te Amsterdam. 
THE

\section{PROSOBRANCHIA OF THE SIBOGA EXPEDITION} PART I

RHIPIDOGLOSSA AND DOCOGLOSSA

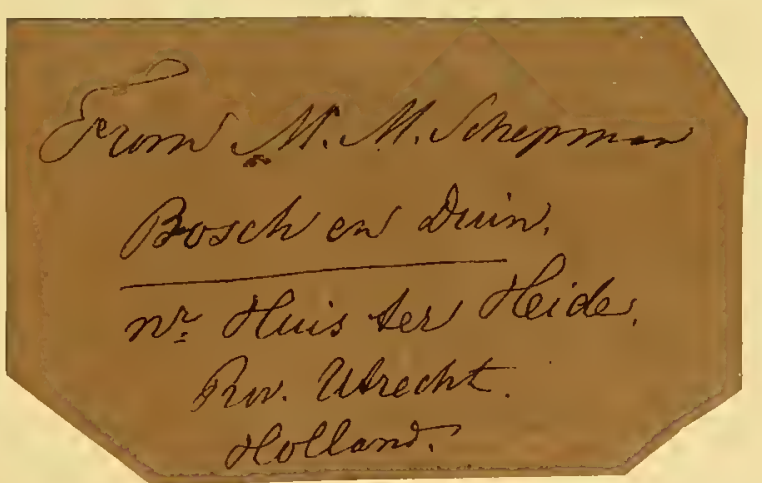



Siboga-Expeditie

XLIX' $^{\prime}$ - !

\title{
THE PROSOBRANCHIA OF THE SIBOGA EXPEDITION
}

\author{
BY \\ M. M. $\underset{\text { Rhoon (Hollani) }}{\mathrm{SCHEPMAN}}$ \\ PART I \\ RHIPIDOGLOSSA AND DOCOGLOSSA \\ WITH AN APPENDIX BY PROF. R. BERGH
}

With 9 plates and 3 textfigures 



\title{
PART I \\ RHIPIDOGLOSSA AND DOCOGLOSSA
}

\author{
WITH AN APPENDIX by PROF. R. BERGH.
}

\section{INTRODUCTION.}

As the number of species of prosobranchiate Gastropods, collected during the cruise of the "Siboga" is rather large (the collection contains far more than two thousand bottles and tubes, besides a considerable number of boxes) I proposed to Prof. Weber, to publish the results of my researches in four or five parts, in order to save priority. The first part dealing with the Rhipidoglossa and Docoglossa is now ready. It is the most interesting but I think the most difficult group to deal with, as the systematic position of many of the Trochidae and of the patelliform shells is very uncertain. By preparing the radulae of doubtful species, I have been able to throw some light in a few cases, and have been induced to erect some new genera. In many respects I have followed the systematic arrangement of Fischer (Manuel de Conchyliologie etc. Paris, I $880-87$ ) unless changes proved to be desirable on anatomical grounds or on account of other new investigations.

As to synonymy I have not tried to render it complete; as a rule I have only cited the author who first described the species, and those of the larger monographs I could consult; moreover I have cited the descriptions and figures of RuMpH, in the "Amboinsche Rariteitkamer", as this publication is in fact the only faunistic work on marine Mollusks of a considerable part of the East Indian Archipelago, and finally a few other authors, in whose works I found interesting particulars on, or better figures of the species mentioned in this part.

The number of species dealed with in this part, amounts to about 210 , amongst which 68 which I consider to be new, moreover a few new varieties. In order to avoid as much as possible the description of species already known, I have in many cases, before describing them, asked the assistance of Mr. E. A. SMrtu of the British Museum of Natural History, who with his usual kindness has compared the specimens with those of the conchological collections, for 
which assistance I here express my thanks; especially such comparison is necessary, with a view on the numerous species of the brothers $H$. and A. ADAms, as their descriptions are often very short and insufficient and have mostly not been accompanied by figures. I have to thank also many other persons, who assisted me by loaning books or specimens or by giving advice.

The conservation of the specimens was as a rule very good, however I think formol must be rejected if one cares to keep the shells in good condition; it seems that it renders the shells very brittle and their surfaces dull.

Those specimens to which an asterisk has been prefixed, have not been taken by the Expedition, but they belong to the collections of the Zoological Museum of the University or of the Royal Zoological Society of Amsterdam.

At the end of this part is annexed an appendix by Prof. R. Bergh, who had received amongst the Nudibranchs a few Prosobranchs, and has described them or has given anatomical particulars; a few of these species belong to the Taenioglossa, which will form the second part of the Prosobranchs. 


\title{
GASTROPODA.
}

\author{
Order PROSOBRANCHIATA Milne Edwards. \\ Suborder Scutibranchiata Civier. \\ Section Rhipidoglossa Troschel. \\ Fam. Neritacea Lamarck.
}

\section{Nerita Adanson.}

I. Nerita (Theliostyla) exuvia Linné.

LinnÉ. Syst. Nat. Ed. X, p. $779, N^{0} 646$.

Rumpir. Amb. Rariteitkamer, p. 78, tab. 22, fig. N.

ReEve. Conch. Icon. Vol. IX, Nerita, fig. I.

v. Martens. Martini-Chemnitz, Conch. Cab. Ed. II, Nerita, p. I2, Taf. I, Fig. I7, I8; Taf. 4, Fig. 16-19.

Stat. 50. Bay of Badjo, West coast of Flores. Up to 40 M. I Spec.

Stat. 5 I. Madura-bay. Reef. 7 Spec.

Stat. 152. Wunoh-bay, N. W. coast of Waigeu-island. Reef. I Spec.

Stat. 277. Kulewatti-bay, Dammer-island. Reef. I Spec.

*2. Nerita (Theliostyla) costata Chemnitz.

Chemnitz. Conch. Cab. Vol. V, p. 243 and 299, Pl. i91, fig. 1966, I967.

ReEve. Conch. Ic. Vol. IX, Nerita, fig. 6.

v. Martens. Martini-Chemn. Conch. Cab. Ed. II, Nerita, p. 62, Pl. I, fig. I1, I2; Pl. 4, fig. S-I I.

"Java. 3 Spec.

3. Nerita (Theliostylla) albicilla Linné.

Linné. Syst. Nat. Ed. X, p. $778, N^{0} 640$.

RUMPH. Amb. Rariteitkamer, p. 78 , tab. 22, fig. 8.

ReEve. Conch. Ic. Vol. IX, Nerita, fig. 64.

v. Martens. Martini-Chemn. Conch. Cab. Ed. II, Nerita, p. 25, Taf. 3, Fig. I-4,6-9; Taf. S, Fig. I, 2. 
"Java. 2 Spec.

"Amboina. I Spec.

Stat. I6. Bay of Kankamaraän, South coast of Kangeang. Shore. 4 Spec.

Stat. I9. Bay of Labuan Tring, West coast of Lombok. 18-27 M. 3 Spec.

Stat. 33. Bay of Pidjot, Lombok. Up to 22 M. I Spec.

Stat. 47. Bay of Bima near South fort. Shore. 6 Spec.

Stat. 50. Bay of Badjo, West coast of Flores. Up to 40 M. I Spec.

Stat. 51. Madura-bay. Reef. I Spec.

Stat. 53. Bay of Nangamessi, Sumba. Up to 36 M. 5 Spec.

Stat. 78. Lumu-Lumu-shoal, Borneo-bank. 34 M. 2 Spec.

Stat. I 25. Sawan, Siau-island. Reef. 4 Spec.

Stat. I 27. Taruna-bay, Sangir-island. Reef. I Spec.

Stat. I 29. Kawio and Kamboling-islands, Karakalang-group. 23-3 I M. 9 Spec.

Stat. I42. Laiwui, coast of Obi Major. Reef. I Spec.

Stat. I 52. Wunoh-bay, N. W. coast of Waigeu-island. Reef. 9 Spec.

Stat. 193. Sanana-bay, East coast of Sula Besi. Reef. I Spec.

Stat. 225. Reef of Lucipara-island. I Spec.

Stat. 240. Banda. Reef. 5 Spec.

Stat. 296. Noimini, South coast of Timor. Reef. 4 Spec.

Stat. 299. Buka-bay, South coast of Rotti-island. Reef. I Spec.

Stat. 304. Lamakera. Reef. I Spec.

The specimens vary in the usual manner, being more or less dark, till nearly black, or with more or less conspicuous dark zones.

*4. Nerita (Theliostyla) chamaeleon Linné.

Linné. Syst. Nat. Ed. X, p. $779, \mathrm{~N}^{0} 644$.

RUMPH. Amb. Rariteitkamer, p. 77, tab. 22, fig. 6.

ReEve. Conch. Ic. Vol. IX, Nerita, fig. 60. (stella).

v. Martens. Martini-Chemn. Conch. Cab. Ed. II, p. 19, P1. 2, fig. I3-i6; P1. 5, fig. 5-I3.

"Java. 4 Spec.

var. squamulata Guillou.

Le Guillou. Revue Zool. 184 I, p. 344 .

REEve. Conch. Ic. Vol. IX, Nerita, fig. 63 .

v. Martens. Martini-Chemn. Conch. Cab. Ed. II, Nerita, p. I9, Pl. 5, fig. I4, I5.

Stat. 47. Bay of Bima, near South fort. Shore. I2 Spec.

Stat. 86. Dongala; Palos-bay, Celebes. Reef. 4 Spec.

Stat. I3 I. Beo, Karakelang-islands. I3 M. I Spec.

"Java. I Spec.

The specimens belong without doubt to the var. squamulata, by their shape and sculpture.

The basal spiral ribs are stronger and are arranged less close than in the type of the species.

*5. Nerita (Theliostyla) reticulata Karsten.

Karsten. Mus. Leskeanum, p. 296, P1. 2, fig. 8.

ReEve. Conch. Ic. Vol. IX, Nerita, fig. 44. (signata).

v. Martens. Martini-Chemn. Conch. Cab. Ed. II, Nerita, p. 22, Pl. 5, fig. $1-4$.

"Java. I Spec. 
6. Nerita (Theliostyla) patula Recluz.

RecluZ. Revue Zool. I84I, p. I48.

ReEve. Conch. Ic. Vol. IX, Nerita, fig. 84 .

v. Martens. Martini-Chemn. Conch. Cab. Ed. II, Nerita, p. 52, i I I, Pl. 7, fig. 8-I3.

Stat. 33. Bay of Pidjot, Lombok. 22 M. I Spec.

Stat. 47. Bay of Bima, near South fort. Shore. I Spec.

v. Martens (1.c. p. II 1 ) is in doubt if his patula is the same species as that of Recluz, as this author describes it, as having and epidermis and a smooth operculum, with a striated zone at the outer margin, like $N$. polita. I have often met with in collections, shells of Nerita with a false operculum, especially if bought from dealers. Both specimens of the Siboga collection, have the operculum as v. Martens describes it; that from Stat. 33 has the darkest shell.

As to an epidermis, the specimen of Stat. 33 is smoother than that of Stat. 47, and seems to have a very thin epidermis; the sculpture forms a passage to the var. Beaniana Recluz, the specimen from Stat. 47 , agreeing in shape better with the figures of v. Martens.

7. Nerita (Cymostyla) maxima Chemnitz.

Chemnitz. Conch. Cab. V, p. 287, Pl. I90, fig. 1942, 1943.

ReEve. Conch. Ic. Vol. IX, Nerita, fig. I8.

v. Martens. Martini-Chemn. Conch. Cab. Ed. II, Nerita, p. 29, Pl. 6, fig. I-5.

Stat. 279. Roma. Reef. I I Spec.

Stat. 296. Off Noimini, South coast of Timor. Reef. I Spec.

\#ava. 2 Spec.

"Amboina. 2 Spec.

8. Nerita (Cymostyla) semimugosa Recluz, var. subglobosa Martens.

RecLuz. Revue Zool. I84I, p. I02 (semirugosa).

ReEve. Conch. Ic. Vol. IX, Nerita, fig. I7 $a, b$ (maura).

v. Martens. Martini-Chemn. Conch. Cab. Ed. II, Nerita, p. 3I, Pl. 6, fig. 9; Pl. I, fig. 5, 6.

Stat. So. Borneo-bank. 50-40 M. I Spec.

By the higher spire, this specimen belongs to the variety subglobosa Mart., it agrees also in colour, very well with his fig: 9 .

9. Nerita (Cymostyla) undata Linné.

LinnÉ. Syst. Nat. Ed. X, p. $779, \mathrm{~N}^{0} 645$.

Runph. Amb. Rariteitkamer, p. 79, P1. 22, fig. 4.

ReEve. Conch. Ic. Vol. IX, Nerita, fig. 15 a (Le Guillounana).

v. Martens. Martini-Chemn. Conch. Cab. Ed. II, Nerita, p. 34, Pl. 6, fig. 10-16.

Stat. 19. Bay of Labuan Tring, West coast of Lombok. I $8-27$ M. 6 Spec.

Stat. 50. Bay of Badjo, West coast of Flores. Up to 40 M. 9 Spec.

Stat. 64. Kambaragi-bay, Tanah Djampeah. Reef. 5 Spec.

The specimens vary much in colour, from nearly white to very dark, both extremes live in the same localities. 
IO. Nerita (Cymostyla) Spengleriana Recluz.

Recluz. Proc. Zool. Soc. Lond. I843, p. 201.

ReEve. Conch. Ic. Vol. IX, Nerita, fig. 47 (oleagina).

v. Martens. Martini-Chemn. Conch. Cab. Ed. II, Nerita, p. 39, Pl. 7, fig. 6, 7 .

Stat. 16. Bay of Kankamaraän, South coast of Kangeang. 22 M. I Spec.

Stat. 5I. Madura-bay. Reef. I Spec.

Stat. 142. Laiwui, coast of Obi Major. Reef. I Spec.

Stat. 165. N. E. side of Daram-island. East coast of Misool. Reef. 2 Spec.

Stat. 296. Noimini, South coast of Timor. Reef. I Spec.

Stat. 299. Buka-bay, South coast of Rotti-island. Reef. I Spec.

Java. 2 Spec.

I I. Nerita (Cymostyla) striata Burrow.

Burrow. Elements of Conch. p. 172, Pl. 20, fig. 8.

REEvE. Conch. Ic. Vol. IX, Nerita, fig. IS (chrysostoma).

v. Martens. Martini-Chemn. Conch. Cab. Ed. II, Nerita, p. 37, Pl. 7 , fig. I-5.

Stat. 131. Beo, Karakelang-islands. I3 M. 7 Spec.

12. Nerita (Cymostyla) flammulata Recluz.

ReCluZ. Revue Zool. i 84 I, p. I8o.

v. Martens. Martini-Chemn. Conch. Cab. Ed. II, Nerita, p. 46, Pl. 7, fig. I3, I4.

Stat. 86. Dongala, Palos-bay, Celebes. Reef. 2 Spec.

Stat. 131. Beo, Karakelang-islands. I 3 M. I6 Spec.

The specimens are darker than that figured by v. Martens. Most of them show obviously the alternating larger and narrower concentric ribs.

3. Nerita (Pila) plicata Linné.

Linné. Syst. Nat. Ed. X, p. $779, \mathrm{~N}^{0} 642$.

RumpH. Amb. Rariteitkamer, p. 78, Spec. VI (Falvata sulcata alba).

REEvE. Conch. Ic. Vol. IX, Nerita, fig. 42.

v. Martens. Martini-Chemn. Conch Cab. Ed. II, Nerita, p. 63, Pl. 10, fig. 6-1o.

Stat. 16. Bay of Kankamaraän, South coast of Kangeang. 22 M. I Spec.

Stat. 33. Bay of Pidjot, Lombok. 22 M. I Spec.

Stat. 50. Bay of Badjo, West coast of Flores. Shore. I Spec.

Stat. 5 I. Madura-bay. Reef. 8 Spec.

Stat. 64. Kambaragi-bay, Tanah-Djampeah. Reef. 3 Spec.

Stat. 129. Kawio- and Kamboling-islands, Karkaralong-group. 23-3I M. I Spec.

Stat. I3 I. Beo; Karakelang-islands. 13 M. I Spec.

Stat. 165. North E. side of Daram-island, E. coast of Misool. Reef. I Spec.

Stat. 279. Roma. Reef. I Spec.

Stat. 296. Noimini, South coast of Timor. Reef. 2 Spec.

Stat. 301. Pepela-bay, East coast of Rotti-island. Reef. 2 Spec.

Java. 9 Spec.

Amboina. 2 Spec.

Only the specimen from Stat. I 3 I and one from Java, have regular black spots, arranged 
in three zones; some specimens from Madura-bay are marked with a few scattered spots, the other specimens are whitish in different shades.

14. Nerita (Ilynerita) planospira Anton.

Anton. Verzeichniss I839, p. 30.

Rusiph. Amb. Rariteitkanier, p. 78. Sp. 4, (gramulata 2d Sp.?)

REEvE. Conch. Ic. Vol. IX, Nerita, fig. 38. (atropurpurea).

v. Martens. Martini-Chemn. Conch. Cab. Ed. II, Nerita, p. 23, Pl. 4, fig. 4-7.

Stat. 19. Bay of Labuan-Tring, West coast of Lombok. I 8-27 M. I Spec.

Stat. 86. Dongala, Palos-bay, Celebes. Reef. I Spec.

The reference to RuMpH is somewhat doubtful, his description being rather too short and not sufficiently characteristic to recognize the species with certainty.

I 5. Nerita polita Linné.

LinNÉ. Syst. Nat. Ed. Xn, p. $778, N^{0} 638$.

RUMPH. Amb. Rariteitkamer, p. 77, Pl. XXII, fig. I, K.

REEve. Conch. Ic. Vol. IX, Nerita, fig. 2.

v. Martens. Martini-Chemn. Conch. Cab. Ed. II, Nerita, p. 72, Pl. 3, fig. 5, IO-I 5; Pl. I4, fig. I-7.

Stat. I9. Bay of Labuan-Tring, IV. coast of Lombok. I8-25 M. I Spec.

Stat. 225. Lucipara-island. Reef. 2 Spec.

Stat. 279. Roma. Reef. I Spec.

var. Rumphii Recluz.

Recluz. Revue Zool. 1841, p. I08.

Rumph. Amb. Rariteitkamer, p. 78 , Sp. 8 p.p., PI. 22, fig. 7 .

REEve. Conch. Ic. Vol. IX, Nerita, fig. 62a-k.

v. Martens. Martini-Chemn. Conch. Cab. Ed. II, Nerita, p. 74, Pl. I4, fig. 8-iz.

Stat. 19. Bay of Labuan-Tring, W. coast of Lombok. $18-27$ MI. 3 Spec.

Stat. 47. Bay of Bima, near South fort. Shore. 10 Spec.

Stat. 51. Madura-bay. Reef. 2 Spec.

Stat. 86. Dongala, Palos-bay, Celebes. Reef. 4 Spec.

Stat. 152. Wunoh-bay, N. W. coast of Waigeu-island. Reef. I Spec.

*Java. I Spec.

The shell figured on Pl. 22, fig. 7 , by Schinvoet, in Rumph's Amb. Rariteitkamer, seems to me to agree better with the variety than. with the type, with which v. Martens (Rumphius Gedenkboek) identifies it; this figure shows distinctly the spiral riblike striae, characteristic for the variety.

16. Nerita antiquata Recluz.

RECLUZ. Revue Zool. is4I, p. I06.

REeve. Conch. Ic. Vol. IX, Nerita, fig. 5.

v. Martens. Martini-Chemn. Conch. Cab. Ed. II, Nerita, p. 81, Pl. I4, fig. I9-2I.

Stat. 19. Bay of Labuan-Tring, W. coast of Lombok. I $8-27$ M. I Spec.

Stat. 47. Bay of Bima, near South fort. Shore. 4 Spec.

Stat. 50. Bay of Badjo, W. coast of Flores. Shore. 2 Spec. 
I 7. Nerita insculpta Recl. var. arata Hombron \& Jacquinot.

Hombron et Jacquinot. Voy. au pole du Sud. Moll. Pl. 16, fig. 12, 13. v. Martens. Martini-Chemn. Conch. Cab. Ed. II, Nerita, p. 88, Pl. I1, fig. 2, 3.

Stat. I65. North coast of Daram-island, East coast of Misool. Reef. I Spec.

The only specimen has on the posterior part of the last whorl only 20 ribs, as in the type, on the back.side, small intermediate threads make their appearance, and become soon thicker, so as nearly to equal the primary ribs; only the basal zone remains free from intermediate ribs; the total number at the outer margin amounts to 34 . The colour is darker than in the figures of v. Martens, resembling the var. pacifica Recl., but the columellar margin has only very slight indications of teeth.

I 8. Nerita (Amphinerita) incerta v. d. Busch.

v. D. Busch in: Philippi, Abb. u. Beschr. neuer oder wenig gek. Conch. I, p. 85, Nerita, Pl. I, fig. 6.

v. Martens. Martini-Chemn. Conch. Cab. Ed. II, Nerita, p. $8_{3}$, Pl. in, fig. 19-21.

Stat. I. Madura-strait. 37 M. I Spec.

Stat. 165. N. E. side of Daram-island, East coast of Misool. Reef. I6 Spec.

This species, which was known by v. Martens only from Java and Mindanao, seems to be widely distributed. I possess numerous shells from the Sangir-islands, and have seen in the Leyden Museum specimens from Larantuka, one from Timor, one from the Red Sea; the specimens vary in colour; that from Madura-strait is nearly typical, dark with a few white spots on the back; those from Stat. 165 are:

a. dark (black or grey) with small white spots; 5 Spec.

b. more or less dark with small white spots and 3 indistinct darker zones; 7 Spec.

c. dark grey, with numerous much larger white spots and dark zones; 2 Spec.

d. grey, mixed with white, dark zones very indistinct; 2 Spec.

19. Nerita (Melanerita) argus Recluz.

ReCluz. Revue Zoologique, I84I, p. 150.

ReEve. Conch. Ic. Vol. IX, Nerita, fig. 53.

v. Martens. Martini-Chemn. Conch. Cab. Ed. II. Nerita, p. 93, Pl. il, fig. I7, 18.

Stat. 33. Bay of Pidjot, Lombok. 22 M. I Spec.

The only specimen is separated from the next species, chiefly on account of the columellar teeth being much more conspicuous, and of the well developed granules and folds of the pillar lip; the shell is however nearly smooth.

20. Nerita (Melanerita) ocellata Guillou.

Le Guillou. Revue. Zool. I841, p. 344.

v. Martens. Martini-Chemn. Conch. Cab. Ed. II, Nerita, p. 95, Pl. i I, fig. 12-16.

Stat. I9. Bay of Labuan-Tring, W. coast of Lombok. I8-27 M. I Spec. 
Though in this specimen the ribs are more conspicuous, than in the preceding species, which ought to be the contrary, the characters of the aperture are those of ocellata viz. a nearly smooth pillar lip, with very small teeth on its margin. As v. Martens (1.c. p. 96) mentions also intermediate specimens, I should incline to the opinion that $N$. ocellata has only varietal rank.

\section{Neritina Lamarck.}

I. Neritina (Neritaea) auriculata Lamarck.

Lamarck. Encyclop. Méthodique. Vers. II, Pl. 455, fig. 6.

- - Animaux s. vert. Ed. Desh. Vol. VIII, p. 572.

v. Martens. Martini-Chemn. Conch. Cab. Ed. II, Neritina, p. 30, Pl. 6, fig. 13-15, 24-27. - Weber, Zool. Ergebn. Band IV. Süss- u. Brackw. Moll. p. 76.

Stat. 33. River near Pidjot, Lombok. 4 Spec.

Three of the specimens are very young and scarcely recognizable. As far as I know, this species has not yet been recorded from Lombok.

*2. Neritina (Neritaea) bicanaliculata Recluz.

Recluz. Journ. de Conch. Vol. I, 1850, p. I45.

ReEve. Conch. Ic. Vol. IX, Neritina, fig. 79.

v. Martens. Martini-Chemn. Conch. Cab. Ed. II, Neritina, p. 35, Pl. 9, fig. 3, 4.

"Java. 2 Spec.

This species was onIy recorded from the Philippines, the largest specimen is very characteristic.

3. Neritina (Neritaea) crepidularia Lamarck, var. exaltata Recluz.

RECLUZ. Journ. de Conch. Vol. I, IS50, p. 65, P1. 3, flg. 3 .

v. Martens. Martini-Chemn. Conch. Cab. Ed. II, Neritina, p. 44, Pl. 7, fig. I, 2.

Stat. 71. Near Makassar. I Spec.

4. Neritina (Neritaea) pulligera Linné.

LinNÉ. Syst. Nat. Ed. XII, p. 1253.

Runph. Amb. Rariteitkamer, p. 76 , P1. 22, fig. H.

v. Martens. Martini-Chemn. Conch. Cab. Ed. II, Neritina, p. 49, Pl. I, fig. 4, 5.

- Weber, Zool. Ergebn. Band IV. Süss- u. Brackw. Moll. p. 77.

Stat. 82. Batu Pangal, Mahakkam-river; Borneo. I Spec. .

Stat. I31. Beo, Karakelang-islands; shore. 19 Spec.

*var. sumatrana Dautzenberg.

Dautzenberg. Contribution à la Faune Mal. de Sumatra. Ann. Soc. Mal. Belg. Tom. XXXIV, p. 23 , Pl. I, fig. I2.

"Java. 13 Spec.

The specimens from Java, perfectly agree with those from Sumatra and with the description of Dautzenberg. If the locality "Java" be correct, it is a new addition to the fauna of that island. 
5. Neritina (Neritaea) variegata Lesson.

Lesson. Voy. de la Coquille, p. 378.

v. Martens. Martini-Chemn. Conch. Cab. Ed. II, Neritina, p. 98 , Pl. 10, fig. I I-I7.

- Weber, Zool. Ergebn. Band IV. Süss- u. Brackw. Moll. p. 78.

Stat. I 3 I. Beo, Karakelang-islands; shore. I Spec.

Stat. 180. North coast of Pulu Kelang; small river. I Spec.

*var. strigillata Lamarck.

Lamarck. An. s. vert. Ed. Desh. Vol. VIII, p. 574.

ReEve. Concl. Icon. Vol. IX, Neritina, fig. 3 I (turrita).

v. Martens. Martini-Chemn. Conch. Cab. Ed. II, Neritina, p. 105, Pl. 11, fig. $18,19$.

*Java. I4 Spec.

The specimen of Stat. I 3 I has no red spot on the pillar lip.

6. Neritina (Neritaea) turrita Chemnitz, var. Cumingiana Recluz.

ReCluz. Revise Zool. i 842 , p. 76.

V. Martens. Martini-Chemn. Conch. Cab. Ed. II, Neritina, p. 105, Pl. II, fig. 20, 2 I.

Stat. I 3 I. Beo, Karakelang-islands; shore. I Spec.

*7. Neritina (Neritaea) semiconica Lamarck.

Lamarck. An. s. vert. Ed. I, Vol. VI, p. 187.

Mousson. Land- u. Süssw. Moll. v. Java. p. So, Pl. I2, fig. II.

v. Martens. Martini-Chemn. Conch. Cab. Ed. II, Neritina, p. I05, Pl. 11, fig. 22, 23.

Java. 9 Spec.

The specimens are large, the largest, which is decollated, measures still 33 Mill., if not decollated, it would have reached 40 Mill. or more.

I have mentioned $N$. semiconica as a distinct species, because Troschel has found differences between the radulae of this form and $N$. turrita.

\section{Neritina (Neritaea) communis Quoy \& Gaimard.}

Quoy \& Gamard. Voy. de l'Astrolabe. Zool. Vol. III, p. I95, Pl. 65, fig. I2-I4.

v. Martens. Martini-Chemn. Conch. Cab. Ed. II, Neritina, p. II3, Pl. II, fig. I-9.

- Weber, Zool. Ergebn. Band IV. Süss- u. Brackw. Moll. p. 79.

Stat. I 3I. Beo, Karakelang-islands; shore. I Spec.

Stat. 200. Rivulet near Bara-bay, North coast of Buru-island. I Spec.

Both specimens are of a simple character, yellowish with waved black lines.

9. Neritina (Neritaca) sulculosa v. Martens.

v. Martens. Martini-Chemn. Conch. Cab. Ed. II, Neritina, p. 69, Pl. 8, fig. 23-26 (spirialis), p. 278 (sutculosa).

Stat. 204. Between islands of Wowoni and Buton. 75-94 M. sand with dead shells. 2 Spec. 
Both specimens are young and rather worn, this last perhaps on account of the marine locality, the dead shells probably having been washed from a brook, or river to the sea. They agree sufficiently with a specimen from Celebes in my possession. One of the specimens (the other being broken) and that from Celebes, have a very small tubercle near the base of the pillar-edge, though v. Martens says (1. c. p. 69) "ohne Leiste".

10. Neritina (Neritodryas) dubia Chemnitz.

Chemnitz. Conch. Cab. V, p. 324, PI. I24, fig. 2019, 2020.

v. Martens. Martini-Chemn. Conch. Cab. Ed. II, Neritina, p. I36, Pl. i2, fig. I-7.

Stat. I 3. Beo, Karakelang-islands; shore. 3 Spec.

Stat. 200. Rivulet near Bara-bay, North coast of Buru-island. I Spec.

11. Neritina (Neritodryas) subsulcata Sowerby.

Sowerby. Conch. Illustr. $\mathrm{N}^{0} 50$.

v. Martens. Martini-Chemn. Conch. Cab. Ed. II, Neritina, p. I42, Pl. I2, fig. II, I 2.

Stat. I 3 I. Beo, Karakelang-islands; shore. I Spec.

Stat. I 8o. North coast of Pulu-Kelang, small river. 2 Spec.

One of the specimens from Stat. 180 has a yellowish streak near the outer margin of the operculum, this is also the case in a specimen from Ternate.

12. Neritina (Clithon) brevispina Lamarck. Pl. VIII, fig. 4.

Lamarck. An. s. vert. Ed. I, Vol. VI, p. I 85.

Rumph. Ainb. Rariteitkamer, p. 7 S, Pl. 22, fig. O.

v. Martens. Martini-Chemn. Conch. Cab. Ed. II, Neritina, p. 156, Pl. 17, fig. I-4, 9.

-_- Weber, Zool. Ergebn. Band IV, Süss- u. Brackw. Moll. p. 79.

Stat. Nusa-laut, small river. I Spec.

Stat. 19. Bay of Labuan-Tring, West coast of Lombok, river. 5 Spec.

Stat. 33. Bay of Pidjot, Lombolk, river. 32 Spec.

The specimens belong to the variety mutica v. Martens, only a few ones from Stat. 33 have one or two very short spines, the colour of the specimens from this locality is very variable.

According to V. Martexs, (Mon. Neritina, p. 158) the radula of this species should be variable; Schacro should have found in spiniferous specimens from Amboina, the mushroomlike tooth with 24 very sharp denticles, and the uncini with 8 denticles, whereas those from Timor should have those teeth with smooth margins. I have examined the radulae of two specimens from Stat. 33, which agree in nearly every point; the rhachidian tooth has a larger, nearly square cusp, the first laterals are oblong, with a cusplike margin, the two small laterals are covered by the mushroomlike tooth (P1. V111, fig. 4), its margin is provided with about 30 small denticles, the uncini have about 10 small teeth on the outer margin.

* 13. Neritina (Clithon) diadema Recluz.

ReCLUZ. Revue Zool. i841, p. 277.

v. Martens. Martini-Chemn. Conch. Cab. Ed. II, Neritina, p. I54, P1. I5, fig. 22-26.

Java. 2 Spec. 


\section{Neritiza (Clithon) subocellata Schepman.}

SchepMan. Notes from the Leyden Museum. Vol. VII, p. 49, Pl. 4, fig. $3,3 a, 3 b$.

- Nachrichtsbl. der deutschen Mal. Gesellsch. I903, p. 20.

Stat. 33. River near bay of Pidjot, Lombok. 4 Spec.

The specimens from Lombok, are less smooth than those from Java and Celebes, but agree in every other respect, with those at my disposal. I find no spines, but this may be due in part, to the corrosion of 3 of the specimens. Those from Celebes, mentioned by GredLer, (Nachrichtsbl. I902, p. 62) do not belong to this species, but to N. subpunctata Recl., and one, I think, to $N$. brevispina Lam., as I have observed by ocular inspection, by the kindness of GrEDLER. The largest specimen from Lombok, is slightly larger than the described types, being about 15 Mill. in height and in diameter, instead of 13 and 14 . Lombok is a new locality.

I 5. Neritina (Clithon) squarrosa Recluz.

Recluz. Proc. Zool. Soc. Lond. 1842, p. 174 .

v. Martens. Martini-Chemn. Conch. Cab. Ed. II, Neritina, p. 162, Pl. 16, fig. 13-18.

- Weber, Zool. Ergebn. Band IV, Süss- u. Brackw. Moll. p. So.

Stat. 33. River near bay of Pidjot, Lombok. 3 Spec.

The specimens are small, probably young, without spines, one with indistinct bands. Not yet recorded from Lombok.

16. Neritina (Clithon) subpunctata Recluz.

RecLuz. Proc. Zool. Soc. Lond. I843, p. I99.

v. Martens. Martini-Chemn. Conch. Cab. Ed. II, Neritina, p. 179, Pl. I8, fig. 19, 20, 22-24.

Stat. 33. River near bay of Pidjot, Lombok. 2 Spec.

Stat. 234. Nusa laut, hot river. I Spec.

var. glandiformis v. Martens.

v. Martens. 1. c. p. i8o, Pl. 19, fig. 3, 4 .

Stat. 33. River near bay of Pidjot, Lombok. I8 Spec.

The specimens of var. glandiformis v. Mart. agree with those named by v. Martens from Adonara, but they are smaller. From both localities the colour-markings are much less conspicuous than in the type, not only by incrustation, but even in perfectly clean specimens, seen by transparent light. A few of the specimens from Lombok (a new locality) have traces of spines, like those from Adonara, recorded by v. Martens (1.c. p. I8I).

17. Neritina (Clithon) olivacea Recluz.

ReCLUZ. Proc. Zool. Soc. Lond. I 842 , p. I 72.

v. Martens. Martini-Chemn. Conch. Cab. Ed. II, Neritina, p. 183, Pl. 19, fig. 5-7.

Stat. ISo. River N. coast of Pulu Kelang. 2 Spec.

Stat. 234. Nusa laut, hot river. 4 Spec. 
The specimens from Nusa laut are small, though probably adult, measuring only from 13 to 8 Mill. in their largest diameter. The largest specimen from Pulu Kelang, is 24 Mill. in this dimension.

18. Neritina (Clithon) flavovirens Busch.

v. D. Busch. Phil. Abb. u. Beschr. neuer Conch. I, Neritina, Pl. I, fig. 6.

v. Martens. Martini-Chemn. Conch. Cab. E.d. II, Neritina, p. I84, Pl. 19, fig. I, 2, 12.

- Weber, Zool. Ergebn. Band IV, Süss- u. Brackw. Moll. p. 8I, Pl. IO, fig. i 2, 15, 16.

Stat. 33. River near bay of Pidjot, Lombok. I Spec.

Stat. 179. Kawa-bay, West coast of Ceram, river. I Spec.

The only specimen from Lombok has a few spines, which are not mentioned by v. D. Busci, but v. Martens has known this form, without mentioning the locality, and mentions such specimens from Celebes, collected by WEBER, mixed with a spineless specimen. I possess Io specimens from several localities on Java, namely 4 from Besuki, one of which spined; 4 from Palabuan, all spined, and 2 spineless from the Pamenug-river. Lombok is a new locality for the species.

19. Neritina (Clithon) ualanensis Lesson.

Lesson. Duperey, Voy. Coquille. Zoologie II, p. 379.

v. Martens. Martini-Chemn. Conch. Cab. Ed. II, Neritina, p. 193, Pl. 20, fig. I-24.

-_ Weber, Zool. Ergebn. Band IV, Süss- u. Brackw. Moll. p. 82.

Stat. 71. Near Makassar. 5 Spec.

Stat. 125. Sawan, Siau-island. Reef. I Spec.

The specimens from Stat. 7 I belong to the vars. conferta $v$. Martens and polydelta v. Martens, with an intermediate specimen, that from Stat. 125 , belonging to var. polydelta contains a small crustacean, belonging to the Paguridae, which accounts for its being captured on the reef.

Fam. Neritilidae Schepman. Pl. VIII, fig. 5 .

The examination of the radula of the typical species of the subgenus Neritilia v. Martens, has convinced me, that it not only belongs to a separate genus, but even to a new family, which I have placed provisionally at the end of Neritina, though I think it is not its proper place. The species has no rhachidian tooth, as far as I can see; though I have examined the uncoloured and coloured radula I could not detect it; the first lateral $(5, I)$ are very thin and transparent, and only by colouring I could make out the complicated shape; it has some affinity with the corresponding tooth in the Neritidae, but its position is much more in a perpendicular direction, the margin seems to be reflected; at its proximal side, there is a projection or knob, also with a reflected margin, apparently ending in a hook; by the smallness and thinness, it is not easy to be satisfied on every particular, moreover a slight alteration in position, essentially 
alters the appearance; at the distal end, I can detect only one of the small teeth, of which 2 are usually found in Neritidae and Neritopsidae. The tooth corresponding to the mushroomlike teeth of the last named families, $(5,2)$ has an erect position, quite different from the horizontal position in Neritidae, its basal part is triangular, with the shortest margin below, the reflected margin is provicled with about ${ }_{5}$ small denticles; the uncini $(5, U)$ are very numerous, each with about 8 denticles; the arrangement of the teeth on the radula, resembles that of Hydrocena. This radula agrees with that of Neritopsis, by its wanting the rhachidian tooth, but otherwise it is quite different; from the Neritidae it differs by the same character and by the shape and number of teeth. Its place may be near some genus of operculate landshells. How far the other species, located by v. Martens in Nerititia, agree in structure of the radula, must be made out by further researches, especially of those species, without an appendix at the operculum. I think, Neritilia has as much or even more right to stand as a separate family than Neritopsis. As the family characters are the same as those of the subgenus as defined by v. Martens, I have not repeated them.

\section{Neritilia v. Martens.}

\section{Neritilia rubida Pease.}

PEase. Proc. Zool. Soc. Lond. i 865 , p. 5 I 4.

- American Journ. of Conch. III, p. 285, Pl. 24, fig. 5.

v. Martens. Martini-Chemn. Conch. Cab. Ed. II, Neritina, p. 244, l'l. 23, fig. 19, 20.

Stat. I I5. Kwandang, North Celebes, river. I I Spec.

Stat. 142. Obi Major, river. 8 Spec.

This species is the second Neritilia from Celebes, the first from Obi. It was only known from the Pacific, where it lives on several Polynesian isles. I at first thought, it might be a new species, as I found the spire rather blunt, the pillar lip not quite flat, and observed moreover a small sharp angle at the basal part of the aperture, near the junction of the outer and basal margins; this seems to be a character of the group, not yet observed by authors, I find the same angle in $N$. succinea Recl. from Guadeloupe and in $N$. Manoeli Dohrn from West Africa. Opposed to the assertion of v. Martens, I see also a very small list, behind the lower muscle-scar, inside the aperture, but I find the same in the specimen of $N$. rubida Pse, received from v. MARTENs. So it seems to have escaped his attention. I have convinced myself, by means of the point of a needle, that it is truly a convexity and no optical illusion, as is sometimes the case, for instance in some Trochidae.

\section{Septaria Férussac.}

I. Septaria suborbicularis Sowerby.

Sowerby. Cat. of Shells Earl of Tankerv. Appendix p. IO, $\mathrm{N}^{0}$ Iog2.

Rumpri. Amb. Rariteitkamer, p. 123, Pl. 40, fig. O.

v. Martens. Martini-Chemn. Conch. Cab. Ed. II, Navicella, p. 3r, Pl. 6, fig. 5-I4.

- Weber, Zool. Ergebn. Band IV, Süss- u. Brackw. Moll. p. 84 .

Stat. 33. Bay of Pidjot, Lombok. River. 7 Spec.

Stat. 50. River near Labuan Badjo. I Spec.

Stat. 180. North coast of Pulu Kelang. River. 8 Spec. 
2. Septaria tessellata Lamarck, var. lincata Lamarck.

Lamarck. Encycl. Meth. Pl. 456, fig. 2 (lineata).

- An. s. vert. Ed. Desh. VIII, p. 564 (lincata).

v. Martens. Martini-Chemn. Conch. Cab. Ed. II, Navicella, p. 38, Pl. 8, fig. 7-9.

Stat. 33. Bay of Pidjot, Lombok; river. I Spec.

The only specimen, which is not adult, is not quite as narrow as the figure of v. MARTENs, but much more so, as his figs I and 3 of the same plate, which v. Martens names var. compressa with the subvar. lineata.

\section{Fam. Phenacolepidae.}

\section{Phenacolepas Pilsbry.}

I. Phenacolepas galathea Lamarck.

Lanarck. An. s. vert. Ed. Desh. Vol. 7, p. 539 (Patella).

Delessert. Recueil de Coq. Pl. 23, fig. 10.

Chenu. Manuel de Conch., fig. 2815.

Stat. 115. East side of Pajunga-Island, Kwandang-bay. Reef. I Spec.

The only specimen has a length of I 2 Mill. but has no juvenile appearance, though it is considerably smaller than LAMARCK's specimens, which are described as having a lenght of 7 to 8 lines, the shell is rather strong and thick.

Pilsbry has named the genus Phenacolepas (The Nautilus, Vol. V, I89I, p. 88) the name Scutellina being twice preoccupied. Since he has given (The Nautilus, Vol. XIV, I900, p. 6I) a list of the species, "more complete than that in the Manual of Conchology". In this list Ph. galathea is mentioned, but not in the Monograph. Scutellina asperulata A. Adams and costata A. Adams, according to E. A. Smith, should be synonyms. ADAms however has only mentioned them in his "Genera of Shells" p. 46I, but they have not been described. The shell resembles much "Patella pectinata" Born, but may be distinguished at once, by the position of the muscle-scar.

\section{Phenacolepas radiata n. sp. Pl. I, fig. I.}

Stat. 282. Between Nusa Besi and the N.E. point of Timor. Reef. I Spec.

Shell small, depressed, oval, inaequilateral, yellowish, with scarcely elevated, distant, brown, radiating ribs, crossed by faint, irregular, concentric striae, more conspicuous at large intervals. Apex posterior, placed at nearly ${ }^{11} / 12$ of the length, obtuse, compressed, directed to the left, brown (perhaps by erosion). Front and side slopes convex, posterior slope concave. The shell is covered by a yellowish epidermis. Interior brown, yellow in front and towards the margin, with brown radii. Muscle-scar open in front.

Long. 3, lat. $2^{1} / 4$, alt. I Mill. 
It is not without some hesitation, that I have described this species as a Phenacolepas; it is much smoother than most of the described species, and has a conspicuous epidermis. I know no species with which to compare it. As the soft parts wanted, I was not able to get sufficient certainty.

\section{Pseudococculina n. g.}

Shell patelliform, white, with a posterior, inclined apex and a compressed, subspiral nucleus. Inside porcellaneous, muscle-scar horseshoe-shaped, interrupted over the head. Animal with a plumate gill, at the right side of the head; the right tentacle thickened; two epipodial filaments at the posterior part of the foot.

Radula with large rhachidian teeth, cusp wanting or very obsolete, first laterals triangular, followed by 3 smaller, contorted laterals, with distinct cusps, a large cusped fifth lateral, and numerous uncini.

The radulae of the species described hereafter, seem to be different from those of similar mollusks, however I think it is nearest allied to Phenacolepas, by the shape of the first lateral; in other respects it differs sufficiently, to make it necessary to establish a new genus. The shells resemble very much those of Cocculina, the only difference, if it prooves to be constant, is that no regular radial sculpture is to be found, as is the case in all the species of Cocculina $I$ have examined. In the species described as Ps. rugosoplicata, it is present in some degree, but of a different character, consisting of coarse short striae, quite overwhelmed by the concentric sculpture.

I. Pseudococculina mugosoplicata n. sp. Pl. I, fig. 2; Pl. VIII, fig. 6.

Stat. $221.6^{\circ} 24^{\prime}$ S., $124^{\circ} 39^{\prime}$ E. $279^{8}$ M. 4 Spec.

Shell small, white, elevated, oval, thin, the margin rests entirely on a plane surface; front slope the largest, convex, side slopes irregularly convex, being slightly compressed at some distance from the apex, posterior slope slightly concave, apex blunt, placed at about $2 / 3$ of the total length; the nucleus wanting, by a strong erosion of the apex. Sculpture consisting of irregular concentric rugosities or wrinkles, generally more distant from each other towards the apex, more crowded towards the margin, with a tendency to form lamellae; on some parts the upper side of the rugosities has coarse, short, riblike radiant striae, wanting in other places, perhaps by erosion. Inside smooth.

Long. 6, lat. $4^{1} / 2$, alt. $2^{3} / 4$ Mill.

The characters of the shell, as well as the external characters of the animal, agreed sufficiently with those of the genus Cocculina, but the radula is quite different.

The rhachidian tooth $(\mathrm{R})$ is elongate with convex sides, it has no reflected cusp, the upper margin being only irregularly waved, near the base an oval spot seems to be thickened, the first lateral tooth (I) is triangular, also without distinct cusp, but with a reflected or thickened upper margin, followed by three laterals $(2,3,4)$, which are little different from each other, with a winged body, having the appearance of being turned outwards, the cusp standing at the distal side; their cusps are simple, the next lateral (5) has a quadrate body with a thickened stalk 
at its median line, and a cusp consisting of a sharp tooth at the proximal side, and a wing-like part on the distal side, with a slightly denticulate margin. Of the numerous uncini (U), the proximal ones, which are the largest, have simple cusps, while those placed more outwards have small denticles.

This species may be at once distinguished from the next one, by its very characteristic sculpture, it is a much higher shell; the radulae though being very similar in general construction, are sufficiently distinct.

2. Pseudococculina granulata n. sp. Pl. I, fig. 3 ; Pl. VIII, fig. 7 .

Stat. $88.0^{\circ} 34^{\prime} .6$ N., I $19^{\circ} 8^{\prime} .5$ E. I zor M., grey and yellow mud. I Spec.

Shell small, white, depressed, oval, very thin, broader towards the front, the ends slightly raised, front and side-slopes slightly convex, posterior slope nearly straight, with a very small impression below the nucleus, this latter smooth, compressed, subspiral, placed at a little more than $6 / 1$ of the total length of the shell. Sculpture consisting of a few concentric striae, moreover the whole surface is covered by very small, crowded granules of an irregular oval, potatolike shape, sometimes two or three granules are confluent, they are placed in oblique rows. Inside smooth. Long. $5^{1} / 2$, lat. $3^{1} / 2$, alt. I Mill.

The shell of this species, in every respect, save sculpture, calls in mind the species of Cocculina. As the animal was not in a sufficient state of preservation, I could not observe the external characters, but a look at the radula, shows at once that this species is congeneric with the preceding one, and quite different from Cocculina. The rhachidian tooth $(R)$ has an oblong shape, with convex sides towards the middle, concave towards the top, with slightly reflected margin, the upper margin without cusp, but irregularly convex; about the centre of this tooth, an irregular spot seems to be thickened and slightly coloured (one could think, this is the cusp, were it not that in the allied species, a similar spot stands quite near the base) the first lateral (I) has a subtriangular shape, with a thickened or reflected upper margin, followed by three laterals, $(2,3)$ of a shape similar to those of the preceding species, with a simple cusp, the outermost lateral (5), is so much concealed by the large uncini, that its shape could not be traced, it seems to have a simple cusp, without the sharp denticle of the preceding species. The proximal uncini $(\mathrm{U})$ are strongly hooked and simple, the median ones seem to be serrated and the exterior one again simple.

Fam. Cocculinidae Dall.

\section{Cocculina Dall.}

I. Cocculina subquadrata n. sp. Pl. I, fig. 4 ; Pl. VIII, fig. 8 .

Stat. $173.3^{\circ} 27^{\prime} .0$ S., $131^{\circ} 0^{\prime} .5$ E. 567 M., fine yellow grey mud. 3 Spec.

Shell large, white, patelliform, oblong, depressed, sides subparallel, the shell being slightly broader behind, the ends are broadly rounded and slightly elevated, the anterior slope, which 
is a trifle longer than the posterior one, is nearly straight, only a little convex towards the subcentral apex in the largest specimen, more convex in the smaller ones, posterior slope slightly concave, more so just behind the apex, side-slopes nearly straight, except for a more or less pronounced compression, at some distance from the apex. Nucleus compressed, subspiral, smooth. The surface of the shell is covered by regular, very fine, concentric growth-striae and irregular grooves, crossed by faint radiating striae, more conspicuous on the rare spots, where a yellowish epidermis still adheres. Interior of shell porcellaneous.

Long. 17 , lat. $11^{1} / 2$, alt. 5 Mill.

In the smaller specimens the posterior slope seems to be shorter, apparently on account of the margin being not intact.

The species resembles in many respects C. Rathbuni Dall (Proc. U. S. Nat. Mus. I 881 , p. 402) figured in the "Blake Gastropoda", Pl. 25, figs. 7, $7 a$, but the new species is less depressed and more elongate. C. laevis Thiele (in v. Martens, die beschalten Gastrop. der deutschen TiefseeExp. I $898-99$, p. 127 , Pl. 5, fig. I I, I 2) is the nearest ally from the Indian Ocean, but is not as broad, and has more regularly curved sides, being probably much less radiately striated.

The radula has much resemblance with that of $C$. laevis Thiele, the shape of the rhachidian tooth $(R)$ is really the same, but the upper and side margins are thickened and may be considered as a cusp, the first lateral ( $\mathrm{I}$ ) is much more elongate, not subtriangular, its cusp and that of the second lateral (2) has three denticles, the cusp of the third lateral (3) is simple, the fourth (4) seems to be narrower towards the lower part of the body. The uncini (U) have cusps with a few denticles. The foot has the two epipodial filaments, which characterize the Section Cocculina s. str. of DaLL.

2. Cocculina oblonga n. sp. P1. I, fig. 5 ; Pl. VIII, fig. 9.

Stat. $126.3^{\circ} 27^{\prime} .1$ N., $125^{\circ} 18^{\prime} .7$ E. 2053 M., hard sand. 2 Spec.

Shell white under a rather thick epidermis, patelliform, oblong, not much depressed, with a rather acute apex, with curved sides, passing imperceptibly in the regularly rounded ends, which are slightly elevated; anterior slope slightly longer than the posterior one, slightly concave, especially in the lower part, posterior- and side-slopes concave. Apex subcentral, but placed on the posterior half. Nucleus pointed, directed backwards, not spiral, smooth.

The shell is covered by a very conspicuous, yellowish-brown, fibrous epidermis, which gives to the shell the appearance of being strongly radiately ribbed. Under this epidermis, the shell has numerous concentric and radiating striae, much less conspicuous than those of the epidermis, producing a somewhat cancellated sculpture; interior of shell white.

Long. 9, lat. $5^{1} /$, alt. 3 Mill.

The nearest ally seems to be $C$. radiata Thiele, of which species I could compare a typical specimen, by the kindness of Dr. Mörius; this had only a few patches of epidermis, which are however much thinner, yellowish and less fibrous. In $C$. radiata the front slope is convex, the posterior and side-slopes are also very slightly convex, the front slope is the shortest. The new species is stronger radiately striated, especially on those parts, provided with 
the epidermis, but also when this has been removed. The apex in the new species is sharper and more elevated than in radiata.

The animal has two epipodial filaments near the posterior part of the foot. The radula differs in many respects from that of $C$. radiata. The rhachidian tooth $(R)$ is nearly quadrate, with convex sides and front margin, and sharp corners, the front and side margins are thickened, the first has a very small simple cusp. The first lateral (1) has an oblong body and probably: in a normal position 2 or 3 denticles, the second lateral (2) is still more elongated, with 2 or 3 denticles, the third (3) has a simple cusp; the fourth (4) much larger lateral, has a very large cusp, with a smaller denticle below it. The uncini are hooked, with simple cusps. The number of denticles in the laterals is rather inconstant, on the right side the first one has 2 or 3 denticles, but on the left side only one; in the second the number varies from 2 to 3 on the right side, on the left I constantly see 3 denticles. The most conspicuous differences from $C$. radiata are: the quadrate rhachidian tooth, which in radiata according to THiele (Die beschalten Gastrop. der deutschen Tiefsee-Exp. p. I52, Pl. 6, fig. I 3 ) is much longer in proportion to its breadth, and in its simple cusp, which in radiata has small denticles, (Thuele, 1. c. p. I53).

\section{Cocculina cingulata n. sp. Pl. I, fig. 6.}

Stat. 137. Channel between Makjan and Halmaheira. 472 M., fine, dark muddy sand. 1 Spec.

Shell small, yellowish, patelliform, rather depressed, oval, with moderately curved subparallel sides and bluntly rounded ends. Front slope the largest, convex, posterior slope nearly straight, especially under the apex, but slightly convex towards the margin, side slopes slightly convex. Sculpture consisting of (for the small shell) conspicuous, regular, concentric lirae, separated by much broader intervals, which are crossed by much weaker radiant striae. The nucleus, which is placed at about $2 / 3$ of the length of the shell, is slightly compressed, directed backwards, and is spiral on the right side. Inside porcellaneous.

Long. $2^{5} / 6$, lat. $2^{1} \%$, alt. I Mill.

The animal seems to have two short but broad epipodial appendages on each side of the posterior end of the foot, but on account of the smallness of the much shrunken animal, they are very inconspicuous.

This species seems to be allied to C. leptalea Verrill, (Trans. Connecticut Acad. VI, p. 202, Pl. 32, fig. 20, 20a, 20b) according to the description and figures copied by Pilsbry (Man. of Conch. Vol. XII, p. 133, Pl. 2, fig. 7,8 ) but the nucleus is more central in the new species, the outline of the base is broader in proportion to its length, it is more depressed than leptalea. The sculpture seems to be similar, however the radial striae are less conspicuous, the concentric lirae are less crowded near the apex.

\section{Cocculina orata n. sp. Pl. I, fig. 7 ; Pl. VIII, fig. Io.}

Stat. 312. Saleh-bay, North coast of Sumbawa. 274 M., fine, sandy mud. 3 Spec.

Shell small, patelliform, oval, with subparallel sides, moderately depressed, white under a thin, yellowish, fibrous epidermis, ends broadly rounded and elevated, the anterior slope, which 
is conspicuously longer than the posterior one, is slightly convex, but nearly straight towards the apex, posterior slope a little concave near the apex and towards the margin, convex in the middle part, side-slopes straight, only a little concave near the margin, with a very small concavity near the apex. Nucleus compressed, subspiral, smooth under a lens, but with very small pits under the microscope; it is placed at about $6 / 11$ of the total length.

Sculpture consisting of rather strong, elevated, concentric striae, less strong but more numerous than in the preceding species, crossed by weaker, but still very conspicuous radiating striae, giving to the shell a somewhat cancellated appearance. Inside of the shell smooth.

Long. $5^{1} / 2$, lat. $4^{3} / 4$, alt. 2 Mill.

The foot of the animal with 2 epipodial filaments.

This species is closely allied to C. alveolata Schepm. but differs by its much more elevated apex and weaker sculpture; from $C$. leptalea Verrill and C. cingulata Schepm. it differs by its weaker concentric striae, and the nucleus is placed much more near the centre.

The radula has a rhachidian tooth $(\mathrm{R})$ of an oblong shape, broader near the front than at the posterior margin, with curved sides, the front margin is convex and like the side margins thickened, this thickening forms in the centre a point directed towards the base; this tooth has a small simple cusp. The elongated first (I) and second (2) laterals, have tricuspid cusps, the third (3) has only a simple cusp. The cusp of the fourth lateral (4) is large, divided into two denticles, the lower or distal one is the smallest. The uncini (U) have rather short, thick cusps, with indistinct denticles.

5. Cocculina alveolata n. sp. Pl. I, fig. 8; Pl. VIII, fig. II.

Stat. 312. Saleh-bay, North coast of Sumbawa. 274 M., fine, sandy mud. 3 Spec.

Shell small, patelliform, oval, depressed, pellucid, white, with small patches of a thin, yellowish epidermis; ends broadly rounded and elevated; anterior, posterior and side-slopes convex, with only a slight depression behind the depressed apex. Nucleus very much depressed, compressed, scarcely spirally striated under a lens, but under the microscope the nucleus is covered by rows of conspicuous alveoli (much more conspicuous than in the preceding species). It is placed at about $5 / 9$ of the length of the shell, the front slope being the largest.

The sculpture consists of conspicuously elevated concentric striae, of which a few are stronger than the rest, they are crossed by radial striae, which are but slightly weaker, a little waved and make the concentric striae slightly beaded, especially the stronger ones. The shell is still more cancellated than in the preceding species. Inside shining.

Long. $4^{1 / 2}$, lat. $3^{1 / 4}$, alt. $1^{1} / 2$ Mill.

Foot of the animal with epipodial filaments.

This species, as already mentioned, differs from the preceding one, by its depressed apex and stronger sculpture, moreover by the convex slopes and the nuch larger pits or alveoli of the nucleus, this character being not visible in C. ovata with the same lens as in the present species.

I examined the radula of one of the specimens. This agreed in every respect with those of the other species of Cocculina, examined by THIELE and by me, but the median tooth wanted; 
as however the shell-characters and the animal agree very well with the other species, I think the radula will be only abnormal. The first and second laterals $(1,2)$ have three denticles at their cusps, that of the third (3) is simple and the fourth (4) has the same characters as in the preceding species, being however broader, the uncini have small denticles. The peculiar sculpture of the shell, seemed at first to be favourable to generic separation, but it is connected to those species with smooth nucleus, by the preceding species.

\section{Coccutina subcompressa 11. sp. Pl. 1, fig. 9; Pl. VIII, fig. 12.}

Stat. 302. $10^{\circ} 27^{\prime} .9$ S., $123^{\circ} 28^{\prime} .7$ E. 216 M., sand and coral sand. 2 Spec.

Shell rather small, white, patelliform, oblong, compressed, moderately elevated, the ends broadly rounded and conspicuously elevated, sides subparallel, being slightly broader in front. The anterior slope, which is a trifle longer than the posterior one, is slightly convex, the posterior has a small depression near the apex, and is from thence nearly straight, the side slopes are decidedly convex. The apex is subcentral, with a subspiral, compressed nucleus, which is smooth even under the lens. The shell is covered by a rather thin, yellowish, fibrous epidermis, which is conspicuously wave-striated. Sculpture of the shell consisting of elevated radial striae, which are crossed, at irregular intervals, by concentric striae, these latter are more crowded near the apex. Inside of shell smooth, white.

\section{Long. $67 / 8$, lat. $4^{3} / 4$, alt. $21 \%$ Mill.}

This species might be mistaken for the young of C. subquadrata Schepm., but its shape is more regular, it is much less depressed, the epidermis is much coarser, the sculpture more conspicuous.

The foot of the animal has 2 epipodial filaments.

The rhachidian tooth ( $R$ ) of the radula is much elongated, with subparallel sides, however the body is broader towards the anterior margin. It has a small, simple cusp, the anterior and side margins are thickened. The other teeth have the usual shape, the first (I) and second (2) laterals have a cusp with three small denticles, the cusp of the third lateral (3) is simple. That of the fourth (4), if seen in situ, has the usual large cusp, with a small secondary one. If turned outwards it has on the other side of the chief cusp, still two smaller ones. I think however this will be the case in many of the described species, as I have often observed it more or less distinctly. The uncini $(\mathrm{U})$ have a few small denticles, better visible in reversed teeth.

\section{Cocculina striata n. sp. Pl. I, fig. ro; Pl. IX, fig. I.}

Stat. $173.3^{\circ} 27^{\prime} .0$ S., $131^{\circ} 0^{\prime} .5$ E. 567 M., fine, yellow grey mud. 2 Spec.

Shell rather small, patelliform, oblong, depressed, pellucid, white, ends regularly rounded, slightly elevated, sides convex. The anterior slope considerably longer than the posterior one, both a little convex, with a small depression behind the nucleus, side slopes more convex. Apex depressed, with a compressed, subspiral, smooth nucleus, placed at ${ }^{13} / 20$ of the length of the shell. The surface of the shell, covered by a rather thick, yellowish-brown, fibrous epidermis, having 
the appearance of being, wave-striated by elevated radial striae. The sculpture of the shell, on spots where the epidermis has been lost, consists of elevated radial striae, a few concentric striae are not very conspicuous. Inside of shell white, smooth, with a few impressed striae, especially near the margin of the front slope.

Long. 5, lat. 3, alt. $\mathrm{I}^{1} / 4$ Mill.

This species resembles by its shape and epidermis, my $C$. oblonga, but is distinguished by its sharper striae and the position of the nucleus, which in striata is placed much more posteriorly. Both specimens are broken, I have described the best one, which gives a perfect idea of the species, as only one side of the posterior slope is slightly defective. The epidermis of the other specimen, is less fibrous, the striae are more crowded, this however may be individual.

The foot has two epipodial filaments.

The radula has a rhachidian tooth $(R)$ with a subquadrate body, with an elongate front margin, the sides are slightly convex, the front angles rounded, the tooth has a simple cusp, larger than in any of the preceding species; the front and side margins are thickened; the first (1) and second (2) laterals have tricuspid, the third (3) a simple cusp; the fourth (4) has the usual shape, but is more elongate, than in most species. The uncini $(U)$ have very inconspicuous denticles.

From the descriptions of the shells and radulae of the new species of Cocculina, it is clear that species nearly allied in their shells, still differ in their radulae, especially the rhachidian tooth is characteristic, for though the first and second laterals, have nearly always three denticles, they prooved to be inconstant. The third lateral has invariably a simple cusp and a body, the shape of which is not easily traced with sufficient accuracy, on account of its being always more or less covered by the fourth lateral, which is also less characteristic, and varies very much in appearance, if it is turned a trifle towards the right or left. The value of the rhachidian tooth for distinguishing the species, is shown at once, by comparing this tooth in the present species (striata) with that of $C$. oblonga, the shells differing only in the position of the nucleus and slight secondary characters.

The epipodial filaments were not always very conspicuous, however I have found traces of them in every species.

Fam. Turbinidae.

Phasianella Lamarck.

I. Phasianella histrio Reeve.

ReEve. Conch. Ic. Vol. XIII, Phasianella. fig. 15.

Stat. 240. Banda. 9-45 M., black sand. 2 Spec.

Banda is a new locality for this species, which Reeve has mentioned only from the Philippines. I have seen also subfossil specimens from Celebes. 


\section{Turbo Linné.}

I. Turbo petholatus Linné.

LinnÉ. Syst. Nat. Ed. X, p. $762, N^{0} 533$.

Rumph. Amb. Rariteitkamer, p. 71, Pl. 19, fig. D.

REEvE. Conch. Ic. Vol. IV, Turbo, fig. I2.

Kiener. Coq. Viv. Turbo, p. 50, Pl. 24, fig. I.

Tryon. Man. of Conch. Vol. X, Turbo, p. 193, Pl. 40, fig. 14.

Stat. 53. Bay of Nangamessi, Sumba. Up to 36 M., coral sand. I Spec.

Stat. 240. Banda. 9-45 M., black sand. 2 Spec.

The "Siboga"-specimens are very young and display two characters, which often want in museum-specimens, and as far as I know, are not recorded by authors, namely: $1^{0}$ that the whole shell is covered by microscopic striae, running nearly spirally, but in an oblique direction from behind and above towards the aperture, $2^{0}$ that the embryonic whorls are quite different from the rest of the shell, showing at the suture short projections which render it angular, as if the embryonic shell should have been spined, moreover these whorls are plicated, and have near the middle of their upper surface, a kind of keel, which is elegantly beaded, the uppermost whorl is slightly immersed.

2. Turbo (Senectus) sparverius Gmelin.

Gmelin. Syst. Nat. Ed. XIII, p. 3594 .

Reeve. Conch. Ic. Vol. IV, Turbo, fig. 30 .

Kiener. Coq. Viv. Turbo, p. 49, Pl. 2 I, fig. I (margaritaceus).

Tryon. Man. of Conch. Vol. X, p. 194, P1. 47, fig. 26.

Stat. 8 I. Pulu Sebangkatan, Borneo-bank. 34 M., coral bottom and Lithothamnion. r Spec.

Stat. 90. $I^{\circ} 17^{\prime} .5$ N., I I $8^{\circ} 53^{\prime}$ E. 281 M., coral, sand and stones. I Spec.

Stat. 131. Beo, Karakelang-islands. 13 M., mud and sand. 3 Spec.

The specimens from Stat. 8I and 90 are very young; consequently their identification remains somewhat uncertain. It seems strange that the specimen from Stat. 9o, should have lived at this depth; it may have entered the dredge with a drifting piece of wood or seaweed.

\section{Turbo (Senectus) aurantius Kiener.}

Kiener. Coq. Viv. Turbo, p. 55, Pl. 27, fig. 3 .

TRYON. Man. of Conch. Vol. X, p. 198, Pl. 48, fig. 30 (argyrostomus var.).

Stat. 58. Seba, Savu. Up to 27 M., sand. I Spec.

The only specimen is unfortunately very young, measuring only 17 Mill. in altitude, while KiENER's type is 43 Mill. The operculum and soft parts wanting. I cannot agree, without new material, with TRyon's views, who has considered this species to be a variety of $T$. argyrostomus. The habitat was unknown to KIENER and Tryon. 
4. Turbo (Senectus) chrysostomus Linné.

LinNÉ. Syst. Nat. Ed. X, p. $762, \mathrm{~N}^{0} 535$.

Rumph. Amb. Rariteitkamer, p. 71, P1. 19, fig. E.

ReEve. Conch. Ic. Vol. IV, Turbo, fig. 28.

Kiene1. Coq. Viv. Turbo, p. 18, Pl. 4, fig. 2.

Trion. Man. of Conch. Vol. X, p. 200, Pl. 40, fig. I9.

Stat. 37. Sailus-Ketjil, Paternoster-islands. Reef. I Spec.

Stat. 89. Pulu Kaniungan-Ketjil. Reef. I Spec.

Stat. 193. Sanana-bay, East coast of Sula Besi. Reef. 2 Spec.

5. Turbo (Senectus) intercostalis Menke.

Menke: in Philippi, Mart. Chemn. Conch. Cab. Ed. II, Turbo, p. 42, 68, Pl. I I, fig. 3 , Pl. 16 , fig. 4-5.

Kiener. Coq. Viv. Turbo, p. 83, Pl. 39, fig. I.

? Trion. Man. of Conch. Vol. X, Pl. 43, fig. 5I, Pl. 47, fig. 22.

Stat. 50. Bay of Badjo, West coast of Flores. Reef. I Spec.

Stat. 71. Makassar. I Spec.

Stat. I74. Waru-bay, N. coast of Ceram. Reef. I Spec.

Stat. 193. Sanana-bay, E. coast of Sula-Besi. Reef. I Spec.

The identification of this species is difficult. Authors don't agree about its specific value. TrYon cites as synonyms: disjunctus Anton, concinnus Phil., articulatus Reeve, elegans Phil., radiatus Reeve. v. Martens wrote me, that T. Winteri Phil. is identical. The largest specimen from Stat. 193, has squamous lirae, that from Makassar, though collected alive, is much worn and remains uncertain. The other specimens are mere shells.

6. Turbo (Senectus) ticaonicus Reeve.

ReEve. Proc. Zool. Soc. Lond. 1842 , p. 185 .

- Conch. Ic. Vol. IV, Turbo, fig. 23.

Kiener. Coq. Viv. Turbo, p. 87, Pl. 32, fig. 2.

Tryon. Man. of Conch. Vol. X, p. 202, Pl. 47, fig. 22, Pl. 43, fig. 5 I.

Stat. 7. Near reef of Batjulmati (Java). I5 M. I Spec.

Stat. I6. Bay of Kankamaraän, S. coast of Kangeang. 22 M., mud. I Spec.

Stat. 34. Labuan Pandan, Lombok. Reef. 7 Spec.

Stat. 37. Sailus-Ketjil, Paternoster-islands. 27 M. and less, coralsand. 4 Spec.

Stat. 50. Bay of Badjo, W. coast of Flores. Up to 40 M., mud and sand. I Spec.

Stat. 5 t. Madura-bay. Shore. 3 Spec.

Stat. I 3r. Beo, Karakelang-islands. Reef. 4 Spec.

Stat. 299. Buka- or Cyrus-bay, S. coast of Rotti-island. Reef. 2 Spec.

*Amboina. I Spec.

It is often very difficult, to separate the species of the subgenus Senectrus, after shell characters; the specimens mentioned above are not umbilicate, and only show in some specimens a very small umbilical slit, which character seems to distinguish this species from $T$. concinnzts Phil. and intercostalis Mke. After having examined the radula of a rather doubtful specimen, 
I see it agrees as good as may be desired, with the figure of Troschel (Gebiss der Schnecken, P1. I9, fig. 11) and is quite different from his figure of the radula of T. concinnus (1.c. P1. I9, fig. 9). This concerns particularly the lateral teeth with large cusps, as the shape of the rhachidian tooth can not easily be traced.

7. Turbo (Senectus) gemmatus Reeve. Pl. VI, fig. i i.

ReEve. Proc. Zool. Soc. Lond. 1848 , p. 50.

- Conch. Ic. Vol. IV, Turbo, fig. 62.

Tryon. Man. of Conch. Vol. X, p. 206, Pl. 44, fig. 68, 69.

Stat. 33. Bay of Pidjot, Lombok. 22 M. 3 Spec.

Stat. 99. North-Ubian. 16-23 M. Lithothamnion-bottom. 3 Spec.

Stat. 109. Pulu-Tongkil, Sulu-Archipelago. I 3 M. Lithothamnion-bottom. 1 Spec.

Stat. 240. Banda. I $8-36$ M. Lithothamnion-bottom. 3 Spec.

Stat. 313. Dangar Besar, Saleh-bay. Up to 36 M. Sand, coral and mud. 15 Spec. - Reef. 2 Spec.

Stat. 315. Sailus Besar, Paternoster-islands. Up to 36 M. Lithothamnion-bottom. 2 Spec.

Only one specimen from Stat. 3I3, has the typical colour, as described by REeve namely: uniformly red; the other specimens vary much in colour and markings, some specimens are nearly typical, varying from light orange-red to dark coral-red, and a few are olive-green; nearly all the specimens are marked with white spots or flames, often mixed with dark or black granules. Many of them have a row of granules next the suture, forming a necklace of white and black. There is a tendency to have four such zones on the bodywhorl, the second at the shoulder, the third lower, the fourth near the base, occupying as a rule the first, fourth, seventh and eleventh or twelfth row of granules, but as there is some variation in the sculpture, there may be some rows more or less, in most cases, I see very small intermediate granules. The columella is surrounded by a thicker rib at its base, which may be indicated as crenate, this rib is yellowish-white, with darker yellow in the interstices. This lighter colour extends in a few specimens over the base of the shell. In some specimens, more rows of granules are variegated with dark and white, giving to the shell a very beautiful mottled appearance. The granules are mainly strongly developed, but in two specimens they are somewhat obliterated. The operculum, which as far as I am aware, has not yet been described, is slightly oval, one specimen being Io Mill. in its largest diameter and 9 Mill. in breadth; the inner surface is covered by a light brown cuticle, darker towards the outer margin and towards the margin of the outer whorls, the number of which seems to be four; the outer one is very broad, the nucleus is subcentral, but approaches the basal and columellar margins. The external surface is porcelain-white, very thick near the left upper part, less so on the right side; it is covered with not very conspicuous, somewhat vermiform rugosities, and has a marked depression on the lower half, slightly to the left, nearly opposite to the nucleus on the internal side. The right margin is smooth and shining.

\section{Turbo (Senzectus) margaritaceus Linné.}

LinNé. Syst. Nat. Ed. X, p. 764, N0 545 .

Stat. 53. Bay of Nangamessi, Sumba. Up to 36 M. Coralsand. 1 Spec. 
The only specimen is a very young dead one, with rather smooth ribs, so I have applied the name margaritaceus, as the specimen was too poor, to decide of it might belong to $T$. argyrostomus Lin., now taken by most authors as a synonym or variety.

\section{Turbo (Senectus) sp.?}

Stat. 78. Lumu-Lumu-shoal, Borneo-bank. Shore. 3 Spec.

Stat. 2I3. South-island. Reef. 4 Spec.

There are in the collection some small shells, belonging to the genus Turbo and probably to the subgenus Senectus, which are probably young, but I am unable to state, to which species they belong. They are very diversified in colour, less so in sculpture, but agree in the white operculum. I doubt that they belong to one and the same species. Those from Station 78 belong I think, to two species, those from the South-island to two or three.

\section{1о. Turbo (Marmorostoma) porphyrites Martyn.}

Martyn. Universal Conchol., Pl. 70.

ReEve. Conch. Ic. Vol. IV, Turbo, fig. 53, fig. ig (versicolor).

Kiener. Coq. Viv. Turbo, p. 7I, Pl. 7 , fig. 2, Pl. 36 , fig. 6.

Tryon. Man. of Conch. Vol. X, p. 2 ז5, Pl. 50, fig. 58.

Stat. I9. Bay of Labuan Tring, West coast of Lombok. I8-27 M. Coralsand. 5 Spec.

Stat. 47. Bay of Bima near South fort. 55 M. Coralsand. 2 Spec.

Stat. 50. Bay of Badjo, West coast of Flores. Up to 40 M. Sand. 4 Spec.

Stat. 5 I. Madura-bay. Reef. 5 Spec.

Stat. 86. Dongala; Palos-bay, Celebes. Reef. I Spec.

Stat. r27. Taruna-bay, Great Sangir-island. 45 M. Sand. 2 Spec.

The specimens vary much in colour, one from Madura-bay, one from Stat. 50 and both from Stat. 127, are very dark, and approach, or may belong to var. lugubris Kiener (1.c. Pl. 28, fig. 2). Their operculum is also darker, than in more typical specimens. Many have the orange-red bands. Two of the specimens from Stat. 50, agree very well with the figure of T. mespitum in Fischer's Monograph (Coq. Viv. p. 73, Pl. 35, fig. 2) but this name seems to belong to another species or variety, not to be found in the "Siboga" collection.

Most authors call $T$. versicolor Gmel. a synonym of $T$. porphyrites Martyn, though Troschel observed differences in the radula; as it is scarcely possible to make out, to which forms his shells belonged, and TROSCHEL has dissected only one specimen of $T$. porphyrites, I have followed the first method.

\section{Guildfordia Gray.}

1. Gritdfordic yoca Jousseaume.

Jousseaume. Le Naturaliste i 899 , p. $4^{8 .}$

Stat. $25 \mathrm{I} .5^{\circ} 28^{\prime} .5$ S., $132^{\circ} 0^{\prime} .5$ E. 204 M. Hard coralsand. 2 Spec.

Stat. $253.5^{\circ} 48^{\prime} .2$ S. I $32^{\circ}$ I $3^{\prime}$ E. 304 M. Grey, hard clay. I Spec.

Of the specimens from the first locality, one specimen is very young, its largest diameter, 
without the spines, being only 10 Mill.; its upper surface being quite smooth, in accordance with the other specimens. The other specimen from Stat. $25 \mathrm{I}$ is a broken shell. The third specimen from Stat. 253, though still young is a splendid shell. At first I thought it would be a new species, as I found some differences with the original description, which Dr. Jousseaume had the kindness to copy for me, but after subsequent correspondence, Jousseaume stated that he found the characters I had observed, also on the upper whorls of his shell. The "Siboga"specimen is very light brownish, not purple-brown, with only 6 whorls instead of 7 , the upper whorls are smooth, then follows the last whorl with scarcely 2 rows of granules, instead of 7 or 8 , towards the keel it has very irregular radiating ribs, which leave however a nearly smooth zone above the keel, with only a few spiral striae; the base is less convex than the upper part, I find no rose-coloured line round the umbilical callosity. The diameter, without the spines, is 29 Mill., the altitude 17 Mill. As the shell from Stat. 25 , with a diameter of 32 Mill., has already 6 rows of granules near the aperture, and the other characters agree, I can, after the assertions of JousseaUme, find no reason to describe a new species. Only by direct comparison, it would be possible to find more characters, which could justify a new species. The operculum in the two living specimens is oval, thick, with the nucleus in the external lower corner; the outer surface is slightly rugose, by irregular wrinkles, almost parallel with the basal margin of the operculum. The nucleus is marked by an olive spot.

\section{Astralium Link.}

I. Astralium (Pseudastralium) abyssorum n. sp. Pl. II, fig. I.

Stat. I2. $7^{\circ} 15^{\prime}$ S., $115^{\circ} 15^{\prime} .6$ E. 289 M. Mud and broken shells. 4 Spec.

Stat. 59. Western entrance Samau-strait. 390 M. Coarse coralsand. I Spec.

Stat. S9. Pulu Kaniungan Ketjil. Shore. I Spec. $\left.{ }^{1}\right)$.

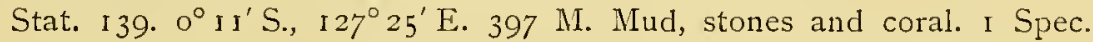

Stat. $156.0^{\circ} 29^{\prime} .2$ S., $130^{\circ} 5^{\prime} \cdot 3$ E. 469 M. Coarse sand. 4 Spec.

Stat. $159.0^{\circ} 59^{\prime}$. S S., $129^{\circ} 48^{\prime} .8$ E. 4 II M. Coarse sand. 4 Spec.

Stat. $279.10^{\circ} 39^{\prime}$ S., $123^{\circ} 40^{\prime}$ E. 520 M. Mud and sand. I Spec.

Shell trochiform, flattened below, imperforate (except in a very young specimen) whorls 7 , the upper ones with flattened sides, the last slightly convex; the sculpture of the upper whorls, consists of a row of small, close-set beads at the suture, being foldlike in the second whorl, they become larger, round and more remote on the next whorls, where they form the only sculpture, till on the ultimate or penultimate whorl, spiral rows of scales make their appearance, beginning with are single row, above the lower suture, they reach the number of 9 on the last whorl, near the aperture. Of these rows, eight are complete, while the lowest one is interrupted by the spines, which are present on all the whorls, except the embryonic one. These spines amount to 14 on the last whorl; they vary in length, are depressed, and provided on the upper surface, with radiating lirae. The beads of the upper whorls persist on the last one, where they number 20 or more. The sutures are deep, channelled, bordered above by the spiniferous

I) "This locality is most probably a lapsus calami for Stat. $9 \mathrm{~S} .6^{\circ} 9^{\prime} \mathrm{N}$, $120^{\circ} 2 \mathbf{1}^{\prime} \mathrm{E}$. $35^{\circ}$ M. Sand. 
keel. Young specimens are nacreous and nearly colourless on the upper surface, with only a light flesh-red tint, which is more apparent on the penultimate and ultimate whorls, these two being in a fine specimen (from Stat. 59) yellow near the suture. Base with a nearly perpendicular zone below the keel, bearing about 4 rows of scales, similar to those of the upper surface, then flat, with radiating, riblike and nine concentric lirae, which are scaly near the periphery and beaded towards the centre. Colour of the base yellowish, its centre covered by a rounded, porcellaneous pad, which spreads in the most adult specimen over a large space of the base, being more circumscribed towards the aperture (especially in younger specimens) where it ends in an obuse, toothlike angle. Aperture squarely-oval, upper part of the outer margin curved, thin, nacreous, columellar margin thick, rounded, basal part rather thin and slightly expanded. Interior of the aperture nacreous, but not strongly iridescent, smooth; the margin only slightly crenulated by the spiral lirae.

In one very young specimen, a small umbilical slit is distinctly present, it is surrounded by a row of white beads, which seem to be covered as soon as the callous pad becomes more developed. Operculum oval, thick, its outer surface white, convex near the margins, slightly impressed near the centre, where it is also slightly tuberculiferous. Its inner surface is flat, brown, with two broad and about ten narrower whorls, around a subcentral nucleus.

Lat. (without spines) 24 , alt. 17 , apert. alt. 8, lat. I I Mill.

This species varies more or less in the altitude of the spire, even in specimens of about the same diameter, in the place where the spiral rows of scales appear and in the length of the spines. I have hesitated in erecting a new subgenus for it, but I could not locate it in any of the existing subgenera. It has somewhat the appearance of Guildfordia, but differs in its suture being spiniferous in the upper whorls; the callous pad of the base is not provided with a pit as in Guildfordia. The subgenus may be characterised by the slender spines and the shape of the porcellaneous pad. I think its nearest ally is Turbo (Calcar) henicus Wats. (Challenger Exp. part 62, p. I30, Pl. 6, fig. I I) the description agreeing in many particulars, but it may be distinguished at once, by that species being beaded instead of scaly as in the new species. The operculum has many features in common.

The radula of one of the smaller specimens, has given only an imperfect result, by its great brittleness; in cleaning it, it fell in pieces. As far as I can judge, it has much affinity with that of Bolma.

2. Astralium (Bolma) modestum Reeve, var. girgyllus Reeve.

Reeve. Conch. Ic. Vol. XIII, Trochus, fig. 53.

Kítener. Coq. Viv. Vol. X, Calcar, p. 6, Pl. 76, fig. I.

Tryon. Man. of Conch. Vol. X, p. 230, Pl. 55, fig. 65.

Stat. 100. $6^{\circ}$ I I' N., I $20^{\circ} 37^{\prime} \cdot 5$ E. 450 M. Dead coral. I Spec.

The only specimen is a dead shell, with the spines broken; the suture is shallower, the whorls are less inflated, than in the only specimen I could compare. (A. girgyllus is only known from China, but the circumstance that it has been collected at such a great depth, with 
dead corals, may account for this more extended range. Duxker (Ind. Moll. Maris Jap. p. I zo) says that $A$. modestzun is variable in sculpture.

3. Astralium (Bolma) turcicus Reeve.

REeve. Proc. Zool. Soc. Lond. I 848 , p. 50.

- Conch. Ic. Vol. IV, Turbo, fig. 60.

Kiener. Coq. Viv. Turbo, p. 93, Pl. 42, fig. 3.

SMith. Zool. Coll. of H. M.S. "Alert" p. 504, Pl. 44, fig. U-U².

Tryon. Man. of Conch. Vol. X, p. 230, Pl. 48. fig. 35.

Stat. 285. Near South coast of Timor. 34 M. Lithothamnion-bottom. 2 Spec.

It is with some doubt, that Tryor places this species in Bolma, and indeed, the shell and operculum, agree very well with Turbo, the base of the aperture being angularly expanded. The operculum is convex, with only a slight depression opposite to the subcentral nucleus. The spines of the shell in young specimens, seem to have induced Tryor, to give the species its present position in the system.

\section{Astralizm (Cyclocantha) calcar Linné.}

Linné. Syst. Nat. Ed. X, p. $762, \mathrm{~N}^{0} 538$.

Runph. Amb. Rariteitkamer, p. 73, Pl. 20, fig. I.

ReEve. Conch. Ic. Vol. XIII, Trochus, fig. $52 \alpha$.

Kiener. Coq. Viv. Trochus, p. 27, Pl. 23, fig. I (aculeatum Gmel.).

Tryon. Man. of Conch. Vol. X, p. 231, Pl. 52, fig. 27, 29, 30; Pl. 56, fig. 74.

Stat. 50. Bay of Badjo, West coast of Flores. Up to 40 M. Sand. I Spec.

Stat. 6o. Haingsisi. Reef. I Spec.

Stat. 93. Pulu Sanguisiapo, Tawi-Tawi-islands, Sulu-Archipelago. Reef. I Spec.

Stat. I 3 I. Beo, Karakelang-islands. Reef. 3 Spec.

Stat. 234. Nalahia-bay, Nusa-laut-island. Reef. 3 Spec.

Stat. 250. Kilsuin, West coast of Kur-island. 20-45 M. Coral and Lithothamnion. 2 Spec.

"Amboina. I Spec.

The specimens vary much in shape, some specimens could as well be located with the variety helicinum, and are associated with the type, only on account of longer spines or flatter apex or more conspicuously detached whorls.

\section{var. helicinum Gmelin.}

GuiElin. Syst. Nat. Ed. XIII, p. $3600, N^{0} 48$.

ReEve. Conch. Icon. Vol. XIII, Trochus, fig. $52 b$.

Kiener. Coq. Viv. Trochus, p. 27, Pl. 23, fig. 3.

Tryon. Man. of Conch. Vol. X, p. 232, PI. 52, fig. 28, 3 T.

Stat. I6. Bay of Kankamaraän, South coast of Kangeang. Shore. I Spec.

Stat. 142. Laiwui, coast of Obi Major. Reef. I Spec.

Stat. 250. Kur. Reef. I Spec.

The specimen of Kur-reef is the most characteristic, the other ones are more or less different from the description of the typical helicinum. 


\section{Astratium (Cyclocantha) laciniatum Gould.}

Gould. Proc. Boston Soc. Nat. Hist. Vol. III, I849, p. 90.

Kiener. Coq. Viv. Calcar, p. 29, Pl. 79, fig. $3,4$.

Tryon. Man. of Conch. Vol. X, p. 232, P1. 53, fig. 32, 33.

Stat. 96. South-east side of Pearl-bank. Sulu-Archipelago. 15 M. 2 Spec.

Stat. 99. North-Ubian. I6-23 M. Lithothamnion-bottom. I Spec.

Stat. 174. Waru-bay, North coast of Ceram. Reef. I Spec.

Stat. 240. Banda. 9-45 M. Lithothamnion-bottom. I Spec.

Stat. 3 I 5. East of Sailus Besar, Paternoster-islands. Up to 36 M. Lithothamnion-bottom. 2 Spec.

The specimen from Stat. I74, is the only one which is adult and agrees with KiEner's fig. 3, but it is a rather bad shell, covered with incrustations and inhabited by one of the Paguridae. The other specimens are young and agree with Gould's description and fig. 4 of KIENER, though they are still younger. Such juvenile specimens, always remain somewhat uncertain, unless one has large series of specimens for comparison. TRYon sees in laciniatum only a variety of $A$. calcar Lin.

6. Astralinm (Cyclocantha) lapillus Reeve. P1. II, fig. 2.

REeve. Conch. Ic. Vol. XIII, Trochus, fig. 65.

Stat. 240. Banda. 9-45 M. Lithothamnion-bottom. I Spec.

Stat. 282. Between Nusa Besi and the N.E. point of Timor. 27-54 M. Sand and Lithothamnion. 3 Spec.

Stat. 315. East of Sailus Besar, Paternoster-islands. Up to 36 M. Lithothamnion. I Spec.

The specimen from Stat. 3 I 5 agrees exactly with ReEve's figure and description, but it is smaller. Mr. E. A. Surrm has had the kindness to compare it with the type in the British Museum, and has approved my identification; the specimen from Banda is younger, but agrees in most respects with the other one. Of the specimens from Stat. 282, the smallest agrees with that from Banda, but is smaller, another differs only slightly from the specimen from Stat. $3^{15}$, but the third, which is much larger, has long puzzled me, untill I observed that the upper whorls agree exactly in sculpture, with those of the other specimens, from the same locality, and so I am convinced, that it represents the adult state of the typical $A$. lapillus, which has a somewhat juvenile appearance. Most of the specimens are strongly covered with incrustations, which render it impossible to count the whorls. This large specimen seems to have nearly one whorl more, which gives to the shell a very different aspect, this whorl being much flatter than the upper ones, the ribs are less nodulous; the whorl is rather sharply keeled and this keel bears in the specimen before me, towards the aperture, two broad lamellae, succeeding the spines of the penultimate whorl. These lamellae are of an irregular shape, they are sculptured with spiral ribs on the upper surface, the basal surface being slightly concave, with indistinct spiral lirae and fine radiating lamellae; the margin is more or less lobed. The aperture has rose-coloured margins. The interior of the aperture is grooved at some distance from the margin; only the groove corresponding to the keel, reaches the outer margin. The operculum 
in all the specimens is externally very convex, with close-set granules, the margin is deep violet, especially the columellar one.

The measurements of this adult specimen are:

Diam. maj. without lamellae 20, with lamellae 25, alt. I5 Mill.

7. Astralium (Cyclocantha) provisorizm n. sp. P1. II, fig. 3 .

Stat. 144. North of Salomakiëe-(Damar)-isiand. 45 M. Lithothamnion-bottom. I Spec.

Shell conoidal, with a flat base, imperforate, whorls about 5 , the upper three eroded and nearly covered by incrustations, but apparently rather smooth, penultimate whorl with oblique wrinkles, crossed by 3 or 4 spiral rows of square granules; towards the last whorl, irregular tubercles make their appearance, about $S$ on the last whorl; these are also covered by the wrinkles and granules, below the tubercles, the last row of granules runs uninterrupted and is succeeded towards the keel by short plications, which have about the same direction as the wrinkles. Moreover the upper surface of this whorl is covered by spiral lirae, only visible under a lens. The whorls are inflated at their upper part, concave at the lower portion and are then again broader, thus covering the sutures and even part of the subsequent whorls. Keel very sharp, with short spines, about 17 in number, if seen from the base. These spines are compressed, open in front. Base flat, with 8 irregular lirae, with compressed scales; towards the keel, a few undulating spiral striae appear; this sculpture is crossed by small radiating riblets.

Aperture rhomboidal, very oblique, with sharp edges and an internal nacreous layer, at some distance from the margin, with Io lirae near this margin, and a groove corresponding to the keel; basal margin smooth, columella emarginate, thick, thickened towards the base and forming a toothlike angle, at the junction with the basal margin. Colour of the shell yellowisholive; the top-whorls, a zone at the base of the whorls, especially of the last one rose-coloured; the base tinted with the same colour.

Alt. 10, lat. I I; apert. alt. from upper to basal margin $6 \frac{1}{2}$, lat. $4 \frac{1}{2}$ Mill.

This shell has the appearance of being not adult, it resembles much the juvenile state of the preceding species, and also, but less, ReEve's figure of Trochus hexagonus (ReEve, Trochus fig. 61). It differs from both by the peculiar colour, and the beautiful row of spines or scales. Though I should prefer to wait for more materials, it is so improbable that these will be procured in a short time, that I have described this species and named it in accordance with its somewhat doubtful character.

\section{Leptothyra Carpenter.}

\section{Leptothyra sp.}

Stat. 43. Pulu Sarassa, Postilion-islands. Up to 36 M. Coral. I Spec.

One small, probably young specimen, which I could not identify with certainty, too incomplete for description, differs from the next species by the very numerous spiral lirae, of which one, near the shoulder is stronger, and by its prominence, forms a slight angle, the upper whorls are beaded. 
2. Leptothyra laeta Montrouzier. Pl. IX, fig. 2.

Montrouzier. Journ. de Conch. I863, p. 277, Pl. i2, fig 2 (Turbo).

Trion. Man. of Conch. Vol. X, p. 25s, Pl. 63, fig. 29, 30.

Stat. 7. Near reef of Batjulmati (Java). 15 M. Coral and stones. I Spec.

Stat. 37. Sailus Ketjil near Paternoster-islands. Shore. 9 Spec.

Stat. 53. Bay of Nangamessi, Sumba. Up to 36 M. Coralsand. 7 Spec.

Stat. $6 \mathrm{I}^{\mathrm{n}}$. North coast of Adonara. Shore. I Spec.

Stat. 78. Lumu-Lumu-shoal, Borneo-bank. Shore. 3 Spec.

Stat. I29. Kawio- and Kamboling-islands, Karkaralong-group. Reef. 2 Spec.

Stat. 240. Banda. Reef. 3 Spec.

There is considerable variation in the painting of this species, as stated in the original description, some specimens being nearly entirely covered by the confluent flammules; the colour varies in being in most cases reddish or brownish, but some specimens are of a bright crimson; however they agree in other respects, and it seems not to be doubtful, that they are one and the same species. Melvill and Standen (Proc. Zool. Soc. 1901, p. 352) mention this species or an allied form, as being uniformly pink, but more finely striate, from lat. $18^{\circ} 58^{\prime} \mathrm{N}$., long. $70^{\circ} 45^{\prime} \mathrm{E}$., which shows that it is widely distributed. PILSBRy (I. c.) cites L. supragranosus Smith (Journ. Linn. Soc. XII, p. 558, Pl. 3 O, fig. I 5) as a synonym; this figure is far more characteristic than the original one, displaying the beaded sculpture of the superior whorls. The radula has about the same appearance, as that of $L$. Carpenter $i$ Pils. and $L$. sangarensis Schrenck, as figured by PILsbry. The rhachidian tooth $(R)$ has a narrower projection above, I could not detect a reflected cusp; the first lateral (1) has a rather large cusp, turned towards the outer side, with 3 or 4 denticles on the proximal side, the proximal uncini seem to have long, simple cusps, only the first one (U) having an elongate body, with a simple narrowly reflected margin; the distal uncini are more or less serrated on both sides.

\section{Fam. Delphinulidae.}

\section{Delphinula Lamarck.}

I. Delphinula laciniata Lamarck.

Laliarck. An. s. Vert. Ed. Desh. Vol. IX, p. 86.

Rumph. Amb. Rariteitkamer, p. 73, $\mathrm{N}^{0}$ I, Pl. 20, fig. H.

Kiener. Coq. Viv. Vol. IX, Delphinula, p. 3, Pl. I, fig. I.

ReEve. Conch. Ic. Vol. I, Delphinula, fig. 9.

Pilsbry. Man. of Conch. Vol. X, p. 266, Pl. 67, fig. 1, 2, 4.

Stat. Sg. Pulu Kaniungan Ketjil. Reef. Io Spec.

Stat. I74. Waru-bay, N. coast of Ceram. Reef. I Spec.

Stat. 240. Banda. 9-45 M. Lithothamnion-bottom. 2 Spec.

Stat. 250. Kilsuin, West coast of Kur-island. 20-45 M. Lithothamnion-bottom. I Spec. and Reef. I Spec.

The specimen from Stat. 174 is somewhat intermediate between the type and var. atrata Chemn., by the shorter laciniate appendages and more rounded aperture; the specimens from Banda are very young. 
var. atrata Chemnitz.

Chemnitz. Conch. Cab. Vol. V, p. 158, Pl. 175, fig. 1729, 1730, 1731 .

ReEve. Conch. Ic. Vol. I, Delphinula, fig. 4.

Pilsbry. Man. of Conch. Vol. X, p. 267, Pl. 66, fig. 15.

Stat. 86. Dongala, Palos-bay, Celebes. Reef. I Spec.

Stat. 225. South Lucipara-island. Reef. I Spec.

Stat. 250. Kur. Reef. 1 Spec.

The last-mentioned specimen is very typical, that from Stat. 86 , approaches the type by its aperture. It is indeed no easy task, to separate a large number of specimens. Troschel who has described the radula of both forms, found no important differences between them, and suggests, also on this ground, that they may be merely varieties of one species:

2. Delphinula sphaerula Kiener. PI. IX, fig. 3 .

Kiener. Coq. Viv. Vol. IX, Delphinula, p. 5, Pl. 3, fig. 3.

ReEve. Conch. Ic. Vol. I, Delphinula, fig. I3.

PILsBry. Man. of Conch. Vol. X, p. 268, Pl. 67, fig. 5; Pl. 68, fig. 20.

Stat. 99. North-Ubian. 16-23 M. Lithothamnion-bottom. 2 Spec.

Stat. 133. Lirung, Salibabu-island. Up to 36 M. Hard sand. I Spec.

Stat. 240. Banda. 9-45 M. Lithothamnion-bottom. 2 Spec.

The specimens collected by the "Siboga" are young, those from Stat. 99 even very young; in consequence the characteristic appendages are not very conspicuous. The operculum does not differ materially from that of $D$. laciniata Lam. In the largest specimen, with a diameter of 22 Mill. (without the appendages) it is more delicate, being smoother, of a lighter colour, the concentric whorls a trifle narrower, than in a specimen of D. laciniata from Amboina, of the same diameter, which I could compare with the specimen under consideration. The operculum of a still smaller specimen from Banda, shows under the microscope about i 6 whorls, of which those near the nucleus are very narrow. The radula has about the same aspect, as that of D. Laciniata, figured by Troschel (Gebiss der Schnecken, Vol. II, pl. 2I, fig. S); the cusp of the rhachidian tooth is simple, while in a radula of $D$. laciniata from Amboina, each side of the cusp seems to have a small, very pellucid denticle, which has not been mentioned by Troschel, perhaps on account of its thin structure; the body is higher in proportion to its breadth, if compared with $D$. laciniata or atrata; the fourth and fifth laterals $(4,5)$ are considerably larger, than either in D. laciniata, or in its variety atrata, as figured by TRoscheL, the length of the cusps surpassing much the diameter of the rhachidian tooth; they have on their base a secondary denticle, which is more distinct, than in my specimen of $D$. laciniata. Moreover the primary cusps in $D$. laciniata are directed nearly horizontally, in sphaerula more oblique.

\section{Liotia Gray.}

\section{Liotia varicosa Reeve.}

ReEve. Proc. Zool. Soc. Lond. 1843 , p. 142 (Delphinula).

_- Conch. Ic. Vol. I, Delphinula, Sp. ז2. 
Stat. 64. Kambaragi-bay, Tanah Djampeah. Up to 32 M. Coralsand. I Spec.

Stat. 7I. Makassar. 27-32 M. Sand with mud. 3 Spec.

Stat. I09. Pulu Tongkil, Sulu-Archipelago. I3 M. Lithothamnion-bottom. I Spec.

Stat. 133. Lirung, Salibabu-island. Up to $36 \mathrm{M}$. Hard sand. I Spec.

Stat. 240. Banda. 9-45 M. Lithothamnion-bottom. I 3 Spec.

Stat. 30I. Pepcla-bay, East coast of Rotti. 22 M. Lithothamnion-bottom. I Spec.

Stat. 3I3. East of Dangar-Besar, Saleh-bay. Up to 36 M. Sand and mud. 19 Spec.

According to the long list of Stations, this species is widely distributed in the Archipelago. The specimens vary in size and in sculpture, some specimens being more angular at the shoulder; the puncturing, as observed by ReEve, is more or less obvious.

\section{Liotia Peronii Kiener.}

Kiener. Coq. Viv. Vol. IX, Delphinula, p. 9, Pl. III, fig. 5.

ReEve. Conch. Ic. Vol. I, Delphinula, fig. Io.

Stat. 125. Sawan, Siau-island. Reef. 2 Spec.

Stat. 250. Kur. Reef. I Spec.

The specimens vary still more in size, than those of the preceding species, that from Kur is $19 \%$ Mill. and apparently not yet adult. That from Stat. 125 measures scarcely 9 Mill. in its largest diameter. The latter specimen agrees with Kiener's figure, those from Kur with that of ReEve.

\section{Liotia sp.}

Stat. 37. Sailus Ketjil, Paternoster-islands. Up to 27 M. Coralsand. I Spec.

Stat. 66. Bank between islands of Bahuluwang and Tambolungan, south of Saleyer. 8 M. I Spec. Stat. 96. South east side of Pearl-bank, Sulu-archipelago. 15 M. Lithothamnion-bottom. 2 Spec. Stat. 240. Banda. 9-45 M. Lithothamnion-bottom. I Spec.

The specimens are very young; they seem to be allied to the preceding species, but differ a. o. by their more raised embryonic whorls, in which character they agree with two specimens of a Liotia, received from the Samoa-islands as L. Hermanmi Dkr. TRYon (Man. of Conch. Vol. X) considers this species as a synonym of $L$. Peronii Kien.. I can only say that the "Siboga" specimens don't agree in their upper whorls with those of $L$. Peronii from the same collection

\section{Liotia (Arene) radiata Kiener?}

Kiener. Coq. Viv. Vol. IX, Delphinula, p. 7, Pl. 4, fig. 9.

Reeve. Conch. Ic. Vol. I, Delphinula, fig. 24.

Stat. 59. Western entrance Samau-Strait. 309 M. Coarse coralsand. I Spec.

Stat. $95.5^{\circ} 43^{\prime} .5$ N., $119^{\circ} 40^{\prime}$ E. 522 M. Stony bottom. 1 Spec.

It is only with much doubt, that I have identified the young specimens with Kiener's species, which according to E. A. SMith, is identical with L. muricata Reeve, (1.c. fig. I \&). ReEve gives as locality for both East Indies and Indian seas, though Humphreys had in his collection L. radiata from the West Indies. Trvon who keeps the two species separated, mentions 
"West Indies" for L. radiata and "Australia" and "Philippines" for L. murricata. I possess a specimen better agreeing with $L$. muricata, than with L. radiata, from Curaçao. The "Siboga" specimen from Stat. 59, agrees in the spines of the keel and in the red spots, but the upper surface has more beaded spirals, and the base is sculptured by waved, radiating striae instead of beads. However this may depend on age or variability; it seems very unsafe to make conclusions on one small and not quite intact specimen. The other one is very young.

\section{Liotia (Arene) crenata Kiener.}

Kiener. Coq. Viv. Vol. IX, Delphinula, p. i1, Pl. 4, fig. 8.

ReEve: Conch. Ic. Vol. I, Delphinula, fig. 19.

Stat. 37. Sailus Ketjil, Paternoster-islands. Shore. I Spec.

Though the only specimen is very young, I don't hesitate about its identification; the characteristic sculpture, perfectly agrees with that of the upper whorls, of an adult specimen, received from New Caledonia.

\section{Liotia sp.}

Stat. 81. Pulu Sebangkatan, Borneo-bank. 34 M. Lithothamnion-bottom. I Spec.

A small specimen, probably new, but not in sufficiently good condition for description.

\section{Liotia (Arene) sp.}

Stat. 8I. Pulu Sebangkatan, Borneo-bank. 34 M. Lithothamnion-bottom. I Spec.

Allied to L. crenata Kien., but differing in several particulars, especially in the much narrower umbilicus. It is perhaps new, but the shell is too much worn, for giving a sufficient description of the sculpture.

\section{Liotia (Arene) armata Adams var. P1. III, fig. I.}

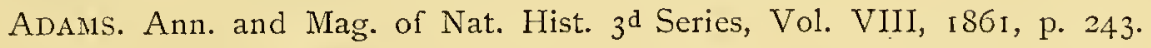

Stat. $95.5^{\circ} 43^{\prime} \cdot 5$ N., $119^{\circ} 40^{\prime}$ E. 522 M. Stony bottom. 1 Spec.

This species has been described by Adaus, from Korea-strait, from a depth of only 46 fathoms. The specimen under consideration is dead, as it is however in good condition, it has been figured. According to E. A. Sumtr, who has compared it with the collection of the British Museum, the spire is flatter at the top than in the type.

\section{Liotia (Arene) lamellosa n. sp. Pl. III, fig. 2.}

Stat. $95.5^{\circ} 43^{\prime} \cdot 5$ N., $119^{\circ} 40^{\prime}$ E. 522 M. Stony bottom. I Spec.

Shell depressedly turbinate, yellowish-white, whorls $4 \frac{1}{2}$, upper ones forming a slightly concave spire, nucleus rather smooth, followed by a whorl, with regular, distinct ribs, slightly angular at some distance from the suture, from there towards the aperture the suture is excavated 
and the shell bears strong ribs, becoming more distant as they approach the aperture, and being obsolete on the last half whorl; these ribs have blunt spines, bordering the margin of the subsutural excavation, and sharper ones at the periphery, which is keeled in the interstices of the ribs. Last whorl with another keel at some distance from the periphery, with rather obsolete indications of spines, corresponding to those of the upper keel, the space between the keels and above the periphery somewhat concave. Umbilicus pervious, its margin strongly crenulated or folded, the folds entering the umbilicus and partly running upwards, towards the lower keel. Aperture circular, its inner lip protracted, outer lip very broad and thick, broadest at its upper part, slightly excavated and reflected externally. The whole exterior of the shell covered by low, crowded lamellae.

Alt. 4, diam. maj. $7^{1} / 2$, apert. alt. et lat. $2 \%$ Mill.

Allied to L. siderea Reeve, but more depressed if seen on the apertural side, the shape differs by the more prominent peripheral keel, the outer lip is broader etc.

\section{Fam. Cyclostrematidae.}

\section{Cyclostrema Marryat.}

I. Cyclostrema reeveana Hinds.

Hinds. Voy. of the Sulphur, p. 52, Pl. 16, fig. 17.

REEve. Conch. Ic. Vol. I, Delphinula, fig. 17.

- Conch. Ic. Vol. XIX, Cyclostrema, fig. 13.

Adans. Proc. Zool. Soc. Lond. 1850 , p. 42.

Stat. 47. Bay of Bima, near south fort. 13-54 M. Mud with coralsand. 1 Spec.

The only specimen though adult, is smaller than one from Cebu, having only a diameter of 9 Mill., the sculpture however is the same; the body whorl has on its upper half three principal keels, of which the uppermost forms an angle; on the flat space between this angle and the suture, run three secondary keels or lirae; the lirae of the base, five in number, are placed closer, the last one borders the umbilicus, or is partly placed into it. A short keel and two fainter ones run in the umbilicus, these last rendering the external border of the columellar margin crenulate. The radiating ribs, about fourty in number on the last whorl, form small cusps, where they cross the lirae. Moreover the shell has in the interstices very fine growthstriae, which become lamellose near the suture. The umbilicus has a lamellose appearance, by the continuation of the ribs.

Both Reeve and Adans cite Proc. Zool. Soc. Lond. 1843 for this species, but I cannot find the description there.

\section{Teinostoma Adams.}

I. Teinostoma sibogae n. sp. Pl. II, fig. 5 .

Stat. 105. $6^{\circ} 8^{\prime}$ N., $121^{\circ} 19^{\prime}$ E. 275 M. Coralbottom. I Spec.

Shell depressedly globose, imperforate, surface smooth, with scarcely visible lines of $3^{6}$ 
growth and an impressed line below the suture. Colour yellowish-white, whorls about $3^{1} / 2$, slightly convex, with a conspicuous suture. Aperture circular, peristome rather thick, separated by a groove, from a subtriangular lobe at the upper part of the aperture, and from a tongueshaped callus covering the umbilical region; around this callus, another larger, semicircular one is separated by a groove, from the slightly depressed basal surface, this latter callus is grooved by a few radiating striae.

Alt. $2^{2} / 5$, diam. maj. 3, diam. of apert. $1^{1 / 4}$ Mill.

\section{Teinostoma sp.}

Stat. $297.10^{\circ} 39^{\prime}$ S., $123^{\circ} 40^{\prime}$ E. 520 M. Soft, grey mud. 5 Spec.

The largest of the specimens has a diameter of 3 Mill.; they are probably young and could not be identified.

Fam. Trochidae.

Trochus Linné.

I. Trochus (s. str.) niloticus Linné.

LinNÉ. Syst. Nat. Ed. XII, p. I227.

Runph. Amb. Rariteitkamer, p. 74, P1. 2 I, fig. A.

Kiener. Coq. Viv. Vol. X, Trochus, p. 66, Pl. Io.

Pilsbry. Man. of Conch. Vol. XI, p. I7, Pl. I, fig. 5-S.

Stat. 53. Bay of Nangamessi, Sumba. Up to 36 M. Coralsand. I Spec.

Stat. 78 . Lumu-Lumu-shoal, Borneo-bank. Shore. 2 Spec.

Stat. I29. Kawio and Kamboling-islands, Karakalong-group. Reef. I Spcc.

Stat. 225. Lucipara-island. Reef. I Spec.

Stat. 31 3. Dangar Besar, Saleh-bay. Up to 36 M. Sand. I Spec.

"Amboina. I Spec.

The specimens from Stat. 78 contain Paguridae, that from Stat. $3 \mathbf{I} 3$ is the only adult one, with expanded last whorl.

2. Trochus (s. str.) fenestratus Gmelin.

GileLin. Syst. Nat. Ed. XIII, p. 5582 .

RUMPH. Amb. Rariteitkamer, p. 75, Pl. 21 , fig. 8.

REEve. Conch. Ic. Vol. XIII, Trochus, fig. I6, 17, I8 (exaltatus, cremulatus, fenestratus).

Kiener. Coq. Viv. Vol. X, Trochus, p. II 7 , Pl. 38 , fig. 3 .

Pilsbry. Man. of Conch. Vol. XI, p. 22, Pl. 4, fig. 28, 29.

Stat. I6. Bay of Kankamaraän, South coast of Kangeang. Shore. 2 Spec.

Stat. Si. Pulu Sebangkatan, Borneo-bank. 34 M. Coral and Lithothamnion. I Spec.

Stat. 93. Pulu Sanguisiapo, Tawi-Tawi-islands, Sulu-archipelago. I2 M. Lithothamnion. I Spec.

Stat. I42. Laiwui, coast of Obi-Major. Reef. I Spec.

Stat. 193. Sanana-bay, East coast of Sula Besi. Reef. 2 Spec.

Stat. 225. Lucipara-island. Reef. I Spec.

Stat. 240. Banda. 9-45 M. Lithothamnion. I Spec.

Amboina. I Spec. 
3. Trochus (Lamprostoma) maculatus Linné.

LiNNÉ. Syst. Nat. Ed. X, p. $756, \mathrm{~N}^{0} 502$.

Rumpi. Amb. Rariteitliamer, p. 74, fig. C?, 5.

Kiener. Coq. Viv. Vol. X, Trochus, p. IoI, Pl. 29, fig. I, Ia.

ReEve. Conch. Ic. Vol. XIII, Trochus, fig. 4 and 66 (smaragdus).

Pilsbry. Man. of Conch. Vol. XI, p. 24, Pl. 9, fig. 94, IOO, I, 2, 3.

Stat. 33. Bay of Pidjot, Lombols. 22 M. Coralsand. I Spec.

Stat. I 3 I. Beo, Karakelang-islands. Reef. I Spec.

Stat. 193. Sanana-bay. East coast of Sula Besi. Reef. 2 Spec.

Stat. 23I. Amboina. Reef. 2 Spec.

Stat. 250. Kilsuin, West coast of Kur-island. 20-45 M. Coral and Lithothamnion. I Spec.

Stat. 3 I3. East of Dangar Besar, Saleh-bay. Up to 36 M. Sand. I Spec.

The specimen from Stat. $13 \mathrm{I}$, is the only quite typical one, with nearly straight outlines and a sharp keel; the other specimens show some affinity to the next variety and to $T$. verrucosus Gmel, which, according to Pilsbry belongs to this species. Indeed it is very difficult, if not impossible, to classify every specimen of a rather large series, if one admits many species.

var. granosis Lamarck.

Lamarck. An. s. vert. Ed. Desh. Vol. 9, p. 137.

Kiener. Coq. Viv. Vol. X, Trochus, p. I03, Pl. 34, fig. 1.

Reeve. Conch. Ic. Vol. XIII, Trochus, fig. 67 (gibberulus).

Pilsbri. Man. of Conch. Vol. XI, p. 26, Pl. 6, fig. 51, 60, Pl. 9, fig. 4.

Stat. I31. Beo, Karakelang-islands. Reef. I Spec.

Stat. 225. Lucipara-islands. Reef. I I Spec.

"Amboina. 2 Spec.

The specimen from Stat. I 3 I seems to belong to the form called gibberalus by Adams, it is higher, the altitude being 43 Mill., with a diameter of 37 Mill. Even those from Stat. 225, are higher in proportion to their diameter, like the figure of KIENER, copied by PILSBRY; in only one specimen, not quite adult, the altitude is surpassed by the diameter.

4. Trochus (Lamprostoma) incrassatus Lamarck.

Lamarck. An. s. vert. Ed. Desh. Vol. 9, p. izs.

REeve. Conch. Ic. Vol. XIII, Trochus, fig. 77 ?

Kiener. Coq. Viv. Vol. X, Trochus, p. II 3 , Pl. 37, fig. I.

PILSBRy. Man. of Conch. Vol. XI, p. 26, Pl. 6, fig. 48, 49 (50?).

Stat. 40. Pulu Kawassang, Paternoster-islands. Reef. I Spec.

"Amboina. I Spec.

"Java. 3 Spec.

The specimens agree very well with the figures and description of Fischer in KIENER's Coq. Viv., copied by Pilsbry; much less with Reeve's figure 77 (Pilsbry, fig. 50) the outlines of the spire in these figures, not being convex. Perhaps these figures represent another allied species. 
5. Trochus (Lamprostoma) creniferus Kiener.

Kiener. Coq. Viv. Vol. X, Trochus, p. I09, Pl. 34, fig. 3.

Pilsbry. Man. of Conch. Vol. XI, p. 27, Pl. 7 , fig. $67,68$.

Stat. 66. Bank between islands of Bahuluwang and Tambolungan. 8-10 M. I Spec.

Stat. I42. Laiwui, coast of Obi-Major. 23 M. Mud. I Spec.

The specimen from Stat. 66 is very young and accordingly of somewhat doubtful identification, that from Stat. I42, though not adult, is easily recognizable. PILSBRy considers this species to be a variety of the preceding species, but as the sculpture in the two specimens I could compare, is rather different, I have kept them separated. The sculpture of the base in this species, consists of beaded spiral lirae, with comparatively broad interstices, about twice as broad as the granules, with radiating and faint spiral sculpture, while in incrassatzos, the granules are much larger and either nearly touch the neighbouring row, or the lirae are separated by interstices, which are considerably narrower than the lirae.

6. Trochus (Lamprostoma) $s p$.

Stat. Iog. Pulu Tongkil, Sulu-Archipelago. I3 MI. Lithothamnion-bottom. I Spec.

This specimen is too small for identification. I think it does not belong to one of the preceding species.

\section{Trochus (Lamprostoma) tubiferus Kiener.}

Kiener. Coq. Viv. Vol. X, Trochus, p. i i6, Pl. 37, fig. 3 .

REEve. Conch. Ic. Vol. XIII, Trochus, fig. I5 (concinnus).

Pilsbry. Man. of Conch. Vol. XI, p. 31, Pl. 6, fig. 62, 63.

Stat. 250. Island Kur. Reef. I Spec.

The only specimen agrees better with ReEve's figure of $T$. concinmus, than with the typical one of Kiener, copied by Pilsbry; as however according to Fischer, Kiener's specimen was not adult and the species is very variable, I have applied Kiener's older name.

\section{Clanculus Montfort.}

I. Clanculus unedo Adams.

Adans. Proc. Zool. Soc. Lond. 1851, p. i6i.

Kiener. Coq. Viv. Vol. X, Trochus, p. 323, Pl. IOI, fig. 2.

Pilsbry. Man. of Conch. Vol. XI, p. 70, Pl. Io, fig. 17, 18.

Stat. 66. Bank between islands of Bahuluwang and Tambolungan. 8-io MI. I Spec.

Stat. 30I. Pepela-bay, East coast of Rotti-island. 22 M. Lithothamnion-bottom. I Spec.

Both specimens though young and broken, are recognizable by the characteristic contour and sculpture. 
2. Clanculus atropurpureus Gould.

Gould. Proc. Bost. Soc. Nat. Hist. Vol. III, p. 107.

Kiener. Coq. Viv. Vol. X, Trochus, p. 239, P1. 82, fig. 2 (samoensis).

Pilsbry. Man. of Conch. Vol. XI, p. 77, Pl. I 5, fig. 50, 5 I; Pl. 11, fig. 28-32; Pl. 13, fig. 86, 87.

Stat. 6o. Haingsisi, Island Samau. Reef. I Spec.

The only specimen is very dark in the interstices of the lirae, which are yellowish-brown. Hedley (Proc. Linn. Soc. N. S. Wales, 1902, p. I6) suggests, that C. atropurpureus GId. and C. samoensis Hombr. \& Jacq., should be the same as $C$. denticulatus Gray. As he says however "a p pear to be synonyms", I have left Gould's name to the species in question. It seems to be rather variable in colour.

\section{Monodonta Lamarck.}

I. Monodonta (s. str.) labio Linné.

Linné. Syst. Nat. Ed. X, p. 759.

Rumph. Amb. Rariteitkamer, p. 75, Pl. 2I, fig. E.

Kiener. Coq. Viv. Vol. X, Trochus, p. 223, Pl. 73, fig. I, Pl. 74, fig. 4.

Pilsbry. Man. of Conch. Vol. XI, p. 86, Pl. I9, fig. 95, 96.

Stat. 19. Bay of Labuan Tring, West coast of Lombok. i8 -27 M. Coralsand. 3 Spec.

Stat. 47. Bay of Bima, near south fort. Shore. I Spec.

Stat. 50. Bay of Badjo, West coast of Flores. Up to 40 M. Sand. 4 Spec.

Stat. 51. Madura-bay. Shore. I Spec.

Stat. 64. Kambaragi-bay, Tanah-Djampeah. Up to 32 M. Coralsand. 3 Spec.

Stat. 86. Dongala, Palos-bay, Celebes. Shore. I Spec.

Stat. $9^{8} .6^{\circ} 9^{\prime}$ N., $120^{\circ} 21^{\prime}$ E. 350 M. Sand. I Spec.

Stat. I3I. Beo, Karakelang-islands. Reef. 2 Spec.

Stat. 277. Kulewatti-bay, Dammer-island. 45 M. Sand. 2 Spec.

The specimens vary much in colour and coarseness of sculpture. The great depth on which the specimen from Stat. 98 has been dredged, may be due to its being an empty shell, which will have sunken to the bottom.

2. Monodonta (s. str.) canalifera Lamarck.

LAMarcK. An. s. vert. Ed. Desh. Vol. 9, p. 177.

Kiener. Coq. Viv. Vol. X, Trochus, p. 225, P1. 73, fig. 2, 3.

PIlsbry. Man. of Conch. Vol. XI, p. 88, P1. 62, fig. 87 .

Stat. 51. Madura-bay. Shore. 4 Spec.

Stat. 64. Kambaragi-bay, Tanah-Djampeah. Up to 32 M. Coralsand. I Spec.

Stat. I65. N.E. side of Daram-island, East coast of Misool. 49 M. 5 Spec.

Stat. 277. Kulewatti-bay, Dammer-island. 45 M. Sand. I Spec.

The specimen from Stat. 64 is the largest, being considerably larger than the measurements given by Fischer and Pilsbry (Alt. 24, diam. 20 Mill.) and surpassing even those of Lamarck's shell (diam. is lignes), the Siboga-specimen measuring: Alt. 31, diam. 291/2 Mill. Its sculpture and painting is also coarser than in the specimens from the other Stations. 


\section{Chrysostoma Swainson.}

1. Chrysostoma paradoxum Born.

BorN. Test. Mus. Caes. Vindob. p. 349, P1. I 3, fig. 16, 17.

ReEve. Conch. Ic. Vol. XIII, Turbo, fig. 48 (nicobaricus).

Kiener. Coq. Viv. Vol. X, Turbo, p. 68, P1. 36, fig. 5 (nicobaricus).

Pilsbry. Man. of Conch. Vol. XI, p. 466, Vol. X, Pl. 45, fig. 91, 92.

Stat. 66. Bank between islands of Bahuluwang and Tambolungan. 8 M. I Spec.

Stat. 81. Pulu Sebangkatan, Borneo-bank. Reef. I Spec.

Stat. 240. Banda. 9-45 M. Lithothamnion-bottom. 2 Spec.

Stat. 258. Tual-anchorage, Key-islands. 22 M. Lithothamnion-bottom. I Spec.

Stat. 3I5. East of Sailus Besar, Paternoster-islands. Lithothamnion-bottom. I Spec.

Java. 2 Spec.

Troschel (Das Gebiss der Schnecken, II, p. 22 I, PI. 21, fig. 7) has described and figured with some doubt, the radula of this species, of which he had received the soft parts without the shell, from G. Nevill, and though he has recognized, that its place is not in the group Unbonizinae, he still left it in that company. He says that the radula more resembles that of Gibbula. Pilsbry (1. c.) says: "the radula has teeth considerably like Monodonta and Diloma, but still locates the genus in the Umboniinae. The radula of a specimen from Banda, examined by me, agrees with Trosches's figure and description, and thus no doubt about the correctness being left, I think the genus may be removed from that group. As PiLsbry (1.c. p. 6) places the species without a jaw in the subfamily Trochininae, those with a jaw in the Gibbulinae, and neither Troschel nor I have observed a jaw, it should be provisionally located in the subfamily Trochininae.

\section{Cantharidus Montfort.}

I. Cantharidus Giliberti Montrouzier. P1. IX, fig. 4.

Montrouzier. Journ. de Conch. 1878 , p. 207, I879, p. 33, Pl. III, fig. 7 (Trochus).

Kiener. Coq. Viv. Vol. X, Trochus, p. 401, Pl. i19, fig. 2.

Pilsbry. Man. of Conch. Vol. XI, p. 128, P1. 45, fig. 37,38 .

Stat. 37. Sailus Ketjil, Paternoster-islands. Up to 18 M. Coralsand. 3 Spec.

Stat. 43. Pulu Sarassa, Postillon-islands. Up to 36 M. Coral. 2 Spec.

Stat. 66. Bank between Bahuluwang and Tambolungan. 8-io M. 4 Spec.

Stat. 90. $1^{\circ} 17^{\circ} .5$ N., $118^{\circ} 53^{\prime}$ E. 28 I M. Coral and sand. I Spec.

Stat. I09. Sulu-Archipelago. I3 M. Lithothamnion-bottom. 2 Spec.

Stat. 315. Sailus Besar, Paternoster-islands. Up to $36 \mathrm{M}$. Lithothamnion-botton. I Spec.

Though the specimens from the mentioned localities, differ in some respects from the description, I think this may depend upon their juvenile state, the largest specimen having only an altitude of 9 Mill. instead of 13 , and 9 whorls instead of 12 , with I l lirae against $15-16$ in the original description, $15-18$ in Journ. Conch. I 879 . As however the specimens vary in this respect, and the other characters agree, I think it unnecessary to give them even a new varietal name. The colour is slightly variable, being more or less painted with white. The top-whorls are in a few specimens painted with coral-red. 
The operculum is very thin, light yellow, with about $\mathrm{I} 2$ whorls, which under the microscope show fine radiating and spiral striae, which by their intercrossing, give a somewhat beaded appearance to the outer surface.

The animal has a brown mufle, the tentacles are moderately long, whitish, articulated with brown, the eyes black, with white rings. I see two cirri on each side of the epipodial line, but their number may have been larger, as the end of the foot has been lost.

The rhachidian tooth $(R)$ has an elongated triangular body, with a small tricuspid cusp; the first (I), second (2) and third (3) laterals, have also elongated bodies and a cusp with a larger denticle, and smaller ones at the proximal and distal sides, one or two on the proximal side, depending perhaps on the position of the tooth, and invariably two on the distal side; the fourth (4) and fifth (5) have one denticle on the proximal side; the fourth two, the fifth three denticles on the distal side, their bodies are quadrangular. Of the numerous uncini the outer ones have two denticles, the other seem to have but one; these become smaller towards the margin of the radula, those of the median part, on the contrary, become larger from the centre towards the uncini. Number of rows about $3 \hat{3}$.

\section{Cantharidus articuluris Adanıs.}

A. Adans. Proc. Zool. Soc. Lond. 1851, p. 170.

PILSbRy. Man. of Conch. Vol. XI, p. 150.

Stat. Iog. Pulu Tongkil, Sulu-Archipelago. 23 M. Lithothamnion-bottom. I Spec.

Unfortunately the only specimen is a small, dead shell, not fit for figuring, the peripheral lirae of each whorl are slightly prominent and striated, the base has about seven lirae besides a few intermediate ones.

3. Cantharidus (Thalotia) elongatus Wood.

WooD. Ind. Test. Suppl. Pl. 5, fig. 19.

Kiener. Coq. Viv. Trochus, p. 28I, Pl. 92, fig. I.

PILSBRy. Man. of Conch. Vol. XI, p. I43, Pl. 45, fig. 56.

Stat. 8I. Pulu Sebangkatan, Borneo-bank. 34 M. Lithothamnion-bottom. I Spec.

Stat. 240. Banda. 9-45 M. Lithothamnion-bottom. 2 Spec.

Stat. 282. Between Nusa Besi and N.E. point of Timor. 27-54 M. Lithothamnion-bottom. 2 Spec.

Stat. 31 5. East of Sailus Besar, Paternoster-islands. Up to 36 M. Lithothamnion-bottom. I Spec.

Only the specimen from Stat. $8 \mathrm{I}$ is adult, the largest of the remaining 5 specimens having only a length of $\mathrm{I}_{3}$ Mill.

\section{Cantharidus (Thalotia) polychroma Adams.}

A. Adal1s. Proc. Zool. Soc. Lond. i851, p. 168 (Zizyphinuls).

ReEve. Conch. Ic. Vol. XIV, Zizyphinus, fig. 40.

Pilsbry. Man. of Conch. Vol. XI, (Calliostoma), p. 356, Pl. I7, fig. $3 \mathrm{I}$.

Stat. 215. I300 M. from N. point of Kabia-island. Reef. I Spec. 
As the columella of this species is slightly thickened in the middle, I have located it in Cantharidus. I see eleven striae on the last whorl, the uppermost and lower two, border slightly prominent lirae. Base with about 10 lirae, convex.

\section{Cantharidus (Thalotia) maldivensis Smith.}

Siith. The Fauna and Geography of the Maldive and Laccadive Archip. Vol. II, part 2. Marine Mollusca, p. 617, Pl. 35, fig. 25, 26.

Stat. 37. Sailus Ketjil, Paternoster-islands. 18 and 17 M. Coralsand. 5 Spec.

Stat. 99. North-Ubian. I6-23 M. Lithothamnion-bottom. I Spec.

Stat. Iog. Pulu Tongkil, Sulu-Archipelago. 13 M. Lithothamnion-bottom. 5 Spec.

Stat. I33. Lirung; Salibabu-island. 36 M. Hard sand. I Spec.

Stat. 240. Banda. 9-45 M. Lithothamnion-bottom. 3 Spec.

E. A. Surth has described (1. c.) two colour-varieties. The specimens of the Siboga Expedition show a larger range of variability. Some specimens are nearly typical, others are typical in painting, but with white flames on a purple ground, or of a uniform green, shaded with yellow, with or without the spotted band at the base of each whorl. In most specimens the colour is mixed with yellow granules, and sometimes also with nearly black ones. The largest specimen, from Stat. 99 has a length of $12^{1} / 2$ Mill. and slightly coarser sculpture. Besides the sculpture described by Sмiтh, I observed still another system of sculpture, visible only under the lens; between the rows of granules, are a ferw fine, spiral, elevated striae, $I$ to 3 in each interstice of the last whorl, crossed by oblique, slightly lamellose striae. On the base of the shell I observed also one distinct, and often $\mathrm{I}$ or 2 very small intermediate lirae, and also less crowded oblique striae.

\section{Cantharidus (Thalotia) pliciferus n. sp. PI. III, fig. 3 .}

Stat. 109. Pulu Tongkil, Sulu-Archipelago. I3 M. Lithothamnion-bottom. I Spec.

Shell conical, with a rather elevated spire and convex base, angular at the periphery, imperforate. Whorls 6 , slightly convex, upper 3 whorls white, the fourth rosy, turning to crimson on the fifth; last whorl whitish, rather regularly ornamented by brown blotches in 5 spiral rows, angle or keel articulated with white and black, base with 6 rows of blackish-brown blotches. Embryonic whorls wanting at least for a large part; first persisting whorl, smooth at first, then with 4 spiral lirae, with narrow interstices, which are punctured; on the fourth whorl radiating ribs make their appearance, running from suture to suture, and making the upper edge of this and the subsequent whorls crenulated near the suture, which is very deep and waved at the base of each whorl, by the bluntly ending ribs. On the last whorl, the ribs are nearly white, especially towards the periphery, this whorl and the penultimate one have 5 spiral lirae exclusive of the peripheral keel. Base with 6 spirals of which that near the columella is uniformly white, like the ground-colour of the base, the other ones have the blackish spots; their interstices are broad, with slightly scaly striae; moreover the whole shell in covered with very fine growthstriae, visible only under a strong lens. Aperture subquadrate, outer and basal margins thin, 
curved; columella rather straight, truncated at the base and with a toothlike tubercle about halfivay its length, it forms a distinct angle at its junction with the basal margin.

Alt. 10, diam. maj. 9; apert. alt. $4^{3 /}$, lat. $4^{1 / 2}$ Mill.

Though the only specimen has a somewhat juvenile appearance, it is so much different from the described species known to me, that I thought it desirable to describe it; the most salient characters are: the diversity of colours, being white-, crimson- and black-blotched on the same shell, and the ribs which are especially conspicuous towards the keel.

\section{Monilea Swairson.}

1. Monilica calyculus Wood. Pl. IX, fig. 5 .

IVOod. Ind. Test. Suppl. I'l. 6, fig. 44.

Nevilu. Journ. Asiatic Soc. Bengal, 1874, p. 28, Pl. I, fig. I (Alasoni).

SMrTir. I'roc. Zool. Soc. Lond. is78, p. Sis.

I'Ilsbrr. Man. of Conch. Vol. NI, p. 247 and 470, Pl. 4l, fig. 14, is.

Stat. 37. Sailus Ketjil, Patemoster-islands. Up to 18 M. Coralsand. I Spec.

Stat. 133. Lirung, Salibabu-island. 36 M. Hard sand. 2 Spec.

Stat. 240. Banda. 9-36 M. Lithothamnion-bottom. 4 Spec.

Stat. 313. East of Dangar Besar, Saleh-bay. Up to 36 M. Sand. 6 Spec.

Some controversy has existed about the specific value of this form; many authors unite it with $M$. callifora Lam. So Pulsbry (1. c.) declared it a synonym on page 247 , and as doubtless distinct on page 470 . I think, after comparing several specinens of both forms, that Pilsbry is right in his last opinion. Both species though very variable in colour and painting, seem to be considerably different in shape and sculpture.

Operculum thin, light brown, with few (about 6) whorls, very concave exteriorly, shining and very convex on the inner side.

The radula has a very delicate appearance, the three median teeth being very pellucid. The rhachidian tooth $(R)$ has a broad, triangular body, with convex sides, the cusps of this and of the first laterals are rery inconspicuous, and have more the appearance of a thickening of the margin, than of a real cusp; the body of the first lateral ( $\mathrm{I}$ ) resembles one half of the rhachidian tooth, that of the second lateral (2) is slightly more oblong; the third (3), fourth (4) and fifth (5) are quite oblong, this last has at its distal upper corner a small auricle. The uncini (U) have conspicuous cusps on long bodies, and a small denticle at their distal margin, their shape however is not easy to be made out, on account of their standing so crowded; their number is more than 100 on each side.

\section{Monila celibinsis n. sp. Pl. II, fig. 10 .}

Stat. 7 I. Makassar and surroundings. 27-32 MI. 1 Spec.

Shell small, depressed-conoidal, with about 6 angular whorls; nucleus smooth, followed by 2 whorls, each with 2 spiral lirae, of which the uppermost, standing about midway the whorl, is more prominent and renders the whorls angular, these whorls being flattened towards the suture, 
on the second post-nuclear whorl, a third spiral appears near the suture, on the penultimate whorl the number of lirae is four, of which 2 strong ones on the basal, 2 smaller ones on the upper half; last whorl with 9 lirae on the upper surface and about io on the base, often but not regularly, they are alternately stronger and weaker. The whole shell is crossed by conspicuous growth-lines, rendering the lirae more or less beaded. The colour is yellowish-white, with interrupted, blackish-brown flammules and a lighter zone above the periphery; the base is nearly covered by the darker colour. Umbilicus moderately wide, radiately striated interiorly, with a conspicuous funicle and a very slight second one near the margin, which is bordered by the last of the lirae, which is strong and conspicuously beaded. Aperture almost rhombic, outer and basal margin thin, thickened in the interior, the outer one internally with 5 strong lirae, the basal with 4 slightly elongated teeth, columellar margin excavated, upper end appressed to the body-whorl, its margin slightly reflected, its basal end with two small denticles, corresponding to the grooves under the umbilical funicles.

Diam. maj. $5^{3} / 1$, alt. $4^{1} / 2$; apert. alt. 2 , lat. $2^{1 / 2}$, diam. of umbilicus $1^{1} /$, Mill.

I should have hesitated to describe this species as new, were it not that Mr. E. A. Simin has compared it with the collection of the British Museum, where many of the types of the numerous unfigured species of ADAMs and Gould are preserved. It is remarkable by its angular whorls; it calls in mind many species of the genus Minolia, but the conspicuous funicle has induced me to describe it as a Monilea.

\section{Monilea (Rossiteria) nuclea Philippi.}

Philippi. Zeitschr. f. Malak. I849, p. 171 (Trochus).

-_ Mart.-Chemn. Conch. Cab. Ed. II, Trochus, p. 306, Pl. 44, fig. 9.

Kiener. Coq. Viv. Vol. X, Trochus, p. 256, Pl. 86, fig. 2.

Pilsbry. Man. of Conch. Vol. XI, p. 257, Pl. 6i, fig. 31 , 32.

Stat. 240. Banda. 9-36 M. Lithothanmion-bottom. 6 Spec.

Stat. 248. Ruma Lusi, North point of Tiur-island. 36 M. I Spec.

As stated in the descriptions, this species is very variable in colour, and in the Siboga specimens also in coarseness of sculpture. A peculiarity not mentioned in the descriptions at my disposal, is that the outer margin of the shell has a conspicuous sinus below the periphery; as however the margin is often broken, this may account for the fact, that most observers have overlooked this peculiarity, which is often more clearly seen in former striae of growth.

\section{Priotrochus Fischer.}

I. Priotrochus (?) incertus n. sp. Pl. II, fig. 4.

Stat. 59. Western entrance, Samau-strait. 390 II. Coarse coralsand. I Spec.

Shell conical, with convex base, imperforate, yellowish-white. Whorls 6, convex, separated by a deep suture, which is waved by the ends of the ribs. Nucleus smooth, the other whorls with strong ribs, of which there are 12 on the last whorl, they are crossed on the lower whorls by 2 spiral cords, producing tubercles on the ribs, these ribs extend on the base till the first 
infraperipheral cord. Base convex, with 5 spiral lirae; the whole shell is covered with microscopic, oblong punctures. Aperture nearly circular, the outer and basal margin regularly curved, thin, slightly thickened interiorly. Columella nearly straight, with an inconspicuous tubercle about halfway, near the base with a rounded angle. Inside of aperture nacreous.

Alt. $4 \frac{1}{2}$, diam. maj. $3^{3} / 4$; apert. alt. 2, lat. $5^{3} / 4$ Mill.

It is with much doubt, and chiefly on the authority of Mr. E. A. Simth, who writes that he is also uncertain on this point, that I have located this species in the genus Priotrochus, the shape of the columella calls in mind some species of Thalotia and MIonodonta. Only fresh specimens can clear up its true position.

Minolia Adams.

I. Minolia ornatissina n. sp. PI. III, figs $4,4 a ;$ Pl. IX, fig. 6.

Stat. I8r. Amboina. 54 M. Sand. I Spec.

Stat. 193. Sanana-bay, E. coast of Sula-Besi. Reef. I Spec.

Stat. 213. Saleyer. 9-36 M. I Spec.

Stat. $260.2,3$ Miles N. $63^{\circ}$ W. from North point of Nusa Jaan, Kei-islands. 90 M. Sand. 2 Spec. Stat. 26I. Elat, West coast of Great Kei-island. 27 M. Mud. I Spec.

Shell depressed, with low conoidal spire, broadly umbilicate, thick, greenish-yellow, topwhorls and a band round the umbilicus brown, lower whorls with a row of large brown blotches at the suture, last whorl at the periphery with a zone, articulated by oblong brown squares, alternating with yellow spaces, upper and lower surface more or less distinctly variegated with brown flames and spiral dots of the same colour. Whorls $5^{1 / 2}$ separated by an impressed suture, rather convex and slightly angular by the projection of one of the numerous lirae, these number about 6 on the penultimate whorl, and 7 on the upper part of the last whorl, besides several intermediate, elevated striae, which become very numerous towards the aperture; last whorl angular at the periphery, its convex base with numerous, crowded, elevated striae (partly wanting in a few specimens); the whole surface of the shell is covered with radial striae, crossing the lirae and giving them a beaded appearance, especially near the suture and the umbilicus, where they form regular folds. Umbilicus pervious, funnel-shaped, its wall with flat spiral lirae, crossed by much more crowded, radial, elevated striae, separated by a conspicuous angle from the basal surface. Aperture subquadrate, its upper margin slightly curved, but less so than the basal one, columellar margin nearly straight, joining the basal margin with an angle, at the end of the umbilical angle, slightly crenulated by the umbilical lirae; the margins are connected by a thin nacreous layer; interior of the aperture nacreous, smooth, slightly thickened near the margins.

Diam. maj. 6, alt. 5 , apert. alt. $2^{1} / 2$, lat. 2, diam. of umbilicus $2 \frac{1}{6}$ Mill.

Operculum of a not quite adult specimen very thin, yellowish, concave exteriorly, with many whorls, each whorl spirally striate near its proximal margin, then follows a zone sculptured only by the growth-striae, the distal margin has conspicuous radiant striae, giving to that margin a fringed appearance. The species varies in painting, some specimens, though fresh, being much less marked with brown, the markings wanting nearly entirely in the specimen from Stat. 26r, 
which has a still thicker shell and a purplish hue near the aperture, but sufficiently agrees in every other respect, to be nothing more than an individual variation.

Minolia omatissima seems to be allied to $M$. tasmanica $T$. Woods and $T$. eudeli Desh. but differs in colour, in particulars of a sculpture and especially in the umbilical angle, which is surrounded by a brown zone, not mentioned in the allied species. The radula agrees in many respects with that of Minolia vitiliginea Mke. as figured by Troschel (Gebiss der Schnecken, Band II, Pl. 25, fig. 24). The rhachidian tooth (R) is subquadrate, without reflected margin, the upper corners are rounded, the lower ones angular, the upper margin is slightly pointed in the centre. At the first lateral (I) I can detect no reflected margin, but the proximal upper corner, which is slightly pointed, and the proximal margin are thickened, the shape is oblong; the second (2) and third laterals are similar, the fourth one is simple, the fifth (5) has a very complicate structure, which could not well be traced, by its being covered by the adjacent teeth. The uncini are elongated, with simple cusps, at least I could discover no smaller denticles at their sides. This radula at once separates the species from the genus Solariella, to which it might be referred on account of its conchological characters.

\section{Minolia sp.}

Stat. 37. Sailus Ketjil, Paternoster-islands. Up to 28 M. Coralsand. I Spec.

The specimen is young and not taken alive. I can not identify it with any species I know, but it is in too poor condition for description.

\section{Minolia sp.}

Stat. 258. Tual-anchorage, Kei-islands. 22 M. Lithothamnion-bottom. I Spec.

The specimen is in still worse condition than the preceding one.

\section{Solariella S. Wood.}

1. Solariella olivaceostrigata n. sp. Pl. III, fig. 5 ; Pl. IX, fig. 7 .

Stat. $95.5^{\circ} 34^{\prime} .5$ N., $119^{\circ} 40^{\prime}$ E. 522 M. Stony bottom. 4 Spec.

Stat. 100. $6^{\circ} 1^{\prime}$ N., $120^{\circ} 37^{\prime} .5$ E. 450 M. Dead coral. I Spec.

Shell depressed-conoidal, rather thin, upper whorls nacreous, with a very beautiful purple and green tinge, last whorls whitish, adorned on the upper surface by rather broad, olivaceous streaks. Whorls 6 , the nucleus smooth, followed by a $2^{\mathrm{d}}$ and $3^{\mathrm{d}}$ whorl, each with 6 spiral lirae of which the upper ones are slightly undulate, on the fourth whorl the lirae disappear, only the upper one remains and becomes beaded, it borders the broadly canaliculated suture, which in this and in the fifth whorl, is crossed by conspicuous striae, which run partly also on the convex, smooth, lower part of these whorls; near the last whorl the beads disappear, the suture becomes less broad and deep. This last whorl is nearly smooth, except for most tender spiral and radiating striae, only visible under a strong lens, and a few remote deeper striae near the suture, being 
the continuation of the beads; it is strongly depressed, more convex above than below, with a blunt angle, but no keel. The umbilicus is funnel-shaped, moderately wide, pervious, its walls are smooth, with only a few growth-striae, it is bordered by a spiral ridge, which is indistinctly beaded. Aperture rounded-triangular, the upper and basal margins regularly rounded, the upper one being more curved. Columellar margin nearly straight, slightly expanded at its upper end above the umbilicus, thickened below and forming a distinct angle with the basal margin, largely due to the ending of the umbilical ridge. Interior of aperture strongly iridescent. Operculum thin, corneous, with many whorls (about Io), outer surface hollow, with irregular, radiating striae, which are more numerous and regular near the sutural line, inner surface convex, and very smooth.

Alt. $9^{1} / 2$, diam. maj. $\mathrm{I}^{1} / 2$, apert. alt. 6 , lat. $4^{1 / 2}$ Mill.

This species, by its smoothness, may be considered as an intermediate form between the sculptured species without special colour and S. zacallus Melv. and allies, it is still much more conical and the umbilicus is much narrower (only 2 Mill.) than in those species.

As an exception the state of preservation of the soft parts was insufficient, however I was able to study the radula and maxillae. These last consist of triangular plates, with rounded angles, dark brown towards the free margin, with a fibrous texture, which disappears towards the posterior margin.

The radula has about 26 rows of teeth and 7 median rows, with a large number of uncini. The rhachidian tooth (R) has a subquadrate body with winged sides and a long triangular cusp with convex sides, which are serrated, the body of the first lateral ( $\mathrm{I}$ ) is nearly quadrate, with a broad triangular cusp, serrated on the distal and part of the proximal margin, the second lateral (2) is oblong and serrated like the first one, the third (3) has a quadrangular body, with a simple cusp, the fourth lateral is very large, its body irregular, its cusp long, serrated on both sides, but this is only visible on the upper side in its normal position; the uncini (U), the number of which I cannot ascertain, are long, slender, and apparently smooth, though in some of them, a few very small denticles are present, but they are only visible in an expanded position. The bodies of the median teeth are brown especially towards the centre.

\section{Solariella zacalloides n. sp. P1. III, fig. 6 .}

Stat. 204. Between islands of Wowoni and Buton. 75-94 M. Sand with dead shells. II Spec.

Shell depressed, slightly conical, rather thin, upper surface yellowish-white, with ziczac-lines and blotches of yellowish-brown, forming more or less distinct bands, of which one, consisting of triangular white spots and very small blotches, borders the suture, a peripheral band distinctly articulated with white and brown and an intermediate band of more arrow-headed blotches; the interstices are filled by the yellowish-brown lines, which are often confluent, leaving only small whitish spots; basal surface lighter, with scarce markings, of which a band of blotches, bordering the umbilicus, is the most conspicuous; whorls about 5 ; nucleus smooth, the next two whorls with a few (3 or 4) lirae, which are slightly irregular, the upper one is beaded; the lirae become less distinct, being broader and flatter on the next whorl, and are transferred in distant striae with smooth interstices; the infrasutural beads, cease on the penultimate whorl; besides this 
sculpture, the whole shell has a smooth, shining appearance, with very fine lines of growth, the last whorl having only a few spiral striae near the periphery. The whorls are slightly convex, the last one is a little depressed and much enlarged, but has no keel; basal surface smooth, with fine lines of growth and short, radiating striae round the umbilicus, which is large, pervious, funnel-shaped, sculptured with lines of growth and about 9 spiral lirae. Aperture subcircular, slightly angular above, compressed near the periphery, outer margin thin, columellar margin sinuous, thickened, slightly reflected above, runining without appreciable angle into the basal margin. Interior of the aperture nacreous.

Alt. 6, diam. maj. $10^{1} / 2$, apert. alt. 3, lat. 4, diam. of umbilicus 3 Mill.

This species varies only slightly in painting, the ziczac-lines being more or less numerous and the bands more or less distinct, the blotches are often very distinct, but sometimes obvious towards the aperture.

S. zacalloides has been named on account of its very near relationship to S. zacalles Melv. (Ann. Mag. Nat. Hist. Ser. 7, Vol. XII, I 903, p. 295, P1. 20, fig. 1 2), indeed it might be considered with nearly the same right, as a variety of that species. Melvilu had the kindness to send me his only specimen for comparison, and at the first view it seemed to be identical. A close examination however, has shown the following differences: the new species is larger (diam. maj. IO $\frac{1}{2}$ instead of 9 Mill.) thicker, less conical, the last whorl is broader in proportion, its diameter being $2 / 5$ of that of the whole shell, being only $1 / 3$ in S. zacalles, consequently the aperture is less rounded. The embryonic and postembryonic whorls are more depressed, they are provided with a more obvious depression near the suture. The granules near the suture are less sharp, the concentric striae shallower, on the penultimate whorl these striae extend in zacalles upwards to the beads, in zacalloides there remains a smooth zone between the upper groove and the beads. The colour is not reddish-brown (except in 2 specimens, probably on account of a rusty box), the bands are more distant. The base in zacalles has conspicuous brown flames, in zacalloides the design consists of a fine network, with a more or less conspicuous white zone and often a band of darker blotches around the umbilicus. The radiating sulci round the umbilicus, are less. developed, especially towards the aperture, and are more crowded. The lirae in the umbilicus are not beaded as in zacalles, but nearly smooth, the grooves less impressed.

S. zacalloides, forms with zacalles Melv., laevissima Martens, Minolia congener Sow. and some other allied species, a group of smooth, coloured species of Solariella. According to the radula it is not doubtful that they belong in part, and probably all to that genus.

3. Solariella mutabilis n. sp. Pl. III, fig. 7 ; Pl. IX, fig. 8 .

Stat. 59. Western entrance, Samau-strait. 390 M. Coarse coralsand with small stones. 6 Spec.

Stat. $95.5^{\circ} 43^{\prime} .5$ N., $119^{\circ} 40^{\prime}$ E. 522 M. Stony bottom. 4 Spec.

Stat. 159. $0^{\circ} 59^{\prime} .1$ S., $129^{\circ} 48^{\prime} .8$ E. 4 I I M. Coarse sand. I Spec.

Stat. $253.5^{\circ} 48^{\prime} .2$ S., $132^{\circ} 13^{\prime}$ E. 304 M. Grey clay, hard and crumbly. 1 Spec.

Stat. $260.2,3$ miles N. $63^{\circ}$ W. from N. point of Nusa Jaan, Kei-islands. 90 M. Sand, corals and shells. I Spec.

Shell trochiform, moderately strong, yellowish, with a rose coloured zone on the upper part of the lower whorls, upper ones nacreous. Whorls $5^{1 /}$; nucleus smooth, followed by a 
whorl with 4 or 5 raised striae, and by about four ones provided with two distinct keels, of which one, at a little distance from the suture, the other at the periphery, accompanied on the last whorl by a third keel, at a little distance from the periphery, nearly on the base; these three keels are in typical specimens adorned by sharp nodules, about 30 on the upper keel, 38 on the peripheral one, and 34 on the visible part of the lower one; moreover there are 2 raised spiral striae between suture and upper keel, 5 between this and the peripheral one and 2 in the space between periphery and lower keel. This concerns the last whorl; on the upper ones, the finer sculpture disappears gradually. Umbilicus bordered by a row of coarse, compressed beads, 17 in number; space between basal and umbilical keel with 5 smooth lirae. The lower whorls have a distinct, nearly horizontal space, from the suture towards the upper keel, with small, radiating plicae, corresponding to the nodules, the spaces above and below the peripheral keel are slightly concave, the suture laying by this construction in a sort of canal. Base nearly flat, but slightly convex. Umbilicus funnel-shaped, rather large, pervious, its wall with raised, concentric and radiating striae, more or less beaded; aperture rounded-quadrangular, with angles at the ends of the keels, especially of the umbilical one; margin sharp, columella curved and slightly reflected at the upper part; interior of aperture smooth, nacreous.

Operculum many-whorled, outer 2 whorls broad; whorls sculptured by radiating and concentric striae, causing a latticed appearance, radiating striae stronger on the distal half of each whorl. Alt. $4^{3} / 4$, diam. maj. $5^{4} / 5$, apert. alt. 2 , lat. $2^{1} / 6$; diam. of umbilicus $2^{1} / 2$ Mill.

This description is made from a specimen, which I consider as the type, as it shows the characters in their full development. As however the name indicates, there are many varieties or mutations. The variations of colour consist of the greater or lesser development of the rosy colour, which is either limited to the last whorl or extends on the penultimate, even still on preceding whorls, this colour is plain, or with a tendency to form flammules, a more important difference consists in the more or less complete disappearance of the nodules on the lower keels, which seems to coincide with the sharper sculpture of the interior of the umbilicus. I have separated such specimens as:

var. laevior n. var. P1. III, fig. $7 a$.

Shell with the peripheral and infraperipheral keel quite or nearly smooth (in one instance also the upper keel), sculpture of the umbilicus more conspicuous.

The specimen from Stat. 260 is quite intermediate, the nodules being present on the peripheral and infrasutural keels, I have distinguished it as forma intermedia. The finer sculpture of the upper part of the whorls and of the base, varies also in some degree, this last one so much, that it is nearly but never quite smooth. I have with much doubt, united with var. laevior, a specimen from Stat. 59, with more rounded, less deeply separated upper whorls; as it is however not in good condition, I think it ought not to be named separately.

A young specimen of $4 \frac{1}{2}$ whorls from Stat. 253 , is distinguished by its pronounced sculpture, the lower whorls being crossed by plications, as however traces of plicae are present on other specimens, there is no reason for separating it specifically, it may however be separated as a variety under the name of: 
var. plicifera n. var. Pl. III, fig. 76 .

Shell with radiating plicae, corresponding to the nodules, and with a conspicuous raised line below the infrasutural keel, and between the peripheral and infraperipheral keels, and below this last.

The radula has a rhachidian tooth $(R)$ with a quadrangular body, the basal corners are much wider apart, than the upper ones, the sides being expanded, the basal margin is rounded, the cusp triangular, with about 4 denticles on each side of the median cusp; the body of the first (1) and second (2) laterals are subquadrate, the cusp of the first, with about 6 , of the second, with about 9 denticles, the third lateral (3) is broader and has a simple cusp. The fourth (4) is elongated, with serrated edges, the fifth tooth (5) is quadrangular without distinct cusp, the uncini are long, slender and simple, they cover the fifth lateral, which may exist in many other species.

The nearest ally of this species is S. infralaevis v. Martens (Die beschalten Gastropoden der deutschen Tiefsee-Expedition, $1898-99$, P. I 23 , Pl. IV, fig. 21 ) but that species is "margaritacea, anicolor", mutabilis partly rose-coloured; infralaevis is smooth in the interstices of the keels and on the base, the umbilicus is much smaller than in mutabilis, and has smooth walls, the canal at the suture, not mentioned in the diagnose, is much narrower.

\section{Solariella marginata n. sp. P1. III, fig. 8.}

Stat. 102. $6^{\circ} 4^{\prime} .1$ N., $120^{\circ} 44^{\prime}$ E. 535 M. Fine, yellow sand. I Spec.

Shell depressedly-conoidal, smooth, shining, grey, umbilicate. The only specimen, which is slightly broken, has $4^{1} / 2$ whorls. Nucleus smooth, followed by about 2 whorls, sculptured by spiral lirae, 6 in number on the third whorl, these lirae become fainter on the fifth whorl, where they are crossed by concentric ribs, beaded where they cross the lirae; last whorl smooth, with microscopic growth-striae, angular at the periphery; near the suture runs a flat cord, which is crenulated by short plicae, about 25 in number; base slightly convex, smooth, with strong radiating plicae round the umbilicus, each with a separate bead bordering the umbilicus, which is moderately wide, funnel-shaped, pervious, with fine spiral lirae and concentric plicae, crossing and interrupting them. Aperture broken, subtriangular, with convex upper and basal margins, columella rather straight, with a conspicuous angle near the basal margin.

Alt. $4 \frac{1}{2}$, diam. maj. probably about $6 \frac{1}{2}$ Mill.

This species is evidently allied to S. biradiatula v. Martens (Die beschalten Gastropoden der deutsch. Tiefsee-Exp. I $898-99$, p. I23, Pl. V, fig. 3), but may be easily distinguished by the sculpture of the upper whorls, and the beads of the plicae, bordering the umbilicus; these plicae are stronger and longer.

\section{Subg. Ethaliopsis n. subg.}

Shell depressed-conical, beaded near the suture, polished, umbilicus partly or entirely covered by a callus. Operculum horny, with numerous narrow whorls. 
5. Solariella (Ethaliopsis) callomphala n. sp. Pl. IV, fig. 1, I a; Pl. IX, fig. 9.

Stat. 59. Western entrance of Samau-strait. 390 M. Coarse coralsand with small stones. 3 Spec.

Stat. $95.5^{\circ} 43^{\prime} .5$ N., I I $9^{\circ} 40^{\prime}$ E. 522 M. Stony bottom. I Spec.

Stat. $98.6^{\circ} 9^{\prime}$ N., $120^{\circ} 21^{\prime}$ E. 350 M. Sand. I Spec.

Stat. I00. $6^{\circ}$ I $1^{\prime}$ N., $120^{\circ} 37^{\prime} .5$ E. 450 M. Dead coral. 3 Spec.

Shell depressed-conical, polished, nacreous, with a thin, pellucid, white, external layer and often a yellow line below the suture. Whorls 4 to 5 , nucleus smooth, subsequent 2 whorls microscopically spirally striate, crossed by weaker growth-striae, last $2 \frac{1}{2}$ whorls smooth, with only very faint traces of growth-striae and spiral striae, but with a row of oval beads, just below the conspicuous suture, periphery rounded; base nearly flat, impressed near the centre, which is more or less filled by a thick callus, which is white, with radiating striae on its external margin, granular near the columellar margin, and is ornamented there, with 4 or 5 granules. The base of the shell round the callus, is likewise provided with radiating grooves. Aperture subtriangularly rounded, very oblique, outer margin thin, slightly thickened interiorly, columellar margin thickened, its upper end pressed to the body-whorl, with a thin layer connecting the margins.

Operculum as described above, externally concave, yellow.

Varying in altitude of the shell, in the presence or absence of the yellow subsutural line and especially in the characters of the umbilicus, which is either closed, or more or less open. This is not dependent on age; for of the three specimens from Stat. 59, the largest and smallest specimens have it open, the intermediate one quite closed. In those from Stat. 100, it is quite closed or leaves perhaps a nearly imperceptible chink, in the specimen from Stat. 95, a conspicuous slit remains, that from Stat. $9^{8}$ is closed.

The shell, most resembling this species is Unbonizun bairdii Dall ("Blake" Gastropoda p. 359, P1. 21, fig. 6), but that species is less depressed, the beads are stronger, no mention is made of spiral sculpture on the post-nuclear whorls, nor of radiating sculpture on and around the callus, or of granules on the columellar margin. I think these characters would not be overlooked by such an exact observer as DALL, and so I may conclude to its specific distinction.

If I had not examined the radula, I certainly should have.located this species in the genus Ethatia, but the radula is quite of the same type, as that of the other species of Solariclla. It is short, with a rather restricted number of uncini, and the shape of the teeth agrees with that of the known species. The rhachidian tooth $(\mathrm{R})$ has a subquadrate body, narrower in front, with concave upper and convex basal margin, its cusp is large, longer than the base, with about 4 to 6 denticles on each side of the median denticle, the first lateral (1) has a subquadrate body, its cusp has very small denticles. at its proximal, more conspicuous ones at its distal margin, the second lateral (2) has a similar body, with larger cusp and more numerous denticles at its distal margin; the body of the third lateral (3) is elongate, with a moderate cusp and only a few denticles, the fourth (4) has a very large cusp, with about ro small denticles and a rhombic body, moreover I see a fifth lateral (5) without cusp, as described before in S. mutabilis. Perhaps this tooth exists in many or in all the species, but it is so much covered by the other teeth in their normal position, that it may be easily overlooked. The uncini are not very numerous, and as far as I can see, they have simple cusps. Except the callus this species resembles 
S. zacalles Melv. and $S$. sacalloides Schepm. but the callus at once distinguishes it from all the species described as Solariella.

\section{Solariellopsis n. g.}

Shell resembling Solariella, but differing in the radula, which is longer, with a larger number of uncini. Teeth of the median part less denticulated. In "Die beschalten Gastropoden der deutschen Tiefsee-Expedition, i $898-99$ " Prof. v. MARTens has (p. 124-i 27 ) described two species "patula" and "aethiopica" under the generic name of Basilissa, and located two other forms $B$. ottoi Phil, and var. Chuni in the same genus, on account of resemblance with B. patula, with the type of the genus: $B$. lampra Watson, and Dr. TH1ele (1.c. p. I 61 ) has described the radula. At my request Prof. H. M. Gwatkin of Cambridge, had the kindness to send me for comparison, the radula of a specimen of the typical species ( $B$. lampra), from the same lot that served for the description in the "Challenger" report; which proved to be of so different structure, as will be described in treating on that genus, that it is impossible, if one lays any systematic value on the characters of the radula, to keep these species in the same genus. It may be very difficult to find conchological characters to separate them, unless all the species resembling $S$. aethiopica, prove to belong to the new genus. A separation will be only possible, if the radulae of a much larger number of species have been examined. v. Marters (1. c. p. 123) has observed that the characteristic sinus of the outer margin is conspicuous in B. patula, much less in B. aethiopica and wants in $B$. ottoi; in the figure (1.c. pl. 4 , fig. 17 ) this is not visible, as v. Martexs says, on account of the insufficient condition of that margin. Perhaps the sinus, which is conspicuous in Basilissa, will proove to give the best character for that genus.

To Solariellopsis belong the three species mentioned by v. Martexs and S. calcarata now to be described below, moreover I have located in it, such species as seem to belong to it by their shell characters, though I have just now demonstrated, how dangerous it is to classify such 'species, without any knowledge of the soft parts.

I. Solariellopsis calcarata n. sp. Pl. IV, fig. 2 ; Pl. IX, fig. 10.

Stat. 302. $10^{\circ} 27^{\prime} .9$ S., $123^{\circ} 28^{\prime} .7$ E. 216 M. Sand and coralsand. I Spec.

Shell depressedly conoidal, sharply keeled, with a flat base and large umbilicus; it is nacreous under a thin, transparent, yellowish-white layer. Whorls $5^{1} / 2$, slightly convex, especially the last one. Nucleus smooth, shining. The sculpture consists on the upper whorls of rather distant, radiating ribs, crossed about halfway by a spiral rib or keel, forming small, sharp tubercles where they cross each other; on the third whorl, another series of tubercles appears, at some distance from the deep suture; on the penultimate whorl, the number of rows of tubercles amounts to three and the suture is conspicuously crenulated by the keel, which rests on the last whorl; this whorl is adorned by 5 spiral rows of tubercles, of which the second from above is the smallest, moreover the keel is surmounted by short, conical, rather sharp spines of which 38 are visible, if seen from below. Base nearly flat, more convex towards the 
aperture, with 7 spiral rows of beads on rounded lirae, and a row of stronger ones, bordering the umbilicus. Moreover the whole last whorl is covered with irregular radiating wrinkles or riblets, instead of the regular ribs on the upper whorls, these ribs are especially conspicuous and more regular on the base, except towards the periphery where they form thinner, irregular wrinkles. Umbilicus pervious, funnel-shaped, its walls with strong wrinkles. Aperture rhombic, its upper margin regularly convex, not very thin, thickened interiorly, separated from the basal margin by a groove, corresponding to the keel, basal margin convex, crenulated, thickened interiorly. Columellar margin rather thick, concave in its upper part, terminating in a sort of tooth below. Parietal wall covered by a thick layer of enamel, thickened at its margin and connected to the pillar by a broad, rounded tongueshaped projection, covering part of the umbilicus, whose largest diameter, from the base of the columella to the opposite side, is about $2 / 5$ of the diameter of the shell.

Operculum thin, horny, many-whorled, concave at the outer side.

Diam. maj. (without spines of keel) 8 , alt. $4 \%$; apert. alt. 2, lat. $3^{3} \%$ Mill.

This is a beautiful, peculiar shell, quite unlike to anything I know.

The radula has the teeth in about $4 \delta$ rows. The rhachidian tooth $(R)$ has a rounded body, with crooked hooks at the angles of the very concave posterior margin, and is thickened by a plate of a triangular shape, with concave sides, the cusp is considerably narrower than the body, which is large in front; it has a sharp point and a few small denticles on each side; the body of the first lateral tooth (I) is larger, subquadrate, with a sharply pointed cusp and a few smaller denticles, the second one (2) has a similar, but more elongated shape and a sharper cusp, also with a few smaller denticles; the third lateral (3) is long and slender, strongly hooked, with denticles at the base of the cusp, and resembles more the uncini; of the uncini the outer ones have a toothed margin, the outermost is broader with many small denticles (U). I think most if not all the uncini, will be more or less denticulated, if seen in a favorable position.

2. Solariellopsis limbifera n. sp. P1. IV, fig. 3 .

Stat. $95.5^{\circ} 43^{\prime} \cdot 5$ N., $119^{\circ} 40^{\prime}$ E. 522 M. Stony bottom. I Spec.

Shell moderately depressed, conical, slightly convex below, with a very strong, rounded keel, widely umbilicate, yellowish-white, whorls $6 \%$; nucleus smooth, upper whorls with concentric ribs and traces of one or two spiral lirae, producing small tubercles on the ribs; whorls flattened near the suture, above the upper row of tubercles, this depression is roughened by small lamellae; lower part of the whorls slightly convex. On the lower whorls, the sculpture consists of a row of rather strong tubercles, at some distance from the suture, the flattened space between suture and tubercles is also lamelliferous; a second row of smaller tubercles makes its appearance, and becomes more conspicuous on the last whorl; at some distance from the lower suture, a spiral rib, with inconspicuous beads, is crossed by irregular, waved lamellae, which spread on the large keel, which is flat above, rounded at its periphery, and adorned by sharp, compressed folds, which make it crenulated. Base sculptured by five beaded spirals, of which the outer one, placed at some distance from the margin, and the most central one, bordering the umbilicus are 
double; the whole base is covered by radiating very oblique riblets. Umbilicus pervious, funnelshaped, with 2 spiral lirae, of which the lower one is beaded, and radiating riblike striae, its largest diameter is about $1 / 3$ of the base. Aperture rhombic; outer margin rather thin, convex, internally lirate, with short folds between the lirae; basal margin short, convex, internally with a few lirae; columella broad, concave, with a conspicuous fold near the base and a small denticle above it, its upper part connected to the outer margin by a conspicuous layer of enamel, with thickened margin, and a free ear-shaped projection, covering part of the umbilicus.

Diam. maj. I2, alt. 8, apert. alt. $3 \frac{1}{2}$, lat. 5 Mill.

I have located this very peculiar shell in the new genus, on account of its general resemblance with the preceding species; in many particulars it is so much different, that it is superfluous, to insist upon its specific distinctness.

3. Solariellopsis pulchra n. sp. PI. IV, fig. 4 .

Stat. $256.5^{\circ} 26^{\prime} .6$ S., $132^{\circ} 32^{\prime} .5$ E. 397 M. Greyish green mud. I Spec.

Shell depressedly conoidal, with nearly flat base, sharply keeled, yellowish-white, with a large umbilicus; whorls about 6 , slightly convex; nucleus smooth, upper whorls with concentric ribs; on the third whorl they are pointed above, at some distance from the suture, and near the base of this whorl, appears a row of tubercles on a spiral rib. The subsequent whorls are slightly concave or canaliculated near the suture, the fourth is sculptured by concentric ribs, with stronger tubercles at the top, near that depression; on the fifth, the sculpture consists of a row of tubercles and 3 beaded lirae, of which the third, near the keel is the strongest, this keel is compressedly crenulate, the space between suture and tubercles has short, irregular folds. The same sculpture persists on the last whorl, where the tubercles, about 30 in number, are compressed and show a tendency to become double, the crenules of the keel are slightly concave from above to below. Base nearly flat with 5 concentric beaded lirae, the beads bordering the umbilicus are the largest; the whole base is covered with rather regular, riblike striae and very fine microscopic ones, visible also on the upper part of the shell. Umbilicus large, occupying from the base of columella to the opposite side, about $\%$, of the diameter of the shell, it is funnel-shaped, pervious, its wall spirally striate, with a single, spiral, beaded rib and radiating plicae. Aperture rhombic, probably not quite developed, thin, upper margin convex, basal one nearly straight; columellar margin slightly convex, reflected above, parietal wall with a thin layer of enamel.

Diam. maj. I 3 , alt. $6 \frac{1}{2}$; a pert. alt. $3^{1} / 4$, lat. $5^{1 / 2}$ Mill.

Resembling the preceding species, but with a much less conspicuous keel and different sculpture, the specimen is apparently not quite adult, and the characters of the aperture are not developed.

4. Solariellopsis spimulosa n. sp. Pl. IV, fig. 5 .

Stat. I 59. $0^{\circ} 59^{\prime} .1$ S., $129^{\circ} 48^{\prime} .8$ E. 4 II M. Coarse sand. 2 Spec.

Shell depressed, with low conical, convex spire; strongly keeled, base convex; yellowish- 
white, umbilicus large; shell (not adult) consisting of about 5 slightly convex whorls, with a conspicuous suture; sculpture consisting of 2 spiral rows of short, thick tubercles, 15 or 16 in number on the last whorl, resembling small spines, one row bordering a depression at the upper part of the whorls, the other near the base, the tubercles connected by traces of spiral lirae; on the upper whorls the tubercles are connected by concentric ribs. The keel, visible on the penultimate whorl, is very conspicuous, crenulated by slightly erect tubercles. Base convex, with four beaded spiral lirae, and two intermediate ones near the aperture; that bordering the umbilicus is the strongest. Umbilicus funnel-shaped, pervious, its largest diameter occupying about $\%$ of that of the shell, its walls finely striate, like the whole surface of the shell. Aperture rhombic, upper margin convex, basal one nearly straight; columellar margin slightly convex; interior smooth.

Diam. maj. 9, alt. 5 ; apert. alt. 3, lat. $3^{1 / 2}$ Mill.

Though the specimens are obviously not adult, I have named and described the species, as it will be easily recognized by its sculpture. It is clearly allied to the preceding species, but differs by the position of the keel, the base being nearly as convex as the spire. The sculpture is remarkable by the erect character of the tubercles.

\section{Solariellopsis bicarinata n. sp. P1. IV, fig. 6 .}

Stat. 59. Western entrance of Samaul-strait. 390 M. Coarse coralsand with small stones. I Spec.

Shell depressed-conical, spire convex, flatter below, yellowish-white, largely umbilicated; whorls about $5 \frac{1}{2}$, convex, nucleus wanting. The sculpture consists on the upper whorls of concentric ribs, with small erect tubercles of the upper part and still smaller at the lorver part of the median whorls, the upper ones bordering a concave depression near the suture. On the penultimate whorl, appears a smooth space; the sculpture consisting of 2 rows of tubercles, of which the upper ones are still a little riblike and the lower is formed of short scales, about 30 on the last whorl, hollow on the front-side; the infrasutural zone of the last 2 whorls is adorned by numerous, slightly irregular plicae; on the last whorl, the scales are placed on a flat spiral cord, having the appearance of a keel, which is separated by a sulcus from the true keel, which is strong, cord-like and slightly crenulated; near the aperture traces of intermediate lirae make their appearance. Base moderately convex, with 3 beaded spiral lirae, the innermost bordering the umbilicus. The base is moreover sculptured by radiating elevated striae, and like the upper surface, with microscopic growth-striae. Umbilicus funnel-shaped, pervious, its largest diameter from the base of the columella, to the opposite side is about $1 / 2$ of the diameter of the shell. Its wall has strong, waved, concentric lamellae. Aperture subquadrangularly-rounded, upper margin convex, basal one a little less, crenulate by the endings of the basal lirae. Columella nearly straight, slightly convex near the middle, slightly reflected in a wavy manner over the umbilicus; interior of aperture smooth, nacreous.

Diam. maj. 6, alt. $4^{1} / 4$; apert. alt. 2, lat. $2^{2} / 3$ Mill.

Differing from the preceding species, by the sulcus separating the false keel from the true one, and other particulars of the sculpture, umbilicus, etc. 
6. Solariellopsis multisquamosa n. sp. P. IV, fig. 7 .

Stat. $95.5^{\circ} 43^{\prime} \cdot 5$ S., I $19^{\circ} 44^{\prime}$ E. 522 M. Stony bottom. I Spec.

Shell conical, with rounded periphery and slightly convex base, umbilicated, white, scarcely with a yellowish tinge. Whorls $6^{1} / 2$, convex. Nucleus smooth, the subsequent whorl with concentric ribs. On the lower whorls the sculpture consists of radiating ribs, with a row of compressed tubercles, at some distance from the channelled suture, which disappear on the upper whorls; these ribs are crossed by 2 spiral cords, with short, hollow scales, about 25 in number on the last whorl. On the last, rounded whorl, the base is bordered by a third row of smaller scales. Base slightly convex, with 3 rather large, spiral cords, of which that bordering the umbilicus is the broadest; they are crossed by concentric ribs, running over the whole base and making the cords crenulated. Umbilicus funnel-shaped, pervious, its wall with concentric, riblike striae, and a spiral, beaded cord near the base, its larger diameter occupies $1 / 3$ of that of the shell. Aperture subcircular, straighter on the side of the slightly concave columella, which forms a conspicuous angle with the basal margin, parietal wall with a thin layer of enamel, forming a small projection, covering part of the umbilicus. Interior of aperture smooth, nacreous, with a flattened rib near the outer and basal margin.

Diam. maj. $5^{1} / 4$, alt. $5^{1} / 2$, apert. alt. 2, lat. 2 Mill.

Differing from the allied species, by the rows of short scales, and from all the preceding species, by the rounded periphery of the last whorl.

7. Solariellopsis muricata n. sp. Pl. IV, fig. 8.

Stat. 59. Western entrance Samau-strait. 390 M. Coarse coralsand with small stones. I Spec.

Shell conical, with rounded but keeled periphery and convex base, umbilicate, yellowishwhite. Whorls 6 , convex, nucleus wanting. Sculpture consisting on the upper two whorls, of nearly simple concentric ribs, on the next two, the ribs are crossed by two spiral lirae, producing short tubercles on the ribs, where they cross them. Last two whorls with plicae near the channelled suture, with a row of tubercles, bordering an infrasutural sulcus; another similar row, a little lower on the concentric ribs and a third, consisting of compressed tubercles, (about 30 on the last whorl) near the base of the whorls; these tubercles, especially those of the peripheral row, are connected by spiral lirae, of which the lowest represents the keel. The convex base is sculptured by four spiral cords, of which that near the keel, bears strong, compressed tubercles; those of the more central cord are smaller, and the innermost two are strongly beaded, the inner one borders the umbilicus; moreover the base is sculptured by irregular, radiating riblets and like the upper part, by microscopic striae. Umbilicus funnel-shaped, pervious, concentrically striated and plicated, and with two beaded spirals near the base, its largest diameter about $\%$ of that of the shell. Aperture subcircular, outer and basal margin with short plicae in the interior. Columella concave, reflected over the umbilicus, with two denticles near its base, of which the basal one is the largest, parietal wall with a layer of enamel, connecting the margins, slightly projected over the umbilicus, its margin a little thickened; interior of aperture inconspicuously nacreous. 
Diam. maj. $5^{1 / 2}$, alt. $4^{3} / 4$; apert. alt. $2 \frac{1}{4}$, lat. $2^{1 / 2}$ Mill.

Allied to the preceding species, but more depressed, with two denticles on the columella and differing also by many particulars of sculpture.

\section{Solariellopsis concavospira n. sp. Pl. V, fig. I.}

Stat. $178.2^{\circ} 40^{\prime}$ S., $128^{\circ} 37^{\prime} \cdot 5$ E. 835 M. Blue mud. I Spec.

Stat. 286. $8^{\circ} 50^{\circ}$ S., $127^{\circ} 2^{\prime} .2$ E. 883 M. Mud, evidently a thin layer. 3 Spec.

Shell depressed, with a conical spire, having a concave outline of the upper part, thin, with a very thin yellowish outer layer, only appreciable in a dry state, the shell being entirely nacreous if wet, with exception of the uppermost whorls, which are whitish; whorls 6 , rather convex. Nucleus smooth, next whorl with radiating ribs; the subsequent whorls have 2 spiral. keels, they are, like the last whorl, excavated near the suture; this excavation is bordered by the uppermost keel, which is adorned by short, rather sharp spines, 27 in number on the last whorl. Between this keel and the peripheral one, runs a second spiral keel with 39 smaller spines; on the peripheral keel, they are still more numerous, and have more the character of compressed folds, which extend a little upwards and less downwards, the upper part being also visible on the upper whorls, like small folds, bordering the linear suture; the space between the ${ }^{{ }^{s t}}$ and $2^{\mathrm{d}}$ keel is traversed by folds, running downwards from the spines of the upper keel, they often, but not always, reach the $2^{d}$ keel, which projects also small folds in both directions, which however are shorter and don't reach the next keels; the space below the suture is likewise provided with folds, partly projecting from the upper keel, partly free. Base of the shell a little convex, with three spirals, which are slightly crenulated, and a strongly crenulated spiral (in one specimen accompanied by a secondary one) bordering the large umbilicus, which is pervious, funnel-shaped, its wall with elegantly curved, riblike striae or folds, which extend over the base of the shell, the infraperipheral space only remaining smooth. The whole shell is covered with very fine growth-striae, visible only under a lens. Aperture rounded-quadrangular, margins sharp, upper margin convex, basal one more straight, but still convex, columellar margin curved and forming a distinct angle with the basal margin, at the end of the umbilical keel. Columellar and outer margins connected by a very thin, nacreous layer. Interior of aperture nacreous.

Alt. 6 ; diam. maj. $8^{3} / 4$; apert. alt. $3^{1 / 2}$, lat. $3^{1 / 2}$, diam. of umbilicus 4 Mill.

The nearest allies of this species seem to be Solariella actinophora Dall and S. effossima Loc., but it differs in many particulars of sculpture, a. o. the new species has not the spirals in the umbilicus, on which LOCARD lays much value, and effossima is a thicker species; $S$. actinophora is less depressed, though apparently similar in the shape of the spire.

I at first located this species in Solariella, before I knew the dentition of the species now located in Solariellopsis, but now I think it may be removed with equal right to the new genus Solariellopsis.

9. Solariellopsis metallica Wood-Mason \& Alcock.

Wood-Mason and AlCock. Ann. Mag. Nat. Hist. Ser. 6, Vol. 8, I891, p. 444, with figurès in the text. 
Stat. $18.7^{\circ} 28^{\prime} .2 \mathrm{~S}$, $115^{\circ} 24.6 \mathrm{E}$. $1018 \mathrm{M}$. Fine grey mud. 2 Spec.

Stat. 52. $9^{\circ} 3^{\prime} .4$ S., $119^{\circ} 56^{\prime} .7$ E. 959 M. Globigerina ooze. 2 Spec.

Stat. 76. $4^{\circ} 22^{\prime} .1$ S., 1 I $8^{\circ} 16^{\prime} .9$ E. 2029 M. Fine grey mud (Globigerina). I Spec.

Stat. 300. $10^{\circ} 48^{\prime} .6$ S., $123^{\circ} 23^{\prime}$. I E. 918 M. Fine grey mud. I Spec.

The description of this species is very short, the author says only: "A brillantly nacreous species, ornamented with two spiral rows of conical tubercles and four smooth carinae on the base, exclusive of a faintly granulated one which bounds the umbilicus". The specimen is from a depth of 738 fathoms, in the Gulf of Manaar. As no measurements are given, and the rather rude figure showed some differences with the "Siboga"-shells, I hesitated to identify them, though the "Siboga"-specimens seemed to be very nearly allied. Mr. Smith after comparing them with an authentic specimen, declared them to be the same species. A specimen of about the same diameter as the figure is higher in proportion, the measurements of the largest specimen with 8 whorls are: Alt. 22, diam. maj. 19, apert. alt. 10, lat. 8 Mill. The figure of Wood-Masor and Alcock, has the same diameter but is only 19 Mill. in height, the upper corner of the aperture in the figure, looks as if the suture should be canaliculate, but not so in the specimens. The shell is not so lustrous as the authors say. They suggest that "the glistening metallic lustre of the whole exterior is largely though not entirely due to the erosion of the delicate extemal layer of the shell". In the "Siboga"-specimens the whole shell, perhaps with exception of the embryonic whorls, is covered by a thin yellowish layer, having the aspect of an epidermis, and only when this is removed, the metallic lustre appears. The basal carinae, if not eroded, are not smooth, in the majority of the specimens; there are only 3 of them, and a trace of an intermediate one near the aperture, the most central keel is decidedly adorned with small tubercles and also the other ones are slightly beaded or crenulated. The outer layer of the shell has a fibrous texture, in the interstices between the umbilical keel and the second basal keel, the surface has distinct riblike striae. The funnel-shaped, pervious umbilicus has the same riblike striae on its wall. The only specimen from Stat. 76 has a fourth basal keel, but the upper row of tubercles is wanting on the last whorl.

After comparing a specimen of Basilissa acthiopica v. Martens (Die beschalten Gastrop. d. deutsch. Tiefsee-Exp. 1898-99, p. 125, Pl. 4, fig. 20) I think this form cannot be separated as a good species from $S$. metallica, for the distinctive characters which v. Martens has observed may be ascribed to the condition of the shell described by WooD-MASON and ALcock and to their figure. B. aethiopica is a larger, more developed form and should, as far as I can see, have only a varietal rank.

\section{Io. Solariellopsis sp.}

Stat. $88.0^{\circ} 34^{\prime} .6$ N., $119^{\circ} 8^{\prime} .5$ E. I 30 I M. Fine grey mud. I Spec.

One specimen of a shell, too much worn for description, may belong to the genus Solariellopsis, and may be allied to the next species, it seems to be more conical, with a less canaliculate suture and a very narrow umbilicus. I have made mention of it, only on account of the great depth where it has been found. 


\section{I. Solariellopsis pagodiformis n. sp. Pl. V, fig. 2.}

Stat. $178.2^{\circ} 40^{\prime}$ S., $128^{\circ} 37.5$ E. 835 M. Blue mud. I Spec.

Stat. 300. $10^{\circ} 48^{\prime} .6$ S., $123^{\circ} 23^{\prime} .1$ E. 918 M. Fine grey mud. 2 Spec.

Shell conical, with convex base, nacreous, covered by a very thin, transparent layer of yellowish shelly matter. The largest specimen has 8 whorls. Nucleus white, smooth, occupying about one whorl. The next 3 whorls are straight on their upper part and separated from the lower part of each whorl by a sharp keel, crossed by rather distant radiating ribs, which form sharp tubercles in crossing the keel, and on the third whorl also near the suture. These ribs become obsolete, and disappear on the last whorls, which are smooth on their upper surface, which is only very slightly convex, with a spiral row of spinous nodules, at a little distance from the canaliculate suture, and a strong keel at the periphery; below this keel the whorls are excavated, so as to form with the channel of the next whorl, a rather wide, deep channel, over which the keel projects, producing the pagodiform shape; of the spinous nodules, the largest specimen has 25 at the keel, and about 30 near the suture. The base is rather convex, with a small umbilicus, bordered by a rather strong, crenulated, spiral rib, between this and the peripheral keel run 4 spiral lirae, which are more or less beaded, the outer one nearest to jthe keel, borders the concave inferior space of the upper whorls, and on this spiral runs the suture, which is slightly crenulate. Aperture subquadrangular, outer and basal margins sharp, irregular by the ends of the spirals; columella nearly straight, with a distinct angle where it oins the basal margin; this angle is caused by the umbilical rib, its upper part is slightly reflected over the umbilicus and covers it partly. The umbilicus is somewhat roughened by the lines of growth. The whole shell is covered with irregular, interrupted, hairlike lines of growth, visible only under a lens. Interior of aperture smooth.

Alt. $14^{1} / 2$, diam. maj. $12^{1} / 2$. Apert. alt. 6 , lat. 6 Mill.

The three specimens of this species vary slightly in the lirae of the base; in the largest specimen from Stat. 300 , the outer one is regularly beaded or crenulate; the inner less so, especially near the aperture, the two intermediate ones are nearly smooth; the smallest specimen, from the same locality, has them all beaded, though the $2^{\mathrm{d}}$ and $3^{\mathrm{d}}$ are smoother near the aperture, and in the only specimen from Stat. I 78 , the lirae are nearly smooth, only that next the umbilicus is obsoletely beaded.

This species has in outline some resemblance to Solariella lissocona Dall, but may be at once distinguished from that species, by its excavated sutural area and the narrower umbilicus, in the first particular it resembles S. mogadorensis Locard, but is quite different in shape and in many other respects. Solariella oxycona Smith, which has been figured ${ }^{1}$ ) may be allied, but is according to the description, still more conical, and it has no indication of a canaliculate suture. The species seems also closely allied to Basilissa ottoi (Phil.) var. Chuni v. Martens (Die beschalten Gastrop. der deutschen Tiefsee-Expedition I $898-99$, pag. 1 27 , Pl. 4, fig. 19), but it is quite different from Philipri's original figure (Fauna Moll. Regni utriusque Siciliae, pl. 28, fig. 9) of this Sicilian fossil; from the figure of v. Martwass (1.c.) it differs especially by 
the much narrower umbilicus, by the direction of the lower row of tubercles, which in $B$. Chuni are erect, and on the contrary straight or nearly declined in S.pagodiformis, and other characters of less importance.

\section{Guttula n. gen.}

Shell small, conoidal, smooth, pearly, perforate, aperture rounded, with an angle at the base, operculum few-whorled.

It is chiefly on account of the peculiar radula, that I have located the only species in a new genus; conchologically it resembles Margarita, were it not for the angular aperture. It may prove to be only a young shell, but a similar radula I have only found in what I describe with some doubt as a Basilissa and in the type of that genus; however the differences of the radulae are too obvious, to join them in one genus.

I. Guttula sibogae n. sp. Pl. II, fig. 7 ; Pl. IX, fig. I I.

Stat. ${ }_{7} 8.2^{\circ} 4 \mathrm{o}^{\prime}$ S., ${ }_{3} 8^{\circ} 37^{\prime} .5$ E. 835 M. Blue mud. 4 Spec.

Shell conoidal with elevated spire, periphery and base rounded, perforate, pearly, outer layer, if present, very thin and pellucid. Whorls 5, very convex, smooth, only under a strong lens very faint growth-striae and microscopic punctuations may be observed, sutures well-marked, marginated, last whorl rounded, with a convex base and a small perforation, nearly concealed by the columella. Aperture rounded, slightly angular above and stronger so below, outer margin thin, regularly curved, columellar margin concave, reflected over the small umbilicus, angular near the base, where it joins the basal margin, and slightly protracted there. Operculum thin, horny, with few whorls, concave at the outer side.

Alt. $5^{1} / 2$, diam. maj. $4^{1 / 2}$, apert. alt. $3^{1 / 2}$, lat. $2^{3} / \star$ Mill.

The radula has scarcely the length of $\mathrm{I}$ Mill. and is about $1 / 3$ Mill. in breadth; it has about 20 transverse rows of teeth; the rhachidian tooth $(R)$ is broad, depressed quadrangular with rounded upper angles and pointed basal ones, it has a large reflected cusp with one strong median denticle and two smaller ones on each side, the laterals ( $\mathrm{r}$ ), one on each side, have a depressed rhombic base, with a reflected margin, ending in a sharp cusp at the proximal side. The other teeth $(\mathrm{U})$ have the characters of being uncini, they are long, slender and hooked, with apparently smooth cusps, the outer ones are shorter broader, with a few denticles on each side, near the top, visible if expanded. The number of uncini is not large, but I could not ascertain the exact number.

\section{Basilissa Watson. Fig. I.}

To the kindness of Prof. H. M. Gwatkin, I owe the knowledge of the radula of the type of the genus Basilissa lampra Wats. from a specimen of the original lot, collected off Jedo, at 1875 fathoms. This radula has a very peculiar appearance, which is quite different from that of the species located by v. MARTEns in this genus, and which I have united, with 
some others, in the new genus Solariellopsis. In the radula now under consideration, only 3 rows obviously belong to the median part, and it is strange that the cusps instead of being

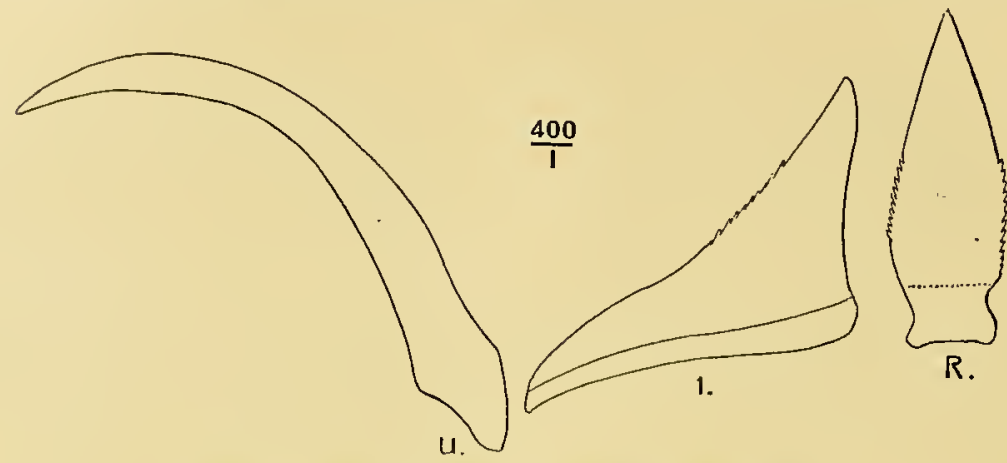

Fig. I. Teeth of Radula of Basilissa lampra. Wats. reflected, as is usually the case, are stretched forwards. The rhachidian tooth $(R)$ has a subquadrate body with somewhat protracted, rounded posterior angles, the cusp is lanceolate, with a rather sharp point and numerous, very fine denticles at the sides towards the base, the lateral (I) is triangular, with small denticles at the outer margin of the cusp. The uncini (U) which are not numerous, and of which perhaps the innermost must be considered as still belonging to the median part, are long, slender, with small denticles near their top, if seen quite flat, but which I cannot detect, if seen in the common, though reflected position.

As the next species. agrees in many respects with this description (the cusps are however reflected) I have provisionally located it in this genus. The preceding genus, though allied by its radula, differs very much conchologically.

I. Basilissa sibogae n. sp. P1. V, fig. 3 ; Fig. 2.

Stat. 88. $0^{\circ} 34^{\prime} .6$ N., I I $9^{\circ} 8.5$ E. I 30 I M. Grey and yellow mud. 3 Spec.

Stat. $21 \mathrm{I} .5^{\circ} 40^{\prime} .7 \mathrm{~S}$., I $20^{\circ} 45^{\prime} .5$ E. II 58 M. Coarse grey mud. I Spec.

Shell conical, with concave sides, a sharp keel and slightly convex base, umbilicate, nacreous under a thin, yellowish-white layer. Whorls 7 , slightly convex, especially the lower ones.

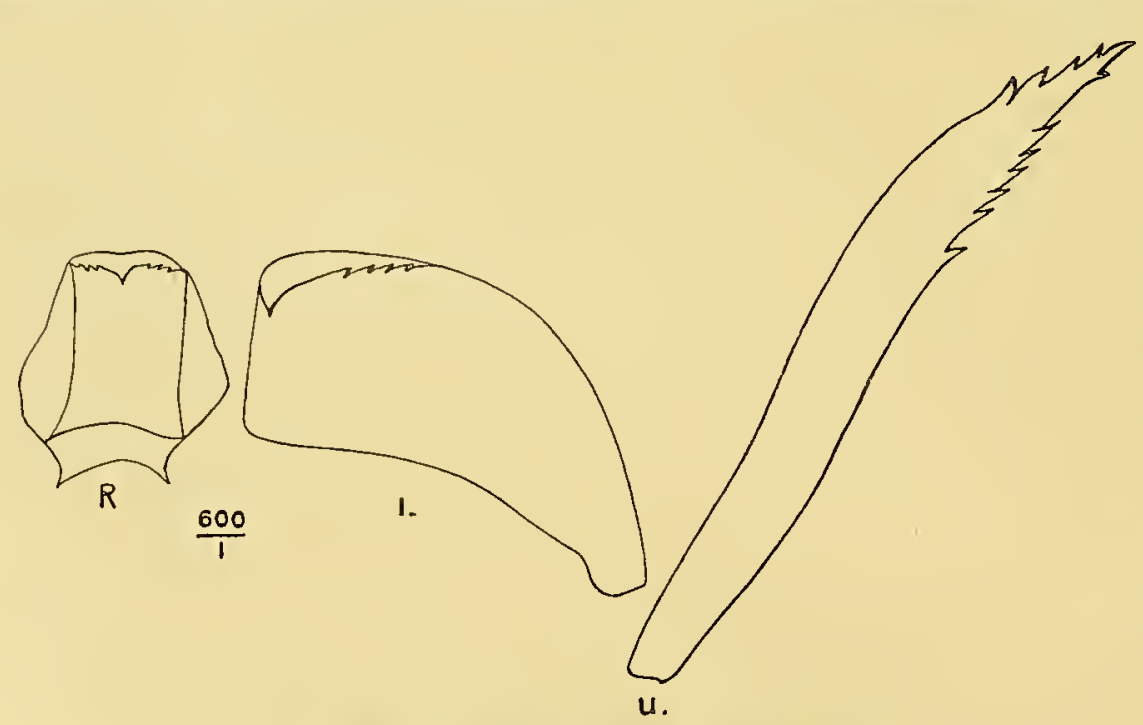

Fig. 2. Teeth of Radula of Basilissa silogae Schepm.
Nucleus smooth, shining; by the strong keel, which is also visible on the upper whorls, the suture is wellmarked. The sculpture consists on the upper whorls of thin, strongly curved, radiating riblets, which are rather crowded, but much more distant on the lower whorls, and nearly disappear on the last two, these riblets are slightly thickened towards the upper suture and below towards the keel,

which is crenulate by their crossing it; one or two spiral elevated striae may be observed on 
part of the upper whorls. Moreover the whole shell is covered with fine growth-striae, which form a large sinus above near the suture and are protracted below near the keel, following the direction of the riblets; base rather smooth, but sculptured by similar striae as on the upper part, being partly riblike; the whole base is covered with spiral striae, most conspicuous towards the umbilicus and keel, leaving a smoother median space. Umbilicus pervious, funnel-shaped, its largest diameter occupying nearly $1 / \neq$ of that of the base, its margin bordered by a strongly beaded rib, which can be followed still a little in its interior, which is otherwise rather smooth, though sculptured by very fine radiating and spiral striae. Aperture rhombic, upper margin thin, slightly broken, but judging after the growth-striae, sinuous above, protracted towards the keel, which appears to have been toothlike; basal margin sinuous in the same manner; columellar margin sinuous, reflected, forming an angle with the basal margin. Operculum very thin, corneous, with few whorls.

Alt. $61 / 2$, diam. maj. 9 ; apert. alt. 3 , lat. $3^{3} / 4$ Mill.

This species has a slight resemblance to $B$. alta Wats., but is much more depressed, with concave sides, and differing in many other respects, on closer examination.

The rhachidian tooth $(R)$ of the radula has a subquadrate body, with rounded posterior corners, enlarged sides and a short, reflected cusp, with a few denticles; lateral (I) subtriangular, with a short, reflected cusp, with small denticles at the distal margin. I can detect no more teeth, belonging with certainty to the median part. Uncini $(U)$ long, slender, with distinct smaller teeth near the top.

If the cusps of the median teeth were stretched out, they would resemble those of $B$. lampra, however they would be less slender.

\section{Basilissa sp.?}

Stat. $178.2^{\circ} 40^{\prime}$ S., $128^{\circ} 37^{\prime} \cdot 5$ E. 835 M. Blue mud. I Spec.

With much doubt I mention a broken shell, as belonging perhaps to this genus, only on account of some resemblance to the preceding species.

\section{Calliostoma Swainson.}

I. Calliostoma rufomaculatum n. sp. Pl. V, fig. 4 .

Stat. 204. Northern entrance of Buton-strait. 22 M. Sand with dead shells. I Spec.

Shell elevated-conical, imperforate, flesh-coloured, with rufous spots on the upper surface, and oblong streaks of the same colour above the suture, upper whorls violet. Sides of the spire concave towards the top, convex towards the periphery. Whorls 9 , nucleus white, nearly smooth, but under a lens, with rows of small pits, the subsequent 4 violet whorls, with 3 spirals, crossed by numerous ribs, beaded where they cross each other, leaving square interspaces; lower whorls with conspicuously beaded spirals, of which there are 6 larger on each whorl, and in the interstices a much smaller thread, more or less beaded; last whorl angular at the periphery. Base convex, with 14 spiral lirae and a few intermediate ones, some of these intermediate lirae 
bear subquadrate beads, the colour of the base is nearly white, with spiral rufous streaks on the lirae. Aperture subquadrate, nacreous, outer margin with 5 strong lirae, basal margin with 5 weaker ones, the margins are thin, thickened interiorly. Columella cylindrical, bluntly angulated near the middle, angular but not toothed at its base. Umbilical region slightly impressed.

Alt. $14^{1} / 2$, diam. maj. $12^{1} / 2$, apert. alt. $5^{1} / 2$, lat. $6^{1} / 2$ Mill.

By its shape this species is allied to $C$. speciosum Ads., but it differs by its regular, conspicuous sculpture and by its painting, it is also a much smaller shell, though probably adult, judging after its interiorly thickened margins of the aperture. Though I have described this species with somé doubt as new, I could not identify it with any known form.

2. Calliostoma simplex n. sp. Pl. V, fig. 5 .

Stat. $253 \cdot 5^{\circ} 4^{\prime} .28$ S., $123^{\circ}$ I $3^{\prime}$ E. 304 M. Grey clay, hard and crumbly. I Spec.

Shell elevated conical, imperforate, unicoloured, yellowish. Whorls $7^{1} / 2$, slightly convex, with spiral lirae, increasing from 2 on the upper body whorl, to 6 on the penultimate and 7 on the upper surface of the ultimate one; suture not deep but distinct, accompanied by the upper part of a nearly covered spiral. The spirals are closely beset with compressed beads; the upper row of each whorl is slightly the largest. Last whorl angular, keeled by the last spiral. Base nearly flat, with Io conspicuous, beaded spirals and a few very thin ones near the aperture. Moreover the whole shell is covered with oblique, undulating, slightly laminar, radiating striae, very distinct on the base. A perture subquadrate, outer margin thin, a little convex, with 5 spiral grooves, basal margin convex. Columella cylindrical, slightly concave, patulous but not toothed at the base, interiorly ending in a flat layer of nacre, running over the basal margin.

Alt. I 4 , diam. maj. I I $\frac{1}{2}$; apert. alt. $4^{3} / 4$, lat. 5 Mill.

Resembling in shape C. apicinm Dall, but differing by its colour, especially by its coarser sculpture, its simple columella and not the least, by its size.

\section{Calliostoma multispinosum n. sp. Pl. V, fig. 6.}

Stat. $87.0^{\circ} 32^{\prime}$ S., $119^{\circ} 39^{\prime} .8$ E. 655 M. Fine grey mud. I Spec.

Shell conical, with concave sides, imperforate, unicoloured, yellowish. Whorls 8 , flat or slightly concave, with spiral lirae, of which 3 on the upper, io on the last whorl. Nucleus obsolete, next whorls with spirals and radiating ribs, forming small spines when they cross; on the last 3 whorls the ribs disappear and only the spirals remain, the uppermost being in the last 5 whorls, conspicuously the largest; these lirae are closely beset with compressed spines, which resemble squamae, with very fine growth-striae in the interstices; periphery with a very sharp weakly crenulated keel. Base slightly convex, with fine growth-striae and more conspicuous spirals, of which 5 near the periphery and 5 near the centre are considerably stronger, the latter are more or less nodulous. Aperture subquadrate, outer margin nearly straight, thin, with 7 shallow grooves interiorly, basal margin convex. Columella cylindrical, slightly concave, obsoletely angular at the junction with the basal margin.

Alt. 20, diam. maj. 2 I; apert. alt. 8, lat. Io Mill. 
This species seems to be allied to C. sublaeve Smith (Ann. Mag. Nat. Hist. Ser. 6, Vol. 16, 1895, p. 8, Pl. 1, fig. 12) and still nearer to its var. Chuni v. Martens (Die beschalten Gastrop. der deutschen Tiefsee-Exp. 1898-99, p. 121, P1. 4, fig. 13), but differs by its much more developed sculpture, which covers the whole upper surface of the shell in the new species. Only by a large number of intermediate forms, it might prove to be an extreme form of $C$. sublaeve.

\section{Calliostona sp.}

Stat. $45.7^{\circ} 24^{\prime}$ S., I I $8^{\circ}$ I 5'.2 E. 794 M. Fine grey mud, with radiolariae and diatomes. I Spec.

Certainly a very interesting species, but unfortunately too much broken for description; the lower whorls are smooth at the upper part of the supraperipheral slope, with a double spiral rib at the periphery and another strong one, about half way the whorls. These spirals are sculptured by fine spiral and concentric, elevated striae, so the shell, if in good condition, must be of exquisite beauty.

\section{Calliostoma quadricolor n. sp. Pl. V, fig. 7 .}

Stat. $49^{a}$. Sapeh-strait. 69 M. Coral and shells. 1 Spec.

Stat. 257. In Du-roa-strait, Kei-islands. Till 52 M. Coral. I Spec.

Shell elevated-conical, with slightly concave sides, imperforate, yellowish, with a greenish tinge, the peripheral keel articulated with white and rufous, spire purplish at the top; whorls 7 , flat, nucleus nearly smooth, under the lens with a few rows of pits, other whorls with spirals, 2 on the upper whorls, increasing to 7 on the last whorl; these spirals are crossed by concentric ribs, connecting the spirals and producing beads in crossing them, the lowest, bicoloured spiral of each whorl is the strongest, the beads on it becoming spiny, and forms a conspicuous keel on the last whorl, it is double. Base flat, with 13 unequal spirals, crossed by numerous radiating ribs, making them beaded. Aperture rhombic, upper margin straight, basal one slightly convex, columella cylindrical, slightly concave, angular at its junction with the basal margin, outer wall grooved interiorly by about 5 shallow grooves.

Alt. $8 \frac{1}{2}$, diam. maj. 7 ; apert. alt. 3, lat. 3 Mill.

As I could not identify this shell, I begged Mr. E. A. Sirth to compare it for me. According to his observations it is allied to, but not identical with $C$. scobinatus Ads. which is more convex at the base and differs in colour.

\section{Calliostoma (Astele) virgo n. sp. Pl. V, fig. 8.}

Stat. I22. $1^{\circ} 5^{\prime} .5$ N., $125^{\circ} 0^{\prime} .5$ E. I $165-1264$ M. Stony bottom. I Spec.

Shell conoidal, perforate, white; whorls $6 \frac{1}{2}$, convex, lower ones slightly concave below the suture; nucleus rather smooth, next whorls with from 2 to 4 weak spiral lirae below the suture, crossed by weaker radiating ribs, and with 2 or 3 stronger lirae on the lower part of each whorl, with a faint intermediate one, on the penultimate and last whorl, the spiral lirae increase in number, to about 10 weaker spirals on the upper part and 4 or 5 stronger ones 
at the lower part of the upper surface, and numerous intermediate ones. Below the rounded periphery appear two or three more remote lirae, with intermediate ones and numerous, regular, flatter lirae on the convex basal part, becoming broader towards the umbilicus; the whole shell is crossed by oblique, fine, but conspicuous growth-striae. Umbilicus narrow, in the front view concealed by the columellar margin, with rather smooth walls. Aperture rounded-quadrangular, upper margin thin, curved, running uninterruptedly in the basal margin, columellar margin partly reflected over the umbilicus. Interior of aperture nacreous, with a few shallow grooves, corresponding to the stronger external lirae. Operculum brown, outer surface concave, manywhorled, each whorl divided in two parts, a central one, with oblique, strong and an external part with nearly perpendicular, fine striae.

Ait. 30, diam. maj. 30 ; apert. alt. 17, lat. 15 Mill.

This species resembles in shape C. yutatecanum Dall (Blake Gastropoda, p. 37o, Pl. 24, fig. 4), but is quite different in sculpture and many other characters. I know no other species, with which to compare it.

\section{Calliostoma (Astele) scitulum Adams.}

A. Adamis. Proc. Zool. Soc. Lond. 1854, p. 38.

REEve. Conch. Ic. Vol. XIV, Zizyphinus, fig. 44.

Kiener. Coq. Viv. Vol. X, Trochus, p. 274, Pl. 90, fig. 3.

Pilsbry. Man. of Conch. Vol. XI, p. 402; Vol. X, pl. 4I, fig. 27.

Stat. 144. North of Salomakic̈-(Damar)-island. 45 M. Coral bottom and Lithothamnion. 2 Spec.

Stat. 282. Between Nusa Besi and the N.E. point of Tinor. 27-54 M. Sand, coral and Lithothamnion. I Spec.

The specimens agree sufficiently with those I received from Port Jackson, especially with one of the 4 specimens in my collection; the species till now, was only known from South Australia. The specimens from Stat. 144 are not quite adult, that from Stat. $2 S_{2}$ is very young.

\section{Calliostoma (Astele) expansum n. sp. Pl. V, fig. 9.}

Stat. 59. Western entrance Samau-strait. 390 M. Coarse coralsand with small stones. 5 Spec. Stat. 302. $10^{\circ} 27^{\prime} .9$ S., $123^{\circ} 28^{\prime} .7$ E. 216 M. Sand and coralsand. 1 Spec.

Shell depressed-conical, with convex sides, umbilicate, yellowish, with purple-brown blotches at the peripheral keel and rarely (in one specimen) with fainter blotches and flames of the same colour; whorls 6 , convex, slightly depressed above the suture and consequently above the keel of last whorl; nucleus smooth, followed by about one whorl with only a few spiral striae, next whorls with conspicuous, spiral, beaded lirae; with radiating plicae extending either over the whole whorl or more or less at the upper part of each whorl; last whorl with io spiral lirae, of which the lower form a sharp keel and the upper one is the strongest; the lirae are elegantly beaded and connected by irregular, rather strong, elevated striae or plicae in the interstices; base nearly flat, slightly convex, especially towards the aperture, with eight beaded, spiral lirae and a few intermediate ones, the interstices are wider than on the upper surface, the most central one runs nearly in the umbilicus. The base is crossed by rather regular, radiating plicae, not running 
in one direction; umbilicus rather large, pervious, its wall nearly smooth, it is partly covered by the columellar margin. Aperture rhombic, upper margin convex, thin, with a broad callosity interiorly; basal margin convex, thick; columella thickened, curved, with a knob at some distance from the base, expanded at its upper part, and partly covering the umbilicus; margins connected by a callous layer; columella joining the base by a blunt angle. Interior of aperture nacreous, smooth.

Alt. $5^{1 / 2}$, diam. maj. $7^{1 / 2}$; apert. alt. $2^{1 / 2}$, lat. $3^{1 / 2}$ Mill.

I know no species with which to compare this new form. It has no resemblance with any of the figured species, but the aperture agrees sufficiently with such species as C. perspectivum Koch.

9. Calliostoma (Astele) crassicostatum n. sp. Pl. VI, fig. 1.

Stat. 133. Lirung, Salibabu-island. 36 M. Mud and hard sand. I Spec.

Shell elevated-conical, with nearly straight sides, slightly attenuated towards the spire, yellowish with purple-brown flames and rufous spots on the lirae. Whorls $7^{1} / 2$, nucleus probably smooth, but slightly worn, followed by three whorls, each with 3 strong, spiral lirae, of which the basal one is the strongest, they are beaded where they are crossed by concentric ribs, which disappear on the subsequent whorls; these have 3 strong spirals, of which the basal one forms a conspicuous keel, a little above the linear suture, which on the lower whorls is accompanied by a thin thread and a shallow channel between this and the keel; an intermediate spiral, between the $1^{\text {st }}$ and $2^{\mathrm{d}}$ one, becomes on the last whorl nearly a $4^{\text {th }}$ spiral; on the fourth whorl the lirae are still beaded, on the fifth this is only the case with the upper one, the interstices of the last 4 whorls are nearly smooth, with very fine growth-striae and only a few deeper ones, especially on the upper whorls; base rather convex, with 8 lirae, the external one bordering the subperipheral channel, the external 5 lirae are narrow, with broad, smooth interstices, the central 3 are broad, all are ornamented with rufous spots; the base is covered with very fine growth-striae and more remote deeper striae, rendering the central 2 lirae crenulated. Umbilicus moderately wide, but seen from the base, nearly closed by a very strong, white, striated funiculus. Aperture depressedly-rounded, with a thin but not quite intact margin, which is crenulated by the external lirae. Columella cylindrical, very concave, slightly reflected over the umbilicus, its base only very little angular; interior of aperture nacreous, smooth.

Alt. 9, diam. maj. 8; apert. alt. 3, lat. $3^{1 / 2}$ Mill.

This new species has some superficial resemblance with the european C. zizyphimnm, but is at once distinguished by its umbilicus, bordered by a strong funiculus or rib. I know no species of the group Astele, allied to it.

ro. Calliostoma (Astele) sp.

Stat. 273. Pulu Jedan, east coast of Aru-islands. I3 M. Sand and shells. I Spec.

Too young for identification or for description as a new species. 
11. Calliostoma (Astcle) monodon n. sp. P1. VI, fig. 2.

Stat. $95.5^{\circ} 43^{\prime} .5$ N., $119^{\circ} 40^{\prime}$ E. 522 M. Stony bottom. 3 Spec.

Shell conical with slightly convex sides, perforate, yellowish-white. Whorls 6 , slightly convex, nucleus smooth, the other whorls sculptured by numerous concentric ribs and spiral lirae, about 9 in number on the penultimate whorl, producing a cancellated appearance; where they cross, they form small tubercles. Last whorl angular at the periphery. Base flat, sculptured by 12 spiral lirae and by radiating riblets, which make the inner 9 lirae beaded, the outer ones being crenulated. Umbilicus small, funnel-shaped, pervious, with smooth walls. Aperture rhombic, upper margin nearly straight, thin, thickened interiorly by a broad, white rib, with a ferv short plicae; basal margin slightly convex, with a few inconspicuous plicae and a strong tooth near the columella, forming the end of an internal rib, winding round the columella. Columella nearly straight, its upper part thickened, covering part of the umbilicus, parietal wall with a thin layer of enamel.

Alt. $4^{3} / 4$, diam. maj. $5 \frac{1}{2}$; apert. alt. 2, lat. $2^{3} / 4$ Mill.

The generic position of this species is a little uncertain, I know of no species to which it is allied; it is very remarkable by the tooth at the base of the aperture, which is only developed in one of the three specimens, the other ones being young.

\section{Calliostoma (Perrinia) Elisa Gould.}

Gould. Proc. Bost. Soc. Nat. Hist. I 849 , p. 92.

PIlsbry. Man. of Conch. Vol. XI, p. 417, Pl. 67, fig. 67, 68, 69, 74.

Stat. $49^{2}$. Sapeh-strait. 70 M. Coral and shells. I Spec.

Stat. 64. Kambaragi-bay, Tanah Djampeah. 32 M. Coral, coralsand. 2 Spec.

Stat. 71. Makassar and surroundings. Up to 32 M. Mud, sand with mud. 2 Spec.

Stat. 260. Near Nuhu Jaan, Kei-islands. 9o M. Sand, coral and shells. I Spec.

Stat. 313. East of Dangar Besar, Saleh-bay. Up to 36 M. Sand, coral and mud. 8 Spec.

Stat. ? I Spec.

As PIlsbry mentions as localities Singapore and China, it is not strange to find this species also on different spots of the East Indian Archipelago, however it has not yet been recorded from there, as far as I know.

13. Calliostoma (Perrinia) squanocarinatum n. sp. Pl. VI, fig. 3.

Stat. 5I. Madura-bay. 69-9I M. Fine grey sand; coarse sand with shells and stones: 2 Spec. Stat. 260. Near Nuhu Jaan, Kei-islands. 90 M. Sand, coral and shells. I Spec.

Shell elevated-conical, with slightly convex sides, yellowish grey, with dark brown spots at the upper part of whorls and below the periphery; whorls $6 \frac{1}{2}$, slightly convex, with a prominent keel, narrowly perforate. Nucleus rather smooth, blunt, followed by a whorl which is simply costate, the other whorls have 3 spiral lirae, crossed by ribs, which form blunt spines on the upper spiral, round beads on the median one and compressed, spinelike squamae on the third spiral or peripheral keel; on the last whorl these ribs become lamellose and double, 
each rib consisting of about 2 lamellae, sutures deeply channelled. Base convex, with 5 beaded spirals and lamellose ribs. Moreover the whole shell is covered with microscopic growth-striae. Umbilicus narrow, partly covered by the columellar margin. Aperture subquadrangularly rounded, outer and basal margins rounded in outline, thin, thickened interiorly, with ro spiral lirae; columellar margin cylindrical, only slightly curved, with a rather strong transverse fold, its base running without angle in the basal margin, slightly expanded over the umbilicus, its upper part, connected by a thin layer, with the outer margin.

Alt. $6 \frac{1}{4}$, diam. maj. $4^{3} / 4$; apert. alt. $2 \frac{1}{2}$, lat. $2^{1 / 2}$ Mill.

Closely allied to $C$. elisa Gld. which is however imperforate, without brown markings and has not the conspicuous spinous keel of the new species. In colour it should resemble C. maculata Brazier, which has however four spiral lirae and is imperforate.

\section{Calliostoma (Perrinia) nigromaculatum n. sp. Pl. VI, fig. 4.}

Stat. 43. Pulu Sarassa, Postillon-islands. Up to 36 M. Coral. I Spec.

Shell elevated-conical, with convex sides, imperforate, yellowish-white, with black-brown square spots, running from the suture to the keel, and more numerous narrow spots and streaks of the same colour on the base; nucleus wanting; remaining whorls $7^{1} / 2$, slightly convex, separated by a narrow channelled suture. Upper whorls slightly worn, with 3 and 4 spiral lirae, which increase to 5 in number on the last 4 or 5 whorls; they are crossed by slightly undulating ribs, with beads where they cross each other, the lowest of the lirae forming the peripheral keel is the largest, and on this one the beads have a tendency to become squamate, (but not so much as in the preceding species). Last whorl descending in front and here the ribs form irregular lamellae; periphery of last whorl angular. Base convex, with 5 spiral, beaded lirae, the interstices with strong, irregular lamellae. Aperture nearly round, angular at the upper part and very faintly so at the base of the columella. Outer and basal margins thin, thickened interiorly, with 10 conspicuous lirae, that nearest the columella toothlike. Columella cylindrical, with a groove round its upper part, running at its left side towards a square notch, formed by a square, toothlike fold at the basal part and the most proximal of the internal lirae of the base, below the notch are one large and two small denticles; parietal wall callous.

Alt. $\mathrm{IO}^{1} / \mathrm{t}$, diam. maj. $6^{1} / 2$; apert. alt. $3^{1 / 2}$, lat. $3^{1 / 4}$ Mill.

Distinguished from the preceding species, with which it is allied, by its strongly elevated shape, by 5 lirae instead of 3 (C. maculata Braz. with 4 ) and by the characters of the columella, which are more complicated than in the allied species. The columellar notch calls in mind, that of some species of Monodonta and Euchelus.

\section{Calliostoma (Perrinia) cancellatum n. sp. Pl. VI, fig. 5 .}

Stat. 59. Western entrance of Samau-strait. 390 M. Coarse coralsand with small stones. I Spec.

Shell elevated-conical, with convex sides, imperforate, yellowish-white, with a nacreous lustre and numerous yellowish-brown spots, which are darker near the upper part of each whorl and on the third whorl, the first and second being without markings. Nucleus wanting, remaining 
whorls 5, slightly convex, with a narrow canaliculate suture. First whorl with rather distant ribs. Next whorl with 3 spiral lirae and radiating ribs; last 3 whorls with 5 spirals and thinner radiating ribs, which make the shell cancellated; these ribs become lamellose on the lower whorls; lirae beaded where the ribs cross them, less obvious on the lower whorls, the uppermost of the lirae on each whorl with a series of small tubercles, giving a coronated appearance to the whorls. Last whorl rounded, the peripheral spiral being only very little prominent. Base convex, with 6 beaded lirae, cancellated by numerous, irregular, radiating ribs. Aperture nearly rounded, outer and basal margins rounded, thin, thickened interiorly, with about 17 short lirae on the internal rib, of which that near the columella slightly tooth-like. Columella cylindrical, rather straight, with a tooth-like fold at the base, bordering a rounded notch, parietal wall callous. Interior of aperture with a few grooves.

Alt. 7 , diam. maj. 5 ; apert. alt. $2^{3} / 4$, lat. $2^{1} / 2$ Mill.

Though the only specimen is slightly broken, I have described it, as all the characters were present and the species seemed to be new. I know no species in the group Pcrrinia which is nearly allied to it.

\section{Euchelus Philippi.}

I. Euchelus atratus Gmelin.

Gmelin. Syst. Nat. Ed. XiII, p. 360 r.

Kiener. Coq. Viv. Vol. X, Trochus, p. 293, Pl. 94, fig. 3.

Pilsbri. Man. of Conch. Vol. XI, p. 439, Pl. 38, fig. 22; Vol. X, Pl. 41, fig. $25,26$.

Stat. I6. Bay of Kankamaraän, S. coast of Kangeang. Shore. I Spec.

Stat. 34. Labuan Pandan, Lombok. Coral reef. I Spec.

Stat. 58. Seba, Savu. Reef. 2 Spec.

Stat. 6o. Haingsisi, Saman. Reef. I Spec.

Stat. 64. Kambaragi-bay, Tanah Djampeah. 32 M. Coral, coralsand. I Spec.

Stat. 7I. Makassar and surroundings. Up to $32 \mathrm{M}$. Mud, sand with mud. 2 Spec.

Stat. S6. Dongala, Palos-bay, Celebes. Reef. I Spec.

Stat. S9. Pulı Kaniungan Ketjil. Reef. I Spec.

Stat. 93. Pulu Sanguisiapo, Tawi-Tawi-islands, Sulu-archipelago. I2 M. Lithothamnion-bottom, sand and coral. I Spec.

Stat. II6. West of Kwandang-bay-entrance. $72 \mathrm{M}$. Fine sand with mud. I Spec.

Stat. 127. Taruna-bay, Great Sangir-island. Reef. I Spec.

Stat. I3I. Beo, Karakelang-islands. Reef. I Spec.

Stat. 169. Atjatuning, IVest coast of New-Guinea. Reef. I Spec.

Stat. I74. Waru-bay, N. coast of Ceram. Reef. I Spec.

Stat. I93. Sanana-bay, East coast of Sula Besi. Reef. 2 Spec.

Stat. 23I. Amboina. Reef. 2 Spec.

Stat. 240. Banda. Reef. I Spec.

Stat. 273. Pulu Jedan, East coast of Aru-islands. I3 M. Sand and shells. 2 Spec.

Stat. $3^{\mathrm{I}} 3$. East of Dangar Besar, Saleh-bay. Up to $36 \mathrm{MI}$. Sand, coral and mud. 35 Spec.

The numerous specimens vary in shape, size and colour, as already stated by different authors.

2. Euchclus ruber A. Adams.

A. Adans. Proc. Zool. Soc. Lond. IS51, p. 176.

Pilsbri. Man. of Conch. Vol. XI, p. 440, Pl. 67 , fig. 79. 
Stat. 93. Pulu Sanguisiapo, Tawi-Tawi-islands, Sulu-archipelago. Reef. 3 Spec.

Stat. 99. North-Ubian. I6-23 M. Lithothamnion-bottom. 3 Spec.

Stat. 301. Pepela-bay, East coast of Rotti-island. 22 M. Mud, coral and Lithothannion. 2 Spec.

Stat. 3 5. Sailus Besar, Paternoster-islands. Up to $36 \mathrm{M}$. Coral and Lithothamnion. I Spec.

The species is new for the E. Indian-Archipelago, at least Pilsery mentions only China as the habitat. It is a much smaller species than the preceding one, the type may be at once distinguished by the beautiful rose-colour.

var. brunneus Pilsbry.

PILSBRy. Proc. Acad. Nat. Sciences Philadelphia, 1901, p. 28.

Stat. 240. Banda. 9-45 M. Black sand, coral, Lithothamnion-bank. I Spec.

This shell agrees exactly in sculpture with E.-ruber and with specimens of var. brunneus received from Japan, it is still smaller than Pilsbry's specimens, being only $5 \%$ Mill. in altitude instead of $6^{1} / 2$. In colour it differs little from many specimens of the preceding species. The interstices of the spiral lirae are narrow, as well in the type as in the variety. I can detect no intermediate lirae, nearly always very distinct in E. atratus, only faint traces of them may be eventually found, when the interstices are slightly broader.

\section{Euchelus intricatus Gould.}

Gould. Proc. Boston Soc. Nat. Hist. I 849 , p. 167.

Kiener. Coq. Viv. Vol. X, Trochus, p. 249, Pl. 84, fig. 3 (Bourcieri Crosse).

Pilsbry. Man. of Conch. Vol. XI, p. 440, Pl. 67, fig. 62, 63 .

Stat. 7 S. Lumu-Lumu-shoal, Borneo-bank. 34 M. Coral and coralsand. 1 Spec.

This species is also new to the fauna, its habitat, mentioned by PILSery, being Viti-islands, New Caledonia, and with doubt also Japan. In his "Catalogue of the Marine Mollusks of Japan, collected by F. Stearns", published in i 895 , Pilsbry does not mention it.

4. Euchelus ringens n. sp. PI. VI, fig. 6.

Stat. $9^{8} .6^{\circ} 9^{\prime}$ N., $120^{\circ} 21^{\prime}$ E. 350 M. Sand. I Spec.

Shell globose-conical, probably imperforate, rather thin, flesh-coloured, with 3 rows of dark brown spots on the upper whorls, nucleus white, lower $2 \frac{1}{2}$ whorls with faint brown blotches near the upper part and scattered brown dots. Sutures deep, canaliculate, whorls 5, convex. Nucleus smooth; upper whorls with from 2 to 3 , penultimate one with 5 , last with 14 spiral lirae, and a few intermediate ones, becoming more numerous towards the aperture, the principal lirae are conspicuously beaded, the intermediate ones less so, the interstices are crossed by lamellae, often corresponding to the beads. Body whorl slightly depressed but not angular. Aperture rounded, very oblique, margin slightly expanded, with a broad, flat rib interiorly, with numerous elongate wrinkles and a few shorter intermediate ones at the outer margin; margins connected by a thin expanded callosity with regular wrinkles, the whole circumference of the 
aperture is wrinkled; columellar margin broken, probably smooth, ending in a large subbifurcate tooth, bordering a rather narrow, deep notch; opposite to this tooth a smaller tooth of the basal margin, borders the notch. Umbilical region with a groove.

Alt. $7 \%$, diam. maj. $S$; apert. alt. 4, lat. 6 Mill.

This shell resembles in shape, sculpture and in some degree in colour E. baccatus Menke, but it is considerably smaller and more depressed. The margins are more wrinkled, the tooth of the columella and the notch are much larger, the right margin is expanded; the lirae are less numerous, with larger interstices and more conspicuous intermediate lirae.

It is with some hesitation that I have described this species, the only specimen being incomplete; there is a small hole at the place of the umbilicus, but it has the appearance of being caused by the same accident, that has mutilated the columella.

\section{Euchclus (Hybochchus) fossulatus Souverbie.}

Souverbie. Journ. de Conch. I 875 , p. 39, Pl. 4, flg. 5.

Kiener. Coq. Viv. Vol. X, Trochus, p. $39 \mathrm{I}$, Pl. i1 7 , fig. 2.

Prlsbri. Man. of Conch. Vol. XI, p. 444, Pl. 38, fig. 15, 16.

Stat. $25 \mathrm{~S}$. Tual-anchorage, Kei-islands. 22 M. Lithothamnion, sand and coral. 2 Spec.

The specimens are young, one of them is very small, but even the largest has a whorl less than has been recorded in the original description, its diameter is only $7^{1 / 2}$ Mill. against io in Souverbie's specimen, and $12 \%$ as stated by Pilsbry. The species was hitherto only known from New Caledonia and the Andamans.

\section{Euchelus (Tallorbis) roscola Nevill.}

G. and H. Nevill. Journ. Asiatic. Soc. Beng. Vol. 38 , I 865 , p. I60, Pl. I7, fig. 5 . Pilsbry. Man. of Conch. Vol. XI, p. 446, Pl. 57, fig. 15.

Stat. 66. Bank between islands of Bahuluwang and Tambolungan, South of Saleyer. 8 M. Dead coral; Lithothamnion. 1 Spec.

The shell, though very characteristic, seems to be young, its diameter being scarcely $5 \%$ Mill. instead of 11 in Nevill's description. Its locality is new, as Nevill had got it only from the Southern Province of Ceylon. Pilsbry is in doubt about its systematic position. Indeed I should think Nevill was right in creating the new genus Tallorbis for it. However I think he was wrong in approaching it to Thalotia, as it resembles much more the preceding species, than any Thalotia I know. As the only specimen is inhabited by a crustacean, I am unfortunately unable to decide the question, by examining the radula.

\section{Danilia Brusina.}

I have made use of the name Danitia for this group of shells, in accordance with. PILSBR: (Man. of Conch. Marine Series, Vol. XI, p. 44S, ISS9) though Locard in a more recent publication (Expéditions scientifiques du Travailleur et du Talisman, pendant les anneés is 66 - I 893 . Moll. Testacés, Tome II, I $\$ 9 S$, p. I 9 ) has choosen the older name Craspciotus Phil., for PiLSbrr, 
1.c. has stated that this name has been used in 1844 for a genus of Curculionidae by Schonnherr; Locard agrees with Pilsbry in rejecting the name Olivia, employed by Cantraine, as this name was preoccupied by Bertholini in 1810 , for a genus of Sponges. The only recent species $D$. Tinci Calcara was known from the Mediterranean and Adriatic Seas and the Gulf of Gascogne, when in 1896 Dautzenberg and Fischer (Extr. des Mémoires de la Soc. Zool. de France 1896 , p. 81, Pl. XX, fig. 9, 10) described a new species D. affinis from the Azores. As long as the anatomy of this group is not known, I think it is better to consider it as a separate genus and not as a subgenus of Euchehus, like PILSBRy has done; indeed the strong varix of the outer lip and the particulars of the dentition of the aperture, seem sufficient to separate it generically. The latter calls in mind some species of Clanculus rather than of Euchelus.

1. Danilia Weberi n. sp. Pl. II, fig. 6.

Stat. $105.6^{\circ} 8^{\prime}$ N., $121^{\circ} 19^{\prime}$ E. 275 M. Coralbottom. 6 Spec.

Shell globose-conoidal, imperforate, thin, spire more or less elevated, embryonic whorls wanting, remaining whorls about 6 , very convex, especially the penultimate and ultimate ones, the upper whorls forming a cone. Colour shightly variable, ground-colour light yellowish-brown, nearly plain or with darker flames and blotches, which are always present on the varix, the majority of the specimens has two or three series of darker spots on the upper whorls and two specimens have a row of large blackish patches near the suture of the last whorl. The shell is covered with a large number of spiral lirae, often with intermediate ones, the number of lirae being about 7 on the penultimate whorl, but amount with the intermediate ones to 15 or I6; they are crossed by numerous riblike striae, producing short spines on the points of intersection, and very fine lines of growth; on the upper whorls the lirae dininish in number, they become nearly obsolete on the uppermore whorls, and disappear at last, leaving only the concentric ribs. The suture is deep, especially between the penultimate and ultimate whorls, on this last the suture descends conspicuously. The periphery of last whorl is rounded, only apparently keeled by the strong peripheral lira. The base is ornamented by about I 2 beaded lirae, with ribbed interstices. The oblique aperture is rounded-ovate, with a very thin, slightly expanded outer and basal margin, encircled by a strong, compressed, external varix. The margin is thickened interiorly by a rather strong crenulated rib at some distance from the outer rim; the parietal wall is covered by a much expanded, smooth layer, loosened from the body-whorl near the place of the wanting umbilicus. The columella is very strong and tortuous, thickened above, then slightly attenuated, with a strong square tooth, from which a tortuous rib runs to the left, enclosing a triangular pit and forming a deep sinus between the columella and basal margin. Interior of aperture very iridescent, but covered in part in the adult shells, by the porcellaneous internal rib.

Alt. I6, diam. maj. I I; apert. alt. 6, lat. 5 Mill.

Alt. I $2^{1} / 2$, diam. maj. Io; a pert. alt. $5^{1} / 2$, lat. $4^{1 / 2}$ Mill.

Alt. $11^{1} / 2$, diam. maj. $9^{1 / 2}$; apert. alt. $5^{1 / 2}$, lat. $4^{1} / 2$. 
This new species of Danilia differs (according to the figures) so much in shape, size and sculpture from $D$. Tinei and $D$. affinis, that it seems superfluous to make an exact comparison.

I have the pleasure to name it after the leader of the expedition.

Fam. Umboninae.

\section{Umbonium Link.}

I. Umbonizm depresszm, Adams.

A. Adams. Proc. Zool. Soc. Lond. 1853 , p. i88.

ReEve. Conch. Ic. Vol. XX, Rotella, fig. 2.

PIlsbry. Man. of Conch. Vol. XI, p. 45 I, Pl. 58, fig. 24, 25.

Stat. 323. Sangkapura-roads, Bawean-island. I2 M. Mud. I Spec.

Not wishing to decide the question, if $U$. depressum is a good species, or merely a variety of $U$. vestiarum Lin., I have left to this single specimen the name applied by ADAMs. It is only an empty shell, so I was unable to look for differences in the radula.

\section{Ethalia Adams.}

I. Ethalia guamensis Quoy and Gaimard. Fig. 3.

Quov \& Gamard. Voy. de l'Astrolabe. Zool. Vol. III, p. 267, Pl. 61, fig. 32, 33. (Rotella). KIENER. Coq. Viv. Rotella, p. 7, Pl. 2, fig. 18.

Fischer. Coq. Viv. Vol. X, Trochus, p. 378, Pl. 115, fig. 3 (callosus).

ReEve. Conch. Ic. Vol. XX, Rotella, fig. I8.

Pilsbry. Man. of Conch. Vol. XI, p. 458, Pl. 59, fig. 38, 39; Pl. 57, fig. 41, 42.

Stat. 37. Sailus Ketjil, Paternoster-islands. Up to $18 \mathrm{M}$. Coral and coralsand. 2 Spec.

Stat. 184. Kampong Kelang, South coast of Manipa-island. 36 M. Coral, sand. 2 Spec.

Stat. 240. Banda. 9-36 M. Lithothamnion-bank. is Spec.

Stat. 279. Rumah-Kuda-bay, Roma-island. 18-45 M. Mud and sand. I Spec.

In nearly all the specimens the callus is white, only in that from Stat. 37 , it is light pink; those from Banda are generally dark-coloured at the upper surface. The species was not yet mentioned from the Archipelago.

The radula has not yet been described, as far as I know. The teeth, especially those of the central part are very thin and transparent, without distinct cusps; the rhachidian tooth (R) is broadly winged, bow-shaped, at its upper part it is thickened, but I cannot detect a true cusp, the first (I), second (2), third (3) and fourth (4) laterals are about equal in shape, the first one is subtriangular, with a slightly concave inner and convex outer margin, thickened at its upper part, the second is very similar, the third is narrower and the fourth is more subquadrangularly elongate; the fifth (5) or last lateral is club-shaped, thickened above, without cusp. Of the uncini (U) the proximal one has a short, broad cusp, with a small denticle near the base of the distal margin; the second is more elongate, also with a small denticle; the 
subsequent ones are much more elongate, I can detect no denticles, perhaps because the cusps lie so close together, as to cover each other in part.

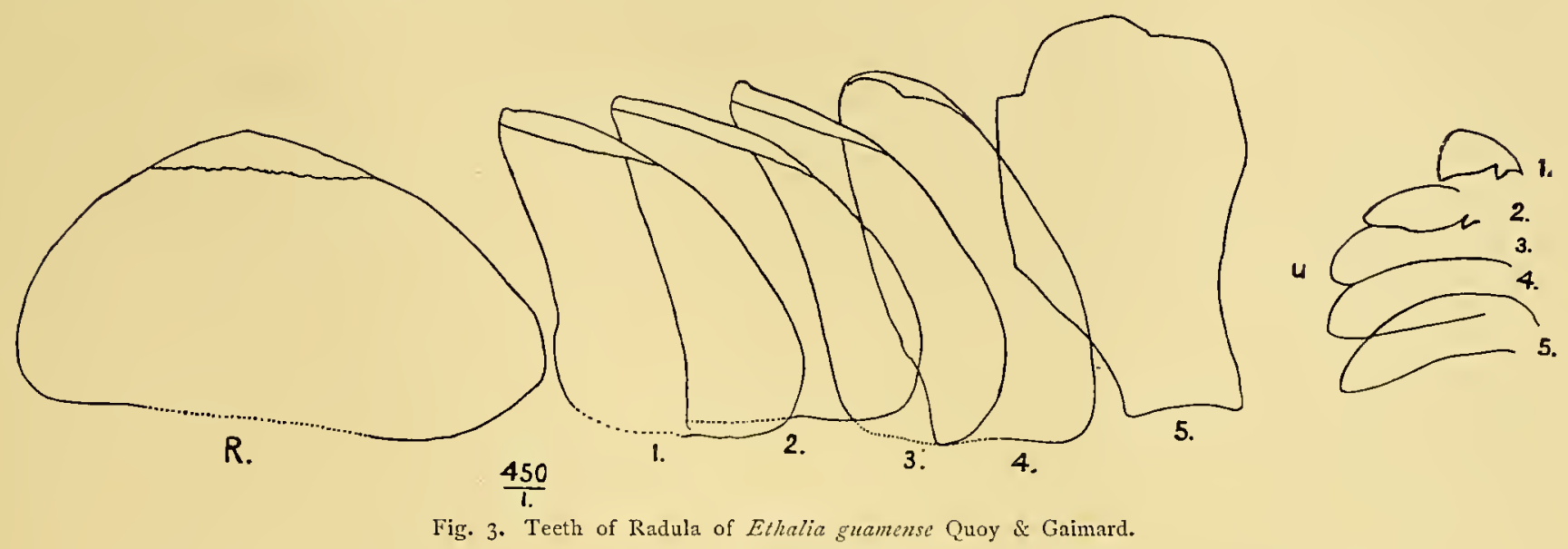

The shape of the rhachidian tooth differs much from that of Umbonizm (Rotella) as figured and described by Troschel (Gebiss der Schnecken, Vol. II, p. 220, Pl. 2 I, fig. 5 and 6), for though Troschel says of Rotella elegans, that the rhachidian tooth is: "viel breiter als lang", he says on the contrary of the genus: "Die Mittelplatte ist länger als breit", and in his figures, of which that of $R$. elegans is somewhat strange and irregular, the median teeth are elongate. Of the measurements he says (1.c. p. 221 ): "Breite der Mittelplatte 0,OI25 mm., Länge derselben $0,03 \mathrm{~mm}$. The shape of the other teeth, which in Unbonizm, according to Troschel, have no cusps in the median field, agrees sufficiently, to admit relationship.

\section{Ethalia striolata Adams, var. trilobata Sowerby.}

Sowerby in: Reeve, Conch. Ic. Vol. XX, Rotella, fig. 20. PILsbry. Man. of Conch. Vol. XI, p. 460, Pl. 58, fig. 20.

Stat. 133. Lirung, Salibabu-island. Up to $36 \mathrm{M}$. Hard sand. I Spec.

Stat. 313. East of Dangar Besar, Saleh-bay. Up to 36 M. Sand. 3 Spec.

It seems that PIlsbry has not seen this species, as he gives no measurements; of the largest Siboga-specimen they are:

Diam. maj. I $3^{1} / 2$, alt. $8^{1} / 2$; apert. alt. 7 , lat. 6 Mill.

3. Ethalia minolina Melvill, var. infralaevior n. var. Pl. VI, fig. 7 .

Stat. 37. Sailus Ketjil, Paternoster-islands. Up to 18 M. Coral and coralsand. 2 Spec.

Stat. 66. Bank between islands of Bahuluwang and Tambolungan, south of Saleyer. \& M. Dead coral, Halimeda, Lithothamnion. 2 Spec.

Stat. 240. Banda. 9-36 M. Lithothamnion-bank. I Spec.

Melvill has described (Mem. and Proc. Manch. Literary and Philos. Soc. Vol. 4 I, p. 20, Pl. 7, fig. 24) the type of a new species, allied to E. striolata Ads. from the Persian Gulf, and though the specimens under consideration, differ in some degree from a specimen from that locality, they agree in so many points, that $I$ think it is better to give them only varietal rank. 
The Siboga specimens are slightly less depressed, the whorls are more convex, especially below the suture, the last whorl is less angular, the umbilicus narrower. The chief character, which distinguishes the variety is that the base of the shell is much smoother, in one specimen from each station, the spiral striae are completely wanting, in one from Stat. 37, which is however of very doubtful identification, as it is very young, and in another from Stat. 66; spiral striae are visible, but less strong than in the typical specimen, especially these last intermediate specimens have induced me, to consider the shells as belonging to a variety. The sculpture consisting of rather irregular spiral striae, crossed by fine but inconspicuous, oblique growth-striae, is quite identical. The colour-pattern though variable, is similar, especially in the specimens from Banda.

Fam. Haliotidae Fleming.

Haliotis Linné.

1. Haliotis squamata Reeve.

REEvE. Conch. Ic. Vol. XII, Haliotis, fig. 35.

Weinkauff. Mart.-Chemn. Conch. Cab, Ed. II, Haliotis, p. 59, Pl. 23, figs. I, 2.

Pilsbry. Man. of Conch. Vol. XII, p. 9i, Pl. I8, fig. 2.

Stat. 34. Labuan Pandan, Lombok. Reef. I Spec.

To this species I must refer the only specimen from Stat. 34; which has a rather juvenile appearance. It is less elongated in proportion to its breadth, than in the cited figures, and two specimens from Port Jackson, in my collection. ReEve gives no measurements, those known by me, are:

Weinkauff, 1. c. long. 43, lat. 26 Mill.

Pilsbry, 1. c. long. 69, lat. 42 Mill.

largest specimen from Port Jackson, long. 78 , lat. 48 Mill.

smaller specimen from Port Jackson, long. 60, lat. 38 Mill.

specimen from Stat. 34, long. 38, lat. 28 Mill.

moreover only 5 perforations are open. According to Weinkauff, this should be from 6 -8, Pilsbry says 7 or 8 . In the specimens from Port Jackson, one has 6 the other 7 open perforations and of this last specimen the $8^{\text {th }}$ is again closed. As however the other characters, especially those of sculpture agree and the number of open perforations and of relative length and breadth vary, I don't venture to describe a new species on such slight differences.

2. Haliotis varia Linné.

LinnÉ: Syst. Nat. Ed. X, p. 780 , sp. 650.

Rumph. Amb. Rariteitkamer, p. 121, Pl. 4I, fig. G.

ReEve. Conch. Ic. Vol. XII, Haliotis, fig. 4.

Weinkauff. Mart.-Chemn. Conch. Cab. Ed. II, Haliotis, p. Io, Pl. 3, fig. 4.

Pilsbry. Man. of Conch. Vol. XII, p. 95, Pl. 17, figs. 91, 93, 99, 100; Pl. 23, figs. 52- 55. 
Stat. 34. Labuan Pandan, Lombok. Shore. 2 Spec.

Stat. I 3 I. Beo, Karakelang-islands. Reef. 4 Spec.

Stat. 152 . Wunoh-bay, Waigeu. Reef. I Spec.

Stat. 240. Banda. Reef. 2 Spec.

Stat. 250. Kilsuin, West coast of Kur-island. Reef. I Spec.

Stat. 299. Buka-bay, South coast of Rotti-island. Reef. 2 Spec.

The specimens of the majority of the localities have the animal brown; in those from Stat. $I^{1}$ and 250 they are tinged in many parts with green, especially the specimen from Stat. 250 is very beautiful, the upper part of the foot, the muzzle, the tentacles, many of the epipodial fringes and the border of the mantle are green, the under surface of the foot and part of the epipodial fringes remain brown.

The shells are very variable in colour, markings, sculpture and even in shape, some specimens. being more elongated and the spire is more or less flattened, even in specimens from the same locality.

\section{Haliotis coccoradiata Reeve.}

ReEve. Conch. Ic. Vol. XII, Haliotis, fig. 46.

Weinkauff Martini-Chemn. Conch. Cab. Ed. II, Haliotis, p. 6o, Pl. 23, figs. 3, 4.

Pilsbry. Man. of Conch. Vol. XII, p. IIS, Pl. 4, figs. I6, 20.

Stat. II5. Kwandang-bay, East-side of Pajunga-island. Reef. I Spec.

Stat. 255. Er-island, Kei-islands. 22 M. Coral. I Spec.

Both specimens are very young, the largest one being only is Mill. in length, the fullgrown ones reach, according to PILSBRy 42 Mill. in length, Weinkauff says even 45 Mill. Though the radiating folds in the specimen from Stat. 115 are more conspicuous than in the zustralian specimens I could compare, I cannot separate them, especially as the other specimen of scarcely 9 Mill. agrees very well with the upper whorls of the adult shells.

Hediey in his paper on: the effect of the Bassian isthmus upon the existing marine Fauna (Proc. Linn. Soc. New South Wales, 1903, p. 876), has mentioned this species as characteristic for his Peronian. Fauna. As this paper has been written with the view to show the difference between the species of the eastern and western part of South Australia, rather than to trace the northern limits, it seems not to be excluded that this species should live in New Guinea, the Kei-islands etc.

4. Haliotis (Padollus) ovina Chemnitz.

Chemnitz. Conch. Cab. Ed. I, Vol. X, p. 315, Pl. 166, fig. 1609.

ReEve. Conch. Ic. Vol. XII, Haliotis, fig. 23.

Weinkauff. Martini-Chemn. Conch. Cab. Ed. II, p. 18, Pl. 6, fig. II.

PILŚBry. Man. of Conch. Vol. XII, p. 124, Pl. I9, figs. 7, S.

Stat. 133. Lirung, Salibabu-island. Reef. I Spec.

Of this beautiful species, one specimen of a deep coral-red, with scarce whitish spots, has been collected; according to WeinkaufF it lives also in the Moluccos. 
5. Haliotis (Teinotus) asinina Linné.

LinNÉ. Syst. Nat. Ed. X, p. 7 So, sp. 652.

RuMph. Amb. Rariteitkamer, p. I2 I, figs. E, F.

Reeve. Conch. Ic. Vol. XII, Haliotis, fig. is.

Weinkauff. Martini-Chemn. Conch. Cab. Ed. II, Haliotis, p. 5, Pl. 1, fig. 5; Pl. 9, figs. 2, 3. Pilsbry. Man. of Conch. Vol. XII, p. I26, Pl. I4, fig. 76.

Stat. 2. Madura-strait. 56 M. I Spec.

Stat. 58. Seba, Savu. Reef. I Spec.

Stat. 6o. Haingsisi, Samau-island, Timor. Reef. 3 Spec.

Stat. 93. Pulu Sanguisiapo, Tawi-Tawi-islands, Sulu-Archipelago. 12 M. 6 Spec.

Stat. 30 I. Pepela-bay, East coast of Rotti. Reef. I Spec.

*Amboina. 2 shells with soft parts of 3 specimens.

Many of the specimens have the shell partly covered by the epipodial lobes, this may be the case in a more conspicuous manner in living specimens. The foot even in specimens in alcohol is considerably longer than the shell. In a specimen from Haingsisi, with a shell of 49 Mill., the foot is 72 Mill. in length, in another from Stat. 30 I, it is 60 Mill. with a shell of 57 Mill. The breadth of the foot in the first-mentioned specimen, is about 39 Mill. Corresponding to this more developed foot, the operculigerous lobe (as usually without operculum) is much more conspicuous, as well as the longitudinal furrow, characterizing the subgenus Teinotus by features taken from the soft parts.

\section{Fam. Stomatellidae A. Adams}

\section{Stomatella Lamarck.}

I. Stomatella papyracea Chemnitz.

Cinennitz. Conch. Cab. Vol. V, p. 215 , Pl. i82, figs. i817, is 18.

ReEve. Conch. Ic. Vol. XIX, Stomatella, fig. 3.

Pilsbry. Man. of Conch. Vol. XII, p. io, Pl. 52, figs. 46, 47; Pl. 5 I, fig. 9.

Stat. 37. Sailus Ketjil, Paternoster-islands. 27 M. Coral and coralsand. I Spec.

Stat. 43. Pulu Sarassa, Postillon-islands. 36 M. Coral. 2 Spec.

The soft parts agree in most respects with the description of Pilsbry (Proc. Ac. Nat. Sc. Philad. 1891, p. 7I, 72) but both specimens have a long foot, which is pointed, not emarginate behind, this posterior part is not furrowed longitudinally as strongly as the anterior part, it is strongly keeled at the upper surface, with small fringes at the keel. The epipodial ridge bears 3 instead of 2 cirri, accompanied by fringed lobes, the third one is placed at the posterior part of the foot. I think however that this difference may result from the faculty, ascribed by A. Adams only to Stomatia and Gena (Proc. Zool. Soc. Lond. i 850, p. 29) "of spontaneously detaching a considerable portion of the hind part of the 'foot when disturbed or irritated", indeed the specimens show a groove, which, if one supposes the part behind it were lost, would give a shape corresponding to Pilsbry's figure. I see no operculum. 
2. Stomatella haliotoidea Sowerby.

Sowerby. Thes. Conch. Vol. II, p. 837, Pl. 174, figs. 10, I1.

REEve. Conch. Ic. Vol. XIX, Stomatella, fig. 4 .

Pilsbry. Man. of Conch. Vol. XII, p. 20, Pl. 52, figs. 40, 41 .

Stat. 81. Pulu Sebangkatan, Borneo-bank. Reef. I Spec.

Stat. 176. Lilintah, South coast of Misool. Shore. I Spec.

The two specimens differ in colour of the shell, that from Stat. 176 being marked with dark brown flames on a yellowish-ground, the other is of a lighter hue, with a few white spots.

3. Stomatella exquisita Sowerby.

Sowerby. Journ. of Malacology, Vol. X, 1903, p. 76, Pl. 5, fig 4.

Stat. 299. Buka- or Cyrus-bay, south coast of Rotti-island. Up to $36 \mathrm{M}$. Mud, coral and Lithothamnion. I Spec.

The only specimen of this beautiful species is still young, its diameter being scarcely $5 \%$ Mill.; it is however interesting, as Sowerby did not know the locality of his specimen.

In this and in the preceding species the posterior part of the foot is wanting.

\section{Stomatia Helbling.}

I. Stomatia phymotis Helbling. .

Helbling. Abh. Privat-Gesellsch. Böhmen. Math. Vaterl. Gesch. u. Naturgesch. IV, p. 124. ReEve. Conch. Ic. Vol. XIX, Stomatella, fig. 2.

Pilsbry. Man. of Conch. Vol. XII, p. 30, Pl. 54, figs. 16, 17 .

Stat. 93. Pulu Sanguisiapo, Tawi-Tawi-islands, Sulu-Archipelago. 12 M. Lithothamnion-bottom, sand and coral. I Spec.

The specimen is very elongated and strongly scalar, more than in any of the cited figures.

\section{Stomatia acuminata A. Adams.}

A. Adams. Proc. Zool. Soc. Lond. 1850, p. 35.

REEve. Conch. Ic. Vol. XIX, Stomatia, fig. 7 .

Pilsbry. Man. of Conch. Vol. XII, p. 32, Pl. 54, fig. I8.

Stat. 93. Pulu Sanguisiapo, Tawi-Tawi-islands, Sulu-Archipelago. Reef. 2 Spec.

Stat. Iog. Pulu Tongkil, Sulu-Archipelago. I3 M. Lithothamnion-bottom. I Spec.

The shells seem to be variable in colour; ADANis calls it "reddish-brown", ReEve "brown", PILsbry "rather brown"; the two specimens from Stat. 93 may perhaps be called reddish-brown, though I should rather say brownish-red. The shell from Stat. Iog is variegated with large white streaks, the sculpture however agrees with that of the more typical specimens. As one of the specimens from Stat. 93 contains the soft parts, the lighter hue cannot be ascribed to bleaching of the shells after death. 
3. Stomatia rubra Lamarck.

LamarCiK. An. s. vert. Ed. Desh. Vol. IX, p. 16 (Stomatella).

ReEve. Conch. Ic. Vol. XIX, Stomatia, fig. 8.

PIlsbrir. Man. of Conch. Vol. XII, p. 33, Pl. 5 1, figs. 26-28; Pl. 53 , fig. 96; Pl. 54, figs. $31-33$.

Stat. $98.6^{\circ} 9^{\prime}$ N., $120^{\circ} 21^{\prime}$ E. $35^{\circ}$ M. Sand. I Spec.

Stat. 99. North-Ubian. 16-23 M. Lithothamnion-bottom. I Spec.

The specimen from Stat. 98 is a young, dead shell of somewhat doubtful identification, its spire being more elevated than in any specimen I have seen; the great depth at which it has been collected, may be caused by the sinking down of the dead specimen. The other typical specimen from Stat. 99 contains the soft parts. The upper surface of the foot is tuberculate and spotted with black, and the tentacles are ringed by the same colour, on a yellowishgrey ground.

4. Stomatia planulata n. sp. Pl. VI, fig. S.

Stat. 93. Pulu Sanguisiapo, Tawi-Tawi-islands, Sulu-Archipelago. Reef. I Spec.

Stat. 99. North-Ubian. 16-23 M. Lithothamnion-bottom. i Spec.

Shell much depressed, the spire only a trifle above the last whorl; colour variable: in both specimens a greenish-grey colour predominates, in the largest one, the top whorls are variegated with crimson and a large patch of the same colour occupies the upper part of the last whorl, near the aperture; the upper part is covered by microscopic spiral rows of darker arrowhead-shaped spots, the basal part is more yellowish. Number of whorls about $3^{1} / 2$, the last rapidly increasing; they are very convex, with a deep suture, and short subsutural folds. The sculpture consists of a keel at some distance from the suture, enclosing a concave zone, and another keel near the periphery; between these keels runs a row of elongated, slightly oblique tubercles, moreover the whole shell is covered with fine spiral striae and still finer growth-striae. Aperture very oblique, its upper margin concave near the body whorl, then strongly convex.

Alt. 3, diam. maj. $9^{1 / 2}$, diam. min. $7^{1} / 2$; apert. alt. $3^{1} / 2$, oblique about $5^{1 / 2}$ Mill.

The specimen from Stat. 99 is much younger, partly covered by a chalky deposit, it has an interrupted, spiral, crimson band at the periphery.

I know no species with which to compare the new one, the excavation of the upper part of both specimens, give it a very exceptional character, resembling a large Planorbis. Animal large, upper surface of foot granular and tuberculate, with three epipodial cirri, of which the third is placed on the detachable part of the foot.

\section{Gena Gray.}

1. Gena planulata Lamarck.

Lamarck. An. s, Vert. Ed. Desh. Vol. IX, p. 17 (Stomatelta).

- Runph. Amb. Raritcitkamer, p. I2 I, Pl. 40, fig. I.

Reeve. Conch. Ic. Vol. XIX, Gena, fig. 3:

Pilsbry. Man. of Conch. Vol. XII, p. 3S, Pl. 55, figs. 1, 23; Pl. 2, figs. 17一20. 
Stat. 127. Taruna-bay, Great Sangir-island. Reef. I Spec.

Stat. 231. Amboina. Reef. 6 Spec.

This easily recognized species, distinct by its very flattened shape, its striated surface and large dimensions, should belong to the subgenus Gena s. str.. Fischer (Manuel de Conchyliologie etc., Paris, 1887, p. 840) has proposed the new subgenus Plomacotis for G. laevis Pease and its allies, on account of the presence of epipodial cirri, which should be wanting in $G$. planulata, nigra and lutea, according to the researches of Quoy and GAnMARD, moreover G. laevis should possess a siphon on each side of the neck. Now in the specimens of the Siboga-expedition from Amboina, I see distinctly those siphons, though much shorter by the contraction in alcohol, and in one of them, I find on the right side, 3 epipodial cirri, accompanied by a lobed appendage and one distinct cirrus on the left side; in the other specimen the cirri are scarcely or not at all visible, and so former observers may have failed to perceive them. In most other respects the description of the soft parts agrees with that of $G$. laevis, for though I cannot detect that the tentacles and eye-stalks are hirsute, this may depend on contraction. One of the specimens from Amboina, and from Stat. I 27 have lost their tails.

Though Lamarck (l.c.) has cited the figure of Rusiph for Stomatella auricula, it is not doubtful that Rumph has had in view $G$. planulata, his figure and short description, with the remark that they have scarcely a length of a phalanx of a finger, agrees only with this species, the more so, if one looks at the long fingers of that author on his portrait in the "Rariteitkamer".

\section{Gena nigra Quoy \& Gaimard.}

Quoy \& Gaimard. Voy. de l'Astrolabe, III, p. 307, Pl. 66 bis, figs. 10-I2.

Pilsbrey. Man. of Conch. Vol. XII, p. 38, Pi. 5 I, fig. 20, 2 I.

Stat. 30r. Pepela-bay, East coast of Rotti-island. Reef. I Spec.

The only shell from the named locality agrees sufficiently with the description and figures, it is blackish with a few very small white dots.

Long. I $6^{3} /$, lat. 8 Mill.

(See also Appendix).

\section{Gena lintricula Adams.}

A. Adanis. Proc. Zool. Soc. Lond. 1850, p. 38.

Reeve. Conch. Ic. Vol. XIX, Gena, fig. 1.

Pilsbry. Man. of Conch. Vol. XII, p. 44, Pl. 55, fig. 14.

Stat. 144. North of Salomakië-(Damar)-island. 45 M. Coralbottom and Lithothamnion. I Spec.

The specimen differs from the original description in colour; the posterior part of the shell is nearly entirely yellowish-white with a green tinge, moreover a few smaller patches of the same colour are dispersed over the anterior part, a few dark spiral lines are more conspicuous on the posterior part. The surface is covered with very fine, close-set spiral and by more remote concentric striae. The species may be easily recognized by its very elongate shape. 
4. Gena auricula Lamarck.

Lamarck. An. s. vert. Ed. Desh. Vol. IX, p. 17 (Stomatella).

PILsbri. Man. of Conch. Vol. XII, p. 44, Pl. 2, figs. 29-31; Pl. 55, figs. 8, 9 (lutea).

Smitus. Marine Mollusca. Fauna and Geography of the Maldive and Laccadive Archipelago, p. $618, \mathrm{~N}^{0} 27 \mathrm{I}$.

Stat. 37. Sailus Ketjil, Paternoster-islands. is and 27 M. Coral and Coralsand. 3 Spec.

Stat. 5S. Seba, Savu. Reef. I Spec.

Stat. 8r. Pulu Scbangkatan, Borneo-bank. Reef. I Spec.

Stat. 89. Pulu Ǩaniungan Ijetjil. Reef. I Spec.

Stat. 93. Pulu Sanguisiapo, Tawi-Tawi-islands. Reef and 12 M. 6 Spec.

Stat. 99. North-Ubian. 16-23 M. Lithothamnion-bottom. 1 Spec.

Stat. 133. Lirung; Salibabu-island. 36 M. Hard sand. I Spec.

Stat. 213 . Pulu Pasi, Tanette. Reef. 2 Spec.

Stat. 2 I3. South-island. Reef. I Spec.

Stat. 220. Saleyer. Reef. I Spec.

Stat. 234. Nalahia-bay, Nusa-laut-island. Reef. I Spec.

Stat. 240. Banda. 9-45 M. Lithothamnion-bottom. 12 Spec.

Stat. 282. Between Nusa Besi and the N.E. point of Timor. Reef and $27-54$ M. 3 Spec.

Stat. 3 I 5. East of Sailus Besar, Paternoster-islands. Up to $36 \mathrm{M}$. Lithothamnion-botton. 3 Spec.

The specimens vary much in colour, but agree in sculpture, consisting of fine spiral striae on the upper whorls and a few near the basal or left margin, and very fine radiating striae on the last whorl, being more conspicuous towards the right margin.

The colour varies from carmine to white and even blackish, with more or less numerous white spots and often darker, articulated, spiral bands. The upper whorls are commonly of another colour than the bodywhorl. The nomenclature is far from clear; LAMARCK cites RuMPII, Pl. 4o, fig. I, as belonging to his Stomatclla auricula, which is certainly erroneous; PILSbry seems to have in view this species for his $G$. latca Linn., though he agrees with HAnLev's opinion that Patella lutea of Linne is unidentifiable, he believes that it is the G. lutca of Adaris. I have followed the advice of Mr. E. A. Surth, in accordance with the specimens of the British Museum.

In the animal the siphons and epipodial cirri are present, so it does not differ materially from G. plamlata. Some specimens have lost their tails, even a few seem to have shed it off after being placed in alcohol, at least I found loose tails. The teeth of the radula agree in most respects with the description and figure of teeth of G. luted by Thiele (Troschel, Gebiss der Schnecken, Vol. II, p. 263, Pl. XXV, fig. 25) only the number of the smaller cusps of each tooth is slightly different, so I find only two denticles at the external or fifth lateral, instead of 3 ; this seems however to be of little importance for specific distinction.

5. Gena ornata A. Adams.

A. Adans. Proc. Zool. Soc. Lond. 1850, p. 39.

Reeve. Conch. Ic. Vol. XIX, Gena, fig. 9 .

Pilsbry. Man. of Conch. Vol. XII, p. 45, P1. 55 , figs. 29, 30.

Stat. 282. Between Nusa Besi and the N.E. point of Timor. $27-54$ MI. Sand, coral and Lithothamnion. 3 Spec.

Agreeing in shape with the mentioned figures; two of the specimens seem to be young 
and are nearly entirely rose-coloured, the nucleus and a few spots below the suture are white; in the largest specimen the last whorl is blackish with rose-coloured, spiral lines. The upper whorls are spirally striated, base with a few striae. Though this species has more the shape of a Stomatella than of Gena, the smooth, shining, last whorl agrees with its location in the genus Gena.

\section{Miraconcha Bergh.}

1. Miraconcha obscura Bergh.

(See Appendix).

Fam. Scissurellidae.

\section{Scissurella Orbigny.}

1. Scissurella maxima n. sp. Pl. VI, fig. 9.

Stat. $178.2^{\circ} 40^{\prime}$ S., $128^{\circ} 37^{\prime} .5$ E. 835 M. Blue mud. 2 Spec.

Shell large, thin, depressed, yellowish-white; whorls about $4^{1} / 2$, convex above, concave towards the slit, rapidly increasing; nucleus smooth, sculpture consisting of numerous fine, curved, radiating ribs, interrupted on the lower whorls by the slit-fasciole, these ribs are crossed by spiral lirae of which there are about ro on the upper surface, besides a few secondary ones, they form small square beads when they cross each other; the sculpture of the base is similar, with the ribs more crowded towards the aperture; slit long, peripheral, rather wide, deep, with upturned edges, striated by arched, lamellose striae. Umbilicus partly covered by the columellar margin. Aperture rounded, very oblique, angular at the insertion on the body-whorl and at the periphery, outer and basal margin rounded, thin, columellar margin slightly concave, a little reflected at the upper part, stronger so below, where it joins the basal margin; on the body whorl the margins are connected by a thin layer of enamel.

Alt. $4 \frac{1}{2}$, diam. maj. $6^{1} / 2$; a pert. alt. 3 , lat. 3 Mill.

This species may be distinguished by its shell, which is large for the genus, in shape but not in sculpture, it resembles Sc. umbilicata Jeffr.

\section{Scissurella exquisita n. sp. Pl. VI, fig. 10.}

Stat. $95.5^{\circ} 43^{\prime} \cdot 5$ N., $119^{\circ} 40^{\prime}$ E. 522 M. Stony bottom. I Spec.

Shell rather large, very thin, transparent, white, depressed, whorls about $3^{1} / 2$, convex above, concave towards the slit, rapidly increasing; nucleus rather smooth, sculpture of the upper whorl consisting of very numerous, radiating, elevated striae, which are curved and crossed from about halfway the penultimate whorl by weaker spiral ones, about 15 on the upper part of last whorl, sculpture of the base similar, slit-fasciole a little above the sutures, rather wide, with upturned edges, striated across by arched striae, slit $3 \frac{1}{2}$ Mill. Umbilicus narrow, partly covered 
by the columellar margin. Aperture rounded, moderately oblique, angular at the upper and peripheral part, margins curved, the columellar one slightly concave, a little reflected, especially at the upper part. Margins connected on the parietal wall, by a thin layer of enamel.

Alt. $2^{3} / 4$, diam. maj. $3^{1} / 2$; a pert. alt. 2 , lat. 2 Mill.

The species resembles in shape the preceding one, but is much smaller, with more delicate sculpture. It is allied to Sc. acthoria Melv. \& Standen, but is much larger and the slit-fasciole runs at some distance above the suture, which seems not to be the case in Sc. actheria (Ann. and Mag. of Nat. Hist. Ser. 7, Vol. XIl, p. 300, Pl. 21, fig. 6).

\section{Fam. Fissurellidae Risso.}

Fissurella Bruguière.

\section{Fissurella (Cremides) sibogae n. sp. Pl. VI, fig. I 2.}

Stat. $88.0^{\circ} 34^{\prime} .6 \mathrm{~N} ., 119^{\circ} 8^{\prime} .5$ E. I 30 I M. Fine grey mud. I Spec.

Shell depressed-conical, oval, with slightly convex sides, orifice in front of the middle. Sculpture consisting of numerous, unequal, radiating riblets, about too in number, besides a few intermediate ones, and rather numerous concentric lirae, making the riblets slightly nodose, moreover with close-set growth-striae, outer surface whitish. The orifice is not quite intact, rounded-oblong. Inside whitish, muscular impression very indistinct, border of the orifice greyish, without distinct callus. Nargin rather acute, indistinctly crenulated, slightly raised at the sides.

Long. I 7 , lat. I 3 , alt. 6 ; length of front slope $5^{1 /}$, orifice $2^{1} / 2$, post. slope 9 Mill.

The only specimen is a dead shell, the margins of the base and of the orifice are slightly injured, I have located it with doubt in the subgenus Cremides, as I know no species without hole-callus. Nay it have been lost? If normal, this species might form a new group. In sculpture it is very peculiar and calls in mind several species of Glyphis, but the interior has no traces of a truncated callus.

\section{Macroschisma Swainson.}

I. Macroschisma maxima A. Adams.

ADAlis. Proc. Zool. Soc. Lond. 1850, p. 202.

Pilsbri. Man. of Concl. Vol. XII, p. 192, P1. 62, fig. 22.

- Cat. Marine Mollusks Japan, p. Io6 (M. macroschisma Chemn.).

Stat. 240. Banda. 9-45 M. Lithothannion-bottom. 2 Spec.

Stat. ? I Spec.

Stat. 282. Between Nusa Besi and N.E. point of Timor. 27-54 M. Lithothamnion-bottom. 1 Spec.

I owe to Mr. E. A. Surth the identification of this species; the specimens from Banda are red with white rays at the sides; the specimens are considerably smaller than the figure of Pilsbri, which is a copy of the original figure given by AdAus (Genera of recent Moll. IIl, 
pl. 5 I, fig. 5) the largest specimen has a shell of ro Mill. in length, against 2 I Mill. in the figure of Pilsbry, the foramen is not so abruptly dilated posteriorly, but this may perhaps depend on age, as this character is still less conspicuous in the smallest specimen from the same locality and in those from Stat. ? and 282 , which are rather doubtful, being very small.

var. elongata n. var. Pl. VII, fig. 1.

Stat. 313. East of Dangar Besar, Saleh-bay. Up to 36 M. Sand, coral and mud. I Spec.

Shell more elongated, grey with darker markings, sculpture in the front part of shell more regular.

Length of shell 14 , breadth 6 Mill.

Distinguished from the type by its length, which is nearly $21 / 2$ times the breadth, in the figure of ADAMs, it is only about 2 times as long as broad, the colour agrees with Adan's description. The animal is dark grey, white at the sides, darker on the back, the anal tube black, the head light grey, with the tentacles and border of muffle white, foot yellowish.

\section{Glyphis Carpenter.}

I. Glyphis subcalyculata n. sp. P1. VII, fig. 2.

Stat. $310.8^{\circ} 30^{\prime}$ S., $119^{\circ} 7^{\prime} .5$ E. 73 M. Sand with few pieces of dead coral. 1 Spec.

Shell ovate, elevated, conical, with concave slopes, especially the posterior one, yellowish with a green tinge in some parts, especially on the posterior slope, and a few scattered, short, purple-brown streaks; the sculpture consists of eleven prominent, radiating ribs, of which those on the posterior slope are strongest, the interspaces on the front-side each with 3 riblets, of which the middle one is the strongest; on the sides and posterior slope they amount to seven, of which the fourth is stronger than the others, the second and sixth are thinner, the first, third, fifth and seventh are the thinnest. The ribs are crossed by very fine growth-striae and by about 20 concentric lirae, forming rather conspicuous scales on the radiating ribs, the strongest on the posterior 3 ribs. Foramen inclined towards the front, keyhole-shaped, rounded in front, enlarged behind, with 2 inconspicuous denticles at each side. Base oval, margin crenulated and angular, especially at the ends of the 3 posterior ribs; interior white, with grooves corresponding to the principal ribs; hole-callus thick, truncated behind, with a rather deep pit behind the truncature.

Long. 20, lat. 13 , alt. 9 , length of front slope $61 / 2$, of posterior one $\mathrm{r}^{1} \mathrm{x}^{1} / 2$, of perforation 2 Mill.

This new species is allied to $G$. calyculata Sow., but differs by the concave posterior slope, which is convex in G. calyculata, by the elongated keyhole-shaped perforation, by the smaller number of prominent ribs, which aré much differentiated, especially on the front part, by the colour, which is yellowish instead of pink, by the strong hole-callus, with shallower pit behind.

I have used the generic name Glyphis though PILsbry has shown (Nautilus, Vol. V, p. 104) that it ought to be Fissuridea Swains. As he has however applied this name to another group in his Manual of Conchology, and many authors have afterwards used the name Glyphis, 
I follow their example, in order to avoid confusion, which will doubtless result by using the same name for different but nearly allied animals.

\section{Glyphis Sicboldii Reeve.}

ReEve. Conch. Ic. Vol. VI, Fissurella, fig. 102.

Pilsbry. Man. of Conch. Vol. XII, p. 204, Pl. $3 S$, fig. $5 \&, 59$.

Stat. 240. Banda. 9-45 M. Lithothamnion-bottom. I Spec.

Stat. 2S2. Between Nusa Besi and N.E. point of Timor. 27-54 M. Sand, coral and Lithothamnion. 4 Spec.

Three of the specimens from Stat. $2 S 2$ are very small and not characteristic, however they agree sufficiently with the upper part of larger specimens.

3. Glyphis Reevei nom. nov.

$=$ Fissurella excelsa Reeve. Conch. Ic. Vol. Vi, fig. II 3 (not Adams and Reeve).

Stat. 51. Madura-bay and other localities in the southern part of Molo-strait. 69-9I M. Fine grey sand; coarse sand with shells and stones. I Spec.

Stat. 6o. Haingsisi. 36 M. I Spec.

Stat. 71. Makassar and surroundings. Up to $32 \mathrm{M}$. Mud, sand with mud. 1 Spec.

Stat. 116. West of Kwandang-bay-entrance. 72 M. Fine sand with mud. I Spec.

Stat. 162. West-coast of Salawatti. is M. Coarse and fine sand with clay and shells. I Spec.

Stat. $164.1^{\circ} 42^{\prime} .5$ S., $130^{\circ} 47^{\circ} .5$ E. 32 M. Sand, small stones and shells. I Spec.

In the year 1848 , Adams and Reeve (Zool. "Samarang", Moll. p. 70, Pl. I I, fig. 5) have described a different species under the name excelsa. The plate of ReEve's Conch. Ic. being of I 850 , his species must have a new name.

As the figures of Reeve and PILsbry (Man. of Conch. Vol. XII, pl. 39, fig. 96) represent the species only from the back-view and they give no measurements, I give those of the largest specimen, from Stat. 71 .

Long. $14 \frac{1}{2}$, lat. 9 , alt. 9 Mill.

Pilsbry (1. c. p. 209) suggests that Fissurella excelsa Reeve should be a synonym of Glyphis alta C. B. Adams from Panama, though ReEve says: "Eastern seas", but though the figure of PILsbry, agrees in many respects with the Siboga specimens, I think it is not probable that they belong to the same species, since the latter specimens justify ReEve's locality.

\section{Glyphis ticaonica Reeve.}

ReEve. Conch. Ic. Vol. VI, Fissurella, fig. I07.

Pilsbry. Man. of Conch. Vol. XlI, p. 225, Pl. 36, fig. 20.

Stat. $98.6^{\circ} 9^{\prime}$ N., $120^{\circ} 21^{\prime}$ E. 350 M. Sand. 2 Spec.

Stat. 144. North of Damar-island. $45 \mathrm{M}$. Coral bottom and Lithothamnion. I Spec.

Stat. 25 S. Tual-anchorage, Kei-islands. 22 M. Lithothamnion, sand and coral. I Spec.

The shells from Stat. 98 are dead; it is not without doubt that I have identified them, but they agree rather well with those from the other localities, and may have lived at similar depth. 
5. Glyphis nigriradiata Reeve.

ReEve. Conch. Ic. Vol. VI, Fissurella, fig. Si.

Stat. 258. Tual-anchorage, Kei-islands. 22 M. Lithothamnion, sand and coral. 1 Spec.

Agreeing exactly with the figure and description of REEvE, except that the interrupted character of the black rays is not conspicuous. PILSBry thinks it may be the young of $G$. Riippellii Sow. (Man. of Conch. Vol. XII, p. 217) but this suggestion seems to be erroneous, as the orifice in the present species is rounded-oval, in accordance with REEvE's figure, whereas in Rïppellii it is "squarish-oblong".

\section{Glyphis sp.}

Stat. $98.6^{\circ} 9^{\prime}$ N., $120^{\circ} 21^{\prime}$ E. 350 M. Sand. I Spec.

A dead, much worn shell, too bad for identification or description, belongs to the genus Glyphis and is certainly distinct from the preceding species.

\section{Glyphis corbicula Sowerby?}

Sowerby. Thes. Conch. Fissurclla, p. 200, fig. I 80.

Pilsbry. Man. of Conch. Vol. XII, p. 220, Pl. 61, fig. 20.

Stat. I15. East side of Pajunga-island, Kwandang-bay. Reef. I Spec.

Stat. I16. West of Kwandang-bay-entrance. 72 M. Fine sand with mud. I Spec.

Stat. 152. Wunoh-bay, N.W. coast of Waigeu-island. Recf. Lithothamnion-bottom. I Spec.

Stat. 258. Tual-anchorage, Kei-islands. 22 M. Lithothamnion, sand and coral. I Spec.

The specimens are small, probably young, and are very nearly allied to $G$. corbicula, the slight differences may perhaps depend on age or on variability. The description in Sowerby's Thesaurus, copied by Pilsery, is very short and insufficient. The specimens under consideration resemble also G. Townsendi Melv. (Mem. and Proc. of the Manchester Lit. and Phil. Society, Vol. 41, p. 20, Pl. 7, figs. $27,27 a$ ) but the shape of the shell and the position of the orifice agree better with the figures of $G$. corbicula.

\section{Puncturella Lowe.}

1. Puncturella gemmata n. sp. Pl. VII, fig. 3 .

Stat. $280.8^{\circ} \mathrm{I}^{\prime} \cdot 4 \mathrm{~S} ., 127^{\circ} 30^{\prime} .7$ E. I 224 M. I Spec.

Shell elevated, conical, with oval base and curved apex. Front slope convex, posterior slope concave, side slopes convex below, concave towards the apex, which is slightly bent towards the left and shows scarcely one spiral whorl on the right side. Colour yellowish. Sculpture consisting of numerous, radiating riblets, which are alternately stronger, the intermediate weaker ones don't reach the summit but end at about $2 / 3$ of the height, they are surmounted by rounded-triangular or pear-shaped beads, the interstices are rather irregularly concentrically wrinkled; orifice oval, lying just before the apex, slightly narrower above, its length is about I Mill., its breadth a little more than $1 / \%$. Interior white, smooth; septum large, nearly straight, only slightly curved, 
directed towards the front-side, apparently slightly incised in the centre (this is not certain, the margin not being quite intact); a thin slitcallus seems to exist.

Long. 6, lat. 5, alt. $3^{1 / 2}$ Mill.

This interesting species will be easily distinguished by its beaded sculpture, I find in litterature only $P$. agger Wats. (Challenger Gastrop. p. 40, Pl. 4, fig. 6) which has a similar, but still different sculpture, and may be distinguished by its shape, slit, septum, etc.

\section{Puncturella (Cranopsis) gigantea n. sp. Pl. VII, fig. 4.}

Stat. $122.1^{\circ}{ }_{5}^{\prime} .5$ N., $125^{\circ} 0^{\prime} .5$ E. $1165-1264$ M. Stone. I Spec.

Shell depressed, conical, base oval, apex curved. Front slope convex, posterior and lateral slopes concave, the apex shows about one volution at its right side, placed at nearly $2 / 3$ of the total length. Sculpture consisting of close-set, radiating riblets, which are alternately stronger and are crossed by concentric 'ridges, which make the riblets crenulated, the weaker riblets come near to, but don't reach the summit. Slit-fasciole rather deep, long about 7 Mill. crossed by thin lamellae, orifice about 4 Mill. in length, perhaps largest above (or slightly broken) ending in a blunt point, at $7^{3} \%$ Mill. from the front margin. Interior white, with shallow, radiating grooves, corresponding to the exterior riblets, and making the thin margin crenulated; from the summit runs the septum, closing the upper part of the slit-fasciole, thickened at the sides of the fasciole and along the orifice, below this follows a rather strong, interior rib.

Long 29, lat. $22^{1} \frac{1}{2}$, alt. $12^{1} / 2$ Mill.

Allied to P. (Cranopsis) aethiopica v. Martens (Die beschalten Gastropoden der deutschen Tiefsee-Exp. г $898-99$, p. 128, Pl. 5, fig. 9) but much larger, more elongated, with (according to the figure) much finer sculpture, the apex more terminal; the slit is more regular and symmetrical, I think however this last character has not much value, as it may be individual, like v. Martens suggested.

\section{Rimula Defrance.}

I. Rimula carinifera n. sp. P1. VII, fig. 5 .

Stat. 105. $6^{\circ} 8^{\prime}$ N., $121^{\circ} 19^{\prime}$ E. 275 M. Coralbottom. 1 Spec.

Shell depressed, conical, with curved apex, base oval. Front slope very convex, side slopes moderately convex, posterior slope slightly concave, apex with about one volution, visible at the right side; it is placed at about $\% / 11$ of the total length. Colour white. Sculpture consisting of rather strong radiating ribs and a few intermediate ones, and weaker concentric ridges, making the ribs crenulated and leaving in the interstices subquadrate pits. Perforation oblong, oval, long $3 / 4$, broad $1 / 3$ Mill. Slit-fasciole just above the perforation shallow, higher up the shell prominent, so as to make it carinated; the fasciole crossed by rather thin, slightly curved lamellae, which towards the perforation are transformed in scales. Interior white, smooth, but having the appearance, by the transparency of the shell, of being grooved; margin crenulated, slightly elevated at the sides, apex deeply pitted. 
Long. $5^{1 / 2}$, lat. $3^{1 / 2}$, alt. $2^{1 / 4}$ Mill.

Closely allied to $R$. carinata A. Ads. (Proc. Zool. Soc. Lond. 185 I, p. 226) but more coarsely sculptured, the number of radiating ribs being only about 34 and a few intermediate ones; ADAMS says: "ornamented with very many simple, close radiating riblets; interstices cancellated"; in the species now under consideration; the ribs are not simple but conspicuously crenulated, the concentric lirae crossing the ribs.

\section{Emarginula Lamarck.}

I. Enarginula variegata A. Adams.

A. Adans. Proc. Zool. Soc. Lond. I85 I, p. 84.

ReEve. Conch. Ic. Vol. XIX, Emarginula, fig. 22.

Pilsbry. Man. of Conch. Vol. XII, p. 263, Pl. 28, fig. I2.

Stat. 6I. Lamakera, Solor. Reef. I Spec.

Stat. 86. Dongala, Palos-bay, Celebes. Shore. I Spec.

Stat. I27. Taruna-bay, Great Sangir-island. Reef. I Spec.

Stat. 296. Noimini, South coast of Timor. Reef. I Spec.

According to the figures and collected specimens, this species seems to be rather variable in colour; the specimen from Stat. 296 is nearly entirely yellowish-white, with a few rays and spots, those from the other localities are much darker; however they agree sufficiently in sculpture, to consider them as one and the same species.

2. Emarginula paucipunctata n. sp. Pl. VII, fig. 6.

Stat. 2I3. Saleyer. Reef. I Spec.

Shell elongated-oval, obtuse in front, slightly depressed. Front slope very convex, side slopes and posterior one less so, the latter concave just below the slightly eroded apex, which is placed at about $2 / 3$ of the total length. Colour white, with a few black spots on some of the ribs, but no more than 3 on one rib; one of these spotted ribs on the front slope and 3 or 4 on each side. Sculpture consisting of $I_{5}$ strong radiating ribs, with a thinner rib in each interstice, and often with still fainter ones in the intervals; they are crossed by about ro conspicuous, concentric lirae, making the ribs crenulated, and numerous striae. Slit-fasciole shallow, with

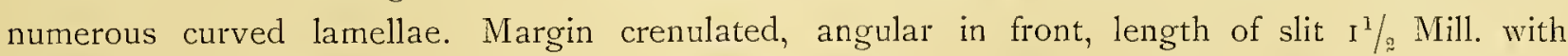
thickened margins and a short, flat rib towards the apex. Interior smooth, white, space within the muscle-scar yellowish-brown, the ribs and black spots are visible through the shell.

Long. $5^{3} /$, lat. $3^{3} /$, alt. $2^{1} / \pm$ Mill.

I know no species" to which this is allied. E. punctata, which agrees perhaps in some respects, is much more rounded. The small black spots give a very peculiar aspect to this species.

3. Emarginula multisquamosa n. sp. Pl. VII, fig. 7 .

Stat. г3 1. Beo, Karakelang-islands. Reef. I Spec.

Shell elongated-oval, depressed. Front slope long, convex, side slopes slightly convex, 89 
posterior slope concave. Apex compressed, with one whorl at the right side, placed at about $4 / 5$ of the total length. Colour yellowish-white; sculpture consisting of about 44 radiating ribs, and a few intermediate ones at irregular intervals, and one or two very fine, radiating threads in each interstice, the whole shell is crossed by fine concentric ridges, forming on the ribs conspicuous compressed scales. Slit-fasciole rather large, elevated, forming a strong rib or keel on the front slope, with close-set, strong, curved lamellae. Margin crenulated by the ribs, raised at the sides, the shell resting on its ends; slit long $2 \frac{3}{4}$, broad $3 / 5$ Mill., its margin slightly thickened, a strong groove runs towards the deeply pitted apex. Interior white, smooth, apparently cancellated, in consequence of the transparency of the shell.

Long. $9^{1} / 2$, lat. $6 \frac{1}{2}$, alt. 3 Mill.

Resembling in shape Emarginula harmilensis Sturany (Exp. S. M. Schiff "Pola" in das Rothe Meer, Gastropoden, p. 27 (235) pl. V, fig. 12) but differing in colour, that species being variegated by spots, lines and points of a brownish to greenish colour, the apex is placed still nearer to the posterior end, and the ribs are not scaled, but only beaded.

\section{Emarginula curvata n. sp. P1. VII, fig. S.}

Stat. $95.5^{\circ} 43^{\prime} \cdot 5$ N., $119^{\circ} 40^{\prime}$ E. 522 M. Stony bottom. I Spec.

Stat. $105.6^{\circ} 8^{\prime}$ N., $121^{\circ} 19^{\prime}$ E. 275 M. Coralbottom. I Spec.

Stat. I $64 . I^{\circ} 42^{\prime} .5$ S., I $30^{\circ} 47^{\prime} .5$ E. 32 M. Sand, small stones and shells. I Spec.

Shell very elongated, oval, capuliform, front slope very convex, side slopes moderately convex, posterior slope very short, nearly straight, excavated below the apex, which if seen from above, surpasses the posterior margin. Colour white (brownish in two small specimens). Sculpture consisting of about 46 rather strong, radiating ribs, a weaker one in most of the interstices and very fine intermediate ones; they are crossed by comparatively strong, concentric ridges, forming short, solid scales on the ribs. Slit-fasciole moderately large and deep, crossed by close-set lamellae. Margin conspicuously crenulated by the ribs, raised at the sides, slit long 4 , large nearly $1 / 2$ Mill., its margin thickened interiorly, a large, depressed rib runs towards the deeply pitted apex. Interior smooth, white, the external sculpture visible through the shell.

Length of base $9^{3} / 4$, of shell with apex $10^{1} / 2$, lat. $6^{1} / 2$, alt. $5^{1 / 2}$ Mill.

Allied to E. galericulata Ads. (Proc. Zool. Soc. I 85 I, p. 84 ) but according to the figures of Reeve (Conch. Ic. Emarginula sp. 15) and of Putsbry (Man. of Conch. Vol. XII, pl. 28, fig. 20) which is a copy of the original figure in the Thesaurus Conchyliorum, this species is much larger, the apex is more curved and its distance from the basal margin is consequently smaller; the rather short description gives no conspicuous differences, the character of ADAus: "front rib granulate-punctate above the slit" however, does not correspond to the specimens. I think the specimens from Stat. 105 and 164 may be young ones of this species, though their colour is brownish, as I can detect no difference in sculpture or shape of any importance, which may not depend on age. If however more materials proved these differences to be constant, they will form two species. 
5. Enarginula sublaevis n. sp. Pl. VII, fig. 9.

Stat. $280.8^{\circ} 17^{\prime} \cdot 4$ S., $127^{\circ} 3^{\prime} .7$ E. I 224 M. Probably hard bottom. I Spec.

Shell oval, moderately depressed, front and side slopes convex, posterior slope concave in the upper part, slightly convex below. Colour yellowish-white, with a row of small, brown spots at each side of the slit and fasciole. Apex placed posteriorly, at about $11 / 13$ of the total length, with a whorl on the right side. Sculpture consisting of rather numerous, thin, radiating riblets, about 33 on each side, which are alternately stronger, with broader interstices, with commonly 3 smaller intermediate riblets. This radiating sculpture is crossed by numerous concentric ridges, giving to the shell the appearance of being covered by elongate granules. Slitfasciole narrow, laying deep, by the -strongly elevated margins, sculptured by rather remote arched lamellae and intermediate striae. Slit long about 3, large nearly $1 / 2$ Mill., its margin thickened interiorly, a rather shallow groove, deep near the slit, with a rather strong rib at each side, runs towards the apex. Interior slightly grooved, white in the centre, yellowish towards the slightly crenulated margin, which is a little raised at the sides.

Long. I3, lat. $9 \frac{1}{2}$, alt. 7 Mill.

I know no species to which this one is closely allied, its weak though very beautiful sculpture is very peculiar.

\section{Emarginula dubia n. sp. Pl. VII, fig. io.}

Stat. $95 \cdot 5^{\circ} 43^{\prime} \cdot 5$ N., $119^{\circ} 40^{\prime}$ E. 522 M. Stony bottom. I Spec.

Shell oval, sub-depressed, yellowish-white, front slope very, side slopes slightly convex, posterior slope slightly concave, much so below the apex, which is placed at about $6 / 7$ of the total length, and has a whorl on the right side. Sculpture consisting of numerous radiating riblets about I 6 in number, with a smaller one in the majority of the interstices; they are crossed by thin concentric ridges, forming beads on the riblets. Slit-fasciole rather deep, with numerous lamellae crossing it. Slit long 2, large $1 / 3$ Mill., its margins thickened interiorly, a flattened rib runs towards the apex. Interior smooth, yellowish, margin crenulated, with slightly raised sides.

Long. 7 , lat. $5^{1 / 2}$, alt. $3^{1 / 2}$ Mill.

Resembling the figure of $E$. bellulla Adams, in Pilsbry's monograph (Man. of Conch. Vol. XII, Pl. 28, fig. 37) but the apex is placed more central, the slit-fasciole is not punctured etc. I am however not quite certain, that this species of simple characters has not been described, but have failed, even with the assistance of Mr. E. A. Sirith, to identify it with any known species.

7. Emarginula foveolata n. sp. Pl. VII, fig. I. I.

Stat. 105. $6^{\circ} 8^{\prime}$ N., $121^{\circ} 19^{\prime}$ E. 275 M. Coralbottom. 1 Spec.

Shell oval, broader behind, conical, colour grey (probably not the natural colour), front slope strongly, side slopes slightly convex, posterior slope concave, apex curved, placed at about $2 / 3$ of the total length, the apex being slightly worn, no whorl is visible. Sculpture consisting 
of numerous radiating ribs, about 22 at each side, with an intermediate one in the interstices at the sides, and a few at irregular intervals, they are crossed by weaker concentric ridges, which form small beads on the ribs, and leave deep pits in the interstices. Slit-fasciole rather large and deep, with conspicuous arched lamellae; slit long $2 \frac{1}{2}$, large nearly I Mill. at the base, its margin is thickened, a flat, broad, slightly grooved rib runs towards the apex, interior smooth, margin crenulated, with slightly raised sides.

Long. $14^{1} / 2$, lat. $1 \mathrm{I}^{1} / 2$, alt. $7^{1} / 2$ Mill.

The only specimen is slightly worn, and I think the grey colour must depend on its long abode in mud. It is allied to E. puncticulata Ads. (Proc. Zool. Soc. Lond. I 85 I, p. 84) which is still larger and differs in sculpture, that species has according to the description, only 28 ribs, with 3 small riblets in the interstices and in the figures the shell is much less pitted.

S. Emarginula scabricostata A. Adams.

A. Adans. Proc. Zool. Soc. Lond. I851, p. 85.

REEve. Conch. Ic. Vol. XIX, Emarginula, fig. 54.

Pilsbry. Man. of Conch. Vol. XII, p. 268, Pl. 28, fig. 24.

Stat. 282. Between Nusa Besi and the N.E. point of Timor. Reef. 1 Spec.

The figures of Reeve and of Pilsbry, which is a copy of that in Sowerby's Thesaurus Conch. don't show the radiating buff bands, nor can I detect them in the Siboga-specimen, but the scabrous ribs are very characteristic.

9. Enarginula (Enarginella) clypens A. Adams. P1. VII, fig. I2.

A. Adalis. Proc. Zool. Soc. Lond. $185 \mathrm{I}$, p. 83.

ReEve. Conch. Ic. Vol. XIX, Emarginula, fig. 2r.

Pilsbri. Man. of Conch. Vol. XII, p. 265, Pl. 28, fig. 7 .

Stat. 50. Bay of Badjo, West coast of Flores. Up to 40 M. Sand. I Spec.

This species proves to belong to the subgenus Emarginella, founded by PiLsbry (1. c.) for $E$. Cuvieri Audouin, on account of the voluminous animal, which partly envelops the shell. This is also the case with E. clypeus. The animal has a dark coral-red foot, the tentacles, under surface of the mantle, and the epipodial papillae are of the same colour, the muzzle as far as visible is much darker, and the upper surface of the mantle, which covers the margin of the shell, is dark flesh-colour, strongly pigmented with black, so as to give to the upper surface a brown appearance. According to the figure given by PILSBRy (1.c. pl. 64, fig. 32) the sculpture of the shell differs in being closely ribbed, whereas in $E$. Cuvieri the ribs seem to be more spaced.

10. Emarginula (Emarginella) sibogae n. sp. P1. VIII, fig. 1.

Stat. 49. Sapeh-strait. 69 M. Coral and shells. I Spec.

Stat. I33. Lirung, Salibabı-island. 36 M. Hard sand. 2 Spec.

Stat. 305. Mid-Channel of Solor-strait, Kampong Menanga. 1 1 3 M. Stony. I Spec.

Stat. 315 . East of Sailus Besar, Paternoster-islands. Up to 36 M. Lithothamnion-bottom. 1 Spec. 
Shell oval, broader behind, much depressed, front slope convex, the other slopes convex above, but concave towards the margin, which is still more depressed. Colour white. Apex placed at about $7 / 1$ of the total length, slightly curved, without distinct whorl. Sculpture consisting of about 56 radiating ribs, some of which are thinner; they are crossed by numerous, thin, rather close-set, concentric ridges, which are straight in the interstices, arched on the ribs, forming short scales. Slit-fasciole large, very deep, crossed by numerous, thin, arched lamellae, slit large, length about $2^{3} / 4$, breadth I Mill. Margin thick, crenulated by the ribs, its sides slightly raised. Interior smooth, white, bluish towards the centre; margins of the slit much thickened, with a very short rib, running in the direction of the apex.

Long. I I, lat. 8, alt. 3 Mill.

The animal is yellowish-white, it has rather long tentacles and about 12 epipodial filaments on each side.

This species is allied to the preceding one, but may be at once distinguished by the colour of the animal, the shell is less elongated than in E. clyperss, the apex is more elevated and recurved, the slit is larger and longer, the sculpture seems to be coarser. I have not seen a loose shell of E. clypeus.

\section{Subemarginula Blainville.}

I. Subemarginula tricarinata Born.

Born. Test. Mus. Caes. Vindob. p. 423 , Pl. i 8 , fig. 6. REEve. Conch. Ic. Vol. XIX, Emarginula, fig. 43 (pankiensis).

Pilsbry. Man. of Conch. Vol. XII, p. 276, Pl. 29, figs. 7, 8, 9.

Stat. 37. Sailus Ketjil, Paternoster-islands. Up to 18 M. Coralsand. I Spec.

Stat. I 44. North of Salomakiee-(Damar)-isiand. 45 M. Lithothamnion-bottom. 2 Spec.

Stat. 301. Pepela-bay, East coast of Rotti-island. Reef. I Spec.

The specimens are young, that from Stat. 37 has dark rays, especially visible in the interior, though I have not seen this character, amongst the numerous specimens I have compared, I think it may be individual. The sculpture agrees with typical specimens.

2. Subemarginula plana n. sp. Pl. VIII, fig. 2.

Stat. 282. Between Nusa Besi and the N.E. point of Timor. Reef and $27-45$ MI. 3 Spec.

Shell oblong, oval, much depressed, apex placed at about $\%$ of the length. Front slope convex, side slopes moderately, posterior slope very concave. Colour white, eventually with short brown lines at the margin, more conspicuous at the interior. Sculpture consisting of rather numerous radiating ribs, the front rib very strong and two conspicuous but less strong ones at some distance on each side, the total number of ribs is about 25 , in most cases with small intermediate ribs; they are crossed by numerous fine growth-striae and concentric ridges, making them slightly crenulated. Margin thin, strongly crenulated by the ends of the ribs. Interior white, with a very distinct mushroom-like figure inside the silvery muscle-scar, deeply pitted at the apex, 
front groove conspicuous, ending at a short distance from the apex; notch conspicuous but not deep, subquadrate. Sides of the shell slightly raised and even a little turned up.

Long. $\mathrm{I}^{1} / 2$, lat. $7^{3} / 4$, alt. $2^{1} / 2$ Mill.

This species has a slight resemblance with the upper view of $S$. imbricata A. Ads., as figured by Pilsbry (Man. of Conch. Vol. XII, Pl. 29, figs. 14, 15), but the apex is placed much more towards the posterior end, it differs also in colour and in many other particulars. As usually with the species of ADAns, no measurements are given, even no mention has been made of the relative altitude of the shell.

3. Subcmarginula dubia n. sp. Pl. VIII, fig. 3 .

Stat. 126. $3^{\circ} 27^{\prime} .1$ N., $125^{\circ} 18^{\prime} .7$ E. 2053 M. Hard bottom. I Spec.

Shell small, conical, compressed, oval, apex worn, placed slightly posteriorly, front and posterior slopes slightly convex, side slopes straight. Colour white, covered by a brown epidermis. Sculpture consisting of about i 8 strong, radiating ribs and numerous intermediate riblets and striae; ribs crenulated. Margin thin crenulated by the ends of the ribs. The front rib is stronger, with a point at the margin. Interior smooth, white, with a conspicuous groove, corresponding to the front rib. Muscle-scar only slightly hooked inward.

Long. $4^{1} / 2$, lat. $2^{1 / 5}$, alt. $\mathrm{I}^{1} / 2$ Mill.

This species has much puzzled me, as the small animal was too much contracted to allow a sufficient study of it. As the apex is placed posteriorly, it is no Patella or Acmaea; it might perhaps belong to Phenacolepas or to a new genus, but the internal groove on the front side has induced me, to describe it provisionally as a Subemarginula.

\section{Scutus Montfort.}

1. Scutus unguis Linné.

Linné. Mus. Ulricae, p. 69 (Patella).

REEve. Conch. Ic. Vol. XVII, Scutus, fig. 7 (corrugatus).

Pilsbri. Man. of Conch. Vol. XII, p. 291, Pl. 40, figs. 4-8.

Stat. 248. Ruma Lusi, N. point of Tiur-island. 36 M. I Spec.

Stat. 250. Kilsuin, West coast of Kur-island. Reef. I Spec.

The specimen from the last-named locality is nearly covered by the mantle of the animal. For the anatomy and other localities, see Appendix by Prof. Bergir, for a figure of the living animal P1. III, fig. 20 of monograph L of this work (R. Bergh, Die Opisthobranchia der Siboga-Expedition). 
Section Docogrossi Troschel.

Fam. Acmaeidae Carpenter.

Acmaea Eschscholtz.

I. Acmaea striata Quoy \& Gaimard, var. bomeensis Reeve.

Reeve. Conch. Ic. Vol. VIII, Patella, fig. 113.

PIlsbly. Man. of Conch. Vol. XIII, p. 48, Pl. 35, fig. 25-29.

Stat. 50. Bay of Badjo, IVest coast of Flores. Up to 40 M. Sand. I Spec.

Stat. 51. Madura-bay. Shore. I Spec.

Stat. 115. Kwandang-bay, East side of Pajunga-islands. Reef. 3 Spec.

Stat. 127. Taruna-bay, Great Sangir-island. Reef. 2 Spec.

Stat. 165. N. E. side of Daram-island, East coast of Misool. Reef. I Spec.

The specimens have a more or less juvenile appearance, the largest being only 24 Mill. in length; on account of the shape and sculpture I think they belong to var. borneensis or somewhat intermediate forms, between this variety and typical $A$. striata.

2. Acmaea neglecta n. sp. P1. I, fig. I I.

Stat. 47. Bay of Bima near South fort. Shore. 3 Spec.

Stat. 86. Dongala, Palos-bay, Celebes. 36 M. Fine grey mud. I Spec. - Shore. 3 Spec.

Stat. 127. Taruna-bay, Great Sangir-island. Reef. 9 Spec.

Stat. 277. Kulewatti-bay, Dammer-island. Reef. I Spec.

Shell oval, broader behind, thin, depressed, anterior slope nearly straight, posterior and side slopes convex, the blunt apex placed at about $3 / \%$ of the total length, surface radiately many-striated, the striae are slightly irregular, at intervals stronger, more crowded at some parts of the shell, the interstices have nearly microscopical striae; the radiating striae are crossed by minute, scaly, concentric striae, much weaker and often obsolete in the interstices. Colour very variable, yellowish-white, often with brown rays and adorned with brown lines, which form a more or less complete network, many specimens with conspicuous white spots, especially at some distance from the apex. The dark rays may be wanting or broken up in dark spots. Interior of the shell bluish-white, porcellaneous, the margin more or less dark, according to the external colour-pattern; central area yellowish-brown.

Long. 20, lat. I6, alt. 5 Mill. (typical specimen).

Long. 18, lat. I6, alt. $7^{1 / 2}$ Nill. (from Stat. 86).

Allied to the preceding species, but differing by the large number of striae, which are squamous and by the pattern of coloration. Perhaps it has hitherto been confounded with striata, with which it lives at the same localities.

The only specimen from Stat. 86 differs in shape from those from the other localities, being more conical and less elongate, as however it agrees in other respects, especially in colourpattern, I think these differences may be individual. 


\section{Acmaea saccharina Linné.}

Linné. Syst. Nat. Ed. X, p. $781, N^{0} 660$.

Runph. Amb. Rariteitkamer, p. I2I, Pl. 40, fig. B.

ReEve. Conch. Ic. Vol. VIII, Patella, fig. 72.

Pilsbry. Man. of Conch. Vol. XIII, p. 49, Pl. 36, figs. 60-62, 78; Pl. 18, figs. 3I, 32;

Pl. 24, figs. $12, \mathrm{I}_{3}$.

Stat. 16. Bay of Kankamaraän, South coast of Kangeang. Shore. 6 Spec.

Stat. 6o. Haingsisi, Samau. Reef. I Spec.

Stat. 125. Sawan, Siau-island. Reef. 1 Spec.

Stat. 127. Taruna-bay, Great Sangir-island. Reef. I Spec.

Stat. 13I. Beo, Karakelang-island. I3 M. Mud and sand. 1 Spec.

Stat. 152. Wunoh-bay, N. W. coast of Waigeu-island. Reef. I Spec.

Amboina. I Spec.

The specimen from Stat. 152 resembles the figure of var. stellaris $Q$. \& G. but has no dotted central area, as represented in the figures of Pilsbry (1.c. pl. 36 , figs. 63, 64, 67, 68); if this be the only distinguishing character, it seems to be of very little importance. The specimen has the same rounded, conspicuous ribs as in the original figure, but is much smaller and has a rather juvenile appearance. In some of the specimens from Stat. 16 I see a few brown dots in the central area, but they have no prolonged ribs.

\section{Pectinodonta Dall.}

I. Pectinodonta orientalis n. sp. Pl. II, fig. 8 .

Stat. $88.0^{\circ} 32^{\prime}$ S., $119^{\circ} 8^{\prime} .5$ E. I 301 M. Fine grey mud. 1 Spec.

Shell elongate-ovate, elevated, yellowish-white, anterior slope the shortest, nearly straight but slightly convex near the middle, more so near the margin, with a small concavity near the apex, posterior slope conspicuously convex, side slopes irregularly convex. Apex blunt, nearly smooth, save for very fine growth-lines and a few microscopic hairlines; nucleus placed at about $5 / 18$ of the length, deciduous. Sculpture consisting of more or less crowded, slightly wavy, radiating ribs or threads, wanting at irregular spaces; they are crossed by rather regular concentric lirae, slightly stronger than the radii, with very fine striae in the interspaces. Margin rather thick, the whole shell solid, slightly raised in the middle, so that if the shell be placed on a level surface, it rests upon the ends. Inside as far as visible, smooth.

Long. Is, lat. $\mathbf{x}_{3}$, alt. 9 Mill.

This shell may easily be distinguished from the only species that was known; it is higher with much coarser sculpture, and the posterior slope is much less convex and shorter in proportion to the whole length of the shell. The great depth at which it has been found, together with the external characters of the animal, which has a large head and no eyes, induced me to bring the species to the genus Pectinodonta, which was only known from the western Atlantic. Still I should have hesitated, were it not that the small specimens, enumerated sub $\mathrm{N}^{0} 3$, had produced the characteristic dentition of that genus. 
2. Pectinodonta alta n. sp. PI. II, fig. 9 .

Stat. 59. Western entrance Samau-strait. 390 M. Coarse coralsand with small stones. I Spec.

Shell rounded-ovate, elevated, yellowish-white, solid, anterior slope very short, slightly convex, posterior slope very convex, side slopes moderately convex, apex rather blunt, slightly eroded, consequently without sculpture, placed of about $1 / 8$ of the total length. Sculpture consisting of rather flat, concentric lirae, which are considerably broader than the interstices, which on some parts have the character of mere striae. They are crossed by radiating striae, which are however rather obscure, probably on account of the somewhat worn state of the shell. Margin rather thick with the sides raised, though less than in the preceding species. Inside smooth, yellowish, with a large white central area.

Long. $8 \frac{1}{2}$, lat. $7 \frac{1}{5}$, alt. 5 Mill.

Differing from the known species by the more anterior position of the apex, the smoother sculpture, the height of the shell etc. I have located it in the genus Pectinodonta, on account of the same considerations as for the former species, as far as concerns the shell, but I must admit, that with such limpet-like species, certainty is only to be obtained by anatomical characters.

3. Pectinodonta sp. P1. VIII, fig. I 3 .

Stat. $297.10^{\circ} 39^{\prime}$ S., $123^{\circ} 40^{\prime}$ E. 520 M. Soft, grey mud. 15 Spec.

The specimens collected at Stat. 297 are very small, the largest being about $2 \frac{1}{2}$ Mill. in length, nearly 2 Mill. in breadth, alt. $3 / 5$ Mill. They are oblong-ovate, much depressed, white, smooth to the naked eye or under a weak lens. Under a stronger lens they are concentrically striated and have a subcentral rounded nucleus, under the microscope they show fine hairlines, radiating from the nucleus and varying in length, but always short. They resemble much the apex of $P$. orientalis, but it is impossible to make out if they are identical, they seem to be more elongate. As the nucleus of $P$. orientalis was wanting, no comparison can be made. The shape of the head of the animal is very similar. The radula has given an imperfect result, the cusps being loosened by the action of caustic potash, but the isolated cusps are similar in general appearance to those of $P$. arcuata Dall ("Blake" Gastrop. pl. 35, fig. 3) they have however only 5 denticles at their proximal margin, whereas in $P$. arcuata they are much more numerous (I 1); this may depend partly on age, partly on specific difference. Though isolated, some of the pairs of cusps had their natural position, as shown in my figure.

Fam. Patellidae Guilding.

Patella Linné.

1. Patella (Scutellastra) stellaeformis Reeve.

Reeve. Conch. Syst. Vol. II, p. 15, Pl. 136, fig. 3.

- Conch. Ic. Vol. VIII, Patella, fig. 48 (pentagona).

Pilsbry. Man. of Conch. Vol. XiII, p. 98, Pl. 17, figs. 25-27; Pl. 61, figs. 62-65. 
98

Stat. I6. Bay of Kankamaräan, South coast of Kangeang Shore. 2 Spec.

Stat. 125. Sawan, Siau-island. Reef. I Spec.

Stat. I69. Atjatuning, West coast of New-Guinea. Reef. 1 Spec.

As I am in doubt if the figure of Rumpr (Amb. Rariteitkamer, P1. 40, fig. C) really belongs to this species, like v. Martens (Die Mollusken etc. in Rumph's Rariteitkamer, p. I6) has suggested, I have not cited that author. The figure resembles more a Siphonaria, but v. Martens assures that the Museum of Berlin possesses a similar form.

\section{Helcioniscus Dall.}

1. Helcioniscus testudinarius Linné.

Linné. Syst. Nat. Ed. X, p. $783, \mathrm{~N}^{0} 674$.

Rumph. Amb. Rariteitlamer, p. I2 I, Pl. 40, fig. A.

Reeve. Conch. Ic. Vol. VIII, Patella, fig. 6.

Stat. 50. Bay of Badjo, West coast of Flores. Up to 40 M. Sand. I Spec.

Stat. 51. Madura-bay. Reef. I5 Spec. - Shore. 4 Spec.

Stat. 64. Kambaragi-bay, Tanah Djampeah. Reef. 8 Spec.

Stat. I 52. Wunoh-bay, N. W. coast of Waigeu-island. Reef. 4 Spec.

Stat. ? I Spec.

It is strange that PILSBry does not mention the granules on the radiating riblets, very conspicuous in younger shells, but also, though rarely, in adult ones, they are mentioned by LamarcK, with the words "decussatim striata" (An. s. vert. Ed. Desh. Vol. VII, p. 532). This state of the shell has been figured by Martini (Conch. Cab. Ed. I, pl. 6, fig. 46).

2. Helcioniscus enneagonus Reeve.

Reeve. Conch. Ic. Vol. VIII, Patella, fig. 44.

PIllsbry. Man. of Conch. Vol. XIII, p. 152, Pl. 28, figs. 35, 36.

Stat. 152. Wunoh-bay, N. W. coast of Waigeu-island. Reef. I Spec.

*3. Helcioniscas rota Gmelin.

GMelin. Syst. Nat. Ed. XIII, p. 3720 .

ReEve. Conch. Ic. Vol. VIII, Patella, fig. 39 pars., fig. 56 (petalata), fig. 86 (Luzonica), fig. 89 (scalaris).

PILsbry. Man. of Conch. Vol. XIII, p. 144, P1. 72, figs. 65-80.

"Amboina. (N. A. M.). 2 Spec.

Both specimens are young; and so it could not be made out, to which of the forms mentioned by Pilsbry they belong. The shells are dark chestnut in the centre. v. Martens (Die beschalten Gastrop. der deutschen Tiefsee-Exp. I898-I899, p. I4I) has listed the species as living in the Malay-archipelago. 


\section{APPENDIX \\ ZU DEN \\ PROSOBRANCHIATA \\ (PECTINIBRANCHIATA) \\ VON}

R. BERGH.

Fissurellidae.

Scutus Mtf.

Scutus Mtf. Conch. system. II, 1810, p. 58.

Parmophorus Blainville. Bull. soc. philomat. 1817, p. 28. - Man. de malac. 1825, p. 50 I.

Diese Gattung ist anatomisch wenig untersucht. Quoy und Gaimard, v. Jhering und besonders Boutax ( 1885 ) haben Angaben über das Centralnervensystem geliefert, Pelseneer (1889) uber den Mantel. Gray hatte ( 1857 ) eine rohe Abbildung des Raspelbaus gegeben; der Bau des Schlundkopfs wurde später durch eine Untersuchung von mir ${ }^{1}$ ) etwas genaucr gekannt.

I. Scutus anguis (L.). Taf. III, Fig. 20.

Patella unguis L. Mus. Lud. Ulr. 1764, p. 69.

Parmophorus corrugatus Reeve. Conch. syst. pl. I39, fig. I.

Scutus unguis (L.), var. c (Parm. corrugatus R.). EDG. Smiti, notes on the sp. of the gen. Scutus. Journ. of conchol. II, I879. p. (252-264), $26 \mathrm{I}$.

Am 9 Aug. wurde am Ankerplatz nördlich von Salomakië (Insel Damar) (St. I 44) ein Individuum gefischt und nach dem Leben abgebildet. Ein anderes ganz ähnliches wurde am Riffe der Pepela-Bai an der Ostküste der Insel Rotti (St. 30I) erbeutet. - Das erste wurde anatomisch untersucht.

Lebend hatte dasselbe eine Körperlänge von $5 \mathrm{~cm}$. bei einer Breite bis 3,5; der Kopf

A nм. Durch einen unglïcklichen Zufall sind die (37) Figuren, die Herr Prof. BERgh im Juni rgo4 zur Erlüuterung der nachfolgenden Beschreibungen eingeliefert hatte, verloren gegangen. Die im Text citirten Figuren der "Tafel III" beziehen sich auf Tafel IIt in R. BERGH, Die Nudibranchiaten der Siboga-Expedition. 1905.

DIE REDAKTION.

I) R. Bergh, Opisthobranchiaten (Külkenthal). Abhandl. d. Senckenbergischen naturf. Ges. XXilV, I. p. I2.4-127. Taf. XII, Fig. 16-2 I; Taf. X111, Fig. 29-36 (Sc. granulatus (Blv.)). 
mit den $(S \mathrm{~mm}$.) langen Tentakeln ragte noch $5 \mathrm{~mm}$. über dem Mantelrand hervor; das Mantel(Schalen-)Loch I $9 \mathrm{~mm}$. lang bei einer Breite von 5. Die Farbe der Rückenseite war durchgehends schwarz und contrastirte stark gegen die weisse Schale.

Das a ufbewahrte Individuum war $5 \mathrm{~cm}$. lang bei einer Breite von 3,3 und einer Höhe von $1, j \mathrm{~cm}$., die mediane Kiemenspalte $5 \mathrm{~mm}$. lang, das Mantelloch $18 \mathrm{~mm}$. lang bei einer Breite von 4; die Breite des Mantelgebräms (an der Unterseite gemessen) Io mm.; die Länge der Tentakel $7 \mathrm{~mm}$; die Länge des Fusses $4 \mathrm{~cm}$. bei einer Breite von 2,2, seine Höhe in der Mitte der Länge $S \mathrm{~mm}$., die Länge des Schwanzes $5 \mathrm{~mm}$. - Die Farbe der Rückenseite war schwarz wegen ganz dicht stehender, durch mininale gräulich-gelbliche Zwischenräume geschiedener flacher ganz kleiner Papel; die Unterseite des Mantelgebräms gräulichweiss, gegen den Rand schwärzlich. Der Kopf mit den Tentakeln ist schwarz. Die obere Seite des Fusses mitsamt den epipodialen Papillen (bräunlich-)schwarz; die Fusssohle weisslich.

Die Formverhältnisse die gewöhnlichen. Der Rücken schien dem unbewaffneten Auge eben; der Mantel deckte (hier) den grössten Theile der Schale. Dieselbe war von einer dünnen gelblichen Cuticula ibberzogen, stark, oben wie unten kalkweiss, von gewöhnlicher Schildform, $27 \mathrm{~mm}$. lang bei einer Breite von 14 und einer Höhe von etwa $3,5 \mathrm{~mm}$; die Beschaffenheit der Rückenseite wie sonst bei dem Scutus beschrieben. Der Mantelrand zackig, die meisten Zacken grob und gerundet. Die Unterseite des breiten Mantelrandes ganz eben. Die lange Reihe der dichtstehenden epipodialen Papillen sich bis an den Tentakelgrund erstreckend, hinten geht die Reihe der eine Seite quer über den Schwanzgrund in die der anderen Seite uber; die mitunter an Grösse alternirenden Papillen meistens etwa $0,75 \mathrm{~mm}$. hoch. Der starke Kopf ganz unter den Mantel zurückgezogen; die Augenhöcker am Grunde der Tentakel wie gewöhnlich. Der sehr kräftige Fuss vorne unter dem Kopf $3 \mathrm{~mm}$. hervorragend.

Der Boden der kleinen Kriemenhöhle vorne sammtschwarz, sonst schwarzbraun. Die zwei gleichgrossen Kiemen gelblichweiss, I $2 \mathrm{~mm}$. lang bei einer Breite am Grunde von 3,5; ihr letztes etwa Drittel freiliegend, etwas zugespitzt. Die abgestutzt kegelförmige Analpapille $+\mathrm{mm}$. lang; rechts an ihrem Grunde die genito-urinäre kleine Papille.

Der Schlundkopf $7 \mathrm{~mm}$. lang bei einer Breite ron 4,5 und einer Höhe ron $3 \mathrm{~mm}$.; die denselben hauptsächlich bildenden Zungenknorpel mitsamt ihren hinteren Anhängseln wie frïher beschrieben. Der vorderste Theil der Zunge ist von den grossen Mandibelplatten umfasst: dieselben waren von ovaler Form, im Ganzen ziemlich diinn und brüchig, 2,25 mm. lang; vorne etwas dicker und kastanienbraun, sonst mehr gelblich; ihre stabförmigen Elemente wenigstens bis O, $\mathrm{mm}$. lang bei einer Breite von $0,007 \mathrm{~mm}$. Das Dach der Mundhöhle braun, von gelblicher Cuticula mit hohem farbigem Cylinderepithel ïberzogen. Längs der Raspel ein braungelbes, von der Cuticula gebildetes Band von etwa der halben Breite der Raspel. Die Raspel enthielt I I gelbe Zahnplattenreihen und (unter dem Raspeldache) noch I 6 fast farblose. Die bei einer Breite von 2 rolle $13 \mathrm{~mm}$. lange Raspelscheide hinter der Nitte ihrer Länge nach unten gebogen, ihr Ende geklïftet, zweihörnig; und die Hörner gegen einander gebogen; die Scheide enthielt 55 Zalnplattenreihen, von welchen die etwa 9 hintersten noch in Entwicklung begriffen; die Hörner des Hinterendes enthielten nur odontogene Zellen. Die Formel der Zahnplatten-Bewaffnung wai: c. 50-1-4-I-4-1-50 c. Die Platten waren mit Ausnahme der 
der vorderen Reihen der Raspel fast farblos. Die Breite der medianen war 0,29 $\mathrm{mm}$. bei einer Länge von 0,30 ; die Länge der 4 paramedianen war 0,30 (bei einer Breite von 0,12 )—o,35 (bei einer Breite von 0,08$)-0,35$ und $0,20(-0,25) \mathrm{mm}$; die Länge der Seitenplatten war 0,5 bei einer Länge des umgebogenen Hakens von etwa $0,30 \mathrm{~mm}$; die Höhe der Aussenplatten stieg bis $0.60 \mathrm{~mm}$. Die medianen Platten sowie die paramedianen waren von Form wie früher beschrieben, der umgeschlagene Vorderrand von jenen wie von zwei oder drei von diesen uneben. aber nicht denticulirt. Die Seitenplatten von gewöhnlicher Hakenform, mit der tiefen Kluft im Rücken und mit kurzem und spitzem, starkem Dentikel. Die Aussenplatten (Fächerplatten) auch wie früher beschrieben, die Randdenticulation vielleicht etwas stärker.

Die Speiseröhre, der Magen und der Darm schienen sich wie früher (1. c.) angegeben zu verhalten. Die tief braunschwarze Leber mit breiter medianer Einsenkung der oberen Seite, $20 \mathrm{~mm}$. lang bei einer Höhe von 9 und einer Breite vorne von 12 ; die linke Hälfte vorne etwas mehr als die rechte vorspringend, das Hinterende der Leber gerundet.

Dieses Hinterende wird haubenartig von dem gelben $\mathrm{Hoden}$ umfasst, der lose an die Leber angeheftet ist. Derselbe maass (ausgestreckt) $20 \mathrm{~mm}$. bei einer Höhe von 8,5 und einer Dicke von 4: seine convexe Hinterseite war eben, die Vorderseite zeigte eine quergehende Furche.

2. Scutus (ungvis (L. ?)).

Auf Stat. 213 wurde „an der Ankerkette” ein Individuum erbeutet.

Dasselbe war (stark erhärtet) $26 \mathrm{~mm}$. lang bei einer Breite von $\mathrm{I}_{3}$ und Höhe von 8 ; die Länge der Tentakel betrug 3, die Breite des Mantelgebräms $3 \mathrm{~mm}$; die Breite des Fusses 7 , die Länge des Schwanzes I,5 mm. - Die Farbe des Rückens war (gräulich-)schwarz, die Unterseite des Mantelgebräms gräulich; die Körperseiten des Fusses schwarz, nach oben mit der Reihe von epipodialen weissen Kegeln von einer Höhe von $0,4-0,5 \mathrm{~mm}$; der Kopf schwarz mit bräunlichem Vorderende, die Tentakel bräunlich, die Fusssohle weisslich.

Die Formverhältnisse die gewöhnlichen, nur schoss der Stirnrand des Mantels jederseits in einen gerundeten Lappen hervor, und der Rand desselben war nicht zackig. Der Rücken war eben, die Schale nur in einer Länge von 3 und in einer Breite von $0,5 \mathrm{~mm}$. entblösst. Diese Schale war von gewöhnlicher Schildform, der Umbo doch vielleicht weiter nach hinten liegend, kalkweiss, 5,2 $\mathrm{mm}$. lang bei einer Breite von 3 .

Der Schlundk opf weiss, $4 \mathrm{~mm}$. lang bei einer Breite von 2,5; die Scheide an Länge $8,25 \mathrm{~mm}$. messend. Das Dach des Nundhöhle braun schmutzig, mit dichtstehenden, nicht recht steifen Dornen besetzt, die eine Höhe bis $0,4 \mathrm{~mm}$. erreichten. An der Raspel und unter dem Raspeldache 24 Zahnplattenreihen; in der am Anfange des letzten Drittels nach unten gebogenen Scheide 64 Reihen, von welchen die 7 hintersten noch unreif; das Ende der Scheide auch in zwei kurze Hörner auslaufend, die aber divergirten. Die Länge der medianen Platten betrug o, 8 mm., die der Seitenplatten (in gerader Linie zwischen den Spitzen) o, 30, die der Aussenplatten bis 0,37 , wozu noch eine Länge der umgebogenen Spitze von $0,06 \mathrm{~mm}$. kam. Die medianen, die 4 paramedianen, die Seitenplatten und die Aussenplatten ganz wie oben beschrieben.

Die Leber braun, die Geschlechtsdrüse weiss. 


\section{Stovatellidae.}

Miraconcha Bgh. N. Genus.

Corpus quasi nonnihil limaciforme. Notaeum anticum testa membranacea, magnopere irisante tectum. Operculum nullum.

Formula radularis: $\infty-5-\mathrm{I}-5-\infty$.

Die Stellung dieser Rhipidoglosse ist, hauptsächlich auch wegen der ungenügenden Untersuchung, etwas zweifelhaft, sie scheint zu den Stomatelliden zu gehören.

Ich habe nur eine Kieme gesehen. Auch die Form des Thíeres oder wenigstens der hinteren Hälfte mit ihrer limacoiden Ähnlichkeit ist sonderbar, noch mehr die membranartige stark irisirende Beschaffenheit der Schale. Der zackige Rand, der den Schalenrand einfasst, repräsentirt wohl die epipodiale Linie. Ein Deckel fehlt.

\section{Miraconcha obscura Bgh. n. sp.}

Am 28 Aug. wurde (St. I72) am Ankerplatz zwischen der Insel Gisser und Ceram-Laut von Korallen- und Lithothamnion-Boden ein Individuum gefischt.

Dasselbe hatte in $4 \%$ Formol bewahrt eine Länge von $28 \mathrm{~mm}$. bei einer Breite von I I und einer Höhe von $10 \mathrm{~mm}$., die Breite der Fusssohle in ihrer Mitte war I I mm. Der Kopf hatte eine Länge von 5, die Tentakel von $6 \mathrm{~mm}$. - Die Farbe war durchgehends schwärzlich-braun an der oberen Seite, die Fusssohle war weisslich.

Die Form war länglich, von der Mitte der Länge ab nach vorn und besonders nach hinten etwas verschmälert, im Ganzen etwas limaxartig, der etwas gewölbte Rücken fiel allmählig gegen den Fuss hinunter ab, dessen Rand fast nicht hervortrat. Der Rücken zeigte in seiner ganzen Ausdehnung (bis auf die Gegend der Schale) kleine gerundete und gerundet-eckige Felder von einem Durchmesser bis etwa $0,75 \mathrm{~mm}$., welche leicht gewölbt waren und in der Mitte sich in einen spitzen Kegel erhoben. Von der Mitte des Rückens ab bis an sein Vorderende war der Rücken von einer ganz eigenthümlichen Schalenbildung bedeckt, die eine Länge von fast $10 \mathrm{~mm}$. hatte und eine ähnliche Breite, und hinten eingerollt etwa wie bei Haliotis schien. Die membranartig dünne Schale zeigte einen äusserst starken Perlmutterglanz und trug Anwuchsstreifen gewöhnlicher Art; bei der leichtesten Berïhrung löste sich die Schale in Fetzen auf. Die Öffnung für die Schale war von einem weissen fein-zackigen Rande eingefasst und in der Nähe derselben waren die Hautkegel besonders gross, sich zu eine Höhe von $0,6 \mathrm{~mm}$. erhebend, und immer mit dunkel-schwarzer Spitze. Die Kiemenspalte war ziemlich schmal, aus derselben ragte die Spitze der Kieme hervor. Der Kopf nicht klein; eine Querfalte an der convexen oberen Seite desselben erhob sich jederseits in einen zugespitzten Fortsatz, die Falte setzte sich jederseits nach hinten an das kurze Ophthalmophor fort, unter der Commissur trat der ziemlich allmählig spitz auslaufende Tentakel hervor. Der vorderste Theil des Kopfes war mit feinen Höckern bedeckt. Die Unterseite des Kopfes war etwas plan; das Vorderende war abgeplattet gerundet-dreieckig, 
weisslich. Der Fuss war gegen seine Enden ein wenig verschmälert, besonders nach hinten, vorne gerundet.

Die Öffnung an den Ophthalmophorien war sehr deutlich.

Der Schlundkopf war von Form ganz wie bei anderen Rhipidoglossen, 4,5 mm. lang bei einer Breite von 2,5 und einer Höhe von 3. Im Innenmunde fand sich jederseits eine $0,75 \mathrm{~mm}$. lange, braungelbe Mandibelplatte, von dicht gedrängten kleinen Kegeln gebildet, die eine Höhe bis $0,016 \mathrm{~mm}$. erreichten. Die weissliche $\mathrm{Zunge}$ hatte vom Raspeldache ab eine Länge von $3 \mathrm{~mm}$. bei einer Breite von I,75, aber nur der letzte I mm. ragte frei, von der unteren Wand der Mundhöhle gelöst, hervor. An den Rändern der tiefen Zungenkluft zeigten sich die Ränder der gelben Raspel. An dieser letzteren fanden sich 17 Zahnplattenreihen, den 5 vordersten fehlte aber die ganze mittlere Parthie; die Raspelscheide war wie gewöhnlich lang. Die medianen Platten waren mehr lang als breit, die Länge o,2 mm. betragend; sie waren vorne ganz schmal, hinten breit- und gerundet, der kurze Haken an dem Grunde denticulirt. Die 5 Seitenplatten fast von derselben Grösse und Form, etwa $0,1 \mathrm{~S}$ mm. lang, am Grunde des längeren Hakens jederseits 3-4 Dentikel. In der langen Reihe von Aussen- oder Randplatten wurden gegen etwa 200 Platten gezählt; sie waren (bis etwa $0,2 S \mathrm{~mm}$.) lang, aufrecht, an beiden Rändern der rechtwinkelig gebogenen Spitze gezähnelt, die inneren oben von etwas anderer Form als die mehr nach aussen liegenden. - Die milchweissen Stützknorpel der Zungenmuskelmasse $4 \mathrm{~mm}$. lang, vorne verschmälert und nach innen gedreht; die Structur die gewöhnliche, so genannt knorpelige.

Weissliche Speicheldrüsen schienen an den Seitentheilen des Schlundkopfes vorzukommen.

Die Kiemenhöhle lang; die Kieme lanzetförmig, $12 \mathrm{~mm}$. lang bei einer Breite bis 3,5, gelblichweiss; von den zwei Reihen von Blättern war die untere viel schmäler.

Die Eingeweidemasse erstreckte sich nur an die Gegend des Hinterrandes der Schale. Jene zeigte hinten eine ganz kurze und spitze Einrollung.

Eine einigermaassen eingehende Untersuchung war bei dem vorliegenden Material nicht möglich. Der hinten liegende Magen verlängert sich nach vorn in einen ( $\$ \mathrm{~mm}$. langen) Blindsack, dessen Ende spiralig eingerollt ist. Die Leber braun. Das weissliche Ovarium enthielt grosse Eizellen.

\section{Gena Gray.}

GRAY, A list of the genera of recent moll. Proc. Zool. Soc. $1847 \cdot$ p. 146.

Gray. Proc. Zool. Soc. 1850 . p. 37.

GRAY, Guide. I857. p. 159, Fig. 85.

H. and A. AdAMS, The genera of recent moll. I, i858. p. 437.

Corpus fere ut in Miraconcha. Notaeum anticum testa calcarea depressa, spira parva, apertura lata instructum; operculum nullum.

Formula radularis: $\infty-5-\mathrm{I}-5-\infty$.

Diese Form steht der Gattung Miraconcha sehr nahe, hat aber eine harte Schale.

Die. Zungen-Bewaffnung ist der der Miraconcha sehr ähnlich. 
4. Gena nigra (Q. et G.).

Stomatella nigra Quoy et Gaim. Voy. de l'Astrolabe, III, 1834. p. 307, Pl. 66 bis, Fig. 10-12.

Von dieser Form lag nur ein einziges Individuum vor, in der Pepela-Bai an der Ostküste der Insel Rotti (St. 30I) aus einer Tiefe von 27-45 M. gefischt.

Die von Quoy und Gamard dargestellte Form schien hier vorzuliegen; dieselbe ist aber vielleicht von der Gena nigra von Reeve (Conch. ic. XIX, I874. Gena, Pl. II, Fig. I r) verschieden.

Das aufbewahrte, zusammengezogene und erhärtete Individuum war $55 \mathrm{~mm}$. lang bei einer Breite von 6 und einer Höhe bis $5 \mathrm{~mm}$. Die Farbe (bräunlich-)schwarz, das Periostracum der Schale dunkel grau; die Fusssohle gelblichgrau.

Der Fuss überall bis an seine Ränder mit ganz feinen Wärzchen bedeckt; rechts und hinten finden sich an seinem oberen Rande neben der Schale einige (etwa 5) I,75 mm. hohe schwarze Cirrhi; die Fusssohle mit schwacher medianer Längsfurche. Der. Kopf (dem der Miraconcha ganz ähnlich) mit ganz feinen Höckern dicht bedeckt, der Vorderrand ganz fein zackig, die hinteren Spitzen etwas stärker, die obere Querlinie jederseits in zwei-drei Spitzen (die wahrscheinlich kurz-ästig gewesen sind) auslaufend. Die Tentakel ( $5 \mathrm{~mm}$.) lang, an ihrem Grunde die kurzen Ophthalmophorien miz deutlichen offenen Augen; am Grunde des rechten hinten die zusammengefaltete $2 \mathrm{~mm}$. lange Athemröhre. Die Schale $10 \mathrm{~mm}$. lang bei einer Breite von 6 und Höhe von 2; kalkweiss, nicht ganz dünn, aber (jetzt) sehr zerbrechlich. Links ragte aus der Kiemenhöhle die Spitze der grössten Kieme hervor; der freie Theil derselben hatte eine Länge von $3 \mathrm{~mm}$. bei einer Breite am Grunde von 2; das obere Blatt schmaler als das untere.

Der Schlundkopf wie gewöhnlich. Die Raspel $2 \mathrm{~mm}$. lang, die Raspelscheide etwa $3 \mathrm{~mm}$. lang; die letztere frei hervorragend, in 2 ziemlich langen, gebogenen Zipfeln herausgezogen. Die gelbliche Raspel mit 20 Zahnplattenreihen, in der Scheide kamen deren gegen.50 vor. Die Platten der mittleren Parthie der Raspel gelblich, die übrigen farblos; die Länge der medianen betrug $0,13 \mathrm{~mm}$. bei einer Breite hinten von 0,06; die 5 Seitenplatten von etwa derselben Länge; die Höhe der innersten Aussenplatten etwa O, 2 mm., die Höhe der Aussenplatten bis O, 8 mm. steigend um nach aussen durch eine lange Reihe bis zu o,oS mm. zu sinken. Die medianen Platten fast denen der Miraconcha ähnlich; die 5 Seitenplatten alle einander ähnlich, ihr Haken mit stumpfer Spitze und am Grunde derselben jederseits 2-3 Dentikel; die inneren Aussenplatten mit stark umgebogener Spitze, mehr nach aussen wurden sie ganz dünn. - Die weisslichen "Knorpel" der Zunge wie bei Miraconcha.

Der Zustand des Individuums gestattete keine weitere Untersuchung.

\section{MARSENIIDAE.}

Lamellariacea Lovén. Öfvers. Vetensk. Ak. Handl. 1847. p. 192.

Marseniadae Bergh. Bidr. til en Monogr. af Marseniaderne. Kgl. Danske Vidensk. Selsk. Skr. 5 B. Naturvidensk. og mathem. Afdel. III, i 853. p. 243-359. Tab. I-V.

Marseniadae. BERGH, malacolog. Unters. IV. Supplementheft III u. IV, I 886-I887. p. I 3 I-225. Taf. $M-Z$. 
105

Die Familie umfasst die dioecischen Gattungen Chelyonotzs (Sw.), Marsenia (Leach), Marseniclla (B.) und Marseniopsis (B.); und die monoecischen Marsenina (Gr.) und Onchidiopsis (B.).

\section{Marsenia Leach.}

BERGH, Malacol. Unters. Supplementhefte IIJ, I 886. p. I60(-173).

Animalia dioecia; notaeo sat laevi, plica inspiratoria brevi.

Pars inferior vasis deferentis in cavitate abdominali pro parte libera.

Eine Reihe von Arten ist aus den verschiedensten Meeresgegenden beschrieben (vgl. l.c. p. $162-163)$.

5. Marsenia perspicua (L.). 1. c. I905. Taf. III, Fig. IS.

Auf St. 273 Jedan, Aru-Inseln, I 3 M. Sandboden und auf St. 310 in der Nähe von Sumbawa in 73 M. Tiefe auf toten Korallen, wurde je ein Individuum gefischt und lebend abgebildet.

Lebend hatte letzteres eine Länge von 3,2 bei einer Breite von $2,8 \mathrm{~cm}$. Die Farbe der Rückenseite war röthlichgelb, am eigentlichen Rücken mehr röthlich.

Das a ufbewahrte, weibliche Individuum zeigte sich 2,4 $\mathrm{cm}$. lang bei einer Breite von 2 und einer Höhe von $1 \mathrm{~cm}$. Die Farbe war durchgehends weisslich. - Die Formverhältnisse wie gewöhnlich; am sonst ebenen Rücken kamen hier und da kleine runde oder zugespitzte Höcker vor. Un das einzige Individuum zu schonen wurde die Schale nicht herausgenommen; sie bietet ja bei den Marseniaden kaum specifische Charactere.

Der Schlundkopf weisslich, $5 \mathrm{~mm}$. lang bei einer Höhe von 3 und Breite von 4; die Raspelscheide rechts aufgerollt. Die Mandibelplatten gelb, von gewöhnlicher Form. An der schwarz eingefassten gelben Raspel der Zunge 21 Zahnplattenreihen; in der langen Scheide deren noch 39, von welchen die 3 noch unreif; die Gesamtzahl der Reihen somit 6o. Die medianen Platten $0,24 \mathrm{~mm}$. breit, ziemlich symmetrisch, jederseits mit $5-8$ Dentikeln. Die lateralen Platten auch von gewöhnlicher Form, am oberen Schneiderand mit $15-20$ feinen spitzen Dentikeln, am unteren mit 4-6 gröberen.

Die Speiseröhre $6 \mathrm{~mm}$. lang, schwarz. Die Leber dunkel violetgrau.

Diese Form gehört wohl nur der so sehr verbreiteten typischen Art an ${ }^{1}$ ).

\section{Marsenia Sibogae Bgh. n. sp.}

Am Riffe der Insel Pajunga, Kwandang-Bai (St. I I 5) wurde ein weibliches Individuum gefischt.

Dasselbe hatte eine Länge von $22 \mathrm{~mm}$. bei einer Breite von 57 und einer Höhe von 11 ; die Breite des Mantelgebräms war 7, die Länge der Tentakel 3, die des Fusses I 2 bei einer Breite von S, die Tiefe der Inspirationsfalte $4 \mathrm{~mm}$. - Die Farbe der Rückenseite war bräunlichgrau (zum grossen Teil abẹr abgerieben); die Unterseite des Mantelgebräms dicht schwarzbraun gefleckt, die median vom Grunde des Hinterendes ausstrahlenden weissen Linien ungewöhnlich

I) Vgl. R. Bergi, Die Opisthobranchier der Sammlung Platr. l. c. I\$gS. p. 563-(569). 
stark und sich fast an das Vorderende fortsetzend; die Seiten des Unterkörpers schwarzgrau; der Kopf mit den Tentakeln weiss. Die Schale schimmerte nicht durch.

Die Formverhältnisse waren im Ganzen die gewöhnlichen, nur fanden sich in der Gegend des Vorderrandes der Schale 4 und in der des Hinterrandes 3 gerundete Knoten; die Ophthalmophorien waren sehr wenig ausgeprägt.

Die schöne, kalkweisse, feste $\mathrm{Schale}$ I $5 \mathrm{~mm}$. lang bei einer Breite von 10 und einer Höhe von 7 ; die Schalenöffnung I I mm. lang bei einer Breite von 9, die Zahl der Windungen ${ }^{2} / 2$, die Spira ganz klein, starke Zuwachslinien in der letzten etwa Hälfte der letzten Windung. Eingeweide schimmerten nicht durch.

Der weisse Schlundkopf $5 \mathrm{~mm}$. lang bei einer Breite von 4,5 und einer Höhe von 3 . Die Mandibelplatten waren in dem vorderen Theile citrongelb und oben fast rothgelb, sonst fast farblos, 2,5 mm. lang. Die braungelbe Raspel der $Z$ unge enthielt 16 Zahnplattenreihen, in der nach rechts aufgerollten (ausgerollten $10 \mathrm{~mm}$. langen) Raspelscheide 38 Reihen, von welchen die 6 unreif; die Gesamtzahl der Reihen somit 54. Die Zahnplatten in den dickeren Parthien gelb; die Länge der medianen betrug $0,20 \mathrm{~mm}$. bei einer Breite vorne von $0,04-0,05$ und hinten von $0,18-0,20 \mathrm{~mm}$; die Länge der lateralen war 0,55 . Die medianen Platten von gewöhnlicher Grundform, aber vorne stark verschmälert und glattrandig; die lateralen auch von gewöhnlicher Form, der hintere (obere) Rand des Hakens aber glatt, und am anderen kam nur ein starker, nicht spitzer Dentikel vor.

Der an der hinteren Seite der oberen Eingeweidemasse entblösste eigentliche Magen kugelrund, von $4 \mathrm{~mm}$. Durchmesser. Die Leber dunkelgrau. - Die Eierstock röthlich gelblichweiss.

Die Specificität dieser Form kann kaum angezweifelt werden, dazu ist der vom dem der anderen bekannten Marsenien abweichende Raspelbau allzu verschieden ${ }^{1}$ ).

\section{Chelyonotus (Swainson) Bergh.}

Clelinotus Swainson. Treatise of malacology. 1840. p. 353.

Chelyonotus Bergh. Monogr. I853. p. 340. - Malacol. Unters. Supplementheft III, I-2. Die Marseniaden. 1887. p. 174-178, 193-226.

Coriocella Blainville. Dict. Sc. nat. XXXII. 1824. p. 259.

Animalia dioecia, Marseniis propriis similia, sed notaeo tuberculato et plica inspiratoria producta apice interdum bifida instructa.

Vas deferens in cavitate abdominali non liberum, sed in pariete abdominali omnino inclusum.

Der zwar ältere Gattungsname von Blainville hat kaum giltige Ansprüche (vgl. l. c. 1887. p. 174).

Die Chelyonoten sind eigentlich fast nur sehr grosse Marsenien mit stark vortretender Einathmungsfalte und mit grob-knotigem Rücken, im inneren Bau stimmen sie auch wesentlich mit den ächten Marsenien überein, nur ist der untere Theil des Samenleiters nicht theilweise frei, sondern in der Körperwand ganz eingeschlossen.

I) Die Form ist von der der beschriebenen $M$. perspicua des Siam-Meeres verschieden (vgl. Dan.-exped. to Siam. Gasteropoda opisthobranchiata. 1902. p. 213-2I4. Pl. II1, Fig. I3, I4). 
Die Gattung gehört den tropischen und subtropischen Meeresgegenden und enthält bisher kaum mehr als zwei Arten, falls dieselben wirklich specifisch verschieden sind.

I. Ch. Semperi Bgh. M. indic., philippinense.

2. Ch. Tonganus (Quoy et Gaim.). M. indicum.

6. Chelyonotus Semperi Bgh. 1.c. 1905. Taf. III, Fig. 19.

R. Bergit, Malacolog. Unters. Heft IX, I 875 . Taf. XLI, Fig. 9; - 1. c. 1887, p. 175-176, 193-225. Taf. M, N, O, P, Q Fig. I-6.

Am i 6 Dcbr. wurden am Riffe von Tual, Kei-Inseln (St. 258) i 3 Individuen gefischt, und das eine nach dem Leben abgebildet; später noch eins am Riff von Dobo, Aru-Inseln (St. 272), ferner eins bei Samalona bei Makassar (St. 73) sowie auf den Riffen von St. 250 Insel Kur und St. 279 Insel Roma; letzteres ist die var. tessellata.

Die 5 Individuen der erst genannten Station stimmten ganz mit dem typischen Chelyonotus Semperi uberein, zeigten an der Rückenseite ausser den 5 grossen Buckeln zahlreiche, ganz geschiedene, auch sammtschwarze, grössere und kleinere, unregelmässige, wenig vortretende Facetten, fast ganz wie in den von Quov und GaIMARD gelieferten Figuren ihres Chelyonotus (Sigaretus) tonganus ${ }^{1}$ ). Bei den übrigen (10) Individuen kamen solche Facetten nicht vor, die Haut schien (durch starke Contraction?) eine zusammenhängende sammtschwarze Fläche zu bilden (1. c. Taf. III, Fig. I9).

Diese letzteren Individuen waren die grössten; ihre Länge betrug meistens $5-7 \mathrm{~cm}$. bei einer Breite bis 3,2, die Höhe bis an die Spitze des medianen Rückenknotens 2,5 cm., die Höhe der Rückenbuckel betrug $8-10 \mathrm{~mm}$.; die Länge des Fusses $2,9 \mathrm{~cm}$. bei einer Breite von $\delta \mathrm{mm}$.

Ein grösseres (weibliches) Individuum wurde, geöffnet und der Schlundkopf untersucht.

Die Schale war gelblichweiss, ziemlich verkalkt, aber ganz zerbröckelt, ihre Formverhältnisse schienen die gewöhnlichen.

Die Länge des Schlundkopfs betrug $6 \mathrm{~mm}$. bei einer Breite von 4 und einer Höhe von 3; die Raspelscheide war nach rechts flach aufgerollt. Das Dach der Mundhöhle schwarz. Die vorne braungelben, sonst gelben Mandibelplatten 2,25 mm. lang bei einer Höhe von I,5, sonst ganz wie früher beschrieben. Die gelbe Raspel enthielt (innerhalb der braungelben Kante) 9 Zahnplattenreihen, unter dem Raspeldache fanden sich 6, und in der langen Raspelscheide 50 , von welchen die I I noch nicht fertig entwickelt; die Gesamtzahl der Reihen somit 65 . Die Form der medianen so wie der lateralen Zahnplatten ganz wie früher beschrieben.

I) Voy, de I'Astrolabe. Zool. 11, I. I832. p. 217-220. Pl. 66, Fig. 4, 8.

Falls eine Form ohne die grossen Rückenbuckeln wie die der französischen Verff. wirklich existirt, würde ein Chol. Tonganus (Q. et G.) sein specifisches Namen-Recht sich vindicirt haben.

Der von mir (1.c. p. 222) erwähnte Chel. Tonganus, var. Berghi (Desh.) scheint dem Chcl. Simptri an zu gehören. 

PLATES 


\section{PLATE I.}

Fig. 1. Phenacolepas radiata n. sp.

Fig. 2. Pseudococculina rugosoplicata n. sp.

Fig. 3. Pseudococculina granulata n. sp.

Fig. 4. Cocculina subquadrata n. sp.

Fig. 5. Cocculina oblonga.

Fig. 6. Cocculina cingulata n. sp.

Fig. 7. Cocculina ovata n. sp.

Fig. 8. Cocculina alveolata n. sp.

Fig. 9. Cocculina subcompressa n. sp.

Fig. Io. Cocculina striata n. sp.

Fig. I I. Acmaea neglecta n. sp. 

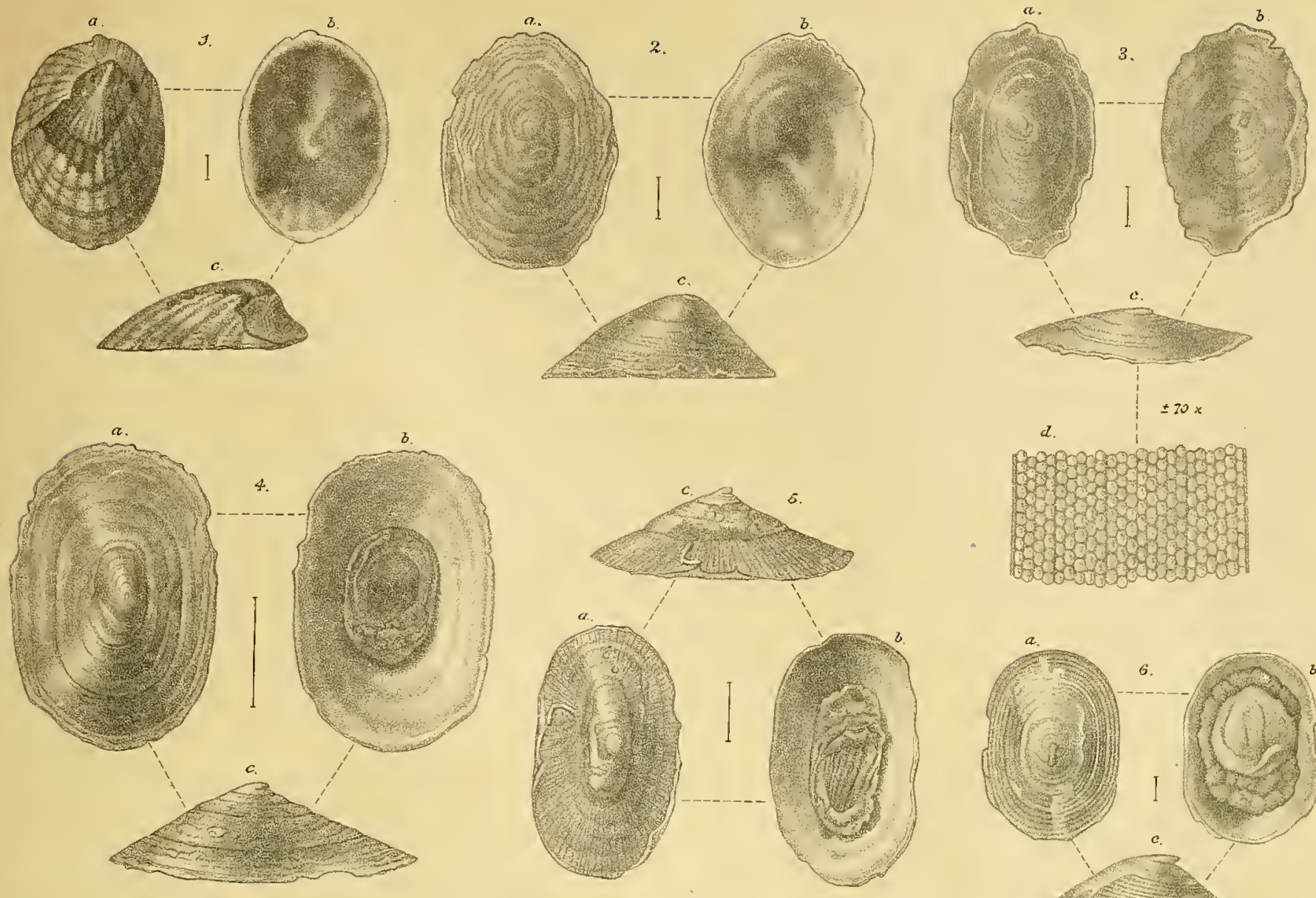

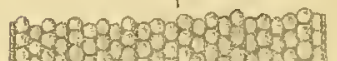
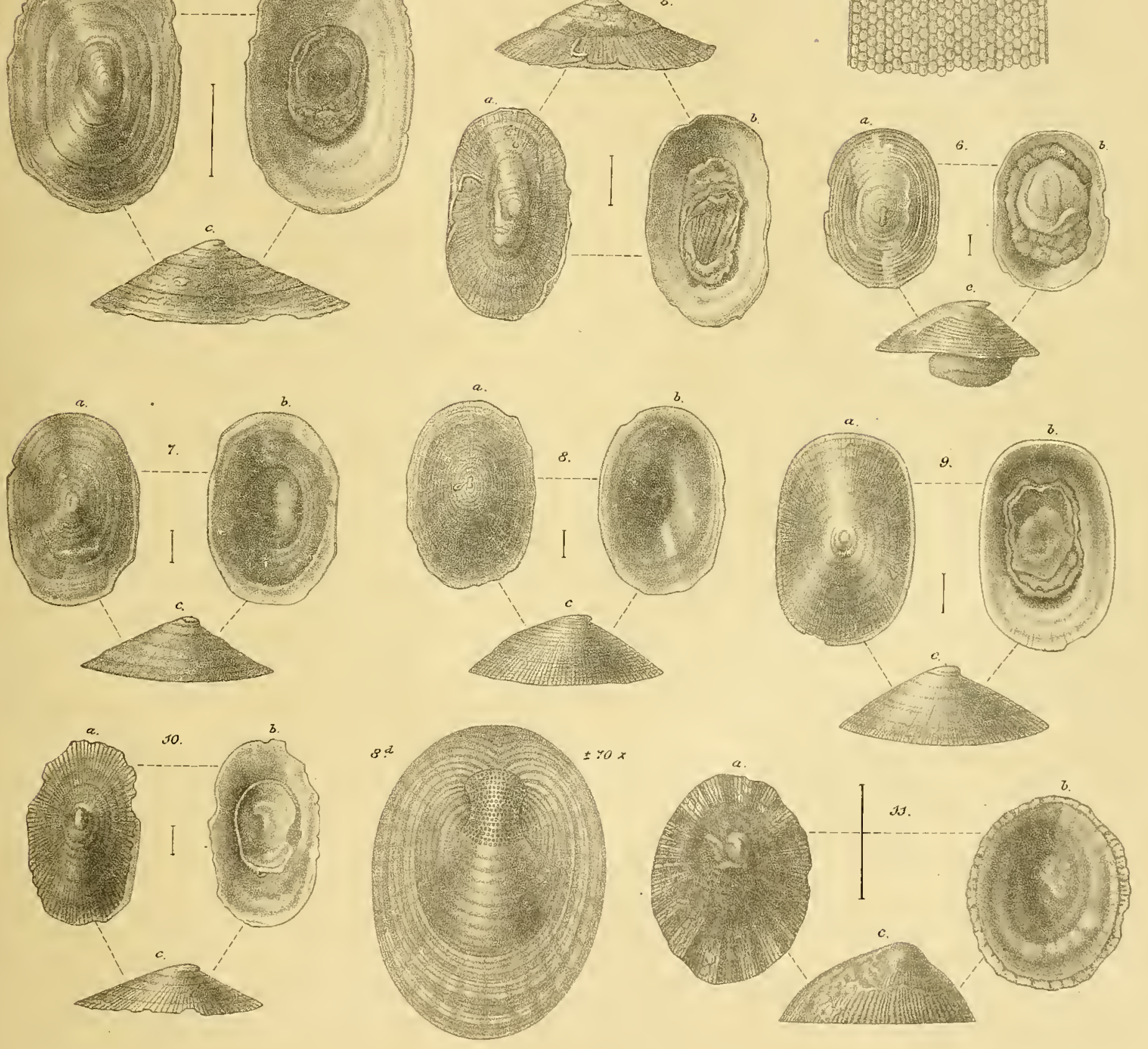

Fa P W. M. Trap impr. 




\section{PLATE II.}

Fig. I. Astralium (Pseudastralium) abyssorum n. sp.

Fig. 2. Astralium lapillus Reeve.

Fig. 3. Astralizm provisorium n. sp.

Fig. 4. Priotrochus incertus n. sp.

Fig. 5. Teinostoma sibogae n. sp.

Fig. 6. Danilia Weberi n. sp.

Fig. 7. Guttula sibogae n. sp.

Fig. 8. Pectinodonta orientalis n. sp.

Fig. 9. Pectinodonta alta n. sp.

Fig. IO. Monilea celebensis n. sp. 

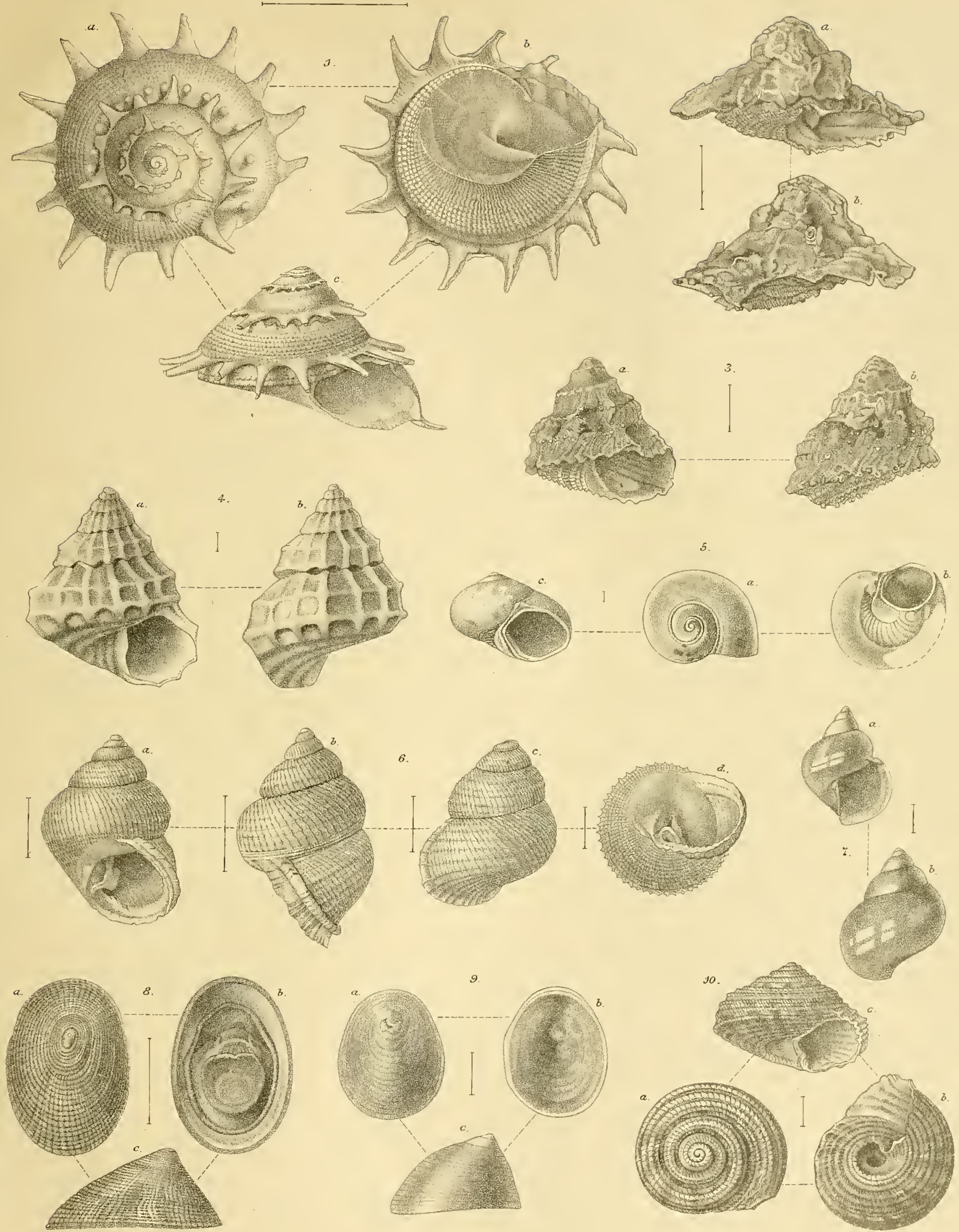

Fa, P. W, M. Trap impr. 




\section{PLATE III.}

Fig. I. Liotia armata Adams, var.

Fig. 2. Liotia lamellosa n. sp.

Fig. 3. Cantharidus pliciferus n. sp.

Fig. 4. Minolia ornatissina n. sp.

Fig. 4a. Minolia ornatissima smaller specimen.

Fig. 5. Solariella olivaceostrigata n. sp.

Fig. 6. Solariella zacalloides n. sp.

Fig. 7. Solariella mutabilis n. sp.

Fig. 7a. Solariella mutabilis var. laevior n. var.

Fig. 7b. Solariella mutabilis var. plicifera n. var.

Fig. 8. Solariella marginata n. sp. 

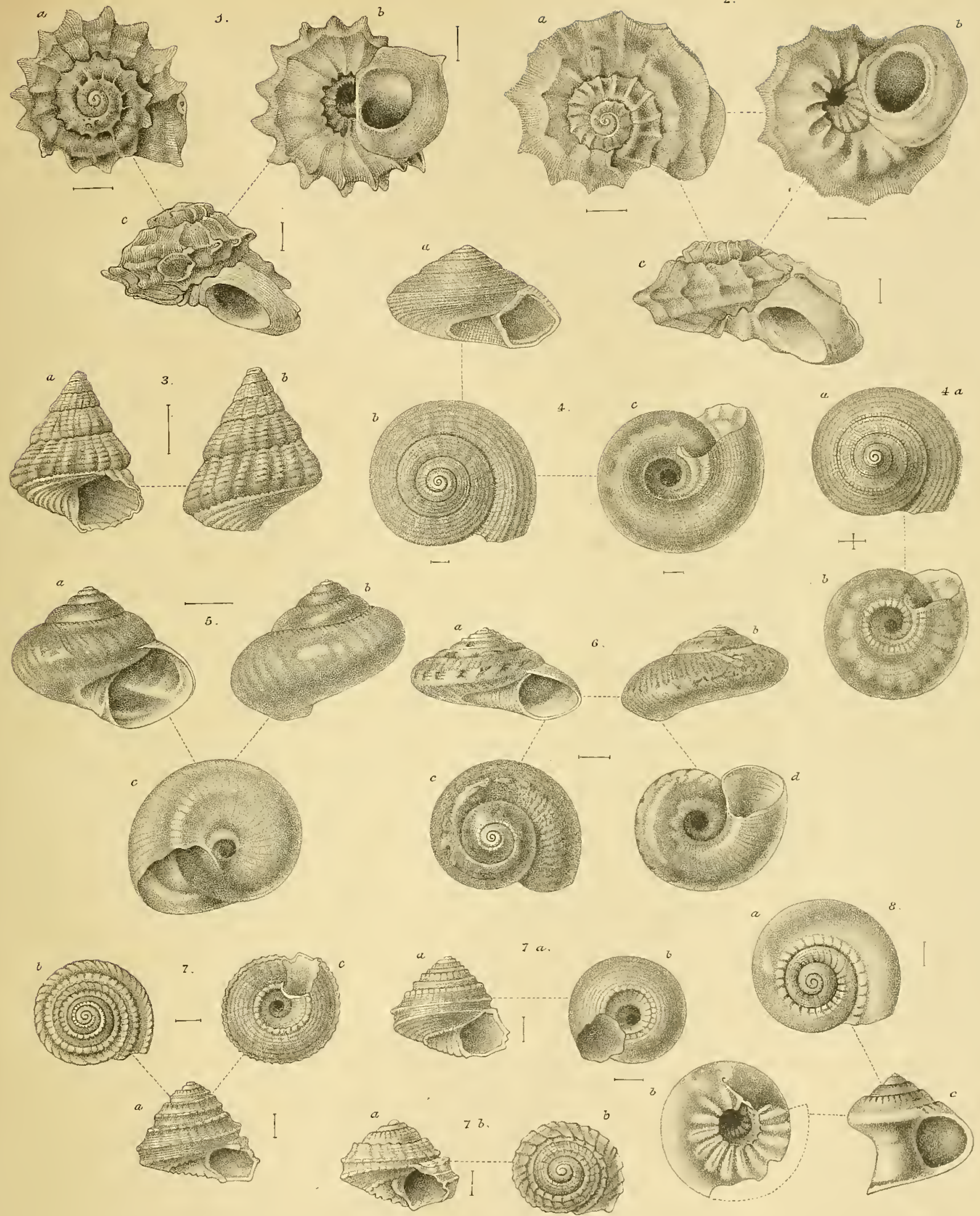

Fa. P. W. M. Trap impr. 




\section{PLATE IV.}

Fig. I. Solariella callomphala n. sp. Ia with umbilicus quite closed.

Fig. 2. Solariellopsis calcarata n. sp.

Fig. 3. Solariellopsis limbifera n. sp.

Fig. 4. Solariellopsis pulchra n. sp.

Fig. 5. Solariellopsis spinulosa n. sp.

Fig. 6. Solariellopsis bicarinata n. sp.

Fig. 7. Solariellopsis multisquamosa n. sp.

Fig. 8. Solariellopsis muricata n. sp. 
3

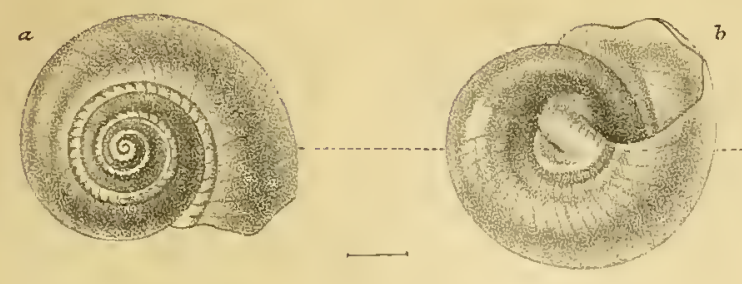

Ia.

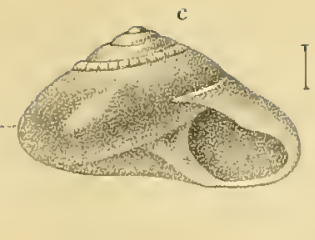

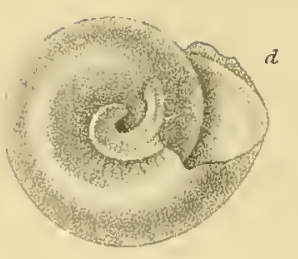
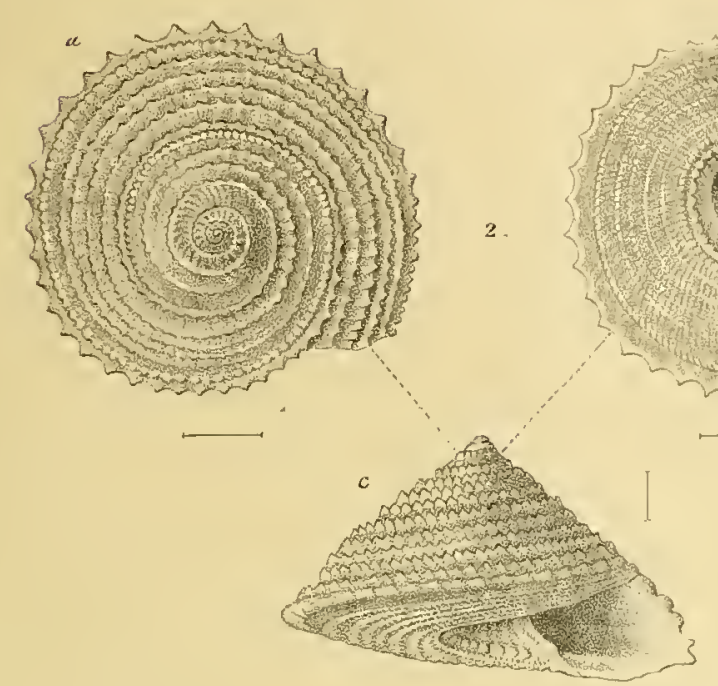
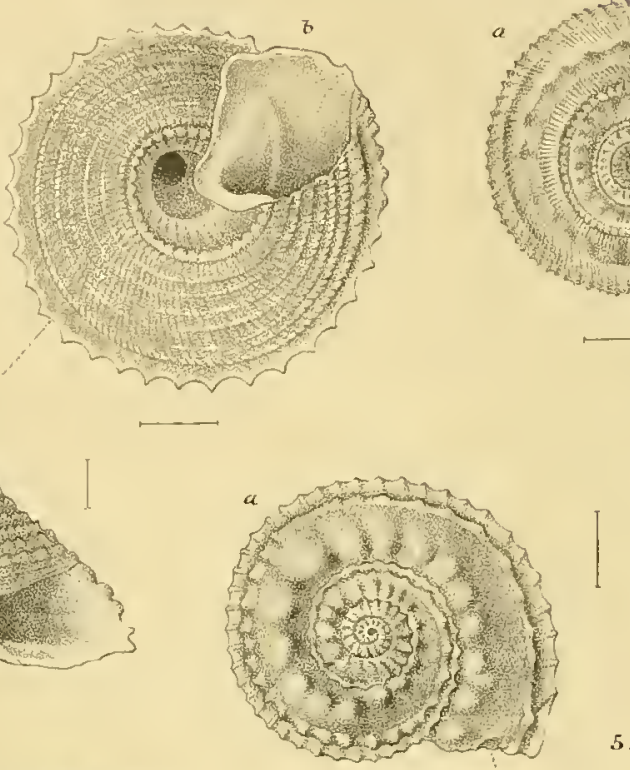
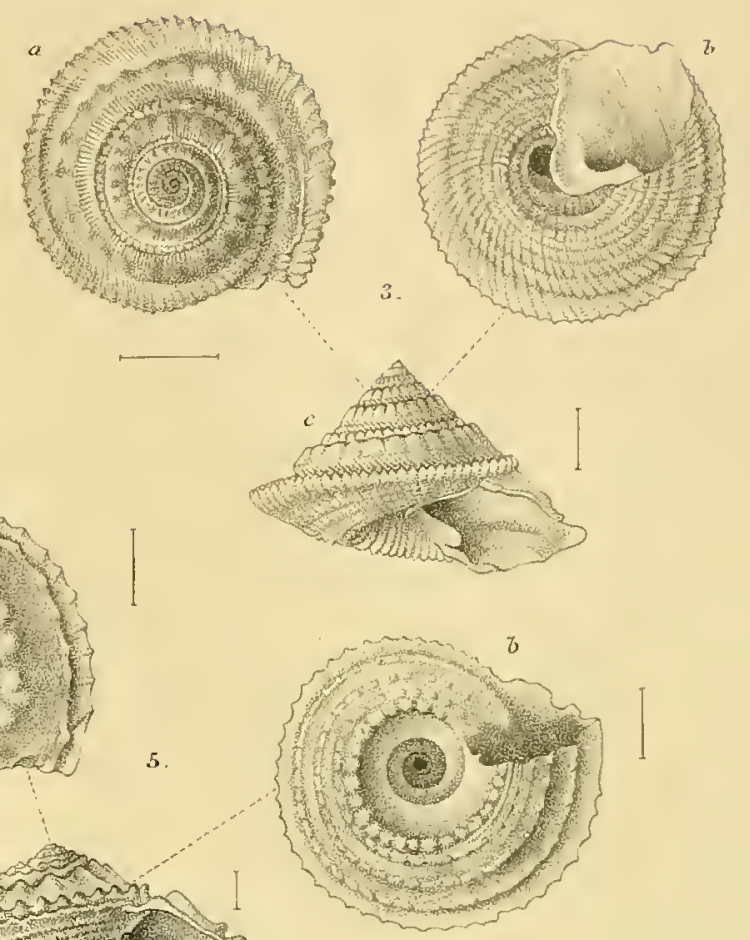
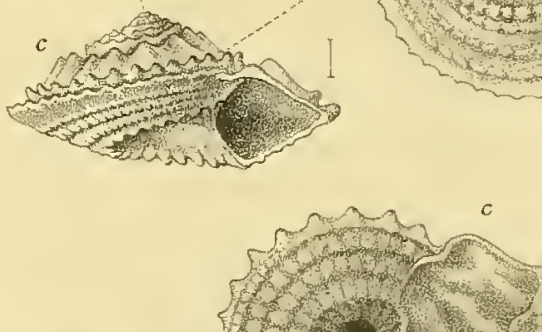
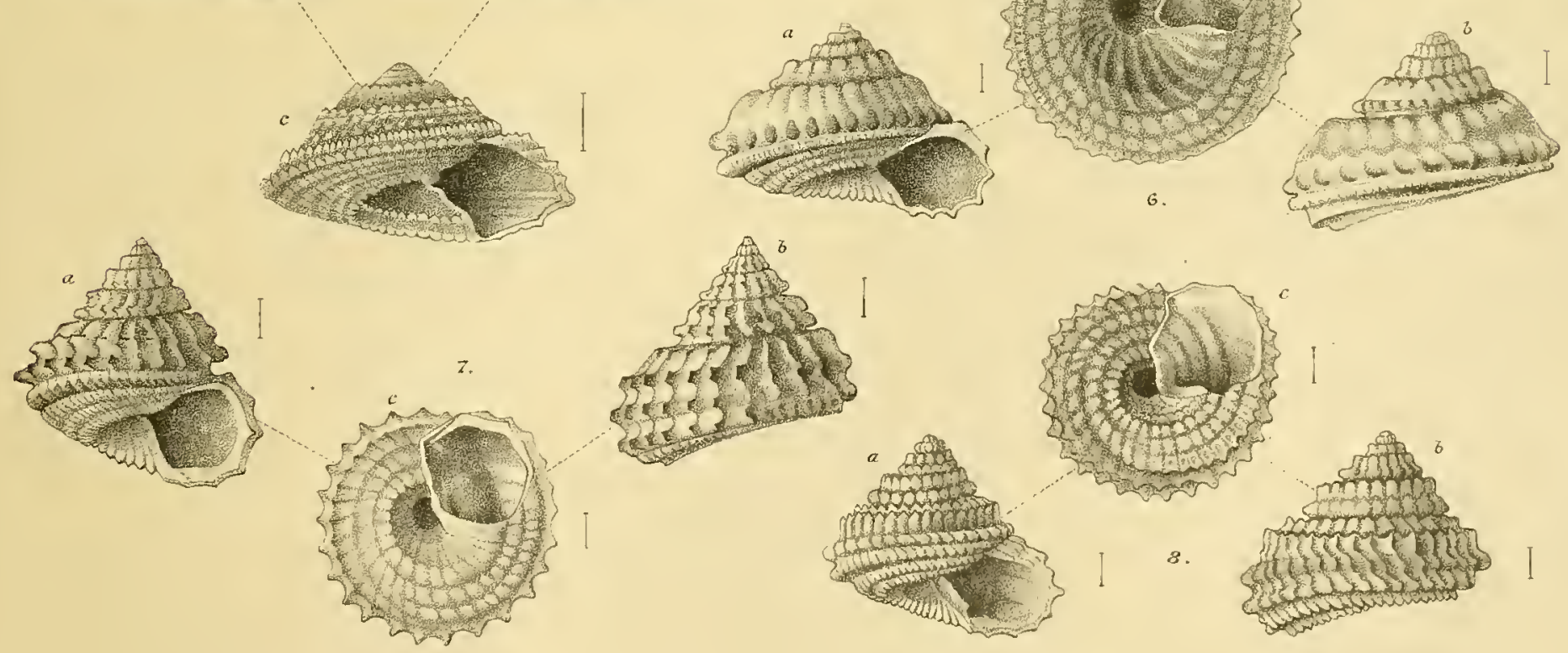

6.
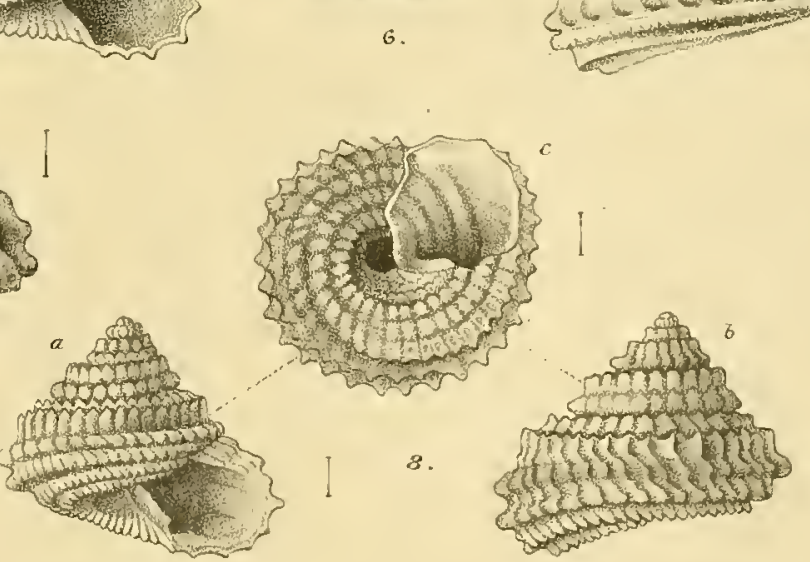

Fa. P. W. M. Trap impr. 




\section{PLATE V.}

Fig. I. Solariellopsis concavospira n. sp. Fig. 2. Solariellopsis pagodiformis n. sp. Fig. 3. Basilissa sibogae n. sp.

Fig. 4. Calliostoma rufonaculatum 11. sp. Fig. 5. Calliostoma simplex n. sp.

Fig. 6. Calliostoma multispinosum n. sp. Fig. 7. Calliostona quadricolor n. sp.

Fig. 8. Calliostoma virgo n. sp.

Fig. 9. Calliostoma expansum n. sp. 

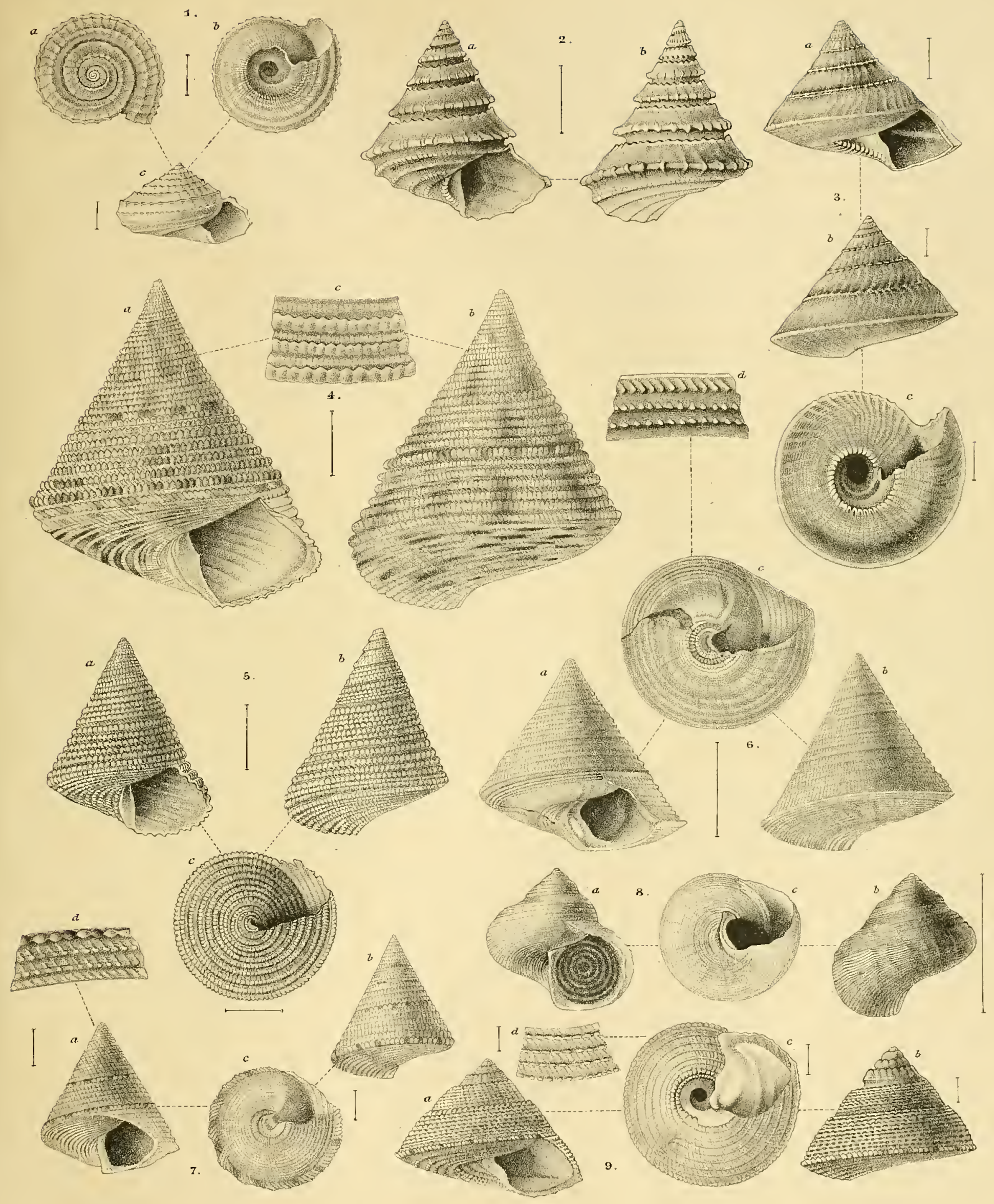

Fa. P. W. M. Trap impr. 




\section{PLATE VI.}

Fig. I. Calliostona crassicostatum n. sp.

Fig. 2. Calliostoma monodon n. sp.

Fig. 3. Calliostoma squamicarinatum n. sp.

Fig. 4. Calliostoma nigromaculatum n. sp.

Fig. 5. Calliostoma cancellatum n. sp.

Fig. 6. Euchelus ringens n. sp.

Fig. 7. Ethalia misolina Melv., var. laevior n. var.

Fig. 8. Stomatia planulata n. sp.

Fig. 9. Scissurella maxima n. sp.

Fig. IO. Scissurella exquisita n. sp.

Fig. I I. Turbo gemmatus Reeve, var.

Fig. I2. Fissurella sibogae n. sp. 

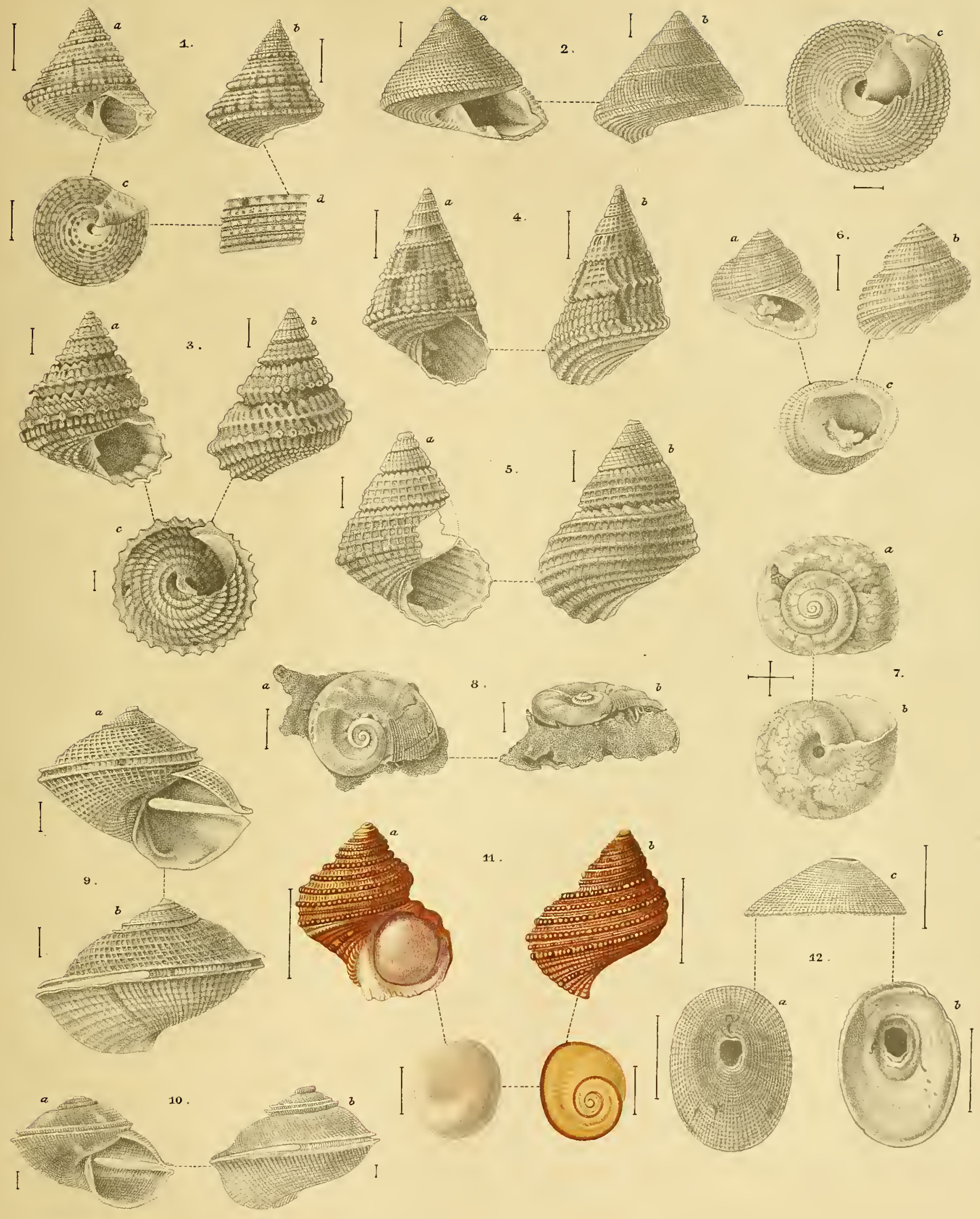

Fa. P. W, M. Trap impr. 




\section{PLATE VII.}

Fig. I. Macroschisma maxima Adams, var. elongata n. var.

Fig. 2. Glyphis subcalyculata n. sp.

Fig. 3. Puncturella gemmata n. sp.

Fig. 4. Puncturella gigantea n. sp.

Fig. 5. Rimula carinifera n. sp.

Fig. 6. Emarginule paucipunctata n. sp.

Fig. 7. Emarginula multisquamosa n. sp.

Fig. 8. Emarginula curvata n. sp.

Fig. 9. Emarginula sublaevis n. sp.

Fig. 10. Emarginula dubia n. sp.

Fig. II. Emarginula foveolata n. sp.

Fig. 12. Emarginula clypeus Adams. 

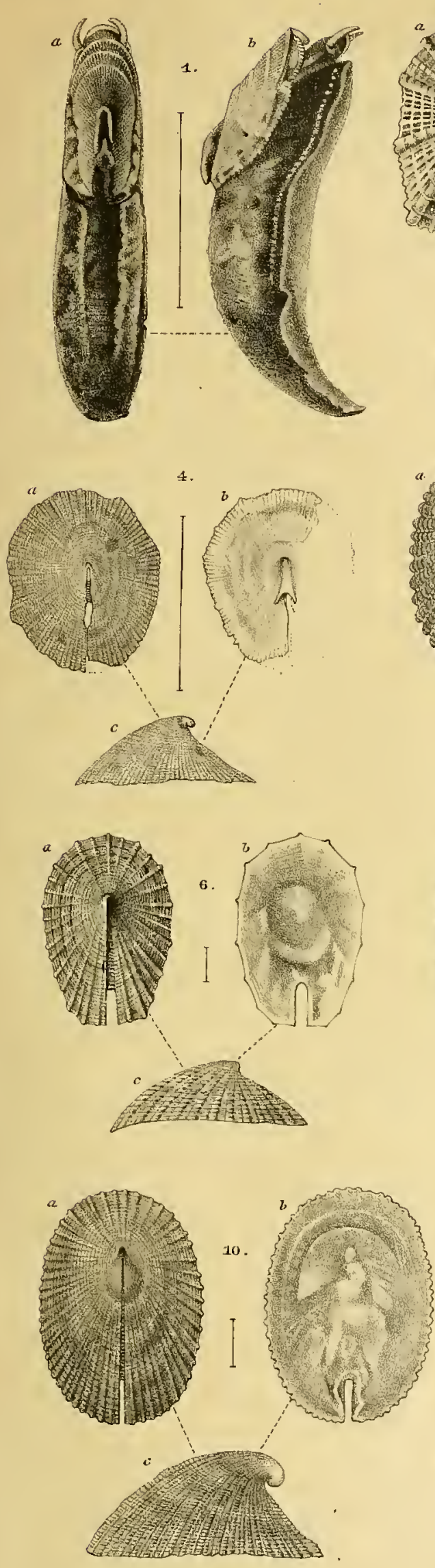
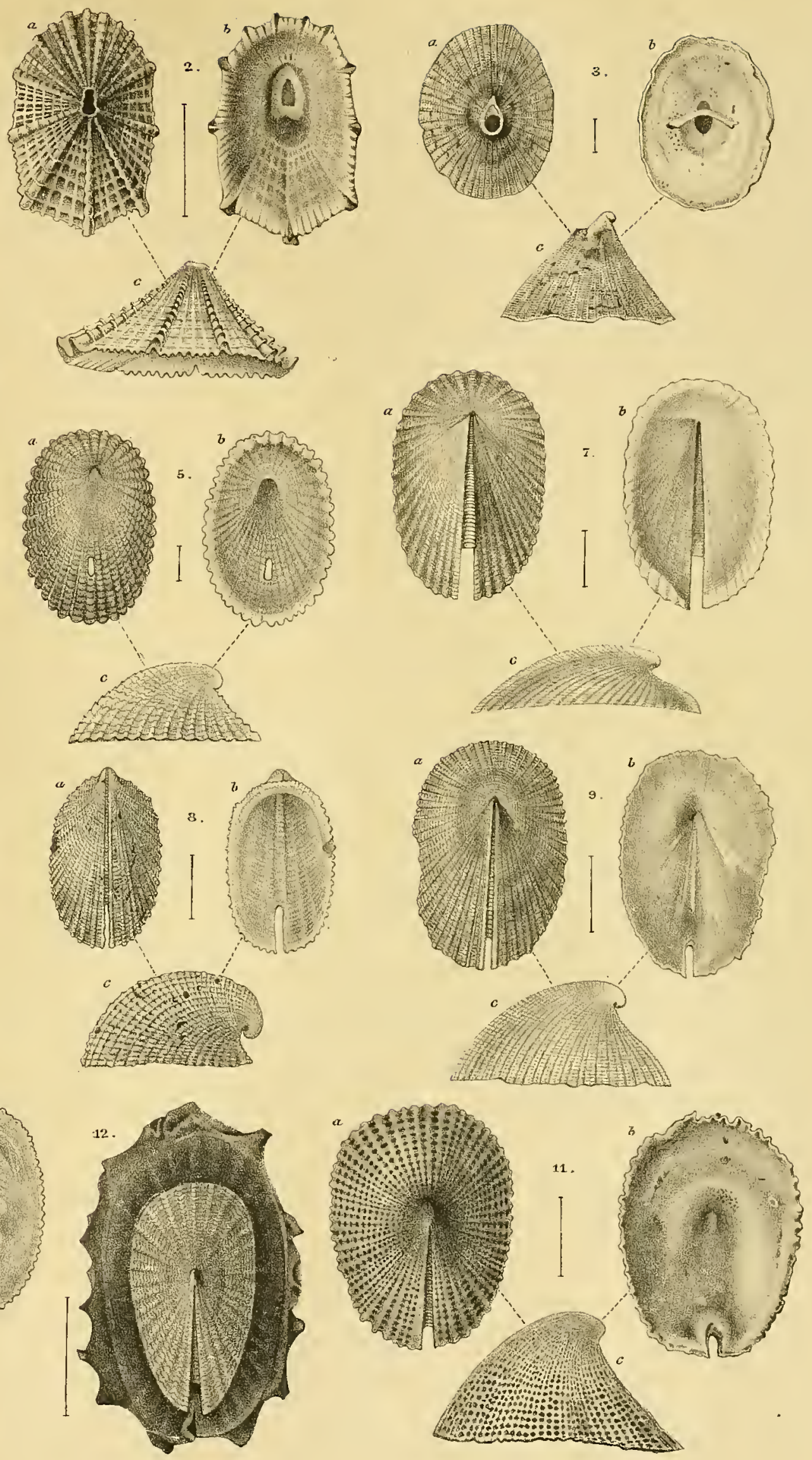

Fa. P. W. M. Trap impr. 



\section{PLATE VIII.}

Fig. I. Enarginula sibogae n. sp.

Fig. 2. Subemarginula plana n. sp.

Fig. 3. Subemarginula dubia n. sp.

Fig. 4. Tooth of Radula of Neritina brevispina Lam. var. mutica Martens.

Fig. 5. Teeth of Radula of Neritilia rubida Pease.

Fig. 6. Teeth of Radula of Pseudococculina mgosoplicata n. sp.

Fig. 7. Teeth of Radula of Pseudococculina granulata n. sp.

Fig. 8. Teeth of Radula of Cocculina subquadrata n. sp.

Fig. 9. Teeth of Radula of Cocculina oblonga n. sp.

Fig. IO. Teeth of Radula of Cocculina ovata n. sp.

Fig. I I. Teeth of Radula of Cocculina alceolata n. sp.

Fig. I2. Teeth of Radula of Cocculina subcompressa n. sp.

Fig. I3. Teeth of Radula of Pectinodonta sp. 

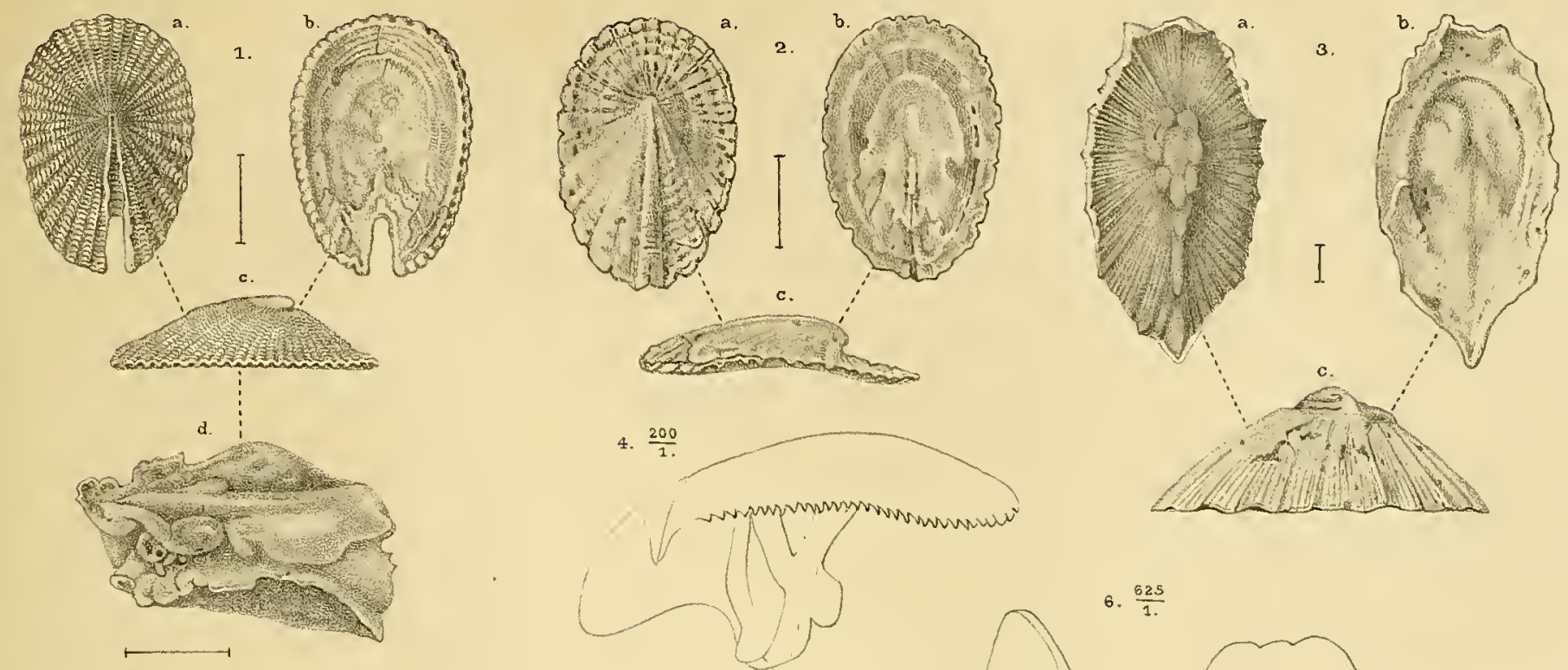

$\int_{\pi}^{\frac{400}{1}} \int_{2 .}^{5} \int_{0}^{5} \int_{2}^{\frac{675}{1}}$

(.

4. $\frac{200}{1 .}$

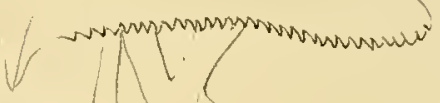

6. $\frac{625}{1 .}$

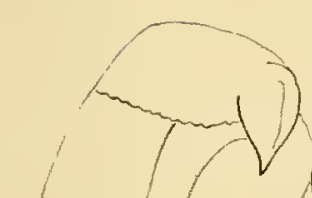
$(2)$

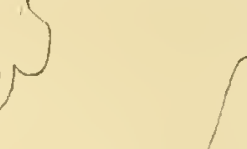<smiles>CCCCC</smiles>
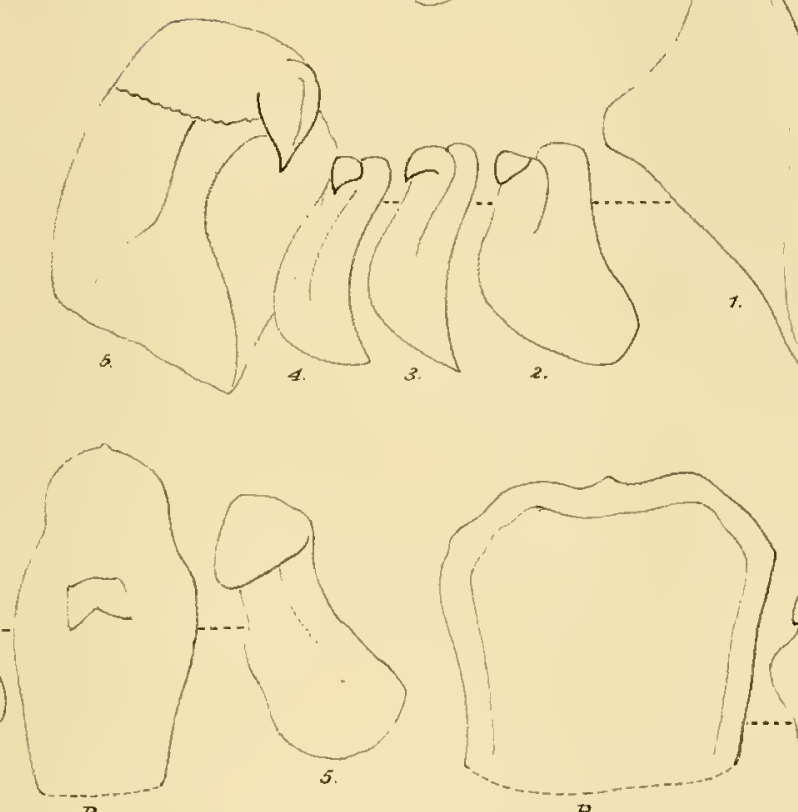

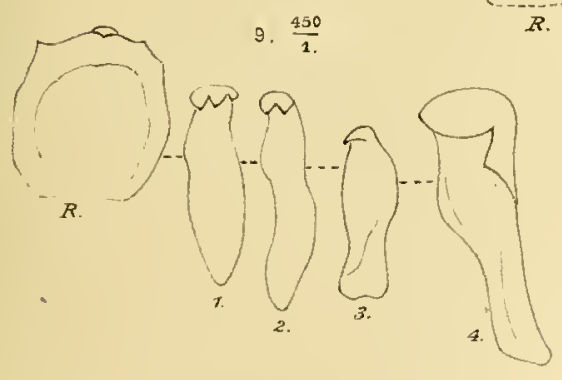
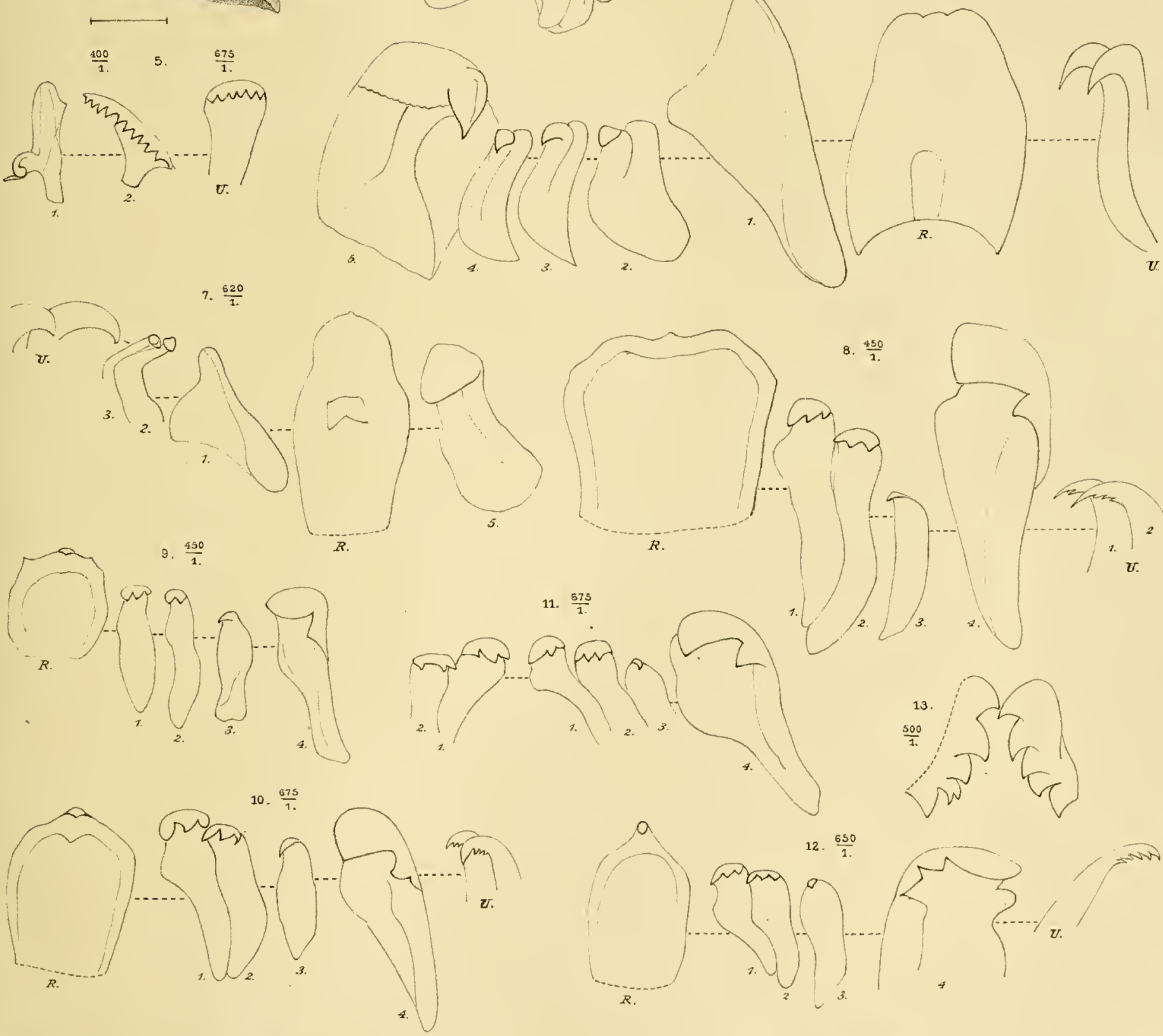


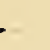

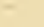





\section{PLATE IX.}

Fig. I. Teeth of Radula of Cocculina striata n. sp.

Fig. 2. Teeth of Radula of Leptothyra laeta Montrouzier.

Fig. 3. Teeth of Radula of Delphinula sphaerula Kiener.

Fig. 4. Teeth of Radula of Cantharidus Giliberti Montrouzier.

Fig. 5. Teeth of Radula of Monilea calyculus Wood.

Fig. 6. Teeth of Radula of Minolia ornatissima n. sp.

Fig. 7. Teeth of Radula of Solariella olivaceostrigata n. sp.

Fig. 8. Teeth of Radula of Solariella mutabilis n. sp.

Fig. 9. Teeth of Radula of Solariella callomphala n. sp.

Fig. 10. Teeth of Radula of Solariellopsis calcarata n. sp.

Fig. I I. Teeth of Radula of Guttula sibogae n. sp. 

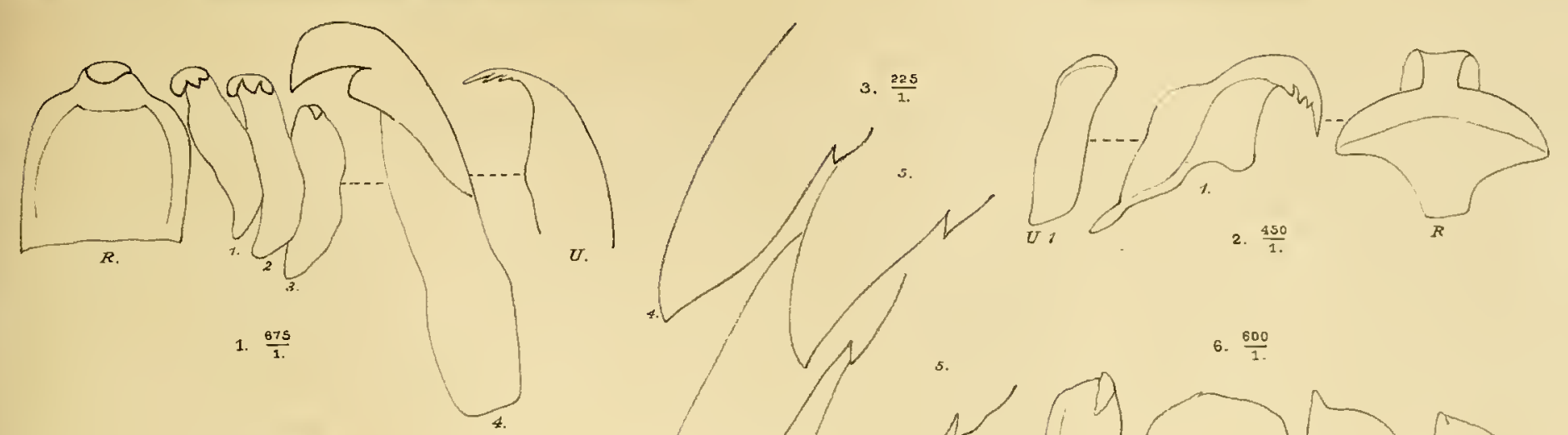

4. $\frac{430}{1 .}$

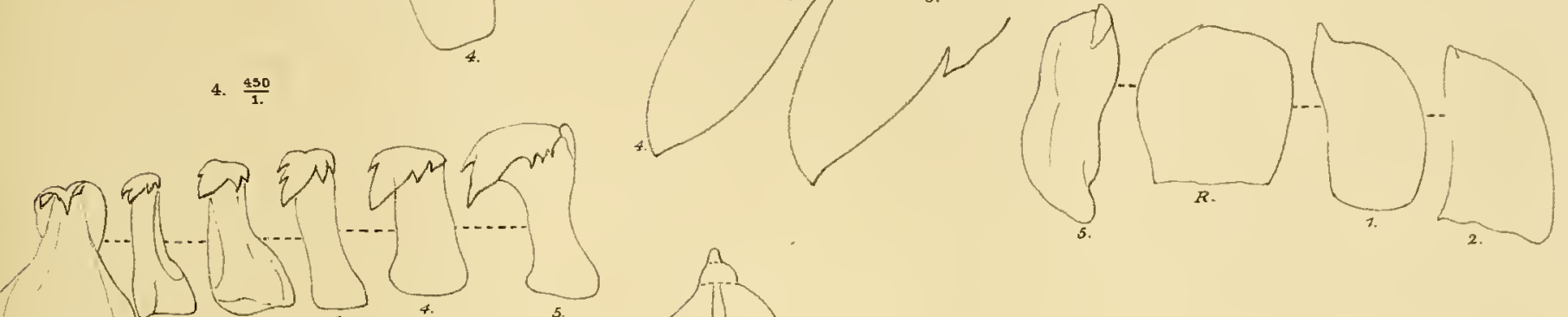

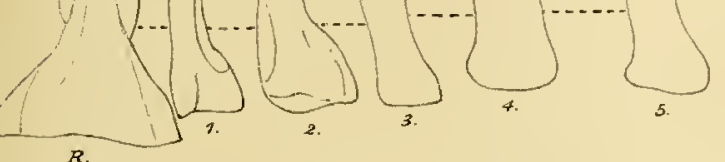
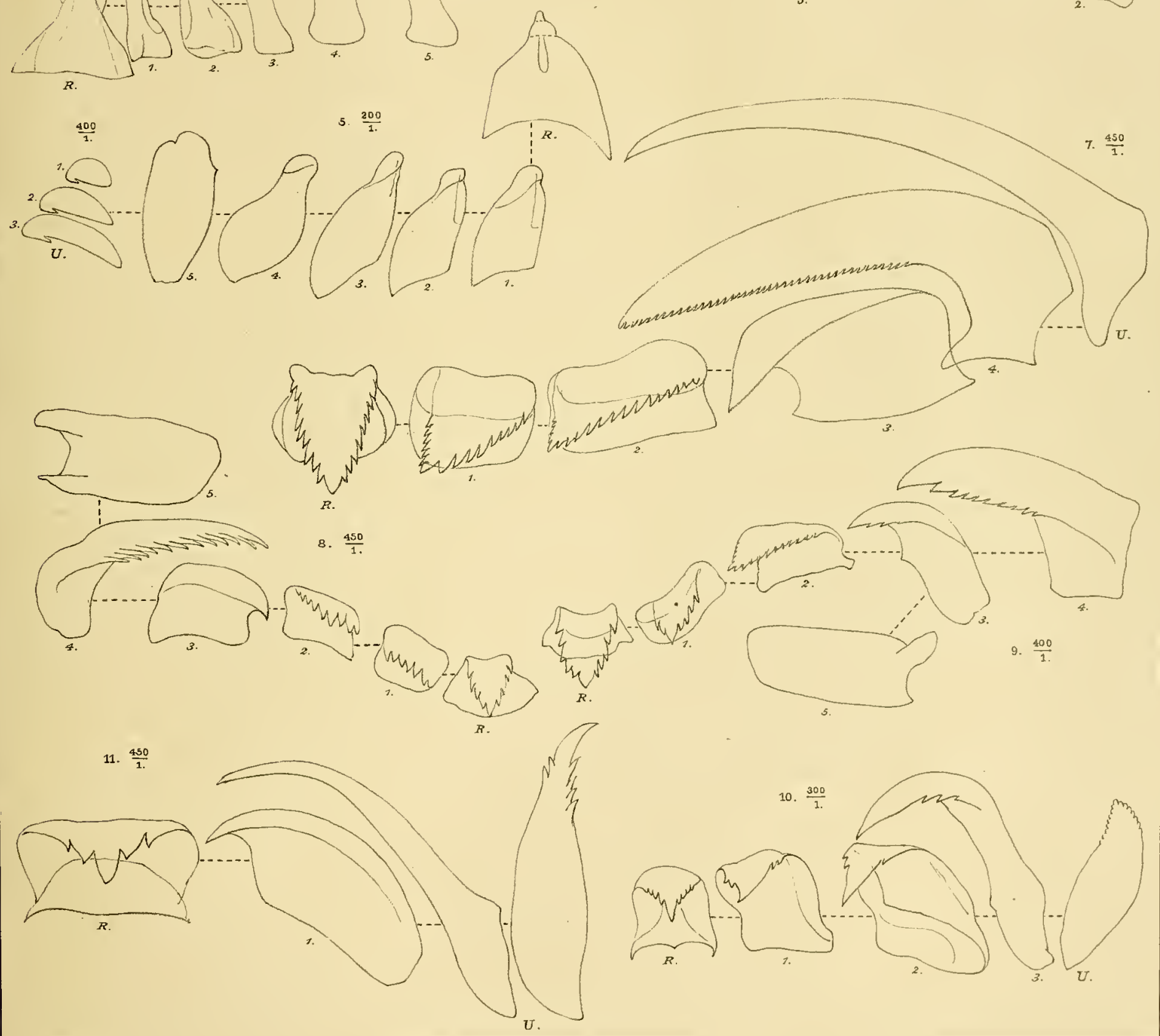

Fa. P. W. MI. Trap impr. 



\section{CONDITIONS GÉNÉRALES DE VENTE.}

$I^{2}$. L'ouvrage du „Siboga" se composera d’une série de monographies.

$2^{\circ}$. Ces monographies paraîtront au fur et à mesure qu'elles seront prêtes.

$3^{\circ}$. Le prix de chaque monographie sera différent, mais nous avons adopté comme base générale du prix de vente: pour une feuille d'impression sans fig. flor. 0.15; pour une feuille avec fig. flor. 0.20 à 0.25 ; pour une planche noire flor. 0.25 ; pour une planche coloriée flor. 0.40 ; pour une photogravure flor. 0.60 .

$4^{\circ}$. Il y aura deux modes de souscription:

a. La souscription à l'ouvrage complet.

b. La souscription à des monographies séparées en nombre restreint.

Dans ce dernier cas, le prix des monographies sera majoré de $25 \%$.

$5^{\circ}$. L'ouvrage sera réuni en volumes avec titres et index. Les souscripteurs à l'ouvrage complet recevront ces titres et index, au fur et à mesure que chaque volume sera complet. 
Ie Livr. (Monogr. XLIV) C. Ph. Sluiter. Die Holothurien der Siboga-Expedition. Mit Io Tafeln.

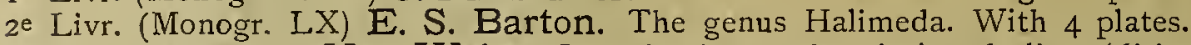

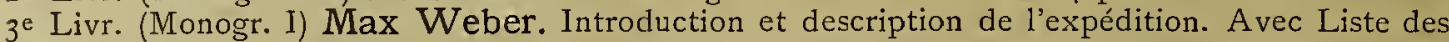
Stations et 2 cartes

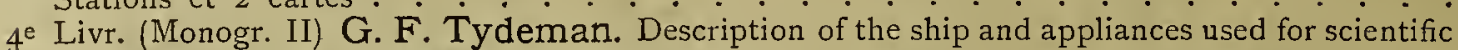
exploration. With 3 plates and illustrations.

$5^{c}$ Livr. (Monogr. XIVII) H. F. Nierstrasz. The Solenogastres of the Siboga-Exp. With 6 plates.

6e Livr. (Monogr. XIII) J. Versluys. Die Gorgoniden der Siboga-Expedition. 1. Die Chrysogorgiidae. Mit I70 Figuren im Text.

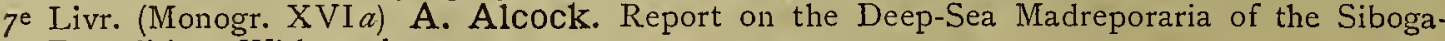
Expedition. With 5 plates.

8e Livr. (Monogr. XXV) C. Ph. Sluiter. Die Sipunculiden und Echiuriden der Siboga-Exp. Mit 4 Tafeln und 3 Figuren im Text. . . . . . . . . . . . . . . . .

ge Livr. (Monogr. VIa) G. C. J. Vosmaer and J. H. Vernhout. The Porifera of the Siboga-

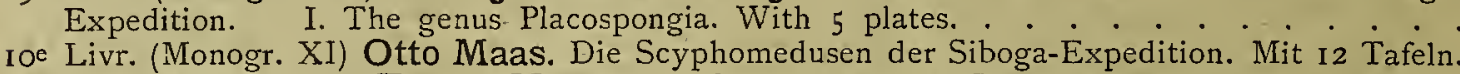

Irc Livr. (Monogr. XII) Fanny Moser. Die Ctenophoren der Siboga-Expedition. Mit 4 Tafeln.

r2e Livr. (Monogr. XXXIV) P. Mayer. Die Caprellidae der Siboga-Expedition. Mit io Tafeln.

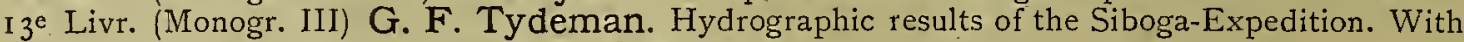
24 charts and plans and 3 charts of depths

I $4^{e}$ Livr. (Monogr. XLIII) J. C. H. de Meijere. Die Echinoidea der Siboga-Exp. Mit 23 Tafeln.

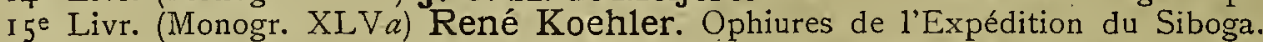

I Partie. Ophiures de Mer profonde. Avec 36 Planches.

I6e Livr. (Monogr. LII) J. J. Tesch. The Thecosomata and Gymnosomata of the SibogaExpedition. With 6 plates.

I ${ }^{2}$ Livr. (Monogr. LVIa) C. Ph. Sluiter. Die Tunicaten der Siboga-Expedition.

I. Abteilung. Die socialen und holosomen Ascidien. Mit I5 Tafeln .

I8e Livr. (Monogr. LXI) A. Weber-van Bosse and M. Foslie. The Corallinaceae of the SibogaExpedition. With 16 plates and 34 textfigures

Ige Livr. (Monogr. VIII) Sydney J. Hickson and Helen M. England. The Stylasterina of the Siboga Expedition. With 3 plates. . . . . . . . . . . . . . . . . . . zoe Livr. (Monogr. XLVIII) H. F. Nierstrasz. Die Chitonen der Siboga-Exp. Mit 8 Tafeln. 2 re Livr. (Monogr. XLVb) René Koehler. Ophiures de l'Expédition du Siboga.

$2^{e}$ Partie. Ophiures littorales. Avec is Planches.

$22^{e}$ Livr. (Monogr. XXVIbis) Sidney F. Harmer. The Pterobranchia of the Siboga-Expedition, with an account of other species. With 14 plates and 2 text-figures. . . . . . . .

$23^{\mathrm{e}}$ Livr. (Monogr. XXXVI) W. T. Calman. The Cumacea of the Siboga Expedition. With 2 plates and 4 text-figures

$24^{e}$ Livr. (Monogr. LVIa) C. Ph. Sluiter. Die Tunicaten der Siboga-Expedition.

Supplement zu der I. Abteilung. Die socialen und holosomen Ascidien. Mit I Tafel.

25e Livr. (Monogr. L) Rud. Bergh. Die Opisthobranchiata der Siboga-Exped. Mit 20 Tafeln. 26e Livr. (Monogr. X) Otto Maas. Die Craspedoten Medusen der Siboga-Exp. Mit r4 Tafeln.

$27^{\mathrm{e}}$ Livr. (Monogr. XIII a) J. Versluys. Die Gorgoniden der Siboga-Expedition.

11. Die Primnoidae. Mit ro Tafeln, i78 Figuren im Text und einer Karte.

28e Livr. (Monogr. XXI) G. Herbert Fowler. The Chaetognatha of the Siboga Expedition. With 3 plates and 6 charts............

2ge Livr. (Monogr. LI) J. J. Tesch. Die Heteropoden der Siboga-Expedition. Mit I4 Tafeln. 3o Livr. (Monogr. XXX) G. W. Müller. Die Ostracoden der Siboga-Exped. Mit 9 Tafeln.

3 I $^{\mathrm{e}}$ Livr. (Monogr. IVbis) Franz Eilhard Schulze. Die Xenophyophoren der Siboga-Exped. Mit 3 Tafeln

$3^{2}$ Livr. (Monogr. LIV) Maria Boissevain. The Scaphopoda of the Siboga Expedition.

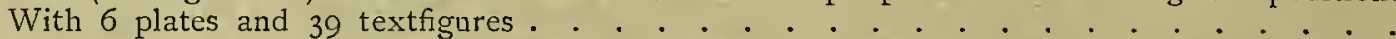

$33^{\mathrm{e}}$ Livr. (Monogr. XXVI) J. W. Spengel. Studien über die Enteropneusten der Siboga-Exp. Mit 17 Tafeln und 20 Figuren im Text.

$34^{\mathrm{e}}$ Livr. (Monogr. XX) H. F. Nierstrasz. Die Nematomorpha der Siboga-Exp. Mit 3 Tafeln.

$35^{\mathrm{e}}$ Livr. (Monogr. XIII c) Sydney J. Hickson und J. Versluys. Die Alcyonidèn der SibogaExped. I. Coralliidæ, II. Pseudocladochonus Hicksoni. Mit 3 Tafeln und 16 Figuren im Text.

36e Livr. (Monogr. XXXIa) P. P. C. Hoek. The Cirripedia of the Siboga Expedition. A. Cirripedia pedunculata. With Io plates

$37^{\mathrm{e}}$ Livr. (Monogr. XLIIa) L. Döderlein. Die gestielten Crinoiden der Siboga-Expedition. Mit 23 Tafeln und 12 Figuren im Text . . . . . . . . . . . . . . . . . . . .

${ }_{3} 8$ e Livr. (Monogr. IX) Albertine D. Lens and Thea van Riemsdijk. The Siphonophores of the Siboga Expedition. With 24 plates and 52 textfigures . . . . . . . . . . . .

$39^{\text {e Livr. (Monogr. XLIX }}{ }^{\prime}$ ) M. M. Schepman. The Prosobranchia of the Siboga Expedition. Part. I. Rhipidoglossa and Docoglossa, with an Appendix by Prof. R. BERGH. With 9 plates and 3 textfigures.

Monographies
vrage complet séparées

$f 6 .-$ f 7.50

" 1.80 n 2.40

๓ 6.75 ॠ 9.

$\Rightarrow 2 .-72.50$

" $3.90 \pi 4.90$

3.- $\gg 3.75$

" 4.60 n 5.75

"3.» 3.75

2.40

$\pi 7.50$

$\pi 2.80$

7.80

"3.-

9.50

" 3.50

9.75

๓9.- ᄁII.25

II - $\gg 18.75$

$\pi 16.50 \pi 20.50$

" $3.75=4.70$

" 6.75 п 9.

$\pi 12.50 \quad$ I 5.50

n 1.50 I. 90

"5.- $" 6.25$

, $10.25,12.75$

๓ 6.75 ๓9.-

$1.80,2.40$

$\pi-.75$

$\pi \mathrm{II} .25$

$\Rightarrow 9.25$

$1 .-$

n I 4.10

12.50

$12.50 \leadsto 16.75$

n $4.20 \gg 5.25$

n $6.75 \geqslant 9 .-$

$n 3.50 \pi 4.40$

त2.40 $\rightarrow 3 .-$

"4.80 76 .

$14 .-717.50$

$n 2.80 \geqslant 3.50$

» 2.20 \2.75

》 $5.40 \cap 6.75$

" 8. - "10.-

ก $13.50 \gg \mathrm{I} 6.75$

" $4.80,6 .-$ 
F. 'l' yde an an

$\pi, M o s e r$

XXI Chetogontha, G, H FO IT Ier.

XIII. Myzostomidae, R van Stum mer.

Polychacta errantia, R. Hors

$\mathrm{Ph}$. Sluiter.

C. Toma

Nierstras

(

J. J. Tesc

III. Imellibractiog. PeIseaeer et Ph. Dantzenberg.

A. Webor.

O. B. BöggiI
PROSOBRANCHIA OP THE SIBOGA EXPPDITION

M. M. SCHEPMAN

TAENIOGLOSSA AND PTENOGLOSSA

With 7 plate 
Voor de uitgave van de resultaten der Siboga-Expeditie hebben bijdragen beschikbaar gesteld:

De Maatschappij ter bevordering van het Natuurkundig Onderzoek der Nederlandsche Koloniën.

Het Ministerie van Koloniën.

Het Ministerie van Binnenlandsche Zaken.

Het Koninklijk Zoologisch Genootschap "Natura Artis Magistra" te Amsterdam.

De ,Oostersche Handel en Reederij" te Amsterdam.

De' Heer B. H DE WAal Oud-Consul-Generaal der Nederlanden te Kaapstad.

M. B. te Amsterdam. 
THE

\section{PROSOBRANCHIA OF THE SIBOGA EXPEDITION}

PART II

TAENIOGLOSSA and PTENOGLOSSA 
Gion MI. H. Shopranes $\frac{\text { Borth ent dein }}{n^{2} \text { Otim des teide. }}$ Giov. Whecht. olollano. 
Siboga-Expeditie $X^{\prime}{ }^{\prime} X^{\prime} b$

\title{
THE PROSOBRANCHIA OF THE SIBOGA EXPEDITION
}

\author{
BY \\ M. M. $\underset{\text { Bosch en Duin near Utrecht (Holland) }}{\mathrm{SCHE}}$
}

PART II

TAENIOGLOSSA DNENOGLOSSA

With 7 plates

LATE E. J. BRILL

PUBLISHERS AND PRINTERS

I.EYDEN - 1909 



\section{TAENIOGLOSSA AND PTENOGLOSSA}

This part contains the enumeration of about 340 species, of which 39 have been described as new to science, moreover a few varieties have been described and partly figured. By comparing these numbers to those of the first part, it is evident that this first part was more interesting, the groups now under consideration not being composed of so many deep water forms, and it is amongst those, as might be expected, that the most interesting species are to be found, as for instance in the genera Morio, Oocory's, Seguenzia.

I have to thank again Mr. E. A. Smith for his assistance in comparing doubtful species also Messrs. J. Cosmo Melvill, Ph. Dautzenberg, E. R. Sykes and others, for assistance, loan of specimens or litterature.

I must repair a few errata in the first part, which I discovered in returning the materials:

p. IO. var. strigillata belongs to $N$. turrita not to variegata.

p. I3. the Neritilidae must follow after Septaria, which belongs to the Neritidae.

p. 7I. for Euchelus intricatus Gould read Euch. instrictus. 


\section{Section Taenioglossa Troschel. \\ Fam. Aquillidae Pilsbry.}

\section{Aquillus Montfort.}

I. Aquillus (Lampusia) pilearis Linné.

Linné. Syst. Nat. Ed. X, p. $749, \mathrm{~N}^{0} 458$.

RuMPH. Amb. Rariteitliamer, p. 96, P1. 29, fig. H.

Kiener. Coq. Viv. Vol. VI, Triton, p. 15, Pl. 7, fig. I.

REEve. Conch. Ic. Vol. II, Triton, fig. 23.

KÚster. Martini-Chemn. Conch. Cab. Ed. II, Triton, p. 196, Pl. 42, fig. 3, 4; Pl. 56, fig. 4. Tryon. Man. of Conch. Vol. III, p. 12, P1. 6, fig. 3I-33, 35, 36.

Stat. 4. Djangkar (Java). 9 M. Coarse sand. I Spec.

Stat. 47. Bay of Bima, near South fort. Shore. 2 Spec.

Stat. 53. Bay of Nangamessi, Sumba. UP to 36 M. Coarse sand. I Spec.

Stat. 172. Gisser. Reef. I Spec.

Kesteven (Proc. Linn. Soc. N. South Wales, I 902, p. 476) says that according to Hanley, (Ipsa Linnaei Conchylia, p. 287) the name pilearis should be applied to the Mediterranean Triton comgatus Lam., and that the species under consideration should bear the name aquatilis Reeve, uniting it, in accordance with TRYON etc. with aquatilis. As Linne says: "Habitat in M. Mediterraneo", this view may be in so far right. But Troschel (Gebiss der Schnecken I, p. 234) has observed small differences in the radulae of Simpulam pilearis Lin. (1.c. Pl. 20, fig. 3) and S. aquatile Reeve (1.c. Pl. 20, fig. 4) so I have left the name pilearis to the species generally known under this nomination.

2. Aquillus (Lampusia) aquatilis Reeve.

ReEve. Conch. Ic. Vol. II, Triton, fig. 24.

Küster. Martini-Chemn. Conch. Cab. Ed. II, Triton, p. I62, Pl. 42, fig. 7, 8.

Tryon. Man. of Conch. Vol. III, p. 12, Pl. 6, fig. 34 (pilearis).

Stat. 225. South-Lucipara-island. Reef. I Spec.

As already stated, PILSBRy unites this form with the preceding species as a synonym, as he finds no characters by which to separate them. I have never found difficulty in distinguishing this species. 
3. Aquillzus (Lampusia) rubecula Linné.

Linné. Syst. Nat. Ed. X, p. $749, \mathrm{~N}^{0} 459$.

Kiener. Coq. Viv. Vol. VI, Triton, p. 20, Pl. 18, fig. 2.

REEVE. Conch. Ic. Vol. II, Triton, fig. 29.

Küster. Martini-Chemn. Conch. Cab. Ed. II, Triton, p. 159, Pl. 4I, fig. 3-1I.

Tryon. Man. of Conch. Vol. III, p. I2, Pl. 7, fig. 40.

Stat. 315. East of Sailus Besar, Paternoster-islands. Up to 36 M. Coral and Lithothamnion. I Spec.

The specimen is still very young, uniformly red.

4. Aquillus (Lampusia) gemmatus Reeve.

ReEve. Conch. Ic. Vol. II, Triton, fig. 60.

Küster. Martini-Chemn. Conch. Cảb. Ed. II, Triton, p. 220, Pl. 6r, fig. 7, 8.

Tryon. Man. of Conch. Vol. III, p. 13, Pl. 7, fig. 41-44.

Stat. 47. Bay of Bima, near South fort. 55 M. Mud with patches of fine coralsand. I Spec.

Stat. 240. Banda. Reef. I Spec.

Stat. 304. Lamakera, Sulor-island. Reef. I Spec.

The specimens from Lamakera and Bima are quite typical, corresponding to ReEve's figures $60 a$ and $b$. That from Banda is yellowish, with a few brown bands, calling in mind some varieties of the preceding species, but there the dark colour occupies the interstices of the spiral lirae, whereas in the specimen of gemmatus the dark colour runs over the lirae. In sculpture I see no difference with the other specimens.

\section{Aquillus (Turritriton) labiosus Wood, var. orientalis Nevill.}

Nevill. Journ. Asiat. Soc. Beng. Vol. 43, 1874, p. 29.

Küster. Martini-Chemm. Conch. Cab. Ed. II, Triton, p. 26I, Pl. 69, fig. 8.

Tryon. Man. of Conch. Vol. III, Triton, p. 17, P1. 9, fig. 68.

Stat. 40. Pulu Kawassang, Paternoster-islands. Coralreef. I Spec.

Stat. 47. Bay of Bima, near South fort. 55 M. Mud with patches of fine coralsand. I Spec.

Stat. 6o. Haingsisi, Samau-island. Lithothamnion-bank. I Spec.

Stat. 240. Banda. 9-45 M. Black sand, coral. Lithothamnion-bank. I Spec.

Stat. 285. South coast of Timor. 34 M. Lithothamnion. I Spec.

Some of the specimens are too young, to decide with certainty if they belong to the variety orientalis Nev., as however the larger specimens are not doubtful, I think they ought to be all placed here.

\section{Aquillus (Turritriton) vespaceus Lamarck?}

Lamarck. An. s. vert. Ed. II, Vol. IX, p. 636.

Kiener. Coq. Viv. Vol. VI, Triton, p. I8, Pl. 3, fig. 2.

Reeve. Conch. Ic. Vol. II, Triton, fig. 6I.

Küster. Martini-Chemn. Conch. Cab. Ed. II, Triton, p. I79, Pl. 52, fig. 3.

TRYon. Man. of Conch. Vol. III, p. 22, Pl. 12, fig. 94, 95.

Stat. 37. Sailus-Ketjil, Paternoster-islands. Up to $27 \mathrm{M}$. Coral and coralsand. I Spec. 
The identification is rather uncertain, the shell is nearly allied to the specimens of $A$. vespacers I could compare, though I found no quite identical specimen. As the species seems to be very variable, I think it is not safe- to erect a new species on one small specimen.

\section{Aquillus (Turritriton) elongatus Reeve, var.}

ReEve. Conch. Ic. Vol. II, Triton, fig. 59.

Kúster. Martini-Chemn. Conch. Cab. Ed. II, Triton, p. 208, Pl. 58, fig. 9.

Tryon. Man. of Conch. Vol. III, p. 22, Pl. i2, fig. 96.

Stat. 37. Sailus-Ketjil, Paternoster-islands. 27 M. Coral and coralsand. I Spec.

Stat. 43. Pulu Sarassa, Postillon-islands. 36 M. Coral. I Spec.

Stat. 193. Sanana-bay, East coast of Sula Besi. Reef. I Spec.

These specimens are also of somewhat doubtful identification, they don't quite agree with ReEve's description, a. o. I see no livid purple ridges, the specimens seem to be more nodulous; but the shape with the long canal agree; so I have united them as a slight variation. Tryon considers this and the next species, to be forms of $A$. vespaceus.

\section{Aquillus (Turritriton) gracilis Reeve.}

ReEve. Conch. Ic. Vol. II, Triton, fig. 58.

Küster. Martini-Chemn. Conch. Cab. Ed. II, Triton, p. 243, Pl. 67, fig. 5.

Tryon. Man. of Conch. Vol. III, p. 22, Pl. 12, fig. 97, 98.

Stat. $164.1^{\circ} 42^{\prime} .5$ S., $130^{\circ} 47^{\prime} \cdot 5$ E. Halmahera Sea. 32 M. Sand, small stones and shells. 4 Spec.

Stat. 273. Pulu Jedan, East coast of Aru-islands. 13 M. Sand and shells. 2 Spec.

The specimens from Stat. 273 are whitish, with a few brown lines, the canal is shorter than in the type, but seems to be slightly broken.

\section{Aquillus (Turritriton) Pfeifferianus Reeve.}

ReEve. Conch. Ic. Vol. II, Triton, fig. 14.

KÜstek. Martini-Chemn. Conch. Cab. Ed. II, Triton, p. 194, Pl. 55, fig. 4, 5.

TrYon. Man. of Conch. Vol. III, p. 23, Pl. 13 , fig. 107.

Stat. 33. Bay of Pidjot, Lombok. 22 M. Mud, coral and coralsand. I Spec.

Stat. 47. Bay of Bima, near South fort. 13-54 M. Mud with patches of fine coralsand. 1 Spec.

Stat. 49". Sapeh-strait. 69 M. Coral and shells. I Spec.

Stat. 7I. Makassar and surroundings. 32 M. Mud, sand with mud. I Spec.

Stat. 77. Borneo-bank. 59 M. Fine grey coralsand. 3 Spec.

Stat. 164. $1^{\circ} 42^{\prime} .5$ S., $130^{\circ} 47^{\prime} \cdot 5$ E. Halmahera Sea. 32 M. Sand, small stones and shells. I Spec

The majority of the specimens is very young.

10. Aquillus sp.

Several young specimens, too young for identification, from Stat. 37, 240 and 315 , seem to belong to one or at least to nearly allied species; another from Stat. 225 is certainly different, but though larger, I cannot identify it with the upper whorls of any of the species I could compare. 
I I. Aquillus (Gutturnium) grandinaculatus Reeve.

ReEve. Conch. Ic. Vol. II, Triton, fig. 20.

Küster. Martini-Chemn. Conch. Cab. Ed. II, Triton, p. 183, Pl. 54, fig. 4.

Tryon. Man. of Conch. Vol. III, p. I9, Pl. Io, fig. 76 .

Stat. 99. North-Ubian, Sulu-archipelago. 16-23 M. Lithothamnion-bottom. I Spec.

The only specimen is still young, but perfectly agrees in sculpture with the upper whorls of an adult specimen from the Philippines. TRYON considers it to be the same as T. lotorizm Lin., he says: "the distinctive characters are individual only". As far as I can judge, I think the differences of sculpture are sufficient to separate them specifically. The young shell is covered by a thin epidermis with long bristles on the radiating ribs and varices.

12. Aquillus (Gutturnium) tuberosus Lamarck.

Lamarck. An. s. vert. Ed. II, Vol. IX, p. 635.

RUMPH. Amb. Rariteitkamer, p. 82, Pl. 24, fig. H.

Kiener. Coq. Viv. Vol. VI, Triton, p. I2, Pl. I4, fig. 2.

ReEve. Conch. Ic. Vol. II, Triton, fig. $1 b$.

Küster. Martini-Chemn. Conch. Cab. Ed. II, Triton, p. 204, Pl. 58 , fig. 5.

Tryon. Man. of Conch. Vol. III, p. 23, Pl. I3, fig. inz.

"Island Enkhuizen near Batavia. I Spec.

The juvenile specimen belongs to the whitish variety, represented by the quoted figures.

\section{Distortrix Link.}

I. Distortrix anus Linné.

LinnÉ. Syst. Nat. Ed. X, p. $750, \mathrm{~N}^{0} 463$.

RUMPII. Amb. Rariteitkamer, p. 82, Pl. 24, fig. F.

Kiener. Coq. Viv. Vol. VI, Triton, p. 22, Pl. 15, fig. I.

ReEve. Conch. Ic. Vol. II, Triton, fig. 44.

KÜster. Martini-Chemn. Conch. Cab. Ed. II, Triton, p. 198, Pl. 57, fig. 1, 2.

Tryon. Man. of Conch. Vol. III, p. 35, Pl. 17, fig. 173, 174; Pl. 15, fig. 153.

Stat. 234. Nalahia-bay, Nusa-Laut-island. Reef. I Spec.

Stat. 240. Banda. 9-45 M. Black sand, coral. I Spec.

2. Distortrix cancellinus Roissy.

Roissy. Buffon, Moll. 6, p. 56, $\mathrm{N}^{\mathrm{n}}$ I2.

Kiener. Coq. Viv. Vol. VI, Triton, p. 21, Pl. I4, fig. I (clathratrum).

ReEve. Conch. Ic. Vol. II, Triton, fig. 45.

Küster. Martini-Chemn. Conch. Cab. Ed. II, Triton, p. 200, Pl. 57, fig. 5, 6.

Tryon. Man. of Conch. Vol. III, p. 35, Pl. 17, fig. 175.

Stat. 1. 1400 M. distant from reef "Zwaantjes-droogtc", Madura-strait. 37 M. Grey mud with small broken shells. I Spec.

Stat. 2. Madura-strait. 56 M. Grey mud with some radiolariae. I Spec.

Stat. 47. Bay of Bima, near South fort. 55 M. Mud, with patches of fine coralsand. I Spec. 
Stat. I 84. Off Kampong Kelang, South coast of Manipa-island. 36 M. Coral, sand. I Spec.

Stat. 282. Between Nusa Besi and N.E. point of Timor. 27-54 M. Sand, coral and Lithothamnion. I Spec.

Stat. 294. $10^{\circ} 12^{\prime} .2$ S., $124^{\circ} 27^{\prime} \cdot 3$ E. Timor Sea. 73 M. Soft mud with very fine sand. I Spec.

Stat. 313. East of Dangar Besar, Saleh-bay. Up to 36 M. Sand, coral and mud. I Spec.

The specimens are young, especially the youngest ones are covered by an epidermis with long bristles.

\section{Gyrineum Link.}

I. Gyrineum gyrinum Linné.

Linné. Syst. Nat. Ed. X, p. $748, \mathrm{~N}^{0} 453$.

Kiener. Coq. Viv. Vol. VI, Ranella, p. 28, Pl. 2, fig. 3 (ranina).

REEve. Conch. Ic. Vol. II, Ranella, fig. 49.

Küster. Martini-Chemn. Conch. Cab. Ed. II, Triton, p. 152, Pl. 40, fig. 4-6.

Tryon. Man. of Conch. Vol. III, p. 43, Pl. 23, fig. 48.

Stat. 33. Bay of Pidjot, Lombok. 22 M. Mud, coral and coralsand. I Spec.

Stat. $47^{3}$. Off Batu Putih, entrance of Bay of Bima. Shore. I Spec.

Stat. 123. North-bay, Biaru-island. 36-27 M. Stone and Lithothamnion-bottom. I Spec.

Stat. 174. Waru-bay, North coast of Ceram. Reef. I Spec.

Stat. 322. South of Tandjong-Lajar, South coast of Bawean. 32 M. Coral. I Spec.

2. Gyrineum bituberculare Lamarck.

Lamarck. An. s. vert. Ed. II, Vol. 9, p. 548.

Kínener. Coq. Viv. Vol. VI, Ranella, p. 26, Pl. 6, fig. 2.

ReEve. Conch. Ic. Vol. II, Ranella, fig. 40.

Küster. Martini-Chemn. Conch. Cab. Ed. II, Ranella, p. 153, Pl. 39a, fig. 9, 12.

Tryon. Man. of Conch. Vol. III, p. 42, Pl. 23, fig. 44.

Stat. 53. Bay of Nangamessi, Sumba. Up to 36 M. Coralsand. 2 Spec.

Stat. I I6. West of Kwandang-bay-entrance. 72 M. Fine sand with mud. I Spec.

Stat. 193. Sanana-bay, East coast of Sula-Besi. Reef. I Spec.

Stat. 285. South coast of Timor. 34 M. On the limit between mud and coral. Lithothamnion.

Stat. 296. Noimini, South coast of Timor. 8-36 M. Sandy mud. I Spec. [2 Spec.

Stat. 313. East of Dangar-Besar, Saleh-bay. Up to 36 M. Sand, coral and mud. 2 Spec.

Stat. $318.6^{\circ}{ }_{3}^{\prime} .5$ S., $140^{\circ} 55^{\prime} .5$ E. Java Sea. 88 M. Fine, yellowish-grey mud. I Spec.

The specimens from Stat. I 6 and 285 are young and have a somewhat misleading appearance, by the closer sculpture. However the species is very variable in this respect, and these specimens are connected to more typical ones by intermediate forms, f. i. those from Stat. 313. TRYON says on this subject (1.c. p. 43): "The tubercles are numerous on the earlier whorls, but (in some instances) coallesce into two large ones between the varices on the last whorl of the adult. When the more numerous tubercles are persistent, the resemblance to the next species ( $R$. tuberculata) is striking".

3. Gyrineum cuspidatum Reeve. Pl. XV, fig. 7 .

ReEve. Conch Ic. Vol. II, Ranella, fig. 48.

Tryon. Man. of Conch. Vol. III, p. 43, P1. 23, fig. 49. 
Stat. 51. Madura-bay. 69-91 M. Fine, grey sand; coarse sand with shells and stones. I Spec.

Stat. I 23. North-bay, Biaru-island. 36-27 M. Stone and Lithothamnion-bottom. I Spec.

Stat. 3 I 5. East of Sailus-Besar, Paternoster-islands. Up to 36 M. Coral and Lithothamnion. I Spec.

The specimen from Stat. 315 is young, but agrees sufficiently with the other specimens to be identified. The long and slender radula, has the teeth in about 108 transverse rows. The rhachidian tooth $(R)$ has a subquadrangular body with the sides strongly excavated in the posterior half, posterior margin much shorter than the anterior one; the cusp has 5 denticles, of which the median one is the largest; the lateral tooth (I) has an oblong shape with a large denticle on the proximal side of the cusp and three smaller distal ones; the uncini (U) are hooked, slender, the first one with a small denticle on the proximal side, only visible by the transparency of the teeth. The construction of the radula, proves that DALL, in his paper (An historical and systematic review of the Frog-shells and Tritons; Smiths, Miscell. Coll. Vol. 47, 1905, p. II4-144) is right in calling the species united as Gyrineum, the nearest allies of Aquillus. He mentions only the radula of Ranella (Apollon) argus Lam., described by Troschel, (Gebiss der Schnecken, Vol. I, pl. 20, fig. I I) which is conchologically a somewhat peculiar species; really the radula now under consideration, shows more resemblance to those of Tritonizm femorata Lin. (1.c. fig. 2) and of $T$. pileare Rve (1.c. fig. 3), the most typical difference being the narrow posterior basal margin.

\section{Gyrineum pusillum Broderip.}

BRoDerip. Proc. Zool. Soc. Lond. 1832, p. 194.

ReEve. Conch. Ic. Vol. II, Ranella, fig. 44 .

Tryon. Man. of Conch. Vol. III, p. 44, Pl. 24, fig. 56, 57.

Stat. 7. Near reef of Batjulmati (Java). i5 M. Coral and stones. \& Spec.

Stat. 33. Bay of Pidjot, Lombok. 22 M. Mud, coral and coralsand. I Spec.

Stat. 60. Haingsisi, Samau-island. Lithothamnion-bank. I Spec.

Stat. I 44. North of Salomakiëe-(Damar)-isiand. 45 M. Coral bottom and Lithothamnion. I Spec.

Stat. ${ }^{1} 54.0^{\circ} 7^{\prime} .2$ N., I $30^{\circ} 25^{\prime} .5$ E. Halmahera Sea. 83 M. Grey inuddy sand, sheils and Lithothamnion. I Spec.

Stat. 162. Between Loslos and Broken-islands. W. coast of Salawatti. IS M. Coarse and fine sand, with clay and shells. I Spec.

Stat. $164.1^{\circ} 42.5$ S., $130^{\circ} 47^{\prime} \cdot 5$ E. Halmahera Sea. 32 M. Sand, small stones and shells. 2 Spec.

Stat. 204. Northern entrance of Buton-strait. 75-94 M. Sand with dead shells. I Spec.

Stat. 260. Kei-islands. 9o M. Sand, coral and shells. I Spec.

Stat. 313. East of Dangar Besar, Saleh-bay. Up to 36 M. Sand, coral and mud. I Spec.

Stat. 315 . East of Sailus Besar, Paternoster-islands. Up to $36 \mathrm{M}$. Coral and Lithothamnion. I Spec.

This species is very variable in colour and also in sculpture; the specimen from Stat. 144 is yellow, and has the spiral lirae scarcely developed on the lower whorls; if this character be not individual, it might give right to a varietal name.

5. Gyrineum (Biplex) perca Perry (P1. X, fig. I, var. aculeata n. var.)

PERRY. Conch. Pl. 4, fig. 5.

Kiener. Coq. Viv. Vol. VI, Ranella, p. 8, Pl. 6, fig. 1 (pulchra).

ReEve. Conch. Ic. Vol. II, Ranella, fig. 47 (pulchra).

Tryon. Man. of Conch. Vol. III, p. 43, Pl. 23, fig. 5 i (pulchra). 
Stat. $95.5^{\circ} 43^{\prime} .5$ N.; $119^{\circ} 40^{\prime}$ E. Sulu Sea. 522 M. Stony bottom. I Spec.

Stat. $289.9^{\circ} 0^{\prime} \cdot 3 \mathrm{~S}$., $126^{\circ} 24^{\prime} \cdot 5$ E. Timor Sea. 112 M. Mud, sand and shells. 3 Spec.

The specimen from Stat. 95 is a worn, broken shell, but quite typical in shape, with two tubercles between the varices. Those from Stat. 289 are small, with 3 or 4 rows of numerous tubercles in each of the upper whorls; they are still more characterised by having distinct spines, only connected at their foot, instead of the broad wings with short spines, characteristic for the type. As the number of recent specimens I could compare, is restricted, I have not described this form as a new species. If the spinous character proves to be constant, it may be called var. aculeata. I have provisionally distinguished it under that name.

6. Gyrineum (Biplex) pulchellum Forbes.

Forbes. Voy. of the "Rattlesnake", Vol. II, p. 382, Pl. 3, fig. $6 a, b$.

E. A. Smitir. Zool. Coll. of H. M. S. "Alert", p. 56.

Stat. 162. Between Loslos and Broken-islands. W. coast of Salawatti. I \& M. Coarse and fine sand with clay and shells. I Spec.

Only one broken shell, which agrees in every respect with my specimen from Torresstrait. TRyon has only mentioned it in his register, as a synonym of $G$. perca, but not in his systematic enumeration. Boog WATson in his "Challenger"-Gastropods, has mentioned it (p. 402) also as a synonym. E. A. Smith (1. c.) and Brazier have separated it, I think on sufficient grounds. Indeed, if one compares the shells, they are very different; with the same number of whorls, the shell is still much smaller, than the var. aculeata of the preceding species, and has the tubercles on the whorls still more numerous, the varices are impressedly striate, not ribbed, with broad interstices, as in $G$. perca.

\section{Bursa Bolten.}

I. Bursa crumena Lamarck.

LAmarck. An. s. vert. Ed. II, Vol. IX, p. 644.

Kiener. Coq. Viv. Vol. VI, Ranella, p. 4, Pl. 3, fig. I (elegans).

REeve. Conch. Ic. Vol. II, Ranella, fig. 17.

Küster. Martini-Chemn. Conch. Cab. Ed. II, Ranella, p. 149, Pl. 39a, fig. 3.

Tryon. Man. of Conch. Vol. III, p. 37, Pl. is, fig. 3.

Stat. 33. Bay of Pidjot, Lombok. 22 M. Mud, coral and coralsand. I Spec.

The only specimen is a dead shell, which seems to have been inhabited by one of the Paguridae.

2. Bursa margaritula Deshayes.

Deshayes. An. s. vert. Ed. II, Vol. IX, p. 550.

Kiener. Coq. Viv. Vol. VI, Ranella, p. I4, Pl. 8, fig. 2.

REeve. Conch. Ic. Vol. II, Ranella, fig. I5.

Küster. Martini-Chemn. Conch. Cab. Ed. II, Ranella, p. I37, Pl. 38, fig. 4, 5 ?

Tryon. Man. of Conch. Vol. III, p. 37, Pl. I 8, fig. 4. 
Stat. 33. Bay of Pidjot, Lombok. 22 M. Mud, coral and coralsand. 3 Spec.

Stat. 50. Bay of Badjo, West coast of Flores. Up to 40 M. Mud, sand and shells. 1 Spec.

Stat. $164 . \mathrm{I}^{\circ} 42^{\prime} .5$ S., I $30^{\circ} 47^{\prime} \cdot 5$ E. Halmahera Sea. 32 M. Sand, small stones and shells.

Stat. 313. East of Dangar Besar, Saleh-bay. Up to 36 M. Sand, coral and mud, 3 Spec.

The specimen from Stat. 50 is white, with a few brown spots and a yellow margin of the aperture, but agrees in other respects. I must doubt if the. figures of the Conchylien-Cabinet really belong to this species, notwithstanding the statement that they had been erroneously united to $R$. albivaricosa. I think the canal resembles much more in shape that of Bursa rana (albivaricosa) than that of $B$. margaritula, which is much shorter and in the back view is directed to the left.

\section{Bursa rana Linné.}

Linné. Syst. Nat. Ed. X, p. $748, \mathrm{~N}^{0} 45^{2}$.

ReEve. Conch. Ic. Vol. II, Ranella, fig. 2 (albivaricosa).

Küster. Martini-Chemn. Conch. Cab. Ed. II, Ranella, p. 133, Pl. 38, fig. 8, 9 (albivaricosa).

Tryon. Man. of Conch. Vol. III, p. 38, Pl. I8, fig. 5, 6 (albivaricosa).

Stat. 2. Madura-strait. 56 M. Grey mud with some radiolariae. 5 Spec.

Stat. 4. Djankar (Java). 9 M. Coarse sand. I Spec.

Stat. 47. Bay of Bima, near South fort. 55 M. Mud with patches of fine coralsand. I Spec.

Stat. 60. Haingsisi, Samau-island. Reef. I Spec.

Stat. 7I. Makassar and surroundings. Up to 32 M. Mud, sand with mud. I Spec.

Stat. 162. Between Loslos and Broken islands. West coast of Salawatti. I8 M. Coarse and fine sand with clay and shells. I Spec.

Stat. 231. Amboina. 40 M. Coralsand. 2 Spec.

Stat. 25 I. $5^{\circ} 28.4$ S., I $32^{\circ} 0^{\prime} .2$ E. Arafura Sea. 204 M. Hard coralsand. I Spec.

Stat. $318.6^{\circ} 36^{\prime} .5$ S., $114^{\circ} 55^{\prime} .5$ E. Java Sea. 88 M. Fine yellowish-grey mud. I Spec.

The specimen from Stat. 25I, which is a dead, broken shell, differs from the other specimens in sculpture, the beads being larger, the spines on the body and varices smaller, it is also slightly different in shape; as however Mr. E. A. Surtu declared it to be merely a variety of $B$. rana I have left this single specimen under that species.

\section{Bursa subgranosa (Beck) Sowerby.}

SOWERBy. Conch. Ill. fig. I 8.

RUMPII. Amb. Rariteitkamer, p. 82, Pl. 24, fig. F.

Kiener. Coq. Viv. Vol. VI, Ranella, p. 5, Pl. 4, fig. I (Beckii).

REeve. Conch. Ic. Vol. II, Ranella, fig. I.

Kúster. Martini-Chemn. Conch. Cab. Ed. II, Ranella, p. I35, Pl. 93, fig. 2.

Tryon: Man. of Conch. Vol. III, p. 38 , Pl. 19, fig. I.

Stat. I $2.7^{\circ}$ I $5^{\prime}$ S., I I $5^{\circ}$ I $5^{\prime} .6$ E. Madura Sea. 289 M. Mud, and broken shells. I Spec.

Stat. 306. $8^{\circ} 27^{\prime}$ S., $122^{\circ} 54^{\prime} .5$ E. Savu Sea. 247 M. Sandy mud. 2 Spec.

The specimens are dead shells, so it is uncertain if they have lived at the considerable depth mentioned on the labels. 
5. Bursa elegans (Beck) Sowerby.

SOWerby. Conch. 1ll., fig. I7.

ReEve. Conch. Ic. Vol. II, Ranella, fig. 22.

KƯster. Martini-Chemn. Conch. Cab. Ed. II, Ranella, p. I56, Pl. 39a, fig. 10.

Tryon. Man. of Conch. Vol. III, Ranella, p. 38, Pl. I8, fig. 7 (subgranosa var.).

Stat. 207. Buton-strait. I48 M. Grey mud. 2 Spec.

Tryon (1. c.) considers this species to be a variety of $B$. subgranosa; I find too important differences in shape, sculpture, especially of the varices and in the canal, to share his opinion.

\section{Bursa (Bufonia) lampas Linné.}

Linné. Syst. Nat. Ed. X, p. $748, \mathrm{~N}^{0} 454$.

Rumph. Amb. Rariteitkamer, p. 94, Pl. 28, fig. C. D.

Kiener. Coq. Viv. Vol. VI, Triton, p. 38, Pl. 5, fig. I.

ReEve. Conch. Ic. Vol. II, Triton, fig. 30.

Küster. Martini-Chemn. Conch. Cab. Ed. II, Triton, p. 175, Pl. 47, fig. 3, 4; Pl. 40, fig. $7,8$. Tryon. Man. of Conch. Vol. III, p. 38, Pl. ig, fig. i2.

Stat. 89. Yulu Kaniungan Ketjil. Reef. i Spec.

Stat. 240. Banda. 9-36 M. Lithothamnion-bank. I Spec.

The specimen from Stat. 89 is only a fragment.

\section{Bursa (Lampadopsis) rhodostoma (Beck) Sowerby.}

Sowerby. Conch. Ill. Ranella, fig. IO.

ReEve. Conch. Ic. Vol. II, Ranella. fig. 32.

Küster. Martini-Chemn. Conch. Cab. Ed. II, Ranella, p. 155, Pl. $39 a$, fig. Ir.

Tryon. Man. of Conch. Vol. III, p. 40, Pl. 2I, fig. 25.

Stat. 66. Bank between islands of Bahuluwang and Tambolungan, south of Saleyer. 8 M. Dead coral, Halimeda, Lithothamnion. I Spec.

Stat. 172. Between Gisser and Ceram-Laut. I8 M. Coral- and Lithothamnion-bottom. I Spec.

The specimen from Stat. 172 is young, and has the aperture not developed, that from Stat. 66 though small, has well-developed apertural margins, which are dark purple, with lighter patches, and resembles in colour of the aperture, ReEve's Ranella venustula (1.c. fig. 37) but does not agree with the description of that species. It resembles also the figures of $R$. Paulucciana Tapp. Can. (Ann. Soc. Mal. Belg. Vol. XV, fasc. I, Pl. 2, fig. I6, I7), but it is not so dark and has a higher spire. The identification of small specimens in this group remains somewhat uncertain. Tryon considers this species to be a variety of $B$. cruentata Sow.

8. Bursa (Ranella) tuberosissima Reeve.

Reeve. Conch. Ic. Vol. II, Ranella, fig. 39.

Kǘster. Martini-Chemn. Conch. Cab. Ed. II, Ranella, p. 157, Pl. 47, fig. I, 2.

Tryon. Man. of Conch. Vol. III, p. 39, Pl. 20, fig. 14. 
Stat. S9. Pulu Kaniungan Ketjil. Reef. I Spec.

Stat. 144. Salomakiëe-island. 45 M. Coral-bottom and Lithothamnion. I Spec.

Stat. 282. Between Nusa Besi and N. E. point of Timor. 27-54 M. Sand, coral and Lithothamnion. I Spec.

The specimen from Stat. 89 is broken, those from the other localities are very young and consequently a little uncertain. TRYon calls this species a synonym of $B$. bufonia.

9. Bursa (Colubrellina) granifera Lamarck.

LAMARCK. An. s. vert. Ed. II, Vol. 9, p. 548.

Kiener. Coq. Viv. Vol. VI, Ranella, p. I6, Pl. i i, fig. 1.

ReEve. Conch. Ic. Vol. II, Ranella, fig. 30.

Küster. Martini-Chemn. Conch. Cab. Ed. II, Ranella, p. I43, Pl. 39a, fig. I.

Tryon. Man. of Conch. Vol. III, p. 4I, Pl. 22, fig. 35, $3^{6 .}$

Stat. 89. Pulu Kaniungan Ketjil. Reef. I Spec.

Stat. I74. Waru-bay, North coast of Ceram. I8 M. Mud. I Spec.

Stat. 213. South-island. Reef. I Spec.

Stat. 23I. Amboina. Reef. I Spec.

Stat. 279. Rumah-Kuda-bay, Roma-island. Reef. I Spec.

10. Bursa (Colubrellina) affinis Broderip.

Broderip. Proc. Zool. Soc. Lond. I832, p. I79.

REEve. Conch. Ic. Vol. II, Ranella, fig. I9.

Küster. Martini-Chemn. Conch. Cab. Ed. II, Ranella, p. I42, Pl. $38 a$, fig. 5.

Tryon. Man. of Conch. Vol. III, p. 42, Pl. 22, fig. 38.

Stat. 58. Seba, Savu. Reef. I Spec.

Stat. I3 I. Beo, Karakelang-islands. 13 M. Mud and Sand. 3 Spec.

Stat. 21 3.. South-island near Saleyer. Reef. I Spec.

Stat. 225. South Lucipara-island. Reef. I Spec.

Stat. 240. Banda. 9-45 M. Black sand and coral. I Spec.

Stat. 279. Rumah-Küda-bay, Roma-island. Reef. 2 Spec.

This species which is rather variable, cannot always be easily separated from the preceding one.

\section{I . Bursa (Craspedotriton) convoluta Broderip.}

Broderip. Proc. Zool. Soc. Lond. I833, p. 7.

ReEve. Conch. Ic. Vol. II, Triton, fig. 92.

KÜSTER. Martini-Chemn. Conch. Cab. Ed. II, Triton, p. 217, P1. 6I, fig. 3 .

Tryon. Man. of Conch. Vol. III, p. 25, Pl. I3, fig. i IS.

Stat. I64. $1^{\circ} 42^{\prime} .5$ S., $130^{\circ} 47^{\prime} .5$ E. Halmahera Sea. 32 M. Sand, small stones and shells. I Spec.

The only specimen of this peculiar species is unfortunately a dead one. Dall (Smithsonian miscell. Coll. Vol. 47, p. 119) locates this species in the genus Bursa, though the anatomy is unknown. 
Fam. Oocorvthidae Fischer.

Oocorys Fischer.

1. Oocorys Weberi n. sp. Pl. X, fig. 2 .

Stat. $175.2^{\circ} 37^{\prime} \cdot 7$ S., $130^{\circ} 33^{\prime} .4$ E. Ceram Sea. 1914 M. Fine grey and green mud. 1 Spec.

Shell globosely-ovate, moderately ventricose, rather strong, white under a yellowish epidermis; whorls about $5 \frac{1}{2}$, (nucleus ones worn) convex, with a distinct suture and with strong spiral lirae, of which there are six on the penultimate whorl; 22 on the last one, including the canal; these lirae are separated by interstices, with a few exceptions about as broad as the lirae themselves, the uppermost liration borders the suture and is separated from the second one, by a broader concave interstice, giving it a channellike appearance; the interstices and in some degree the lirae, are crossed by radiating striae, which are coarser on the upper whorls. Aperture oblong-ovate, angular above, ending in a broad canal directed towards the left, columellar margin with a rather strong layer of enamel, spread over the bodywhorl; it is grooved by the lirae and covered with microscopic granules; columella rounded, curved, strongly bent to the left along the canal; right margin nearly regularly curved, with an angle, corresponding to the second lira, and with an external rib, expanded and grooved interiorly; these grooves extend in the interior of the shell, which is porcellaneous.

Operculum as in the typical species, reddish-brown, with a shallow groove along the right margin.

Alt. 38 , lat. 27 ; apert. alt. incl. perist. 28 , lat. $14^{1 / 2}$.

This species is less globose than O. sulcata Fischer (Journ. Conch. 1883, p. 392) with fewer lirae ( 6 in the penultimate whorl, instead of 8 to 12 ) the radiating striae seem to be much weaker than in sulcata, at least than in the "Challenger" specimen, where the interstices are much broader (Boog Watson: "Challenger" Gastropoda, P1. I7, fig. I I). In Benthodolizm (= Oocorys) abyssorum Verrill (Transact. Connecticut Acad. Vol. VI, 1882-85, p. 177, Pl. 3 I, fig. I2) the spire is much higher if compared with the aperture, the lirae are much more numerous, and the interspaces much broader, the canal much straighter. It appears rather doubtful to me, that these specimens should belong to the same species, unless it be excessively variable. I think the differences enumerated above, will be sufficient to separate shells of such a remote provenience.

\section{Oocory's sulcata Fischer.}

Fischer. Journal de Conchyl. 1883 , p. 392.

- Manuel de Conchyl. p. 679, fig. 536.

Tryon. Man. of Conch. Vol, VII, p. 267, Pl. 6, fig. 42.

Stat. $314 \cdot 7^{\circ} 36^{\prime}$ S., $117^{\circ} 30^{\prime} .8$ E. Flores Sea. 694 M. Fine, sandy mud. I Spec.

The only specimen is a dead, apparently not adult shell, the peristome not being developed. I can find no characters to separate it from the atlantic species, described by Fischer, it agrees in every aspect, as far as may be judged from the description and Fischen's figure, which is 
only a woodcut; the small differences may be individual; the number of spiral lirae described by the author, as being from $8-12$, are at least 12, perhaps 13 ; the most striking difference, the simple. peristome, is probably valueless, as it depends without doubt on age. E. A. Suith (Ann. and Mag. of Nat. Hist. Ser. 7, Vol. I7, I906, p. 170) mentions a specimen under the name of var. indica, with the locality "off S. of Ceylon, 1912 fath." which cannot be separated specifically from the species under consideration.

3. Oocorys elongata n. sp. Pl. X, fig. 3 .

Stat. $221.6^{\circ} 24^{\prime}$ S., $124^{\circ} 39^{\prime}$ E. Banda Séa. $279^{8}$ MI. Solid, bluish-grey mud with Foraminifera. 2 Spec.

Shell elongately-ovate, rather strong, white under a yellowish epidermis; spire rather high; whorls 5 , (nucleus wanting) convex, with an impressed suture and strong spiral lirae, IO to 12 on the penultimate whorl, from 25 to 32 on the last one, they are separated by interstices which are in most cases broader than the lirae; the whole shell (lirae and interstices) is crossed by radiating striae. Aperture oblong-ovate, angular above, ending below in a very short, wide canal, slightly directed towards the left, columellar margin covered by a layer of enamel spread over the bodywhorl, it is grooved by the lirae and microscopically granular, columella rounded, slightly curved, strongly bent to the left, along the canal; right margin regularly curved, slightly expanded but not ribbed exteriorly, thickened and grooved interiorly; aperture porcellaneous. A small umbilical slit, may disappear with age.

Operculum typical, reddish-yellow, with a shallow groove at the right margin.

Alt. $33^{1} / 2$, lat. $221 / 2$; apert. alt. 2 I (incl. perist.) lat. $1 \mathrm{I}^{1} / 2$.

This species differs from $O$. sulcata, in being much more elongate, with a higher spire, the aperture being about $1 \frac{1}{2} \times$ as long as the spire, being nearly $2 \times$ as long in $O$. sulcata, even the more elongate figure of the "Challenger" specimen, is still shorter, and has also a shorter spire in proportion. Benthodolizm abyssorum Verrill, which agrees in this respect, is a much more ventricose shell, with much broader aperture. The two specimens vary in sculpture as stated above, that of the smallest specimen being considerably finer; the upper whorls of this specimen are strongly eroded and the last whorl seems to have been broken, at least at some distance from the thin margin an irregular varix makes its appearance, and the umbilicus is more open. I think however these differences between the two specimens, will prove to be individual and in part accidental.

Fam. Cassididae Herm.

\section{Cassis Klein.}

I. Cassis (Semicassis) pila Reeve.

ReEve. Conch. Ic. Vol. V, Cassis, fig. 2 I.

RUMPH. Amb. Rariteitkamer, p. 84, Pl. 25, fig. C.

Küster. Martini-Chemn. Conch. Cab. Ed. II, Vol. III, Cassis, p. 39, Pl. 51, fig. 9, 10.

Tryon. Man. of Conch. Vol. VII, p. 275, Pl. 5, fig. 75 (saburon var. pila). 
Stat. I. Madura-strait, 1400 M. from reef "Zwaantjes-droogte". 37 M. Grey mud, with small, broken shells. I Spec.

Stat. 2. Madura-strait. 56 M. Grey mud with some Radiolariae. I Spec.

Stat. I 6 . West of Kwandang-bay-entrance. 72 M. Fine sand with mud. I Spec.

The specimen from Stat. I is young but characteristic, those from Stat. 2 and I 6 are less inflated than the type and have only obsolete brown, square spots (perhaps bleached as they are only empty shells).

2. Cassis (Semicassis) bisulcata Schubert \& Wagner.

Schubert \& Wagner. Fortsetz. Martini-Chemn. Conch. Cab. Ed. I, Vol. 12, p. 68, P1. 223, fig. $308 \mathrm{I} / 2$.

ReEve. Conch. Ic. Vol. V, Cassis, fig. 6.

Küster. Martini-Chemn. Conch. Cab. Fd. II, Vol. III, Cassis, p. 19, Pl. 43, fig. 6, 7 .

Tryon Man. of Conch. Vol. VII, p. 276, Pl. 5, fig. 78 (saburon var. bisulcata).

Stat. 231. Amboina. 40 M. Coralsand. 6 Spec.

Stat. 277. Kulewatti-(Sollot)-bay, Dammer-island. 18 M. Sand, white and black, mixed. I Spec.

I cannot agree with TRYov's opinion, that this and the preceding species are only varieties of $C$. saburon Adans., the species now under consideration, may be easily distinguished by its

- last whorl, which is smooth, with exception of the grooves at the upper and basal parts, instead of being spirally striate as in C. pila and saburon, which may on their turn be distinguished from each other, by the lower part of the columella, which is closely plicated in $C$. pila, as Küster (I. c.) has observed, moreover by closer striae on the bodywhorl of that species.

\section{Cassis (Bezoardica) glauca Linné.}

LiNNÉ. Syst. Nat. Ed. X, p. $737, \mathrm{~N}^{0} 391$.

Rumpir. Amb. Rariteitkamer, p. 83 , P1. 25, fig. A.

Kiener. Coq. Viv. Vol. VII, Cassis, p. 27, Pl. 5, fig. 9.

Reeve. Conch. Ic. Vol. V, Cassis, fig. 33 .

Küster. Martini-Chemn. Conch. Cab. Ed. II, Vol. III, Cassis, p. 7, Pl. 37, fig. I, 2.

Tryon. Man. of Conch. Vol. VII, p. 276, Pl. 6, fig. 79, 80.

Stat. 23I. Amboina. Reef. I Spec.

4. Cassis (Casmaria) vibex Linné.

LinNÉ. Syst. Nat. Ed. X, p. $737, \mathrm{~N}^{0} 392$.

RuMPH. Amb. Rariteitkamer, p. 84, Pl. 25, fig. E, 6, 9.

Kiener. Coq. Viv. Vol. VII, Cassis, p. 22, Pl. i I, fig. 20, $20 a$.

ReEve. Conch. Ic. Vol. V, Cassis, fig. $15 b, c$.

Küster. Martini-Chemn. Conch. Cab. Ed. II, Vol. III, Cassis, p. 12, Pl. 38, fig. 5, 7 .

Tryon. Man. of Conch. Vol. VII, p. 277, Pl. 7, fig. 89.

Stat. 53. Bay of Nangamessi, Sumba: Up to 36 M. Coralsand. I Spec.

Stat. 58. Seba, Savu. Reef. I Spec.

Stat. 234. Nalahia-bay, Nusa-Laut-island. Reef. I Spec.

*Java (N. A. M.) i Spec. 
The specimens are small, smooth, those from Stat. 58 and 234 , with the often occurring brown lines. (KIENER, 1. c. fig. 20a).

var. erinacea Linné.

LINNÉ. Syst. Nat. Ed. X, p. $736, \mathrm{~N}^{0} 390$.

Rumph. Amb. Rariteitkamer, p. 84, Pl. 25, fig. D, 7.

Kiener. Coq. Viv. Vol. VII, Cassis, p. 23, Pl. II, fig. 2 I.

ReEve. Conch. Ic. Vol. V, Cassis, fig. I $5 a$, I $5 d$.

Küster. Martini-Chemn. Conch. Cab. Ed. II, Vol. III, Cassis, p. I3, Pl. 38, fig. 6; Pl. 49, fig. 5, 6.

Tryon. Man. of Conch. Vol. VII, p. 277, Pl. 7, fig. 9.

Stat. 64. Kambaragi-bay, Tanah-Djampeah. 32 M. Coral, coralsand. I Spec.

Stat. 193. Sanana, Sula Besi-island. Reef. I Spec.

5. Cassis (Casmaria) torquata Reeve.

REeve. Conch. Ic. Vol, V, Cassis, fig. i $a-c$.

Küster. Martini-Chemn. Conch. Cab. Ed. II, Cassis, p. I5, Pl. 39, fig. 3, 4, $5,6$.

Tryon. Man. of Conch. Vol. VII, p. 278, PI. 7, flg. 92, 93.

Stat. 9I. Muaras-reef, inner side, East coast of Borneo. 54 M. Hard coralsand. I Spec.

Stat. 93. Pulu Sanguisiapo, Tawi-Tawi-islands, Sulu-archipelago. I2 M. Lithothamnion-bottom, sand and coral. I Spec.

The specimen from Stat. 94 belongs to the smooth type, that from Stat. 9 I to the nodulose variety; this latter specimen is very small.

\section{Morio Montfort.}

I. Morio granulosa n. sp. Pl. X, fig. 4 .

Stat. 3 I6. $7^{\circ} 9^{\prime} \cdot 4$ S., I $16^{\circ} 49^{\prime} \cdot 5$ E. $53^{8}$ M. Fine, dark brown, sandy mud. I Spec.

Shell globosely-ovate, ventricose, with a raised, conical spire; white, with a yellowish epidermis; whorls about $6 \frac{1}{2}$, the upper part of the smooth nucleus wanting, the whorls are convex, separated by a deep suture, spirally striate and lirate, the upper ones moreover with obtuse ribs; on the lower whorls the infrasutural liration is strong, divided by a groove, more below the lirae are still stronger and granulose, and number from one on the fourth whorl, to two and three on the penultimate one; these 3 principal lirae are persisting on the last whorl, where they bear about 30 granules, and are succeeded towards the front part of that whorl, by eight granulose lirae, which become however weaker in approaching that front part and are finally succeeded by about $\mathbf{2}$ nearly smooth lirae; the 3 principal lirae are divided by 2 grooves, and a few of the other ones by a single groove, moreover many of the interstices are provided with much smaller lirae, from one to three in number in each interstice; the whole shell is crossed by conspicuous growth-lines. Aperture oblong-ovate, angular above, terminating anteriorly in a short, slightly recurved canal; columellar margin callous, with rugose plicae, corresponding to the lirae, columella rounded, nearly straight, obliquely truncated, its left margin slightly expanded, leaving only a scarcely visible umbilical slit; outer nargin thickened, riblike 
externally, flattened and obscurely denticulate internally, slightly angular at some distance from its upper part, where it joins the body-whorl.

Alt. 54, lat. 38 ; apert. alt. (with canal) 37 , lat. I 4 Mill.

This species has a superficial resemblance with the Mediterranean $M$. echinophora L. but differs in every particular, the canal is much less recurved, the columellar plate is fixed to the body-whorl, not loosened like in echinophora, the labial rib is much stronger, the sculpture more delicate, the shape more pyriform, etc.

\section{Morio lincata n. sp. P1. X, fig. 5 .}

Stat. $173 \cdot 3^{\circ} 27^{\prime}$ S., $131^{\circ} 0^{\prime} 5$ E. 567 M. Ceram Sea. Fine, yellow grey mud. 2 Spec.

Shell globosely-ovate, ventricose, with a rather high spire, thin; under a yellowish epidermis it is white with light brown lirae. Whorls about 8 , of which $4 \frac{1}{2}$ form the smooth, yellow nucleus; the other whorls very convex, with a conspicuous suture and rather strong spiral lirae, about 16 principal ones on the last whorl and small intermediate ones, which are of a still lighter colour, moreover 5 lirae on the canal; after a few thinner lirae below the suture, 9 of the principal lirae are more or less granulose on the dorsal part of the whorl; the shell is crossed by numerous, rather conspicuous, lamellose or riblike striae, which run over the lirae, and very fine growth-striae. Aperture oblong-ovate, angular above, ending below in a short, broad, only slightly recurved canal: columellar margin with a very thin layer of enamel on the bodywhorl, slightly stronger below, on the nearly straight columella, which is slightly oblique near the canal, leaving a very small umbilical slit, nearly closed by the layer of enamel; outer margin regularly curved, exteriorly with a conspicuous rib, which is flattened and rather strongly denticulate interiorly. Interior of aperture with grooves, corresponding to the external lirae, the grooves light brown.

Alt. $41^{1} / 2$, lat. $29^{1} / 2$; apert. alt. (incl. canal) 28 , lat. $12^{2} / 2$ Mill.

This species is allied to the preceding one, but the shell is smaller, thinner, more ventricose, the granules on the brown lirae are weaker and not divided by spiral striae, the canal is shorter, less recurved, the ventral side and columella nearly without enamel.

3. Morio Alcocki Smith. Pl. X, fig. 6 .

Smith. Ann. Mag. Nat. Hist. SSer. 7, Vol. 18, 1906, p. 170.

Stat. $314 \cdot 7^{\circ} 36^{\prime}$ S., $117^{\circ} 30^{\prime} .8$ E. Flores Sea. 694 M. Fine, sandy mud. I Spec.

The specimen has a length of $\mathrm{IO}_{4}$ Mill., its diam. maj. is 68 Mill. and is consequently still a little larger than Sмiтh's type, which is $99 \times 6 \mathrm{I}$ Mill. The species has been or will be figured in Alcock's lilustrations Zool. "Investigator". As this work, of which I owe the parts appeared untill December I906, to the liberality of its author, is not generally known, I have thought it useful to give figures of the magnificent "Siboga" specimen. 
Fam. Dolinde Adams.

\section{Dolium Lamarck.}

I. Dolizm olearium Bruguière.

BruguiÈre. Dict. des Vers. N0 1.

RumPH. Amb. Rariteitkamer, p. 91, Pl. 27, fig. D.

Kiener. Coq. Viv. Vol. ViI, Dolium, p. 6, Pl. I, fig. I.

ReEve. Conch. Ic. Vol. V, Dolium, fig. I4.

Kưster. Martini-Chemn. Conch. Cab. Ed. II, Vol. III, Dolium, p. 68, Pl. 6I, fig. I.

Tryon. Man. of Conch. Vol. VII, p. 262, Pl. 2, fig. 8.

Stat. 33. Bay of Pidjot, Lombok. 22 M. Mud, coral and coralsand. I Spec.

Stat. 142. Laiwui, North coast of Obi major. Reef. I Spec.

Stat. 279. Roma. Reef. I Spec.

Stat. 299. Buka or Cyrus-bay, South coast of Rotti-island. 34 M. Mud, coral and Lithothamnion. I Spec.

Stat. ? 1 Spec.

The specimens belong to the type (Tryon's fig. 8), and not to the varieties or species he has united under $D$. olearium.

2. Dolium costatum Menke.

Menise. Synops. Meth. App. i 828 .

Kiener. Coq. Viv. Vol. VII, Dolium, p. i I, Pl. 4, fig. 6 (fasciatum var.).

Reeve. Conch. Ic. Vol. V, Dolium, fig. 8.

Küster. Martini-Chemn. Conch. Cab. Ed. II, Vol. III, Dolium, p. 6I, Pl. 56, fig. 3; Pl. 57, fig. 3.

Tryon. Man. of Conch. Vol. VII, p. 263, Pl. 4, fig. 19, 20.

Stat. 131. Beo, Karakelang-islands. I 3 M. Mud and sand. I Spec.

Stat. 313. East of Dangar Besar, Saleh-bay. Up to 36 M. Sand coral and mud. I Spec.

Both specimens are very young.

3. Dolizm fasciatum Bruguière.

BRUGuiÈre. Dict. des Vers. $\mathrm{N}^{0} 5$.

Kiener. Coq. Viv. Vol. VII, Dolium, p. i I, Pl. 3, fig. 5 .

ReEve. Conch. Ic. Vol. V, Dolium, fig. I I.

Küster. Martini-Chemn. Conch. Cab. Ed. II, Vol. III, Dolium, p. 62, Pl. 56, fig. 4.

Tryon. Man. of Conch. Vol. VII, p. 263 , Pl. 3, fig. 16.

Stat. I $2.7^{\circ}$ I $5^{\prime}$ S., I I $5^{\circ} 15^{\prime} .6$ E. Bali Sea. 289 M. Mud and broken shells. 2 Spec.

I think it is not probable that this species has lived at a depth of 289 M., both specimens are dead shells, grey without bands, in other respects they exactly agree with specimens in my collection.

\section{Dolizm (Malea) pomum Linné.}

Linné. Syst. Nat. Ed. X, p. $735, \mathrm{~N}^{0} 379$.

RUMiph. Amb. Rariteitkamer, p. 90, Pl. 27, fig. B.

Kiener. Coq. Viv. Vol. VII, Dolium, p. I2, P1. 5, fig. 8. 
ReEve. Conch. Ic. Vol. III, Dolium, fig. 6.

KÜster. Martini-Chemn. Conch. Cab. Ed. II, Vol. III, Dolium, p. 63, Pl. 56, fig. 5, 6.

Tryon. Man. of Conch. Vol. VII, p. 265, Pl. 5, fig. 26.

Stat. I 33. Lirung, Salibabu-island. Reef. I Spec.

Stat. I42. Laiwui, North coast of Obi-major. 23 M. Mud. I Spec.

The specimens are of small size, the largest (from Stat. 142) measuring only 50 Mill., though the aperture is well developed.

\section{Pirula Lamarck.}

I. Pirula gracilis Sowerby.

Sowerby. Cat. Coll. Tankerville. App. p. i 7 .

Kiener. Coq. Viv. Vol. VI, Pyrula, p. 25, P1. i I (Dussumieri).

ReEve. Conch. Ic. Vol. IV, Ficula, fig. 2 (Dussumieri).

Kobelt. Martini-Chemn. Conch. Cab. Ed. II, Vol. III, Ficula, p. IO, Pl. I, fig. I (Dussumieri).

Tryon. Man. of Conch. Vol. VII, p. 266, Pl. 5, fig. 30 (Dussumieri).

Smith. Journ. of Mal. Vol. III, I894. Recent spec. of Pirula, p. 4.

Stat. 2. Madura-strait. 67 M. Grey mud with some radiolariae. 3 Spec.

The localities mentioned in the paper of Surth, are China and Bay of Bengal. Madurastrait may be considered as a connecting link, between these two rather remote stations.

\section{Fam. Cypraeidae Fleming.}

\section{Cypraea Linné.}

I. Cypraea isabella Linné.

LinNÉ. Syst. Nat. Ed. X, p. $722, \mathrm{~N}^{0} 304$.

Rumph. Amb. Rariteitkamer, p. I I 8, Pl. 39, fig. G.

Kiener. Coq. Viv. Vol. I, p. 87, P1. 48, fig. 3-3a.

ReEve. Conch. Ic. Vol. III, Cypraea, fig. 5 I.

Weinkauff. Martini-Chemn. Conch. Cab. Ed. II, Vol. V, Cypraea, p. I7, Pl. 4, fig. 7; P1. I2, fig. IO, It.

Tryon. Man. of Conch. Vol. VII, p. 165, P1. I, fig. 6, 7 .

Stat. 33. Bay of Pidjot, Lombok. 22 M. Mud, coral and coralsand. 1 Spec.

Stat. I 15. East side of Pajunga-island, Kwandang-bay. Reef. I Spec.

Stat. 225. Lucipara-island. Reef. 2 Spec.

Stat. 234. Nalahia-bay, Nusa-Laut-island. Reef. I Spec.

2. Cypraea carneola Linné.

LiNnÉ. Syst. Nat. Ed. X, p. 7 I9, $\mathrm{N}^{0} 290$.

Rumpir. Amb. Rariteitkamer, p. I15, P1. 38, Fig. K.

Kiener. Coq. Viv. Vol. I, p. 83, P1. 37, fig. 3.

Reeve. Conch. Ic. Vol. III, Cypraea, fig. I9.

Weinkauff. Martini-Chemn. Conch. Cab. Ed. II, Vol. V, Cypraea, p. I4, Pl. 3, fig. 8, 9;

Pl. 5, fig. I, 2.

Tryon. Man. of Conch. Vol. VII, p. I66, Pl. 3, fig. 26-30. 
Stat. 53. Bay of Nangamessi, Sumba. Up to $36 \mathrm{M}$. Coralsand. I Spec.

Stat. I64. $\mathrm{I}^{\circ} 42^{\prime} .5 \mathrm{~S}$., I $30^{\circ} 47^{\prime} .5$ E. near West coast of New Guinea. 32 M. Sand, small stones and shells. I Spec.

Stat. 225. Lucipara-island. Reef. I Spec.

Stat. 279. Roma. Reef. I Spec.

\section{Cypraea talpa Linné.}

LinnÉ. Syst. Nat. Ed. X, p. $720, \mathrm{~N}^{0} 292 . \cdot$

RUMPH. Amb. Rariteitkamer, p. I I5, Pl. 38, fig. I.

Kiener. Coq. Viv. Vol. I, p. 79, Pl. I2, fig. 2.

ReEve. Conch. Ic. Vol. III, Cypraea, fig. 5 .

Weinkauff. Martini-Chemn. Conch. Cab. Ed. II, Vol. V, Cypraea, p. I8, Pl. 4, fig. 5, 6.

Truon. Man. of Conch. Vol. VII, p. I67, Pl. 3, fig. 3I-33.

Stat. 16. Bay of Kankamaraän, South coast of Kangeang. Reef. I Spec.

Stat. 133. Lirung, Salibabu-island. Reef. I Spec.

Stat. 279. Ruma-Kuda-bay, Roma-island. Reef. I Spec.

\section{Cypraea fimbriata Gmelin.}

Gmelin. Syst. Nat. Ed. XIII, p. 3423 .

ReEve. Conch. Ic. Vol. III, Cypraea, fig. 92.

Weinkauff. Martini-Chemn. Conch. Cab. Ed. II, Vol. V, Cypraea, p. 3I, Pl. 9, fig. 2, 3, Pl. I3, fig. 5, 8 .

Tryon. Man. of Conch. Vol. VII, p. 168, Pl. 5, fig. 76-78.

Stat. I64. $\mathrm{I}^{\circ} 42^{\prime} \cdot 5$ S., I $30^{\circ} 47 \cdot 5$ E. near West coast of New Guinea. 32 M. Sand, small stones and shells. 2 Spec.

Stat. 2 I3. Saleyer. Reef. I Spec.

Stat. 234. Nusa-Laut-island. Reef. I Spec.

Stat. 282. Between Nusa Besi and the N.E. point of Timor. 27-54 M. Sand, coral and Lithothamnion. I Spec.

Stat. 299. Buka-bay, South coast of Rotti-island. 34 M. Sand, coral and Lithothamnion. 2 Spec.

\section{Cypraea contaminata Gray.}

Gray. Descript. Cat. Cypraea p. i I.

Kiener. Coq. Viv. Vol. I, p. IOI, Pl. 57, fig. 5.

ReEve. Conch. Ic. Vol. III, Cypraea, fig. I2I.

Weinkauff. Martini-Chemn. Conch. Cab. Ed. II, Vol. V, Cypraea, p. 34, Pl. Io, fig. 5, 8.

Tryon. Man. of Conch. Vol. VII, p. I68, Pl. 4, fig. 48, 49.

Stat. 66. Bank between Bahuluwang and Tambolungan, south of Saleyer. 8-10 M. Dead coral, Halimeda, Lithothamnion. I Spec.

Stat. 322. South of Tandjong Lajar, South coast of Bawean-island. 32 M. Coral. I Spec.

Both specimens are slightly worn, the small brown dots on the dorsal side are consequently wanting, but the larger blotch is still present.

\section{Cypraea microdon Gray.}

Gray. Zool. Journ. Vol. IV, p. 7i.

Kiener. Coq. Viv. Vol. I, p. I02, Pl. 56, fig. 5; p. 92, Pl. 56, fig. 4, 4a (chrysalis).

ReEve. Conch. Ic. Vol. III, Cypraea, fig. I39. 
Weinkauff. Martini-Chemn. Conch. Cab. Ed. II, Vol. V, Cypraea, p. 101, Pl. 31, fig. 5 , 8. Tryon. Man. of Conch. Vol. VII, p. I69, P1. 5, fig. 74, 75; p. 172, P1. 4, fig. 64, 65 (chrysalis). Smith. Proc. Mal. Soc. Lond. Vol. V, p. I67.

Stat. 50. Bay of Badjo, West coast of Flores. Up to 40 M. Mud, sand and shells. I Spec. Stat. 301. Pepela-bay, East coast of Rotti-island. 22 M. Mud, coral and Lithothamnion. I Spec.

The specimens are bleached, but they agree in shape, in the narrow aperture and number of teeth, with a fresh specimen from Mauritius; the rosy tips are still recognizable.

\section{Cypraea arsellus Gmelin.}

Gmelin. Syst. Nat. Ed. XIII, p. 3411.

Kiener. Coq. Viv. Vol. I, p. 99, Pl. 33, fig. 4-4a.

Tryon. Man. of Conch. Vol. VII, p. 169, Pl. 4, fig. 54, 55.

Dautzenberg. Journ. Conch. I902, p. 307.

Stat. 213 . South-island, near Saleyer. Reef. I Spec.

Though Weintrauff (Martini-Chemn. Conch. Cab. Ed. II, Vol. V, p. 42, 43) considers this shell, named by him urcellus, to be only a form of $C$. felina Gmel., and suggests that the shell described by GMelis, should be another species (Oweni Gray), I follow the opinion of Dautzenberg (1. c.).

8. Cypraea quadrimaculata Gray.

Gray. Zool. Journ. Vol. I, p. 376 .

Kiener. Coq. Viv. Vol. I, p. 90, Pl. 3, fig. 3.

ReEve. Conch. Ic. Vol. III, Cypraea, fig. I07.

Weinkauff. Martini-Chemn. Conch. Cab. Ed. II, Vol. V, Cypraea, p. 30, Pl. 9, fig. I, 4.

Tryon. Man. of Conch. Vol. VII, p. I67, Pl. 4, fig. 40, 4I.

Stat. 213. Surroundings of Saleyer. UP to 36 M. Mud and mud with sand. I Spec.

9. Cypraca caurica Linné.

Linné. Syst. Nat. Ed. X, p. $723, \mathrm{~N}^{0} 3^{\mathrm{T}} 3$.

Rumph. Amb. Rariteitkamer, p. 115 , Pl. 38 , fig. P.

Kiener. Coq. Viv. Vol. I, p. 54, Pl. 10, fig. 2.

ReEve. Conch. Ic. Vol. III, Cypraea, fig. 46.

Weinkauff. Martini-Chemn. Conch. Cab. Ed. II, Vol. V, Cypraea, p. 12, 34, Pl. 3, fig. 4, 5; P1. 10, fig. 2, 3 .

Tryon. Man. of Conch. Vol. VII, p. I7I, Pl. 5, fig. 88-90.

Stat. 89. Pulu Kaniungan Ketjil. Reef. I Spec.

Stat. 225. South point of Lucipara-island. Reef. I Spec.

E. von Martens (Rumphius Gedenkboek, Mollusca, p. I5) quotes fig. O of Rumph for $C$. caurica and fig. P for variolaria (cruenta), but a look at the plate makes it clear, that fig. P belongs to caurica. Rumph says that his "Variolae" are of two kinds, he describes first the largest one with black spots at the sides (caurica) fig. P; than the smaller one with purple spots (variolaria Lam.) but in the explication of the plate, at the end of the chapter, the words " $13^{\text {th }}$ species, O, red measles, of which a second species is represented at fig. P", is in accordance with my views. 
Io. Cypraea (Aricia) caput serpentis Linné.

Linné. Syst. Nat. Ed. X, p. $720, \mathrm{~N}^{0} 298$.

Rumph. Amb. Rariteitkamer, p. I 14, Pl. 38 , fig. F.

Kiener. Coq. Viv. Vol. I, p. I12, Pl. 69, fig. I.

Reeve. Conch. Ic. Vol. III, Cypraea, fig. 44.

Weinkauff. Martini-Chemn. Conch. Cab. Ed. II, Vol. V, Cypraea, p. 2I, Pl. 5, flg. 20, 2 I. Tryon. Man. of Conch. Vol. VII, p. 173, Pl. 6, fig. 98-ioo.

Stat. 172. Island of Gisser. Reef. I Spec.

Stat. 299. Buka-bay, South coast of Rotti-island. 34 M. Sand, coral and Lithothamnion. 2 Spec.

"Bawean-island? 2 Spec.

11. Cypraca (Aricia) arabica Linné.

Linné. Syst. Nat. Ed. X, p. $718, \mathrm{~N}^{0} 286$.

Rumph. Amb. Rariteitkamer, p. I I5, Pl. 38 , fig. M.

Kiener. Coq. Viv. Vol. I, p. 105, Pl. 17, fig. I.

ReEve. Conch. Ic. Vol. III, Cypraea, fig. 2.

Weinkauff. Martini-Chemn. Conch. Cab. Ed. II, Vol. V, Cypraca, p. 51, Pl. 16, fig. 3-6.

TrYon. Man. of Conch. Vol. VII, p. 174, Pl. 8, fig. 18, 19.

Stat. I6. Bay of Kankamaraän, South coast of Kangeang. Shore. I Spec.

Stat. 19. Bay of Labuan Tring, West coast of Lombok. I $8-27$ M. River-mud, coral, coralsand. 2 Spec.

Stat. 34. Labuan Pandan, Lombok. Coralreef. 2 Spec.

Stat. 37. Sailus Ketjil, Paternoster-islands. Reef. I Spec.

Stat. 53. Bay of Nangamessi, Sumba. Up to $36 \mathrm{M}$. Coralsand. I Spec.

Stat. 58. Seba, Savu. Reef. 2 Spec.

Stat. 93. Pulu Sanguisiapo, Tawi-Tawi-islands, Sulu-archipelago. I2 M. Lithothamnion-bottom, sand and coral. I Spec.

Stat. I3 I. Beo, Karakelang-islands. I3 M. Mud and sand. I Spec.

Stat. 144. North of Salomakiëe-island. Reef. I Spec.

Stat. 174. Waru-bay, North coast of Ceram. Reef. I Spec.

Stat. 225. South of Lucipara-island. Reef. 2 Spec.

Stat. 23I. Amboina. Reef. 3 Spec.

Stat. 261. Elat, West coast of Great-Kei-island. Reef. I Spec.

Stat. 272. Dobo, Aru-islands. Reef. I Spec.

*Amboina. I Spec.

"Bawean-island? 2 Spec.

"Humboldt-bay, N. Guinea. (N. Guinea-Expedition 1903). 5 Spec.

Very variable in size and shape and, though less, in markings. The smallest adult specimen, from Stat. 19, has a length of 36 Mill., the largest, from Stat. 225 , of 63 Mill. I have seen however still smaller and larger specimens.

1 2. Cypraea (Aricia) moneta Linné.

Linné. Syst. Nat. Ed. X, p. $723, \mathrm{~N}^{0} 3 \mathrm{I} 2$.

Rumpir. Amb. Rariteitkamer, p. 1 17, P1. 39, fig. C.

Kiener. Coq. Viv. Vol. I, p. I22, Pl. 34, fig. I.

Reeve. Conch. Ic. Vol. III, Cypraea, fig. 74 .

Weinkauff. Martini-Chemn. Conch. Cab. Ed. II, Vol. V, Cypraea, p. 67, Pl. 20, fig. I, 4.

Tryon: Man. of Conch. Vol. VII, p. 177, Pl. Io, fig. 46; Pl. i I, fig. 51, 52; Pl. 23, fig. 60, 61, 63. 
Stat. 33. Bay of Pidjot, Lombok. 22 M. Mud, coral and coralsand. I Spec.

Stat. 6o. Haingsisi, Samau-island. Reef. I Spec.

Stat. 9I. Moearas-reef, inner side, East coast of Borneo. I Spec.

Stat. I69. Atjatuning, West coast of N. Guinea. Reef. I Spec.

The specimen from Stat. 9 I is typical in shape, that from Stat. 33 is much worn, those from Stat. 60 and 169 are small, the tubercles on the back are obsolete, but at the base they are present.

\section{var. icteriza Lamarck.}

Lamarck. An. s. vert. Ed. Desh. Vol. X, p. 5 Io.

Kíiener. 1. c. p. I23, Pl. 34, fig. 3 .

Weinkauff. 1. c. p. 68, Pl. 20, fig. 2.

Tryon. 1.c. p. 17 , Pl. 23, fig. 62 .

Stat. 7. Near reef of Batjulmati (Java). I5 M. Coral and stones. 5 Spec.

Stat. 71. Pulu Barang, near Makassar. Shore. I Spec.

Stat. 93. Pulu Sanguisiapo, Tawi-Tawi-islands, Sulu-archipelago. 12 M. Lithothamnion-bottom, sand and coral. I Spec.

Stat. 193. Sanana-bay, East coast of Sula Besi. Reef. I Spec.

The specimens from Stat. 7 are large and typical, the longest one has a length of 36 Mill. that from Stat. 193 is much smaller, and those from the other Stations are still smaller and less characteristic, they resemble the vars. atava and plumaria, both of Rochebrune, as figured by TrYon (1. c. Pl. 23, fig. 64, 65 and 69).

\section{I3. Cypraea anzulus Linné.}

LinnÉ. Syst. Nat. Ed. X, p. $723, \mathrm{~N}^{0} 3 \mathrm{I} 4$.

RumPH. Amb. Rariteitkamer, p. I 17, Pl. 39, fig. 5.

Kiener. Coq. Viv. Vol. I, p. 124, Pl. 34, fig. 2.

Reeve. Conch. Ic. Vol. III, Cypraea, fig. 7 I.

Weinkauff. Martini-Chemn. Conch. Cab. Ed. II, Vol. V, Crypraea, p. 69, Pl. 20, fig. 9, I 2. Tryon. Man. of Conch. Vol. VII, p. I78, Pl. II, fig. 57, 59, 61; Pl. 23, fig. 70-72.

Stat. 7. Near reef of Batjulmati (Java). I 5 M. Coral and stones. I I Spec.

Stat. 19. Bay of Labuan Tring, West coast of Lombok. 18-27 M. River-mud, coral, coralsand. 2 Spec.

Stat. 34. Labuan Pandan, Lombok. Coralreef. 6 Spec.

Stat. 37. Sailus Ketjil, Paternoster-islands. 27 M. Coral and coralsand. I Spec.

Stat. 47. Bay of Bima, near South fort. Shore. 5 Spec.

Stat. 8I. Pulu Sebangkatan, Borneo-bank. Reef. I Spec.

Stat. I31. Beo, Karakelang-islands. I3 M. Mud and sand. I Spec.

Stat. 133. Lirung, Salibabu-island. Reef. 2 Spec.

Stat. 169. Atjatuning, West coast of New Guinea. Reef. 2 Spec.

Stat. 174. Waru-bay, North coast of Ceram. Reef. I Spec.

Stat. 193. Sanana-bay, East coast of Sula Besi. Reef. Io Spec.

Stat. 225. South of Lucipara-island. Reef. I Spec.

De Bril near Makassar. Kraay don. I Spec.

*Enkhuizen-island near Batavia. 9 Spec.

The specimens vary considerably in shape, size and colour, those from Stat. 7 are unusually elongate, the largest spécimen measuring 30 Mill. in length and 8 in breadth. 
14. Cypraea (Luponia) tigris Linné.

LinNÉ. Syst. Nat. Ed. X, p. $72 \mathrm{I}, \mathrm{N}^{0} 3 \mathrm{O}$.

Rumph. Amb. Rariteitkamer, p. 113, Pl. 38, fig. A.

Kiener. Coq. Viv. Vol. I, p. 4, Pl. I, fig. I; Pl. 45, fig. I; Pl. 46, fig. I.

Reeve. Conch. Ic. Vol. III, Cypraea, fig. 12.

Weinkauff. Martini-Chemn. Conch. Cab. Ed. II, Vol. V, Cypraea, p. 9I, Pl. 28, 29, 30, fig. I.

Tryon. Man. of Conch. Vol. VII, p. 180, P1. 11, fig. 49, 50.

Stat. 93. Pulu Sanguisiapo, Tawi-Tawi-islands. Sulu-archipelago. I2 M. Lithothamnion-bottom,

Sand and coral. 2 Spec.

Stat. 142. Laiwui, North coast of Obi Major. Reef. 2 Spec.

Stat. I72. Island of Gisser. Reef. I Spec.

Stat. 193. Sanana-bay, East coast of Sula Besi. Reef. I Spec.

Stat. 213. Pulu Pasi near Saleyer. I Spec.

15. Cypraea (Luponia) vitellus Linné.

Linné. Syst. Nat. Ed. X, p. $721, \mathrm{~N}^{0} 300$.

Rumph. Amb. Rariteitkamer, p. 1 I5, Pl. 38, fig. L.

Kiener. Coq. Viv. Vol. I, p. 12, Pl. I9, flg. I.

REEve. Conch. Ic. Vol. III, Cyprae, fig. I4.

Weinkauff. Martini-Chemn. Conch. Cab. Ed. II, Vol. V, Cypraea, p. 38, Pl. i1, fig. 6, 7, io, 11.

Tryon. Man. of Conch. Vol. VII, p. I82, Pl. 13, fig. 72,73 .

Stat. 93. Pulı Sanguisiapo, Tawi-Tawi-islands, Sulu-archipelago. 12 M. Lithothamnion-bottom, sand and coral. 2 Spec.

Stat. 13I. Beo, Karakelang-islands. 13 M. Mud and sand. I Spec.

Stat. 225. South of Lucipara-island. Reef. 3 Spec.

16. Cypraea (Luponia) lynx Linné.

LiNnÉ. Syst. Nat. Ed. X, p. $721, \mathrm{~N}^{0} 303$.

Rumph. Amb. Rariteitkamer, p. I I 5, Pl. 38, fig. N.

Kiener. Coq. Viv. Vol. I, p. Io, Pl. 25, fig. 2 ; Pl. 38 , fig. 2.

Reeve. Conch. Ic. Vol. III, Cypraea, fig. 33.

WeinkaufF. Martini-Chemn. Conch. Cab. Ed. II, Vol. V, Cypraea, p. 79, Pl. 23, fig. 6, 7, 10, i

Tryon. Man. of Conch. Vol. VII, p. I83, Pl. I4, fig. 86, 87.

Stat. I9. Bay of Labuan Tring, West coast of Lombok. 10-27 M. River-mud, coral, coralsand. 2 Spec.

Stat. 47. Bay of Bima. 55 M. Mud with patches of fine coralsand. I Spec.

Stat. 6o. Haingsisi, Samau-island. Reef. I Spec.

Stat. 89. Pulu Kaniungan Ketjil. Reef. 3 Spec.

Stat. 93. Pulu Sanguisiapo, Tawi-Tawi-islands, Sulu-archipelago. I 2 M. Lithothamnion-bottom, sand and coral. I Spec.

Stat. I 33. Lirung, Salibabu-island. Reef. 6 Spec.

Stat. 225. South of Lucipara-island. Reef. 4 Spec.

Stat. 250. Kur. Reef. I Spec.

Varying in size; the specimens from Stat. $47,89,93$ and 225 are very small and young, their identification consequently remains a little uncertain. 
17. Cypraca (Luponia) errones Linné.

LinnÉ. Syst. Nat. Ed. X, p. $723, \mathrm{~N}^{0} 3 \mathrm{II}$.

Rumpir. Amb. Rariteitkamer, p. i 8, Sp. 5 (Casuaris Eijers) Sp. 6, Pl. 39, fig. E?

ReEve. Conch. Ic. Vol. III, Cypraea, fig. 56.

Weinkauff. Martini-Chemn. Conch. Cab. Ed. II, Vol. V, Cypraea, p. 20, Pl. 4, fig. 10, 12?

Tryon. Man. of Conch. Vol. VII, p. I83, Pl. I4, fig. 7 .

Stat. 34. Labuan Pandan, Lombok. Coralreef. 2 Spec.

Stat. 58. Seba, Savu. Reef. 1 Spec.

Stat. 6o. Haingsisi, Samau-island. Reef. i Spec.

Stat. 86. Dongala, Palos-bay. Celebes. Shore. I Spec.

Stat. 93. Pulu Sanguisiapo, Tawi-Tawi-islands, Sulu-archipelago. I 2 M. Lithothamnion-bottom, sand and coral. I Spec.

Stat. 213 . Saleyer. Reef. 1 Spec.

Stat. 225. South of Lucipara-island. Reef. 2 Spec.

Stat. 234. Nalahia-bay, Nusa-Laut-island. Reef. I Spec.

Stat. 282. Between Nusa Besi and N. E. point of Timor. 27-54 M. Sand, coral and Litho-

"Amboina. 2 Spec. thamnion. I Spec.

The very young specimen from. Stat. 282 is of doubtful identification, the specimens from the Stations 93, 225 and Amboina are conchologically intermediate between the type and var. ovum Gmel., they have the large brown spot on the back, but not those near the anterior canal, the shape of the aperture however is in accordance with that of the type.

var. ovum Gmelin.

GMELIN. Syst. Nat. Ed. XIII, p. 3412.

Kiener. Coq. Viv. Vol. I, p. 56, Pl. 29, fig. 4.

Tryon. Man. of Conch. Vol. VII, Pl. 14, fig. 88, 89.

Dautzenierg. Journ. de Conch. 1902, p. 348.

Stat. 19. Bay of Labuan Tring, West coast of Lombok. 18-27 M. River-mud, coral, coralsand. I Spec.

Stat. 7I. Pulu Barang, near Makassar. Shore. 2 Spec.

The specimens agree with the elucidations in DAUTzenberg's paper, they have neither the large brown blotch, nor smaller brown spots near the front-end, but are provided with an orange streak between the teeth.

\section{Cypraea (Luponia) pyriformis Gray.}

Gray. Zool. Journ. I, p. 37 I.

Kiener. Coq. Viv. Vol. I, fig. 42, Pl. 55, fig. 2.

Reeve. Conch. Ic. Vol. III, Cypraea, fig. 52.

Weinkauff. Martini-Chemn. Conch. Cab. Ed. II, Vol. V, Cypraca, p. 59, Pl. is, fig. 2, 3.

Tryon. Man. of Conch. Vol. VII, p. I $84, \mathrm{Pl}$. I4, fig. 5, 6.

Stat. 285. South coast of Timor. 34 M. On the linit between mud and coral. I Spec. 
19. Cypraea (Luponia) Walkeri Gray.

Gray. Descr. Cat. Cypraeidae, p. II.

Kriener. Coq. Viv. Vol. I, p. 33, Pl. I4, fig. 3.

ReEve. Conch. Ic. Vol. III, Cypraea, fig. 50a, h.

Weinkauff. Martini-Chemn. Conch. Cab. Ed. II, Vol. V, Cypraea, p. 78, Pl. 23, fig. I, 4.

Tryon. Man. of Conch. Vol. VII, p. I85, Pl. I5, fig. 10; Pl. I7, fig. 68.

Stat. 77. Borneo-bank. 59 M. Fine, grey coralsand. I Spec.

Stat. 99. North-Ubian, Sulu-archipelago. I6-23 M. Lithothamnion-bottom. 5 Spec.

Stat. I09. Pulu Tongkil, Sulu-archipelago. ${ }_{3} 3$ M. Lithothamnion-bottom. 3 Spec.

Stat. I64. $I^{\circ} 42^{\prime} .5$ S., I $30^{\circ} 47^{\prime} .5$ E. Halmahera Sea. 32 M. Sand, small stones and shells. I Spec.

Stat. 3I3. East of Dangar Besar, Saleh-bay. Up to $36 \mathrm{M}$. Sand, coral and mud. 4 Spec.

The suggestion of Mr. J. Brazier, that this species should live in deep water, has not been confirmed by the collection of the Siboga-Expedition. The specimens vary considerably in colour-pattern, that from Stat. 77 is much bleached, those from Stat. 99 have a broad brown band in the centre of the back, bordered by narrow zones of a light colour and a few spiral rows of brown blotches. A very young specimen from that locality, with scarcely any traces of teeth, is uniformly brown on the back, whitish near the produced spire and along the right margin of the aperture; those from Stat. 109 have but a few brown blotches near the dark central band (broken up in one specimen), that from Stat. I 64 has only a single indistinct band; the specimens from Stat. 3 I 3 are very similar; these differences seem to be only individual, I have failed to recognize one of the described varieties amongst them.

20. Cypraea (Luponia) ziczac Linné.

LinNÉ. Syst. Nat. Ed. X, p. $722, \mathrm{~N}^{0} 307$.

Kiener. Coq. Viv. Vol. I, p. 22, P1. 3I, fig. $2 a$.

ReEve. Conch Ic. Vol. III, Cypraea, fig. 97.

Weinkauff. Martini-Chemn. Conch. Cab. Ed. II, Vol. V, Cypraea, p. 94, P1. 28, fig. IO-I3.

Trion. Man. of Conch. Vol. VII, p. 187, Pl. 15, fig. 12, 13.

Stat. 66. Bank between islands of Bahuluwang and Tambolungan, south of Saleyer. 8 M. Dead coral, Halimeda, Lithothamnion. I Spec.

Stat. 99. North-Ubian, Sulu-archipelago. I6-23 M. Lithothamnion-bottom. I Spec.

Stat. 3 I 3. East of Dangar-Besar, Saleh-bay. Up to 36 M. Sand, coral and mud, and reef. 3 Spec.

The specimens belong to the colour-variety, with white lines arranged into distinct bands.

\section{Cypraea (Luponia) lutea Gronovius.}

Gronovius. Zoophylac. fasc. 3, Pl. I9, fig. I7.

KIEner. Coq. Viv. Vol. I, p. 40, Pl. I4, fig. 4 (Humphreysii).

ReEve. Conch. Ic. Vol. III, Cypraea, fig. I IO $c$.

Wernkauff. Martini-Chemn. Conch. Cab. Ed. II, Vol. V. Cypraea, p. 93, Pl. 28, fig. 6-9.

Tryon. Man. of Conch. Vol. VII, p. 187 , P1. I6, fig. 35, 36.

Stat. 2 I3. Saleyer. Reef. I Spec.

The only specimen is a rather young one, with two white bands and a few brown spots on the back of the shell. 
22. Cypraea (Luponia) asellus Linné.

LinNÉ. Syst. Nat. Ed. X, p. $722, \mathrm{~N}^{0} 309$.

Rumph. Amb. Rariteitkamer, p. I I8, Pl. 39, fig. M.

Kiener. Coq. Viv. Vol. I, p. 93, Pl. 31, fig. 3 .

ReEve. Conch. Ic. Vol. III, Cypraea, fig. 98.

Weinkauff. Martini-Chemn. Conch. Cab. Ed. II, Vol. V, Cypraea, p. 16, Pl. 4, fig. I, 2. TrYon. Man. of Conch. Vol. VIII, p. 187, Pl. 16, fig. 34 .

Stat. 78. Lumu-Lumu-shoal, Borneo-bank. Shore. I Spec.

23. Cypraea (Luponia) clandestina Linné.

LINNÉ. Syst. Nat. Ed. XII, p. 1177 .

Kiener. Coq. Viv. Vol. I, p. 30, Pl. 31, fig. 4.

ReEve. Conch. Ic. Vol. III, Cypraea, fig. IO6.

Weinkauff. Martini-Chemn. Conch. Cab. Ed. II, Vol. V, Cypraea, p. 8I, Pl. 24, fig. I, 4.

Tkyon. Man. of Conch. Vol. VII, p. 187, Pl. 16, fig. 37, 38 .

Stat. 6o. Haingsisi, Samau-island. Reef. I Spec.

The specimen is very young, still in the Bulla-state, it displays very beautifully the red hair-lines, though not so strong as in the perhaps exaggerated figure of WEINKaUfF (1. c.).

24. Cypraea (Luponia) cribraria Linné.

LinNé. Syst. Nat. Ed. X, p. $723, \mathrm{~N}^{0} 3$ IO.

Kiener. Coq. Viv. Vol. I, p. 26, Pl. 29, fig. I.

ReEve. Conch. Ic. Vol. III, Cypraea, fig. 8 I.

Weinkauff. Martini-Chemn. Conch. Cab. Ed. II, Vol. V, Cypraea, p. 1 I5, Pl. 34, fig. IO, II.

Tryon. Man. of Conch. Vol. VII, p. I90, Pl. I7, fig. 71, 72.

Stat. 234. Nalahia-bay, Nusa-Laut-island. Reef. I Spec.

25. Cypraca (Luponia) miliaris Gmelin.

GMelin. Syst. Nat. Ed. XIII, p. 3402 .

Kiener. Coq. Viv. Vol. I, p. 59, Pl. 8, fig. 2 (Lamarckii).

ReEve. Conch. Ic. Vol. III, Cypraea, fig. 36.

IVeinkauff. Martini-Chemn. Conch. Cab. Ed. II, Vol. V, Cypraea, p. I IO, Pl. 33, fig. 9, iz. Tryon. Man. of Conch. Vol. VII, p. 192, Pl. I7, fig. So.

Stat. 163. Seget, West entrance Selee (Galewo)-strait. 29 M. Sand and stone, mixed with nuud. I Spec.

Stat. 313. Dangar Besar, Saleh-bay. Up to $36 \mathrm{M}$. Sand, coral and mud. 2 Spec.

26. Cypraca (Luponia) erosa Linné.

LinNÉ. Syst. Nat. Ed. X, p. 723, $\mathrm{N}^{0} 315$.

Rumpr. Amb. Rariteitkamer, p. I17, Pl. 39, fig. A.

Kiener. Coq. Viv. Vol. I, p. 53, Pl. 9, fig. 2, 3.

ReEve. Conch. Ic. Vol. III, Cypraea, fig. 43.

Weinkauff. Martini-Chemn. Conch. Cab. Ed. II, Vol. V, Cypraea, p. 107, Pl. 33, fig. I-4.

Tryon. Man. of Conch. Vol. VII, p. 192, Pl. i8, fig. 90, 100, I. 
Stat. 43. Pulu Sarassa, Postillon-islands. Up to $3^{6}$ M. Coral. I Spec.

Stat. 47. Bay of Bima, near South fort. Shore. 2 Spec.

Stat. 89. Pulu Kaniungan Ketjil. Reef. 2 Spec.

Stat. 9I. Muaras-reef, inner side, East coast of Borneo. Up to 54 M. Hard coralsand. I Spec.

Stat. 133. Lirung, Salibabu-island. Reef. I Spec.

Stat. 213. Saleyer. Reef. I Spec.

Stat. 234. Nalahia-bay, Nusa-Laut-island. Reef. 3 Spec.

Stat. 285. South coast of Timor. 34 M. Lithothamnion. I Spec.

Stat. 313. East of Dangar Besar, Saleh-bay. Up to 36 M. Sand, coral and mud. I Spec.

"Amboina. I Spec.

The specimens belong to the form with well-developed margins; those from Stat. 47 have red lines on the margins and the base, thus approaching the var. nebrites Melv. (Cat. Cypraea, Mem. and Proc. Manch. Soc. 1888, p. 223).

27. Cypraea (Luponia) helvola Linné.

LinnÉ. Syst. Nat. Ed. X, p. $724, N^{0} 316$.

Rumph. Amb. Rariteitkamer, p. I17, Pl. 39, fig. B.

Kiener. Coq. Viv. Vol. I, p. 68, Pl. 28, fig. I.

ReEve. Conch. Ic. Vol. III, Cypraea, fig. 72.

Weinkauff. Martini-Chemn. Conch. Cab. Ed. II, Vol. V, Cypraea, p. ir6, Pl. 35, fig. I-4.

TRYON Man. of Conch. Vol. VII, p. 194, Pl. 19, fig. 8, 9.

Stat. 79. Pulu Kabala-dua, Borneo-bank. Reef. I Spec.

Stat. 8I. Pulu Sebangkatan, Borneo-bank. Reef. 2 Spec.

Stat. 89. Pulu Kaniungan Ketjil. Reef. I Spec.

Stat. 172. Island of Gisser. Reef. I Spec.

28. Cypraea (Luponia) flaveola Linné.

LinNÉ. Syst. Nat. Ed. X, p. $724, \mathrm{~N}^{0} 320$.

Reeve. Conch. Ic. Vol. III, Cypraea, fig. 95.

Tryon. Man. of Conch. Vol. VII, p. 195, P1. 19, fig. 20-22.

Dautzenberg. Journ. de Conchyl. 1902, p. 369.

Stat. 43. Pulu Sarassa, Postillon-islands. Up to 36 M. Coral. 2 Spec.

Stat. 93. Pulu Sanguisiapo, Tawi-Tawi-islands, Sulu-archipelago. Reef. I Spec.

Stat. 96. South side of Pearl-bank, Sulu-archipelago. I5 M. Lithothamnion-bottom. I Spec.

Stat. 99. North-Ubian. I6-23 M. Lithothamnion-bottom. I Spec.

Stat. 248. Rumah Lusi, North-point of Tiur-island. Reef. I Spec.

Stat. 282 . Betwcen Nusa Besi and N. E. point of Timor. 27-54 M. Sand, coral and Lithothamnion. 2 Spec.

Stat. 285. South coast of Timor. 34 M. Limit between mud and coral. 1 Spec.

Stat. 299. Buka or Cyrus-bay, South coast of Rotti-island. Up to 36 M. Mud, coral and Lithothamnion. I Spec.

Stat. 313. East of Dangar Besar, Saleh-bay. Up to 36 M. Sand, coral and mud. 2 Spec.

I have followed the quoted authors in occupying the name flaveola Lin. for this shell; Weinkauff (Mon. Cypraea, p. IO3) says that it should be only a variety of C. gangrenosa, and that the true $C$. flaveola Lin., might be a small variety of $C$. spurca $L i n$. It is no doubt nearly allied to the next species. 
29. Cypraea (Luponia) gangrenosa Solander.

Solander. Dillwyn. Descr. Cat. I, p. 465.

Kiener. Coq. Viv. Vol. I, p. 50, Pl. 50, fig. 2.

ReEve. Conch. Ic. Vol. III, Cypraea, fig. 96.

Weinkauff. Martini-Chemn. Conch. Cab. Ed. II, Vol. V, Cypraca, p. I2I, Pl. 36, fig. 2, 3.

Tryon. Man. of Conch. Vol. VII, p. 195, Pl. 19, fig. i8, 19.

Stat. 33. Bay of Pidjot, Lombok. 22 M. and less. Mud, coral and coralsand. I Spec.

30. Cypraea (Pustularia) staphylea Linné.

LiNnÉ. Syst. Nat. Ed. X, p. $725, \mathrm{~N}^{0} 324$.

Kiener. Coq. Viv. Vol. I, p. 48, Pl. 36, fig. 2.

Reeve. Conch. Ic. Vol. III, Cypraea, fig. $82 b$.

Weinkauff. Martini-Chemn. Conch. Cab. Ed. II, Vol. V, Cypraea, p. 117, Pl. 35, fig. 5-8.

Tryon. Man. of Conch. Vol. VII, p. 196, Pl. 20, fig. 39, 40.

Stat. 43. Pulu Sarassa, Postillon-islands. Up to 36 M. Coral. I Spec.

Stat. 6o. Haingsisi, Samau-island. Reef. I Spec.

Stat. 66. Bank between Bahuluwang and Tambolungan, South of Saleyer. 8 M. Dead coral, Lithothamnion. 2 Spec.

Stat. 285. South coast of Timor. 34 M. Limit between mud and coral. I Spec.

Stat. $306.8^{\circ} 27^{\prime}$ S., $122^{\circ} 54^{\prime} \cdot 5$ E. Flores Sea. 247 M. Sandy mud. I Spec.

The shell from Stat. 306 is a worn, quite bleached specimen, this accounts for the great depth at which it has been dredged, it will most probably have been washed down.

31. Cypraea (Pustularia) limacina Lamarck.

Lamiarci. An. s. vert. Ed. II, Vol. X, p. 536.

Kiener. Coq. Viv. Vol. I, p. 47, P1. 35, fig. I; Pl. 22, fig. 2.

ReEve. Conch. Ic. Vol. III, Cypraea, fig. $82 a$ (staphylea var.).

Troschel. Gebiss der Schnecken. Vol. I, p. 213, Pl. I7, fig. I9.

TRYon. Man. of Conch. Vol. VII, p. 196, Pl. 20, fig. 42-44 (interstincta).

Stat. 99. North-Ubian. 16-23 M. Lithothamnion-bottom. I Spec.

Though I must admit that the characters of the radula are often insufficient to decide upon the specific value of species, the differences between the radula of the species under consideration and the preceding one, seem to be of too much importance, to consider them as varieties of one and the same species. It would be interesting to examine the radulae of specimens which conchologically are intermediate, and to make out, to which of the two forms they are the nearest allies.

32. Cypraca (Pustularia) mucleus Linné.

LinNÉ. Syst. Nat. Ed. X, p. $724, \mathrm{~N}^{0} 323$.

RuMPh. Amb. Rariteitkamer, p. I I8, Pl. 39, fig. I.

Kútener. Coq. Viv. Vol. I, p. I27, Pl. 3, fig. 2.

Reeve. Conch. Ic. Vol. III. Cypraea, fig. 70. 
Weinkauff. Martini-Chemn. Conch. Cab. Ed. II, Vol. V, Cypraea, p. I30, Pl. 37, fig. I3, I4. Tryon. Man. of Conch. Vol. VII, p. 197, Pl. 20, flg. 48, 49.

Stat. 53. Bay of Nangamessi, Sumba. Reef. I Spec.

Stat. 234. Nalahia-bay, Nusa-Laut-island. Reef. 2 Spec.

\section{- Trivia Gray.}

1. Trivia oryza Lamarck.

LANARCK. An. s. vert. Ed. II, Vol. X, p. 543 (Cypraea).

Rumpi. Amb. Rariteitkamer, p. i 8 , Pl. 39, fig. P.

Kiener. Coq. Viv. Vol. I, Cypraea, p. 140, Pl. 52, fig. 2, $2 a$.

ReEve. Conch. Ic. Vol. III, Cypraea, fig. I40.

Weinkauff. Martini-Chemn. Conch. Cab. Ed. II, Vol. V, Cypraea, p. I53, Pl. 5, fig. I2, I3;

Pl. 4I, fig. I3-I 6 .

Tryon. Man. of Conch. Vol. VII, p. 200, Pl. 21, fig. 82, 83 .

Stat. 58. Seba, Savu. Reef. I Spec.

Stat. 21 3. South-island near Saleyer. Reef. I Spec.

Stat. 234. Nalahia, Nusa-Laut-island. Reef. I Spec.

Stat. 240. Banda. 9-45 M. Black sand, coral. I Spec.

Stat. 250. Kilsuin, West coast of Kur-island. Reef. I Spec.

forma minor.

Stat. 37. Sailus Ketjil, Paternoster-islands. 27 M. and less. Coral and coralsand. I Spec.

Stat. 66. Bank between islands of Bahuluwang and Tambolungan, South of Saleyer. 8-ro M. Dead coral, Halimeda and Lithothamnion. 4 Spec.

Stat. $95.5^{\circ} 43^{\prime} .5$ N., I I $9^{\circ} 40^{\prime}$ E. Sulu Sea. 522 M. Stony bottom. 2 Spec.

Stat. $98.6^{\circ} 9^{\prime}$ N., $120^{\circ} 2 \mathrm{I}^{\prime}$ E. Sulu Sea. 350 M. Sand. 2 Spec.

Stat. 133. Lirung, Salibabu-island. Up to $36 \mathrm{M}$. Mud and hard sand. I Spec.

Stat. 204. Between islands of Wowoni and Buton, Northern entrance of Buton-strait. 75-94 M. Sand with dead shells. I Spec.

Stat. 225. South Lucipara-island. Reef. I Spec.

The specimens which I have united under the name minor are considerably smaller than the typical ones, the largest having only a length of $7^{1 / 2}$, the smallest of 5 Mill. Some of them show a tendency to become rostrate, and thus form a passage to the next variety.

var. scabriuscula Gray.

GRAY. Zoological Journal. Vol. III, p. 364.

Weinkauff. Martini-Chemn. Conch. Cab. Ed. II, Vol. V, Cypraea, p. I52, Pl. 4I, fig. io, II. Tryon. Man. of Conch. Vol. VII, p. 200, Pl. 21, fig. 79.

Stat. 37. Sailus-Ketjil, Paternoster-islands. 27 M. and less. Coral and coralsand. 6 Spec.

Stat. 43. Pulu Sarassa, Postillon-islands. Up to 36 M. Coral. 3 Spec.

Stat. 59. Western entrance Samau-strait. 390 M. Coarse coralsand with small stones. 3 Spec.

Stat. 66. Bank between islands of Bahuluwang and Tambolungan. 8-io M. Dead coral,

Halimeda and Lithothamnion. 2 Spec.

Stat. 91. Muaras-reef, inner side, East coast of Borneo. 54 M. Hard coralsand. I Spec.

Stat. 99. North-Ubian. I6-23 M. Lithothamnion-bottom. I Spec.

Stat. I 44. North of Salomakiëe-(Damar)-island. 45 M. Coral bottom and Lithothannion. I Spec. Stat. 240. Banda. 9-36 M. Lithothamnion. I Spec. 
This variety has been considered as a separate species, as a variety and even merely as a synonym, I have applied the name to specimens, which are conspicuously beaked, but they are connected to the type by the former var.; only one specimen from Stat. 37 is of nearly typical size, being $\mathrm{rO}^{2} / 2$ Mill. in length, the other specimens may belong to Gray's var. $\beta$ minor, though his type of that variety, seems to be more elongate ( $1 / 5$ of an inch long, and $1 / 10$ of an inch broad", Gray l. c.).

\section{Trivia insecta Mighels.}

Mighels. Proc. Boston Soc. nat. hist. Vol. II, I 845 , p. 24.

Kiener. Coq. Viv. Vol. I, Cypraea, p. 149, Pl. 54, fig. 5, 5 a (hordacea).

Weinkauff. Martini-Chemn. Conch. Cab. Ed. II, Vol. V, Cypraea, p. 162, Pl. 43, fig. 5, 8 (hordacea).

Tryon. Man. of Conch. Vol. VII, p. 200, Pl. 21, fig. $84,85$.

Stat. 220. Pasir Pandjang, West coast of Binongka. 55 M. Coralsand. I Spec.

The only specimen is very small, having only a length of about $3^{1 / 4}$ Mill.

3. Trivia globosa Gray.

Gray. Descript. Catalogue p. 14.

ReEve. Conch. Ic. Vol. III, Cypraea, fig. I52.

Weinkauff. Martini-Chemn. Conch. Cab. Ed. II, Vol. V, Cypraea, p. 151, Pl. 14, fig. 6, 7 . TrYon. Man. of Conch. Vol. VII, p. 200, P1. 21, fig. 92, 93.

Stat. 164. $\mathrm{I}^{\circ} 42^{\prime} \cdot 5$ S., I $30^{\circ} 47^{\prime} \cdot 5$ E. Halmahera Sea. $32 \mathrm{M}$. Sand, small stones and shells. I Spec.

Dautzenberg (Journ. de Conch. Vol. 50, p. 382 ) records this species from New Caledonia and Lifu, on the authority of Rossiter and LAMBert.

\section{Trivia brevissina Sowerby.}

Sowerby. Thes. Conch. Vol. IV, Cypraea, p. 47, P1. 37, fig. 523, 524.

Tryon. Man. of Conch. Vol. VII, p. 204, Pl. 21, fig. 90, 91.

Stat. 33. Bay of Pidjot, Lombok. 22 M. Mud, coral and coralsand. I Spec.

In the original description Sowerby says: "sulco dorsali nullo aut inconspicuo"; TryoN has located the species in his section without dorsal impression. In consequence I cannot agree with the view that Cypraca pitula Kiener should be a synonym; Kiener says that the dorsal impression is rather deep in his species. Weinkauff (Conch. Cab. Ed. II, Cypraea, p. I59) says also, dealing with C.pilula: "linea dorsali impressa" and adds in a footnote that the lithographer has forgotten it in the figure. The Siboga-specimen has a very shallow impression, much less conspicuous than the specimen of the former species.

\section{Trivia aby'ssicola n. sp. Pl. XI, fig. I.}

Stat. 59. Western entrance Samau-strait. 390 M. Coarse coralsand with small stones. I Spec. Stat. 98. $6^{\circ} 9^{\prime}$ N., $120^{\circ} \cdot 21^{\prime}$ E. Sulu Sea. 350 M. Sand. I Spec.

Stat. 105. $6^{\circ} 8$ N., $121^{\circ} 19^{\prime}$ E. Sulu Sea. 275 M. Coralbottom. 3 Spec. 
Shell ovate, moderately inflate, white, pellucid, right margin thickened, extremities slightly produced, especially the anterior one, with rather numerous ribs, of which the majority runs from one side to the other and a few intermediate ones, no dorsal sulcus. Aperture rather wide, especially towards the front, slightly arcuate, its right margin but little inflected, thickened exteriorly, strongly crenulated by the ribs, which form from 18 to 21 teeth; anterior sinus wide, posterior one narrower by a crenulated callus, columellar margin not thickened, with about 20 teeth, the interstices of the ribs of both the right and columellar margin granulous, the interstices on the back smooth.

Long. 7, lat. 5, alt. 4 Mill.

The species resembles amongst the white ones without dorsal impression, in some respects T. pellucidula Gaskoin, which has however much more and finer ribs. One of the specimens from Stat. 105 contains the soft parts and may serve as a proof that the species lives at the recorded great depth.

6. Trivia paucicostata n. sp. Pl. XI. fig. 2.

Stat. $95.5^{\circ} 43^{\prime} .5$ N., $119^{\circ} 40^{\prime}$ E. Sulu Sea. 522 M. Stony bottom. 3 Spec.

Shell shortly ovate, swollen, greyish-white (perhaps flesh-coloured in life), with few strong ribs and rather wide, smooth interstices, considerably broader than the ribs; no dorsal impression, the majority of the ribs runs from one side to the other, with a few intermediate ones which don't reach the centre. Aperture rather wide, running on the right side of the ventral face, slightly wider at the anterior end. Right margin relatively thin, with a thickened rib exteriorly and only 13 teeth, columellar margin with about i 4 teeth, slightly excavated interiorly, front sinus large, posterior one narrower, with a small callosity on the left side, anterior end slighty rostrate or produced; interstices of the ribs on the apertural margins granose.

Long. $8^{1} / 2$, lat. $6^{3} / 4$, alt. $5^{1} / 2$ Mill.

This and the next species resemble some of the South-African species by their aperture, which lies on the right side of the base, and is larger than usually in Trivia. In sculpture, but not in shape, it resembles T. Buttoni Melv. (Ann. Mag. Nat. Hist. Ser. 7, Vol. VI, 1900, p. 209) this species is however more regularly ovate in outline, the dorsal view of the new species being subtrigonal, in consequence of the blunt posterior part, in Buttoni the aperture is much narrower and is situated more centrally.

7. Trivia sibogae n. sp. P1. XI, fig. 3 .

Stat. 105. $6^{\circ} 8^{\prime}$ N., $121^{\circ} 19^{\prime}$ E. Sulu Sea. 275 M. Coralbottom. 3 Spec.

Shell shortly-ovate, globose, thin, light flesh-coloured, with numerous rather strong ribs and smooth interstices, which are but a little broader than the ribs, no dorsal impression; several of the ribs don't reach the centre, while others run from one side to the other. Aperture rather wide, slightly enlarged towards the front part, placed at the right side of the ventral face. Right margin slightly involved, strongly thickened exteriorly, its inner margin with 19 or 20 teeth; 
columellar margin with about 2 I teeth and a crenulated callosity at its upper part, bordering the posterior, rather wide sinus; anterior sinus slightly larger and produced, columellar margin excavated interiorly, towards the anterior sinus; margins of the aperture granulose in the interstices. Long. I 2 , lat. 9, alt. $8^{1} /$. Mill., smaller specimen Long. $9^{1 / 2}$, lat. $7^{1} / 2$, alt. $61 / 2$ Mill.

forma minor. Pl. XI, fig. 4 .

Stat. $95.5^{\circ} 43^{\prime} .5$ N., $119^{\circ} 40^{\prime}$ E. Sulu Sea. 522 M. Stony bottom. 4 Spec.

Stat. 3I 5. East of Sailus-Besar, Paternoster-islands. Up to $36 \mathrm{M}$. Coral and Lithothamnion. I Spec.

Two specimens from Stat. 95 are still smaller, being only $7^{1 / 2}$ Mill. in length, but agree in most respects, in sculpture with the type, however the ribs are slightly coarser, the teeth of the right margin less numerous ( 15 and 17 ), the other specimens and that from Stat. 315 are a little doubtful, as they are still considerably smaller, length only 6 Mill., the aperture is not so large and the right margin thicker; as they are dead shells, I prefer to keep them under one name with the variety, instead of describing a new species on a few gradual differences. This species with its variety, differs from the former one, by its much more numerous ribs with numerous intermediate ones, the larger number of teeth and inflated shape.

\section{Erato Risso.}

\section{Erato gallinacea (Hinds Mss) Reeve.}

Reeve. Conch. Ic. Vol. XV, Erato, fig. 7.

Weinkauff. Martini-Chemn. Conch. Cab. Ed. II, Vol. V, Erato, p. I50, Pl. 24, fig. I4, is. Tryon. Man. of Conch. Vol. V, p. io, Pl. 4, fig. 46.

Stat. 37. Sailus Ketjil, Paternoster-islands. Up to I8 M. Coral and coralsand. 2 Spec.

Stat. 47. Bay of Bima, near South fort. 55 M. Mud with patches of fine coralsand. I Spec.

Stat. 258. Tual, Kei-islands. 22 M. Lithothamnion, sand and coral. I Spec.

The specimens agree very will with the figures and descriptions, but they have small granules on the spire and towards the base of the shell.

\section{Fam. Ampuiperasidae Adams.}

Amphiperas Gronovius.

1. Amphiperas ounm Linné.

Linné. Syst. Nat. Ed. X, p. 725, N0 327 .

Rumph. Amb. Rariteitkamer, p. 115, P1. 38, fig. Q.

Kiener. Coq. Viv. Vol. I, Ovula, p. 3, Pl. I and Pl. 3, fig. 5 (oviformis).

ReEve. Conch. Ic. Vol. XV, Ovulum, fig. 3 .

Weinkauff. Martini-Chemn. Conch. Cab. Ed. II, Vol. V, Ovula, p. I68, Pl. 44, fig. 2, 4, 5. Tryon. Man. of Conch. Vol. VII, p. 246, Pl. I, fig. II, I2.

Stat. 21 3. Saleyer. Reef. I Spec.

Stat. 231. Amboina. Reef. I Spec.

Stat. 30I. Pepela-bay, East coast of Rotti-island. 22 M. Mud, coral and Lithothamnion. I Spec. 
Both specimens are very young; a figure after a living animal has been given in Monograph L of this work, amongst the Opisthobranchiata, P1. V, fig. 21.

\section{Amphiperas lacteum Lamarck.}

Lamarck. An. s. vert. Ed. II, Vol. X, p. 469.

Kiener. Coq. Viv. Vol. I, Ovula, p. 8, Pl. 6, fig. I.

ReEve. Conch. Ic. Vol. XV, Ovulum, fig. I.

Weinkauff. Martini-Chemn. Conch. Cab. Ed. II, Vol. V, Ovula, p. I7O, Pl. 44, fig. I, 2.

Tryon. Man. of Conch. Vol. VII, p. 247, Pl. 2, fig. 2, $23,24$.

Stat. 66. Bank between islands of Bahuluwang and Tambolungan, South of Saleyer. 8 M. Dead coral, Halimeda, Lithothamnion. 2 Spec.

Stat. I31. Beo, Karakelang-islands. Reef. I Spec.

I think Tryon is right in uniting $A$. semistriatum with this species. Indeed I have never seen fresh specimens of $A$. lacteum, without more or less impressed striae at both extremities of the shell.

\section{Amphiperas pudicum A. Adams.}

ADAMS. Proc. Zool. Soc. Lond. i854, p. I 31 .

REEve. Conch. Ic. Vol. XV, Ovulum, fig. 6.

Weinkauff. Martini-Chemn. Conch. Cab. Ed. II, Vol. V, Ovula, p. I72, Pl. 45, fig. 3, 4.

Tryon. Man. of Conch. Vol. VII, p. 247, Pl. 2, fig. 29-3I.

Stat. 2. Madura-strait. 56 M. Grey mud with some radiolariae. I Spec.

Stat. $98.6^{\circ} 9^{\prime}$ N., $120^{\circ} 2 I^{\prime}$ E. Sulu Sea. 350 M. Sand. I Spec.

Stat. 285. South coast of Timor. 36 M. Limit between mud and coral. I Spec.

The specimens are very small, that from Stat. $2 S_{5}$ measures only 8 Mill. in length, that from Stat. 98, which is the largest, 11 Mill.; this latter specimen, which may have been washed down to that considerable depth, is bleached and shows only traces of striae on both extremities, which are more distinct on the two other specimens; this latter character reminds $A$. calcdonicum Crosse, but that species has been described as "striated", without the restriction that this should only be at the extremities. Now of the specimens under consideration, that from Stat. 98 is nearly quite smooth, with only a few striae at the posterior extremity and perhaps one or two at the anterior one, that from Stat. 285 has anterior and posterior striae and is smooth at the central part of the back, and that from Stat. 2 has also a few indistinct striae on the back, but it is not decussated, as it should be in $A$. caledonicum, nor can I detect brown spots on the back, for the spots I see on the last-named specimen, seem to be accidental.

\section{Amphiperas margarita Sowerby.}

Sowerby. Spec. Conchyl. Vol I, part I, Ovulum, p. 4, fig. 19, 20.

Kiener. Coq. Viv. Vol. I, Ovula, p. 11, Pl. 6, fig. 4.

ReEve. Conch. Ic. Vol. XV, Ovulum, fig. 10.

Weinkauff. Martini-Chemn. Conch. Cab. Ed. II, Vol. V, Ovula, p. I45, Pl. 46, fig. 2, 3.

Tryon. Man. of Conch. Vol. VII, p. 248, PI. 2, fig. 34, 35. 
Stat. 49". Sapeh-strait. 69 M. Coral and shells. I Spec.

Stat. $164 . I^{\circ} 42^{\prime} .5$ S., $130^{\circ} 47.5$ E. Halmahera Sea. 32 M. Sand, small stones and shells. 1 Spec.

Stat. 313. East of Dangar Besar, Saleh-bay. Up to $36 \mathrm{M}$. Sand, coral and mud. I Spec.

The largest specimen from Stat. 164 measures I 6 Mill. in length, that from Stat. 3I 3 only $81 / 2$ Mill.

\section{Amphiperas concinmum Adams \& Reeve.}

Adams and ReEve. Voy. Samarang. Moll. p. 22, P1. 6, fig. 8.

ReEve. Conch. Ic. Vol. XV, Ovulum, fig. $2 \mathrm{I}$.

Weinkauff. Martini-Chemn. Conch. Cab. Ed. II, Vol. V, Ovula, p. 182, Pl. 47, fig. $5,8$.

Tryon. Man. of Conch. Vol. VII, p. 249, Pl. 3, fig. 59, 60, 74.

Stat. 252. Near Taam-island. 27 M. Coralsand. I Spec.

6. Amphiperas roseomaculatum n. sp. Pl. XI, fig. IO.

Stat. $98.6^{\circ} 9^{\prime}$ N., $120^{\circ} 21^{\prime}$ E. Sulu Sea. 350 M. Sand. 1 Spec.

Stat. $164 . I^{\circ} 42^{\prime} .5$ S., $130^{\circ} 47^{\prime} .5$ E. Halmahera Sea. 32 M. Sand, small stones and shells. I Spec.

Shell small, pyriform, strongly angular on the back, the extremities elongate, thin, transparent white, with rose-coloured, irregular spots, arranged in three bands, one near the spire, one near the centre before the angle, the third near the anterior part, moreover the extremities are rosetinted. Sculpture consisting of rather broad, waved, impressed striae, which are shallow, but at least half as broad as the lirae, they are crossed by fine growth-striae, which are partly stronger, so as to render the surface here and there cancellated; the angle is placed on the posterior half, the shell is rapidly contracted towards the posterior part, regularly contracted towards the anterior part. Aperture narrow, angular, with a short canal at both extremities; outer margin thickened, with numerous fine teeth on the front part, much stronger towards the spire, where they cross the thickened margin and render it crenulate on its external margin, being visible in the dorsal view; columellar margin with a crenulate callus behind, a fold borders the front canal, this margin is excavated internally; a thin layer of enamel covers the columellar side of the shell.

Long. $8 / 4$, lat. 5 Mill.

This species is nearly allied to $A$. concinmum, but differing in many particulars, the shell is stronger angulate, more rapidly contracted towards the spire, a line from the angle of the back towards the spire being nearly straight in $A$. concinnum, strongly excavated in the new species, the striae are much coarser, the lirae narrower, the teeth of the outer margin are stronger, the shell is thinner and different in colour.

The specimen from Stat. I $\sigma_{4}$ is still young, the teeth on the thinner margin are not yet developed.

\section{Amphiperas striatulum Sowerby.}

Sowerby. Species Conchyliorum. Vol. I, part I, Ovulum, p. 7, fig. ${ }_{3} 8$.

ReEve. Conch. Ic. Vol. XV, Ovulum, fig. 28. 
Weinkauff. Martini-Chemn. Conch. Cab. Ed. II, Vol. V, Ovula, p. 186, Pl. 48, fig. $2,3$. Tryon. Man. of Conch. Vol. VII, p. 250, Pl. 3, fig. 76,77 .

Stat. I64. $I^{\circ} 42^{\prime} \cdot 5$ S., I $30^{\circ} 47^{\prime} \cdot 5$ E. Halmahera Sea. 32 M. Sand, small stones and shells. 3 Spec.

The three specimens are slightly different from each other, the smallest agrees with the original description, being small and white, however with orange-coloured extremities (perhaps Sowerby's specimen was a bleached one), the other adult one is larger but agrees with the descriptions of REEVE and WEINKAUFF, the third is a young shell, with a thin right margin; its colour is white on the ventral side, light orange-red on the back, with 3 white bands; perhaps this depends on age. I can see no reason to distinguish this juvenile specimen by a new name, only on partly different colour.

8. Amphiperas (Cyphoma) formosum Adams \& Reeve.

Adams \& Reeve. Voy. Samarang, Moll. p. 22, Pl. 6, fig. 6.

ReEve. Conch. Ic. Vol. XV, Ovulum, fig. 39.

Weinkauff. Martini-Chemn. Conch. Cab. Ed. II, Vol. V, Ovula, p. I89, Pl. 48, fig. Io, ir. TrYon. Man. of Conch. Vol. VII, p. $25 \mathrm{I}$, Pl. 4, fig. I5, I6.

Stat. I64. $1^{\circ} 42^{\prime} .5$ S., I $30^{\circ} 47^{\prime} \cdot 5$ E. Halmahera Sea. 32 M. Sand, small stones and shells. I Spec. Stat. 213. Saleyer. 9-34 M. Mud and mud with sand. 4 Spec.

Stat. 3 IO. $8^{\circ} 30^{\prime}$ S., $119^{\circ} 7^{\prime} .5$ E. Flores Sea. 73 M. Sand with few pieces of dead coral. I Spec.

One of the specimens from Saleyer, with the living animal, has been figured in the Monograph on the Opisthobranchiata of this work, on Plate 5, fig. 20.

\section{Amphiperas (Cyphoma) Semperi Weinkauff.}

Weinkauff. Martini-Chemn. Conch. Cab. Ed. II, Vol. V, Ovula, p. I90, Pl. 48, fig. I4, I5. ReEve. Conch. Ic. Vol. XV, Ovulum, fig. 37 (hordacenn).

Tryon. Man. of Conch. Vol. VII, p. 25 I, Pl. 4, fig. 17, 18; Pl. 5, fig. 19.

Stat. 240. Banda. Reef. 2 Spec.

Stat. 315. East of Sailus Besar, Paternoster-islands. Up to $36 \mathrm{M}$. Coral and Lithothamnion. I Spec.

Wernkauff (1.c.) calls this species $O$. Sempieri, evidently by error, for in his Catalogue of the genus Ovula (Jahrb. der deutschen Mal. Gesellsch. 1882, p. I74) he writes the name Sempcri.

The specimen from Stat. 3 I 5 is more typical, purplish, with narrow aperture; those from Banda are pale yellow, with larger aperture, like TRyos's fig. 19.

\section{Io. Amphiperas (Radius) volva Linné.}

LinNÉ. Syst. Nat. Ed. X, p. 725, $\mathrm{N}^{0} 328$.

Kiener. Coq. Viv. Vol. I, Ovula, p. 26, Pl. 4, fig. I.

REEve. Conch. Ic. Vol. XV, Ovulum, fig. $4 \mathrm{I}$.

Weinkauff. Martini-Chemn. Conch. Cab. Ed. II, Vol. V, Ovula, p. 196, Pl. 50, fig. $4,5$.

Tryon. Man. of Conch. Vol. VII, p. 252, Pl. 4, fig. 94, 95. 
Stat. 240. Banda. 9-45 M. Black sand, coral. I Spec.

Stat. 260. Near Nuhu Jaan, Kei-islands. 90 M. Sand, coral and shells. I Spec.

Stat. $318.6^{\circ} 36^{\prime} .5$ S., $140^{\circ} 55^{\prime} .5$ E. Java Sea. 88 M. Fine, yellowish-grey mud. I Spec.

The specimen from Stat. 260 is very young.

I . Amphiperas (Radius) philippinarum Sowerby.

Sowerby. Proc. Zool. Soc. i 848 , p. I36.

ReEve. Conch. Ic. Vol. XV, Ovulum, fig. 46.

Weinkauff. Martini-Chemn. Conch. Cab. Ed. II, Vol. V, Ovula, p. 199, Pl. 5 I, fig. 2, 3.

Tryon. Man. of Conch. Vol. VII, p. 252, Pl. 4, fig. 100, I.

Stat. 273. Pulu Jedan, East coast of Aru-islands. 13 M. Sand and shells. 5 Spec.

Stat. $310.8^{\circ} 30^{\circ}$ S., $119^{\circ} 7^{\prime} .5$ E. Flores Sea. 73 M. Sand with few pieces of dead coral. I Spec.

The specimen from Stat. 3 10 is still very young and a little doubtful, those from Stat. 273 are fine and adult. I think Tryon has gone too far in uniting so many species to A. plitippinarum, so I have recorded the two next forms as separate species.

The radula is long, yellowish-brown and consists of a large number of transverse rows of teeth. The rhachidian tooth ( $R$ ) has a broad sub-quadrangular body with convex upper and basal margin, a long sharp median denticle and 3 smaller ones on each side, the laterals ( $\mathrm{I}$ ) have an elongate body ending in a tail on the distal side and a tricuspid cusp, composed of a very large central denticle and a small one on each side, the uncini have the ordinary comblike structure, the inner one has 15 denticles, of which the majority is simple, only a few of the distal ones and sometimes one or two others are bifid, the denticles of the outermost of the uncini are as a rule bifid, in a few I see three cusps, the number of denticles is about 40 , with a knoblike one at the distal extremity.

\section{Amphiperas (Radius) Angasi (Adams) Reeve.}

ReEve. Conch. Ic. Vol. XV, Ovulum, fig. 43.

Weinkauff. Martini-Chemn. Conch. Cab. Ed. II, Vol. V, Ovula, p. I99, Pl. 5I, fig. 5, 8.

Tryon. Man. of Conch. Vol. VII, p. 252, Pl. 4, fig. 3, 4 (philippinarum pars).

Stat. I64. I $^{\circ} 42.5$ S., I $30^{\circ} 47.5$ E. Halmahera Sea. 32 M. Sand, small stones and shells. I Spec. Stat. 273. Pulu Jedan, East coast of Aru-islands. 13 M. Sand and shells. 4 Spec.

Stat. 315. East of Sailus Besar, Paternoster-islands. Up to 36 M. Coral and Lithothamnion. I Spec.

The specimen from Stat. 164 is a dead shell with impressed striae over the whole surface, this may however depend on the circumstance that the shell is slightly worn, as I see traces of these striae in a fresh but young specimen from Stat. 273. The shell is in comparison much narrower than the preceding one, the shape is more elegant, in fresh specimens the tips are slightly rosy.

The radula resembles in many respects that of the former species. The rhachidian tooth (R) has a sub-quadrangular body, with a long median denticle and two smaller ones at each side; the laterals ( 1 ) with their tailed body, have also a long cusp with one smaller denticle on the inner, two very small ones on the outer margin. The uncini are comblike, with usually simple and a few bifid denticles amongst the inner ones and bi- and trifid in the outer ones. 
As far as may be judged from a single radula of each species, its characters, in connection with the conchological ones, are favorable to the specific distinctness of the two forms.

13. Amphiperas (Radizs) deflexum Sowerby.

Sowerby. Proc. Zool. Soc. Lond. 1848 , p. 136.

ReEve. Conch. Ic. Vol. XV, Ovulum, fig. 56.

Weinkauff. Martini-Chemn. Conch. Cab. Ed. II, Vol. V, Ovula, p. 206, Pl. 52, fig. 6, 7 .

Tryon. Man. of Conch. Vol. VII, p. 252, Pl. 4, fig. 8.

Stat. 98. $6^{\circ} 9^{\prime}$ N., $120^{\circ} 21^{\prime}$ E. Sulu Sea. 350 M. Sand. I Spec.

Stat. 213 . Saleyer. Reef. I Spec.

The specimen. from Saleyer is a fine, adult one, that from Stat. 98 is worn and partly broken, consequently it remains doubtful; probably washed down.

14. Amphiperas (Radius) birostre Linné.

LinnÉ. Syst. Nat. Ed. XII, p. I I82.

Kiener. Coq. Viv. Vol. I, Ovula, p. 24, Pl. 5, fig. I.

ReEve. Conch. Ic. Vol. XV, Ovulum, fig. 45.

Weinknuff. Martini-Chemn. Conch. Cab. Ed. II, Vol. V, Ovula, p. 200, Pl. 5, fig. $22,23$.

Tryon. Man. of Conch. Vol. VII, p. 253, Pl. 4, fig. IO, II.

Stat. $164.1^{\circ} 42^{\prime} .5$ S., $130^{\circ} 47^{\prime} .5$ E. Halmahera Sea. 32 M. Sand, small stones and shells. 2 Spec.

Stat. 240. Banda. 9-45 M. Black sand, coral. I Spec.

Stat. 273. Pulu Jedan, East coast of Aru-islands. 13 M. Sand and shells. 2 Spec.

One of the specimens from Stat. I 64 is young, the other though by its thickened peristome evidently nearly adult is very small, measuring only 23 Mill. in length, those from Stat. 273 are typical.

15. Ampliperas (Neosimnia) secale Sowerby.

Sowerby. Species Conchyliorum. Vol. I, Part I, Ovulum, p. 8, fig. 36.

ReEve. Conch. Ic. Vol. XV, Ovulum, fig. 66.

Weinkauff. Martini-Chemn. Conch. Cab. Ed. II, Vol. V, Ovula, p. 2 Io, Pl. 53, fig. 6, 7 .

Tryon. Man. of Conch. Vol. VII, p. 254, Pl. 5, fig. 28, 29.

Stat. $253 \cdot 5^{\circ} 48^{\prime} .2$ S., $132^{\circ}{ }_{13}^{\prime}$ E. Arafura Sea. 304 M. Grey clay, hard and crumbly. 5 Spec.

The depth at which the specimens have been captured, makes a somewhat exceptional appearance amongst the other species of the genus ${ }^{1}$ ); the specimens contain the soft parts and so one may conclude that they will have lived on the collecting-ground.

The rhachidian tooth $(R)$ of the radula has a broad, angular body, with a rounded basal line, its cusp has one large median denticle and on each side four smaller ones; the lateral tooth ( $\mathrm{I}$ ) has a rhombic shape with a taillike process on the distal side of the body and a long cusp with four smaller ones on the visible distal side of the reflected margin; the uncini have the family-character, the denticles of the outer ones are bifid and trifid.

I) Those from Stat. 98 probably having been washed down. 


\section{Calpurnus Montfort.}

I. Calpurnuts verrucosus Linné. Pl. XV, fig. Iо.

LinNÉ. Syst. Nat. Ed. X, p. $726, \mathrm{~N}^{0} 330$.

RumpH. Amb. Rariteitkamer, p. I14, Pl. 38, fig. H.

Kiener. Coq. Viv. Vol. I, Ovula, p. 5, Pl. 2, fig. 3.

ReEve. Conch. Ic. Vol. XV, Ovulum, fig. 2.

Wernkauff. Martini-Chemn. Conch. Cab. Ed. II, Vol. V, Ovula, p. I7 I, Pl. A, fig. 7; Pl. 44, fig. 6,8 .

TrYON. Man. of Conch. Vol. VII, p. 256, Pl. 5, fig. 56-58.

Stat. I 3I. Beo, Karakelang-islands. Reef. 6 Spec.

Stat. 26r. Elat, West coast of Great-Kei-island. Reef. I Spec.

Stat. 30r. Pepela-bay, East coast of Rotti-island. Reef. 1 Spec.

According to TRYoN the radula of this species is still unknown, and I am not aware that it has since been described. Its location amongst the Amphiperasidae has even been doubtful. In an old radula of this species from Amboina I see that by the characteristic comblike uncini the genus belongs without doubt to that family. The teeth of the central field are however sufficiently different from its allies to consider the genus Calpurnus as a valid one. The rhachidian tooth $(\mathrm{R})$ has a broad body, with two wings near the base and a very large central cusp, with one or two small denticles at its base. The laterals ( $I$ ) have a subquadrangular body and a very long archlike cusp, with a small denticle about halfway; these teeth are quite different from those of other species of this family figured by TROsciel.

\section{Fam. Stronbidae.}

\section{Strombus Linné.}

I. Strombus canarizum Linné.

Linné. Syst. Nat. Ed. X, p. $745, N^{0} 438$.

Ruмpн. Amb. Rariteitkamer, p. I Iо, Pl. 36, fig. N.

Kiener. Coq. Viv. Vol. III, Strombus, p. 33, Pl. 29, fig. I.

KỨSter. Martini-Chemn. Conch. Cab. Ed. II, Vol. IV, Strombus, p. 43, Pl. 7, fig. 4.

REeve. Conch. Ic. Vol. VI, Strombus, fig. $46 a$.

TRYon. Man. of Conch. Vol. VII, p. IIO, Pl. 2, fig. 18, I9?

Stat. 2I 3. Saleyer. Reef. I Spec.

The specimen is not quite adult, the peristome is still rather thin; it is covered by a comparatively thick fibrous epidermis.

2. Strombus isabella Lamarck.

LAmarck. An. s. vert. Ed. II, Vol. IX, p. 700.

KIEner. Coq. Viv. Vol. III, Strombus, p. 32, Pl. 25, fig. 2.

Küster. Martini-Chemn. Conch. Cab. Ed. II, Vol. IV, Strombus, p. 4I, Pl. 7, fig. 3. 
ReEve. Conch. Ic. Vol. VI, Strombus, fig. 5 I.

Tryon. Man. of Conch. Vol. VII, p. I IO, PI. 2, fig. 20 (canariun var.).

Stat. 4. Djangkar (Java). 9 M. Coarse sand. I Spec.

Stat. 33. Bay of Pidjot, Lombok. 22 M. Mud, coral and coralsand. 2 Spec.

The specimen from Stat. 4 is very young, those from Stat. 33 are fine and adult, the largest one has a shell of 70 Mill. in length, both are covered on the back of last whorl by a fibrous epidermis, resembling that of the former species, but not so thick. Tryos has united the two species and Troschel has found no differences in the radulae. In accordance with the majority of authors, I have kept them separated.

\section{Strombus (Euprotomus) lentiginosus Linné.}

LinnÉ. Syst. Nat. Ed. X, p. $743, \mathrm{~N}^{0} 427$.

Rumph. Amb. Rariteitkamer, p. I I , Pl. 37, fig. Q.

Kiener. Coq. Viv. Vol. III, Strombus, p. 25, Pl. I8, fig. I.

Küster. Martini-Chemn. Conch. Cab. Ed. II, Vol. IV, Strombus, p. 2I, Pl. 4, fig. I, 2; Pl. 5, fig. 2, 3 .

ReEve. Conch. Ic. Vol. VI, Strombus, fig. 3 I.

Tryon. Man. of Conch. Vol. VII, p. I IO, Pl. 3, fig. 23, 24.

Stat. I42. Laiwui, coast of Obi Major. 23 M. Mud. I Spec.

Stat. 193. Sanana-bay, East coast of Sula Besi. 22 M. Mud. I Spec.

Stat. 225. South of Lucipara-island. Reef. 3 Spec.

Stat. 234. Nalahia-bay, Nusa-Laut-island. 46 M. Stony bottom. 3 Spec.

Stat. 250. Kilsuin, West coast of Kur-island. 20-45 M. Coral and Lithothamnion. I Spec.

Stat. 252. West side of Taam-island. Reef. I Spec.

Stat. 30r. Pepela-bay, East coast of Rotti-island. Reef. I Spec.

Though none of the specimens contains the soft parts, they seem to have lived at the collecting-grounds, as many of them have at least traces of a rather thin epidermis.

4. Strombus (Euprotomus) papilio Chemnitz.

Chemnitz. Conch. Cab. Vol. X, Pl. 158, fig. i 510 , 151 it.

Kiener. Coq. Viv. Vol. III, Strombus, p. 26, Pl. i7, fig. i.

KÜster. Martini-Chemn. Conch. Cab. Ed. II, Vol. IV, Strombus, p. 56, Pl. II, fig. 3, 4.

REeve. Conch. Ic. Vol. VI, Strombus, fig. 29.

Tryon. Man. of Conch. Vol. VII, p. I IO, Pl. 3, fig. 25.

Stat. 96. South east side of Pearl-bank, Sulu-archipelago. 15 M. Lithothamnion-bottom. I Spec.

Stat. 240. Banda. 9-45 M. Black sand, coral. I Spec.

Stat. 282. Between Nusa Besi and N.E. point of Timor. 27-54 M. Sand, coral and Lithothamnion. I Spec.

Stat. 299. Buka-bay, South coast of Rotti-island. Up to $36 \mathrm{M}$. Mud, coral and Lithothamnion. I Spec.

The specimens from the three last-mentioned localities are very young, the smallest from Stat. 282 has only a length of $9 \%$ Mill. and should nearly be doubtful, but the sculpture, consisting of 3 nearly regular rows of varices, with about 8 curved ribs in the interstices, crossed by regular spirals is characteristic, also small brown spots near the sutures, behind the varices, agree with those of larger specimens, the nucleus is smooth. The specimen from Stat. 96 is quite adult. 


\section{Strombus (Eupotromus) laciniatus Chemnitz.}

Chemnitz. Conch. Cab. Vol. X, p. 223, P1. 158, fig. I506, 1507.

Kiener. Coq. Viv. Vol. III, Strombus, p. 8, Pl. i I (cristatus).

Küster. Martini-Chemn. Conch. Cab. Ed. II, Vol. IV, Strombus, p. I5, Pl. II, fig. I, 2.

ReEve. Conch. Ic. Vol. VI, Strombus, fig. 25.

Tryon. Man. of Conch. Vol. VII, p. IIo, Pl. 3, fig. 26.

Stat. 37. Sailus Ketjil, Paternoster-islands. Up to I8 M. Coral and coralsand. I Spec.

One young specimen of 31 Mill., perfectly agrees with the upper whorls of my adult specimens from Amboina.

\section{Strombus (Monodactylus) auris Dianae Linné.}

Linné. Syst. Nat. Ed. X, p. $743, \mathrm{~N}^{0} 429$.

Rumph. Amb. Rariteitkamer, p. in I, Pl. 37, fig. R.

Kiener. Coq. Viv. Vol. III, Strombus, p. 22, Pl. i6, fig. 1.

KÜSTER. Martini-Chemn. Conch. Cab. Ed. II, Vol. IV, Strombus, p. 25, Pl. 6, fig. I, 2.

ReEve. Conch. Ic. Vol. VI, Strombus, fig. 36.

Tryon. Man. of Conch. Vol. VII, p. II3, Pl. 4, fig. 37.

Stat. 58. Seba, Savu. Reef. I Spec.

Stat. 89. Pulu Kaniungan Ketjil. Reef. I Spec.

Stat. 234. Nalahia-bay, Nusa-Laut-island. 46 M. Stony bottom. 3 Spec.

\section{Strombus (Monodactylus) guttatus Martini.}

Martini. Conch. Cab. Vol. III, p. I36, Pl. $8_{4}$, fig. $8_{40}$.

Kitener. Coq. Viv. Vol. III, Strombus, p. 24, Pl. I5, fig. I.

Küster. Martini-Chemn. Conch. Cab. Ed. II, Vol. IV, Strombus, p. 26, Pl. 6, fig. 3 .

Reeve. Conch. Ic. Vol. VI, Strombus, fig. 33.

Tryon. Man. of Conch. Vol. VII, p. II3 (auris Dianae pars).

Stat. 58. Seba, Savu. Reef. I Spec.

Stat. I72. Island Gisser. Reef. I Spec.

Stat. 234. Nalahia-bay, Nusa-Laut-island. 46 M. Stony bottom. 3 Spec.

Tryon has united this species to $S$. auris Dianae Lin. In dozens of specimens I found no real doubtful ones.

8. Strombus (Gallinula) vittatus Linné.

LinNÉ. Syst. Nat. Ed. X, p. $745, \mathrm{~N}^{0} 439$.

Rumpir. Amb. Rariteitkamer, p. I I0, Pl. 36 , fig. O.

Kiener. Coq. Viv. Vol. III, Strombus, p. 40, Pl. 23, fig. I, I $a$,

Küster. Martini-Chemn. Conch. Cab. Ed. II, Vol. IV, Strombus, p. 44, Pl. 7, fig. 5, 6, 8, 9. Reeve. Conch. Ic. Vol. VI, Strombus, fig. 44.

Tryon. Man. of Conch. Vol. VII, p. II4, Pl. 4, fig. 4I, 42.

Stat. 1. I 400 M. from "Zwaantjes-droogte", Madura-strait. 37 M. Grey mud with small broken shells. I Spec.

Stat. 7r. Makassar and surroundings. 27-32 M. Mud, sand with mud, coral. 2 Spec.

Stat. 273. Pulu Jedan, East coast of Aru-islands. I3 M. Sand and shells. I Spec.

The last mentioned specimen is an adult but dead shell, corresponding to fig. I $a$ of 
Kiener (l. c.), that from Stat. 1 is young and resembles the upper whorls of Kiener's fig. I ; the specimens from Stat. 7 I belong perhaps to var. turritus Lam. but are too young to be quite certain about them; by comparing fig. $\mathrm{O}$ of $\mathrm{RuMpH}$, with the figure of Chemsitz, quoted by LAMARCK for his var. turritus, I think v. MARTENS was wrong in identifying that fig. $\mathrm{O}$ with the var. turritus. In the type the back view of the last whorl occupies at least half the length of the shell, in the variety it is shorter, in CHEmnitz's figure it scarcely surpasses a third part of the length. Tryov's fig. 43 may still belong to the type of the species.

\section{Strombus (Gallinula) labiosus Gray.}

Gray. Wood. Ind. Test. Suppl. Pl. 4, fig. 3.

Kiener. Coq. Viv. Vol. III, Strombus, p. 54, Pl. 22, fig. 2.

KÜstER. Martini-Chemn. Conch. Cab. Ed. II, Vol. IV, Strombus, p. 70, Pl. 20, fig. I.

ReEve. Conch. Ic. Vol. VI, Strombus, fig. 50.

Tryon. Man. of Conch. Vol. VII, p. il6, Pl. 5, fig. 51.

Stat. ? I Spec.

Stat. $289.9^{\circ} 0^{\prime} \cdot 3$ S., $126^{\circ} 24^{\prime} .5$ E. Timor Sea. 112 M. Mud, sand and shelis. I Spec.

Both specimens are empty shells, they are very small, being only 29 and $321 / 2$ Mill. in length. They differ from the descriptions by the columella; which is wrinkled in its whole length instead of being only wrinkled above and below, but as these wrinkles are less conspicuous in the specimen from unknown locality, I suppose this character may have but little value. By these wrinkles the shells are allied to $S$. deformis (GRAY in Griffrth's Animal Kingdom, Vol. XII, pl. 25, fig. 5), but the shape of the apertural wing agrees with that of S. labiosus; the Siboga-specimens are in some degree intermediate between the two species.

Io. Strombus (Gallinula) pulchellus Reeve.

Reeve. Conch. Ic. Vol. VI, Strombus, fig. 52.

Tryon. Man. of Conch. Vol. VII, p. II9, Pl. 6, fig. 70 (dentatus var.).

Stat. 133. Lirung, Salibabu-island. Reef. I Spec.

Stat. 279. Ruma-Kuda-bay, Roma-island. Reef. I Spec.

Stat. 313. East of Dangar Besar, Saleh-bay. Up to 36 M. Sand, coral and mud. I Spec.

The specimen from Stat. I 33 agrees very well with REEvE's figure but it is smaller and less intensely coloured, that from Stat. 279 is still smaller and has a basal row of obtuse tubercles, the third from Stat. 3 I 3 is young, this latter specimen has some resemblance with the species of the dentatus-group, but I cannot conceive how TRyon considers this species to be a variety of $S$. dentatus, as it is very conspicuously winged; the observation of REEVE, that many specimens of $S$. labioszs are nearly allied, fully agrees with the specimen from Stat. I 33. Unfortunately none of the specimens contained the soft parts.

I I. Strombus (Gallinula) epidromis Linné.

Linné. Syst. Nat. Ed. X, p. $745, N^{0} 437$.

Rumph. Amb. Rariteitkamer, p. I 10, Pl. 36, fig. M. 
Kiener. Coq. Viv. Vol. III, Strombus, p. 48, Pl. 26, fig. I.

Küster. Martini-Chemn. Conch. Cab. Ed. II, Vol. IV, Strombus, p. 45, Pl. 7, fig. 7.

Reeve. Conch. Ic. Vol. VI, Strombus, fig. 54.

Tryon. Man. of Conch. Vol. VII, p. i i6, Pl. 5, fig. 55.

Stat. I04. Sulu-harbour, Sulu-island. 4 M. Sand. I Spec.

A mboina. I Spec.

12. Strombus (Gallinula) succinctus Linné.

LiNnÉ. Syst. Nat. Ed. XII, p. I212, N0 509 .

Stat. 296. Noimini, South coast of Timor. 9-36 M. Sandy mud. I Spec.

A very young specimen, long 22 Mill., containing the soft parts, sufficiently agrees with the upper whorls of my fullgrown specimens to identify it. I have quoted no figures, as such don't exist of this young state, as far as I am aware.

I3. Strombus (Gallinula) variabilis Swainson.

Swainson. Zool. Illustr. Ser. I, Vol. I, Pl. io.

Kiener. Coq. Viv. Vol. III, Strombus, p. 49, Pl. 2 I, fig. 2.

Küster. Martini-Chemn. Conch. Cab. Ed. II, Vol. IV, Strombus, p. 37, Pl. 4a, fig. I, 2.

Reeve. Conch. Ic. Vol. VI, Strombus, fig. 21.

Tryon, Man. of Conch. Vol. VII, p. 117 , Pl. 6, fig. 59.

Stat. 313. East of Dangar Besar, Saleh-bay. Up to 36 M. Sand, coral and mud. I Spec.

This specimen belongs to var. B of KÜSTER (1. c.), without brown spot on the columella.

14. Strombus (Gallinula) columba Lamarck.

LAMARCK. An. s. vert. Ed. II, Vol. IX, p. 702.

Kiener. Coq. Viv. Vol. III, Strombus, p. 5 I, Pl. 25, flg. 1.

Küster. Martini-Chemn. Conch. Cab. Ed. II, Vol. IV, Strombus, p. 67, Pl. 15, fig. I, 2, 3.

Reeve. Conch. Ic. Vol. VI, Strombus, fig. 26.

Tryon. Man. of Conch. Vol. VII, p. II5, Pl. 5, fig. 49, 50.

Stat. I. I 400 M. distant from reef "Zwaantjes-droogte", Madura-strait, 37 M. Grey mud with small broken shells. I Spec.

Stat. 7I. Makassar and surroundings. Up to 32 M. Mud, sand with mud, coral. 2 Spec.

Stat. 3I 3. East of Dangar Besar, Salelh-bay, Sumbawa. Up to 36 M. Sand, coral and mud. 29 Spec.

Twelve of the specimens from Stat. 3 I 3 are adult, they agree sufficiently with the figures of Reeve and Trvon (the latter is a copy of ReEve's fig.) but they are considerably smaller, the smallest one having only a length of 29 Mill., the largest of $4 \mathrm{I}$ Mill. The brown spot on the columella is wanting, and the columellar ridges are only conspicuous on one specimen, in the other specimens these ridges are only present on both extremities, the intermediate part of the columella being smooth. The margin of the right lip is in a few specimens produced a little above the penultimate whorl. According to a communication of Mr. E. A. Sirith, the British Museum possesses similar specimens, which are however larger. 


\section{Strombus (Canariam) muricatus Martini.}

Martini. Conch. Cab. Ed. I, Vol. III, p. 85, 98, 165, Pl. 78, fig. $80_{3}-6$.

Kiener. Coq. Viv. Vol. III, Strombus, p. 60, Pl. 15, fig. 2; Pl. 30, fig. 2, 3 (urceus).

Küster. Martini-Chemn. Conch. Cab. Ed. II, Vol. IV, Strombus, p. 51, Pl. 9, fig. 4-6 (urceus).

ReEve. Conch. Ic. Vol. VI, Strombus, fig. 24 (urceus).

Tryon. Man. of Conch. Vol. VII, p. ins, Pl. 6, fig. 65-67 (urceus).

BOOG WATSON. Challenger Reports, Gastropoda, p. 417.

Stat. 16. Bay of Kankamaraän, South coast of Kangeang. Shore. I Spec.

Stat. 47. Bay of Bima, near South fort. Shore. 5 Spec.

Stat. 7 I. Pulu Barang. Shore. I Spec.

Stat. 169. Atjatuning, West coast of N. Guinea. Reef. I Spec.

Stat. 285. South coast of Timor. 34 M. Limit between mud and coral. I Spec.

Stat. 3I3. East of Dangar Besar, Saleh-bay. Up to 36 M. Sand, coral and mud. 2 Spec.

Stat. ? 3 Spec.

"Java (N. A. M.) 8 Spec.

The specimens are very variable in shape, size and colour, also in colour of the columella which is as in the quoted figures blackish, more or less deep orange or white. In employing the name muricatus for this species, I have followed Boog Watson (l.c.) though it is generally known as $S$. urceus. But the reasons of that author for changing the name, seem to be too convincing, to neglect them. Hedley (Proc. Linn. Soc. New South Wales, 1904, p. I 8S) applies the name S. ustulatus Schumacher for this species; this name is however of more recent date.

\section{Strombus (Canarium) dentatus Linné.}

Linné. Syst. Nat. Ed. X, p. 745 .

RUMph. Amb. Rariteitkamer, p. I I I, Pl. 37, fig. F.

Kiener. Coq. Viv. Vol. III, Strombus, p. 62, P1. 3I, fig. I (plicatus).

Küster. Martini-Chemn. Conch. Cab. Ed. II, Vol. IV, Strombus, p. 59, Pl. I3, fig. 3, 4 (plicatus).

ReEve. Conch. Ic. Vol. VI, Strombus, fig. I7.

TrYon. Man. of Conch. Vol. VII, p. 1I8, Pl. 7, fig. 67-70.

Stat. I93. Sanana-bay, East coast of Sula Besi. 22 M. Mud. 6 Spec.

Stat. 234. Nalahia-bay, Nusa-Laut-island. Reef. I Spec.

Stat. 279. Roma. Reef. I Spec.

*Amboina (N. A. M.). I Spec.

\section{var. Rüppellii Reeve.}

ReEve. Conch. Ic. Vol. VI, Strombus, fig. I3.

Trron. Man. of Conch. Vol. VII, P1. 6, fig. 62 (erythrimus).

Stat. 33. Bay of Pidjot, Lombok. 22 M. Mud, coral and coralsand. I Spec.

Stat. 37. Sailus Ketjil, Paternoster-islands. Up to I8 M. Coral and coralsand. I Spec.

Stat. 299. Buka-bay, South coast of Rotti-island. Up to 36 M. Mud, coral and Lithothamnion. 2 Spec.

Stat. 3I 5. East of Sailus Besar, Paternoster-islands. Up to $36 \mathrm{M}$. Coral and Lithothamnion. I Spec.

Stat. 322. South of Tandjong Lajar, Bawean-island. 32 M. Coral. I Spec.

Some of the specimens agree very will with ReEve's fig. (1. c.), those from Stat. 299 and 3 I 5 are more allied to the type of the species, but differ sufficiently to identify them with the variety. 
I 7. Strombus (Canarium) urceus Linné.

LINNÉ. Syst. Nat. Ed. X, p. I45, N0 440.

Rumph. Amb. Rariteitkamer, p. i I I, Pl. 37, fig. W.

Kiener. Coq. Viv. Vol. III, Strombus, p. 63, Pl. 32, fig. 1 (floridus).

Kưster. Martini-Chemn. Conch. Cab. Ed. II, Vol. IV, Strombus, p. 53, Pl. 9, fig. 8-io (floridus).

REEve. Conch. Ic. Vol. VI, Strombus, fig. i I a (floridus).

Tryon. Man. of Conch. Vol. VII, p. I I9, Pl. 7, fig. 73-76 (foridus).

Boog Watson. Challenger Reports, Gastropoda, p. 417 (note).

Stat. 53. Bay of Nangamessi, Sumba. Up to 36 M. Coralsand. I Spec.

Stat. 58. Seba, Savu. Reef. 2 Spec.

Stat. 81. Pulu Sebangkatan, Borneo-bank. Reef. I Spec.

Stat. 174. Waru-bay, North coast of Ceram. 18 M. Mud. 2 Spec.

Stat. 193. Sanana-bay, East coast of Sula Besi. Reef. I Spec.

Stat. 250. Kilsuin, West coast of Kur-island. 20-45 M. Coral and Lithothamnion. I Spec.

Stat. 279. Roma. Reef. I Spec.

This is the species better known as S. floridus Lam., which after HanLEy (cfr. Boog Watson 1.c.) ought to bear the Linnean name of $S$. urceus. LinNe himself quotes fig. $T$ of RumpH, which is certainly not LaMarck's floridus, but probably $S$. dentatus Lin. if not $S$. muricatus Martini; as the fig. G of plate 32 of Gualtrerr (Index testarum conchyliorum), likewise quoted by Lrnsé, is however quite another species of Strombus, the original specimen is the only safe source, and so this shell must bear the name urceus, how inconvenient it may be to alter long familiar names.

I 8. Strombus (Canarium) gibberulus Linné.

LinnÉ. Syst. Nat. Ed. X, p. $744, \mathrm{~N}^{0} 433$.

Runiph. Amb. Rariteitkamer, p. i II, Pl. 37, fig. V.

Kiener. Coq. Viv. Vol. III, Strombus, p. 37, Pl. 28, fig. I.

KÜster. Martini-Chemn. Conch. Cab. Ed. II, Vol. IV, Strombus, p. 48, Pl. 8, fig. 3-9, 1 I. ReEve. Conch. Ic. Vol. VI, Strombus, fig. 15.

Tryon. Man. of Conch. Vol. VII, p. I21, Pl. 8, fig. 85 .

Stat. 37. Sailus Ketjil, Paternoster-islands. 27 M. Coral and coralsand. I Spec.

Stat. 6o. Haingsisi, Samau-island. Reef. I Spec.

Stat. 225. South of Lucipara-island. Reef. 2 Spec.

Stat. 279. Roma. Reef. I Spec.

"Java (N. A. M.). 2 Spec.

Very variable in size, shape and colour of the outer and inner surface of the shell.

19. Strombus (Canarium) bulbulus Sowerby.

Sowerby. Proc. Zool. Soc. Lond. 1842, p. I44.

ReEve. Conch. Ic. Vol. VI, Strombus, fig. 8.

Tryon. Man. of Conch. Vol. VII, p. I2I, Pl. 8, fig. 86.

Stat. 40. Pulu Kawassang, Paternoster-islands. I2 M. Coralreef. I Spec.

Though the only specimen is still rather young and approaches by its shape S. terebellatus the columella is brown and agrees with that of the rare S. bulbulus, also with the figures of 
Duclos (Illustrations Conch. Strombus, Pl. 7, fig. 7, 8; Pl. 15, fig. 9, 10) and with subfossil specimens from Celebes, which are rather variable in shape. The characteristic wrinkles of the aperture are still wanting.

20. Strombus (Canarium) samar Chemnitz.

Chemnitz. Conch. Cab. Vol. X, p. 22I, Pl. 157, fig. I50I, 02.

Runph. Amb. Rariteitkamer, p. II 2, Pl. 37, fig. Y.

Kiener. Coq. Viv. Vol. III, Strombus, p. 64, Pl. 26, fig. 2 (tridentatus).

Küster. Martini-Chemn. Conch. Cab. Ed. II, Vol. IV, Strombus, p. 54, Pl. 9, fig. 12-I5 (tridentatus).

REeve. Conch. Ic. Vol. VI, Strombus, fig. 53 (samarensis).

Tryon. Man. of Conch. Vol. VII, p. I2I, Pl. 8, fig. 88.

Stat. 240. Banda. 9-45 M. Black sand, coral. I Spec.

Stat. 299. Buka-Bay, South coast of Rotti-island. 36 M. Mud coral and Lithothamnion. I Spec.

21. Strombus (Conomurex) luhuanus Linné.

Linné. Syst. Nat. Ed. X, p. $744, \mathrm{~N}^{0} 432$.

Rumpir. Amb. Rariteitkamer, p. i i , Pl. 37, Fig. S.

Kínner. Coq. Viv. Vol. III, Strombus, p. 39, Pl. 27, fig. I.

KƯsterr. Martini-Chemn. Conch. Cab. Ed. II, Strombus, p. 46, Pl. 8, fig. I, 2, 10.

REeve. Conch. Ic. Vol. VII, Strombus, fig. I9.

Tryon. Man. of Conch. Vol. VII, p. I22, Pl. 8, fig. 9I, 92.

Stat. 37. Sailus Ketjil, Paternoster-island. Up to 18 M. Coral and coralsand. I Spec.

Stat. 78. Lumu-Lumu-shoal, Borneo-bank. Shore. 6 Spec.

Stat. 93. Pulu Sanguisiapo, Tawi-Tawi-islands, Sulu-archipelago. I2 M. Lithothamnion-bottom, sand and coral. 2 Spec.

Stat. 225. South of Lucipara-island. Reef. I Spec.

Stat. 240. Banda. 9-45 M. Black sand and coral. 2 Spec.

Stat. 250. Kilsuin, West coast of Kur-island. 20-45 M. Coral and Lithothamnion. I Spec.

Stat. 299. Buka-Bay, South coast of Rotti-island. Up to $3^{6}$ M. Mud, coral and Lithothamnion. I Spec.

Stat. 313. Dangar Besar, Saleh-bay. Up to 36 M. Sand, coral and mud. 2 Spec.

*Amboina (N. A. M.). I Spec.

Pterocera Lamarck.

I. Pterocera lambis Linné.

LiNNÉ. Syst. Nat. Ed. X, p. $743, \mathrm{~N}^{0} 425$.

Rumph. Amb. Rariteitkamer, p. I 10, Pl. 35, fig. E, F; Pl. 36, fig. G.

Kiener. Coq. Viv. Vol. III, Pterocera, p. 7, Pl. 3; Pl. 9, fig. 2; Pl. 4, fig. I, I I.

Küster. Martini-Chemn. Conch. Cab. Ed. II, Vol. IV, Strombea, p. 82, Pl. Io, fig. 7; P1. I6,

fig. 3, 4; Pl. 17, fig. 3; Pl. I8, fig. 5, 6.

ReEve. Conch. Ic. Vol. VI, Pterocera, fig. 8.

Tryon. Man. of Conch. Vol. VII, p. I24, Pl. 8, fig. I-3.

Stat. 7. Near reef of Batjulmati (Java). I 5 M. Coral and stones. I Spec.

Stat. I6. Bay of Kankamaräan, South coast of Kangeang. Shore. I Spec.

Stat. 78. Lumu-Lumu-shoal, Borneo-bank. Shore. 2 Spec.

Stat. I42. Laiwui, North coast of Obi Major. 23 M. Mnd. 3 Spec. 
Stat. 234. Nalahia-bay, Nusa-Laut-island. Reef. I Spec.

Stat. 252. West side of Taam-island. Reef. I Spec.

Stat. 279. Ruma-Kuda-bay, Roma-island. Reef: I Spec.

"Amboina (N. A. M.). I Spec.

This is the most common species of the genus.

\section{Ptcrocera chiragra Linné.}

Linné. Syst. Nat. Ed. X, p. $742, \mathrm{~N}^{0} 423$.

Rumph. Amb. Rariteitkamer, p. I09, Pl. 35, fig. A-D.

Kiener. Coq. Viv. Vol. III, Pterocera, p. 5, Pl. 5, Pl. io, fig. 2.

Reeve. Conch. Ic. Vol. VI, Pterocera, fig. 2.

Tryon. Man. of Conch. Vol. VII, p. I 26.

Stat. 234. Nalahia-bay, Nusa-Laut-island. Reef. 2 Spec.

Stat. 258. Tual, Kei-islands. 22 M. Lithothamnion, sand and coral. I Spec.

\section{Rostellaria Lamarck.}

1. Rostellaria Porvisii Petit. Pl. XVI, fig. 2.

Petit. Magazin de Zoologie, I842, Pl. 53.

Kiener. Coq. Viv. Vol. III, Rostellaria, p. 6, Pl. 2, fig. 2.

KÜster. Martini-Chemn. Conch. Cab. Ed. II, Vol. IV, Strombea, p. 97, Pl. 25, fig. 2, 3.

ReEve. Conch. Ic. Vol. VI, Rostellaria, fig. 4.

Tryon. Man. of Conch. Vol. VII, p. I28, Pl. i I, fig. 22.

Stat. $306.8^{\circ} 27^{\prime}$ S., $122^{\circ} 54^{\prime} \cdot 5$ E. Savu Sea. 247 M. Sandy mud. 7 Spec.

Stat. 3I2. Saleh-bay, North coast of Sumbawa. 274 M. Fine, sandy mud. 2 Spec.

One of the specimens from Stat. 312 is a very fine large shell, agreeing with Rexve's figure by the prominence of the third liration on the last whorl, which is also broader; the seventh liration is also more conspicuous, though less than the third one; this specimen contains the soft parts, the other specimen shows the same peculiarities, but is a dead shell and slightly broken. The specimens from Stat. 306 are small and young.

var. abyssicola n. var. Pl. XI, fig. 5 .

Stat. I 39. $0^{\circ}$ I I'S., I $27^{\circ} 25^{\prime}$ E. Molucca-Passage. 397 M. Mud, stones and coral. 4 Spec.

Shell small, whitish, thinner than the type, the upper whorls nearly smooth, with only one conspicuous groove, bordering a narrow spiral cord, just below the suture; this is continuous untill the aperture, the upper part of last whorl, below that groove, smooth on the ventral side, angular on the place where in the type runs the third of the lirae, on the back with indistinct spirals, beginning with a row of punctures, more conspicuous behind the apertural margin, base of last whorl with conspicuous spiral cords, separated by punctured grooves; denticles and other particularities of the aperture, as in the type.

Length of largest specimen 39 Mill. of smallest 33 Mill., it may have been in both specimens a little more, since the canal seems to be slightly broken. 
This fine shell has much puzzled me; after comparing it carefully with typical specimens, I can see nothing in it but a dwarfed form with obsolete sculpture, probably owing its peculiar character to the considerably greater depth. A young specimen is scarcely different from young ones from Stat. 306. Unfortunately the shells contained nothing but some mud.

The radula of a small specimen from Stat. 306 agrees in many respects with those of other Strombidae, it is short, with about 35 rows of teeth, its colour is yellowish. The rhachidian tooth $(R)$ has a body which is broad in front and suddenly' narrower about halfway; its cusp has I I denticles, of which the central one is the largest; the lateral tooth (I) has a transversely much elongated body and about 9 denticles on its reflected margin. The uncini (U) are long; slender, much curved, with a few small denticles on the sides. It was a male specimen with a long slender penis, ending in a thickened, spear-shaped point.

\section{Rimella Agassiz.}

I. Rimella cancellata Lamarck.

LamarcK. An. s. vert. Ed. II, Vol. IX, (Strombus) p. 7 Io.

Kiener. Coq. Viv. Vol. III, Rostellaria, p. 9, Pl. 3, fig. 3.

KÜSTER. Martini-Chemn. Conch. Cab. Ed. II, Vol. IV, Strombea, p. 73, Pl. 20, fig. 5.

REEve. Conch. Ic. Vol. VI, Rostellaria, fig. Io.

Tryon. Man. of Conch. Vol. VII, p. I29, Pl. 10, fig. 18, 20.

Stat. 58. Seba, Savu. Up to 27 M. 2 Spec.

Stat. $7 \mathrm{I}$. Makassar and surroundings. Up to $32 \mathrm{M}$. Mud, sand with mud, coral. 5 Spec.

Stat. 23I. Amboina. 54 M. Coralsand. I Spec.

Stat. ? 2 Spec.

forma minor.

Stat. 133. Lirung, Salibabu-island. Up to 36 M. Mud and hard sand. 9 Spec.

Shell only from 19 to nearly 23 Mill. in length, more conspicuously banded.

I have maintained Rimella as a genus, though it has been considered by Fischer and Tryon as a subgenus of Rostellaria, but the operculum is serrate as in Strombus, instead of being smooth-margined as in Rostellaria.

The forma minor distinguishes itself by its smallness and the vivid painting, the specimen from Amboina which has a length of 26 Mill. and which is also more gayly coloured may be considered as a link between the type and forma minor.

2. Rimella crispata Sowerby.

Sowerby. Thes. Conch. Part I, p. 26, Pl. 8, fig 62, 63.

Kiener. Coq. Viv. Vol. III, Rostellaria, p. Io, Pl. 4, fig. 2.

Küster. Martini-Chemn. Conch. Cab. Ed. II, Strombea, p. 76, Pl. 25, fig. 4, 5.

REEve. Conch. Ic. Vol. VI, Rostellaria, fig. S.

Tryon. Man. of Conch. Vol. VII, p. I29, Pl. 10, fig. I9.

Stat. I74. Waru-bay, North coast of Ceram. Reef. I Spec.

Stat. 260. North point of Nuhu Jaan, Kei-islands. 9o M. Sand, coral and shells. I Spec.

Stat. 26r. Elat, West coast of Great-Kei-island. Reef. 9 Spec. 
Varying much in size; of the 8 probably adult specimens from Stat. 261, with welldeveloped outer lip and a varix on the opposite side of the body-whorl, the largest specimen has a length of 22 Mill. the smallest of only ro Mill.; the full-grown intermediate specimens have the length of $12,15^{3} / 4,17^{1} / 2,18$ and $20^{1} / 2$ Mill.

3. Rimella Tyleri H. \& A. Adams. Pl. XV, fig. 5 ; Pl. XVI, fig. 1.

H. \& A. Adams. Proc. Zool. Soc. Lond. i 863 , p. 428.

TRYON. Man. of Conch. Vol. VII, p. I I9.

Stat. 4. Djankar (Java). 9 M. Coarse sand. ro Spec.

Stat. 33. Bay of Pidjot, Lombok. 22 M. Mud, coral and coralsand. I Spec.

Stat. 47. Bay of Bima, near South fort. 55 M. Mud with patches of fine coralsand. 1 Spec.

Stat. 50. Bay of Badjo, West coast of Flores. Up to $40 \mathrm{M}$. Mud, sand and shells. 1 Spec.

Stat. 7 I. Makassar and surroundings. Up to $32 \mathrm{M}$. Mud, sand with mud, coral. 3 Spec.

Stat. 213. Saleyer. Up to $36 \mathrm{M}$. Coralreefs, mud and mud with sand. 1 Spec.

Stat. ? Io Spec.

This species is also very variable in size, the smallest specimen from Stat. 4 being only I 4 Mill. in length, the largest from the same lacality 23 Mill., this latter being only surpassed by a specimen from Stat. ? measuring 25 Mill. The operculum is serrate, as in $R$. cancellata; as far as I know this species has not been figured before.

The radula which, as far as I am aware, was not yet known is very small, its length is about $3 / 4$, its breadth $1 / 3$ of a Mill., with about 35 transverse rows. The rhachidian tooth (R) is broadly rounded in front, contracted behind, with a cusp bearing one moderately large central denticle and about 6 smaller ones on each side, the laterals (1) are strongly transversely elongate with a simple reflected margin, terminating in a sharp point towards the centre of the radula, the uncini $(U)$ are long and slender, strongly curved, with a few indistinct denticles. The general appearance of the radula is much the same as that of the preceding genus, as far as may be judged from one radula of each, the chief difference being the smooth margin of the laterals, which are provided with many denticles in Rostellaria.

\section{Terebellum Klein.}

1. Tercbcllum terebellum Linné.

LinnÉ. Syst. Nat. Ed. X, p. $7 \mathrm{I} 8, \mathrm{~N}^{0} 284$.

RUмiph. Amb. Rariteitkamer, p. 101, Pl. 30, fig. S.

Kiener. Coq. Viv. Vol. I, Terebellum, p. 2, Pl. I, fig. 1 (subutatunn).

REEvE. Conch. Ic. Vol. XVI, Terebellum, fig. I (punctatumi).

Tryon. Man. of Conch. Vol. VII, p. 13I, Pl. II, fig. 27-30 (subutatum).

Stat. 33. Bay of Pidjot, Lombok. 22 M. Mud, coral and coralsand. 1 Spec.

Stat. 37. Sailus Ketjil, Paternoster-islands. Reef. I Spec.

Stat. 47. Bay of Bima, near South fort. 55 M. Mud with patches of fine coralsand. 4 Spec.

Stat. 64. Kambaragi-bay, Tanah-Djampeah. 32 M. Coral, coralsand. I Spec.

Stat. 7 I. Makassar and surroundings. 27-32 M. Mud, sand with mud, coral. 2 Spec.

Stat. 240. Banda. 9-45 M. Black sand, coral. I Spec.

Stat. 258. Tual, Kei-islands. 22 M. Lithothamnion, sand and coral. I Spec.

Stat. 299. Buka-bay, Rotti-island. Up to 36 M. Mud, coral and Lithothamnion. 2 Spec.

Stat. 3 I 3. East of Dangar Besar, Saleh-bay. Up to 36 M. Sand coral and mud. 7 Spec. 
Very variable in colour-pattern, the majority of the specimens agrees with KIENER's fig. I and $\mathrm{I} b$ or is intermediate, that from Stat. 64 , with his fig. I $c$.

Prof. Bergh has (Zool. Jahrb. Bd 8, Abth. für Anat. p. 372, Pl. 22, fig. I I-I 4) described and figured the radula of this species.

\section{Fam. Cerithididae. \\ Cerithium Adanson.}

I. Cerithizun nodulosum Bruguière.

Bruguière. Encycl. Meth. Pl. 442, fig. 3.

Rumph. Amb. Rariteitkamer, p. IoI, Pl. 30, fig. O.

Kiener. Coq. Viv. Vol. IV, Cerithium, p. 4, Pl. 2, fig. I.

REEve. Conch. Ic. Vol. XV, Cerithium, fig. 3 .

TRYon. Man. of Conch. Vol. IX, p. I22, Pl. I9, fig. 13, 14; Pl. 20, fig. I5.

Koвelt. Martini-Chemn. Conch. Cab. Ed. II, Vol. I, Cerithium, p. 76, Pl. I5, fig. I.

Stat. 78. Lumu-Lumu-shoal, Borneo-bank. Shore. I Spec.

Stat. 89. Pulu Kaniungan Ketjil. Reef. I Spec.

Stat. 225. Siouth of Lucipara-island. Reef. I Spec.

Stat. 313. Dangar Besar, Saleh-bay. Up to 36 M. Sand, coral and mud. I Spec.

Three of the specimens of this common species are young, dead shells. That from Stat. 3 I 3 is a fine specimen, probably containing the soft parts, which are too much withdrawn to be seen.

2. Cerithium columna Sowerby.

Sowerby. Genera of shells. Vol. II, Pl. 204, fig. 7.

Kiener. Coq. Viv. Vol. IV, Cerithium, p. 7, Pl. 3, fig. I (echinatum).

ReEve. Conch. Ic. Vol. XV, Cerithium, fig. 2.

TRYon. Man. of Conch. Vol. IX, p. I23, Pl. 20, fig. „I7, I8.

Kobelt. Martini-Chemn. Conch. Cab. Ed. II, Vol. I, Cerithium, p. 85, Pl. 16, fig. 7, 8.

Stat. 78. Lumu-Lumu-shoal, Borneo-bank. Shore. I Spec.

Stat. 8 I. Pulu Sebangkatan, Borneo-bank. Reef. I Spec.

Stat. 99. North-Ubian. I6-23 M. Lithothamnion-bottom. I Spec.

Stat. 225. South of Lucipara-island. Reef. I Spec.

Stat. 240. Banda. Reef. I Spec.

Stat. 260. North point of Nuhu Jaan, Kei-islands. 9o M. Sand, coral and shells. I Spec.

Stat. 279. Rumah-Kuda-bay, Roma-island. Reef. I Spec.

The specimen from Stat. 78 is very small, reaching only a length of 17 Mill.

3. Cerithium citrinum Sowerby.

Sowerby. Thes. Conch. Vol. II, p. 855, Pl. 179, fig. 66.

Kiener. Coq. Viv. Vol. IV, Cerithium, p. Io, Pl. 4, fig. I (colntmna).

REEve. Conch. Ic. Vol. XV, Cerithium, fig. I.

Tryon. Man. of Conch. Vol. IX, p. I23, Pl. 20, fig. 2 I.

Kobelt. Martini-Chemn. Conch. Cab. Ed. II, Vol. I, Cerithium, p. IIo, Pl. 22, fig. $2,3$. 
I 58

Stat. 40. Pulu Kawassang, Paternoster-islands. Coralreef. 2 Spec.

Stat. 99. North-Ubian. 16-23 M. Lithothamnion-bottom. I Spec.

Stat. I23. North-bay, Biaru-island. 36-27 M. Stone and Lithothamnion-bottom. I Spec.

Stat. I44. North of Salomakiëe-island. 45 M. Coralbottom and Lithothamnion. I Spec.

Stat. 172. Gisser. Reef. I Spec.

Stat. 206. Buton-strait. 5 I M. Fine, green mud. I Spec.

Stat. 3 I 5. East of Sailus Besar, Paternoster-islands. Up to 36 M. Coral and Lithothamnion. I Spec.

Varying considerably in size; of the two specimens from Stat. 40, the length of the largest one is 35 , that of the smallest only 24 Mill., though both have the lip expanded and thickened and may be considered to be adult.

4. Cerithium echinatum Lamarck.

Lamarck. An. s. vert. Ed. II, Vol. IX, p. 29 r.

ReEve. Conch. Ic. Vol. XV, Cerithium, fig. IO.

TRYon. Man. of Conch. Vol. IX, p. 123, Pl. 20, fig. 25.

Kobelt. Martini-Chemn. Conch. Cab. Ed. II, Vol. I, Cerithium, p. IoI, Pl. 20, fig. 5, 6.

Stat. 225. South point of South Lucipara-island. Reef. I Spec.

The only specimen, which is broken at the aperture, belongs to the short, thick form, represented by the quoted figures.

5. Cerithizm novaehollandiae Adams.

A. Adams. Thes. Concl. Vol. II, p. 864, P1. 178, fig. 54.

ReEve. Conch. Ic. Vol. XV, Cerithium, fig. 30.

TRYon. Man. of Conch. Vol. IX, p. I24, Pl. 2 I, fig. 34 .

Kobelt. Martini-Chemn. Conch. Cab. Ed. II, Vol. I, Cerithium, p. 123, P1. 23 , fig. 8.

Stat. 258 . Tual, Kei-islands. 22 M. Lithothamnion, sand and coral. 2 Spec.

Of the two specimens, one is characteristic, being white with a broad brown band at the base of each whorl, it seems to differ from the figures by one or two of the spirals being slightly prominent, in the other specimen I see a few brown spots on the base of the whorls, but no distinct band, and two spirals so much developed as to form one row of small tubercles on the upper whorls, about halfway, and a second row, nearly concealed by the suture. Both specimens are young. If adult they might be described as a variety, but now I prefer to make only mention of these characters, as constituting individual aberrations of the type.

\section{Cerithium coralium Kiener.}

Kiener. Coq. Viv. Vol. IV, Cerithium, p. 32, Pl. 8, fig. 3.

REeve. Conch. Ic. Vol. XV, Cerithium, fig. 29 (corallinum).

Tryon. Man. of Conch. Vol. IX, p. I25, Pl. 21, fig. 36 (corallinum).

Kobelt. Martini-Chemn. Conch. Cab. Ed. II, Vol. I, Cerithium, p. 218, Pl. 39, fig. I, 2.

Stat. 7I. Makassar. Up to 32 M. Mud, sand with mud, coral. 5 Spec.

Stat. 86. Dongala, Palos-bay. Reef. I Spec.

The name of this species has been written in very different manners; according to KIENER, it has been named, but I think not described by Dufresne as C. coralium, on Kimener's 
plate the name is coraillizm, v. Martens (Journ. Lin. Soc. Vol. 2 I, p. r9o) has recorded it from the Mergui-archipelago as C. corallium Defrance, REEve and TRYon write Corallinum. I have applied the original name but with KIENER's name as the author. The species varies considerably in size.

7. Cerithium rostratim Sowerby.

Suwerby. Thes. conch. Vol. II, p. 86I, Pl. iso, fig. IO4.

ReEve. Conch. Ic. Vol. XV, Cerithium, fig. 95.

TRYON. Man. of Conch. Vol. IX, p. I30, Pl. 23, fig. 90, $9 \mathrm{I}$.

Kobelt. Martini-Chemn. Conch. Cab. Ed. II, Vol. I, Cerithium, p. 2I I, Pl. 37, fig. 8, 9.

Stat. 37. Sailus Ketjil, Paternoster-islands. Up to I 8 M. Coral and coralsand. 5 Spec.

Stat. 43. Pulu Sarassa, Postillon-islands. Up to $36 \mathrm{M}$. Coral. I Spec.

Stat. 206. Buton-strait. 5 I M. Fine, green mud. 2 Spec.

The quoted figures give but a faint idea of the delicacy and beauty of this species, which is of a transparant white, with very fine brown dots and streaks, the canal stained with blackish brown.

\section{Cerithium balteatum Philippi.}

PhilıPpI. Zeitschr. f. Mal. I848, p. 22.

- Abbildungen neuer Conch. III, p. 16, Cerithium, Pl. I, fig. Jo.

ReEve. Conch. Ic. Vol. XV, Cerithium, fig. $72 a$.

Tryon. Man. of Conch. Vol. IX, p. I3 I, Pl. 23, fig. 2, 3 .

Kobelt. Martini-Chemn. Conch. Cab. Ed. II, Vol. I, Cerithium, p. I89, Pl. 34, fig. 16, 17.

Stat. 299. Buka-bay, South coast of Rotti-island. 36 M. Mud, coral and Lithothamnion. 3 Spec.

The only adult specimen agrees very well with REEVE's fig. $72 a$.

9. Cerithium serratum Wood.

Wood. Index testac. Pl. 28, fig. I 58.

REEve. Conch. Ic. Vol. XV, Cerithium, fig. 75 (rubus).

Tryon. Man. of Conch. Vol. IX, p. 131, Pl. 23, fig. 4-9 (rubus).

Kobelt. Martini-Chemn. Conch. Cab. Ed. II, Vol. I, Cerithium, p. 2I3, Pl. 38 , fig. I.

Stat. 8r. Pulu Sebangkatan, Borneo-bank. 34 M. Coral-bottom and Lithothamnion. I Spec. Stat. 240. Banda. 9-45 M. Black sand, coral. 2 Spec.

Stat. 299. Buka-bay, South coast of Rotti-island. 36 M. Mud, coral and Lithothamnion. I Spec.

Stat. 313. Dangar Besar, Salch-bay. Up to 36 M. Sand, coral and mud. About 120 Spec.

Stat. ? 4 Spec.

Very variable in colour, yellowish, brown, whitish, often more or less banded and variegated with darker colours, however shape, size and sculpture agree with such specimens as may be considered to belong to the type. Cerithizm mbas of Martvn, seems to be quite another species; according to Pilsbry (Proc. Acad. Nat. Sc. Philadelphia, 1901, p. 392) it should be the same as C. echinatum of LAMARcK; if this be right; the species recorded above sub $\mathrm{N}^{0} 4$, ought to bear that name. 
var. sordidula Gould.

GCULD. Otia Conch. p. 6r.

ReEve. Conch. Ic. Vol. XV, Cerithium, fig. 87 .

TRYON. 1. c. p. I32, Pl. 23, fig. I 5.

Kobelt. Martini-Chemn. Conch. Cab. Ed. II, Vol. I, Cerithium, p. 2 I 5 , Pl. 38, fig. 8.

Stat. 285. South coast of Timor. 34 M. On the limit between mud and coral. I Spec.

Only differing from the type by its sharper sculpture and slightly broader shape.

10. Cerithim granosum Kiener.

Kiener. Coq. Viv. Vol. IV, Cerithium, p. 57, Pl. 4, fig. 3.

ReEve. Conch. Ic. Vol. XV, Cerithium, fig. 73.

Kobelt. Martini-Chemn. Conch. Cab. Ed. II, Vol. I, Cerithium, p. 22 I, Pl. 39, fig. I2, I3.

Stat. I9. Bay of Labuan Tring, West coast of Lombok. 18-27 M. River-mud, coral, coralsand. I Spec.

Stat. 86. Dongala, Palos-bay, Celebes. Reef. I Spec.

Stat. 204. Between islands Wowoni and Buton. 75-94 M. Sand with dead shells. I Spec.

TRYON considers this species to be a synonym of the preceding one; it differs sufficiently in shape and sculpture, to be separated as a good species.

I . Cerithim tenellum Sowerby.

Sowerby. Thes. Conch. Vol. II, p. 857, Pl. I88, fig. 88-90.

ReEve. Conch. Ic. Vol. XV, Cerithium, fig. $7 \mathrm{I}$.

Truon. Man. of Conch. Vol. IX, p. I 32, Pl. 23, fig. Io, II.

Kobelt. Martini-Chemn. Conch. Cab. Ed. II, Vol. I, p. 213, Pl. 38, fig. 2, 3.

Stat. 43. Pulu Sarassa, Postillon-islands. Up to 36 M. Coral. 2 Spec.

Stat. 78. Lumu-Lumu-shoal, Borneo-bank. Shore. Io Spec.

The specimens from Stat. 78 , one of which is of a rosy hue, are smaller than ReEve's figure, they have only a length of about I5 Mill. instead of 22, one of the specimens from Stat. 43 on the contrary, reaches 22 Mill.

12. Cerithium morun Lamarck.

Lamarck. An. s. vert. Ed. II, Vol. IX, p. 302.

Kiener. Coq. Viv. Vol. IV, Cerithium, p. 52, Pl. I 5, fig. I.

Reeve. Conch. Ic. Vol. XV, Cerithium, fig. 42.

Tryon. Man. of Conch. Vol. IX, p. I33, Pl. 24, fig. 32, 33.

Kobelt. Martini-Chemn. Conch. Cab. Ed. II, Vol. I, Cerithium, p. So, Pl. I5, fig. 6, 7.

Stat. I9. Bay of Labuan Tring, West coast of Lombok. I8-27 M. River-mud, coral, coralsand. I Spec.

Stat. 37. Sailus Ketjil, Paternoster-islands. 27 M. Coral and coralsand. I Spec.

Stat. 43. Pulu Sarassa, Postillon-islands. Up to 36 M. Coral. 2 Spec.

Stat. 47. Bay of Bima, near South fort. Shore. I Spec.

Stat. I74. Waru-bay, North coast of Ceram. Reef. I Spec.

"Island Enkhuizen near Batavia. (N. A. M.). I Spec. 
var. monilifera Kiener.

Stat. 19. Bay of Labuan Tring, West coast of Lombok. 18-27 M. River-mud, coral, coralsand. I Spec.

This specimen agrees with the original figure of KiEver, less with those of ReEve, Tryon and KoBelt.

I 3. Cerithium tuberculatum Linné.

LINNÉ. Syst. Nat. Ed. XII, p. I213, No 514.

SMith. Zool. Coll. of H. M. S. "Alert", p. 63-65.

TRYon. Man. of Conch. Vol. IX, p. I33, Pl. 24, fig. 25-27.

Stat. 7. Near reef of Batjulmati (Java). 15 M. Coral and stones. I Spec.

Stat. 19. Bay of Labuan Tring, West coast of Lombok. I8-27 M. River-mud, coral, coralsand. 2 Spec.

Stat. 34. Labuan Pandan, Lombok. Coralreef. I Spec.

Stat. 129. Kawio- and Kamboling-islands, Karkaralong-group. Reef. I Spec.

Stat. I 31. Beo, Karakelang-islands. Reef. 2 Spec.

Stat. 193. Sanana-bay, East coast of Sula Besi. Reef. I Spec.

Stat. 225. South point of South Lucipara-island. Reef. 2 Spec.

Stat. 277. Dammer-island. Reef. 5 Spec.

Stat. 279. Ruma-Kuda-bay, Roma-island. Reef. 2 Spec.

Stat. 296. Noimini, South coast of Timor. Reef. I Spec.

var. variegatum Quoy and Gaimard.

QUoy \& Gaimard. Voy. de l'Astrolabe. Vol. III, p. 129, Pl. 55, fig. I7.

REEve. Conch. Ic. Vol. XV, fig. 4I.

Stat. 86. Dongala, Palos-bay, Celebes. Reef. 5 Spec.

Stat. 142. Laiwui, North coast of Obi Major. Reef. I Spec.

As to the identification of $C$. tuberculatum and its variety variegatzm, I have followed the views of E. A. SMrri (1.c.) the specimens agree with such, formerly named by that author, in my private collection.

\section{Cerithium maculosum Mighels.}

Mighels. Proc. Bost. Soc. Nat. Hist. Vol. II, p. 22.

ReEve. Conch. Ic. Vol. XV, Cerithium, fig. 97.

Tryon. Man. of Conch. Vol. IX, p. 137, Pl. 26, fig. 75.

Kobelt. Martini-Chemn. Conch. Cab. Ed. II, Vol. I, Cerithium, p. I99, Pl. 35, fig. 18, 19.

Stat. 225. South point of South Lucipara-island. Reef. I Spec.

The only specimen is not yet adult.

15. Cerithiun clavis (Sowerby) Reeve.

(Sowerby) ReEve. Conch. Ic. Vol. XV, Cerithium, fig. 94.

Kobelt. Martini-Chemn. Conch. Cab. Ed. II, Vol. I, Cerithium, p. 227, Pl. 40, fig. 5.

Stat. $95.5^{\circ} 43^{\prime} \cdot 5$ N., $119^{\circ} 40^{\prime}$ E. Sulu Sea. 522 M. Stony bottom. 39 Spec.

Specimens agreeing sufficiently with the figure and description of REEve, to be identified 
with this species, described without locality in the quoted works. The brown band is only faintly visible in one specimen. Unfortunately the specimens are dead, partly worn shells, so it cannot be made out if they have really lived at the great depth of $522 \mathrm{M}$.

\section{Cerithinm aduncum Gould.}

Gould. Proc. Boston Soc. Nat. Hist. Vol. III, 1849, p. I19.

ReEve. Conch. Ic. Vol. XV, Cerithium, fig. 56 (dorsuosum) fig. 57 (aduncum).

Trion. Man. of Conch. Vol. IX, p. 139, Pl. 26, fig. 96, 97.

Kobelt. Martini-Chemn. Conch. Cab. Ed. II, Vol. I, Cerithium, p. 103, Pl. 20, fig. 9, 10.

Stat. 50. Bay of Badjo, West coast of Flores. Up to 40 M. Mud, sand and shells. 11 Spec.

According to REeve, the only difference between $C$. aduncum and dorsuosum should be, that in the former the outer lip is ridged, being smooth in dorsuosum. Now, as the very old specimens from the above locality have the outer lip smooth, the younger ones have it ridged, with every grade between them, I think they ought to be united, as for the first time has been done by Tryon, afterwards by Kobelt on Tryon's authority; the "Siboga"-specimens are less humped, than the figure of admancum, the colour also agrees with ReEve's dorsuosum, but in size and in shape of upper whorls, they come nearer to his aduncum.

17. Cerithium zebrum Kiener.

Kiener. Coq. Viv. Vol. IV, Cerithium, p. 71, Pl. 25, fig. 4.

Reeve. Conch. Ic. Vol. XV, Cerithium, fig. 136?

Tryon. Man. of Conch. Vol. IX, p. ${ }_{13} 8$, Pl. 26, fig. 78-82.

Kobelt. Martini-Chemn. Conch. Cab. Ed. II, Vol. I, Cerithium, p. 220, PI. 39, fig. 7-10.

Stat. 215. North point of Kabia-island. Reef. 1 Spec.

Reeve's locality "Gallapagos-Islands" makes it doubtful, if he had in view the true C. zebram.

\section{I8. Cerithium pauxillum A. Adams.}

A. Adans. Proc. Zool. Soc. Lond. 1854 , p. 86.

REEve. Conch. Ic. Vol. XV, Cerithium, fig. 144.

Tryon. Man. of Conch. Vol. IX, p. 14I, Pl. 34, fig. 95.

Kobelt. Martini-Chemn. Conch. Cab. Ed. II, Vol. I, Cerithium, p. 228, P1. 40, fig. 8.

Stat. 144. Laiwui, North coast of Obi Major. 23 M. Coral-bottom and Lithothamnion. 3 Spec.

Stat. 285. South coast of Timor. 34 M. Limit between mud and coral. 19 Spec.

Though the specimens have a fourth row of nodules on each whorl, in contradiction to the original description of ADAus, who says "triseriatim granosis", they belong no doubt to the species under consideration, as they have been compared with the types in the British Museum by Mr. E. A. Simst; the shell has a tendency to be banded with fulvous above the suture, the fourth series of nodules is smaller and so may have been overlooked, moreover I see a few intermediate lirae especially on the last whorl. There is a single varix on the left side of the bodywhorl and another bordering the aperture externally; the whole shell is covered with fine growth-striae, only visible under a strong lens. 
19. Cerithium (Colina) Koperbergi Schepman.

Schepman. Posttertiäre Moll. von Celebes. Samml. Geol. Mus. Leiden, Ser. I, Bd 8, p. I88, Pl. 12, fig. I.

Stat. 43. Pulu Sarassa, Postillon-islands. Up to 36 M. Corai. 3 Spec.

I cannot separate this form from the subfossil ones from Celebes. The sculpture of these latter seems to be sharper, but this may depend on its fossil state or on local influence. The recent specimens are dark yellowish-brown, mottled with white, mixed with irregular patches of crimson on the last whorl; the aperture especially the columella and canal is stained by the same colour.

20. Cerithium (Liocerithium) piperitum Sowerby.

Sowerby. Thes. Conch. Vol. II, p. 867, Pl. I 8 I, fig. I36, 137.

Reeve. Conch. Ic. Vol. XV, Cerithium, fig. $8 \mathrm{I}$.

TRYON. Man. of Conch. Vol. IX, p. 144, P1. 27, fig. 31, 32.

Kobelt. Martini-Chemn. Conch. Cab. Ed. II, Vol. I, Cerithium, p. I17, Pl. 22, fig. I2.

Stat. 43. Pulu Sarassa, Postillon-islands. Up to $36 \mathrm{M}$. Coral 1 Spec.

Stat. 78. Lumu-Lumu-shoal, Borneo-bank. Shore. 9 Spec.

Stat. 240. Banda. Reef. I Spec.

Stat. 213. South-island, near Saleyer. Reef. I Spec.

Stat. 273. Pulu Jedan, East coast of Aru-islands. 13 M. Sand and shells. I Spec.

Stat. 30 I. Pepela-bay, East coast of Rotti-island. Reef. I Spec.

I have omitted the quotation of Kiener's work, as his figure represents a shell from Senegal described as $C$. punctatum by Brugujère. ReEve and Tryon think they are synonyms, KOBELT that they are different.

\section{Cerithium (Liocerithium) lacteun Kiener.}

Kiener. Coq. Viv. Vol. IV, Cerithium, p. 58, Pl. 7 , fig. 3 .

ReEve. Conch. Ic. Vol. XV, Cerithium, fig. 85 .

TRYON Man. of Conch. Vol. IX, p. 143, Pl. 27, fig. 29, 30, 33.

Kobelt. Martini-Chemn. Conch. Cab. Ed. II, Vol. I, Cerithium, p. I30, Pl. 24, fig. I2, I3.

Stat. 225. South point of Lucipara-island. Reef. 2 Spec.

Stat. 279. Roma. Reef. I Spec.

22. Cerithium Tydenani n. sp. Pl. XI, fig. 6.

Stat. 3 I 3. Dangar Besar, Saleh-bay. Up to 36 M. Sand, coral and mud. 2 Spec.

Shell elongate, yellowish-brown, with many convex whorls. Nucleus wanting, remaining whorls 12, the uppermost closed by a calcareous septum, upper ones regularly convex, lower ones with a broad excavation below the suture, which is not deep, slightly compressed at the sides. Of the two specimens (which are unfortunately not adult) the largest has 4 varices on the lower whorls. Sculpture consisting of 5 spiral cords, of which one borders the base of each whorl, the uppermost bordering the subsutural excavation. The whole shell, as well the spiral 
I 64 .

cords as the interstices and the excavation, is covered with regular spiral rows of small granules, giving to many parts a cancellated appearance, one could as well say that in the upper whorls, the shell is cancellated by granular spirals and concentric riblike striae; moreover the shell has on the lower whorls, especially of the smaller specimen, indistinct ribs; last whorl carinated by the strong peripheral cord, its basal part with two stronger and a great number of finer spiral cords or lirae, crossed by very fine growth-striae. Aperture subquadrangular, its characters cannot be made out, by the juvenile state; the right margin, which will most probably be varicose in the adult shell, is still thin, columellar margin curved, terminating in a short canal, directed towards the left and slightly upturned.

This new species is very peculiar by its shape and sculpture. I know no species to which it may be allied and think, if it were adult, it would prove to constitute a new section.

\section{Clava Martyn.}

I. Clava (Psezdovertagus) aluco Linné.

LinNÉ. Syst. Nat. Ed. X, p. $755, \mathrm{~N}^{0} 497$.

Rumph. Amb. Rariteitkamer, p. Ioo, Pl. 30, fig. N.

Kiener. Coq. Viv. Vol. IV, Cerithium, p. 17, Pl. 6, fig. 1.

ReEve. Conch. Ic. Vol. XV, Vertagus, fig. 3.

TRYon. Man. of Conch. Vol. IX, p. I45, Pl. 27, fig. 38.

Kobett. Martini-Chemn. Conch. Cab. Ed. II, Cerithium, p. I6, Pl. 3, fig. 4-6.

Stat. 34. Labuan Pandan, Lombok. Coralreef. I Spec.

Stat. 193. Sanana-bay, East coast of Sula Besi. Reef. I Spec.

Stat. 250. Kilsuin, West coast of Kur-island. 20-45 M. Coral and Lithothamnion. 4 Spec.

Stat. 31 3. East of Dangar Besar, Saleh-bay. Up to $36 \mathrm{M}$. Sand, coral and mud. I Spec.

"Java. (N. A. M.). I Spec.

2. Clava sinensis Gmelin.

Gmelin. Syst. Nat. Ed. XIII, p. 3542.

Kiener. Coq. Viv. Vol. IV, Cerithium, p. I5, PI. 5, fig. I (obeliscus).

ReEve. Conch Ic. Vol. XV, Vertagus, fig. 7 (obeliscus).

Tryon. Man. of Conch. Vol. IX, p. 146, Pl. 27, fig. 39 (obeliscus).

Kobelt. Martini-Chemn. Conch. Cab. Ed. II, Vol. I, Cerithium, p. 20, Pl. 4, fig. 2-8.

Stat. 53. Bay of Nangamessi, Sumba. Up to $36 \mathrm{M}$. Coralsand. I Spec.

Stat. 8I. Pulu Sebangkatan, Borneo-bank. Reef. I Spec.

Stat. 174. Waru-bay, North coast of Ceram. Reef. I Spec.

Stat. 225. South point of South Lucipara-island. Reef. 4 Spec.

The specimens from the last named locality, nearly reach the recorded maximum of length of 2,5 inches.

\section{Clava articulata Adams \& Reeve.}

Adams \& ReEve. Voy. Samarang, p. 43, Pl. Io, fig. I4.

ReEve. Conch. Ic. Vol. XV, Vertagus, fig. i6.

Tryon. Man. of Conch. Vol. IX, p. 146, Pl. 28, fig. 5 (gemmatum pars).

Kobelt. Martini-Chemn. Conch. Cab. Ed. II, Vol. I, Cerithium, p. 33, Pl. 7, fig. 8, 9. 
Stat. 66. Bank between islands of Bahuluwang and Tambolungan, South of Saleyer. \& M. Dead coral, Halimeda, Lithothamnion. 4 Spec.

Stat. 90. $1^{\circ}{ }^{1} 7^{\prime} .5$ N., $118^{\circ} 53^{\prime}$ E. Celebes Sea. 28 I M. Coral, sand and stones. I Spec.

Stat. 99. North-Ubian. 16-23 M. Lithothamnion-bottom. 6 Spec.

Varying much in sculpture, one of the young specimens from Stat. 66 has the nodules at the suture much more developed than those from Stat. 99.

4. Clava tenuisculpta Sowerby.

SOWERby. ReEve. Conch. Ic. Vol. XV, Vertagus, fig. 22.

TrYon. Man. of Conch. Vol. IX, p. 146, P1. 27, fig. 43 (gemmatus pars).

Stat. I04. Sulu-harbour, Sulu-island. I4 M. Sand. I Spec.

Probably only a variety of the preceding species; the only specimen is young and consequently the identification rather uncertain; in accordance with the figure of ReEve, the spire is more acuminate than in $C$. articulata.

\section{Clava Kochi Philippi.}

Philippi. Abb. u. Beschr. Vol. III, p. 14, Cerithium, Pl. I, fig. 3.

ReEve. Conch. Ic. Vol. XV, Vertagus, fig. 26.

TrYon. Man. of Conch. Vol. IX, p. I47, PI. 28, fig. 48, 49.

Kobelt. Martini-Chemn. Conch. Cab. Ed. II, Vol. I, Cerithium, p. I05, P1. 21, fig. 3, 4?

Stat. 4. Djangkar (Java). 9 M. Coarse sand. I Spec.

Stat. 58. Seba, Savu. Reef. I Spec.

Stat. 7I. Makassar. 27-36 M. Mud, sand with mud, coral. 2 Spec.

Stat. I33. Lirung, Salibabu-island. 36 M. Mud and hard sand. 6 Spec.

Stat. 313. East of Dangar Besar, Saleh-bay. Up to 36 M. Sand, coral and mud. 6 Spec.

KoвELt, whose figures are not very characteristic, especially not in the shape of the canal, says: "Aus dem indopacifischen Ocean ist sie meines Wissens noch nicht bekannt geworden, wenn nicht etwa Cerithium graniferım Pease hierher gehört". Dunker (Index Molluscorum maris Japonici, p. IOS) has recorded the species from Japan, and has observed specimens with brown lines in the interstices of the lirae, more rarely whitish ones, agreeing with PhiLippi's figures. Previous to this record is that of Lischke (Japanische Meeres-Conchylien, Band I p. 72, Band. III p. 49); v. Martens (Moll. Mauritius p. 280) quoted by Kobelt, prefixes an "I" to the species, meaning that it lives also in the Indian Ocean (Nicobaren, Ceylon, Malaischer Archipel). In the majority of the specimens, the interstices of the lirae have distinct brown lines, where they are wanting, this seems to be caused by fading, in dead specimens. The. canal, if intact, is by no means so straight as in Kobert's figures, so I have left the species in the genus Clava $=$ Vertagzis.

\section{Clava Pfefferi Dunker.}

Dunker. Index Moll. Maris Japonici, p. 108, Pl. 4, fig. 12-14.

Tryon. Man. of Conch. Vol. IX, p. I47, PI. 28, fig. 56 (turritum).

Kobert. Martini-Chemn. Conch. Cab. Ed. II, Vol. I, Cerithium, p. 145, Pl. 27, fig. I2, I3. 
Stat. 4. Djangkar (Java). 9 M. Coarse sand. I Spec.

Statl 7. Near reef of Batjulmati (Java). 15 M. Coral and stones. 2 Spec.

Stat. 33. Bay of Pidjot, Lombok. 22 M. Mud, coral and coralsand. 3 Spec.

Stat. 64. Kambaragi-bay, Tanah Djampeah. 32 M. Coral, coralsand. 2 Spec.

Stat. 71. Makassar and surroundings. Up to $32 \mathrm{M}$. Mud, sand with mud, coral. 12 Spec

Stat. I42. Laiwui, North coast of Obi major. 23 M. Very fine, hard sand, mud. 2 I Spec.

Stat. 205. Lohio-bay, Buton-strait. 22 M. Sandy mud. I05 Spec.

Stat. 23I. Amboina. 54 M. Coral. I Spec.

Stat. 260. North point of Nuhu Jaan, Kei-islands. 9o M. Sand. coral and shells. 3 Spec.

Stat. 26r. Elat, West coast of Great-Kei-island. 27 M. Mud. 2 Spec.

Stat. 279. Rumah-Kuda-bay, Roma-island. I8-35 M. I Spec.

Stat. 296. Noimini, South coast of Timor. 9-36 M. Sandy mud. I Spec.

Stat. 3I3. East of Dangar Besar, Saleh-bay. Up to 36 M. Sand, coral and nud. 40 Spec.

This species has been ascribed both to Vertagus (= Clava) and Cerithium. Dunker himself and Tryon, describe it as Vertagus, Kobelt and WAtson (Challenger-Gastropoda) as Cerithizm. PILsbry, who in his "Catalogue of the marine Mollusks of Japan, i 895, p. 56, enumerates it as Clava Pfefferi, says in Igo I (Proc. Acad. Nat. Sciences, Philadelphia, p. 393) "The Vertagus Pfefferi of Dunker is not a Vertagus or Clava, but a true Cerithium". The "Siboga"-specinens agree in every particular with the original figure and description of DunkER, but if one looks into the aperture in an oblique direction, one sees a more or less distinct fold on the columellar side, which is very strong in young and broken specimens, if one looks however at the adult shell en face, the fold is not visible at all. The species varies not only in colour, at has been stated by DUNkER, but also considerably in size.

\section{Clava aspera Linné.}

Linné. Syst. Nat. Ed. X, p. 756, N ${ }^{0} 500$.

Rumph. Amb. Rariteitkamer, p. I00, $\mathrm{N}^{0} 3$.

ReEve. Conch. Ic. Vol. XV, Vertagus, fig. 21.

Tryon. Man. of Conch. Vol. IX, p. I48, Pl. 28, fig. 62.

Stat. 93. Pulu Sanguisiapo, Tawi-Tawi-islands, Sulu-archipelago. I2 MI. Lithothamnion-botton, sand and coral. I Spec.

Stat. ? I Spec.

\section{Clava martiniana Pfeiffer.}

Pfeiffer. Krit. Reg. Martini-Chemn. Conch. Cab. p. I.

Rumph. Amb. Rariteitkamer, p. 100, Pl. 30, fig. K.

Kiener. Coq. Viv. Vol. IV, Cerithium, p. 22, Pl. is, fig. i (procerum).

Reeve. Conch. Ic. Vol. XV, Vertagus, fig. 9 (fasciatus).

Tryon. Man. of Conch. Vol. IX, p. I49, Pl. 28, fig. 64 (fasciatus).

Kobelt. Martini-Chemn. Conch. Cab. Ed. II, Vol. I, Cerithium, p. 26, Pl. 6, fig. I-8.

Stat. 37. Sailus Ketjil, Paternoster-islands. Up to is M. Coral and coralsand. I Spec.

Stat. 172. Island of Gisser. Reef. I Spec.

Though C. fasciata Brug. may be only a variety, I have followed the newest monograph of KoBELt, in keeping the two species separated, else the name of Bruguitere should have 
priority. It appears that the figure of RUMPH belongs to this species, rather than to $C$, vertagus as $r$. Martens has suggested, the latter being a much more ventricose species.

9. Clava Pharos Hinds.

Hinds. Voy. Sulphur, p. 27, Pl. I I, fig. 3, 4.

ReEve. Conch. Ic. Vol. XV, Vertagus, fig. I3.

TrYon. Man. of Conch. Vol. IX, p. 149, Pl. 29, fig. 68.

Kobelt. Martini-Chemn. Conch. Cab. Ed. II, Vol. I, Cerithium, p. 10, Pl. 2, fig. 3, 4.

Stat. 234. Nalahia-bay, Nusa-Laut-island. Reef. I Spec.

Stat. 240. Banda. 9-45 M. Black sand, coral, Lithothamnion-bank. 7 Spec.

Stat. 282. Between Nusa Besi and N.E. point of Timor. 27-54 M. Sand, coral and Lithothamnion. I Spec.

This species is still nearly allied to the preceding one, the specimen from Stat. $2 S_{2}$, though not so sharply sculptured as the other ones, has however the same narrow shape. I have not quoted KiENER's C. subulatum Lam., as the figure differs too much from those of the other authors.

I O. Clava vertagus Linné.

LinNé. Syst. Nat. Ed. XII, p. I 225.

Kiener. Coq. Viv. Vol. IV, Cerithium, p. 20, Pl. 18, fig. 2.

ReEve. Conch. Ic. Vol. XV, Vertagus, fig. I9 (vulgaris).

Trion. Man. of Conch. Vol. IX, p. 149, Pl. 29, flg. 69.

Kobelt. Martini-Chenn. Conch. Cab. Ed. II, Vol. I, Cerithium, p. 23, Pl. 5, fig. I-6.

Stat. I6. Bay of Kankamaraän, South of Kangeang. 22 M. Mud. 2 Spec.

Stat. 7 I. Makassar. Up to 32 M. Mud, sand with mud, coral. I Spec.

Stat. 78. Lumu-Lumu-shoal. Borneo-bank. Reef. I Spec.

Stat. 93. Pulu Sanguisiapo, Tawi-Tawi-islands, Sulu-archipelago. 12 M. Lithothamnion-bottom, sand and coral. 4 Spec.

Stat. 172. Island of Gisser. Reef. 2 Spec.

Stat. 193. Sanana-bay, East coast of Sula Besi. Reef. 3 Spec.

Stat. 225. South point of South Lucipara-island. Reef. I Spec.

Stat. 23I. Amboina. Reef. I Spec.

"Amboina (N. A. M.). 2 Spec.

The specimen from Makassar is banded, but less strong than C. taeniata $Q$. \& G.

\section{Bittium Gray.}

1. Bittium glariosum Gould.

Gould. Proc. Bost. Soc. I861, p. 387.

Reeve. Conch. Ic. Vol. XV, Cerithium, fig. I 3 I.

Tryon. Man. of Conch. Vol. IX, p. 155, Pl. 30, fig. I9 (glareosum).

Kobelt. Martini-Chemn. Conch. Cab. Ed. II, Cerithium, p. 249, Pl. 43, fig. 8.

Stat. 4. Djangkar (Java). 9 M. Coarse sand. I Spec.

I owe the identification of this very small specimen, which is moreover a dead shell, to the kindness of Mr. E. A. Smith, who compared it with the British Museum specimens. 
Potamides Brongniart.

1. Potamides (Tympanotonos) furviatilis Potiez \& Michaud.

Potiez \& Michaud. Cat. Moll. Douai, p. 363, Pl. 31, fig. 19, 20.

Kiener. Coq. Viv. Vol. IV, Cerithium, p. 92, Pl. 29, fig. 3.

ReEve. Conch. Ic. Vol. XV, Tympanotonos, fig. 9.

TRYON. Man. of Conch. Vol. IX, p. 159, Pl. 3 ! , fig. 38 .

Stat. 7. Near reef of Batjulmati (Java). I5 M. Coral and stones. I Spec.

Stat. 33. Bay of Labuan Tring, West coast of Lombok. 18-27 M. River-mud, coral, coralsand. I Spec.

Stat. 47. Bay of Bima, near South fort. Shore. i Spec.

2. Potamides (Terebralia) palustris Linné.

LinNÉ. Syst. Nat. Ed. XII, p. 1213.

RUMPH. Amb. Rariteitkamer, p. IOI, Pl. 30, fig. Q.

Kiener. Coq. Viv. Vol. IV, Cerithium, p. 8 I, Pl. I.

ReEve. Conch. Ic. Vol. XV, Pyrazus, fig. 2.

Tryon. Man. of Conch. Vol. IX, p. 160, Pl. 32, fig. 4I, 42.

Kobelt. Martini-Chemn. Conch. Cab. Ed. II, Vol. I, Cerithium, p. 35, Pl. 8, fig. I, 2; Pl. 9, fig. I, 2.

Stat. 86. Dongala, Palos-bay, Celebes. Shore. I Spec.

Stat. 213. Saleyer. Reef. I Spec.

\section{Potamides (Terebralia) sulcatus Born.}

Born. Testacea Mus. Caes. Vindob. p. 320.

Rumph. Amb. Rariteitkamer, p. 101, Pl. 30, fig. T.

Kiener. Coq. Viv. Vol. IV, p. 89, Pl. 27, fig. I, 2.

Reeve. Conch. Ic. Vol. XV, Pyrazus, fig. I.

Tryon. Man. of Conch. Vol. IX, p. I60, Pl. 32, fig. 46, 47.

Kobelt. Martini-Chemn. Conch. Cab. Ed. II, Vol. I, Cerithium, p. 40, Pl. 8, fig. 7, 8.

Stat. 4o. Pulu Kawassang, Paternoster-islands. Coralreef. I Spec.

Stat. 50. Bay of Badjo, West coast of Flores. Shore. 4 Spec.

Stat. 71. Makassar. Up to $32 \mathrm{M}$. Mud, sand with mud, coral. I Spec.

Stat. 86. Dongala, Palos-bay, Celebes. Shore. 4 Spec.

Stat. 131. Beo, Karakelang-islands. Reef. 5 Spec.

Varying much in shape and size, the smallest fullgrown specimen from Stat. 86, reaching only a length of about 30 Mill., the largest from Stat. 50 of 47 Mill., but I have seen larger ones.

\section{Cerithidea Swainson.}

1. Cerithidea ornata A. Adams.

A. Adans. Thes. Conch. Cerithium, p. 887, Pl. 186, fig. 277,278 .

Reeve. Conch. Ic. Vol. XV, Cerithidea, fig. 22.

TRYon. Man. of Conch. Vol. IX, p. I62, Pl. 33, fig. 64 .

Kobetr. Martini-Chemn. Conch. Cab. Ed. II, Vol. I, Cerithium, p. 5 I, Pl. II, fig. I, 2. 
Stat. 200. Bara-bay, North coast of Buru-island. Up to 54 M. Mud and stone. 7 Spec.

Rather variable in the bands, which are more or less broad and distinct, this latter difference may however be due to the state of freshness of the shell, though they are all living specimens.

\section{Cerithiopsis Forbes \& Hạnley.}

I. Cerithiopsis (Seiia) Verslaysi n. sp. P1. XI, fig. 7 .

Stat. 23r. Amboina. Reef. I Spec.

Shell small, turriculate, brown, with about 10 postnuclear, flat whorls, the nuclear ones wanting; each whorl with three spiral ribs, of which the upper and basal ones are thick, the median one is narrower, the interstices are wider than the ribs, distinctly radiately striate; on the last whorl the number of spiral ribs amounts to five, two ribs appearing below the peripheral one: moreover two small intermediate striae appear towards the aperture. Suture not conspicuous. Aperture subquadrangular, right margin straight, simple, but not sharp; columellar margin smooth, with a rather thick layer of enamel, upper corner of the aperture with an entering rib, formed by a continuation of the most basal of the lirae, canal short, rather wide, directed towards the left.

Alt. $5 \frac{1}{2}$, lat. 2 Mill.

This small species may be allied to $C$. dextroversa Ads, by its sculpture consisting of 3 carinae of which the central one is smaller, but that species is whitish, much larger and has a larger number of whorls, for even if complete, the new species scarcely could have more than 12 whorls.

\section{Argyropeza Melvill \& Standen.}

I. Argyropeza divina Melvill \& Standen. Pl. XV, fig. II.

Melvill \& Standen. Proc. Zool. Soc. Lond. I901, p. 372, P1. 2i, fig. 3.

Stat. I 39. $0^{\circ} \mathrm{II}^{\prime} \mathrm{S}$., I $27^{\circ} 25^{\prime} \mathrm{E}$. Molucca-Passage. 397 M. Mud, stones and coral. I Spec.

Stat. 312. Saleh-bay, North coast of Sumbawa. 274 M. Fine, sandy mud. 7 Spec.

Part of the specimens is slightly larger than the type described by Melvill and Stander, moreover they are more or less variegated with brown. The operculum is rounded-oval, with many whorls, I think about 8, of which the outer ones are broad, the central ones so small that I cannot count them with accuracy.

The radula is exceedingly small and of difficult observation, its breadth being scarcely $1 / 6$ of a Mill., its length could not be ascertained, as it fell to pieces, but it may not have exceeded 1/2 Mill. The rhachidian tooth $(\mathrm{R})$ has a broad, subquadrangular shape, with curved sides, the cusp has one larger denticle and three smaller ones on each side, it seems that along the basal margin, runs a narrow very indistinct zone, but by the excessive thinness, I am not quite certain about this, the laterals (I) have an elongately subrhombical shape, the cusp has one 
large denticle and one proximal, 5 distal, smaller ones, the uncini (U) are very slender, rather long and considerably curved, one of the two rows seems to be very indistinctly denticulate.

As to the systematic position of this species, I think it advisable to keep it as the type of a separate genus, the rhachidian and lateral teeth resemble in several particulars the figures of radulae of the genera Cerithiopsis and Litiopa by Troschel (Gebiss der Schnecken Pl. XI, fig. I 2 and 14) but the uncini seem to be more slender and are distinctly denticulate in these genera, whereas in Argyropeza, the denticles, if they exist at all, are very faint. The operculum of Cerithiopsis has been described by Fischer (Manuel de Conchyliologie) as suboval, paucispiral, with sublateral nucleus, placed at the left side of the aperture, that of Litiopa as oval, very thin, paucispiral, with subterminal nucleus. As stated above the operculum in Argyropeza is suboval, multispiral and has a subcentral nucleus. From Bittium, of which I find no description of the radula, it should be distinguished by its many-whorled operculum.

\section{Argyropeza Melvilli n. sp. Pl. XII, fig. 1.}

Stat. 102. $6^{\circ} 4^{\prime} \cdot 1$ N., $120^{\circ} 44^{\prime}$ E. Sulu Sea. 535 M. Fine, yellow sand. I Spec.

Shell small, pyramidal, white, whorls $11^{1} / 2$, of which nearly 2 form the nucleus, the first is rather bulbous and smooth, the second radiately ribbed one is also swollen; remaining whorls regularly increasing, slightly contracted above and below, nearly straight towards the middle, with two spiral rows of pointed nodules, connected by slight spirals and oblique radiating ribs, moreover the shell has a thin spiral, just above the linear suture. The rest of the surface is smooth and shining, with a slight nacreous lustre and with numerous fine growth-striae. Bodywhorl conspicuously keeled below the periphery and with a second keel at some distance on the smooth base. Aperture subrhombic, outer margin thin, angulate at the end of the lower row of nodules, columellar margin rounded, slightly curved, ending in a point, where it joins the basal margin.

Alt. $\mathrm{IO}^{1} / 2$, lat. $3^{1 / 4}$; apert. alt. $1^{3} / 4$, lat. $1^{1 / 2}$ Mill.

This species has much puzzled me, more than once I had compared it with the preceding one, but the very different nucleus and the aperture abstained me from considering it as belonging to the genus Argyropeza, unfortunately the operculum and the soft parts are wanting; at last I asked the assistance of Mr. J. Cosuo Melvill, who suggested it would be a Cerithopsoid shell, probably belonging to the genus Argyropeza. As to the different nucleus, I found it had much resemblance with that of Cerithium obcliscoides Jeffr. (Proc. Zool. Soc. Lond. I 885, p. 55, Pl. VI, fig. 4). Jeffreyss (1. c. p. 59) divided the species of Cerithiopsis in two sections: "A. typical with acuminated apex and B. Eumeta Mörch, Apex blunt". If the species now under consideration, really belongs to the genus Argyropeza, this genus could be divided in the same manner. I have named it after one of the authors of the genus. The new species is larger, more elongate, with less convex whorls than $A$. divina, it has a nearly smooth base and quite different nucleus. 
Fam. Planaxidae.

Planaxis Lamarck.

I. Planaxis sulcatus Born.

BORn. Mus. Vindobon. p. 250, Pl. IO, fig. $5,6$.

ReEve. Conch. Ic. Vol. XX, Planaxis, fig. 4.

Tryon. Man. of Conch. Vol. IX, p. 276, Pl. 52, fig. 22, 23.

Stat. 19. Bay of Labuan Tring, West coast of Lombok. I8-27 M. River-mud, coral, coralsand. is Spec.

Stat. 47. Bay of Bima, near South fort. Shore. 3 Spec.

"Java (N. A. M.). 27 Spec.

A very variable species; I cannot detect however specimens agreeing sufficiently with the species or varieties breviculus Desh. or Savignyi Desh.

2. Planaxis nigra Quoy \& Gaimard.

Quoy \& Gaimard. Voy. Astrol. Zool. II, p. 49I, Pl. 33, fig. 22-24.

ReEve. Conch. Ic. Vol. XX, Planaxis, fig. I3.

Tryon. Man. of Conch. Vol. IX, p. 278, Pl. 52, fig. 37.

Stat. 165 North-east side of Daram-island, East coast of Misool. Reef. 24 Spec.

The specimens are young; from the West Indian $P$. mucleus Wood they differ by their convex whorls, from $P$. abbreviata Pease, in being larger. TRyon (1.c.) has for that species given a length of $7 \frac{1}{2}$ Mill., whereas the juvenile specimens under consideration, reach a length of 10 Mill. The specimens have a white nucleus, one groove below the suture and a few ones near the base.

\section{Quoyia Deshayes.}

1. Quoyia decollata Quoy \& Gaimard. P1. XVI, fig. 4.

Quoy \& Gainard. Voy. Astrol. Zool. II, p. 489, Pl. 33, fig. 33, 34.

ReEve. Conch. Ic. Vol. XX, Planaxis, fig. 37.

Tryon. Man. of Conch. Vol. IX, p. 280, Pl. 53, fig. $7 \mathrm{I}$.

Stat. 13 I. Beo, Karakelang-islands. Reef. $3^{2}$ Spec.

Operculum paucispiral, with a subterminal nucleus on the left or columellar side.

The radula is rather long, about $7^{1 / 2}$ Mill. in length; its rhachidian tooth $(R)$ has a broad body, with elongated wings on each side and an appendix at the basal margin, cusp broad, rounded, two denticles on the body or basal part; lateral tooth (I) with apparently subtriangular body, with a long tail at the distal side, a large reflected cusp and 3 smaller denticles on its distal side, probably also a few on the proximal side, which are however covered by the central cusp; uncini (U), with an elongate body, the inner one has a cusp with 6 denticles, moreover if placed in a favorable position, I see a very thin part along the body, ending in a 
denticle which is separated from the body, by a distinct sinus; the outer one has 8 or 9 denticles and a very thin plate of an elongate, triangular shape. If the teeth lay in their natural position the uncini cover each other in such a degree, that their arrangement is scarcely clear, so it might be that I have erred in the appreciation of what is the inner and outer of the uncini. This description agrees only in part with that of the radula of Planaxis by Troschel (Gebiss der Schnecken, Vol. I, p. I5O, I5I, Pl. I 2, fig. 7-9), for though the rhachidian tooth is really of the same construction, the uncini are quite different by the lateral appendices. In this respect they better agree with Cerithidea and Pyrazus (1.c. Pl. 12, fig. 4 and 5), I have consequently not followed the example of Fischer (Manuel de Conchyliologie) Tryon (l. c) and others, who consider Quoyia as a subgenus of Planaxis; I think that its conchological character of the plicated columella, together with the differences in the radulae, will be fully sufficient, to keep them separate.

Fam. Modulidae.

\section{Modulus Gray.}

I. Modulus tectum Gmelin.

Gmelin. Syst. Nat. Ed. XIII, p. 3569.

Tryon. Man. of Conch. Vol. IX, p. 260, Pl. 48, fig. 87.

Stat. 37. Sailus-Ketjil, Paternoster-islands. 27 M. Coral and coralsand. I Spec.

Stat. ? I Spec.

Both specimens are still young, that from Stat. 37 is moreover broken, but sufficiently characteristic.

\section{Fam. TRIPHORIDAe.}

Triphora Blainville.

1. Triphora (Euthymia) princeps Sowerby.

Sowerby. Proc. Mal. Soc. Lond. VI, 1904, p. I74 (fig.).

Stat. 6o. Haingsisi, Samau-island. Reef. I Spec.

The only specimen, though young (it has only a length of 24 Mill. instead of 57 ) is still a giant in the genus. Sowerby (l.c.) did not know the habitat of this species, described after a specimen, from the collection of the late admiral Keppel.

2. Triphora (Euthymia) sculpta Hinds.

Hinds. Ann. and Mag. of Nat. Hist. Vol. XI, 1843, p. I7.

Tryon. Man. of Conch. Vol. IX, p. 178, P1. 37 , fig. 82,83 .

Stat. 250. Kilsuin, West coast of Kur-island. 27 M. Coral and Lithothamnion. I Spec. 
The specimen is very large, nearly I 7 Mill., the length stated by Hinds (1.c.) being only $4 \%$ line; it perfectly agrees with a younger specimen, received from SowERBY, with the locality "New-Caledonia". At the base of each whorl is still a small liration, articulated with white and brown; the whole shell between the lirae is covered with microscopical spiral lines.

\section{Triphora (Euthymia) elegans Hinds.}

Hinds. Ani1. and Mag. of Nat. Hist. Vol. XI, I 843 , p. I 8.

Tryon. Man. of Conch. Vol. IX, p. I89, Pl. 39, fig. 62.

Stat. 125. Sawan, Siau-island. Reef. I Spec.

The specimen, which is not complete, perfectly agrees in sculpture and colour with a specimen received from Sowersy from New-Caledonia, under the name of picturata Sow. (Proc. Mal. Soc. Lond. IV, p. 2 IO, P1. 22, fig. I I), which according to Suitr (Fauna of the Maldive and Laccadive Archipelago, Vol. II, part 2, p. 613) is a synonym of $T$. elegans. The species, like the preceding one has very fine spiral striae between the lirae.

\section{Triphora (Euthymia) Vershu'si n. sp. Pl. XI, fig. 8.}

Stat. $310.8^{\circ} 30^{\prime}$ S., $119^{\circ} 7^{\prime} .5$ E. Flores Sea. 73 M. Sand with few pieces of dead coral. 1 Spec.

Shell rather large, conical, with slightly convex sides. Nuclear whorls wanting, remaining ones about I 2, concave, with two spirals, consisting of beads, the basal one the strongest, between these two, but nearer to the upper one, runs a third spiral, which is much narrower and not beaded but waved, at the shallow suture a trace of a fourth spiral makes its appearance, it is quite visible on the last whorl, where it proves to be less strong than the basal one of former whorls, and to be less conspicuously beaded, it is accompanied by a fifth spiral, placed at a small distance; moreover the whorls are sculptured by perpendicular grooves and flat ribs, connecting the beads of the upper and lower rows of beads, and finally the whole shell with exception of the beads, is covered with microscopical spirals and radiating striae, which fill also the space between the $5^{\text {th }}$ liration and the canal, the base is also plicated by a few radiating folds; the beads of the upper row on each whorl are constantly yellowish, those of the basal row alternately (but not regularly) white and yellowish-brown, with occasionally brown spots between them, the colour of the rest of the shell is of an ashy violet. Aperture subquadrate, columellar margin thickened, with two small callosities, of which the lower one borders the short canal, which is a little curved backwards.

Long. (incl. canal) I 3 , lat. $3^{1} \frac{2}{2}$ Mill.

The specimen is slightly bleached by time, perhaps by the action of spirits. I know no species to which it is really allied, but it has a superficial resemblance with $T$. malvacea Jouss. belonging however to another section of the genus.

\section{Triphora (Euthymia) Schmidti n. sp. P1. XI, fig. 9.}

Stat. 43. Pulu Sarassa, Postillon-islands. Up to 36 M. Coral. I Spec.

Shell narrowly conical, with nearly straight sides, but slightly acuminate. Nuclear whorls 
wanting, remaining whorls 14 , convex, each with 4 spirals, of which the uppermost is placed at a small distance from the suture, the third is the most prominent and the fourth borders the lower suture, these spirals are not really beaded, but waved by the radiating grooves and flat ribs covering the shell; on the second and third spiral however, they have more or less the appearance of compressed beads, moreover I see very fine growth-striae. Colour whitish, with yellowish-brown upper spirals and small brown spots between the beads of the third spiral; last whorl carinated by the fourth spiral, its base radially striate, bearing a fifth spiral. Aperture subquadrangular, with a small notch in the upper corner, columellar lip callous below, canal short, directed towards the right and backwards.

Long. (incl. canal) $10^{1} / 2$, lat. $2 \frac{1}{4}$ Mill.

\section{Triphora (Euthymia) pura Smith.}

Smith. Fauna Maldive and Laccadive Archipelago. Vol. II, part. 2, p. 6I4, Pl. 35, fig. 20, 21.

Stat. 47. Bay of Bima, near South fort. I3-54 M. Mud with patches of fine coralsand. 1 Spec. Stat. 99. North-Ubian, Sulu-archipelago. I6-23 M. Lithothamnion-bottom. I Spec.

Larger than the type, which is only 14 Mill. in length, the Siboga-specimens are 17 and 18 Mill., the latter is adult, the former is still young.

\section{Triphora sp.}

Stat. $95 \cdot 5^{\circ} 43^{\prime} \cdot 5$ N., $119^{\circ} 40^{\prime}$ E. Sulu Sea. 522 M. Stony bottom. I Spec.

The specimen is not adult, the nuclear whorls are wanting, it is worn and bleached. I cannot identify it with any of the known species, but it is in too bad condition for description and I only make mention of it, as it would be remarkable for the great depth at which it has been dredged. It is however not certain that it has really lived there.

\section{Triphora (Iniforis) fuscoapicata Sowerby.}

Sowerby. Proc. Mal. Soc. Lond. VII, 1907, p. 30I, Pl. 25, fig. 9.

Stat. 93. Pulu Sanguisiapo, Tawi-Tawi-islands, Sulu-archipelago. Reef. I Spec.

The specimen is slightly larger than the type, having a length of nearly $6^{1} / 2$ Mill. instead of $5^{1} / 2$, but a cotype received from the author, from the island Cebu, the original locality, is even 7 Mill. in length. Both specimens perfectly agree. The brown apical whorls are not smooth, as has been stated in the description (l. c.) but only the uppermost one may be called so, the other are bicarinate and are crossed by narrow riblike striae.

\section{Triphora (Iniforis) concors Hinds.}

Hinds. Ann. and Mag. Nat. Hist. Vol. XI, I843, p. 17.

Tryon. Man of Conch. Vol. IX, p. 178, Pl. 37, fig. 80.

Stat. 47. Bay of Bima, near South fort. $14-31$ and 55 M. Mud with patches of fine coralsand. 3 Spec. 
Stat. 90. $\mathrm{I}^{\circ} \mathrm{I} 7^{\prime} \cdot 5 \mathrm{~N}$., I $18^{\circ} 53^{\prime}$ E. Celebes Sea. 28 I M. Coralsand and stones. 2 Spec.

Stat. 93. Pulu Sanguisiapo, Tawi-Tawi-islands, Sulu-archipelago. I2 M. Lithothamnion-bottom, sand and coral. I Spec.

Stat. 95. $5^{\circ} 43^{\prime} .5$ N., I $19^{\circ} 40^{\prime}$ E. Sulu Sea. 522 M. Stony bottom. I Spec.

Stat. 240. Banda. $9-45$ M. Black sand, coral. I Spec.

Stat. 258. Tual, Kei-islands. 22 M. Lithothamnion, sand and coral. I Spec.

Neither Hinds nor TrYon (1. c.) have made mention of the colour of this species; it is white with brown apical whorls, which are however wanting in most specimens; the somewhat rude figure of TRYON, which should be a copy of Hinds' figure in the Voy. "Sulphur" is brownish. Mr. E- A. Sмiтн has compared a specimen from Stat. 47 , so I have no doubt about the identity. The specimens recorded from the great depths are dead shells. T. fuscoapicata Sow. much resembles the species under consideration, one might think it could be a dwarf-form.

ro. Triphora (Viriola) corrugata Hinds.

Hinds. Ann. and Mag. Nat. Hist. Vol. XI, I843, p. 18.

Tryon. Man. of Conch. Vol. IX, p. I89, Pl. 39, fig. 59.

Stat. 37. Sailus Ketjil, Paternoster-islands. Up to I 8 M. Coral and coralsand. I Spec.

Stat. 6o. Haingsisi, Samau-island. Reef. 2 Spec.

Stat. 66. Bank between islands of Bahuluwang and Tambolungan, South of Saleyer. 8 M. Dead coral, Halimeda and Lithothamnion. 2 Spec.

Stat. 71. Makassar. Up to 32 M. Mud, sand with mud, coral. I Spec.

Stat. 99. North-Ubian, Sulu-archipelago. 16-23 M. Lithothamnion-bottom. I Spec.

Stat. I 14. Kwandang-bay-entrance, North Celebes. 75 M. Hard sand, very fine. I Spec.

Stat. 123. North-bay, Biaru-island. 27-36 M. Stone and Lithothamnion-bottom. I Spec.

Stat. 162. Between Loslos and Broken-island, West coast of Salawatti. I8 M. Coarse and fine sand, with clay and shells. I Spec.

Stat. $164.1^{\circ} 42^{\prime} .5$ S., $130^{\circ} 47^{\prime} .5$ E. Halmahera Sea. 32 M. Sand, small stones and shells. 2 Spec.

Stat. 240. Banda. 9-45 M. Black sand, coral. 3 Spec.

Stat. 285. South coast of Timor. 34 M. Limit between mud and coral. Lithothamnion. 2 Spec.

Stat. 3 I 5. East of Sailus Besar, Paternoster-islands. Up to $36 \mathrm{M}$. Coral and Lithothamnion. I Spec.

Variable in size, in colour and in sharpness of the keels, however these latter differences may depend on the more or less fiesh condition of the shells.

\section{I. Triphora (Viriola) cancellata Hinds.}

Hinds. Ann. and Mag. Nat. Hist. Vol. XI, I843, p. I8.

Tryon. Man. of Conch. Vol. IX, p. I89, Pl. 39, fig. 64 .

Stat. 285. South coast of Timor. 34 M. Limit between mud and coral. Lithothamnion. I Spec. Stat. $310.8^{\circ} 30^{\prime}$ S., $119^{\circ} 7^{\prime} .5$ E. Flores Sea. 73 M. Sand with few pieces of dead coral. I Spec.

This fine species has been recorded by Hinds and Tryon only from the Strait of Malacca.

\section{Triphora (Mastonia) rubra Hinds.}

Hinds. Ann. and Mag. Nat. Hist. Vol. XI, 1843, p. 19.

Tryon. Man. of Conch. Vol. IX, p. 182, Pl. 38, fig. 13-16.

Hedley. Memoirs Austral. Mus. Vol. III, I S99, p. 44I, fig. 29. 
Stat. $47^{7}$. Entrance bay of Bima. 320 M. Fine sand. 2 Spec.

Stat. 2I3. South-island, near Saleyer. Reef. I Spec.

The specimen from Stat. $2 \mathrm{I}_{3}$ is rather young but agrees in sculpture with those from the bay of Bima.

13. Triphora (Mastonia i) sp.

Stat. 93. Pulu Sanguisiapo, Tawi-Tawi-islands, Sulu-archipelago. I2 M. Lithothamnion-bottom sand and coral. I Spec.

The specimen is too young to ascertain even its subgeneric position.

\section{Triphora (Mastonia) sp.}

Stat. 273. Pulu Jedan, East coast of Aru-islands. I 3 M. Sand and shells. I Spec.

The specimen, though probably belonging to an undescribed species, is too young for description.

\section{Triphora (Inella) sp.}

Stat. 3 10. $8^{\circ} 30^{\prime}$ S., $119^{\circ} 7^{\prime} .5$ E. Flores Sea. 73 M. Sand with few pieces of dead coral. I Spec.

The only specimen is not quite adult and of irregular shape, by haying been broken in its youth, so I don't venture to describe it as new.

Fam. Trichotropidae.

Trichotropis Broderip \& Sowerby.

I. Trichotropis pulcherrima Melvill \& Standen.

Melvill \& Standen. Ann. and Mag. Nat. Hist. Ser. 7, Vol. XII, p. 296, Pl. 20, fig. i5.

Stat. 313. East of Dangar Besar, Saleh-bay. Up to 36 M. Sand, coral and mud. I Spec.

The "Siboga"-specimen is smaller than the type, being only 16 Mill. in length, the type 24 Mill., the columellar margin is not so straight as is the quoted figure. I think these differences may depend on age or be individual. Shape and sculpture agree so well with the figure, that I dare not describe a new species on such slight differences. One should expect to find such arctic animals only at considerable depths, but the specimen from the Gulf of Oman has been found at 25 fathoms.

\section{Trichotropis orientalis n. sp. Pl. XII, fig. 2.}

Stat. 21 I. $5^{\circ} 40^{\prime} .7$ S., I $20^{\circ} 45^{\prime} \cdot 5$ E. Banda Sea. I 58 M. Coarse grey mud. I Spec.

Shell turbinate, subdiscoid, with three strong keels or spiral ribs on the last whorl, yellowish-brown. Whorls 6 , of which 4 nuclear ones are smooth, convex, and form a small cone; 
subsequent whorls 2 , the upper one with 2 , the last with 3 strong keels; these whorls are flat between suture and upper keel, more or less concave between the lower keels and towards the base. Sculpture consisting of faint spiral grooves with rather large interstices, crossed by stronger growth-striae, the keels of last whorl are sculptured by strong spirals, the shell is covered by a thick, fibrous, yellowish-brown epidermis, with strong grooves, a few spinous fibres are visible here and there on the keels. Aperture subcircular, but with many angles, of which one at the upper part, three are formed by the keels, which are hollow interiorly, and one by a basal channel. Columellar margin concave, interrupted by the basal keel, tortuous below, terminating in a blunt point, joining the basal margin by the rounded basal channel, the columella is provided with a layer of enamel, nearly covering an umbilical slit..

Operculum oval, corneous, with some strong ribs at the distal margin.

Alt. $3_{3}^{1} / 2$, lat. I 6 ; apert. alt. $9^{1} / 2$, lat. $7^{1} / 2$, with keels $81 / 2$ Mill.

This is a very remarkable species; amongst those described it has only a remote resemblance with $T$. bicarinata Brod. and Sow. and $T$. coronata Gould, it differs however so much from both, that it is not necessary to insist upon the differences. The three very strong, hollow spiral keels are most characteristic. As to the generic position, the epidermis, shape of aperture with basal channel and the operculum have guided me. As I would not destroy the only specimen, I was unable to examine the radula.

\section{Genus ?}

I. sp. Pl. XII, fig. 3 ; Pl. XVI, fig. 3 .

Stat. 21 I. $5^{\circ} 40^{\prime} \cdot 7$ S., $120^{\circ} 45^{\prime} \cdot 5$ E. Banda Sea. 1158 M. Coarse grey mud. 2 Spec.

I found in the same tube containing the former species, two smaller shells, both perhaps young, which I could not identify even generically; they have a superficial resemblance with the new Trichotropis, by being turbinate, with a fibrous epidermis and three keels, but these keels are much less sharp or conspicuous, and the chief difference consists in the aperture, which is slightly angular but not channelled below, the number of whorls is about 4 of which about $I^{1} / 2$ form a rather large nucleus, and $2^{1} / 2$ are depressed above, between the conspicuous suture and the uppermost keel.

Alt. $6^{1} / 4$, lat. $6 \frac{1}{2}$; apert. alt. $3^{1 / 2}$, lat. $3^{1 / 4}$ Mill.

I sent the largest specimen to Mr. E. A. Surth, who was also in doubt about its systematic position, so I have abstained myself from naming it.

The radula resembles more that of Crucibulum than of Trichotropis, the rhachidian tooth ( $R$ ) is subquadrangular, with a large multicuspidate cusp, I see 8 small denticles on each side of the median one, the laterals (1) are subrhombic, with a long cusp with denticles on both sides, about 8 on the distal side; the uncini (U) are elongate, with a few denticles near the point. This latter character is not in accordance with what is known of Trichotropidae. (Should it be possible that these small denticles have been overlooked? In Trichotropis the teeth much cover each other). 
Fam. Seguenzidae.

Seguenzia Jeffreys.

\author{
1. Seguenzia Melvilli n. sp. Pl. XII, fig. 4; Pl. XV, fig. I 2.
}

Stat. $88.0^{\circ} 34^{\prime} .6$ N., $119^{\circ} 8^{\prime} .5$ E. 1301 M. Fine grey mud. I Spec.

Shell moderately large for the genus, conical, scalar, umbilicate, whitish. Whorls about 7 , nucleus wanting, upper whorls eroded, lower ones each with three spiral lirae, of which the upper one runs at a little distance from the shallow but distinct suture, which is slightly undulate; from the first liration to the second, the shell is slightly convex, this latter liration is strong, prominent and divides the whorls in two subequal parts; below this liration the shell is concave towards the basal or peripheral liration, which in the upper whorls, runs just in the suture and in the last one borders the basal surface; these lirations are slightly spinous; distinct undulating plications run from one to the other of the lower lirae, with the convex side towards the aperture, on the upper part they are directed in an opposite way, being less distinct about halfway the interspace between the upper and median liration; moreover the whole shell is covered with much weaker striae, having the character of growth-striae and traces of more remote spiral striae. Basal face subconvex, but quite flat in the centre, with a shallow groove between the peripheral keel and the first of the basal lirae, this space is rather smooth, though crossed by plicae running from the peripheral spines in an oblique direction; the outermost of the basal lirae, which is not broad, is followed by two similar ones, about as strong as their interstices, the central ones, five in number, increasing in breadth towards the centre, (one of them nearly double) being larger than the interstices, these lirae are connected by small radiating riblets in the interstices; umbilicus bordered by a liration, consisting of a row of subquadrate beads, this umbilicus is pervious, funnelshaped, its wall is radiately striated and has one faint spiral rib. Aperture rounded-subquadrate, its right margin incomplete, its columellar margin curved, with a denticle in the basal part, it is slightly reflected over the umbilicus. Interior nacreous, (the nacreous texture of the inner layers is clearly visible on some of the exterior parts, where the outer layer has been removed by accidents during the youth of the animal).

Alt. $4 \%$, lat. $5 \frac{1}{6}$; apert. alt. $1^{3} / 4$, lat. $2 \frac{1}{4}$; diameter of umbilicus about 1 Mill.

This species has by its conical shape some resemblance with S. trispinosa Watson, but that species is considerably smaller, with less distinct spines, which have more the character of rounded tubercles, it has smooth interstices, without the conspicuous plications of the new species. The circumstance that the base of the specimens of trispinosa which I could compare is much smoother, seems to give no reliable distinguishing-character, at least WATSor ("Challenger". Gastropoda, p. I Io) says: "has some faint spirals". I have named the new species in honour of Mr. J. C. Melvill, who has kindly sent me for comparison all his materials of this genus.

As to the radula of this species, it is a very small and rather obscure object, and only by teasing it to pieces, I could get an idea of the shape of the teeth, the uncini quite covering the median rows, and crossing even the uncini of the opposite side. The rhachidian or median tooth $(\mathrm{R})$ has a subquadrate basal part, with rounded, convex posterior and less convex lateral 
margins, it has a broad, triangular cusp, with one small median denticle and about 6 smaller ones on each side; the laterals (I) one on each side, have a transversely triangular shape, with an unarmed, arched upper and concave proximal and basal margin, with blunt points at the proximal and distal extremities of the basal margin; on each side I see at least 3 , but I suppose there are 4 uncini $(U)$ which are long, slender and strongly curved. Though this radula has some resemblance with that of Aporrhais, like Verrill (Mollusca of the New England coast, Transact. Connecticut Acad. of arts and sciences, Vol. VI, May 1884, p. I86 and i 88) has stated, and like his figure (1.c. pl. 31, fig. I4b) affirms, I cannot agree without doubt with his view that it should be Taenioglossate, as the "Siboga"-specimen has a radula with at least 9 rows of teeth and probably II. The nacreous character of the shell agrees with the Rhipidoglossa, and so does the larger number of uncini. I should think the genus will belong to the Rhipidoglossa with a restricted number of teeth, such as Basilissa. As however only a knowledge of other anatomical particulars, the position and structure of the gills, of the heart etc. can decide the question I have left the family near Trichotropis, in accordance with the newest systematic arrangement of Pelseneer (A treatise on Zoology, edited by Ray Lankester, Part V, Mollusca, 1906, p. 156.

2. Seguenzia Dautzenbergi n. sp. P1. XII, fig. 5 .

Stat. 88. $0^{\circ} 34^{\prime} .6$ N., $119^{\circ} 8^{\prime} .5$ E. Makassar Strait. I 301 M. Fine grey mud. I Spec.

Stat. $178.2^{\circ} 40^{\prime}$ S., $128^{\circ} 37^{\prime} .5$ E. Ceram Sea. 835 M. Blue mud. I Spec.

Stat. $211.5^{\circ} 40^{\prime} .7$ S., $120^{\circ} 45^{\prime} \cdot 5$ E. Banda Sea. 1158 M. Coarse grey mud. I Spec.

Shell rather small, spire forming a short gradate cone, umbilicate, whitish-yellow. Whorls 7 , of which the uppermost forms the smooth nucleus, followed by about 2 whorls with a submedian keel and displaying a cancellated appearance by the intercrossing of subequal spiral and radiating riblets. The other whorls have each 3 spirals, of which the uppermost runs at a little distance from the suture, the next which is the strongest, renders the whorls carinate about halfway, and a third which seems to run just in the rather conspicuous suture; moreover the interstices have more or less numerous fine spirals (numerous in the type, where they quite fill the spaces); this spiral sculpture is crossed by radiating riblets, running straight in an oblique direction, from the suture to the upper spiral, where they form small crenulations, in the next interstice they are concave and at last convex towards the basal liration; last whorl rounded, with a strong peripheral keel, being the basal one of the upper whorls, and a convex base, with another spiral at some distance from the peripheral keel, and 12 basal spirals of which three more spaced ones, at a larger distance from the subperipheral spiral, and 9 more central spirals, which are flatter, at subequal distances, the innermost bordering the umbilicus; these spirals are connected by small radiating riblets in the interstices, moreover these interstices are filled, as far as I can see, with similar finer spirals as in the spire. Umbilicus moderately wide, probably pervious, funnel-shaped, its wall with fine radiating striae and a conspicuous spiral groove, terminating in a strong dentiform projection on the columellar margin. Aperture moderately large, irregular in shape, with a rather deep sinus at the suture (about $\mathrm{r}^{1} / 2$ Mill, behind the most projecting part of the outer margin), it is rounded behind, with an upturned margin; the 
outer margin is thin, angular by the terminations of the spiral keels; columellar margin strongly excavated above, this excavation being bordered by the strong toothlike projection formed at the end of the umbilical groove, it has the appearance of a compressed fold; below this tooth, the columellar margin runs obliquely back and terminates in a projecting point where it joins the slightly curved basal margin. Interior nacreous.

Alt. $4 \frac{1}{5}$, lat. $3^{5} / 6$; apert. alt. $2 \frac{1}{4}$, lat. $1^{2} / 3$; diam. of umbilicus about $5 / 6$ Mill.

This description is made after the specimen from Stat. 178 , which was the most complete one, the other specimens slightly differ by the number and disposition of the basal spirals, and more considerably in the finer spirals of the interstices between the keels, which in some parts are nearly wanting and are, for instance, reduced to $I$ and 3 in the spaces below the infrasutural spiral and above the peripheral keel in the specimen from Stat. $S S$, as however all other characters are really the same, I think these differences will prove to be individual. I may bring in remembrance what Dall says (Bull. Mus. Comp. Zool. Vol. XVIII, p. 269), dealing on Segucnzia: "Either each separate individual is to be regarded as a species, or the variability is very great. Persistant study of the specimens has convinced me, that the latter is the true solution, and that the most evident characters, such as the umbilicus (in some adult specimens) may be present or absent, that the number of spiral threads, their strength and sharpness on the basal disk, are entirely inconstant".

This species seems to be nearly allied to S. elegans Jeffr. (Proc. Roy. Soc. i 876, p. 200, Proc. Zool. Soc. Lond. I $S 8_{5}$, p. 42, P1. 5, fig. I, I $a$ ) but the radiating sculpture in the new species is much less crowded and coarser, the same is the case with the basal spirals, the new species is less flattened below the suture, more conical etc. These differences in specimens from such a remote provenience, have induced me to consider them as specifically distinct.

3. Seguenzia Sykesi n. sp. Pl. XII, fig. 6.

Stat. $241.4^{\circ} 24 \cdot 3$ S., $129^{\circ} 49^{\prime} \cdot 3$ E. Banda Sea. I 570 M. Dark sand with small stones. I Spec.

Shell small, subglobose, spire forming a short, subgradate cone; umbilicate, whitish-yellow, with a slight nacreous lustre. Whorls about 6 , of which about one forms the blunt, smooth nucleus; the next whorls, including the penultimate, have only one strong median keel, the space above and below this keel is slightly concave, with a few microscopic spiral threadlike striae; two whorls next to the nucleus are crossed by conspicuous radiating riblets, straight but in an oblique direction above the keel, convex below it, these riblets then suddenly disappear, only very fine striae succeeding them, being scarcely perceptible on the last whorl, with is bicarinate; a third keel borders the flattened base; suture rather conspicuous but shallow, with very slight traces of being margined, probably by the covered keel; base with 7 spirals of which the distal one, separated from the third keel by a slightly concave space, and one bordering: the umbilicus are stronger; moreover the whole base is covered with microscopic radiating striae, beautifully waved in an S-like manner. Umbilicus moderately wide, pervious, funnel-shaped, its wall wave-striated, with a shallow spiral groove terminated by a tooth on the columella. Aperture irregularly subquadrate, its outer margin so much broken, that no sinus remains, it 
is strongly sinuous by the terminations of the keels, of which the upper one becomes double at a little distance from the mouth, columellar margin connected to the outer one, by a thin layer of enamel on the body-whorl, it is first strongly excavated above by a rather deep sinus, reaching the columellar tooth, below this tooth it is again concave and terminates in an angle when it joins the basal margin at the point terminating the umbilical keel.

Alt. 3, lat. $3 \frac{1}{2}$; apert. alt. $1^{5} / 6$, lat. $1^{2} \%$, diam. of umbilicus about I Mill.

These measurements will be more or less altered in a specimen with complete aperture.

This new species has some resemblance with S. elegans Jeffr. but differs sufficiently by the number of keels and by the aperture, which, though broken, has other characters, the columella in elegans being much longer than it can be in a complete specimen of $S$. Sykesi, the whole shape of S. elegans is consequently more obliquely elongate, the sculpture is much less developed in the new species. It has also resemblance with $S$. polita Verco (Trans. and Proc. Roy. Soc. South Austr. Vol. 30; 1906, p. 222, Pl. 9, fig. 3, 4, 5), especially in its sculpture, but that species, according to Verco (1.c. Pl. 9, fig. 5) is only rimate and the keels are blunt and placed in a different manner. The nearest ally is S. ionica Wats. (Journ. Linn. Soc. Lond. 1878, Vol. 14, p. 589; "Challenger"-Gastrop. p. 107, Pl. 7, fig. 3), and indeed I have been in doubt if it should not be an oriental variety, but that species, as figured, is much more depressed, has a more conspicuous liration at some distance from the suture, and the radiating sculpture seems to be more conspicuòus in $S$. ionica.

Named in honour of Mr. E. R. Sykes, who has sent me for comparison a beautiful lot of specimens of this genus.

4. Seguenzia costulifera n. sp. Pl. XII, fig. 7 .

Stat. 211 . $5^{\circ} 40^{\prime} .7$ S., $120^{\circ} 45^{\prime} .5$ E. $115^{8}$ M. Coarse grey sand. I Spec.

Shell rather small, conoidal, with a high spire and convex base, scalar, rimate, yellowishwhite. Whorls about 7 , of which the upper one forms the smooth, bulbous nucleus, followed by 2 whorls, which have a strong median keel and traces of a third one below the suture; these lirations become more conspicuous on the lower whorls, which have the median keel, another one just below the suture and in some parts traces of a third one, running entirely or partly in the deep suture; moreover the whole shell is covered with microscopic, close-set, spiral threads; this sculpture is crossed by conspicuous riblets, fainter on the upper whorls, very strong on the lower ones, and by very fine growth-striae; the riblets are not close-set and form conspicuous spines below the suture of the lower whorls; when they cross the upper spiral, they run obliquely from behind and are curved in the lower part of the space between the upper and median keel, being concave below; below this median keel they are convex; on the last whorl runs a third keel, which is crenulated by the ribs, this is also the case with the median keel, though not so strong; at some distance from the third keel a fourth one makes its appearance, this is a little fainter and less crenulate, the riblets between it and the third keel being also weaker. The interspaces of the keels described above are conspicuously concave. From the fourth keel untill the centre run 5 spirals, of which the distal one at a considerable 
distance from the $4^{\text {th }}$ keel, the innermost borders the umbilicus; these spirals are narrow, cordlike, with large interspaces, crossed by riblets in very various direction. Umbilicus rather large, but nearly closed by the columellar margin, leaving only a fissure. Aperture incomplete, a rather broad but not deep fissure at the upper part, rounded and turned up behind; shape of aperture subquadrangular, irregular by the terminations of the keels, columellar margin expanded towards the left, formed by a deep, rounded sinus above and another narrower one below, with a strong tooth between them, this tooth is strongly compressed, as if formed by pinching the columellar margin,

Alt. 5, lat. $3^{1 / 2}$; apert. alt. $I^{1} / 2$, lat. $I^{3} / 4$ Mill.

This species resembles in shape var. lineata Wats. of $S$. monocingulata (Watson's Journ. Lin. Soc. Lond. Vol. 14, p. 587 ; "Challenger"-Gastropoda, p. 106, P1. 7, fig. 1); but the general outline is more convex and the elaborate sculpture is quite different, so I don't hesitate to describe it as new.

\section{Seguenzia sp.}

Stat. $300.10^{\circ} 48^{\prime} .6 \mathrm{~S} ., 123^{\circ} 23^{\prime} .1$ E. Timor Sea. $918 \mathrm{M}$. Fine, grey mud. I Spec.

From this Station a specimen has been collected, belonging to the rimate species, it differs from the preceding one by its broader, less conical shape and its very simple sculpture, consisting, as far as I can see, of a strong median keel on the upper whorls, of a very weak one at the upper suture and traces of a third one at the lower suture, which latter keel is conspicuous on the last whorl, moreover very faint interstitial spiral striae, crossed by radiating, threadlike striae. The nucleus and a great deal of the outer layer of the shell are wanting, its beautiful nacreous inner layer being visible in many parts; in consequence the sculpture is only visible on some small parts, as other parts have still suffered of corrosion; the columella and umbilicus have the same character, as in the preceding species. The outer margin of the aperture is quite defective, as well as the basal sculpture. In these circumstances I have not ventured to name the species, nor have I accurately described it, though it will be probably new.

\section{Seguenzia monocingulata Seguenza.}

Seguenza. Bull. del Com. Geol. Vol. VII, 1876, p. 188.

VERRILl. Trans. Connecticut Acad. Vol. VI, 1882-85, p. 186 (formosa).

Tryon. Man. of Conch. Vol. IX, p. 46, Pl. 8, fig. 71.

Stat. $137.0^{\circ} 23^{\prime} .8$ N., $127^{\circ} 29^{\prime}$ E. Between Makjan and Halmahera. 472 M. Fine, dark, muddy sand. 2 Spec.

Stat. 24 I. $4^{\circ} 24^{\prime} \cdot 3$ S., $129^{\circ} 49^{\prime} \cdot 3$ E. Banda Sea. 1570 M. Dark sand with small stones. I Spec.

These specimens have much puzzled me, those from the two stations being considerably different. That from Stat. 241 is more slender and has a coarser sculpture, somewhat different from the specimens collected at Stat. I37. The reasons that I have united them to the Atlantic S. monocingulata are: the great variability of that species, as already stated by DALL in his publication on the "Blake" Mollusca, quoted before in dealing with S. Dautzenbergi; the differences 
in the figures at my disposal, and last not least, the specimens received for comparison of Mr. Dautzenberg and of Mrs. J. C. Melvill and E. R. Sykes, the specimen from Stat. 241 more resembling the specimens of Dautzenberg and Sykes by its stronger, shorter, more remote, concave riblets between the sutural and next keel, while the specimens from Stat. I37, of which one is a beautiful shell containing the soft parts, better agrees with Mr. Mrivilu's specimens, with weaker, longer, more crowded riblets in the same space, these riblets being nearly straight and only curved in their basal part, in this respect more resembling S. eremita Verrill (Trans. Conn. Acad. Vol. VI, P1. 3I, fig. 15); these latter specimens have the subsutural liration but very little developed, much less so than in the specimens of Dautzenberg and part of those of Sykes, which are slightly variable in this respect.

\section{Fam. Vermetidae.}

This family is perhaps the most disagreeable amongst Gastropods to deal with; the extreme variability in the majority of the species and the often vague descriptions, render it impossible in many cases, to make safe identifications, except in a few instances, if the species have prominent characters. Many of the names applied below are more or less doubtful and not a few specimens must remain without name. In vain I hoped that the keeper of the mollusca in the British Museum, where the types of МӧвcH are preserved as far as I know, with his usual kindness should give me assistance, but he wrote me he knew nothing about that family; and though "nothing" will probably be too strong an expression, I could not get the hoped for certainty.

Tenagodus Guettard.

I. Tenagodus (s. str.) ponderosus Mörch.

Mörch. Proc. Zool. Soc. Lond. I 860, p. 409.

REeve. Conch. Ic. Vol. XX, Siliquaria, fig. 3 .

Tryon. Man. of Conch. Vol. VIII, p. i88, Pl. 57, fig. il.

Stat. 273. Pulu Jedan, East coast of Aru-islands. 13 M. Sand and shells. 5 Spec.

The specimens, agree very well with the quoted figures, though they are smaller, surpassing however considerably the other East-Indian species in size. The species has only been recorded from Australia.

\section{Tenagodus (s. str.) trochlearis Mörch.}

Mörcir. Proc. Zool. Soc. Lond. I860, p. 408.

REEve. Conch. Ic. Vol. XX, Siliquaria, fig. 4.

TRYon. Man. of Conch. Vol. VIII, p. 189, Pl. 57, fig. 14.

Stat. 66. Bank between islands of Bahuluwang and Tambolungan, South of Saleyer. S M. Dead coral, Halimeda, Lithothamnion. I Spec.

Stat. 125. Sawan, Siau-island. 27 M. Stone and some Lithothamnion. 1 Spec.

Stat. 144. Damar-island. 45 M. Coral-bottom and Lithothamnion. 2 Spec. 
Stat. 285. South coast of Timor. 34 M. Limit between mud and coral. Lithothamnion. I Spec.

Stat. 3 IO. $8^{\circ} 30^{\prime}$ S., I $19^{\circ} 7^{\prime} .5$ E. Flores Sea. 73 M. Sand with few pieces of dead coral. I 8 Spec.

Many of the specimens are young and consequently of very doubtful identification.

\section{Tenagodus (Agathirses) Cumingi Mörch.}

Mörch. Proc. Zool. Soc. Lond. is6o, p. 403.

REEve. Conch. Ic. Vol. XX, Siliquaria, fig. 2.

Tryon. Man. of Conch. Vol. VIII, p. 190, Pl. 57, fig. 19; Pl. 58, fig. 21.

Stat. 53. Bay of Nangamessi, Sumba. Up to 36 M. Coralsand. I Spec.

Stat. 154. $0^{\circ} 7^{\prime} .2$ N., $130^{\circ} 25^{\prime} .5$ E. Near Waigeu-island. 83 M. Grey muddy sand, shells and Lithothamnion. I Spec.

Stat. I64. $1^{\circ} 42^{\prime} .5$ S., I $30^{\circ} 47^{\prime} .5$ E. Halmahera Sea. 32 M. Sand, small stones and shells. Io Spec.

Stat. 204. Between islands of Wowoni and Buton, Northern entrance of Buton-strait. 75-94 M. Sand with dead shells. 2 Spec. .

Stat. $310.8^{\circ} 30^{\prime}$ S., $119^{\circ} 7^{\prime} .5$ E. Flores Sea. 73 M. Sand with few pieces of dead coral. 6 Spec.

I have united under this name those specimens with granular lirae below, it is the only species which, according to the descriptions of MÖRCH and TRYon, possesses this character. In Reeve's Conch. Ic. no mention has been made of this character.

\section{Tenagodus (Agathirses) Bernhardi Mörch.}

MÖRCH. Journ. de Conch. I860, p. 368.

REeve. Conch. Ic. Vol. XX, Siliquaria, fig. 9.

Tryon. Man. of Conch. Vol. ViII, p. I90, Pl. 58, fig. 22.

Stat. 77. Borneo-bank. 59 M. Fine grey coralsand. I Spec.

Stat. 3 10. $8^{\circ} 30^{\prime}$ S., I $19^{\circ} 7^{\prime} .5$ E. Flores Sea. 73 M. Sand with few pieces of dead coral. I Spec.

In the specimen from the last named Station the upper whorls are wanting.

\section{Tenagodus (Agathirses) muricatus Born.}

Born. Test. Caes. Vindobon. p. 446, Pl. I 8 , fig. 6.

Rumph. Amb. Rariteitkamer, p. I25, Pl. 4I, fig. H.

ReEve. Conch. Ic. Vol. XX, Siliquaria, fig. 7 (anguina).

Tryon. Man. of Conch. Vol. VIII, p. I90, Pl. 58, fig. 23-25 (anguina).

Stat. I64. $\mathrm{I}^{\circ} 42^{\prime} .5$ S., $130^{\circ} 47^{\prime} .5$ E. Halmahera Sea. 32 M. Sand, small stones and shells. 2 Spec. Stat. 204. Between islands of Wowoni and Buton, Northern entrance of Buton-strait. 75-94 M. Sand with dead shells. 5 Spec.

\section{Tenagodus (Pyxipoma) sp.}

Stat. 43. Pulu Sarassa, Postillon-islands. Up to 36 M. Coral. I Spec.

The specimen resembles the figure of $T$. encausticus Mörch in ReEve's Conch. Iconica (fig. Io) but the description of the slit does not agree with the specimen. As it is broken, I have abstained myself from describing it as new, moreover it seems to be very dangerous in such a variable and most difficult group, to erect species on single specimens. It is the same case with some other small specimens, from the same and other localities. 
7. Tenagodus (Pyxipoma) lacteus (Lam.) Mörch.

Lamarck. An. s. vert. Ed. II, Vol. V, p. 584?

ReEve. Conch. Ic. Vol. XX, Siliquaria, fig. 5 .

TRYon. Man. of Conch. Vol. VIII, p. 191, Pl. 58, fig. 26.

Stat. 273. Pulu Jedan, East coast of Aru-islands. 13 M. Sand and shells. I Spec.

Stat. $310.8^{\circ} 30^{\prime}$ S., $119^{\circ} 7^{\prime} .5$ E. Flores Sca. 73 M. Sand with few pieces of dead coral. 6 Spec.

The specimens agree rather well with the figures and descriptions of REEve and TRYoN (1. c.) and also with the description of Mörch (Proc. Zool. Soc. Lond. 1860, p. 409), but neither with the figure of CHeNu: Illustrations conchyliologiques, Siliquaria, Pl. 2, fig. 1, quoted by MörCu nor with the description of that author (1. c. p. 2), who says a.o.: "coquille semitransparante, très lisse, avec la fissure inarticulée", instead of an articulated slit, closed behind, open near the aperture, like Mörch, Reeve and Tryon have stated. Lamarck's description (1. c.) agrees with that of $\mathrm{CHENU}$, as may be stated by a copy of his diagnose: "S. testa contorta, parvula, semipellucida, candida, laevissima, fissura inarticulata".

\section{Vermetus Adanson.}

This genus is still more perplexing than the former, as has been discussed by TRYoN in his introduction of the genus (Man. of Conch. Vol. VIII, p. I6 3 ). I have only been successful in identifying two of the species and even not quite satisfactorely.

1. Vermetus renisectus (Carpenter) Mörch.

MÖRCH. Proc. Zool. Soc. Lond. I 861 , p. 346.

Tryon. Man. of Conch. Vol. VIII, p. 170, Pl. 49, fig. 25, 26.

Stat. 100. $6^{\circ}$ I $\mathrm{I}^{\prime}$ N., $120^{\circ} 37^{\prime} .5$ E. Sulu Sea. 450 M. Dead coral. 3 Spec. (in a cluster).

Stat. 172. Island Gisser. Reef. I Spec.

Stat. $310.8^{\circ} 30^{\prime}$ S., $119^{\circ} 7^{\prime} .5$ E. Flores Sea. 73 M. Sand with few pieces of dead coral. I Spec.

Stat. $3^{1} 5$. East of Sailus Besar, Paternoster-islands. Up to $36 \mathrm{M}$. Coral and Lithothamnion. 4 Spec.

The specimens from the first-named Station are bleached, they will probably not have lived at that great depth, that from Stat. 172 is fixed on the hollow side of what seems to be one of the squamae of a large Tridacna.

var. ?

Stat. 315. East of Sailus Besar, Paternoster-islands. Up to 36 M. Coral and Lithothamnion. 2 Spec. (cluster).

Appears to be a dark-brown variety of $V$. renisectus, with somewhat faint lamellae. It is however impossible to me, to decide to which of the numerous varieties described by Mörch it may belong.

2. Vermetus sp.

Stat. 299. Buka- or Cyrus-bay, South coast of Rotti-island. 34 M. Mud, coral and Lithothamnion. 2 Spec.

The specimens are strongly ribbed, probably young. I cannot identify them. 
3. Vermetus sp.

Stat. 25 I. $5^{\circ} 28^{\prime} .4$ S., $132^{\circ} 0^{\prime} .2$ E. Arafura Sea. 204 M. Hard coralsand. Many specimens.

A large number of specimens fixed to stones and other substances, has a superficial resemblance with $V$. renisectus, but differs by having no interior lamellae.

\section{Termetus sp.}

Stat. 209. South point of Kabaëna-island. 22 M. Coarse sand. I Spec.

Stat. 303. Haingsisi, Samau-island. Up to 36 M. Lithothamnion. I Spec.

Stat. 31 5. East of Sailus Besar, Paternoster-islands. Up to $36 \mathrm{M}$. Coral and Lithothamnion. I Spec.

I can find no figure agreeing with this rather peculiar species, which has a granular sculpture and seems to agglutinate small foreign bodies. No internal laminae.

\section{Vermetus maximus Sowerby.}

Sotwerby. Cat. Coll. Tankerv. App. N0 23.

Chemntz. Ill. Conch. Vermetus, Pl. 5, fig. 6 (gigas).

TRYON Man. of Conch. Vol. VIII, p. 184, Pl. 55, fig. 89, 90.

Stat. 248. Rumah Lusi, North point of Tiur-islands. Reef. 4 Spec.

The tubes are for a good deal imbedded in coral.

Fam. Turritellidae.

Turritella Lamarck.

I. Turritella (s. str.) tercbra Linné.

LinNÉ. Syst. Nat. Ed. XII, p. I239.

Rumpir. Amb. Rariteitkamer, p. I00, Pl. 30, fig. M.

Kiener. Coq. Viv. Vol. IX, Turritella, p. 4, Pl. 3, fig. 4.

ReEve. Conch. Ic. Vol. V, Turritella, fig. 3.

TRYON. Man. of Conch. Vol. VIII, p. 195, Pl. 59, fig. 32, 33.

Kobelt. Martini-Chemn. Conch. Cab. Ed. II, Vol. I, Turritella, p. 29, Pl. 7, fig, 2.

Stat. I. I 400 M. from "Zwaantjes-droogte", Madura-strait. 37 M. Grey mud with small broken shells. 3 Spec.

2. Turritella (s. str.) leptomita Melvill \& Sykes.

Melvill \& Sykes. Proc. Mal. Soc. Lond. Vol. II, p. 17I, Pl. 13, fig. 12, $12 a$.

Stat. 133. Lirung, Salibabu-island. Up to $36 \mathrm{M}$. Mud and hard sand. I Spec.

Stat. 23 I. Amboina. 40 M. Coralsand. I Spec.

The specimen from Stat. I 33 is larger than the type, being 29 Mill. instead of 21,5 (that from Amboina is young), the whorls, if wet, are faintly stained with brown, especially on the 
keels, but if dry, the shell seems to be "pale ash-colour", in every other respect the specimens agree with the description. The type has been collected at the Andaman-isles.

3. Turritella (s. str.) cingulifera Sowerby.

Sowerby. Cat. Coll. Tankerv. App. p. I4.

Kiener. Coq. Viv. Vol. IX, Turritella, p. 34, Pl. 8, fig. 3 (fragilis).

ReEve. Conch. Ic. Vol. V, Turritella, fig. 64.

Tryon. Man. of Conch. Vol. VIII, p. I98, Pl. 59, fig. 38, 39, 4I.

Kobelt. Martini-Chemn. Conch. Cab. Ed. II, Vol. I, Turritella, p. 23, Pl. 5, fig. I I (cingulata), p. 33 , Pl. 8, fig. 7,8 (fragilis).

Stat. 2. Madura-strait. 56 M. Grey mud with some radiolariae. I Spec.

Stat. 7. Near reef of Batjulmati (Java). 15 M. Coral and stones. 6 Spec.

Stat. 5I. Madura-bay. 69-91 M. Fine grey sand, coarse sand with shells and stones. 6 Spec.

Stat. 53. Bay of Nangamessi, Sumba. Up to 36 M. Coralsand. 8 Spec.

Stat. 58. Seba, Savu. Up to 27 M. Sand. I Spec.

Stat. $6 \mathrm{I}^{2}$. North coast of Adonara. Shore. I Spec.

Stat. 64. Kambaragi-bay, Tanah-Djampeah. 32 M. Coral, coralsand. I Spec.

Stat. 77. Borneo-bank. 59 M. Fine, grey coralsand. I Spec.

Stat. I I4. Kwandang-bay-entrance. 75 M. Hard sand, very fine. 2 Spec.

Stat. 116. West of Kwandang-bay-entrance. 72 M. Fine sand with mud. I Spec.

Stat. 123. North-bay, Biaru-island. 27-36 M. Stone and Lithothamnion-bottom. I Spec.

Stat. 133. Lirung, Salibabu-island. Up to $36 \mathrm{M}$. Mud and hard sand. 2 Spec.

Stat. I42. Laiwui, North coast of Obi Major. 23 M. Mud. I 3 Spec.

Stat. 204. Between islands Wowoni and Buton. 75-94 M. Sand with dead shells. 2 Spec.

Stat. 23 I. Amboina 54 M. Coralsand. 2 Spec.

Stat. 258. Tual, Kei-islands. 22 M. Lithothamnion, sand and coral. 2 Spec.

Stat. 279. Rumah-Kuda-bay, Roma-island. 36 M. Mud and sand. 2 Spec.

Stat. 285. South coast of Timor. 34 M. Limit between mud and coral. Lithothamnion. 3 Spec.

Stat. 306. Near mount Lobetobi. 29 M. Lithothamnion-bottom. 3 Spec.

Stat. 3I3. East of Dangar Besar, Saleh-bay. Up to 36 M. Sand, coral and mud. 62 Spec.

This common and widely spread species is very variable in many respects, and so I can agree with the views of Tryon, who unites several species with it. I have however found no specimens corresponding to $T$. ficsco-cincta Petit. The colour varies from nearly white (probably bleached) to yellowish-brown and even uniformly rather dark brown, in which latter case the brown sutural band is scarcely perceptible. The whorls are more or less convex; in most cases, but not always, the upper whorls are flatter, the lower ones convex. The sculpture varies in distinctness of the keels, which are more or less granular on one, two or on all the lirae, and this only on the upper whorls or on the whole shell, with many intermediate stages; in consequence it is impossible, with so many specimens as I could compare, to separate them in different species, even the specimens from the same locality, are as variable as those from different parts of the Archipelago.

\section{Turritella (Haustator) maculata Reeve.}

ReEve. Conch. Ic. Vol. V, Turritella, fig. 33 .

Tryon. Man. of Conch. Vol. VIII, p. 202, Pl. 63, fig. 83 .

Kobelt. Martini-Chemn. Conch. Cab. Ed. II, Vol. I, Turritella, p. 48, Pl. I5, fig. 7. 
Stat. 47. Bay of Bima, near South fort. 55 M. Mud with patches of fine coralsand. I Spec. Stat. $164 . I^{\circ} 42^{\prime} .5$ S., I $30^{\circ} 47^{\prime} .5$ E. Halmahera Sea. 32 M. Sand, small stones and shells. I 2 Spec. Stat. 3 II. Sapeh-bay, East coast of Sumbawa. Up to 36 M. Mud and sand. I Spec.

The specimens from Stat. 47 and 311 are young and bleached, in consequence their identification is not quite safe. The largest specimen from Stat. I 64 is very characteristic, but the violet colour of the base is wanting; the brown lines of the base are less numerous or even nearly wanting in young specimens. It appears that if the figures of KobeLT, 1.c. Pl. I5, fig. $3-6$, are correct, they belong to some other species. This species seems to be variable, at least I have seen some specimens agreeing in many respects, but differing in other particulars; I describe them as:

var. ornata n. var. Pl. XI, fig. II.

Stat. 33. Bay of Pidjot, Lombok. 22 M. Mud, coral and coralsand. I2 Spec.

Differing from the type in being more painted with yellowish-brown. The spotted band below the suture is broader; base with six white lirae, with small brown spots; the interstices of the lirae are spirally striate, as in the type.

Though at a first look differing considerably from the type, the sculpture is really the same, so I have not ventured to describe a new species on the slight differences recorded above. The majority of the specimens is still young.

\section{Turritella (Haustator) sp.}

Stat. 299. Buka-bay, South coast of Rotti-island. 34 M. Mud, coral and Lithothamnion. I Spec.

This specimen is still very nearly allied to var. ornata of the preceding species, especially. by the colour-pattern of the base, but the whorls are strongly flammulate, and the articulated band below the suture, if present at all, is not conspicuous.

\section{Turritella (Torcula) concava v. Martens.}

v. Martens. Beitr. zur Meeresf. der Insel Mauritius u. Seychellen. Moll. p. 283, Pl. 20, fig. Ig. TrYon. Man. of Conch. Vol. VIII, p. 206, Pl. 64, fig. 6.

Stat. 315. Sailus Besar, Paternoster-islands. Up to $36 \mathrm{M}$. Coral and Lithothamnion. I Spec.

Only one young specimen has been collected, it exactly agrees with the description, however I can find no traces of the small reddish dots, which I have detected on a fossil specimen from Celebes (Samml. des Geol. Reichsmus. Leiden, Ser. I, Vol. VIII, p. I9o) which were also present, though much less conspicuous on a typical specimen, received for comparison, from the Zool. Museum in Berlin.

Moreover a number of small specimens has been collected, they are probably young, but could not be identified, as the upper whorls of adult specimens are nearly invariably wanting and consequently cannot be used for comparison. 
Fam. Melanidae.

Melania Lamarck.

\section{Melania (Stenomelania) funiculus Quoy \& Gaimard.}

Quoy \& Gaimard. Voy. Astrolabe. Zool. Vol. III, p. 158, Pl. 56, fig. 43, 44.

Brot. Martini-Chemn. Conch. Cab. Ed. II, Vol. I, Melania, p. I36, Pl. I7, fig. I.

Stat. 19. River near Labuan Tring, Lombok. I Spec.

Stat. 131. Brook near Beo, Karakelang-islands. 2 Spec.

Stat. 174. Brook near Waru, Ceram. I Spec.

The specimen from Waru is small, with very indistinct folds and spiral striae in the constricted upper part of the whorls and at the base, those from Beo, have costulate upper whorls, but the lower ones are smooth, with only a few spiral striae.

\section{Melania (Stenomelania) turris Brot.}

Brot. Martini-Chemn. Conch. Cab. Ed. II, Vol. I, Melania, p. I46, Pl. I8, fig. 5.

Stat. I31. Brook near Beo, Karakelang-islands. I Spec.

Stat. 174. Brook near Waru, Ceram. I Spec.

The specimens agree very satisfactorily with such formerly identified for me by Dr. Brot.

\section{Melania (Stenonelania) cronulata Deshayes.}

Deshayes. Lam. An. s. vert. Ed. II, Vol. VIII, p. 434.

BRot. Martini-Chemn. Conch. Cab. Ed. II, Vol. I, Melania, p. II4, Pl. I4, fig. 9.

v. Martens. Süss u. Brackw. Moll. Ind. Arch. p. 45.

Stat. 19. River near Labuan Tring, Lombok. 7 Spec.

The specimens belong to one of the smaller varieties, as far as I know the species has not yet been recorded from Lombok.

4. Melania (Stenomelania) nniformis Quoy \& Gaimard.

QUOY \& Gaimard. Voy. Astrolabe. Zool. Vol. III, p. I54, Pl. 56, fig. 30-35.

Brot. Martini-Chemn. Conch. Cab. Ed. II, Vol. I, Melania, p. I24, Pl. 15, fig. 3, $3 \alpha$; Pl. I6, fig. I.

v. Martens. Süss- u. Brackw. Moll. Ind. Arch. p. 46.

Stat. 19. Kiver near Labuan Tring, Lombok. 7 Spec.

v. Martens (1. c. p. 47) says to have seen specimens from Lombok in the Cumingian collection.

5. Melania (Stenomelania) arctecava Mousson.

Mousson. Journ. de Conch. I857, p. 161 .

Brot. Martini-Chemn. Conch. Cab. Ed. II, Vol. I, Melania, p. I65, Pl. 20, fig. I.

SI

SIROGA-EXPEDITIE XLIX' 6 . 
Stat. I 31. Brook near Beo, Karakelang-islands. is Spec.

Stat. I74. Brook near Waru, Ceram. I Spec.

Agreeing with specimens named by BRoT.

\section{Melania (Stenomelania) punctata Lamarck.}

LAMARCK. An. s. vert. Ed. II, Vol. VIII, p. 430.

BRot. Martini-Chemn. Conch. Cab. Ed. II, Vol. I, Melania, p. I68, Pl. 20, fig. 4.

Stat. 13I. Brook near Beo, Karakelang-islands. 2 Spec.

Stat. I33. Brook near Lirung, Salibabu-island. 7 Spec.

The specimens agree with BROT's figures and with specimens named by that authority. Вrот unites $M$. albescens Lea to punctata Lam. and seems to be inclined to unite also $M$. laevigata (1.c. p. I 72), v. Martens (Süss- u. Brackw. Moll. p. 49) is in doubt about this question, but suggests that my $M$. punctata Lam. from Kupang, Timor, belongs to laevigata. Brot has verified and approved my identification of the latter specimens. How this may be, the specimens now under consideration, belong no doubt to the true $M$. punctata Lam.

\section{Melania (Stenomelania) sobria Lea.}

LEA. Proc. Zool. Soc. Lond. I 850 , p. I8 1.

BRot. Martini-Chemn. Conch. Cab. Ed. II, Vol. I, Melania, p. 178, Pl. 21, fig. 5.

Stat. I74. Brook near Waru, Ceram. 6 Spec.

Though small, some specimens seem to be adult; one of them has a slight angle below the suture of last whorl, thus forming a passage to $M$. cochlidium Lea, but it is not so strong as in that species.

\section{Melania (Melanoides) tuberculata Müller.}

MIÚlLER. Hist. Vermium. Vol. II, p. IgI.

Brot. Martini-Chemn. Conch. Cab. Ed. II, Vol. I, Melania, p. 247, Pl. 26, fig. I I.

v. Martens. Suiss. u. Brackw. Moll. Ind. Arch. p. 56.

Stat. 174. Brook near Waru, Ceram. I Spec.

This specimen belongs to a variety with only a few spiral striae at the lower part of the median whorls, somewhat like var. seminuda v. Martens (1.c. p. 58, Pl. IV, fig. I), but that variety according to the figure of $v$. MARTENs and specimens from Adonara in my collection is strongly flamed. By its sculpture it resembles specimens from Supajang (Sumatra).

9. Mclania (Mclanoides) malayana Issel.

Issel. Ann. del Mus. Civ. di Stor. Nat. di Genova. Vol. VI, 1874, p. 463.

Brot. Martini-Chemn. Conch. Cab. Ed. II, Vol. I, Melania, p. 253, Pl. 26, fig. 5 .

Stat. 82. Mahaklam river, Batu Pangal, Borneo. I Spec. 
Though Issen has described this form as a variety of $M$. tuberculata Müll.. I think Brot may be right in separating it, on account of the very flat whorls.

10. Melania (Melanoides) salibabuensis n. sp. P1. XII, fig. 8.

Stat. I 33. Lake Telaga Bindu near Lirung, Salibabu-island. 24 Spec.

Shell pyramidal, dark olive, with faint purple-brown flames, especially on the upper whorls, often completely wanting on the lower ones; strongly decollated, remaining whorls 3 to 4 , slightly convex near the median part, constricted below the sutures, which are very conspicuous. Sculpture consisting of numerous growth-striae, of which several, at irregular distances are stronger and nearly riblike, these striae are crossed by impressed spiral striae, which occupy nearly the whole surface of the upper whorls (in younger specimens), leave the upper part of the median whorls free and are restricted on the median part of last whorl, where the basal part is smooth again. Aperture ovate with a rather sharp angle above, outer margin protracted below, columellar margin with a strong layer of enamel, which is dark grey in its upper part, white below, with a yellow tinge near the base and a black rim all around; base of aperture broadly sinuous.

Alt. (of large specimen) 22, lat. 9 ; apert. alt. 9 Mill.

This species is allied to $M$. turriculus Lea and crepidinata Reeve, but the whorls are much less convex than in the latter species, they better agree in this respect with $M$. turriculus but in that species the base is striated, the aperture not so strongly sinuous. This latter character may serve to distinguish the new species from its allies.

11. Melania (Plotia) scabra Müller.

MÜLleR. Hist. Vermium. Vol. II, p. I36.

Brot. Martini-Chemn. Conch. Cab. Ed. II, Vol. I, Melania, p. 266, Pl. 27, fig. 14, I5.

v. Martens. Süss- u. Brackw. Moll. Ind. Arch. p. 62.

Stat. 33. River near Pidjot, Lombok. 8 Spec.

Stat. 53. River near Waingapu, Sumba. 6 Spec.

Stat. 1 I5. River near Kwandang, North-Celebes. 4 Spec.

12. Melania (Plotia) acanthica Lea.

LeA. Proc. Zool. Soc. Lond. 1850 , p. 194.

Bкот. Martini-Chemn. Conch. Cab. Ed. II, Vol. I, Melania, p. 278, Pl. 28, fig. 1 o.

Stat. 142. River near Laiwui, Obi Major. 28 Spec.

Small but very characteristic by the long spines of the majority of the specimens.

13. Melania (Plotia) Savinieri Brot.

Brot. Recueil Zool. Suisse. Vol. IV, 1886, p. 93, Pl. 5, fig. 9.

MORLET. Journ. de Conch. 1884 , p. 330, Pl. 7 , fig. 2.

Stat. 82. Mahakkam river, Batu Pangal, Borneo. Numerous specimens. 
The species has only been recorded from Java. I cannot distinguish the Bornean specimens from those received from Java, formerly named by Brot.

14. Melania (s. str.) setosa Swainson.

Swainson. Quart. Journ. Science. I824, p. I3.

BRot. Martini-Chemn. Conch. Cab. Ed. II, Vol. I, Melania, p. 297, Pl. 30, fig. 5, 6; Pl. 3 I, fig. I. v. Martens. Süss- u. Brackw. Moll. Ind. Arch. p. 66.

Stat. I3I. Brook near Beo, Karakelang-islands. 9 Spec.

This is as far as I know the first record in litterature for the species, from this locality.

15. Melania (Tiaropsis) rudis Lea.

LEA. Proc. Zool. Soc. Lond. I850, p. 186.

Brot. Martini-Chemn. Conch. Cab. Ed. II, Vol. I, Melania, p. 305, Pl. 32, fig. I.

Stat. 179. River in Kawa-bay, West coast of Ceram. I Spec.

The specimen has the shape of the type, represented by fig. I of Bror, but has three brown bands of which one below the suture, one below the periphery and the third near the base.

16. Melania (Tarebia) celebensis Quoy \& Gaimard.

Quoy \& Gainiard. Voy. Astrolabe. Zool. Vol. III, p. I52, Pl. 56, fig. 26-29.

Brot. Martini-Chemn. Conch. Cab. Ed. II, Vol. I, Melania, p. 317, P1. 32, fig. 15.

v. Martens. Süss- u. Brackw. Moll. Ind. Arch. p. 69.

Stat. 19. River near Labuan Tring, Lombok. I4 Spec.

This species has not yet been recorded from Lombok, the specimens vary in the development of the granules.

17. Melania (Tarebia) granifera Lamarck.

LAMARCK. An. s. vert. Ed. II, Vol. VIII, p. 433.

BroT. Martini-Chemn. Conch. Cab. Ed. II, Vol. I, Melania, p. 32I, Pl. 33, fig. I 3 .

v. Martens. Süss- u. Brackw. Moll. Ind. Arch. p. 7 I.

Stat. 33. River near bay of Pidjot, Lombok. 26 Spec.

I think this species is new for Lombok.

I S. Molania (Tarebia) lateritia Lea.

LEA. Proc. Zool. Soc. Lond. I850, p. I96.

BRot. Martini-Chemn. Conch. Cab. Ed. II, Vol. I, Melania, p. 319, Pl. 33, fig. I.

Stat. 53. River near Waingapu, Sumba. 6 Spec.

Agrees sufficiently with specimens from the island of Sumba formerly named by Brot. 
19. Melania (Tarebia) maniensis Lea.

LEA. Proc. Ac. Nat. Sc. Philad. I 856.

Brot. Martini-Chemn. Conch. Cab. Ed. II, Vol. I, Melania, p. 322, Pl. 33, fig. 7, 8 (9?).

Stat. 53. River near Waingapu, Sumba. 24 Spec.

Brot (1. c. p. 324) says that he is unable to distinguish $M$. crenifera Lea (BRot 1 . c. fig. 9), from $M$. mauiensis; in accordance therewith he may have named specimens from the same island. The specimens now under consideration, agree fairly well with those I had formerly sent to that authority for comparison. v. Martens (Süss- u. Brackw. Moll. p. 305) makes only mention of $M$. crenifera, as inhabiting Java.

Faunus Montfort.

I. Faunzus ater Linné.

Linné. Syst. Nat. Ed. X, p. $746, \mathrm{~N}^{0} 44 \mathrm{~T}$.

Rumph. Amb. Rariteitkamer, p. IoI, Pl. 3o, fig. R.

Brot. Martini-Chemn. Conch. Cab. Ed. II, Vol. I, Melania, p. 4 Io, Pl. 44, fig. 3.

v. Martens. Suss- u. Brackw. Moll. Ind. Arch. p. IgI.

Stat. I79. River in Kawa-bay, West coast of Ceram. 4I Spec.

The largest specimens are still a trifle larger than those ( 75 Mill.) recorded by Brot; one of them has the polished surface on one side, mentioned by v. Martens (1. c. p. I92), the black incrustation is wanting on the whole length, and on more than a third of the length, the epidermis has not only disappeared, but also part of the shelly matter has been ground away and becomes more or less transparent on that side.

Fam. Littorinidae.

Littorina Ferussac.

I. Littorina (Littorinopsis) scabrà Linné.

LinNÉ. Syst. Nat. Ed. X, p. $770, \mathrm{~N}^{0} 584$.

Rumph. Amb. Rariteitkamer, p. 98, Pl. 29, fig. Y.

REEve. Conch. Ic. Vol. X, Littorina, fig. $2 \mathrm{I}$.

Weinkauff. Martini-Chemn. Conch. Cab. Ed. II, Vol. II, Littorina, p. 37, Pl. 4, fig. 7-IO, $12,16-18$.

Tryon. Man. of Conch. Vol. IX, p. 243, Pl. 42, fig. I8-20.

Stat. 37. Sailus Ketjil, Paternoster-islands. Up to 18 and 27 M. Coral and coralsand. 2I Spec.

Stat 47. Bay of Bima, near South fort. I3-31 M. Mud with patches of fine coralsand. I Spec.

Stat. 50. Bay of Badjo, West coast of Flores. Up to 40 M. Mud, sand and shells. I Spec.

Stat. $6 \mathrm{I}^{\mathrm{a}}$. North coast of Adonara. Shore. I Spec.

Stat. 86. Dongala, Palos-bay, Celebes. Reef and 36 M. Io Spec.

Stat. 165. North-east side of Daram-island, East coast of Misool. Reef. I Spec.

Stat. 258. Tual, Kei-islands. 22 M. Lithothamnion, sand and coral. I Spec.

Very variable in colour, but the only specimen that seems to deserve a varietal name is: 
var. lutea Philippi.

Phic.rpr. Abb. u. Beschr. neuer oder wenig gekannter Conch. Vol. III, p. 22I, Littorina, Pl. 5, fig. I I.

Stat. 7 I. Makassar and surroundings. Up to $32 \mathrm{M}$. Mud, sand with mud. I Spec.

Phil.IPr has quoted in the text fig. 6 for this variety, but it evidently is fig. I I that agrees with the description, fig. Io is his variety suturalis, quoted as fig. 7. The figs $6-9$ of that author represent his $L$. intermcdia, considered by many authors to be merely a variety; it is often not an easy task to distinguish it from younger specimens of $L$. scabra. It seems that TRYon (1. c. p. 244, Pl. 42, fig. 21-24) has mixed the two species, for his character "periphery angulated or carinated", is in contradiction with PHILIPpI's original description, the figures 22 and 24 are probably young specimens of scabra.

2. Littorina (Littorinopsis) undulata Gray.

Gray. Zool. Beechey's Voy. p. i40.

Reeve. Conch. Ic. Vol. X, Littorina, fig. 67.

Weinknuff. Martini-Chemn. Conch. Cab. Ed. II, Vol. II, Littorina, p. 73, Pl. 9, fig. 15, 16. Tryon. Man. of Conch. Vol. IX, p. 244, Pl. 43, fig. 39, 40.

Stat. 129. Kawio- and Kamboling-islands, Karkaralong-group. Sand. 2 Spec.

Fam. Rissolidae.

Rissoina d'Orbigny.

1. Rrssoina micans A. Adams.

Adams. Proc. Zool. Soc. Lond. 185 I, p. 265.

Weinkauff. Martini-Chemn. Conch. Cab. Ed. II, Vol. I, Rissoina, p. I7, Pl. 7, fig. 4.

Tryon. Man. of Conch. Vol. IX, p. 37 I, Pl. 55, fig. 28.

Stat. 306. $8^{\circ} 27^{\prime}$ S., $122^{\circ} 54^{\prime} .5$ E. Savu Sea. 247 M. Sandy mud. I Spec.

The only specimen is a bleached shell.

2. Rissoina (Rissolina) plicata A. Adams.

Adans. Proc. Zool. Soc. Lond. 1851, p. 264.

IVeinkauff. Martini-Chemn. Conch. Cab. Ed. II, Vol. I, Rissoina, p. 23, Pl. 8, fig. 5, 6.

Tryon. Man. of Conch. Vol. IX, p. 375, Pl. 56, fig. 58-60.

Stat. 31 5. East of Sailus Besar, Paternoster-islands. Up to $36 \mathrm{M}$. Coral and Lithothamnion. 1 Spec.

This specimen is a dead shell.

3. Rissoina (Rissolina) sp.

Stat. 240. Banda. 9-45 M. Black sand, coral. I Spec.

The shell is too much worn for identification. 
4. Rissoina (Phosinella) erythraea Philippi.

Philippi. Zeitschr. f. Malak. 1851, p. 93.

Weinkauff. Martini-Chemn. Conch. Cab. Ed. II, Vol. I, Rissoina, p. 39, Pl. I1, fig. 6; p. 64, P1. 15, fig. 16; P1. I5c, fig. 2 (Seguenziana).

Tryon. Man. of Conch. Vol. IX, p. 382, Pl. 37, fig. 97-2; Pl. 58, fig. 3, 4.

Stat. 23r. Amboina. Reef. 3 Spec.

The specimens are rather elongate.

5. Rissoina (Mörchiella) spirata Sowerby.

Sowerby. Gen. of Shells. $\mathrm{N}^{0} 40, \mathrm{Pl} .208$, fig 2.

ReEve. Conch. Ic. Vol. XX, Rissoa, fig. I7.

Weinkauff. Martini-Chemn. Conch. Cab. Ed. II, Vol. I, Rissoina, p. 42, Pl. I2, fig. 4.

Tryon. Man. of Conch. Vol. IX, p. 388, Pl. 58, fig. 29.

Stat. 66. Bank between islands of Bahuluwang and Tambolungan. 8-IO M. Dead coral, Halimeda and Lithothamnion. I Spec.

This specimen is sufficiently typical.

mut. deformis Sowerby.

ReEve. Conch. Ic. Vol. XX, Rissoa, fig. 63 .

Tryon. Man. of Conch. Vol. IX, p. 388, Pl. 59, fig. 35.

Stat. I25. Sawan, Siau-island. 27 M. Stone and some Lithothamnion. I Spec.

The only specimen shows more affinity to the next variety than to the type, being more slender and delicate.

var. Montrouzieri Souverbie.

SOUverbie. Journ. de Conch. I862, p. 237 , Pl. 9, fig. 5.

Weinkauff. Martini-Chemn. Conch. Cab. Ed. II, Vol. I, Rissoina, p. 57, Pl. I4, fig. I5.

Stat. 19. Bay of Labuan Tring, West coast of Lombok. I8-27 M. River-mud, coral, coralsand. I Spec.

Stat. 47. Bay of Bima, near South fort. 55 M. Mud with patches of fine coralsand. I Spec.

Stat. 142. Laiwui, North coast of Obi major. 23 M. Mud. I Spec.

The specimens sufficiently agree with the original figure; it is often difficult with so variable a species, to identify every specimen and to bring it to some described form. It is however still more difficult to keep them separate as good species, unless one destroys intermediate specimens.

6. Rissoina (Zebina) tridentata Michaud.

Michaud. Descript. Genre Rissoa, p. 6, fig. 5, 6.

Schwarz. v. Momrenstern. Rissoina, p. 107, P1. 9, fig. 74 .

Stat. 78. Lumu-Lumu-shoal. Borneo-bank. Reef. I Spec.

The specimen is not in very good condition, so. I had, like some of my predecessors, first taken it for an Eulima. 
Rissoia Fréminville.

1. Rissoia sp.

Stat. 285. South coast of Timor. 34 M. On the limit between mud and coral. Lithothamnion. I Spec.

Having much resemblance with the description and figure of $R$. venusta Garret, by its shape and sculpture, consisting of strong, compressed, spiral ridges, of which 2 on the upper whorls, 5 on the body whorl and conspicuous radiating riblets; but the shell is smaller, there are a few secundary spirals, especially on the body whorl and the lip is not varicose; as it is however very thin and fragile, the specimen may be juvenile. Under these circumstances, I am not able to identify this single specimen, nor to describe it as new with a sufficient degree of certainty.

2. Rissoia kwandangensis n. sp. Pl. XII, fig. 9 .

Stat. I15. East side of Pajunga-island, Kwandang-bay, North Celebes. Reef. i Spec.

Shell small, conic-oval, solid, opaque; whorls about 6, slightly convex, separated by a deep suture, colour whitish, with spiral rows of purple-brown spots. Nuclear whorls smooth, sculpture of subsequent whorls consisting of rather thin, straight ribs, about i 8 on the last whorl, crossed by spiral ridges, of which there are 6 on the penultimate whorl and 1 I on the last one, the sixth running just in a channel above the suture; this sculpture renders the shell cancellated; moreover fine growth-striae make their appearance in the squares remaining in the interstices of this sculpture. Of the brown spots the upper spiral row runs a little below the suture, on the alternating ribs, and five fainter ones, on the basal part of last whorl. Aperture rounded oval, slightly angular above, outer margin regularly curved, with a strong varix externally; columellar margin reflected over the pillar and the base. Varix adorned with two larger brown spots, one at the upper and one at the basal part.

Alt. $2^{1} / 2$, lat. $I^{1} / 4$; apert. alt. $4 / 5$, lat. $4 / 7$ Mill.

This small species is allied to $R$. versoverana Melv. (Mem. Manch. Philos. Soc., VII, I 893, p. 6I) but that species is much more ventricose.

Fam. Hydrobiidae.

Bithynia Leach.

1. Bithynia trancata Eydoux \& Souleyet.

Eydoux \& Souleyet. Voy. de la Bonite. Zool. Vol. II, p. 34S, Pl. 31, fig. 22-24. v. Martens. Süss- u. Brackw. Moll. Ind. Arch. p. 25, Pl. 9, fig. il, il b.

Stat. 4. Rivulet near Djangkar (Java). 2 Spec. 


\section{Fam. Viviparidae.}

\section{Vivipara Lamarck.}

I. Vivipara javanica v. d. Busch.

V. D. Busch in Philippi: Abbild. u. Beschr. neuer Conch. Vol. I, p. I I4, Paludina, Pl. I, fig. I I, I2. Reeve. Conch. Ic. Vol. XIV, Paludina, fig. 52.

v. Martens. Süss- u. Brackw. Moll. Ind. Arch. p. 2 I.

Stat. 23I. Brook at Amboina. I Spec.

v. Martens in his list, giving the geographical distribution (1.c. p. 302) records $V$. javanica with doubt from the Moluccos; by this specimen, which though young is in good condition, the proof of its living there, has been delivered.

2. Vivipara costata Quoy \& Gaimard.

Quoy \& Gaimard. Voy. Astrol. Zool. Vol. III, p. 470, Pl. 58, fig. I- 5 .

ReEve. Conch. Ic. Vol. XIV, Paludina, fig. 6.

v. Martens. Süss- u. Brackw. Moll. Ind. Arch. p. 20.

River near Tondano, Celebes. 8 Spec.

Rather small, but quite characteristic.

Fam. Ampullariode.

Ampullaria Lamarck.

I. Ampullaria ampullacea Linné.

LiNnÉ. Syst. Nat. Ed. X, p. 77 I, N0 592.

Rumph. Amb. Rariteitkamer, p. 92, P1. 27, fig. Q.

Reeve. Conch. Ic. Vol. X, Ampullaria, fig. 48.

v. Martens. Süss- u. Brackw. Moll. Ind. Arch. p. 17.

Stat. 47. River at Bima, Sumbawa. I Spec.

The specimen is small, with rather high spire, the shape of the aperture and the operculum are sufficient to distinguish it from the small $A$. scutata; the right margin is thin, so it is a young specimen. This is as far as I am aware the first record for Sumbawa.

Fam. Cyclophoridae.

Leptopoma L. Pfeiffer.

I. Leptopoma diplochilus Sykes.

Sykes. Journ. of Malacology. Vol. X, 1903, p. 66, Pl. 6, fig. I6-is.

Stat. 155. Piapis-bay, N. W. coast of Waigeu-island. Shore. 2 Spec.

89 
The specimens are smaller than those described by Sykes, who calls the colour pale lilac; this is scarcely applicable to the Siboga-specimens, but the strongly projected inner lip which is so characteristic for this species is distinctly present in one specimen, where its length reaches nearly $2 \frac{1}{2}$ Mill., in the other one, which is probably younger, this projection is still very slight, but in nearly every other respect it agrees with the more typical one, so I don't hesitate to unite them.

\section{Cyclotus Guilding.}

\section{Cyclotus kangeanus (v. Mlldff.) n. sp. Pl. XII, fig. 10.}

Stat. 16. Kangeang. 3 Spec.

Shell depressedly turbinate, openly umbilicated, rather smooth, but with conspicuous growth-striae on the upper whorls, fading on the last one, which is irregularly pitted, moreover a large part of the shell, if fresh, is covered by very fine spiral striae and an irregular, impressed line, which is at some places double, runs at some distance from the deep suture; whorls about $4 \frac{1}{2}$, slightly depressed above, especially near the suture, else convexly rounded; colour from yellowish- to dark redbrown, more or less variegated with darker zigzag-markings and a yellowish band at the periphery, often accompanied by a darker zone below. Aperture nearly circular, a little oblique, with a slight angle above, margin white, double, the outer margin rather strongly expanded and slightly reflected, forming a triangular lobe at the body-whorl; this triangle is slightly compressed, with an impressed line on the inner surface. Operculum thick, calcareous, many-whorled.

Diam. 19, alt. 1 2 ; apert. alt. et lat. incl. perist. 9 Mill.

Diam. $19^{3} / 4$, alt. $14^{7} / 8$; apert. alt. et lat. incl. perist. $9^{1} / 4$ Mill.

This species is nearly allied to C. floresianus v. Mart. (Zool. Ergebn. Reise in Niederl. Ost-Indien, p. 2 I I, Pl. I 2, fig. I-3), but it is smaller, has a darker colour, the umbilicus is narrower and the peristome is much more expanded and even reflected. It has been named by v. MollendorfF, but as far as I know, he has never described it. I possess specimens received from FruhstoRfer in I 903, of these one is of much lighter colour. The largest Siboga-specimen is a dead shell, the two other ones have been taken alive.

2. Cyclotus succinctus v. Martens.

V. Martens. Monatsber. Acad. Berlin, 1864, p. 117.

- Ostasiatische Landschn. p. 122, Pl. 2, fig. 6.

Stat. 296. Dry Riverbed near Noimini, Timor. I Spec.

The only specimen of this land-mollusk is a dead shell. it agrees with var. major of v. Martens by its size and feeble keel. 
Fam. Hipponycidae.

Amalthea Schumacher.

I. Amalthea conica Schumacher.

Schumacher. Essai, p. i8 I, Pl. 2i, fig. 4.

TrYon. Man. of Conch. Vol. VIII, p. 136, Pl. 4I, fig. 9-15 (australis).

Stat. 9. $7^{\circ} 44^{\prime} .6$ S., $114^{\circ} 42^{\prime} .6$ E. Madura Sea. 353 M. Soft, fine, grey mud. 2 Spec.

Stat. 6o. Haingsisi, Samau-island. Reef. I Spec.

Stat. 78. Lumu-Lumu-shoal, Borneo-bank. Shore. 3 Spec.

Stat. 93. Pulu Sanguisiapo, Tawi-Tawi-islands, Sulu-archipelago. 12 M. Lithothamnion-bottom, sand and coral. I Spec.

Stat. 125. Sawan, Siau-island. Reef. 7 Spec.

Stat. I42. Laiwui, North coast of Obi Major. Reef. 4 Spec.

Stat. 193. Sanana-bay, East coast of Sula Besi. Reef. I Spec.

Stat. 2I 3. Saleyer. Reef. 2 Spec.

Stat. 225. South of Lucipara-island. Reef. 7 Spec.

The specimens as usually, are very different in shape and colour, they are more or less elevated and entirely white, more or less radiated with brown, or nearly entirely brown. The specimens from a great depth (Stat. 9) are fixed on a much worn shell of a Gastropod, perhaps a Tritonidea, from Stat. 78, on Strombus urceus Lin., from Stat. 225 on Terebra crenulata Lin., Strombus azreus Lin., from Saleyer on large spines of an Echinoderm; probably Acrocladia, from Haingsisi on Cassis vibex Lin. So it is conspicuous that they have no preference for any group of shells, to fix themselves upon. I can detect no basal shell-plate, but especially the older specimens have made conspicuous scars in the shells on which they live. One rather adult specimen from Saleyer, has in accordance with its abode on a spine, a strongly compressed shape. Some adult specimens have young ones on their backs.

\section{Amalthea Danieli Crosse.}

Crosse. Revue Zool. I858, p. I6I, Pl. 3, fig. 2 (Capulus).

- Journ. de Conch. I862, p. I9 (Hippony $x$ ).

TrYon. Man. of Conch. Vol. VIII, p. 136, Pl. 4I, fig. 21, 22.

Stat. 5I. Madura-bay. 69-9I M. Fine grey sand, coarse sand with shells and stones. I Spec.

Stat. 260. Near Nuhu Jaan, Kei-islands. go M. Sand, coral and shells. I Spec.

The specimen from Stat. 5I, which is the most characteristic, was affixed on Gyrineum cuspidatum Rve, but was easily loosened, leaving a scar. This species has been recorded from New Caledonia, by Crosse, Tryon (1. c.) records no other localities, so it may be new for the archipelago.

\section{Amalthea (Malluvium) lissa Smith.}

Smith. Ann. and Mag. Nat. Hist. Ser. 6, Vol. XIV, IS94, p. 166, Pl. 4, fig. 4-6 (Capulus). - Ann. and Mag. Nat. Hist. Ser. 7, Vol. XIV, 1904, p. I.

v. Martens. Beschalte Gastrop. d. deutschen Tiefsee-Exp. 1898-99, p. 117. 
THiEle. Beschalte Gastrop. d. deutschen Tiefsee-Exp. I898-99, p. I65, P1. 8, fig. $4^{6 .}$ Melvill. Proc. Mal. Soc. Lond. VII, Igo6, p. SI.

Sirith. Proc. Mal. Soc. Lond. VII. 1906, p. I 22.

Stat. I 2. $7^{\circ}$ I $5^{\prime}$ S., I I $5^{\circ}$ I $5^{\prime} .6 \mathrm{E}$. Madura Sea. 289 M. Mud, and broken shells. Many specimens. Stat. $95.5^{\circ} 43^{\prime} .5$ N., I $19^{\circ} 40^{\prime}$ E. Sulu Sea. 522 M. Stony bottom. I9 Spec.

Stat. I05. $6^{\circ} 8^{\prime}$ N., I $21^{\circ}$ I $9^{\prime}$ E. Sulu Sea. 275 M. Coralbottom. I Spec.

Stat. I 39. $0^{\circ}$ I I' S., I $27^{\circ} 25^{\prime}$ E. Molucca-Passage. 397 M. Mud, stones and coral. 16 Spec.

Stat. I64. $I^{\circ} 42^{\prime} .5$ S., I $30^{\circ} 47^{\prime} .5$ E. Halmahera Sea. 32 M. Sand, small stones and shells. I Spec.

Stat. 204. Between Wowoni and Buton. 75-94 M. Sand with dead shells. 2 Spec.

The specimens from Stat. I 2 are so numerous and often form small colonies, that it is useless and nearly impossible to count them; the majority from Stat. 12 has been dredged alive on Nenophora pallidula Rve, on a dead Murex belonging to or allied to M. ternispina Lam., other specimens from the same locality live on stones or fragments of very diversified shells; those from Stat. 95 and 105 are dead shells, those from Stat. I 39 are affixed on a dead Xenophora and a young dead Rostellaria. The specimen from Stat. 164, which should have lived at a depth of 32 M. is very flat and broad, but the sculpture, consisting of more or less irregular growthstriae, and shape of spire agree with typical specimens. Mr. SMITH to whom I had sent this doubtful specimen, pronounced it to be: "probably a dilated variety of $A$. lissa", the specimens from Stat. 204, which are dead shells, are from not more than 94. M. Dr. Thiele (1. c.) was the first to state that the species, according to its anatomy belongs to Hipponyx $=$ Amalthea. Afterwards Melvill (1. c.) came to the same conclusion on other grounds, and Smith (Proc. Mal. Soc. Lond. VII, p. I 22) states in a note that Prof. Gwatkin found the radula nearest that of Amalthea. Melvill (1. c.) has erected the subgenus Malluvizm for this smooth species of Amalthea. The Siboga-specimens have no brown colour in the interior of the shells, as far as I could see in loosened ones.

\section{Mitrularia Schumacher.}

\section{Mitrularia equestris Linné.}

LINNÉ. Syst. Nat. Ed. XII, p. I257.

Reeve. Conch. Ic. Vol. XI, Calyptraea, fig. I.

TrYon. Man. of Conch. Vol. VIII, p. I37, Pl. 4I, fig. 25, 26.

Stat. 240. Banda. 9-45 M. Black sand, coral. I Spec.

var. tortilis Reeve.

ReEve. Conch. Ic. Vol. XI, Calyptraea, fig. $2 b$.

Tryon. Man. of Conch. Vol. VIII, p. I38, Pl. 42, fig. 53.

Stat. 225. South Lucipara-island. Reef. I Spec.

var. cicatricosa Reeve.

ReEve. Conch. Ic. Vol. XI, Calyptraea, fig. $3 a$.

Tryon. Man. of Conch. Vol. VIII, p. I38, Pl. 42, fig. 56 .

Stat. 59. Western entrançe of Samau-strait. 390 M. Coarse coralsand with small stones. I Spec.

Stat. II4. Kwandang-bay-entrance, North Celebes. 75 M. Hard sand, very fine. I Spec.

Stat. 234. Nalahia-bay, Nusa-Laut-island. Reef. 2 Spec. 
var. hipponyciformis Reeve.

REEve. Conch. Ic. Vol. XI, Calyptraea, fig. 26.

TrYon. Man of Conch. Vol. VIII, p. 238, Pl. 24, fig. 40, 4 I.

Stat. 240. Banda. 9-45 M. Black sand, coral. I Spec.

A most variable species. I have identified the specimens as well as possible, with the aid of the figures of ReEve's monograph. Only the specimen from Stat. 225 contains the soft parts, the other ones are dead shells, which is especially of interest for the specimen from Stat. 59, which probably will not have lived at that great depth.

2. Mitrularia costifera n. sp. Pl. XII, fig. I I.

Stat. I 16. West of Kwandang-bay-entrance. 72 M. Fine sand with mud. I Spec.

Shell small, suborbicular, thin, depressedly convex, white; nucleus subcentral, but placed a little at the posterior part, smooth, spiral; a zone around the nucleus is sculptured by fine radiating striae, the remaining part of the surface is sculptured by strong radiating ribs, about 23 in number, separated by rather deep grooves or interstices, about as broad as the ribs; the ribs project at the margin and make it conspicuously denticulate, they are slightly nodulous and waved and are covered, as well as the interstices, with radiating striae. Interior of shell smooth, slightly grooved by the ribs. Cup-shaped lamina much broken.

Long. 9, lat. $9^{1} / 2$, alt. $3^{1} / 2$ Mill.

I am not at all proud of this new species, as it is slightly defective, part of the outer shell and of the internal lamina wanting. Moreover I suppose it may be still rather young. As I failed to identify it with any of the known species, I asked the opinion of Mr. E. A. Sмith, who has at his disposal the types of the numerous species described by ReEve; the result was that Mr. Smitr declared it to be new. The most characteristic feature is the presence of comparatively strong ribs, conspicuously surpassing the margin of the shell. The dorsal view calls in mind some flat specimens of Amalthea conica Schum.

\section{Fam. Capulidae.}

\section{Crepidula Lamarck.}

I. Crepidula (Siphopatella) Walchi Herrmannsen.

Herrmannsen in Reeve. Conch. Ic. Vol. I, Crepidula, fig. I7.

TrYon. Man. of Conch. VoI. VIII, p. 130, Pl. 38, fig. 56-58 (Walshii).

Stat. 273. Pult Jedan, East coast of Aru-islands. I 3 M. Sand and shells. I Spec.

This is as far as I am aware the first record from the East Indian Archipelago. Tuyon's enumerated localities are Ceylon, Singapore, China Sea, Japan. I can see no differences from my Japanese specimens. 
Capulus Montfort.

1. Capulus fragilis Smith.

SмITh. Ann. and Mag. Nat. Hist. Ser. 7, Vol. XIV, 1904, p. 1.

Stat. $85.0^{\circ} 36^{\prime} .5$ S., $119^{\circ} 29^{\prime} .5$ E. Makassar Strait. 724 M. Fine, grey mud. 1 Spec.

Stat. $87.0^{\circ} 32^{\prime}$ S., I I $9^{\circ} 39^{\prime} .8 \mathrm{E}$. Makassar Strait. 655 M. Fine, grey mud. I Spec.

Both specimens seem to be young, the largest one having only a length of nearly 8 Mill., those described by SMrth of 13 Mill., but the description agrees in every particular, especially the presence of an internal septum, as in the genus Septaria, is very characteristic. The "Investigator"'-specimens have been dredged in the Laccadive Sea at 105 fathoms and in the bay of Bengal, at 410 fathoms.

Thyca H. \& A. Adams.

1. Thyea crystallina Gould.

Gould. Proc. Boston Soc. Nat. Hist. II, i846, p. i6 г (Capulus).

Tkyon. Man. of Conch. Vol. VIII, p. I36, Pl. 41, fig. I8, I9 (Hipponyx).

Kürenthal. Abh. Senckenb. Gesellsch. Vol. 24, I898, p. 9, Pl. 2, fig. 10-12.

Stat. 6o. Haingsisi, Samau-island. Reef. 13 Spec., on Linckia.

Stat. 231. Amboina. Reef. I5 Spec. on Linckia.

Stat. 234. Nalahia, Nusa-Laut-island. Reef. 4 Spec., on Linckia.

Stat. 279. Ruma-Kuda-bay, Roma-island. Reef. 3 Spec., on Linckia.

Stat. 301. Pepela-bay, East coast of Rotti-island. Reef. I Spec.

For particulars on this species, see the Report on the parasitic Prosobranchia of the Siboga Expedition, Part XLIX ${ }^{2}$ of this work.

Fam. Xenophoridae.

Xenophora Fischer de Waldheim.

I. Xenophora (s. str.) solarioides Reeve.

REeve. Conch. Ic. Vol. I, Phorus, fig. 8 .

Kiener. Coq. Viv. Vol. X, p. 447, Pl. 44, fig. 3.

Tryon. Man. of Conch. Vol. VIII, p. 159, Pl. 44, flg. 77.

Stat. 64. Kambaragi-bay, Tanah-Djampeah. 32 M. Coral, coralsand. 1 Spec.

Stat. 71. Makassar and surroundings. 27-30 M. Mud, sand with mud, coral. 4 Spec.

Stat. 77. Borneo-bank. 59 M. Fine, grey coralsand. I Spec.

Stat. $274.5^{\circ} 28^{\prime} .2$ S., $134^{\circ} 53^{\prime} .9$ E. Near Aru-islands. 57 M. Sand and shells, stones. 2 Spec.

Stat. 313. East of Dangar Besar, Saleh-bay. Up to $36 \mathrm{M}$. Sand, coral and mud. 13 Spec.

This species has only been recorded from the Philippines. A very young specimen from Stat. 3 3 ; has a nearly smooth base, under the lens a row of beads borders the umbilicus, a few very faint spirals surround it and still fainter growth-striae, elegantly curved, make their appearance, the upper surface is quite covered with small stones and large foraminifera, only the nuclear whorls remain uncovered. 
2. Xenophora corrugata Reeve.

ReEve. Proc. Zool. Soc. Lond. 1842 , p. $16_{3}$.

- Conch. Ic. Vol. I, Phorus, fig. 6.

Kiener. Coq. Viv. Vol. X, p. 44I, Pl. 8.

Tryon. Man. of Conch. Vol. VIII, p. 159, Pl. 45, fig. 81, 82 .

Stat. $164.1^{\circ} 42^{\prime} .5$ S., ${ }_{13} 30^{\circ} 47^{\prime} \cdot 5$ E. Halmahera Sea. 32 M. Sand, small stones and shells. 2 Spec.

Stat. 204. Between islands of Wowoni and Buton, northern entrance of Buton-strait. 75--94 M. Sand with dead shells. 2 Spec.

The specimens are rather small, the largest, from Stat. 204, having only a largest diameter of about 35 Mill. without the agglutinated shells and stones, the other one is very young but has already the characteristic sculpture, consisting of rather coarse wrinkles; in the young specimen the umbilicus is still open, in the largest one it is a small perforation.

\section{Xenophora caperata Philippi.}

PHILIPPI. Zeitschr. für Malak, I $85 \mathrm{I}$.

Kiener. Coq. Viv. Vol. X, p. 439, Pl. 79, fig. 1.

Trion. Man. of Conch. Vol. VIII, p. 159, Pl. 44, fig. 78 , 79; Pl. 45, fig. 83.

Stat. 204. Between islands of Wowoni and Buton, northern entrance of Buton-strait. 75-94 M. Sand with dead shells. 6 Spec.

Stat. $289.9^{\circ} 0^{\prime} \cdot 3$ S., I $26^{\circ} 24^{\prime} .5$ E. Timor Sea. I 12 M. Mud, sand and shells. 1 Spec.

This species is very nearly allied to the preceding one, the spiral cords on the base are however developed on a much larger space than in corrugata, as may be seen in the quoted figures, and it is chiefly on this character that I have identified the specimens under consideration.

\section{Xenophora pallidula Reeve.}

Reeve. Proc. Zool. Soc. Lond. I842, p. 162.

- Conch. Ic. Vol. I, Phorus, fig. 4.

Kiener. Coq. Viv. Vol. X, p. 444, Pl. 54.

Tryon. Man. of Conch. Vol. VIII, p. 160, Pl. 44, fig. 79.

Stat. I2. $7^{\circ} 15^{\prime}$ S., $115^{\circ} 15^{\prime} .6$ E. Madura Sea. 289 M. Mud and broken shells. 2 I Spec.

Stat. $38.7^{\circ} 35^{\prime} \cdot 4$ S., $117^{\circ} 28^{\prime} .6$ E. Flores Sea. 521 M. Coral. 4 Spec.

Stat. $95.5^{\circ} 43^{\prime} \cdot 5$ N., I $19^{\circ} 40^{\prime}$ E. Sulu Sea. 522 M. Stony bottom. 2 Spec.

Stat. 139. $0^{\circ} \mathrm{I} \mathrm{I}^{\prime} \mathrm{S}$., I $27^{\circ} 25^{\prime}$ E. Molucca-Passage. $397 \mathrm{M}$. Mud, stones and coral. 1 Spec.

Stat. 289. $9^{\circ} 0^{\prime} \cdot 3$ S., I $26^{\circ} 24^{\prime} .5$ E. Timor Sea. II 2 M. Mud, sand and shells. 2 Spec.

Stat. $297.10^{\circ} 39^{\prime}$ S., $123^{\circ} 40^{\prime}$ E. Timor Sea. 520 M. Soft, grey mud with brown upper layer. 1 Spec.

The majority of the specimens has the umbilicus not quite closed, partly this may depend on their juvenile state, but in many cases the specimens of the same size are variable in this respect. Generally I have observed that the umbilicus is no reliable character in this genus, that in the majority of young specimens, it exists in such species which have it closed when adult, but that the period of being closed is not the same in one and the same species. As to $X$. pallidula, Dunker (Index Molluscorum Maris Japonica, I882, p. 123) has made the same observation, he says: "at contra nostra specimina umbilico angusto perspicuo lamina quidem 
columellae semiobtecto instructo sunt". In other respects, especially in sculpture of the base, the specimens perfectly agree with typical ones, received from Japan.

\section{Xeniophora gigantea n. sp. Pl. XIII, fig. I.}

Stat. $38.7^{\circ} 35^{\prime} \cdot 4$ S., $117^{\circ} 28^{\prime} .6$ E. Flores Sea. 52 I M. Coral. 2 Spec.

Shell large, trochiform, more or less umbilicate, thin, yellowish-white; whorls about 8 , nucleus smooth, subsequent whorls slightly convex, with irregular surface, lower ones sculptured with diagonal, undulating wrinkles, which are moderately strong and are crossed by much feebler growth-striae; suture linear, undulate; the upper surface with various objects agglutinated along the suture and at the peripheral keel of last whorl, these objects consist of small stones and shells, which leave however a large part of the shell free, perhaps with exception of the upper whorls, which seem to have been quite covered, but to have lost the foreign bodies. Last whorl sharply' carinated, with a rather broad margin, marked by a broad, shallow canal on the upper surface; base concave, chiefly by the declining border, nearly smooth, but marked under the lens with faint growth-striae, which are strongly curved towards the distal zone, moreover very faintly crispate. Umbilicus in one specimen open, pervious, partly covered by the columellar margin, in the other specimen it is closed by a thin lamina, leaving a pit, which is also partly overlapped by the columella. Aperture large, oval, its free margin thin, arcuate, its columellar and basal margins strongly curved, the columellar one thickened and reflected, a thin layer of enamel on the body whorl connects the margins. Operculum corneous, thick, nucleus lateral, with a few coarse and very close-set, undulating striae.

Alt. about 60 , diam. 98 ; apert. lat. 67 Mill.

This species, by the sculpture of the base allied to $X$. pallidula Rve, has a much finer sculpture, indeed it is nearly smooth, moreover it is considerably larger, the shape of the basal surface is much more oval, the whorls are less convex, and much less covered by the foreign bodies, which are mainly smaller, are placed more remote and consequently leave a larger part of the lower whorls free. In this respect (if only seen from above) it has some resemblance with Y. calculifera Rve., which has however more convex whorls and a totally different sculpture of the base.

\section{Xenophora (Tugurium) exuta Reeve.}

ReEve. Proc. Zool. Soc. Lond. 1842 , p. 162.

- - Conch. Ic. Vol. I, Phorus, fig. 7 .

Kiener. Coq. Viv. Vol. X, p. 430, Pl. 22, fig. I.

Tryon. Man. of Conch. Vol. VIII, p. I6I, Pl. 46, fig. 90, 91.

Stat. $294.10^{\circ} \mathrm{I} 2^{\prime} \cdot 2$ S., $124^{\circ} 27^{\prime} \cdot 3$ E. Timor Sea. 73 M. Soft mud with very fine sand. 10 Spec.

The specimens are young and very thin; the largest has (inclusive the projections at the keel) only a diam. maj. of 55 Mill. Fischer in Kiener's Coq. Viv. (1. c.) states a diameter of 75 and even of 81 Mill., Tryon of $2^{3} / 4$ inches, corresponding to about 70 Mill. Only 3 of the specimens have agglutinated each one foreign body, consisting in a specimen of a small valve, in the other two of small fragments of Pelecypoda.

The species has, as far as I am aware only been recorded from China and Japan. 
7. Xenophora (Tugurium) calculifera Reeve.

ReEve. Proc. Zool. Soc. Lond. 1842 , p. 162.

- Conch. Ic. Vol. I, Phorus, fig. I.

Kiener. Coq. Viv. Vol. X, p. 438 , Pl. 7 , fig. I.

Tryon. Man. of Conch. Vol. VIII, p. 159, Pl. 44, fig. 75, 76 .

Stat. 3 I $8.6^{\circ} 3^{\prime} .5$ S., $114^{\circ} 55^{\prime} .5$ E. Java Sea. 88 M. Fine, yellowish-grey mud. I Spec.

The spiral sculpture of the base is but faintly developed; this may be due to the youth of the specimen, moreover a large part of the basal surface is broken.

\section{Xenophora (Tugurium) indica Gmelin.}

GMelin. Syst. Nat. Ed. XIII, p. 3575.

ReEve. Conch. Ic. Vol. I, Phorus, fig. 2.

Kiener. Coq. Viv. Vol. X, p. 433, Pl. 9, fig. I.

Tryon. Man. of Conch. Vol. VIII, p. I61, Pl. 46, fig. 92, 93.

Stat. 204. Between islands of Wowoni and Buton, northern entrance of Buton-strait. 75-94 M. Sand with dead shells. I Spec.

The specimen is also very young, the foreign bodies consist of a nearly equal number of Foraminifera and fragments of shells and stones.

9. Xenophora (Onustus) solaris Linné.

Linné. Syst. Nat. Ed. XII, p. I229.

REEve. Conch. Ic. Vol. I, Phorus, fig. 5.

Kiener. Coq. Viv. Vol. X, p. 428, Pl. 3, fig. i.

Tryon. Man. of Conch. Vol. VIII, p. I62, Pl. 47, fig. I, 2.

Stat. $318.6^{\circ}{ }_{3}^{\prime} .5$ S., $114^{\circ} 55^{\prime} .5$ E. Java Sea. 88 M. Fine, yellowish-grey mud. 3 Spec.

Two of the specimens are very young, measuring without the spines only about 22 and 20 Mill. In this juvenile state, the sculpture of the base, so conspicuous in adult ones, is nearly wanting; it consists of short striae radiating from the umbilicus, crossed by a few (3 or 4 ) spirals and leaving a large part smooth, unless for very faint, curved, growth-striae, a little more conspicuous at intervals. The third specimen, though not large, is very characteristic.

Fam. VANIKORIDAE.

Vanikoro Quoy \& Gaimard.

I. Vanikoro cancellata Chemnitz.

Chennitz. Conch. Cab. Vol. X, Pl. 165, fig. 1596, 1597.

ReEve. Conch. Ic. Vol. XX, Vanikoro, fig. 16 .

Tryon. Man. of Conch. Vol. VIII, p. 67, Pl. 29, fig. 60; 61.

Stat. 125. Sawan, Siau-isłand. Reef. I Spec. 


\section{Vanikoro Blainvilleana Recluz.}

Recluz. Rev. Zool. Soc. Cuvier. I845, p. 48.

- Magazin de Zool. 1849, p. 53, Pl. 13 I, fig. 2.

Tryon. Man. of Conch. Vol. VIII, p. 68, Pl. 29, fig. 71.

Stat. 90. $1^{\circ} 17^{\prime} .5$ N., $118^{\circ} 53^{\prime}$ E. Celebes Sea. 28 I M. Coral, sand and síones. I Spec.

The specimen is very young, white under a brown epidermis. TRYon unites it as a slight modification to $V$. ligata Recl. It is characterized by its strong plication on the upper whorls. It agrees, as well as may be desired of such a small specimen, with the figure of REEvE.

\section{Vanikoro Orbignyana Recluz var. tricarinata Recluz.}

Recluz in Sowerby. Thes. Conch. Pl. 482, fig. 24.

Tryon. Man. of Conch. Vol. VIII, p. 70, Pl. 29, fig. 92.

Stat. 7r. Makassar and surroundings. Up to $32 \mathrm{M}$. Mud, sand with mud, coral. I Spec.

The only specimen is strongly depressed. REeve considers this form to be a variety of $V$. Camingiana Reeve, which is a synonym of $V$. Orbignyana.

\section{Vanikoro Recluziana Adams \& Angas.}

Adams \& Angas. Proc. Zool. Soc. Lond. 1863, p. 424.

Tryon. Man. of Conch. Vol. VIII, p. 70, Pl. 29, fig. 87.

Stat. 93. Pulu Sanguisiapo, Tawi-Tawi-islands, Sulu-archipelago. 12 M. Lithothamnion-bottom, sand and coral. I Spec.

I cannot distinguish the only specimen from the typical ones described by ADAms and Angas, from New South Wales. As it is young, it might be that adult specimens show specific differences.

\section{Fam. Naticidae.}

\section{Natica Adanson.}

1. Natica zebra Lamarck.

Lamarck. An. s. vert. Ed. Desh. Vol. VIII, p. 643.

RuMph. Amb. Rariteitkamer, p. 76, Pl. 22, fig. G?

Philippr. Martini-Chemn. Conch. Cab. Ed. II, Vol. II, Natica, p. 18, Pl. 2, fig. 13, I4.

ReEve. Conch. Ic. Vol. IX, Natica, fig. 53.

Tryon. Man. of Conch. Vol. VIII, p. I6, Pl. 2, fig. 32.

Stat. 7. Near reef of Batjulmati (Java). I 5 M. Coral and stones. I Spec.

Stat. 50. Bay of Badjo, West coast of Flores. Up to $40 \mathrm{M}$. Mud, sand and shells. I Spec.

Stat. 3r3. East of Dangar Besar, Saleh-bay. Reef. I Spec.

Some authors are in doubt if the figure of RUMPH belongs to this species, his description is short and may be applied to more than one species: "Sommige zwart, sommige vaal, beide met witte slangetjes geschildert". Subsequent authors describe this shell as white with yellow or brown streaks. 
2. Natica mozaica Sowerby.

Sowerby. Thes. Conch. Vol. V, Natica, p. 92, Pl. IX, fig. I33, 134.

TrYon. Man. of Conch. Vol. VIII, p. 19, Pl. 3, fig. $51,52$.

Stat. 240. Banda. 9-45 M. Black sand, coral. 1 Spec.

The Siboga-specimen agrees in most parts with Sowerby's description and figure, but the umbilicus is not so quite covered, as it ought to be, according to the figure of the front view. This may be due to the youth of the specimen, or the figure may be less accurate. Some doubt remains about this identification.

3. Natica chinensis Lamarck.

Lamarck. An. s. vert. Ed. Desh. Vol. VIII, p. 644.

Runifh. Amb. Rariteitkamer, p. 76. Pl. 22, fig. C.

Philippi. Martini-Chemn. Conch. Cab. Ed. II, Vol. II, Natica, p. 19, Pl. 2, fig. 15-1S.

ReEve. Conch. Ic. Vol. IX, Natica, fig. 182.

Stat. 43. Pulu Sarassa, Postillon-islands. Up to 36 M. Coral. 1 Spec.

Stat. 47. Bay of Bima, near South fort. 55 M. Mud with patches of fine coralsand. I Spec.

Stat. So. Borneo-bank. 50-40 M. Fine coralsand. 1 Spec.

In the specimen from Stat. 43 , the colour-pattern has a tendency to form brown streaks, but shape and sculpture of the shell and the funiculum are the same, that from Stat. 47 is very young with only 2 rows of brown spots.

4. Natica mahesiensis Dufo.

Dufo. Ann. Sciences. Nat. Vol. XIV, 1840, p. 193.

Philipri. Martini-Chemn. Conch. Cab. Ed. II, Vol. II, Natica, p. 12I, Pl. 17, fig. 7.

ReEve. Conch. Ic. Vol. IX, Natica, fig. 58 (malleense).

Tryon. Man. of Conch. Vol. VIII, p. 20, Pl. 3 , fig. 56 (malleensis).

Stat. 260. Near Nuhu Jaan, Kei-islands. 90 M. Sand, coral and shells. 2 Spec.

\section{Natica arachnoidea Gmelin.}

Gmelin. Syst. Nat. p. 3674 .

Philippi. Martini-Chemn. Conch. Cab. Ed. II, Vol. II, Natica, p. 25, Pl. 3, fig. 1 8, 19; Pl. 15, fig. 18. ReEve. Conch. Ic. Vol. IX, Natica, fig. 56 (Raynandiana).

Tryon. Man. of Conch. Vol. VIII, p. 20, Pl. 3, figg. 57 (Raynoldiana).

Stat. 313. East of Dangar Besar, Saleh-bay. Up to 36 M. Sand, coral and mud. 3 Spec.

I have followed the views of PHicippi and other authors, in applying the name arachnoidea for this species, this has been done in recent time by Hinalgo (Cat. de los Mol. Test. de las islas Filipinas, Joló y Marianes, 1904-05, p. 1 57).

6. Natica solida Blainville.

Blainville. Manuel de Malac. Pl. 36 bis, fig. 8.

Rumph. Amb. Rariteitkamer, p. 76, Pl. 22, fig. E.

Phil.ippi. Martini-Chemn. Conch. Cab. Ed. II, Vol. II, Natica, p. 27, Pl. 3, fig. 12, 23 (cinnamomea). 
REEve. Conch. Ic. Vol. IX, Natica, fig. $7 \mathrm{I}$.

Tryon. Man. of Conch. Vol. VIII, p. 45, Pl. 20, fig. 98.

Stat. I9. Bay of Labuan Tring, West coast of Lombok. I8-27 M. River-mud, coral, coralsand. I Spec.

Stat. So. Borneo-bank. From 40-50 M. Fine coralsand. I Spec.

Stat. 258. Tual, Kei-islands. 22 M. Lithothamnion, sand and coral. 2 Spec.

Stat. 313. East of Dangar Besar, Saleh-bay. Up to $36 \mathrm{M}$. Sand, coral and mud. I Spec.

The specimens from Stat. $25^{8}$ are the only ones which have been collected alive, with the operculum, which is calcareous, as has been stated by v. Martens (Runphius Gedenkboek, Moll. p. 6). Menke (Syn. meth. Mollusc. Ed. alt. 1830, p. 47) has not described it, but locates it in his Section B "Ventricoso-globosae; operculo (in omnibus?) corneo". TRYon (1.c.) locates it amongst the species with corneous operculum. As Menke has not described his species I have applied Blatnville's name, which has priority, though he gives no more description than Menre. Perhaps the name lupinus of Deshayes (An. s. vert. Ed. II, Vol. VIII, p. 648) will be the eldest name accompanied by a description.

\section{Natica ala papilionis Chemnitz, var. articulata Philippi.}

Philippi. Martini-Chem1. Conch. Cab. Ed. II, Vol. II, Natica, p. I19, Pl. I7, fig. 4, S.

Stat. 240. Banda. 9-45 M. Black sand, coral. I Spec.

PhILIPpi has separated this form as a valid species. The Siboga-specimen exhibits all the characters, but I think they are only varietal. Tryon (Man. of Conch. Vol. VIII, p. 2I), quotes it simply as a synonym. The specimen is about as small as PHiLippi's fig. 8 , and possesses the fine, sulcated operculum.

\section{Natica euzona Recluz.}

Recluz. Proc. Zool. Soc. Lond. IS43, p. 204.

Philippi. Martini-Chemn. Conch. Cab. Ed. II, Vol. II, Natica, p. I 47 .

ReEve. Conch. Ic. Vol. IX, Natica, fig. $67 c$ (picta pars).

Tryon. Man. of Conch. Vol. VIII, p. 22 (picta pars).

Stat. 47. Bay of Bima, near South fort. Shore. I Spec.

Stat. 5 I. Molo-strait. 69-9r M. Fine, grey sand, coarse sand with shells and stones. 6 Spec.

Stat. 6o. Haingsisi, Samau-island. Reef. I Spec.

Stat. 260. Nuhu Jaan, Kei-islands. 9o M. Sand. coral and shells. 2 Spec.

Stat. 3 I3. East of Dangar Besar, Saleh-bay. Up to 36 M. Sand, coral and nuud. I Spec.

Many authors have considered $N$. euzona to be merely a variety or even a synonym of $N$. picta Recluz; as the Siboga-specimens belong without exception to euzona, I have applied that name. Anatomy perhaps will produce distinguishing characters.

9. Natica marochiensis Gmelin.

GMelin. Syst. Nat. p. 3673 .

ReEve. Conch. Ic. Vol. IX, Natica, fig. 52.

Tryon Maan. of Conch. Vol. VIII, p. 22, Pl. 5, fig. 74, 75 . 
Stat. 37. Sailus Ketjil, Paternoster-islands. Up, to 27 M. Coral and coralsand. 1 Spec.

Stat. 53. Bay of Nangamessi, Sumba. Up to 36 M. Coralsand. I Spec.

Stat. 277. Kulewatti-bay, Dammer-island. 44 M. Sand. I Spec.

These specimens are small and those from Stat. 37 and 53 are moreover bleached, consequently I cannot make out to which variety they belong; the majority of specimens belongs to:

var. tessellata Philippi.

Philippı. Martini-Chemn. Conch. Cab. Ed. II, Vol. II, Natica, p. 48, Pl. 7 , fig. 7 .

Tryon. Man. of Conch. Vol. VIII, p 23, Pl. 5, fig. 79 (lurida).

Stat. 4. Djangkar (Java). 9 M. Coralsand. 2 Spec.

Stat. 33. Bay of Pidjot, Lombok. Up to 22 M. Mud, coral and coralsand. 1 Spec.

Stat. 47. Bay of Bima, near South fort. 55 M. Mud with patches of fine coralsand. 3 Spec.

Stat. II6. West of Kwandang-bay entrance. $72 \mathrm{M}$. Fine sand with mud. I Spec.

Stat. 261. Elat, West coast of Great-Kei-islarid. 27 M. Mud. I Spec.

As the views of authors about $N$. marochiensis, its synonyms and varieties are very different, I have applied the name given by PHILrppi to a shell with characteristic colour-pattern, some specimens are partly of a brownish ground-colour.

10. Natica nebulosa n. sp. Pl. XIII, fig. 2.

Stat. 240. Banda. 9-45 M. Black sand, coral. I Spec.

Shell conically globose, thin, smooth, shining; with traces of a thin epidermis towards the aperture; whorls $5 \frac{1}{2}$, convex. The nuclear and part of subsequent whorls are nearly smooth, but have a few radiating striae and the suture is bordered by a spiral ridge. The last $2^{1} / 2$ whorls are separated by a deep suture, with radiating striae, gathered puckerings below it. Moreover the shell is covered with very fine growth-striae and a few scattered spirals, which are only visible under a strong lens. Colour very light lilac, with a narrow white zone at the suture, and a broader one round the umbilicus; the lilac zone of the shell has very faint rufousbrown streaks, which are more or less waved, forming at the shoulder of last whorl, a row of arrow-headed spots and a row of squarely-oblong blotches, just above the umbilical white zone. Aperture oblong-ovate, rather angular at the upper corner; right margin thin, curved, columellar margin nearly straight, but slightly concave, its upper part reflected on the body whorl, tongueshaped just above the umbilicus, of which only a small, deep pit of the upper part remains, the umbilicus being nearly quite filled by a white, porcellaneous funiculum, with only a groove at its left side, originating from the umbilical pit, becoming shallow towards the base. Operculum calcareous, for a large part smooth and shining, near the nuclear part thickened by a dull layer, bordered at the left by a comma-shaped rim; right margin bordered by 3 raised rims, of which the outermost is narrow and not strongly developed, especially towards the base of the aperture; the median rim is rather narrow, much raised, bordered externally by a shallow, internally by a deeper groove; internal rim the broadest, separated from the rest of the operculum by a deeply incised groove.

Alt. $15^{1} / 2$, lat. $14^{1} / 2$; apert. alt. $12^{1} / 2$, lat. 8 Mill. 
If this species is seen without the operculum, it might be considered to be a variety of the polymorph $N$. marochiensis, but its umbilicus is much more filled by the funiculum. The operculum is quite different from that of marochiensis described by WATSON (ChallengerGastropoda, p. 434) and from specimens which I could compare.

\section{I. Natica strongyla Melvill.}

MeLvill. Memoirs and Proc. Manch. Lit. and Phil. Soc. Vol. 4 I, I $897, N^{0} 7$, p. II, Pl. 6, fig. 20. Stat. $98.6^{\circ} 9^{\prime}$ N., $120^{\circ} 2 \mathrm{I}^{\prime}$ E. Sulu Sea. 350 M. Sand. 1 Spec.

The specimen is a young, empty shell; it is not probable that this species with its prominent colour-markings, has lived at so greath a depth.

\section{Natica ascllus Reeve.}

ReEve. Conch. Ic. Vol. IX, Natica, fig. 136 .

Tryon. Man. of Conch. Vol. VIII, p. 24, Pl. 6, fig. 3, 4.

Stat. 7. Near reef of Batjulmati (Java). I5 M. Coral and stones. I Spec.

The umbilicus of the Siboga-specimen is not quite closed and the row of small dots between the two blue-black bands is wanting. I think these differences are of ton little importance, to be in doubt about the identity.

\section{Natica atypha Watson.}

IVatson. Report Voy. Challenger. Zool. Vol. XV, Part 42, Gaptrop. p. 438, Pl. 27, fig. 2.

Stat. 2. Madura-strait. 56 M. Grey mud with some radiolariae. I Spec.

Stat. 47. Bay of Bima, near South fort. 55 M. Mud with patches of fine coralsand. 1 Spec.

Stat. 116. West of Kwandang-bay-entrance. $72 \mathrm{M}$. Fine sand with mud. 5 Spec.

The specimens are dead, bleached shells.

\section{Natica colliei Recluz.}

Recluz. Proc. Zool. Soc. Lond. 1843 , p. 206.

Philippi. Martini-Chemn. Conch. Cab. Ed. II, Vol. II, Natica, p. 70, Pl. I1, fig. 6.

ReEve. Conch. Ic. Vol. IX, Natica, fig. 112.

Tryon. Man. of Conch. Vol. VIII, p. 26, Pl. 7, fig. 34 .

Stat. 99. North-Ubian, Sulu-archipelago. 16-23 M. Lithothamnion-bottom. I Spec.

\section{Natica buriasensis Recluz.}

RecLuz. Proc. Zool. Soc. Lond. 1843 , p. 212 (buriasiensis).

Philippl. Martini-Chemn. Conch. Cab. Ed. II, Vol. II, Natica, p. I33, Pl. I8, fig. 17.

Reeve. Conch. Ic. Vol. IX, Natica, fig. 128.

Tryon. Man. of Conch. Vol. VIII, p. 29, Pl. 8, fig. 58. 
Stat. 33. Bay of Pidjot, Lombok. 22 M. Mud, coral and coralsand. I Spec.

Stat. 47. Bay of Bima. 55 M. Mud with patches of fine coralsand. I Spec.

Stat. 53. Bay of Nangamessi, Sumba. Up to 36 M. Coralsand. 2 Spec.

Stat. 7 I. Makassar and surroundings. Up to 32 M. Mud, sand with mud, coral. 3 Spec

Stat. 142. Laiwui, North coast of Obi Major. Reef. I Spec.

Stat. 193. Sanana-bay, East coast of Sula Besi. Reef. 2 Spec.

Stat. 311 . Sapeh-bay, East coast of Sumbawa. Up to 36 M. 1 Spec.

The specimens are smaller than they ought to be according to the descriptions and figures, but agree in every other respect.

\section{Natica lineata Lamarck.}

Lanarck. An. s. vert. Ed. Desh. Vol. Vill, p. 640:

Phrlippr. Martini-Chemn. Conch. Cab. Ed. II, Vol. II, Natica, p. ir, Pl. I, fig. 9.

Reeve. Conch. Ic. Vol. IX, Natica, fig. 24.

Tryon. Man. of Conch. Vol. VIII, p. 29, P1. 8, fig. 57.

Stat. 296. Noimini, South coast of Timor. 8-36 M. Sandy mud. I Spec.

\section{7. Natica gracilis Recluz.}

Recluz. Journ. de Conch. Vol. I, i850, p. 387, Pl. 14, fig. 11.

TrYon. Man. of Conch. Vol. VIII, p. 29, Pl. 8, fig. 59.

Stat. 4. Djangkar (Java). 9 M. Coarse sand. I Spec.

Stat. 47. Bay of Bima. 55 M. Mud with patches of fine coralsand. 1 Spec.

Stat. 142. Laiwui, North coast of Obi Major. Reef. 1 Spec.

In the specimen from Stat. 142 the chestnut lines are wanting, but otherwise the shell agrees with typical ones, it may be bleached and is not quite adult; that from Stat. 4 is a fresh specimen, with a brownish epidermis and operculum; the latter is calcareous, white, with 7 deep grooves, separating rather broad lirae, columellar margin of the operculum notched, partly by the terminations of the grooves, partly by 2 shorter grooves, running at a little distance from the margin.

\section{I8. Natica rufa Born.}

Born. Testacea Mus. Vindobon. p. 398, Pl. 17 , fig. 3, 4.

Runre. Amb. Rariteitkamer, p. 76, Pl. 22, fig. D.

Pimllip pr. Martini-Chemn. Conch. Cab. Ed. II, Vol. II, Natica, p. 14, Pl. 2, fig. 1, 2.

ReEve. Conch. Ic. Vol. IX, Natica, fig. 70.

Tryon. Man. of Conch. Vol. VIII, p. 29, Pl. 9, fig. 62, 63 .

Stat. 33. Bay of Pidjot, Lombok. 22 M. Mud, coral and coralsand. I Spec.

Stat. 7 r. Makassar and surroundings. Up to 32 M. Mud, sand with mud. I Spec.

Stat. 279. Rumah-Kuda-bay, Roma-island. 36 M. Mud and sand. 2 Spec.

The operculum has been described with a few words by Runpr, it is thick, especially near the nucleus, where both specimens from Stat. 279 have a knob, resembling a small agglutinated pebble; the whole margin is crenulate, the external rim squamose, and separated from a very 
broad rim, by a large groove, with two intermediate rims, which are also crenulate; at the proximal side of the broad rim runs a groove with a small rim therein.

\section{Natica helvaced Lamarck.}

Lamarck. An. s. vert. Ed. Desh. Vol. Vill, p. 637.

Philippi. Martini-Chemn. Conch. Cab. Ed. II, Vol. II, Natica, p. 2I, Pl. 3, fig. I, 2; Pl. 8, fig. $5($ globosa).

ReEve. Conch. Ic. Vol. IX, Natica, fig. 46 (globosa).

Tryon. Man. of Conch. Vol. VIII, p. 32, Pl. 9, fig. 64 .

Stat. I33. Lirung, Salibabu-island. Up to 36 M. Mud and hard sand. 2 Spec.

Stat. 26r. Elat, West coast of Great-Kei-island. 27 M. Mud. 2 Spec.

The specimens are young.

20. Natica crassa n. sp. Pl. XIII, fig. 3 .

Stat. 58. Seba, Savu. Up to 27 M. Sand. I Spec.

Shell small, subglobose, with blunt spire, thick, shining, with rather strong growth-striae, strongest below the suture, and microscopic waved spirals. Whorls $4 / 2$, slightly convex, especially the upper ones, which are separated by a conspicuous suture, which is shallower in the last whorl; this suture strongly descends towards the aperture, and on this part the growth-striae are very strong and crowded; just behind the aperture the shell is slightly contracted. Colour white, with a large, irregular, yellowish-brown zone near the median part of last whorl, this zone encloses irregular white spots. Aperture small, oval, with a blunt angle above; right margin thick, curved, rounded below; columellar margin nearly straight with a callous pad at the upper part and a thick, subtriangular, porcellaneous deposit, forming in part the end of the funiculum and covering the upper part of the umbilicus, which is narrow interiorly, but apparently pervious; a deeply incised rather broad groove, separates the funiculum from the bodywhorl, base of the columella joined to the thick, rounded basal margin of aperture by an angle which produces a short tongue-shaped layer, just below the umbilical groove. Interior of aperture, smooth, white.

Operculum wanting, but the columella has a slight groove, indicating the presence of a calcareous operculum.

Alt. $7^{1} / 2$, lat. $8^{1} / 2$; apert. alt. $5^{1} / 4$, lat. 3 Mill.

This species may be recognized by its thick shell, by the strongly descending suture, the strong striae near the aperture, which is unusually small. I know no nearly allied species.

2 I. Nalica supraornata n. sp. Pl. XIII, fig. 4.

Stat. $274.5^{\circ} 28^{\prime} .2$ S., $134^{\circ} 53^{\prime} .9$ E. Near Aru-islands. 57 M. Sand and shells, stones. 2 Spec.

Shell small, depressedly subglobose, with blunt spire; rather thick, smooth, whorls $3^{1} / 2$, the nuclear one convex, the remaining nearly flat; sculpture consisting of very fine growth-striae, more conspicuous near the suture and towards the aperture. Colour yellowish-white, with a collar 
of chestnut spots of an irregular shape, but having a tendency to be triangular below the suture and on part of the penultimate whorl; these spots enclose irregular whitish spots. Aperture oval, with rounded basal and outer margin, columellar margin nearly straight; upper angle of aperture blunt, with a thick layer of enamel on the body whorl, forming a rim near the angle of aperture and connected with the funicular tongue-shaped pad, which fills a large part of the umbilicus, this latter seems to be pervious, and is formed below of a deep, large groove round the funiculum, the whole columellar part is light chestnut (perhaps bleached).

Operculum wanting; probably calcareous.

Alt. 6 , lat. $6^{2} / 5$; apert. alt. $4^{1} / 2$, lat. 3 Mill.

This shell is remarkable for its brown columella and the blotches near the suture. It may be allied to $N$. psenstes Watson (Challenger Gastrop. p. 44, Pl. 27, fig. 3 ) but besides the collar, I see no brown markings, as in that species and the umbilicus seems to be different, for WATSON describes it as disappearing behind the pillar callus, and I can introduce a fine needle at a relatively considerable depth.

22. Natica simplex n. sp. Pl. XIV, fig. I.

Stat. $310.8^{\circ} 30^{\prime}$ S., $119^{\circ} 7^{\prime} .5$ E. Flores Sea. 73 M. Sand with few pieces of dead coral. 1 Spec.

Shell conically globose, rather thin, smooth and shining. Whorls $5 \frac{1}{2}$ moderately convex, forming a rained spire. Sculpture consisting of very fine growth-striae, stronger towards the upper suture of each whorl, crossed by microscopic, wavy, spiral striae. Colour of shell light yellowishredbrown, with a narrow white zone below the suture, and a large one occupying the base. Suture of last whorl gradually descending towards the aperture, upper margin of last whorl appressed on the bodywhorl. Aperture ovate, with a blunt angle above, right margin regularly curved, more rounded below and passing imperceptibly into the basal margin; columellar margin nearly straight, with a porcellaneous pad above on the bodywhorl, slightly reflected over the umbilicus, which is rather large, pervious, with scarcely any trace of a funiculum, consequently the columellar margin is only inconspicuously thickened, on the place where the funiculum should terminate. Interior of aperture brownish.

Operculum wanting, probably calcareous, for the columella has a slight ridge.

Alt. $14 \frac{1}{2}$, lat. 14 ; apert. alt. $101 / 2$, lat. 7 .

This species is of a very simple character, in its umbilicus it resembles $N$. semisulcata Gray, by the wanting funiculum.

\section{Natica (Neverita) sp:}

Stat.'204. Between islands of Wowoni and Buton. 75-94 M. Sand with dead shells. 1 Spec.

A probably young, bleached shell belongs to the subgenus Neverita, I cannot identify' it with any described species, but it is not in sufficient good condition, to describe it as new.

\section{Natica (Lunatia) simulans Smith.}

Smith. Ann. and Mag. of Nat. Hist. Ser. 7, Vol. XVIII, 1906, p. 173. 
Stat. 52. $9^{\circ} 3^{\prime} \cdot 4$ S., $119^{\circ} 5^{\prime} .7$ E. Savu Sea. 959 M. Globigerine ooze. I Spec.

Stat. $212.5^{\circ} 54^{\prime} .5$ S., $120^{\circ} 19^{\prime} .2 \mathrm{E}$. Banda Sea. 462 M. Fine grey and green. mud. I Spec.

Stat. $286.8^{\circ} 50^{\prime} .2$ S., $127^{\circ} 2^{\prime} .2$ E. Timor Sea. $88_{3}$ M. Mud. I Spec.

The specimens are young, the largest having only a diameter of Io Mill., whereas the smallest specimen recorded by Surth, has a diameter of 2 I Mill. As the specimens have been compared by the author, I am not in doubt about the identification.

25. Natica (Lunatia) faba n. sp. Pl. XIII, fig. 5 .

Stat. 88. $0^{\circ} 34^{\prime} .6$ N., I $19^{\circ} 8^{\prime} .5$ E. Makassar Strait. I 30 I M. Fine grey mud. I Spec.

Shell small, conically subglobose, with blunt (eroded) spire, thin, nearly smooth, but with very fine growth-striae; white under an olive epidermis. Whorls about $3^{1} / 2$, nucleus wanting, remaining whorls moderately convex, separated by a canaliculate suture, last whorl regularly rounded. Aperture oblong-oval, outer and basal margins regularly curved, columellar margin concave, its upper part forming on the left side a thick layer of enamel on the bodywhorl, becoming narrow towards the median part, where it partly covers the umbilicus and is again thickened and reflected in joining the basal margin. Umbilicus narrow, so much covered, as to leave only a narrow slit. No funiculum. Operculum corneous.

Alt. $5^{1} / 2$, lat. $4^{3} / 4$; a pert. alt. $3^{3} / 5$, lat. $2^{1} / 4$ Mill.

This species is allied to the preceding one, but is more oval, has a smaller umbilicus, a canaliculate suture and the puckerings below the suture, which are present in the specimens of $N$. simulans Smith of the same size, are wanting. It has no juvenile appearance.

\section{Natica (Mamma) aurantia Lamarck.}

Lamarck. An. s. vert. Ed. Desh. Vol. VIII, p. 632.

Rumpir. Amb. Rariteitkamer, p. $76, \mathrm{~N}^{0} 7 c$.

Phicippi. Martini-Chemn. Conch. Cab. Ed. II, Vol. II, Natica, p. 34, Pl. 4, fig. I3, 14.

REEvE. Conch. Ic. Vol. IX, Natica, fig. 20.

Tryon. Man. of Conch. Vol. VIII, p. 42, Pl. 15, fig. 39.

Stat. So. Borneo-bank. 40-50 M. Fine coralsand. I Spec.

var. Mittrei Hombron \& Jacquinot.

Hombron \& JACQUinot. Voy. Astrol. \& Zel. p. 65.

Stat. I14. Kwandang-bay-entrance. 75 M. Hard sand, very fine. I Spec.

Both specimens are young, that identified as var. Mittrei has the umbilicus not quite filled.

var. straminea Recluz.

ReCLUZ. Proc. Zool. Soc. Lond. I843, p. 2 ir.

Philippi. Martini-Chemn. Conch. Cab. Ed. II, Vol. II, Natica, p. I 3 , Pl. 16, fig. 3.

REEve. Conch. Ic. Vol. IX, Natica, fig. 32 (var. lutea s. straminea).

Tryon. Man. of Conch. Vol. VIII, p. 42, Pl. 15, fig. 40.

Stat. 37. Sailus Ketjil, Paternoster-islands. Up to 27 M. Coral and coralsand. I Spec.

Stat. r69. Atjatuning, West coast of New Guinea. Reef. I Spec. 
Stat. 172. Between Gisser and Ceram-Laut. Reef. 7 Spec.

Stat. 193. Sanana-bay, East coast of Sula Besi. Reef. 2 Spec.

Stat. 279. Roma. Reef. I Spec.

In accordance with the majority of authors I have united this form to $N$. aurantia.

27. Natica (Mamma) powisiana Recluz.

Recluz. Proc. Zool. Soc. Lond. I 843, p. 2 Io.

Philippi. Martini-Chemn. Conch. Cab. Ed. II, Vol. II, Natica, p. 46, Pl. 7, fig. 4.

ReEve. Conch. Ic. Vol. IX, Natica, fig. 22.

Tryon. Man. of Conch. Vol. VIII, p. 42, Pl. I5, fig. 42.

Stat. 47. Bay of Bima, near South fort. 55 M. Mud with patches of fine coralsand. I Spec.

Stat. 7 I. Makassar. Up to 32 M. Mud, sand with mud, coral. I Spec.

Stat. I 6 . West of Kivandang-bay-entrance. 72 M. Fine sand with mud. I Spec.

The specimens are young, those from Stat. 47 and 116 are in fresh condition, with the thin yellowish operculum.

28. Natica (Mamma) suffusa Reeve.

Reeve. Conch. Ic. Vol. IX, Natica, fig. 129.

Tryon. Man. of Conch. Vol. VIII, p. 44, Pl. I9, fig. 87 .

Stat. 37. Sailus Ketjil, Paternoster-islands. Up to 27 M. Coral and coralsand. I Spec.

Stat. 64. Kambaragi-bay, Tanah Djampeah. Up to 32 M. Coral, coralsand. I Spec.

Stat. 8o. Borneo-bank. 50-40 M. Fine coralsand. I Spec.

Unfortunately the only specimen from Stat. 80 is an empty shell. It agrees in every respect with the figure and description of ReEve. I think Tryon was quite wrong in suggesting that it should be a variety of $N$. mamilla Lin., it is sufficiently distinct by its apex, umbilicus and colour. The locality recorded by the authors quoted above is New-Ireland. The specimens from Stat. 37 and 64 are still more bleached, the violet colour being only perceptible on the spire.

29. Natica (Mamma) manilla Linné.

Linné. Syst. Nat. Ed. X, p. $77^{6}, N^{0} 627$.

Rumph. Amb. Rariteitkamer, p. 76, Pl. 22, fig. F.

Philippl. Martini-Chemn. Conch. Cab. Ed. II, Vol. II, Natica, p. 31, Pl. 4, fig. 7, 8.

Reeve. Conch. Ic. Vol. IX, Natica, fig. 27.

Tryon. Man. of Conch. Vol. VIII, p. 49, Pl. 16, fig. 46.

Stat. 47. Bay of Bima, near South fort. 55 M. Mud with patches of fine coralsand. I Spec.

Stat. 50. Bay of Badjo, West coast of Flores. Up to 40 M. Mud, sand and shells. I Spec.

Stat. 86. Dongala, Palos-bay, Celebes. 36 M. Fine, grey mud. 3 Spec.

Stat. I74. Waru-bay, North coast of Ceram. Reef. I Spec.

Stat. 23 I. Amboina. 40 M. Coralsand. 2 Spec.

Stat. 258. Tual, Kei-islands. 22 M. Lithothamnion, sand and coral. I Spec.

Stat. ? 3 Spec.

One specimen from Stat. 86, though about fullgrown, has the umbilicus still open, but else it is quite typical. 
30. Natica (Mamma) flemingiana Recluz.

Recluz. Proc. Zool. Soc. Lond. 1843, p. 209.

Philippr. Martini-Chemn. Conch. Cab. Ed. II, Vol. II, Natica, p. I26, Pl. i8, fig. 7. ReEve. Conch. Ic. Vol. IX, Natica, fig. So.

Tryon. Man. of Conch. Vol. VIII, p. 50, Pl. 16, fig. 51.

Stat. 19. Bay of Labuan Tring, West coast of Lombok. I 8-27 M. River-mud, coral, coralsand. I Spec.

A young, slightly broken, dead shell, sufficiently agreeing with the quoted figures.

\section{Natica (Mamma) albumon Linné.}

Linné. Syst. Nat. Ed. X, p. $776, \mathrm{~N}^{0} 626$.

Runph. Amb. Rariteitkamer, p. 76, Pl. 22, fig. 13.

PhilippI. Martini-Chemn. Conch. Cab. Ed. II, Vol. II, Natica, p. 29, Pl. 4, fig. 3, 4.

ReEve. Conch Ic. Vol. IX, Natica, fig. $3 \mathrm{I}$.

Tryon. Man. of Conch. Vol. VIII, p. 47, Pl. 21 , fig. 5.

Stat. 133. Lirung, Salibabu-island. Up to 36 M. Mud and hard sand. I Spec.

v. Martens locates this species in the subgenus Neverita; I have followed other authors f. i. Melvilt, who (Proc. Zool. Soc. Igor, p. 359) mentions it as Mamma.

\section{Natica (Mamilla) melanostoma Gmelin.}

GMelin. Syst. Nat. Ed. XIII, p. 3674 .

RUMPH. Amb. Rariteitkamer, p. $76, \mathrm{~N}^{0}$ VII $b$.

Philıippi. Martini-Chemn. Conch. Cab. Ed. II, Vol. II, Natica, p. 30, Pl. 4, fig. 5, 6, I5, 16. Reeve. Conch. Ic. Vol. IX, Natica, fig. 78 .

Tryon. Man. of Conch. Vol. VIII, p. 50, Pl. 21, fig. 13, 14; Pl. 22, fig. 2 I.

Stat. 8o. Borneo-bank. 40-50 M. Fine coralsand. I Spec.

Stat. 133. Lirung, Salibabu-island. Up to 36 M. Mud and hard sand. I Spec.

Stat. $164 . I^{\circ} 42^{\prime} \cdot 5 \mathrm{~S}$., $130^{\circ} 47^{\prime} \cdot 5$ E. Halmahera Sea. 32 M. Sand, small stones and shells. I Spec.

Stat. I72. Gisser. Reef. 2 Spec.

var. fibrosa Souleyet.

Souleyet. Voy. Bonite. p. 58 I, PI. 35, fig. 8-io.

Tryon. Man. of Conch. Vol. VIII, p. 5 I, Pl. 2i, fig. 17.

Stat. 33. Bay of Pidjot, Lombok. Up to 22 M. Mud, coral and coralsand. I Spec.

Stat. 50. Bay of Badjo, west coast of Flores. Up to 40 M. Mud, sand and shells. I Spec.

\section{Natica (Mamilla) melanostomoides Quoy \& Gaimard.}

Quor \& Gajnakd. Voy. de l'Astrolabe. Vol. II, p. 229, Pl. 66, fig. 4-8.

Philıppi. Martini-Chiemn. Conch. Cab. Ed. II, Vol. II, Natica, p. 58, Pl. 9, fig. 5.

REEve. Conch. Ic. Vol. IX, Natica, fig. Ior.

Tryon. Man. of Conch. Vol. VIII, p. 50, Pl. 21, fig. 16; Pl. 22, fig. 2 I (melanostoma var.).

Stat. 47. Bay of Bima. 55 M. Mud with patches of fine coralsand. 2 Spec.

Stat. 71. Makassar. Up to $32 \mathrm{M}$. Mud, sand with mud, coral. I Spec.

Stat. 131. Beo, Karakelang-islands. 13 M. Mud and sand.' I Spec. 
Philipri and Reeve have held this species separate, Tryos unites it to the preceding species. Troschel (Gebiss der Schnecken, p. i $\delta_{3}$ ) found no valuable differences between the radulae, but conchologically the species is easily recognizable.

34. Natica (Mamilla) simiae Deshayes.

Desilayes in Lamarck. An. s. vert. Ed. Desh. Vol. VIII, p. 652.

Philippi. Martini-Chemn. Conch. Cab. Ed. II, Vol. II, Natica, p. 35, Pl. 4, fig. 17.

ReEve. Conch. Ic. Vol. IX, Natica, fig. 76 .

Tryon. Man. of Conch. Vol. VIII, p. 5I, Pl. 21, fig. 19, 20.

Stat. 66. Bank between Bahuluwang and Tambolungan. 8-10 M. Dead coral. 1 Spec.

Stat. $164.1^{\circ} 42^{\prime} \cdot 5$ S., $130^{\circ} 47^{\prime} \cdot 5$ E. Halmahera Sea. 32 M. Sand, small stones and shells. I Spec.

Stat. 279. Rumah-Kuda-bay, Roma-island. 36 M. Mud and sand. I Spec.

Stat. 3 I3. East of Dangar Besar, Saleh-bay. Up to 36 M. Sand, coral and mud. I Spec.

The specimens are small, probably young, they may be easily recognized by the waved streaks.

35. Natica (Mamilla) filosa Sowerby.

Sowerby in Reeve. Conch. [c. Vol. IX, Natica, fig. 72.

TrYon. Man. of Conch. Vol. VIII, p. 5I, Pl. 22, fig. 22.

Stat. 33. Bay of Pidjot, Lombok. Up to $22 \mathrm{M}$. Mud, coral and coralsand. I Spec.

Stat. 47. Bay of Bima. 55 M. Mud with patches of fine coralsand. I Spec.

Stat. 313. East of Dangar Besar, Saleh-bay. Up to 36 M. Sand coral and mud. I Spec.

The specimens are young but easily recognizable by the spiral striae.

36. Natica (Namilla) manma Bruguière.

Bruguitere. Encycl. Meth. p. 453 , fig. $4 a, b$.

Philippi. Martini-Chemn. Conch. Cab. Ed. II, Vol. II, Natica, p. 58, Pl. 9, fig. 6.

ReEve. Conch. Ic. Vol. IX, Natica, fig. 25.

Tryon. Man. of Conch. Vol. VIII, p. 5 I, Pl. 22, fig. 24.

Stat. 47. Bay of Bima. 55 M. Mud with patches of fine coralsand. 1 Spec.

One very young specimen.

37. Natica (Amauropsis) apora Watson.

Watson. Voy. of H. M. S. Challenger, Zoology, Vol. XV, Part 42, p. 454, Pl. 27, fig. II.

Stat. $48.8^{\circ} 4^{\prime} \cdot 7$ S., $118^{\circ} 44^{\prime} \cdot 3$ E. Flores Sea. 2060 M. Fine grey mud, partially green. i Spec.

Stat. 52. $9^{\circ} 3^{\prime} \cdot 4$ S., $119^{\circ} 56^{\prime} .7$ E. Savu Sea. 959 M. Globigerina ooze. I Spec.

Stat. $76.4^{\circ} 22^{\prime}$. I S., I I $8^{\circ} 16^{\prime} .9$ E. Makassar Strait. 2029 M. Fine grey mud. 3 Spec.

Stat. $271.5^{\circ} 46^{\prime} .7$ S., $134^{\circ} \mathrm{O}^{\prime} \mathrm{E}$. Arafura Sea. I $788 \mathrm{M}$. Bluish green mud of a uniform appearance. 2 Spec.

Stat. 300. $10^{\circ} 48^{\prime} .6$ S., $123^{\circ} 23^{\prime} .1$ E. Timor Sea. 918 M. Fine, grey sand. 2 Spec.

The specimen from Stat. 48 is much larger than W W 27 Nill.; one specimen from Stat. 27 I has the umbilicus not quite closed, but as the columellar 
layer is slightly damaged, this seems to be no difference of any importance; a specimen from Stat. 300 the only one that has been collected alive, has a golden-yellow operculum.

Moreover there are several specimens of Natica, belonging to different subgenera, which are young and in bad condition, so I could not identify them, and even if afterwards one or two might prove to be new, I think it is not advisable to describe new species on such poor specimens, in a genus where the species seldom have prominent characters

\section{Sigaretus Lamarck.}

I. Sigaretus linneanus Recluz.

Recluz in Chenu. Ill. Conch. Vol. III, Sigaretus, Pl, I, fig. 4.

Weinkauff. Martini-Chemn. Conch. Cab. Ed. II, Vol. VI, Sigaretus, p. 37, Pl. 9, fig. 2, 5.

Trion. Man. of Conch. Vol. VIII, p. 59, PI. 25, fig. 89, 90.

Stat. 285. South coast of Timor. 34 M. On the Limit between mud and coral. Lithothamnion. I Spec.

Stat. 294. South coast of Timor. 73 M. Soft mud with very fine sand. I Spec.

The specimen from Stat. 285 is very small and covered by a brown epidermis. I can however see nothing else in it, but a young specimen of S. limneanus Recl.

\section{Fam. Marsenildae Bergh.}

Marsenia Leach.

1. Marsenia perspicua Linné.

2. Marsenia Sibogae Bergh.

Chelyonotus (Swainson) Bergh.

I. Chelyonotus Semperi Bergh.

For this family see appendix by Prof. R. Bergh in Part $\mathrm{I}$ of this publication.

\section{Fam. Solariddae Chemn.}

\section{Solarium Lamarck.}

I. Solarizm perspectivum Linné.

LinNÉ. Syst. Nat. Ed. X, p. $757, \mathrm{~N}^{0} 503$.

Runph. Amb. Rariteitkamer, p. 9I, P1. 27, fig. L.

Philrrpi. Martini-Chemn. Conch. Cab. Ed. II, Vol. II, Solarium, p. 27, Pl. 4, fig. 6 (incisum).

ReEve. Conch. Ic. Vol. XV, Solarium, fig. ir.

Tryon. Man. of Conch. Vol. IX, p. 8, Pl. 2, fig. I8, I9. 
Stat. 19. Bay of Labuan Tring, West coast of Lombok. I8-27 MI. River-mud, coral, coralsand. I Spec.

Stat. 47. Bay of Bima. 55 M. Mud with patches of fine coralsand. I Spec.

Stat. 205. Lohio-bay, Buton-strait. 22 M. Sandy mud. I Spec.

Stat. 231. Amboina. Reef. 2 Spec.

\section{Solarium modestum Philippi.}

Philippi. Zeitschr. für Malakoz. i848, p. i 7 I.

-_ Martini-Chemn. Conch. Cab. Ed. Il, Vol. 11, Solarium, p. I5, Pl. 3, fig. I.

ReEve. Conch. Ic. Vol. XV, Solarium, fig. I2.

Tryon. Man. of Conch. Vol. 1X, p. 9, Pl. 2, fig. 22, 23.

Stat. 4. Djankar (Java). 9 M. Coarse sand. I Spec.

Stat. 33. Bay of Pidjot, Lombok. 22 M. Mud, coral and coralsand. I Spec.

Stat. 47. Bay of Bima. 55 M. Mud with patches of fine coralsand. I Spec.

Stat. 5 I. Madura-bay. 69-9I M. I Spec.

Stat. 58. Seba, Savu. Up to 27 M. Sand. I Spec.

Stat. 3I3. East of Dangar Besar, Saleh-bay. Up to 36 M. Sand, coral and mud. I Spec.

The specimens are young, but well characterized by the white, crenulate umbilical rim.

\section{Solarinm sp.}

Stat. $45 \cdot 7^{\circ} 24^{\prime}$ S., I $18^{\circ} 15^{\prime} \cdot 2$ E. Flores Sea. 794 M. Fine grey mud. I Spec.

Stat. $95.5^{\circ} 43^{\prime} .5$ N., $119^{\circ} 40^{\prime}$ E. Sulu Sea. 522 M. Stony bottom. 2 Spec.

The specimens are young and in very bad condition, too bad to identify them. I think they will not have lived at these great depths.

\section{Solarium (Philippia) hybridum Linné.}

Linné. Syst. Nàt. Ed. X, p. $757, \mathrm{~N}^{1} 504$.

KıEner. Coq. Viv. Vol. IX, Solarium, p. 7, Pl. 3, fig. 5.

Philippi. Martini-Chemn. Conch. Cab. Ed. Il, Vol. II, Solarium, p. 14.

REEve. Conch. Ic. Vol. XV, Solarium, fig. $2 \mathrm{I}$.

TrYon. Man. of Conch. VoI. IX, p. I4, Pl. 5, fig. 61, 62.

Stat. 93. Pulu Sanguisiapo, Tawi-Tawi-islands, Sulu-archipelago. I2 MI. Lithothamnion, sand and coral. I Spec.

Stat. 248 . Runah Lusi, North point of Tiur-island. Up to 36 M. I Spec.

Philippi has not separated this species from the next one.

5. Solarium (Philippia) cingulum Kiener.

İiener. Coq. Viv. Vol. IX, Solarium, p. 6, Pl. 3, fig. 6.

ReEve. Conch. Ic. Vol. XV, Solarium, fig. Ig.

Tryon. Man. of Conch. Vol. IX, p. 15, Pl. 5, fig. 63,64 .

Stat. 258. Tual, Kei-islands. 22 M. Lithothamnion, sand and coral. I Spec.

Stat. 3 II. Sapeh-bay, East coast of Sumbawa. Up to 36 M. Mud and sand. I Spec. 
var. subconcolor v. Martens.

v. Martens. Beitr. zur Molluskenfauna der Insel Mauritius. Moll. p. 290.

Kiener. Coq. Viv. Vol. IX, Solarium, Pl. 3, fig. 5 a (hybridum var.).

Philippi. Martini-Chemn. Conch. Cab. Ed. II, Vol. II, Solarium, Pl. 2, fig. 14, 15.

Stat. I72. Gisser. Reef. I Spec.

This specimen perfectly agrees with the figure.

\section{Fluxina Dall.}

1. Fluxina marginata n. sp. Pl. XIV, fig. 2.

Stat. 24 I. $4^{\circ} 24^{\prime} \cdot 3$ S., I $29^{\circ} 49^{\prime} \cdot 3$ E. Banda Sea. 1570 M. Dark sand with small stones. 2 Spec.

Shell whitish, thin, very depressed, conic, sharply keeled at the periphery, postnuclear whorls about 5, spirally divided into 2 parts, convex above but concave if taken as a whole, nucleus umbilicate; sculpture consisting of very faint spiral striae, crossed by stronger, undulate, riblike, rather distant ones, with faint growth-striae in the interstices; these riblike striae are less conspicuous on the last whorl; the lower part of each whorl has the appearance of a broad margin, slightly concave above, separated from the upper part of each whorl, by a kind of spiral rib, which is slightly crenulated, this marginal part is sculptured by rather conspicuous spiral and stronger, oblique, but nearly straight, riblike radiating striae, which on the upper part make the keel slightly crenulate (on the largest specimen the keel is smooth, on account of the less conspicuous sculpture); basal part of last whorl convex, with a few more or less conspicuous spiral striae around the umbilicus, and faint, strongly curved, radiating striae; margin separated from the central part by a deep groove, with about 7 spirals and faint growth-striae. Umbilicus large, pervious, scalar, bordered by a strong rib which is surrounded by a deep groove, umbilical wall perpendicular. Aperture rhombic, with convex upper, outer and basal margins; keel protracted in a claw in the younger specimen, columellar margin excavated, slightly thickened, angular below near the umbilical keel, and forming there a somewhat tongue-shaped triangle.

Alt. $3^{3} / 4$, lat. $81 / 4$; apert. alt. $1^{3} / 4$, lat. $2^{1 / 2}$ Mill.

Alt. $3^{1 / 2}$, lat. $S$; apert. alt. $1^{3} / 7$, lat. $2^{3} / 4$ Mill.

This is the second species of Fluxina from the Indian Ocean, quite different from the described species, by the broad margin at the periphery; the claw-like angle of the aperture and the umbilical rib, have induced me to locate it in this genus.

2. Fluxina trochiformis n. sp. Pl. XIV, fig. 3 .

Stat. $178.2^{\circ} 40^{\prime}$ S., $128^{\circ} 37^{\prime} .5$ E. Ceran Sea. 835 M. Blue mud. I Spec.

Shell white, thin, conic, sharply keeled, whorls about 6 , nucleus slightly umbilicate, postnuclear whorls with very fine curved growth-striae, nearly smooth, nearly straight, but slightly convex in the upper part, slightly concave near the lower suture, the whorls are prominently keeled above the suture, the keel being finely crenulate. Base a little convex, excavated towards the peripheral keel, with three fine spirals at some distance from the periphery and a few, scarcely 
visible ones towards the central part, moreover with numerous very fine curved growth-striae. Umbilicus moderately large, pervious, scalar, with a rib at its margin and a groove just around this rib. Aperture subtriangular, its margins broken, upper one convex, basal one nearly straight, columellar margin short, excavated, angular below by the end of the umbilical rib.

Alt. $2^{1} / 2$, lat. 5 ; apert. alt. I, lat. $1^{3 / 4}$ Mill.

Resembling the former species by its umbilicus and other general characters, but quite different in many particulars.

\section{Fam. Torinimae.}

\section{Torinia Gray.}

I. Torinia planulata Hanley.

Hanley. Thes. Conch. Vol. III, p. 238, fig. 77 .

Tryon. Man. of Conch. Vol. IX, p. 17, Pl. 5, fig. 77.

Stat. 47. Bay of Bima. 55 M. Mud with patches of fine coralsand. I Spec.

Stat. 99. North-Ubian, Sulu-archipelago. 16-23 M. Lithothamnion-bottom. I Spec.

2. Torinia dorsuosa Hinds.

HINDS. Proc. Zool. Soc. Lond. I844; p. 23.

Philippi. Martini-Chemn. Conch. Cab. Ed. II, Vol. II, Solarium, p. 37.

Tryon. Man. of Conch. Vol. IX, p. 17, Pl. 5, fig. So, 81 .

Stat. 258. Tual, Kei-islands. 22 M. Lithothamnion, saind and coral. I Spec.

Stat. 313. East of Dangar Besar, Saleh-bay. Up to $36 \mathrm{M}$. Sand, coral and mud. 3 spec.

The specimen from Stat. 258 differs from the type, by a third liration at the periphery and finer sculpture of the base; as the only specimen is not yet adult and the sculpture is also variable in the typical, specimens, I have provisionally considered it as a variety or individual aberration. From T. cerdaleum Melv. (Ann. and Mag. Nat. Hist. Ser. 7, Vol. XII, I903, p. 297 , P1. 20, fig. 16) which is also tricarinate, it differs by its wide umbilicus, the structure of the columella etc.

3. Torinia costata n. sp. Pl. XIV, fig. 5 .

Stat. 279. Rumah-Kuda-bay, Roma-island. 36 M. Mud and sand. 2 Spec.

Shell discoidally-depressed, deeply umbilicate, thin, yellowish-brown. Nucleus umbilicate, reddish-brown, smooth, consisting of at least 2 whorls. Subsequent whorls 3 , upper surface nearly flat, with a cord at the upper and lower suture, bordered by a groove; the intermediate zone is yellowish-brown, sculptured by oblique ribs and fine spiral striae in the interstices of the ribs; the cords are crenulate and spotted with white, 2 or 3 white crenules alternating with an equal number. of brown ones. Whorls separated by a conspicuous canal, in which the linear suture is to be seen, canal ribbed in the same manner as the upper surface. Last whorl biangular 
by two cords, the upper one bordering the canal of the upper whorls, the lower cord is of the same construction as the other one, and the interstice is likewise ribbed, base slightly convex, with 5 strongly crenulate spirals, except the peripheral one and placed at some distance from the latter, being separated by a rather-broad, concave, ribbed space, the innermost cord borders the large, pervious, funnel-shaped umbilicus; the base is more or less variegated with white. Aperture subquadrangular, canaliculate where the cords end; columellar margin with a groove in its upper part.

Alt. $3^{1 / 2}$, lat. 9 ; apert. alt. $2^{1} / 2$, lat. $2^{1} / 2$ Mill.

This species is allied to $T$. dorsuosa, but may imnediately be distinguished by the ribbed upper surface.

4. Torinia trochoides Deshayes.

Deshayes. Encycl. Meth. Vol. II, p. 160.

Philippi. Martini-Chemn. Conch. Cab. Ed. II, Vol. II, Solarium, p. 19, Pl. 3, fig. 7 (dealbata). Tryon. Man. of Conch. Vol. IX, p. I8, Pl. 5, fig. 87, 88.

Stat. 215. North point of Kabia-island. Reef. 701 M. Stone. I Spec.

The specimen is larger than the quoted figures, its altitude is 14 Mill., its diameter 13. TrYoN says: "Alt. 20 mill.", but his figure is only 13 Mill. high.

5. Torinia madurensis n. sp. Pl. XIV, fig. 4 .

Stat. 51. Madura-bay. 69-91 M. Fine grey sand, coralsand with shells. I Spec.

Shell small, depressedly conic, white, with traces of a brownish epidermis, nucleus glossy, brown, postnuclear whorls $3^{1 / 2}$, slightly convex, nearly angular a little above the suture, by the prominence of one of the spirals, of which there are 6 on the penultimate whorl, these spirals are separated by narrow, shallow grooves and crossed by oblique striae or grooves, which render the spirals crenulate, moreover finer spiral striae, more clearly visible in the interstices, and fine growth-striae cross each other. The fifth of the spirals, counted from above is the most prominent one. Base moderately convex, with 9 spirals, of which the infraperipheral 2 are prominent; those standing on the basal surface are broader and flat, the innermost is coarsely crenulate. Umbilicus pervious, funnel-shaped. Aperture subcircular, its columellar margin expanded and slightly reflected over the umbilicus.

Alt. $4^{3} / 4$, lat. 6 ; apert. alt. $2^{1} / 2$, lat. $2^{1} / 2$ Mill.

This shell is allied to the preceding species, but it is smaller, broader and has the whorls more conspicuously separated.

6. Torinia mirabilis n. sp. Pl. XIV, fig. 6.

Stat. 212. $5^{\circ} 54^{\prime} .5$ S., $120^{\circ} 19^{\prime} .2$ E. Banda Sea. 462 M. Fine grey and green mud. I Spec.

Shell discoidally depressed, acutely carinated, widely umbilicated, thin, yellowish-brown. Nucleus umbilicate, smooth, postnuclear whorls 4, forming a convex upper surface of shell; 
each whorl flat above, connected by a slightly channelled suture. Sculpture consisting of spiral lirae, $\delta$ in number on the last whorls; the infrasutural, the fifth and seventh spirals are more prominent and stronger than the rest; these lirae are crossed by very fine growth-striae and by moderately fine ribs, rendering the lirae crenulate in crossing them, the fifth is even tuberculiferous in some parts; periphery strongly keeled; keel wavy or denticulate by distant short spines, the spaces between them crenulate; keel flat above, concave below, the rest of base convex untill the umbilicus; base inclusive of the under surface of the keel, sculptured by fine spiral lirae of which the innermost 4 are stronger and granular, especially the spiral bordering the umbilicus, which is tuberculate, the whole base is crossed by radiating striae rendering even the finer lirae crenulate. Umbilicus very large, occupying more than half the diameter, open, leaving the volutions visible, each whorl has a row of large granules along the lower suture and 2 a 3 finer ones crossed by radiating striae. Aperture much broken, probably circular, containing the characteristic operculum.

Alt. 3, lat. $9^{1 / 1}$, lat. of umbil. $4^{3} / 4$ Mill.

This remarkable mollusk, which is not allied to any species I know, was unfortunately considerably damaged, especially at its basal surface, in consequence I could not make out shape and size of the aperture. It probably deserves a subgeneric name, but it being so incomplete, I have provisionally left it in company with the other typical species.

\section{Section Ptenoglossa. \\ Fam. Scalidae.}

\section{Scala Klein.}

\section{Scala Pallasii Kiener.}

Kienet. Coq. Viv. Vol. IX, Scalaria, p. 4, Pl. 2, fig. 3.

REeve. Conch. Ic. Vol. XIX, Scalaria, fig. 40.

Tryon. Man. of Conch. Vol. IX, p. 54, Pl. II, fig. 33.

Clessin. Martini-Chemn. Conch. Cab. Ed. II, Vol. II, Scalaria, p. 59, Pl. I6, fig. 2.

Stat. 248. Rumah Lusi, North point of Tiur-island. Till 54 M. I Spec.

The only specimen is fine but not adult.

\section{Scala alata Sowerby.}

Sowerby. Proc. Zool. Soc. Lond. i 844 , p. Io.

REEve. Conch. Ic. Vol. XIX, Scalaria, fig. 15.

Tryon. Man. of Conch. Vol. IX, p. 55, Pl. II, fig. 40.

Clessin. Martini-Chemn. Conch. Cab. Ed. II, Vol. II, Scalaria, p. 20, Pl. 3, fig. 5.

Stat. 2. Madura-strait. 56 M. Grey mud. I Spec.

Stat. I 16. West of Kwandang-bay-entrance. 72 M. Fine sand with mud. 3 Spec.

The specimens from Stat. I 6 are quite white, perhaps bleached. The whole party is young. 
3. Scala replicata Sowerby.

Sotverby. Proc. Zool. Soc. Lond. I 844, p. I I.

REEvE. Conch. Ic. Vol. XIX, Scalaria, fig. 39.

Tryon. Man, of Conch. Vol. IX, p. 56, P1... I , fig. 43.

Clesssin. Martini-Chemn. Conch. Cab. Ed. II, Vol. II, Scalaria, p. 4, Pl. 2, fig. 2.

Stat. I09. Pulu Tongkil, Sulu-archipelago. I3 M. Lithothamnion-bottom. I Spec.

Stat. I 59. $0^{\circ} 59^{\prime} .1$ S., $129^{\circ} 48^{\prime} .8$ E. Halmahera Sea. 4 I I M. Coarse sand. 2 Spec.

Stat. $3^{\mathrm{I}} 3$. Dangar Besar, Saleh-bay. Up to $36 \mathrm{M}$. Sand, coral and mud. I Spec.

The specimen from Stat. Iog is nearly too bad for identification, but has much resemblance with those from Stat. I59, which are however also broken and dead; this may account for the exceptional great depth.

\section{Scala tenuicostata Sowerby.}

Sowerby. Thes. Conch. Vol. I, Pl. 34, fig. 76.

ReEve. Conch. Ic. Vol. XIX, Scalaria, fig. 3 I.

TRYon. Man. of Conch. Vol. IX, p. 56, Pl. i i, fig. 44.

Clessin. Martini-Chemn. Conch. Cab. Ed. II, Vol. II, Scalaria, p. IO, Pl. 3, fig. 8.

Stat. 51. Madura-bay. 69-91 M. Fine grey sand. I Spec.

\section{Scala deifica Melvill.}

Melvill. Journ. of Conchology. Vol. X, p. 343, Pl. 7, fig. 4 .

Stat. 59. Western entrance, Samau-strait. 390 M. Coarse coralsand with small stones. I Spec.

Though the specimen seems not to be adult, as it has only a length of $81 / 2$ Mill. instead of II, and at least one whorl less than the described type, it is a very beautiful shell and no doubt identical, as Mr. Melvill had the kindness to compare it with his type.

\section{Scala lyra Sowerby.}

Sowerby. Proc. Ziool. Soc. Lond. is44, p. i3.

REEve. Conch. Ic. Vol. XIX, Scalaria, fig. 23 .

Tryon. Man. of Conch. Vol. IX, p. 59, Pl. i2, fig. 69.

Clessin. Martini-Chemn. Conch. Cab. Ed. II, Vol. II, Scalaria, p. 22, Pl. 6, fig. 4 .

Stat. $95.5^{\circ} 48^{\prime} .7$ N., $119^{\circ} 49^{\prime} .62$ E. Sulu Sea. 522 M. Stony bottom. I Spec.

The only specimen which was very young and already broken, unfortunately has been smashed to pieces in extracting the cork from the tube containing the shell.

7. Scala Tydemani n. sp. Pl. XV, fig. I.

Stat. 3 I5. Sailus Besar, Paternoster-islands. Up to $36 \mathrm{M}$. Coral and Lithothamnion. I Spec.

Shell rather small, pyramidal, with a very narrow umbilicus, thin, flesh-coloured, with. violaceous upper whorls. Whorls 6 , nucleus wanting, these whorls are very convex, nearly 
smooth, with only a few irregular impressed striae, suture very deep; the whole shell is crossed by white ribs, the majority of which is rather thin, slightly lamellose towards the upper part of each whorl, but forming no spines; under a strong lens the ribs are finely crenulate at their anterior side; a few of the ribs are stronger, forming varices at irregular intervals, one bordering the aperture, but also the preceding rib is thickened; the number of ribs is 29 on the last whorl. Aperture oval, with a thick, continuous, white lip, slightly reflected over, but not closing the umbilicus. Interior of aperture flesh-coloured, white towards the margin.

Alt. $8^{3} / 4^{\text {, lat. } 4^{1} / 4}$; apert. alt. 3 , lat. $2^{1 / 5}$ Mill.

This fine species may be allied to $S$. clcmentina Grat., and bulbulus Sow. but is more elongate and easily recognized by its violaceous colour.

8. Scala fragilissima n. sp. Pl. XV, fig. 3 .

Stat. 178 . $2^{\circ} 40^{\prime}$ S., $128^{\circ} 37^{\prime} .5$ E. Ceram Sea. 835 II. Blue mud. 2 Spec.

Shell subperforate, pyramidal, very thin, transparent, yellowish-white, nucleus wanting, remaining whorls probably 7 or 8 (both specimens incomplete), very convex, obtusely angular a little above the periphery, with a very deep suture; sculpture consisting of spiral ribs, about 15 in number on the penultimate whorl, and thin, undulating ribs, crossing the spirals and giving a cancellated appearance to the shell; these radiating ribs are, if well preserved, delicately spinose at the upper part and their crest as well as the whole rib is undulated, these undulations corresponding to the spiral ribs; the ribs are subequal, becoming only a little stronger with age, their number is about 23 on the last whorl, which is slightly angular, but has no basal rib. Aperture incomplete, probably nearly circular, only faintly angular above, its right margin thin (young?), its columellar margin slightly reflected over and nearly covering the umbilicus, which in the largest specimen is still circumscribed by a thin rim.

Alt. (of largest specimen) $9^{7} / 8$, lat. $3^{3} / 4$; apert. lat. 2 Mill.

Though the specimens are rather incomplete, I think they are characteristic enough, to deserve a name and description; they resemble in shape S. formosissima, from the Azores, but have still much more convex whorls and much finer and more elaborate sculpture; in this respect they resemble $S$. undulatissima Sow., but that species is only very minutely spirally striate and much broader in proportion to its length.

\section{Scala (Clathrus) pulcherrima Sowerby.}

Sowerby. Proc. Zool. Soc. Lond. IS44.

ReEve. Conch. Ic. Vol. XIX, Scalaria, fig. 67 (Spec. 68).

Tryon. Man. of Conch. Vol. IX, p. 68, P1. 14, fig. 32.

Clessin. Martini-Chemn. Conch. Cab. Ed. II, Vol. II, Scalaria, p. 34, Pl. I0, fig. 1 I (figured as catanuensis).

Stat. 51. Madura-bay. 69-9 I M. Fine grey sand, coarse sand with shells and stones. I Spec.

As stated by TRYon, the figure and description of ReEve don't correspond; the figures of S. pulcherrima and $S$. catanuensis having been changed on the plate. CLEssin, whose 
monograph seems to be in most instances a bad copy and translation of that of REEve, has overlooked that mistake.

10. Scala abyssicoli n. sp. Pl. XV, fig. 2.

Stat. $45 \cdot 7^{\circ} 24$ S., I $S^{\circ} 15^{\prime} \cdot 2$ E. Flores Sea. 794 M. Fine grey mud. 2 Spec.

Shell subperforate, pyramidal, thin, whitish; nucleus wanting, remaining whorls 8 , very convex, obtusely angular at the shoulder, slightly disunited, nearly smooth, but with a few remote spiral striae and fine growth-striae; the whorls" are crossed by thin, slightly reflected ribs, I 8 in number on the last whorl; these ribs are spinous at the shoulder, their margin is serrulate (these serrulations may be natural or caused by friction) they are practically equal, none of them being varix-like; base of shell regularly rounded. Aperture circular, right margin thin (young?) its columellar margin broadly reflected over the perforation and quite covering, but probably not closing it.

Alt. $14^{1} / 2$, lat. 5 Mill.; aperture of a specimen long $9^{1 / 2}$ Mill., ${ }^{1} / 2$ Mill.

This species resembles in shape the preceding one, but it is quite.different by its nearly smooth interstices of the ribs, which are themselves more simple, being undulate in S. fragilissima.

I . Scala (Clathrus) Mclvilli n. sp. Pl. XIV, fig. 9.

Stat. 114. Kwandang-bay-entrance. 75 M. Hard sand, very fine. 1 Spec.

Shell pyramidal, imperforate, very thin, transparent, white. Whorls 9, of which 3 smooth nuclear ones. Postnuclear whorls very convex, slightly shouldered, with a very deep suture; upper and basal part of each whorl smooth, median part with 3 thin spiral ribs in the interstices of the radiating ribs, which are thin, lamellose, flexuous, with an auricle at the suture and another at the shoulder, moreover an undulation at the peripheral part, and a second one near the base of each whorl; in the upper whorls the ribs are more simple. Aperture circular, with a broadly expanded margin, formed by the last rib, of which there are 15 on the last whorl; columellar margin narrowly reflected, accompanied at the place of the umbilicus by a lamellose rim.

Alt. $5^{4} / 7$, lat. $2^{7} / 8$; apert. $1^{3} / 4$ Mill. in diameter.

This species resembles S. malcolmonsis Melvill (Memoirs and Proc. Manch. Lit. and Phil. Soc. Vol. 42, I 898 , p. 20, Pl. 7 , fig. 2), but the ribs of the new species are much more elaborate, being flexuous.

12. Scala (Opalia) lamellosa Lamarck.

LAMarck. An. s. vert. Ed. II, Vol. XIX, p. 73.

Kiener. Coq. Viv. Vol. IX, Scalaria, p. 10, Pl. 3, fig. 7 .

Tryon. Man. of Conch. Vol. IX, p. 74, Pl. 15, fig. $8_{3}, 84,77$.

Stat. I r6. West of Kwandang-bay-entrance. 72 M. Fine sand with mud. I Spec.

Stat. 152. Wunoh-bay, N. W. coast of Waigeu-island. 32 M. Lithothamnion-bottom. I Spec.

Perhaps the name perplexa Pse. would be the most fitting one for this shell, as really 
it is very perplexing to see how the opinion of authors differs in the appreciation of the limits of the species or varieties more or less allied to S. lamellosa. I have followed Messrs. Melvill and Standen (Proc. Zool. Soc. Lond. igoi, p. 356), who have made use of the familiar name lamellosa, Mr. Melvill being in 1903 still of the same opinion (Journ. of Conch. Vol. Io, p. 348).

\section{3. Scala (Opalia) sp.?}

Stat. $45 \cdot 7^{\circ} 24^{\prime}$ S., $118^{\circ} 15^{\prime} .2$ E. Flores Sea. 794 M. Fine grey mud. I Spec.

This species may be new, but it is though large (nearly 20 Mill. in length), too much worn, with broken aperture, consequently not recognizable, so I thought it better not to describe a species, without a knowledge of the true colour, of sculpture and aperture.

14. Scala (Opalia) humerosa n. sp. Pl. XIV, fig. 7.

Stat. 24 1. $2^{\circ} 24^{\prime} \cdot 3$ S., $129^{\circ} 49^{\prime} \cdot 3$ E. Banda Sea. 1570 M. Dark sand with small stones. I Spec.

Shell elongately pyramidal, imperforate, moderately thin, white; nucleus wanting; remaining whorls I I, convex, slightly contracted below the deep suture, there shouldered or angular; sculpture consisting of low spiral ridges, about $\mathrm{I}_{3}$ on last whorl, of which the basal one forms the rib characteristic for the subgenus, a small space above that rib and a larger one below the suture are free of ridges; the whorls are crossed by strong ribs, 13 in number on the last whorl, not quite reaching the upper suture; these ribs are angular at the shoulder and less so below, they are crossed by the ridges, which are however less sharp on the ribs, perhaps on account of friction; the interstices have fine, hairlike, elevated striae, which are also present on the sides of the ribs. Base with traces of ridges and with the hairlike striae, but in a much fainter degree. Aperture subcircular, slightly angular above, below and fainter at the end of the shoulder and of the basal rib. Columellar margin reflected over the umbilical region, outer margin thin (juvenile?).

Alt. I 5 , lat. $4^{1 / 6}$; apert. alt. $2^{1 /}$, lat. 2 Mill.

I know no described species of Opalia, to which this new form is allied.

i 5. Scala (Opalia) Sibogae n. sp. Pl. XIV, fig. 8.

Stat. $159.0^{\circ} 59^{\prime} .1$ S., $129^{\circ} 48^{\prime} .8$ E. Halmahera Sea. 41 I M. Coarse sand. I Spec.

Shell elongately pyramidal, imperforate, solid, corneous; nucleus wanting; remaining whorls $10^{1} / 2$, convex, with a deep suture, slightly shouldered; sculpture consisting of 3 strong spiral ridges and a few spiral striae in the interstices, crossed by strong ribs, I 2 on last whorl, angular above, when the upper spiral crosses the ribs, being slightly nodulous by the intercrossing of the strong spirals; some of the ribs have the appearance of varices, a.o. that next the aperture; last whorl with 4 spirals, of which one is the usual basal one; base with a few very faint spirals; the whole shell, especially the base is covered with very fine growth-striae. Aperture 
oval, slightly angular above, right margin slightly broken, probably varicose in the adult shell; columellar margin thickened below, reflected over the umbilical region.

Alt. 11 , lat. $3^{3} / 5$; apert. alt: 2 , lat. $\mathrm{r}^{1} / 2$ Mill.

This species has superficial resemblance with the preceding one, but has a much coarser sculpture and is much less shouldered.

\section{Scala (Opalia) Nicrstraszi n. sp.}

Stat. I 59. $0^{\circ} 59^{\prime} .1$ S., $129^{\circ} 48^{\prime} .8$ E. Halmahera Sea. 4 I I M. Coarse sand. I Spec.

Shell small, pyramidal, imperforate, solid, white; nucleus wanting; remaining whorls $7^{1} / 2$, moderately convex, with a distinct but no deep suture; sculpture consisting of impressed spiral striae and fine radiating ones over the whole surface, if not rubbed of; ribs strong, thick, incised by the spiral striae, ten on last whorl; the last very thick rib bordering the aperture. Basal rib of last whorl strong; base slightly excavated, sculptured with faint spiral striae, crossed by the growth-striae. Aperture circular with a nearly smooth, rather thick internal lip, bordered on the right and part of basal margin, by a broadly expanded flat varix, with the same sculpture of the outer surface of shell.

Alt. $6^{1} / 2$, lat. incl. perist. $3^{1} / 4$; diam. of apert. $\mathrm{I}^{1 / 6}$ Mill.

I know no species allied to this beautifully sculptured shell.

\section{Scala (Cirsotrema) sp.}

Stat. $153.0^{\circ} 3^{\prime} .8$ N., $130^{\circ} 22^{\prime} \cdot 3$ E. North off Waigeu-island. 14 I M. Fine and coarse sand with dead shells. 2 Spec.

Both specimens are young, they have some resemblance with the upper whorls of $S$. Kieneri Tap. Can. but are different in their sculpture, which is very fine; as even the apertures are incomplete, I have abstained myself from naming and describing them, though they probably belong to a new species. 


\section{SUPPLEMENT.}

Some sheets of the second part of this publication had been printed, when I received a box of shells, found amongst corals of the "Siboga" materials; though this box contained only common species, there were a few not yet enumerated in the first two parts on Gastropoda. I have mentioned them in this supplementary note, and added a few localities of species already dealed with, but I have omitted to mention such cases, when I found one or a few specimens of species recorded in the bulk of the work, from the same localities.

\section{PART I.}

pag. 23. To $\mathrm{N}^{0}$ I, Turbo petholatzs Lin. add:

Stat. 234. Nalahia-bay, Nusa-Laut-island. Reef. 2 adult Śpec.

\section{PART II.}

pag. I Io (2). To $\mathrm{N}^{0}$ 1, Aquillus pilearis Lin. add:

Stat. 193. Sanana-bay, East coast of Sula Besi. Reef. 2 Spec.

Stat. 234. Nalahia, Nusa-Laut-island. Reef. 2 Spec.

pag. I I I (3). To $\mathrm{N}^{0} 3$, Aquillus mubecula Lin. add:

Stat. 234. Nalahia-bay, Nusa-Laut-island. Reef. 3 Spec.

after sp. 4 add:

4a. Aquillus (Lampusia) lotorius Linné.

Linné. Syst. Nat. Ed. X, p. $749, \mathrm{~N}^{0} 457$.

RUMPH. Amb. Rariteitkamer, p. 85, Pl. 26, fig. B.

Kiener. Coq. Viv. Vol. VI, Triton, p. II, Pl. 9, fig. 1.

ReEve. Conch. Ic. Vol. II, Triton, fig. 9.

Stat. 234. Nalahia-bay, Nusa-Laut-island. Reef. 1 Spec.

pag. I 19 (I I). To $\mathrm{N}^{0} 9$, Bursa granifera Lam. add:

Stat. 193. Sanana-bay, East coast of Sula Besi. Reef. I Spec.

I 2 I

SIBOGA-EXPEDITIE XLIX1 $1 b$. 
pag. I 2 I ( 13 ) before $\mathrm{N}^{0} \mathrm{I}$, add:

Cassis rufa Linné.

LinNÉ. Syst. Nat. Ed. X, p. $736, \mathrm{~N}^{0} 385$.

Runph. Amb. Rariteitkamer, p. So, Pl. 23, fig. B, C.

Kiener. Coq. Viv. Vol. VII, Cassis, p. I5, Pl. 7, fig. I 2, I3.

ReEve. Conch. Ic. Vol. V, Cassis, fig. 20.

Stat. 234. Nalahia-bay, Nusa-Laut-island. Reef. I Spec.

pag. 122 (14). To $\mathrm{N}^{0} 4$, Cassis vibex Lin. add:

Stat. 193. Sanana-bay, East coast of Sula Besi. Reef. I Spec.

pag. 123 (15). To var. erinacea Lin. add:

Stat. 234. Nalahia-bay, Nusa-Laut-island. Reef. I Spec.

To $\mathrm{N}^{0} 5$, Cassis torquata Reeve, add:

Stat. 313. East of Dangar Besar, Saleh-bay. Up to $3^{6}$ M. Sand, coral and mud. I Spec.

pag. 125 (17). To $\mathrm{N}^{0}$ 1, Dolizm olearizm Brug. add:

Stat. 193. Sanana-bay, Eảst coast of Sula Besi. Reef. I Spec.

after $\mathrm{N}^{0}$ 3. Dolizm fasciatum Brug. add:

3a. Dolizum perdix Linné.

LinNe. Syst. Nat. Ed. X, p. 734, $\mathrm{N}^{0} 37 \mathrm{~S}$.

Runpi. Amb. Rariteitkamer, p. 90, Pl. 27, fig. C.

Kiener. Coq. Viv. Vol. VII, Dolium, p. 4, Pl. 5, fig. 9.

Reeve. Conch. Ic. Vol. V, Dolium, fig. 9 .

Stat. 193. Sanana-bay, East coast of Sula Besi. Reef. I Spec.

Stat. 225. South point of South Lucipara-island. Reef. I Spec.

pag. 126 (I S). To $\mathrm{N}^{0}$ 4. Dolizm pomum Lin. add:

Stat. 193. Sanana-bay, East coast of Sula Besi. Reef. I Spec.

after Cypraea Lin. add:

Cypraca scarra Chemnitz.

Chemnitz. Conch. Cab. Ed. I, Vol. X, p. 103, Pl. I44, fig. 1338.

Kiener. Coq. Viv. Vol. I, p. 107, Pl. 5, fig. 2; Pl. 50, fig. I.

Reeve. Conch. Ic. Vol. III, Cypraea, fig. 45.

Weinkauff. Martini-Chemn. Conch. Cab. Ed. II, Vol. V, Cypraea, p. I9, Pl. 4, fig. 8, 9;

Pl. 6 , fig. 3,4 .

Trion. Man. of Conch. Vol. VII, p. 165, Pl. 2, fig. 19-21.

Stat. 96. South-east side of Pearl-bank, Sulu-archipelago. I 5 M. Lithothamnion-bottom. i Spec. 
pag. I 27 ( I 9). To $\mathrm{N}^{0}$ 2. Cypraea carneola Lin. add:

Stat. 234. Nalahia-bay, Nusa-Laut-island. Reef. 2 Spec.

To $\mathrm{N}^{0}$ 3. Cypraea talpa Lin. add:

Stat. 234. Nalahia-bay, Nusa-Laut-island. Reef. 2 Spec.

pag. I $2 S$ (20) after $\mathrm{N}^{0}$ 9. Cypraea caurica Lin. add:

9a. Cypraca cruenta Gmelin.

Garlin. Syst. Nat. Ed. XIII, p. 3420.

Rumph. Amb. Rariteitkamer, p. I I5, Pl. 38 , fig. O.

Kiener. Coq: Viv. Vol. I, p. 157, PI. 27, fig. 2 (variolaria).

ReEve. Conch. Ic. Vol. III, Cypraea, fig. 38 .

Weinkauff. Martini-Chemn. Conch. Cab. Ed. II, Vol. V, Cypraea, p. 35, Pl. Io, fig. 9-12 (variolaria).

Stat. 234. Nalahia-bay, Nusa-Laut-island. Reef. I Spec.

96. Cypraea mauritiana Linné.

Linné. Syst. Nat. Ed. X, p. 72 I, N0 299.

Ruмph. Amb. Rariteitkamer, p. I 14, Pl. 38 , fig. E.

Kiener. Coq. Viv. Vol. I, p. I03, Pl. 39, fig. I; Pl. 40, fig. I; Pl. 47, fig. I.

Reeve. Conch. Ic. Vol. III, Cypraea, fig. I.

Weinkauff. Martini-Chemn. Conch. Cab. Ed. II, Vol. V, Cypraea, Pl. 6, fig. 7-9, Pl. 21, fig. $2,6,7$.

Stat. 234. Nalahia-bay, Nusa-Laut-island. Reef. I Spec.

pag. I 3 I (23). To $\mathrm{N}^{\mathrm{I}}$ 14. Cypraen tigris Lin. add:

Stat. 313. East of Dangar Besar, Saleh-bay. Up to 36 M. Sand, coral and mud. I Spec.

To $\mathrm{N}^{0}$ I 5 . Cypraea vitellus Lin. add:

Stat. 234. Nalahia-bay, Nusa-Laut-island. Reef. 2 Spec.

To $\mathrm{N}^{0}$ I 6 . Cypraea lynx Lin. add:

Stat. 193. Sanana-bay, East coast of Sula Besi. Reef. I Spec.

Stat. 234. Nalahia-bay, Nusa-Laut-island. Reef. 2 Spec. 




\section{PLATE X.}

Fig. I $a, b$. Gyrineum perca Perry, var. aculeata n. var. c. larger specimen.

Fig. 2. Oocorys Weberi n. sp.

Fig. 3. Oocorys elongata 11. sp.

Fig. 4. Morio granulata n. sp.

Fig. 5. Morio lineata n. sp.

Fig. 6. Morio Alcocki Smith. 

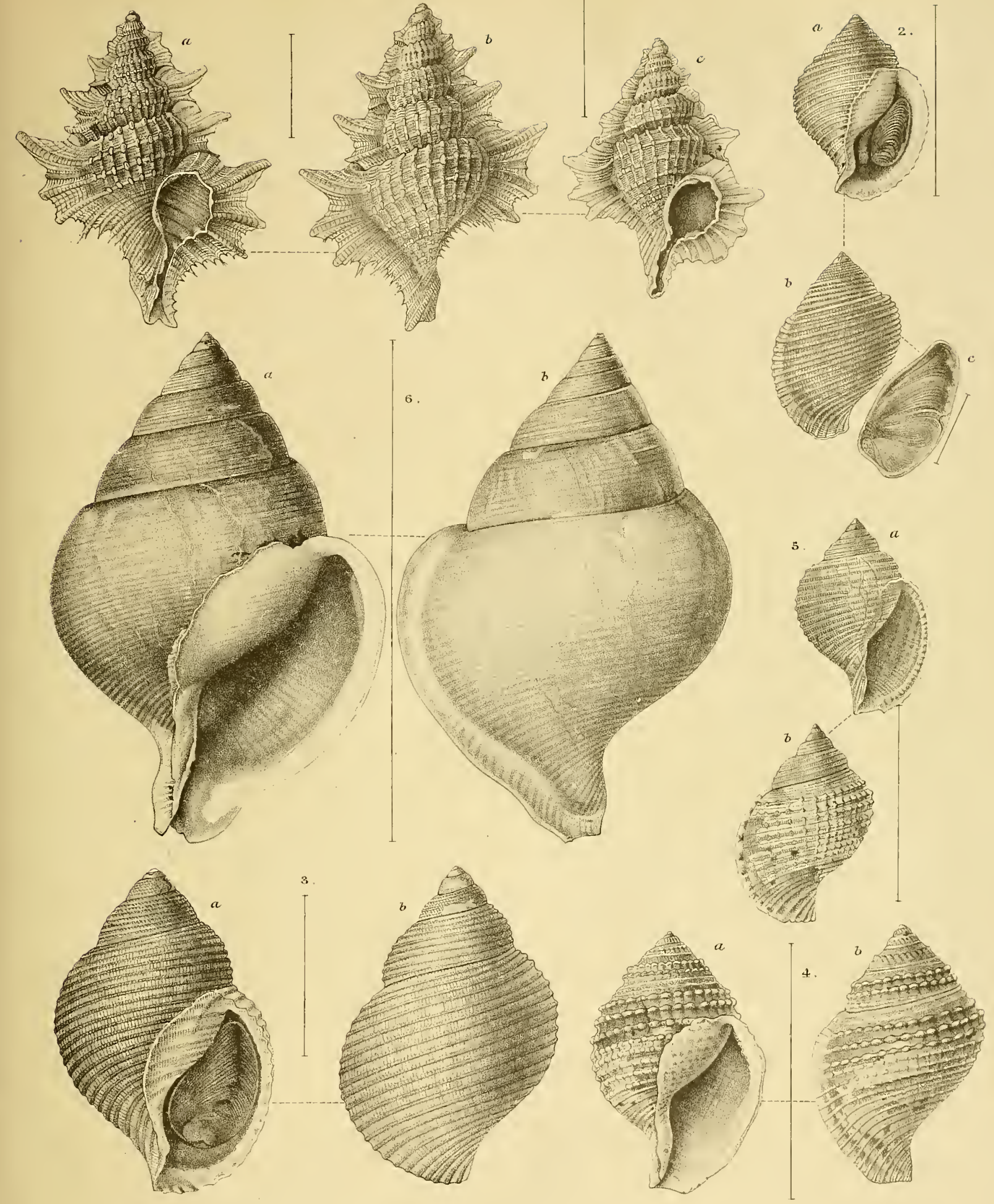

C. Dumont del.

Fa. P. W, M. Trap impr. 



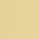




\section{PLATE XI.}

Fig. I. Trivia abyssicola n. sp.

Fig. 2. Trivia paucicostata n. sp.

Fig. 3. Trivia sibogae n. sp.

Fig. 4. Trivia sibogae forma minor.

Fig. 5. Rostellaria Porvisii Recl., var. abyssicola n. var.

Fig. 6. Cerithinm Tydemani n. sp. c. Sculpture.

Fig. 7. Cerithiopsis Vershuysi n. sp.

Fig. 8. Triphora Versluysi n. sp. c. Sculpture.

Fig. 9. Triphora Schnidti n. sp. c. Sculpture.

Fig. 10. Amphiperas roscomaculatum n. sp.

Fig. I I. Turritella maculata Reeve, var. ornata n. var. 

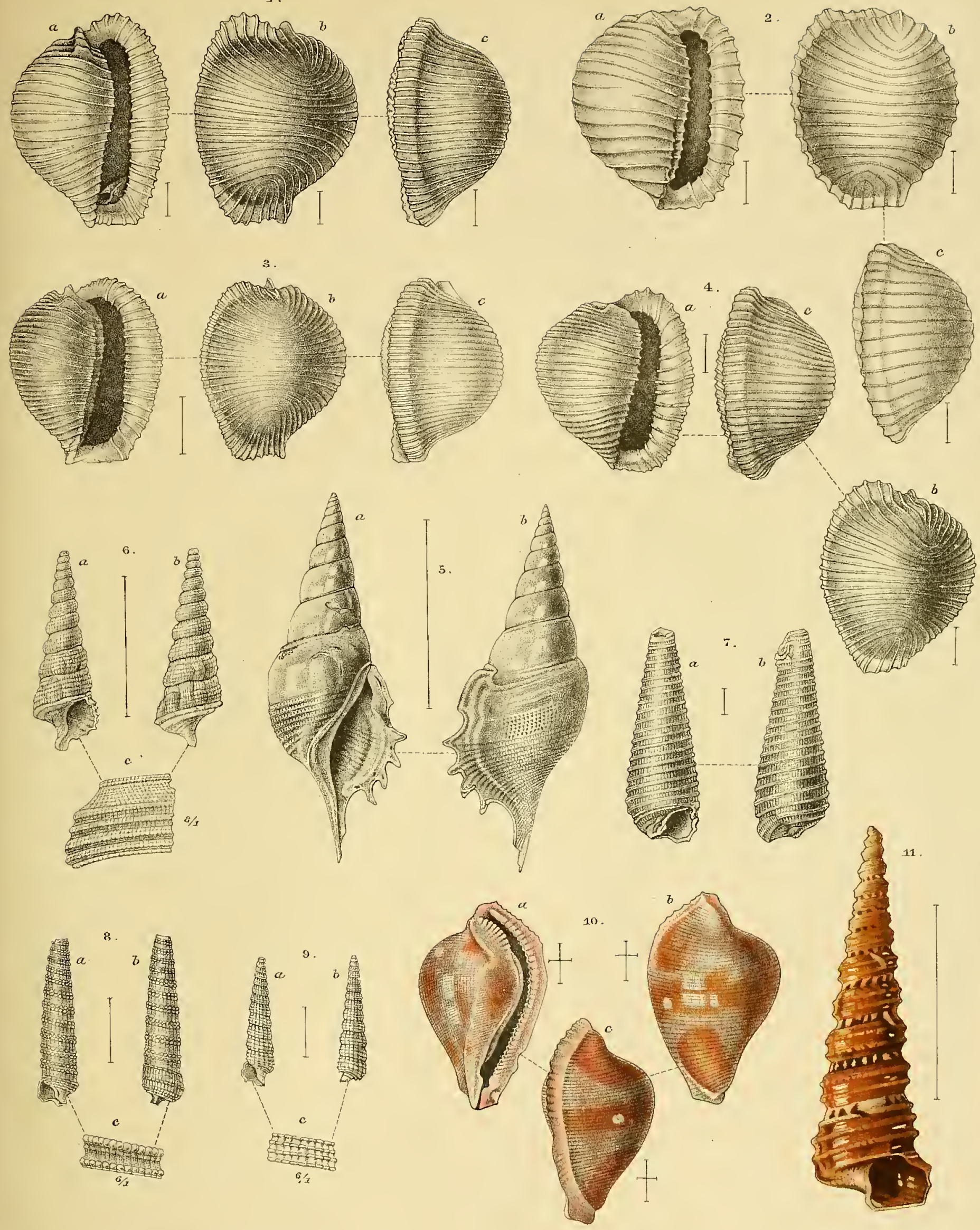

Fig. $1-5$, 10, II, C. Dumont, fig. $6-9$ de Granf def.

Fa. P. W, M. Trap impr. 



\section{PLATE XII.}

Fig. 1. Argyropeza Melvilli n. sp.

Fig. 2. Trichotropis orientalis n. $\mathrm{sp}$.

Fig. 3. Probably belongs to Trichotropidae.

Fig. 4. Seguenzia Melvilli n. sp.

Fig. 5. Seguenzia Dautzenbergi n. sp.

Fig. 6. Seguenzia Sykesi n. sp.

Fig. 7. Seguenzia costulifera $\mathrm{n}$. sp.

Fig. S. Melania salibabuensis n. sp. a. large, b. smaller specimen.

Fig. 9. Rissoa kwandangensis n. sp.

Fig. 10. Cyclotus kangeanus n. sp. $a$. light-coloured, $b-d$. darker specimen.

Fig. II. Mitrularia costifera n. sp. 

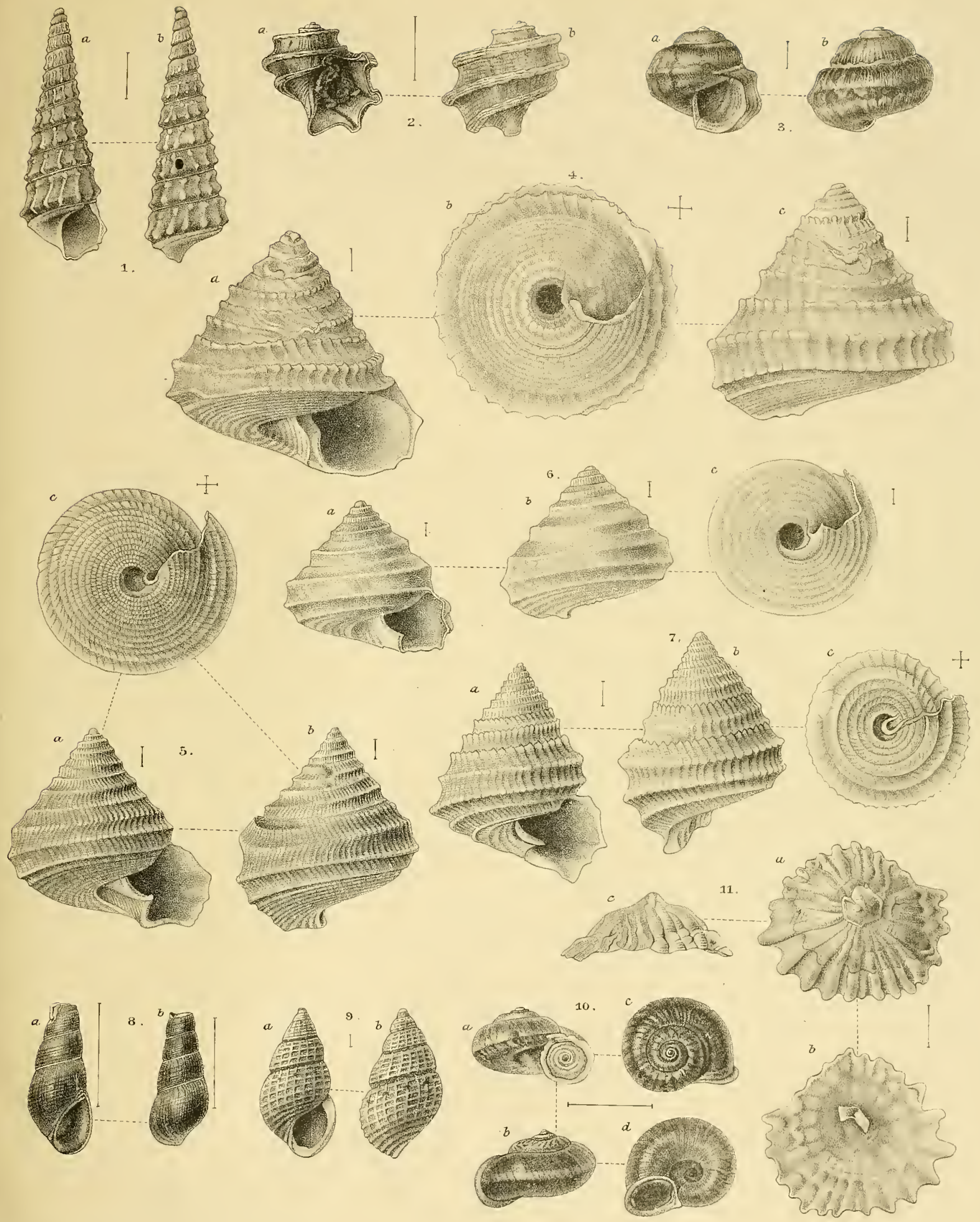

Fis. $1-3 ; 8$, 10 cle Graaf; $4-7,9$, 1 I Dumont del.

Fa P. W. M. Trap impr. 




\section{PLATE XIII.}

Fig. 1. Xenophora gigantea n. sp. a. lateral view (oblique), $d$. operculum.

Fig. 2. Natica nebulosa n. sp.

Fig. 3. Natica crassa n. sp.

Fig. 4. Natica supraornata n. sp.

Fig. 5. Natica faba n. sp. 




\section{PLATE XIV.}

Fig. I. Natica simplex n. sp.

Fig. 2. Fluxina marginata n. sp. a. c. small, b. large specimen.

Fig. 3. Fluxina trochiformis n. sp.

Fig. 4. Torinia madurensis n. sp.

Fig. 5. Torinia costata n. sp.

Fig. 6. Torinia mirabilis n. sp.

Fig. 7. Scala hutnerosa n. sp.

Fig. 8. Scala sibogae n. sp.

Fig. 9. Scala Melvilli n. sp. 

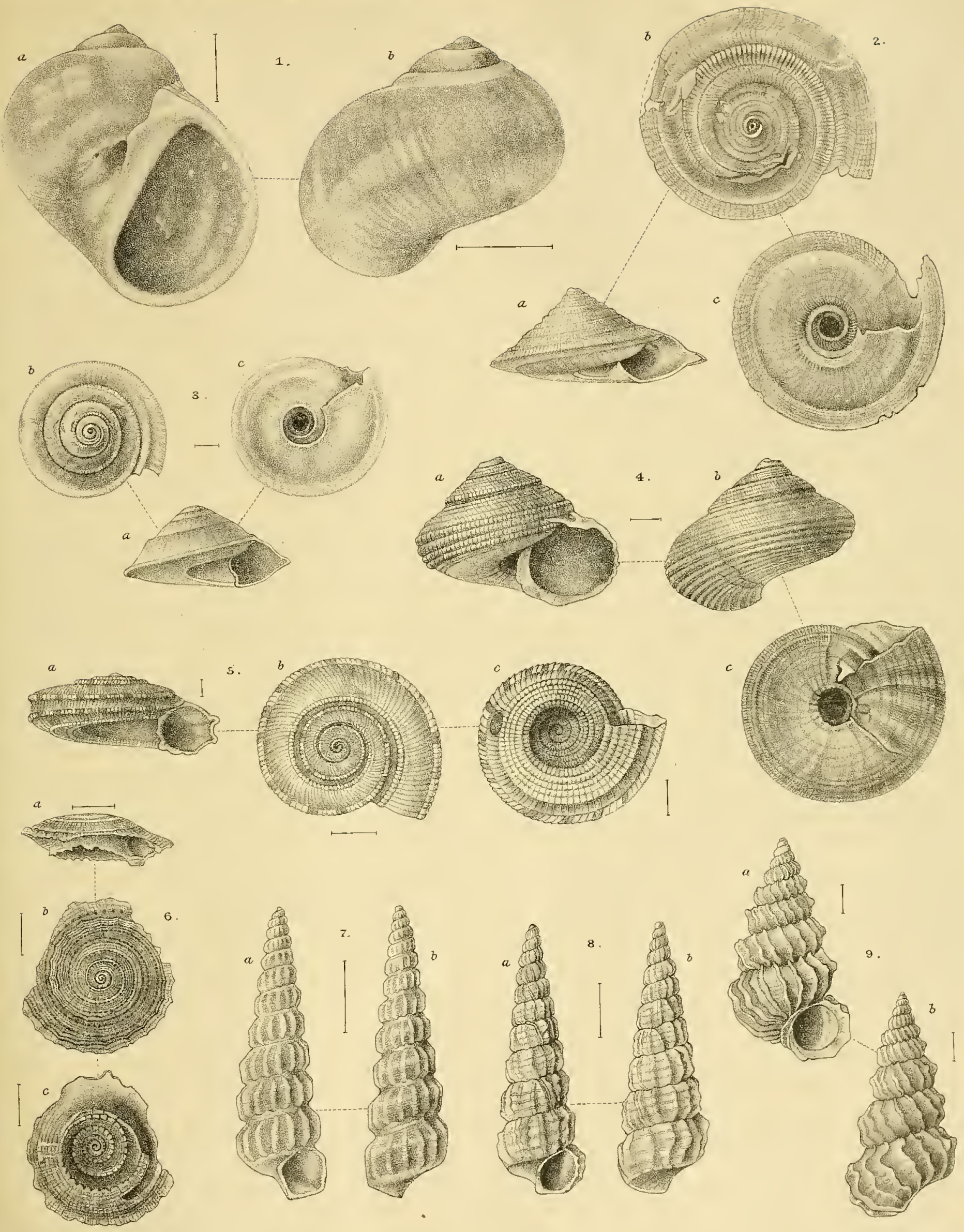

Fig. $1-4,7-9$ C. Dumont: fig. 5, 6 de Graaf del.

Fa P. W. M. Trap impr. 




\section{PLATE XV.}

Fig. I. Scala Tydemani n. sp.

Fig. 2. Scala abyssicola n. sp. a. smaller, b. larger specimen.

Fig. 3. Scala fragilissima 12. sp. a. smaller, b. larger specimen.

Fig. 4. Scale Nierstraszi n. sp.

Fig. 5. Rimella Tyleri Ads. $a$. larger, b. smaller specimen.

Fig. 6. Teetl of radula of Ampliperas plitippinarum Sow. (see p. I44).

Fig. 7. Teeth of radula of Gyrineum cuspidatum Rve.

Fig. 8. Teeth of radula of Amphiperas Angasi (Ads.) Rve. (see p. I44).

Fig. 9. Teeth of radula of Ampliperas secale Sow. (see p. I45).

Fig. IO. Teeth of radula of Calpumus verrucosus Lin.

Fig. I I. Teeth of radula of Argyropeza divina Melv. \& Stand.

Fig. 12. Teeth of radula of Seguensia Melvilli n. sp. 

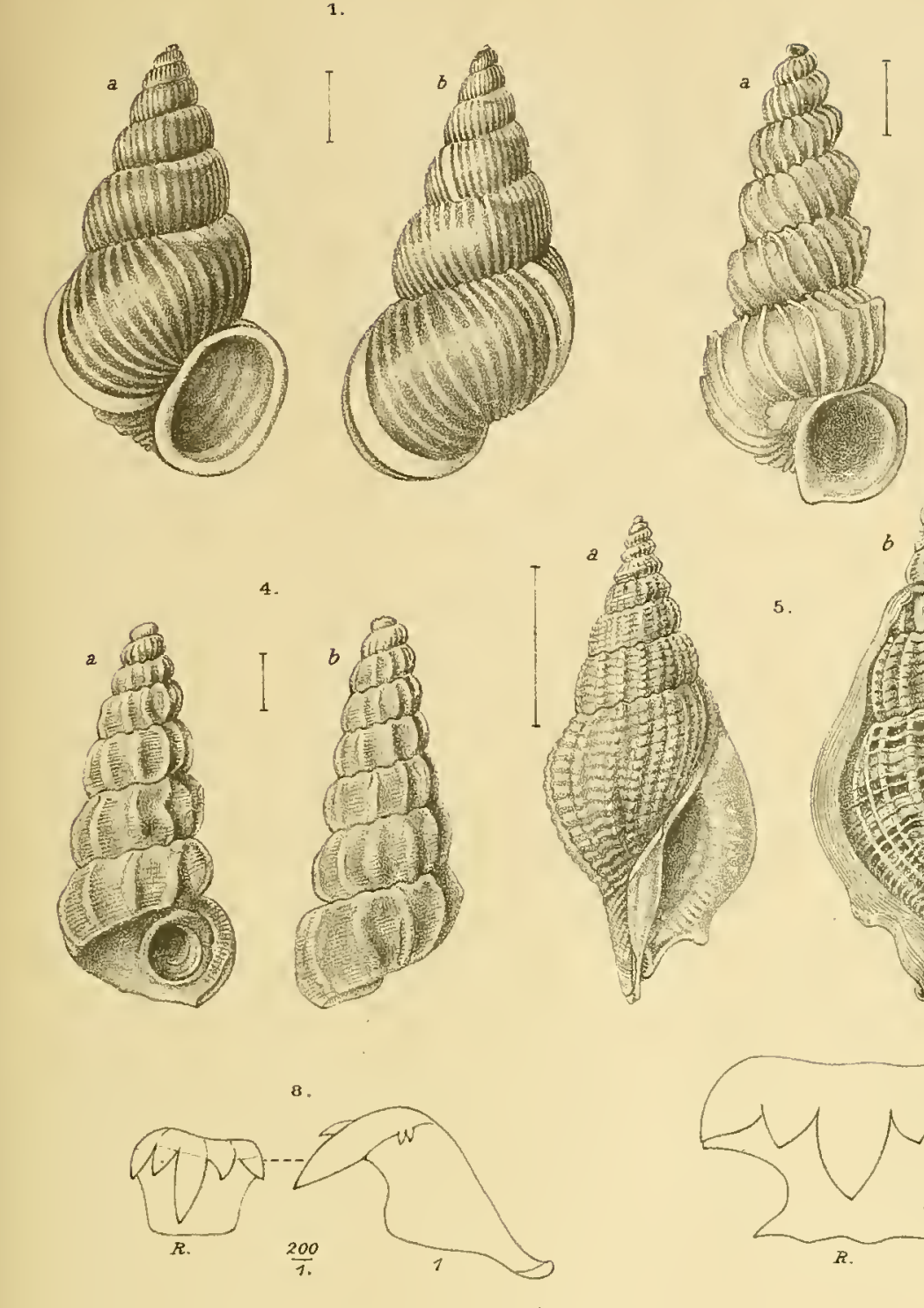

2.
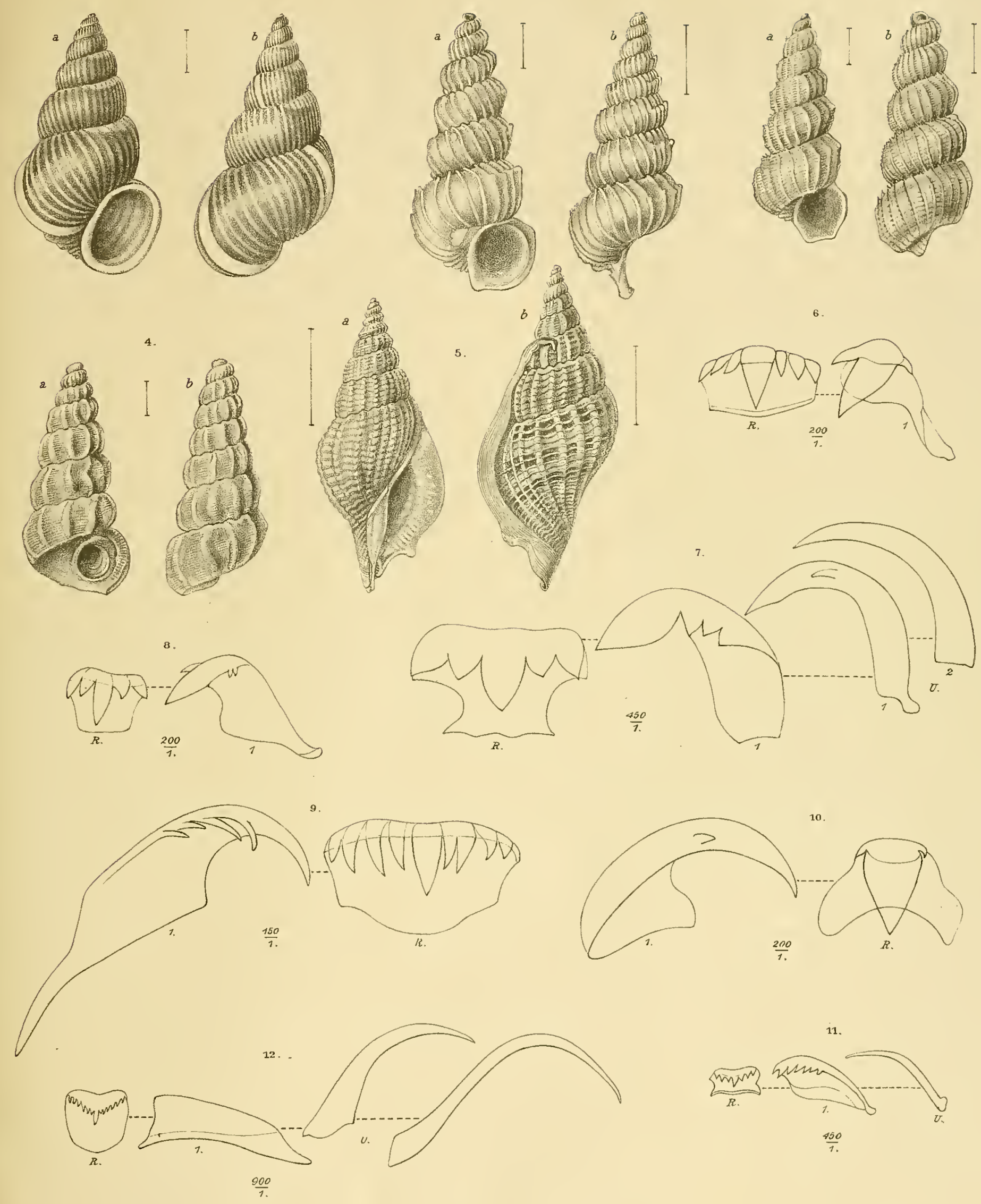

Fig. I-6. C. Dumont, fig. 7-I2 M. M. S. del.

Fa P. W. N. Trap impr. 




\section{PLATE XVI.}

Fig. I. Teeth of radula of Rimella Tyleri Ads.

Fig. 2. Teeth of radula of Rostellaria Porvisii Recl.

Fig. 3. Teetlz of radula of species probably belonging to Trichotropidae.

Fig. 4. Teeth of radula of Qnoyia decollata Quoy \& Gaimard. 

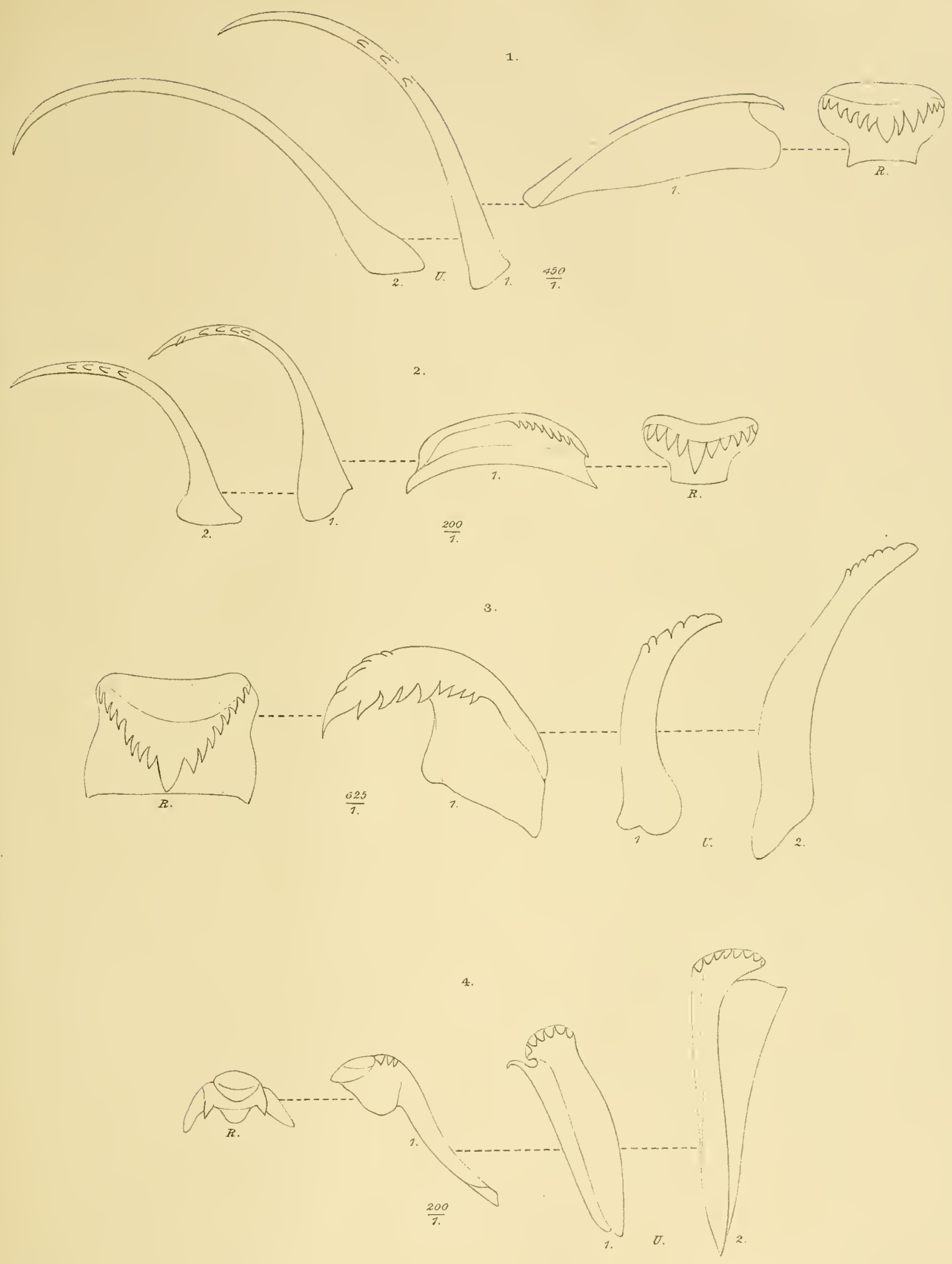



\section{CONDITIONS GÉNÉRALES DE VENTE.}

¡. L'ouvrage du "Siboga" se composera d'une série de monographies.

$2^{\circ}$. Ces monographies paraîtront au fur et à mesure qu'elles seront prêtes.

$3^{\circ}$. Le prix de chaque monographie sera différent, mais nous avons adopté comme base générale du prix de vente: pour une feuille d'impression sans fig. flor. 0.15 ; pour une feuille avec fig. flor. 0.20 à 0.25 ; pour une planche noire flor. 0.25 ; pour une planche coloriée flor. 0.40 ; pour une photogravure flor. 0.60 .

$4^{\circ}$. Il y aura deux modes de souscription:

a. La souscription à l'ouvrage complet.

b. La souscription à des monographies séparées en nombre restreint.

Dans ce dernier cas, le prix des monographies sera majoré de $25 \%$.

$5^{\circ}$. L'ouvrage sera réuni en volumes avec titres et index. Les souscripteurs à l'ouvrage complet recevront ces titres et index, au fur et à mesure que chaque volume sera complet. 
Ie Livr. (Monogr. XLIV) C. Ph. Sluiter. Die Holothurien der Siboga-Expedition. Mit 10 Tafeln.

2e Livr. (Monogr. LX) E. S. Barton. The genus Halimeda. With 4 plates.

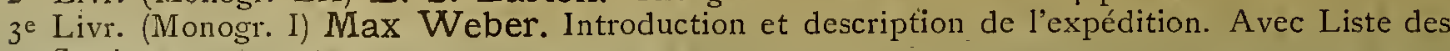
Stations et $\overline{2}$ cartes

$4^{\mathrm{e}}$ Livr. (Monogr. II) G. F. Tydeman. Description of the ship and appliances used for scientific exploration. With 3 plates and illustrations.

e Livr. (Monogr. XLVII) H. F. Nierstrasz. The Solenogastres of the Siboga-Exp. With 6 plates.

6e Livr. (Monogr. XIII) J. Versluys. Die Gorgoniden der Siboga-Expedition.

I. Die Chrysogorgiidae. Mit I70 Figuren im Text.

Livr. (Monogr. XVIa) A. Alcock. Report on the Deep-Sea Madreporaria of the SibogaExpedition. With 5 plates.

Se Livr. (Monogr. XXV) C. Ph. Sluiter. Die Sipunculiden und Echiuriden der Siboga-Exp. Mit 4 Tafeln und 3 Figuren im Text.

ge Livr. (Monogr. VI a) G. C. J. Vosmaer and J. H. Vernhout. The Porifera of the SibogaExpedition. I. The genus Placospongia. With 5 plates.

loe Livr. (Monogr. XI) Otto Maas. Die Scyphomedusen der Siboga-Expedition. Mit i 2 Tafeln. I I Livr. (Monogr. XII) Fanny Moser. Die Ctenophoren der Siboga-Expedition. Mit 4 Tafeln. $12^{e}$ Livr. (Monogr. XXXIV) P. Mayer. Die Caprellidae der Siboga-Expedition. Mit Io Tafeln.

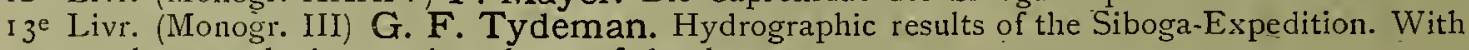
24 charts and plans and 3 charts of clepths

I4 Livr. (Monogr. XLIII) J. C. H. de Meijere. Die Fchinoidea der Siboga-Exp. Mit 23 Tafeln.

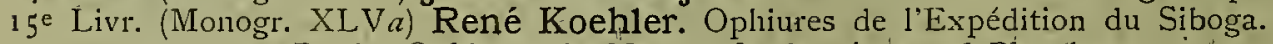

r6 Livr. (Monogr. LII) J. J. Tesch. The Thecosomata and Gymnosomata of the SibogaExpedition. With 6 plates.

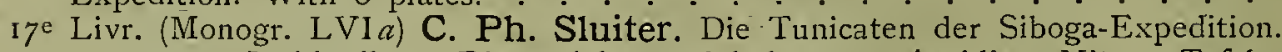

I. Abteilung. Die socialen und holosomen Ascidien. Mit is Tafeln.

Ise Livr.-(Monogr. LXI) A. Weber-van Bosse and M. Foslie. The Corallinaceae of the SibogaExpedition. With 16 plates and $34^{\circ "}$ textfigures

Ige Livr. (Monogr. VIII) Sydney J. Hickson and Helen M. England. The Stylasterina of the Siboga Expedition. With 3 plates.

2o Livr. (Monogr. XLVIII) H. F. Nierstrasz. Die Chitonen der Siboga-Exp. Mit $\dot{\delta}$ Tafeln. 21 e Livr. (Monogr. XLVb) René Koehler. Ophiures de l'Expédition du Siboga.

$2^{2}$ Partie. Ophiures littorales. Avec is 8 Planches.

22 Livr. (Monogr. XXVIbis) Sidney F. Harmer. The Pterobranchia of the Siboga-Expedition, with an account of other species. With 14 plates and 2 text-figures.

$23^{\mathrm{e}}$ Livr. (Monogr. XXXVI) W. T. Calman. The Cumacea of the Siboga Expedition. With 2 plates and 4 text-figures

$24^{\mathrm{e}}$ Livr. (Monogr. LVI a) C. Ph. Sluiter. Die Tunicaten der Siboga-Expedition.

Supplement zu der I. Abteilung. Die socialen und holosomen Ascidien. Mit I Tafel.

25 e Livr. (Monogr. L) Rud. Bergh. Die Opisthobranchiata der Siboga-Exped. Mit 20 Tafeln.

26e Livr. (Monogr. X) Otto Maas. Die Craspedoten Medusen der Siboga-Exp. Mit I4 Tafeln.

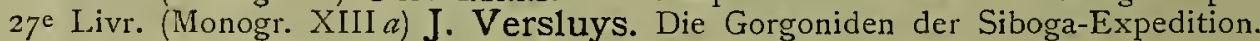

II. Die Primnoidae. Mit ro Tafeln, I 78 Figuren im Text und einer Karte.

28e Livr. (Monogr. XXI) G. Herbert Fowler. The Chaetognatha of the Siboga Expedition. With 3 plates and 6 charts.

$2 g^{e}$ Livr. (Monogr. LI) J. J. Tesch. Die Heteropoden der Siboga-Expedition. Mit I4 Tafeln.

3oe Livr. (Monogr. XXX) G. W. Müller. Die Ostracoden der Siboga-Exped. Mit 9 Tafeln.

3 re Livr. (Monogr. IVbis) Franz Eilhard Schulze. Die Xenophyophoren der Siboga-Exped. Mit 3 Tafeln

$3^{2}$ Livr. (Monogr. LIV) Maria Boissevain. The Scaphopoda of the Siboga Expedition. With 6 plates and 39 textfigures.

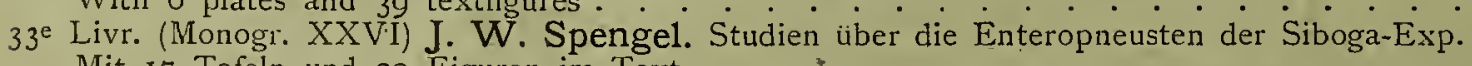
Mit 17 Tafeln und 20 Figuren im Text.

$34^{e}$ Livr. (Monogr. XX) H. F. Nierstrasz. Die Nematomorpha der Siboga-Exp. Mit 3 Tafeln.

$35^{\mathrm{e}}$ Livr. (Monogr. XIII c) Sydney J. Hickson und J. Versluys. Die Alcyoniden der SibogaExped. I. Coralliida, II. Pseudocladochonus Hicksoni. Mit 3 Tafeln und r6 Figuren im Text.

36e Livr. (Monogr. XXXIa) P. P. C. Hoek. The Cirripedia of the Siboga Expedition.

A. Cirripedia pedunculata. With 10 plates

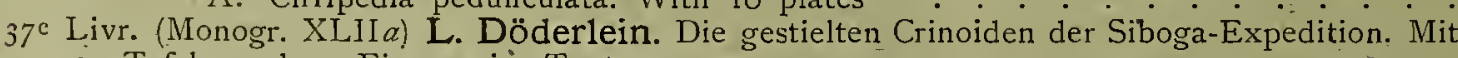
23 Tafeln und 12 Figuren im Text

${ }_{3} 8$ e Livr. (Monogr. IX) Albertine D. Lens and Thea van Riemsdijk. The Siphonophores of the Siboga Expedition. With 24 plates and 52 textfigures

$39^{c}$ Livr. (Monogr. XLIX'a) M. M. Schepman. The Prosobranchia of the Siboga Expedition. Part I. Rhipidoglossa and Docoglossa, with an Appendix by Prof. R. BERGH. With 9 plates and 3 textfigures.

$40^{\circ}$ Livr. (Monogr. XL) J. C. C. Loman. Die Pantopoden der Siboga-Expedition. Mit 15 Tafeln und 4 Figuren im Text.

4 I $^{\mathrm{C}}$ Livr. (Monogr. LVIc) J. E. W. Ihle. Die Appendicularien der Siboga-Expedition. Mit 4 Tafeln und 10 Figuren im Text

$42^{\mathrm{e}}$ Livr. (Monogr. XLIN ${ }^{2}$ ) M. M. Schepman und H. F. Nierstrasz. Parasitische Prosobranchier der Siboga-Expedition. Mit-2 Tafeln .

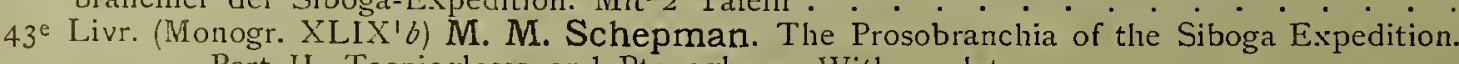
Part II. Taenioglossa and. Ptenoglossa. With 7 plates

f 6 - f 7.50

I.80 $f 7.50$

n 6.75

2.40

2.

3.90

n 9.-

$3 .-$

2.50

4.90

4.60

3.75

" $3 \cdot-$ 5.75

2.40

7.50

2.80

7.80

3.-

, 9.50

" 3.50

ก 9.75

\% 9 -

तI I. 25

"15.-

, 16.50

" I 8.75

, 3.75

, 20.50

6.75

त 4.70

" 12.50

त 9.-

n' 1.50

» 15.50

5.-

I.90

10.25

, I 2.75

, 6.7

, 9.-

$1.80 \div 2.40$

$n-75$

n I I. 25

9.25

$n$ 1. -

ᄁ 14.10

n 12.50

$\eta 12.50,16.75$

" 4.20

n 5.25

6.75

3.50

" 9.-

2.40

$3 .-$

, $4.80,6 .-$

"I $4 .-\geqslant 17.50$

$2.80 \approx 3.50$

$2.20 \gg 2.75$

त 5.40

ก 6.75

8.- , 10.-

$13.50 \quad n 16.75$

$74.80,6 .-$

$6.25,7.80$

त $4.80,6 .-$

$1.20 \approx \mathrm{r} .50$

$4.50 \pi 5.60$ 


\section{Voor de uitgave van de resultaten der Siboga-Expeditie hebben}

bijdragen beschikbaar gesteld:

De Maatschappij ter bevordering van het Natuurkundig Onderzoek der Nederlandsche Koloniën.

Het Ministerie van Koloniën.

Het Ministerie van Binnenlandsche $\grave{Z}$ aken.

Het Koninklijk Zoologisch Genootschap "Natura Artis Magistra" te Amsterdam.

De "Oostersche Handel en Reederij" te Amsterdam.

De Heer B. H DE WAAL Oud-Consul-Generaal der Nederlanden te Kaapstad.

M. B. te Amsterdam.

\section{CONDITIONS GÉNÉRALES DE VENTE.}

I. L'ouvrage du "Siboga" se composera d'une série de monographies.

$2^{\circ}$. Ces monographies paraitront au fur et à mesure qu'elles seront prêtes.

$3^{\circ}$. Le prix de chaque monographie sera différent, mais nous avons adopté comme base générale du prix de vente: pour une feuille d'impression sans fig. flor. O.I5; pour une feuille avec fig. flor. 0.20 à 0.25 ; pour une planche noire flor. 0.25 ; pour une planche coloriée flor. 0.40 ; pour une photogravure flor. 0.60 .

$4^{\circ}$. Il y aura deux modes de souscription:

a. Lå souscription à l'ouvrage complet.

b. La souscription à des monographies séparées en nombre restreint.

Dans ce demier cas, le prix des monographies sera majoré de $25 \%$.

$5^{\circ}$. L'ouvrage sera réuni en volumes avec titres et index. Les souscripteurs à l'ouvrage complet recevront ces titres et index, au fur et à mesure que chaque volume sera complet. 
THE

PROSOBRANCHIA OF THE SIBOGA EXPEDITION

PART III

GYMNOGLOSSA

mailed mas 31/10 

Siboga-Expeditie

$\mathrm{XLIX}^{\prime} \mathrm{c}$

\title{
THE PROSOBRANCHIA OF THE SIBOGA EXPEDITION
}

BY

\author{
M. M. SCHEPMAN \\ Bosch en Duin near Utrecht (Holland)
}

PART III

GYMNOGLOSSA

With 1 plate

LATE E. J. BRILL

PUBLISHERS AND PRINTERS

LEYDEN - I9O9 



\section{GYMNOGLOSSA}

This third part, containing the Gymnoglossa of the Siboga Expedition, is much less bulky than its predecessors, containing only 32 species, of which a few are new to science. It is a very difficult group, and I am much obliged to Mr. J. Cosmo Melvill for his liberal assistance in naming and classifying the doubtful specimens and for procuring specimens for comparison.

I wish here to express my acknowledgement to the library of Teyler's Institution at Haarlem and its librarian, who has in the most obliging manner facilitated the use of the conchological books, represented there in an unusual abundance.

The classification of some specimens remained still a little doubtful, f.i. in the only Eulimella and in one species of Elusa, even after maling use of the papers of DALL and BARTSCH, who have recently made a special study of this section of mollusks. I have repeated the descriptions of the new species of Miucronalia and Stilifer, from my monograph with Dr. Nierstrasz, in order to render this part more complete, than it would have been, by simply quoting them. For these species I have to thank Dr. J. THIELE for the loan of specimens from the Zoological Museum of Berlin. 


\section{Section Gymnoglossa Gray.}

Fam. Eulimidae.

\section{Eulima Risso.}

\section{Eulima Martiniii A. Adams.}

Adaus. Sow. Thes. Conch. Vol. II, p. 795, Pl. 169, fig. 5.

ReEve. Conch. Ic. Vol. XV, Eulima, fig. 6.

Tryon. Man. of Conch. Vol. VIII, p. 266, Pl. 68, fig. 90.

Clessin. Martini-Chemn. Conch. Cab. Ed. II, Vol. I, Eulimidae, p. 4, Pl. I, fig. 10.

Stat. 33. Bay of Pidjot, Lombok. 22 M. Mud, coral and coralsand. I Spec.

The specimen though rather small (about i 8 Mill.) is sufficiently characterized by its numerous whorls, agreeing with the upper whorls of a Japanese specimen.

2. Eulima arcuata Sowerby.

Sowerby. Reeve Conch. Ic. Vol. XV, Eulima, fig. 14.

Tryon. Man. of Conch. Vol. VIII, p. 266, Pl. 68, fig. 94 (major var.).

Clessin. Martini-Chemn. Conch. Cab. Ed. II, Vol. I, Eulimidae, p. I8, Pl. 4, fig. 6.

Stat. 78. Lumu-Lumu-shoal, Borneo-bank. 34 M. Coral and coralsand. I Spec.

3. Eulima polygyra A. Adams.

Adanis. Sow. Thes. Conch. Vol. II, p. 799, Pl. 169, fig. 36.

ReEve. Conch. Ic, Vol. XV, Eulima, fig. 24.

Tryon. Man. of Conch. Vol. VIII, p. 270, Pl. 68, fig. is.

Clessin. Martini-Chemn. Conch. Cab. Ed. II, Vol. I, Eulimidae, p. 24, P1. 5, fig. 4.

Stat. 51. Madura-bay. 69-9I M. Fine grey sand, coarse sand with shells. I Spec.

Stat. 162. Between Loslos and Broken-islands, West coast of Salawatti. I\& M. Coarse and fine sand with clay and shells. I Spec.

Both specimens have lost their apical whorls, and were consequently of rather uncertain identification, so I asked the assistance of Mr. Mecvill, who wrote that the specimen from Stat. 162 is more typical than that from Stat. $5 \mathrm{I}$.

4. Eulinua acuta A. Adams.

Adans. Proc. Zool. Soc. Lond. I851, p. 276.

- Sow. Thes. Conch. Vol. II, p. 797, P1. 169, fig. 29, 30. 
REEVE. Conch. Ic. Vol. XV, Eulima, fig. 15.

Tryon. Man. of Conch. Vol. VIII, p. 268, Pl. 68, fig. 3.

Clessin. Martini-Chemn. Conch. Cab. Ed. II, Vol. I, Eulimidae, p. 10, P1. 2, fig. 9.

Stat. 240. Banda. 9-45 M. Black sand, coral. I Spec.

The specimen sufficiently agrees with fig. 30 of the Monograph of Adams in Sowerbv's Thes. Conch. (1.c.), less so with the other quoted figures. Mr. Melvili wrote about the Sibogaspecimen: "Does not exactly agree, but comes near it". The specimen is perhaps more hyaline, the margin of the outer lip, can scarcely be called straight. As even the figures in the Thesaurus Conch. are considerably different, so much that they can scarcely be considered to belong to one and the same specimen and one might consequently conclude, that the species be slightly variable, I have left this single specimen without a new name.

\section{Eulima aciculata Pease.}

Pease. Proc. Zool. Soc. Lond. i860, p. 438.

REEvE. Conch. Ic. Vol. XV, Eulima, fig. 36 .

Clessin. Martini-Chemn. Conch. Cab. Ed. II, Vol. I, Eulimidae, p. 19, Pl. 4, fig. II.

Stat. 43. Pulu Sarassa, Postillon Islands. Up to 36 M. Coral. I Spec.

As far as I am aware, this species has only been recorded from the Sandwich-isles, but if it be the same as E. acicula Gould, it seems to be more widely spread, at least I have received specimens under this latter name from Mauritius.

\section{Eulima attenuata Sowerby.}

Sowerby. Reeve. Conch. Ic. Vol. XV, Eulima, fig. 46.

Tryon. Man. of Conch. Vol. VIII, p. 282, P1. 70, fig. 97.

Clessin. Martini-Chemn. Conch. Cab. Ed. II, Vol. I, Eulimidae, p. 3, Pl. I, fig. 6.

Stat. $52.9^{\circ} 3^{\prime} \cdot 4$ S., $119^{\circ} 5^{\prime} .7$ E. Savu Sea. 959 M. Globigerine ooze. 2 Spec.

Stat. $178.2^{\circ} 40^{\prime}$ S., $128^{\circ} 37^{\prime} .5$ E. Ceram Sea. 835 M. Blue mud. I Spec.

The specimens don't agree in every respect with the description, a. o. I see no faint band at the suture, the mouth of one of the specimens from Stat. 52, seems to be more effuse, but comparing it with the specimen from Stat. I78, I think this may be caused by its being slightly damaged. So I think it is preferable, not to describe a new species on such slight differences.

\section{Eulima vitrea A. Adams.}

A. Adanis. Sow. Thes. Conch. Vol. II, p. 799, Pl. I69, fig. 35.

REEvE. Conch. Ic. Vol. XV, Eulima, fig. I9.

Clessin. Martini-Chemn. Conch. Cab. Ed. II, Vol. I, Eulimidae, p. Io, Pl. 2, fig. 7 .

Stat. $74 \cdot 5^{\circ} 3^{\prime} \cdot 5$ S., I $19^{\circ} 0^{\prime}$ E. Makassar Strait. 450. M. Globigerine ooze. I Spec.

Exactly agreeing with the quoted descriptions. 


\section{Eulima sp.}

Stat. $95.5^{\circ} 43^{\prime} \cdot 5$ N., $119^{\circ} 40^{\prime}$ E. Sulu Sea. 522 M. Stony bottom. I Spec.

This specimen resembles the figure of $E$. attcnuata in ReEve's Conch. Ic., but is still different, the aperture is too much broken for identification, the columella being partly lost.

9. Eutima Melvilli n. sp. P1. XVII, fig. 5 .

Stat. 99. North-Ubian, Sulu Archipelago. 16-23 M. Lithothamnion-bottom. I Spec.

Shell conical, scarcely distorted to the right, thin, semipellucid, smooth, white. Nucleus wanting; remaining whorls about $6 \frac{1}{2}$, moderately convex, slightly angular just below the deep suture, which seems to be margined interiorly, at least I see a margin shining through the shell; sculpture consisting of very faint, often irregular growth-striae and a few varices, which seem to be often faint, but of which 3 , higher on the spire, are more conspicuous, on what is now the left side of the ventral face of the shell; last whorl rather elongate, without angle. Aperture oval, angular above, its outer margin regularly curved, rather blunt, thickened interiorly by a layer of shelly matter, basal margin rounded, columellar margin nearly straight, but thickened a little about the middle and slightly reflected over what may scarcely be named an umbilical slit.

Alt. $8^{1} / 6$, diam. $3^{1 / 2}$; apert. alt. $2^{1} / 2$, lat. $\mathrm{I}^{1} / 4$ Mill.

This new species is unlike any described form. It is characterized by its comparatively short, inflated shape. With a few of the preceding species it might perhaps be placed by some authors in the genus Subularia. I have restricted that group to the species named Leiostraca by ADAMS.

\section{Subularia Monterosato.}

1. Subularia bivittata H. \&. A. Adams.

H. \& A. Adans. Genera of recent Mollusca, Vol. I, p. 239.

Adans. Sow. Thes. Conch. Vol. II, p. 804, Pl. 170, fig. 18, 19.

ReEve. Conch. Ic. Vol. XV, Leiostraca, fig. 6.

Tryon. Man. of Conch. Vol. VIII, p. 279, Pl. 70, fig. 70.

Clessin. Martini-Chemn. Conch. Cab. Ed. II, Vol. I, Eulimidae, p. 4I, PJ. 8, fig. 3.

Stat. $3^{19}$. $^{\circ}$ I6 .5 S., $114^{\circ} 37^{\prime}$ E. Java Sea. 82 M. Fine yellowish-grey mud. I Spec.

Clessin (1.c.) says: "Vaterland?", though Adans (Thes. Conch.) and Trvon (1.c.) quote: "Sooloo Sea". The Siboga-specimen has been dredged considerably more southwards.

2. Subularia? circumstriata n. sp. Pl. XVII, fig. 6.

Stat. $208.5^{\circ} 39^{\prime}$ S., $122^{\circ} 12^{\prime}$ E. Banda Sea. 1886 M. Solid green mud. I Spec.

Shell fusiform, thin, white (probably bleached) nucleus slightly worn, but apparently heterostrophe, postnuclear whorls about 5, those forming the spire, a little convex, separated by a deep, channelled suture. Last whorl elongated, narrow below. Sculpture consisting of fine 
growth-striae, slightly stronger at irregular intervals, rendering the surface folded, but forming no ribs, and a few indistinct varices; spiral sculpture: a fine raised line at some distance below the suture, a few distant, impressed striae at the lower part of each whorl and very fine microscopic striae on the whole surface; last whorl with abouth 16 impressed striae, beginning a little above the periphery, becoming stronger near the base. Aperture strongly broken, part of the outer and even of the columellar margin wanting. Outer margin probably thin, regularly curved, columellar margin rather straight above, tortuous below, reflected towards the left. Shape of aperture, as far as may be judged, elongate, acutely angular above.

Alt. $8^{3} \%$ (but may have been more), lat. 3 ; apert. alt. $4^{1} / 4$ Mill.

A very puzzling specimen, and were it not for it peculiar characters, I should not have named and described it; in shape it resembles $S$. Aletcalfei A. Ads., but it is more ventricose than my specimens of that species from Lifu, with a much longer last whorl, a different suture, nay, differing in every particular. Its spiral striation is an exceptional feature in the genus, and it is much to be regretted, that the base of columella is wanting, for if this were present, it might prove to be bent towards the left and backwards, which would locate the species in the genus or subgenus Bacula H. and A. Adams ( $186_{3}$ ) containing Arcuella mirifica Nevill (Journ. Beng. Soc. Vol. 43, 1874, Pl. I, fig. Io, copied by Tryon Man. of Conch. Vol. VIII, Pl. 7o, fig. 70) which latter species is also spirally striated, with a distinct subsutural zone; but though the columella is tortuous below and so it might be that it would terminate in an angle of the same construction as that of $B$. mirifica; this seems to be too bold a supposition, to locate it in that genus. Untill fresh or at least complete specimens have been collected, this species will remain one of the numerous enigmas amongst the difficult Gymnoglossa. If it has really lived at the great depth of I $886 \mathrm{M}$, , the probability of getting more materials, will not be very great.

\section{Niso Risso.}

\section{Niso venosa Sowerby.}

Suwerby. Proc. Mal. Soc. Lond. Vol. I, 1895, p. 279, P1. I8, fig. iо, iा.

Stat. 4. Djangkar (Java). 9 M. Coarse sand. 1 Spec.

Stat. 51. Madura-bay, 69-9I M. Fine grey sand, coarse sand with shells and stones. I Spec.

Both specimens are very young and it is only by comparison with a specimen from the original locality, received from the author, that I was able to identify them. The smallest specimen, from Stat. 51 , has only a length of $5 \frac{1}{2}$ Mill. and but very faint traces of "the bright reddish-brown, vein-like lines which here and there cross the whorls". Indeed I see but one brown line at the upper part of the aperture and two short lines below the suture of the last whorl, the upper whorls being uniformly white, with the spiral, supra-sutural line, which even is wanting on the uppermost whorls. However this is also the case in the typical specimens, as far as may be judged after one specimen that has lost its nuclear whorls. The specimen from Stat. 4 is a slightly bleached shell. Cuessin seems not to have noticed this species though his monograph has been published in 1902. 
2. Niso Smithi n. sp. Pl. XVII, fig. 7 .

Stat. 51. Madura-bay. 69-9I M. Fine grey sand, coralsand with shells and stones. I Spec.

Stat. $153.0^{\circ} 3^{\prime} .8$ N., $130^{\circ} 24^{\prime} \cdot 3$ E. Bougainville Strait. 141 M. Fine and coarse sand with dead shells. I Spec.

Shell pyramidal, solid, smooth, porcellaneous, white, umbilicated. Whorls 14 , slowly increasing, slightly convex, separated by a conspicuous suture; last whorl angulated at the periphery, by a slightly cordlike keel; base convex, with a strong keel bordering the umbilicus, this latter is pervious, funnel-shaped, with a rather strong keel interiorly along its wall; this keel is crenulated by rounded crenules, about $\mathrm{ro}$ in last whorl, considerably diminishing the width of the umbilicus. Practically I see no sculpture, but a few growth-striae, which are for the majority very faint and rarely have the character of very indistinct varices.

Aperture elongately subrhombic, protracted below, with an acute angle above, a thin, regularly arched outer margin, scarcely angulated by the peripheral keel; base strongly angular by the terminating of the keel bordering the umbilicus, columellar margin curved, concave, a little reflected, scarcely angulated by the umbilical keel.

Alt. 12, lat. $5 \%$; apert. alt. (obl.) 3, lat. 2 ; entrance of umbilicus 2 Mill.

This new species has a superficial resemblance with $N$. candidula, but is much smaller and that species has a rounded last whorl, it resembles in shape $N$. goniostoma, but that species is still larger, more elongated and quite different in colour. I have named it in honour of Mr. Edgar A. Smith, the well-known keeper of the mollusca in the British Museum.

\section{Mucronalia A. Adams.}

1. Mucronalia gracilis Pease.

PEAse. American Journ. of Conch. Vol. III, p. 295, Pl. 24, fig. 27.

Tryon. Man. of Conch. Vol. VIII, p. 284 , Pl. 7 o, fig. 4.

Schepman, in Schepman \& Nierstrasz. Parasit. Prosobranch. d. Siboga-Expedition, Leiden, I909, p. 2.

Stat. I3I. Beo, Karakelang-islands. I3 M. I Spec. on Echinothrix diadema L.

The only specimen seems to be still young, it agrees very well with the figure of Tryon, which is a copy of the original one, but it is smaller, being only about 3 instead of 4 Mill., the number of whorls (about 7) agrees with that of the description, but an adult specimen in my collection, has a larger number of whorls.

\section{Mucronalia philippinarum Sowerby.}

Sowerby. Proc. Mal. Soc. Lond. Vol. IV, p. 127, Pl. ir, fig. 5.

Schepman, in Schepman \& Nierstrasz. Parasit. Prosobranch. d. Siboga-Expedition. Leiden, 1909, p. 3 .

Stat. 220. Pasir Pandjang, west coast of Binongka. Reef. I Spec. on Heterocentrotus mamitlatus Lin.

The specimen agrees as well with Sowerby's description and figure, as with a specimen 
from Cebu received from the author, though it is slightly smaller than the latter; this may depend on age, but the general aspect and the particulars of the suture are the same.

3. Mucronalia eburnea Deshayes.

Deshayes. Moll. du Réunion, p. 57, Pl. 7, fig. 25.

Tryon. Man. of Conch. Vol. VIII, p. 290, P1. 7I, fig. 43.

KüKenthal. Abh. Senckenb. Gesellsch. I898, p. I, Tf. I, fig. 2, 3; Tf. 3, fig. I4.

Schepman, in Schepman \& Nierstrasz, Parasit. Prosobranch. d. Siboga-Expedition, Leiden, I909, p. 3 .

Stat. 254. $5^{\circ} 40^{\prime}$ S., $132^{\circ} 26^{\prime}$ E. Arafura Sea. 3 10 M. I Spec. on Ophiotlirix deposita Koehler.

Unfortunately the only specimen was broken, consequently the identification slightly doubtful, however the upper whorls and texture of shell agree with the numerous specimens I have seen. Deshayes and Tryon (1. c.) have described the species as a Stilifer. The Sibogaspecimen is provided with an operculum.

\section{Mucronalia Mittrei Petit.}

PETIT. Journ. de Conch. Vol. II, 1851, p. 27, Pl. 2, fig. 8, 9.

Tryon. Man. of Conch. Vol. VIII, p. 290, Pl. 71, fig. 42.

Schepman, in Schepman \& Nierstrasz. Parasit. Prosobranch. d. Siboga-Expedition, Leiden, 1909, p. 3 .

Stat. 312. Saleh-bay, North coast of Sumbawa. 274 M. I Spec. on Ophiothrix crassispina Koehler.

By its shape, especially by that of the penultimate whorl, which is uncommonly developed, I cannot distinguish the shell from the species described by PETit as Stylifer Mittrei, only the Siboga-specimen is much smaller. PЕтіт had only one specimen, without exact indication of locality, and he did not know if it were a parasite; probably the operculum was wanting, at least PETIT does not mention it. With a view on the preceding species it is not strange that this species should be referred to the genus Mucronalia, on account of the operculum in the Siboga-specimen. Moreover its other conchological characters, sufficiently agree with those of the species dealed with sub 2 and 3 , to unite them in the same group. It may be even the question, if after all so many species will stand, when more materials will have been collected. Length of shell 6 Mill., breadth 4 Mill.

\section{Mucronalia parva Schepman. Pl. XVII, fig. I.}

Schepunn, in Schepman \& Nierstrasz. Parasit. Prosobranch. d. Siboga-Expedition, Leiden, I909, p. 4 .

Stat. 3 I2. Saleh-bay, North coast of Sumbawa. 274 MI. 3 Spec. with the preceding species.

Shell small, elongated-oval, imperforate, white, smooth; whorls about 6 of which the two apical ones are mucronate, the other whorls are broader, strongly convex, with a deep suture, last whorl less convex. Aperture ovate, with an acute angle above, right margin thin, considerably flexuous, columella arched; a thin layer of enamel on the body whorl. Operculum thin, horny. 
Long. $3^{1} / 4$, lat. $1^{8} / 4$; a pert. alt. $1^{1} / 2$ Mill.

This species has some resemblance with the preceding one, but is much more slender, it is not the juvenile state, for it should never reach the breadth of that species, if it proved to be the male, this would be an extraordinary case of dimorphism in Mollusca; only the circumstance that it has been found on the same animal, is a reason to be cautious. Mucronalia oxytenes Melv. (Proc. Mal. Soc. Lond. VI, p. 163, fig. I3) is also a species, similar by its size and shape, but with cylindrical whorls.

\section{Mucronalia varicosa Schepman. Pl. XVII, fig. 2.}

Schepman, in Schepman \& Nierstrasz. Parasit. Prosobranch. d. Siboga-Expedition, Leiden, I 909 , P. 4 .

Stat. $164.1^{\circ} 42^{\prime} .5 \mathrm{~S} ., 130^{\circ} 47^{\prime} .5$ E. Near New Guinea. 32 M. 2 Spec. on Astrochalcis tuberculosus Koehler, I loosened one and 4 specimens without exact locality, perhaps from the same station.

Shell small, oval, imperforate, white, rather smooth, with very fine growth-striae and a few riblike varices on the last whorl. Whorls about 6 , of which the two apical ones are mucronate, the other whorls are convex with a deep marginate suture. Aperture subovate, its upper angle moderately acute, right margin thin, slightly expanded, regularly flexuous, stronger so near the upper part, columellar side slightly arched, a little thickened near the base, with a thin layer of enamel on the bodywhorl. Operculum thin, horny.

Long. 4 , lat. $2^{1 / 2}$ to $2^{3} / 4$; apert. alt. $2^{1} / 4$ Mill.

The species varies slightly in shape, some specimens being more swollen than others, which may depend on sex; the varixlike striae on the last whorl are remarkable, they remind those of Stilifer variciferus Hedley (Mem. Austral. Museum, Vol. III, p. 4I1, fig. 5), but that is quite another shell, belonging to the section of exaratus. These varices probably result of former margins, which by being expanded, caused these riblike processes.

After this description was written I found a fine specimen from Stat. 164, amongst the Eulimidae, but this was loosened and consequently not immediately recognized as a parasite. Its length is $5 \%$ Mill. and it has the varices very well developed.

\section{Stilifer Broderip.}

The description of the soft parts or animal of Stilifer are rather different from each other; if one compares the description of Stilifer Turtoni Brod. by Jefrreys (British Conchology, Vol. IV, p. I95) and his figures of the animal (1.c. Pl. 3, fig. 2), with that of Stilifer celebensis Kiükenthal (Abh. Senckenb. Gesellsch. Band 24, 1898 , p. 6, Pl. 1, fig. 6; P1. 3, fig. 16) one would scarcely think that the authors deal with the same genus.

\section{Stilifor sp.}

Schepman, in Schepman \& Nierstrasz. Parasit. Prosobranch. d. Siboga-Expedition, Leiden, 1909, P. 5 .

Stat. 300. $10^{\circ} 48^{\prime} .6$ S., $123^{\circ} 23^{\prime}$.r E. Timor Sea. 918 M. 2 Spec. on Aspidodiadema tonsum Agass. 
Unfortunately both specimens are defective, the spire of the shells being wanting; as they have a very fragile appearance, I was not able to observe them sufficiently, to give even a provisional description, nor could I identify them with any of the known species of Stilifer or Mucronalia. On account of the lobes I have located the species in the genus Stilifer.

2. Stilifer sibogae Schepman. Pl. XVII, fig. 3, 4 .

SchePMan, in Schepman \& Nierstrasz. Parasit. Prosobranch. d. Siboga-Expedition, Leiden, I 909, p. 5 .

Stat. I $53.0^{\circ} 3^{\prime} .8$ N., I $30^{\circ} 24^{\prime} \cdot 3$ E. Bougainville Strait. I4I M. I Spec. on Salmacis Dussumieri Agass.

Stat. $164 . \mathrm{I}^{\circ} 4 \mathrm{I}^{\prime} .5$ S., $130^{\circ} 47^{\prime} .5$ E. Near New Guinea. 32 M. 4 Spec. on Pleurechinuls maculatus Mort.

Stat. $178.2^{\circ} 40^{\prime}$ S., $128^{\circ} 37^{\prime} .5$ E. Ceram Sea. 835 M. I Spec. on Prionechinus sagittiger Agass.

Shell small, oval, imperforate, white, smooth, with very fine growth-striae and traces of still much finer spiral striae; whorls about 6 , of which the two apical ones are mucronate and in some specimens of a brown tinge, in others white (bleached?); the subsequent whorls are more or less convex and separated by a deep, margined suture. Aperture broadly ovate, with a sharp angle above, right margin thin, regularly arched if seen in the aperture, nearly straight if seen laterally, columellar margin strongly curved, thin, running without angle into the basal margin, with a thin layer of enamel on the bodywhorl. The aperture is placed very oblique on the axis of the shell. No operculum.

Long. $3^{1} / 2$, lat. $2^{1} / 2$; a pert. alt. $1^{1} / 2$, lat. about $1 \frac{1}{4}$ Mill.

Though the depth on which the specimens have been caught, varies considerably. I have found no reason to describe more than one species, those from Stat. 164 are smaller and have white nuclear whorls, but I find no other characters to separate them; the convexity of the whorls and consequently the more a less elongated shape of the shell, may depend on sex.

Fam. Pyranidellidae.

Pyramidella Lamarck.

1. Pyramidella dolabrata Linné.

LinnÉ. Syst. Nat. Ed. X, p. $760, N^{0} 522$.

Kiener. Coq. Viv. Vol. IX, Pyramidella, p. 3, Pl. I, fig. 2 (terebellunn).

Adams. Sow. Thes. Conch. Vol. II, p. 805, Pl. I7 I, fig. I, 2, 3.

Reeve. Conch. Ic. Vol. XV, Pyramidella, fig. I3.

Tryon. Man. of Conch. Vol. VIII, p. 300, Pl. 72, fig. $7 \mathrm{I}-74$.

Clessin. Martini-Chemn. Conch. Cab. Ed. II, Vol. I, Eulimidae, p. 48, Pl. I I, fig. I.

Stat. 93. Pulu Sanguisiapo, Tawi-Tawi-islands, Sulu Archipelago. I2 M. Lithothamnion-bottom, sand and coral. 2 Spec.

Stat. 274. $5^{\circ} 28^{\prime} .2$ S., I $34^{\circ} 53^{\prime} .9$ E. Near Aru Islands. 57 M. Sand and shells, stones. I Spec.

v. Martens who quotes the species, with the name terebellum from Mauritius and Indian 
Ocean (Nicobars, Ceylon, Malay Archipelago) (Moll. Mauritius, p. 301), says: "Es ist mir nicht möglich, west- and ostindische Exemplare bestimmt zu unterscheiden". The Siboga-specimens, in accordance with this view, are more like dolabrata, the name mainly taken for the West Indian specimens, than like terebellum.

\section{Pyramidella (Milda) ventricosa Quoy \& Gaimard.}

Quoy and Gaimard. Voy de l'Astrol. Zool. Pl. 65, fig. 37.

Kiener. Coq. Viv. Vol. IX, Pyramidella, p. 4, Pl. I, fig. I.

Adams. Sow. Thes. Conch. Vol. II, p. 806, Pl. I7 I, fig. I3, I5.

ReEve. Conch. Ic. Vol. XV, Pyramidella, fig. I 5.

Tryon. Man. of Conch. Vol. VIII, p. 299, P1. 72, fig. 63, 64.

Clessin. Martini-Chemn. Conch. Cab. Ed. II, Vol. I, Eulimidae, p. 55, Pl. I3, fig. 2.

Stat. 47. Bay of Bima, near South fort. 55 M. Mud with patches of fine coralsand. I S.pec. Stat. 86. Dongala, Palos-bay, Celebes. 36 M. Fine grey mud (rivermud). I Spec.

The specimens are very young. Many authors quote Guerin as the author of this species. As I was not able to settle the question, I followed the recent opinion of DaLl and BARTSCI (Synopsis of the Genera etc. of the Fam. Pyramidellidae, in Proc. Biol. Soc. Washington Vol. XVII, p. 4), who quote however only the name of Quov.

\section{Pyramidella (Lonchaeus) turrita A. Adams.}

Adams. Sow. Thes. Conch. Vol. II, p. 807, Pl. I7 I, fig. I7.

Reeve. Conch. Ic. Vol. XV, Pyramidella, fig. 3.

Tryon. Man. of Conch. Vol. VIII, p. 30I, Pl. 72, fig. 84, 85.

Clessin. Martini-Chemn. Conch. 'Cab. Ed. II, Vol. I, Eulimidae, p. 55, P1. 13, fig. 1.

Stat. 3r3. East of Dangar Besar, Saleh-bay. Up to 36 M. Sand, coral and mud. Io Spec.

The quoted localities I find, are: Albrochos Island, North Australia (Adams, Reeve, Clessin, 1. c.), New Caledonia (Tryon, 1. c.), Lifu (Melvill and Standen, Cat. Hadf. Coll. of shells from Lifu and Uvea, Journ. Conch. I895, p. I22), Funafuti (Hedlex, Mem. Austr. Mus. Vol. III, I899, p. 4I2), Queensland (Hedley, Proc. Lin. Soc. New South Wales, I907, Vol. 32, p. 482); though these localities are all Australian, it is not strange to find the species also near Sumbawa, in the Southern part of the Malay Archipelago.

\section{Pyramidella (Otopleura) auriscati Chemnitz.}

Cireminitz. Conch. Cab. Vol. XI, p. 20, Pl. il 7 , fig. I7 II, i2.

Kiener. Coq. Viv. Vol. IX, Pyramidella, p. 5, Pl. I, fig. 4 (plicata).

Adans. Sow. Thes. Conch. Vol. II, p. 8I2, P1. I72, fig. I, 2.

ReEve. Conch. Ic. Vol. XV, Pyramidelia, fig. $2 \mathrm{I}$.

Tryon. Man. of Conch. Vol. VIII, p. 305, Pl. 73, fig. 95.

Clessin. Martini-Chemn. Conch. Cab. Ed. II, Vol. I, Eulimidae, p. 70, Pl. I4, fig. 5.

Stat. 37. Sailus ketjil, Paternoster-islands. Up to 27 M. Coral and coralsand. 3 Spec.

Stat. 313. East of Dangar Besar, Saleh-bay. Up to 36 M. Sand, coral and mud. I Spec. 
Syrnola A. Adams.

I. Syrnola elegans A. Adams.

A. Adams. Sow. Thes. Conch. Vol. II, p. SoS, Pl. i7i, fig. ig.

Reeve. Conch. Ic. Vol. XV, Pyramidella, fig. 2.

Tryon. Man. of Conch. Vol. VIII, p. 306, Pl. 73, fig. 7.

Clessin. Martini-Chemn. Conch. Cab. Ed. II, Vol. I, Eulimidae, p. 6o, Pl. It, fig. 2.

Stat. I04. Sulu-harbour, Sulu-island. 14 M. Sand. I Spec.

The only specimen is not intact, the spire and aperture being slightly damaged. I owe the identification to Mr. J. C. Melvill.

2. Syrnola sp.

Stat. 66. Bank between islands of Bahuluwang and Tambolungan, south of Saleyer. 8- To M. Dead coral, Halimeda, Lithothamnion. I Spec.

This specimen is too bad for identification or description, the nuclear whorls are wanting, the mouth is severely damaged.

\section{Syrnola sp.}

Stat. $178.2^{\circ} 40^{\prime}$ S., I $28^{\circ} 37^{\prime} \cdot 5$ E. 835 M. Blue mud. I Spec.

Same observation as for the preceding species, the shell is really only a fragment.

Elusa A. Adams.

I. Elusa subcarnea n. sp. P1. XVII, fig. 8.

Stat. 37. Sailus ketjil, Paternoster-islands. Up to 27 M. Coral and coralsand. I Spec.

Shell subulate, gradate, solid, light flesh-coloured, rather shining. Nucleus wanting, subsequent whorls about 8 , at first rapidly increasing in breadth, than subequal, rendering the shell subcylindrical; the whorls are separated by a conspicuous suture and are angular just below it. Sculpture consisting of broad, slightly convex ribs, with distinct intermediate grooves, number of ribs about 20 on last whorl, moreover there are very fine growth-striae, last whorl elongately rounded. Aperture oval, angular and even canaliculate above, rounded below, with a blunt, only slightly arched outer margin; columellar margin arched with a rather strong plait in its upper part, columellar and outer margins connected by a thick layer of enamel on the bodywhorl. Interior of aperture with rather coarse lirae, terminating at some distance from the outer margin. Columellar margin slightly reflected over an umbilical slit.

Alt. $9^{1} / 2$, lat. $2 \frac{1}{2}$; apert. alt. $1^{3} / 4$, lat. I Mill.

I know no species to which this new one is nearly allied; it is remarkable for its subcylindrical shape and flesh-colour. 
2. Elusa? dubia n. sp. Pl. XVII, fig. 9.

Stat. $52.9^{\circ} 3^{\prime} \cdot 4$ S., $119^{\circ} 5^{\prime} .7$ E. Savu Sea. 959 M. Globigerine ooze. 5 Spec.

Shell subulate, rather solid, yellowish-brown, shining. Nuclear whorls eroded, subsequent whorls about $S$, separated by a conspicuous suture in a rather broad channel, caused by the contraction of the whorls just below and still stronger above the suture; the whorls are nearly flat, but slightly convex towards their base. Sculpture consisting of broad, flat ribs on the upper whorls, becoming faint on the fourth whorl and nearly disappearing on the subsequent ones, with the exception of a few occasional ribs; moreover the shell is covered with very fine growth-striae and extremely fine spiral striae, only visible under a strong lens; last whorl with an obtuse angle near the base and in some specimens a few stronger spiral striae below the angle. Aperture ovate, angular above, rounded below, with a thin, nearly straight outer margin, columellar margin regularly curved, slightly reflected, no umbilical slit; the margins are connected by a moderately thick layer of enamel; interior of aperture smooth.

Alt. Io, lat. $2^{3} / 4$; a pert. alt. $2^{1} / 4$, lat. $I^{1} / 4$ Mill.

Alt. 1 I, lat. $2^{3} / 4$; a pert. alt. $2^{3} / \%$, lat. $1^{1} / 4$ Mill.

A very puzzling species, externally resembling an Elusa but without columellar plait. I have sent two specimens to Mr. Melvill, who writes about it: "I incline to Elusa if not a large abnormal Eulimclla; the longitudinal riblets of the apical whorls are like Elusa but there is no columellar plait visible, the apex seems heterostrophe, the brown colour is like Elusa also". As to the plait, I have opened three whorls of a specimen, but could not detect traces of a plait. Should we consider the species as an abnormal Elusa, or as an abnormal Eulimella, or as a representative of a new group? In accordance with Mr. Meivill's predominant view, I have followed the first method, without being quite certain, that it will prove to be the right manner.

\section{Eulimella Forbes.}

I. Eulimella? sibogae n. sp. P1. XVII, fig. iо.

Stat. $52.9^{\circ} 3^{\prime} \cdot 4$ S., $119^{\circ} 5^{6} .7$ E. Savu Sea. 959 M. Globigerine ooze. I Spec.

Shell rather large for the genus, subulate, smooth, yellowish-white. Nuclear whorls a little eroded, subsequent whorls $7^{1} / 2$, slightly convex, separated by a distinct suture. Sculpture consisting of fine and coarser growth-striae, which latter form however no distinct ribs, crossed by very indistinct spiral striae, scarcely perceptible on many parts of the shell; last whorl elongately-rounded. Aperture (not quite intact) ovate, angular above, outer margin thin, regularly arched, base probably rounded, but subangular, (perhaps by the partly broken margin); columellar margin straight, slightly reflected, nearly covering a trace of an umbilical slit. Interior of aperture smooth.

Alt. Io, lat. $3^{1 / 2}$; apert. alt. $2^{3} / 4$, lat. $1^{3} / 4$ Mill.

This is also a very dubious species, it is nearly too bad for description, in so difficult a group, but still in too good condition, to be neglected. So it may be located here, untill further investigation will clear up its somewhat obscure position in the system. 


\section{Turbonilla Risso.}

I. Turbonilla subcylindrica n. sp. Pl. XVII, fig. I I.

Stat. I02. $6^{\circ} 4^{\prime} .1$ N., $120^{\circ} 44^{\prime}$ E. Sulu Sea. 535 M. Fine, yellow sand. I Spec.

Shell rather large, subcylindrical, attenuate towards the spire, white, with a faint yellowish-brown band at the upper part of the whorls, upper whorls more brown. Nuclear whorls bulbous, smooth, abruptly turned to the left, consisting of a little more than one lateral volution; postnuclear whorls about $\mathrm{II}^{1} \frac{1}{2}$, with a deep suture, making the shell subgradate, especially the upper whorls. Sculpture consisting of substraight ribs (about 2 I on last whorl), which are rather broad and are separated by large interstices, about as broad as the ribs, but not deep; moreover I see a microsculpture consisting of very fine growth-striae and still finer spiral striae, and traces of a slight contraction in the upper part of each whorl, especially of the upper ones, scarcely appreciable in the lower whorls. Last whorl elongate, rouncied below. Aperture oval, with an angle in its upper part, a thin, subsinuous outer margin, and arched columellar margin, with an oblique plait above the middle, and is reflected below. No traces of an umbilical slit.

Alt. $10^{1} / 4$, lat. 2 ; apert. alt. $1^{1} / 2$, lat: $5 / 6$ Mill.

This new species is allied to Turbonilla templaris Melv., but it is much larger, even than a specimen which I owe to the liberality of the author (long 61/2 Mill.) more cylindrical and less contracted at some distance below the suture, moreover that species is uniformly glassy white, whereas the new species is faintly banded. 




\section{PLATE XVII.}

Fig. I. Mucronalia parva Schepman.

Fig. 2. Mucronalia varicosa Schepman.

Fig. 3. Stilifer sibogae Schepman juv.

Fig. 4. Stilifer sibogae adult specimen on Salmacis Dussumieri Ang.

Fig. 5. Eulima Melvilli n. sp.

Fig. 6. Subularia circunstriata n. sp.

Fig. 7. Niso Smithi n. sp.

Fig. 8. Elusa subcarnea n. sp.

Fig. 9. Elusa dubia n. sp.

Fig. 10. Eulimella sibogae n. sp.

Fig. I I. Turbonilla subcylindraca n. sp. 
Siboga-Expeditic. XLIX. I. M. M. SchePMan', Prosobranchia.
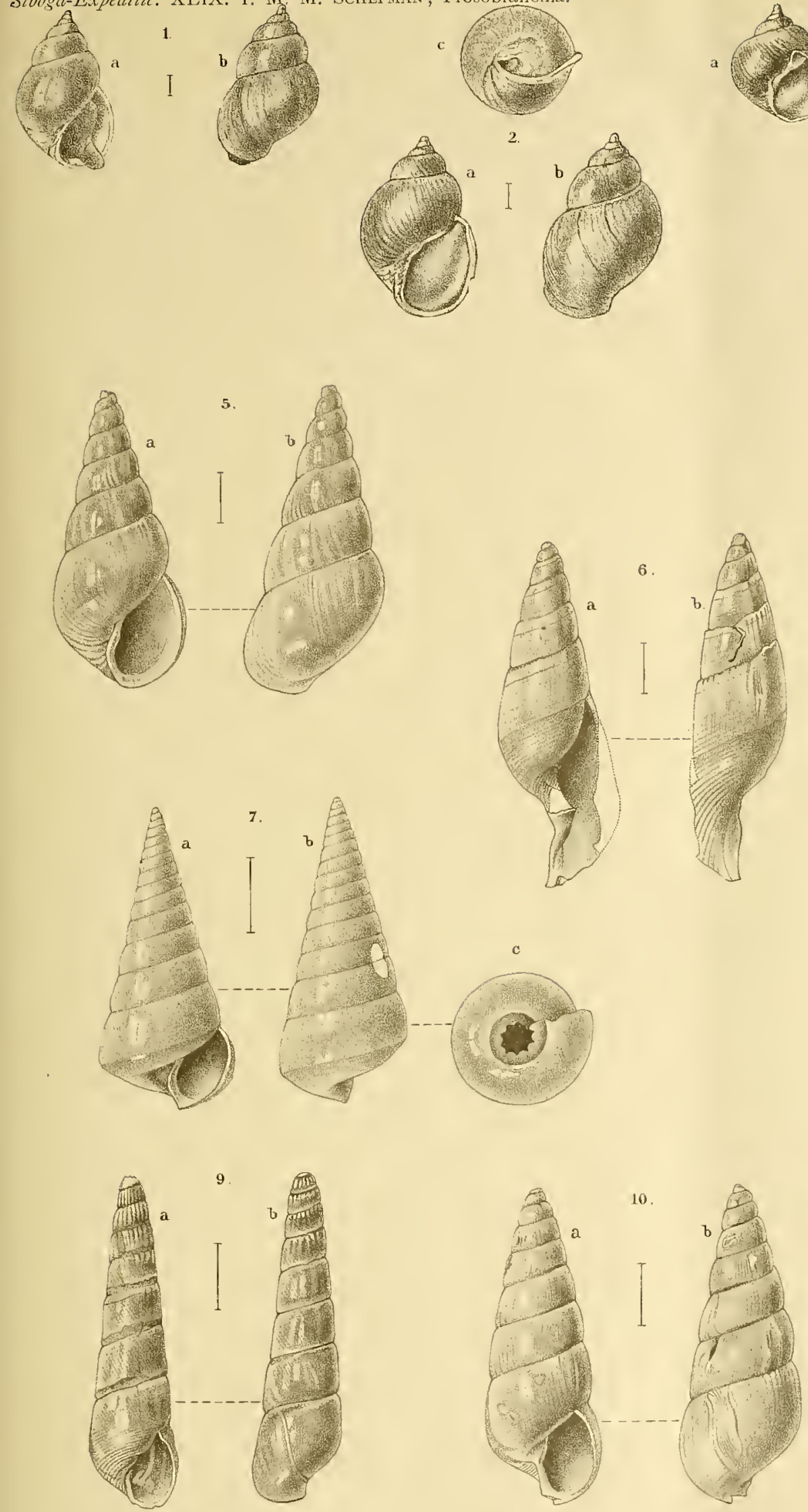

c

(12)

a

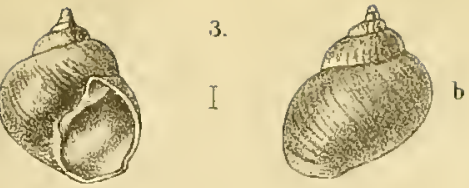

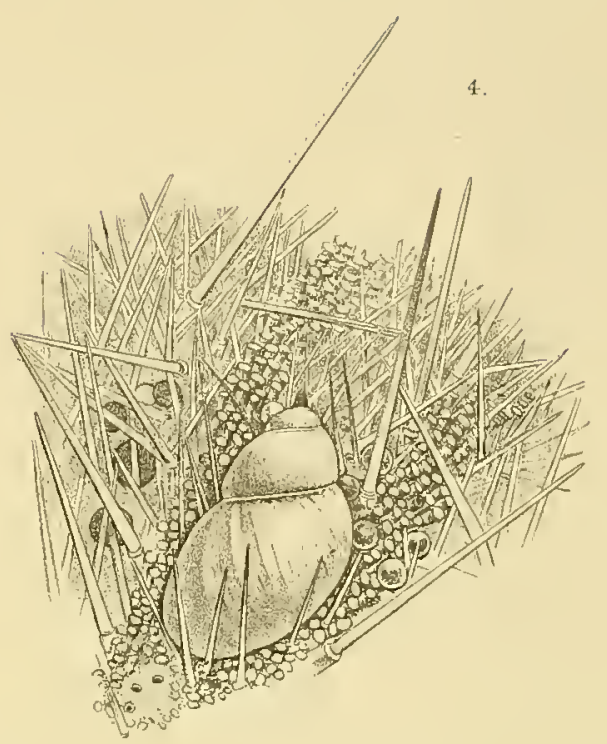

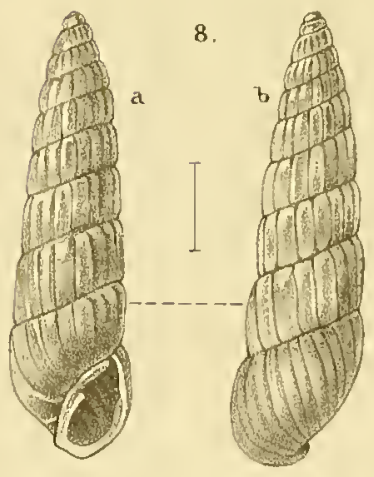

Fig. I-3 H. W. de Graaf, 4 J. Frijs, 5-II Ch. Dumont del. 



\section{Déjà paru:}

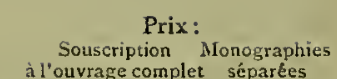

I Livr. (Monogr. XLIV) C. Ph. Sluiter. Die Holothurien der Siboga-Expedition. Mit Io Tafelin. $f$ 6.- $f$ 7.50

2e Livr. (Monogr. LX) E. S. Barton. The genus Halimeda. With 4 plates. . . . . . . " 1.80 „2.40

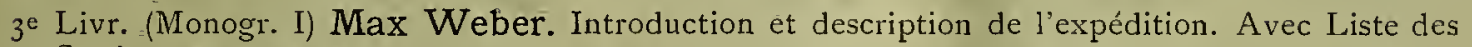

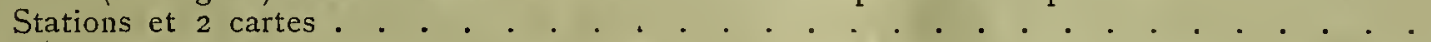

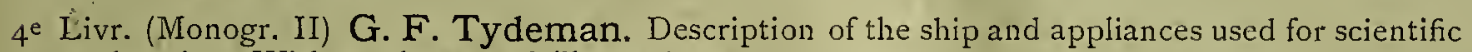
exploration. With 3 plates and illustrations. . . . . . . . . . . . . . . . . .

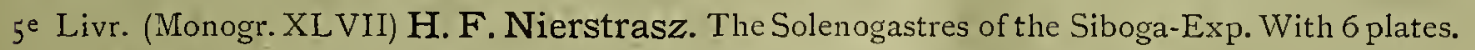
6e Livr. (Monogr. XIII) J. Versluys. Die Gorgoniden der Siboga-Expedition.

I. Die Chrysogorgiidae. Mit 170 Figuren im Text. . . . . . . . . . . " 3.- " 3.75

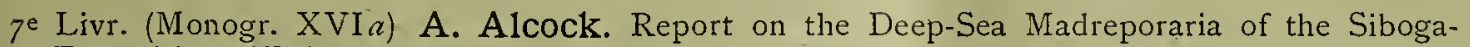
Expedition. With 5 plates. . . . . . . . . . . . . . . . . . . . . . . .

Se Livr. (Monogr. XXV) C. Ph. Sluiter. Die Sipunculiden und Echiuriden der Siboga-Exp. Mit 4 Tafeln und 3 Figuren im Text. . . . . . . . . . . . . . . . . . . . "3.- » 375

ge Livr. (Monogr. VI a) G. C. J. Vosmaer and J. H. Vernhout. The Porifera of the SibogaExpedition. I. The genus Placospongia. With 5 plates. . . . . . . . . . . .

ro Livr. (Monogr. XI) Otto Maas. Die Scyphomedusen der Siboga-Expedition. Mit I 2 Tafeln. I I Livr. (Monogr. XII) Fanny Moser. Die Ctenophoren der Siboga-Expedition. Mit 4 Tafeln.

$12^{\mathrm{e}}$ Livr. (Monogr. XXXIV) P. Mayer. Die Caprellidae der Siboga-Expedition. Mit io Tafeln.

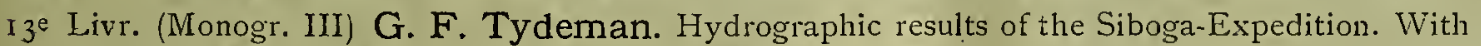
24 charts and plans and 3 charts of depths . . . . . . . . . . . . . . . .

$14^{e}$ Livr. (Monogr. XLIII) J. C. H. de Meijere. Die Echinoidea der Siboga-Exp. Mit 23 Tafeln.

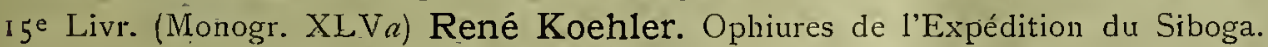

I Partie. Ophiures de Mer profonde. Avec 36 Planches. . . . . . . . . n 16.50 n20.50

16 Livr. (Monogr. LII) J. J. Tesch. The Thecosomata and Gymrosomata of the SibogaExpedition. With 6 plates. . . . . . . . . . . . . . . . . . . . . . . . " 3.75 " 4.70

17 Livr. (Monogr. LVIa) C. Ph. Sluiter. Die Tunicaten der Siboga-Expedition.

I. Abteilung. Die socialen und holosomen Ascidien. Mit is Tafeln . . . . . " 6.75 „9.-

1 se Livir. (Monogr. LXI) A. Weber-van Bosse and M. Foslie. The Corallinaceae of the SibogaExpedition. With I6 plates and 34 textfigures . . . . . . . . . . . . . . . .

19 e Livr. (Monogr. VIII) Sydney J. Hickson and Helen M. England. The Stylasterina of the Siboga Expedition. With 3 plates. . . . . . . . . . . . . . . . . . . . n 1.50 n 1.90

20 Livr. (Monogr. XLVIII) H. F. Nierstrasz. Dic Chitonen der Siboga-Exp. Mit 8 Tafeln. „5.- "6.25 2 re Livr. (Monogr. XLVb) René Koehler. Ophiures de I'Expédition du Siboga. 2e Partie. Ophiures littorales. Avec is Planches. . . . . . . . . . „10.25 „12.75

22e Livr. (Monogr. XXVIbis) Sidney F. Harmer. The Pterobranchia of the Siboga-Expedition, with an account of other species. With 14 plates and 2 text-figures. . . . . . . . . 23е Livr. (Monogr. XXXVI) W. T. Calman. The Cumacea of the Siboga Expedition. With 2 plates and 4 text-figures . . . . . . . . . . . . . . . . . . . . . . .

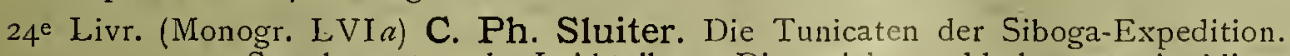

Supplement zu der I. Abteilung. Die socialen und holosomen Ascidien. Mit I Tafel.

"6.75 $\rightarrow 9 .-$

ᄁ $1.80 \gg 2.40$

$\because-75 \geqslant 1 .-$ 
$25^{\mathrm{e}}$ Livr. (Monogr. L) Rud. Bergh. Die Opisthobranchiata der Siboga-Exped. Mit 20 Tafeln.

26e Livr. (Monogr. X) Otto Maas. Die Craspedoten Medusen der Siboga-Exp. Mit 14 Tafeln.

$27^{e}$ Livr. (Monogr. XIII a) J. Versluys. Die Gorgoniden der Siboga-Expedition.

II. Die Primnoidae. Mit ro Tafeln, 178 Figuren im Text und einer Karte.

$\cap 9.25,12.50$

$\ggg 12.50 \quad 16.75$

$28 \mathrm{e}$ Livr. (Monogr. XXI) G. Herbert Fowler. The Chaetognatha of the Siboga Expedition.

With 3 plates and 6 charts. . . . . . . . . . . . . . . . . . . . . .

zge. Livr. (Monogr. LI) J. J. Tesch. Die Heteropóden der Siboga-Expedition. Mit 14 Tafeln.

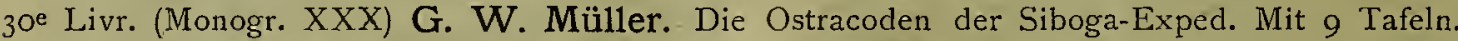

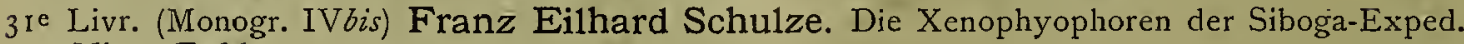

Mit 3 Tafeln . . . . . . . . . . . . . . . . . . . . . . . . . . . .

$3^{2}$ Livr. (Monogr. LIV) Maria Boissevain. The Scaphopoda of the Siboga Expedition.

With 6 plates and 39 textfigures.". . . . . . . . . . . . . . . . . . .

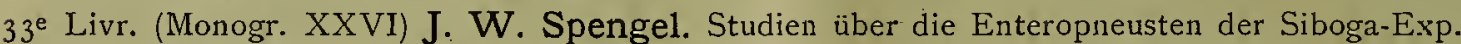

Mit 17 Tafeln und 20 Figuren im Text. . . . . . . . . . . . . . . . . .

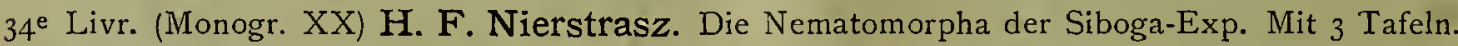

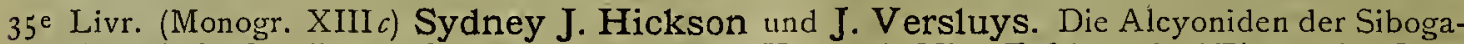

Exped. I. Coralliidæ, II. Pseudocladochonus Hicksoni. Mit 3 Tafeln und I6 Figuren im Text.

36e Livr. (Monogr. XXXI a) P. P. C. Hoek: The Cirripedia of the Siboga Expedition.

A. Cirripedia pedunculata. With to plates . . . . . . . . . . . . . .

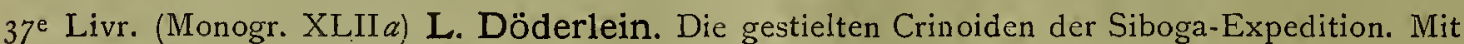

23 Tafeln und 12 Figuren im Text. . . . . . . . . . . . . . . . . . .

$3^{8 e}$ Livr. (Monogr. IX) Albertine D. Lens and Thea van Riemsdijk. The Siphonophores

of the Siboga Expedition. With 24 plates and 52 textfigures. . . . . . . . . . .

$39^{\text {e Livr. (Monogr. XLIX }}{ }^{a}$ a) M. M. Schepman. The Prosobranchia of the Siboga Expedition. Part I. Rhipidoglossa and Docoglossa, with an Appendix by Prof. R. BERGH.

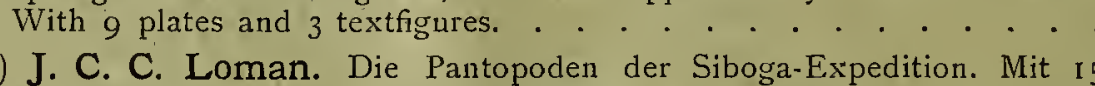

$40^{e}$ Livr. (Monogr. XL) J. C. C. Loman. Die Pantopoden der Siboga-Expedition. Mit 15

Tafeln und 4 Figuren im Text.

$4^{\mathrm{I}}$ Livr. (Monogr. LVI c) J. E. W. Ihle. Die Appendicularien der Siboga-Expedition. Mit 4

Tafeln und 10 Figuren im Text . . . . . . . . . . . . . . . . . . . .

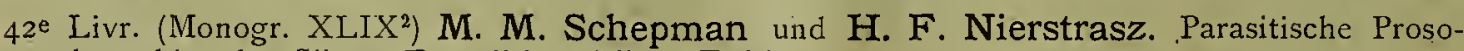

branchier der Siboga-Expedition. Mit 2 Tafeln . . . . . . . . . . . . . . .

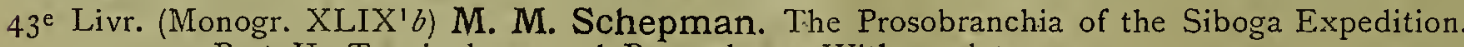
Part II. Taenioglossa and Ptenoglossa. With 7 plates

$\pi 4.20 \geqslant 5.25$

" $6.75,9 .-$

n $3.50 \gg 4.40$

$n 2.40 \quad n 3 \cdot-$

$\eta 4.80,6 .-$

"1 $4 .-\quad$ 17.50

" $2.80 \quad, 3.50$

ᄁ $2.20 \cap 2.75$

\% $5.40,6.75$

"8.- "10.-

$\pi 13.50,16.75$

, $4.80 \quad$ \% $6 .-$

त $6.25 \div 7.80$

$\eta 4.80,6 .--$

$\eta 1.20 \quad 7 \quad 1.50$

$\because 4.50,5.60$

$44^{\mathrm{e}}$ Livr. (Monogr. XXIX $a$ ) Andrew Scott. The Copepoda of the Siboga Expedition.

Part I. Free-swimming, Littoral and Semi-parasitic Copepoda. With 69 plates. • „26.- „32.50

$45^{\mathrm{e}}$ Livr. (Monogr. LVIb) C. Ph. Sluiter. Die Tunicaten der Siboga-Expedition.

II. Abteilung. Die Merosomen Ascidien. Mit 8 Tafeln und 2 Figuren im Text.

46e Livr. (Monogr. XLIX ${ }^{1}$ ) M. M. Schepman. The Prosobranchia of the Siboga Expedition.

Part III. Gymnoglossa. With i plate . . . . . . . . . . : . . . . . n I.- 





